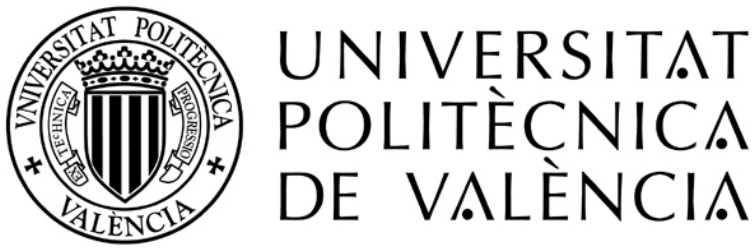

Facultad de Bellas Artes de San Carlos Departamento de Pintura Programa de Doctorado en ArTes Visuales E InTERMedia

\title{
LA TEORÍA FOTOGRÁFICA CONTEMPORÁNEA: HACIA UNA NUEVA PRAGMÁTICA DEL CAMPO FOTOGRÁFICO
}

TESIS DOCTORAL

PRESENTADA POR: José RAúl PÉREZ Fernández DIRIGIDA POR: Dr. D. DAVId Pérez Rodrigo 



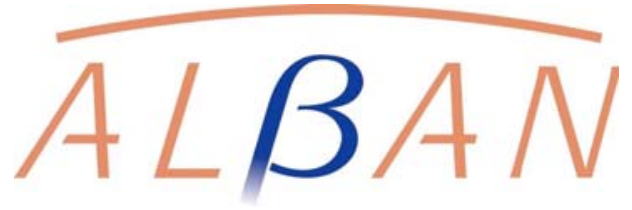

Este trabajo de investigación fue realizado gracias al apoyo del

\section{Programa $A L B A N$}

(América Latina Becas de Alto Nivel)

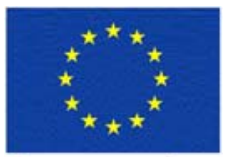

EUROPEAID

CO.OPERATION OFFICE 


\section{LA TEORÍA FOTOGRÁFICA CONTEMPORÁNEA: HACIA UNA NUEVA PRAGMÁTICA DEL CAMPO FOTOGRÁFICO}

\begin{tabular}{l|l} 
ÍNDICE & 4
\end{tabular}

INTRODUCCIÓN: OBJ ETIVOS Y METODOLOGÍA

PRIMERA PARTE: MARCO TEÓRICO

1. LA TEORÍA FOTOGRÁFICA VISTA A TRAVÉS DE LA VENTANA DE SUS AMBIVALENCIAS FUNDAMENTALES 21

1.1. DERIVA INICIAL: EL FOTÓGRAFO ANTE LA VENTANA 23

1.2. UNMEDIO FALSAMENTE ESCINDIDO 33

1.3. HABLAR DESDE LA FOTOGRAFÍA 41

2. EL FOTÓGRAFO ANTE EL ESPEJ O: LA CODIFICACIÓN EN SENTIDO EXTRASEMIÓTICO 43

2.1. UNA ESPECULACIÓN PRELIMINAR 45

2.2. EL CÓDIGO COMO LAS REGLAS DEL J UEGO 57

3. LA CODIFICACIÓN EN UN SENTIDO SEMIÓTICO Y EL GIRO PRAGMÁTICO

3.1. UNA HIPÓTESIS DE TRABAJO 65

3.2. LA SEMIÓTICA DEL ÍNDICE 66

3.3. LA SEMIÓTICA DEL ICONO 69

3.4. LA CODIFICACIÓN ELUDIDA EN EL ANÁLISIS INMANENTE 78

3.5. EL ANÁLISIS EXTRÍNSECO: LOS CÓDIGOS CONTEXTUALES Y EL GIRO PRAGMÁTICO 82

3.6. LA CODIFICACIÓN ASUMIDA 98 


\section{SEGUNDA PARTE: EL ANÁLISIS INMANENTE}

4. LOS CÓDIGOS MIMÉTICOS

103

4.1. PREFACIO: DESPUÉS DEL PROBLEMA DEL ICONISMO 105

4.2. CONTRASTE 108

4.3. ESCALA 121

4.4. ESCORZO 130

5. LOS CÓDIGOS TÉCNICOS 135

5.1. PREFACIO: EN EL LABERINTO DE LA TÉCNICA 137

5.2. CÓDIGO ÓPTICO 145

5.3. CÓDIGO QUÍMICO 149

5.4. CÓDIGO LUMÍNICO 156

5.5. CÓDIGO CINÉTICO 162

5.6. CÓDIGO DIGITAL 166

5.7. EL SOPORTE Y EL FORMATO COMO CÓDIGOS 173

6. LOS CÓDIGOS RETÓRICOS 191

6.1. PREFACIO: LA SUMA, EL SÚMMUM 193

6.2. RETÓRICA DE LOS ACTANTES 199

6.3. RETÓRICA DE LOS OBJ ETOS Y DEL ESPACIO 213

6.4. RETÓRICA DE LA FORMA 223

\section{TERCERA PARTE: EL ANÁLISIS PRAGMÁTICO}

7. LOS ANCLAJ ES INTERPRETATIVOS CONTEXTUALES 237

7.1. CONSIDERACIONES EN TORNO AL ANÁLISIS PRAGMÁTICO 239

7.2. UN MODELO DE ANÁLISIS: EL TRIÁNGULO PRAGMÁTICO 257

7.3. LOS GÉNEROS FOTOGRÁFICOS: ORTODOXIAS, MARIDAJ ES,
HIBRIDACIONES, DECONSTRUCCIONES

7.4. EL ESPACIO DISCURSIVO COMO ELEMENTO SIGNIFICANTE 280

7.5. EL CANAL Y LA SITUACIÓN DE COMUNICACIÓN 292

8. UN NUEVO MARCO PRAGMÁTICO: TRANSFORMACIONES DEL CAMPO FOTOGRÁFICO EN LA ERA DIGITAL 301

8.1. ESTADO DE LA CUESTIÓN 303

8.2. EL CAMPO HIPEREXPANDIDO DE LA FOTOGRFÍA DIGITAL 309

8.3. UN GIRO PRAGMÁTICO: DIGITALIZACIÓNYJ UGARRETAS 333

8.4. HABITAR EL ASÍNDETON 340

8.5. LA FOTOGRAFÍA Y LA PRAGMÁTICA DE LA SOCIEDAD RED 347

9. CONCLUSIONES: EL FOTÓgRAFO ANTE LA PANTALLA 359

$\begin{array}{ll}\text { BibliOgRAFÍA } & 391\end{array}$

RESÚMENES (ESPAÑOL, VALENCIANO, INGLÉS) 407 



\section{INTRODUCCIÓN: OBJ ETIVOS Y METODOLOGÍA}



[...] percibir el significante fotográfico no es imposible (hay profesionales que lo hacen), pero exige un acto secundario de saber o de reflexión. Roland Barthes, La cámara lúcida

Desde su invento, la fotografía no ha cesado de buscar su propia identidad. Surgida durante el primer tercio del siglo XIX producto de una continuidad de avances en el campo de la óptica y la química cuyo origen puede situarse al menos en el Renacimiento, a partir del cual se da la vulgarización progresiva del uso de la cámera obscura, parece deber su modo de representación a otros medios de expresión icónica con una tradición añeja. Sin embargo, esta concepción corre el riesgo de no ser más que una construcción hecha por los historiadores a posteriori, ya que en el período decimonónico esta continuidad no se subraya y, por el contrario, se atribuye a la imagen fotográfica toda un aura de novedad, de modernidad. Lo que muy pronto se llamará una fotografía - en principio denominada mediante diversos apelativos que pronto irán cayendo en desuso- es un objeto absolutamente novedoso que no solamente reta las concepciones existentes hasta ese momento en relación a las posibilidades de la representación visual, sino que, en una perspectiva de futuro, cambiará y modelará a partir de entonces la manera en que los seres humanos miramos, la forma en que nos aproximamos a la realidad y en que configuramos eso que un emblemático estudioso de la fotografía denominó como el inconsciente óptico.

Mucho ha ocurrido desde entonces. Pasada una primera etapa preindustrial, la fotografía se democratizó, se vulgarizó, se desdobló dando origen a otros medios de producción de imágenes técnicas y llegó a ser un elemento tan definitorio de la conformación de nuestro entorno que el siglo $\mathrm{XX}$ fue llamado por algunos el siglo de la imagen. Es un hecho que tanto el desarrollo técnico de la fotografía como la democratización de sus usos no han dejado de modificarse en el transcurso del tiempo. Dicho crecimiento 
continuado fue un factor que contribuyó a su consolidación como una megaindustria, hecho que ha permitido, a su vez, la introducción de buen número de hitos en su camino. Es de notar que, tras un período de décadas de estabilización en la segunda mitad del siglo pasado, a partir de la década de 1990 el campo fotográfico ha presentado un cambio radical debido a la aparición de procesos digitales que, en un lapso de quince a veinte años, han llegado ya a abarcar en su totalidad las diversas facetas de los flujos de trabajo. Hoy, aunque ya seguramente en su última etapa, nos encontramos aún bajo el influjo de esa tan mentada transición de lo analógico a lo digital, acaso sin lograr todavía dimensionar del todo sus consecuencias y alcances, de manera que con certeza podemos considerarla un golpe más a esa evasiva identidad propia del medio.

Durante el brevísimo lapso de menos de dos siglos de su exisencia, el fenómeno fotográfico ha sido estudiado a partir de una multiplicidad de enfoques. Dentro de ese vasto corpus teórico, destacan indudablemente las aportaciones presentadas desde los campos de la técnica, la historia y el diletantismo, este último en la forma de manuales y obras de divulgación; también han destacado, por supuesto, las monografías de autores y los ensayos fotográficos temáticos. Mucho más escasas han sido, en cambio, las aproximaciones al medio desde puntos de vista como el estético y el comunicacional. Haciendo una grosera generalización —que, por supuesto, matizaremos en nuestro marco teórico-, podemos decir que hasta 1989, fecha que consideramos emblemática debido al revuelo que produjo a nivel mundial el festejo del 150 aniversario de la fotografía, con las consecuentes exposiciones y publicaciones conmemorativas que vinieron aparejadas a ese hecho, había - en español o traducidas a él- probablemente solo alrededor de una treintena de obras relevantes que abordaran el fenómeno fotográfico desde un punto de vista teórico mediante enfoques diferentes al histórico, como pueden ser el antropológico, el sociológico, el comunicacional, el estético o las hibridaciones entre ellos.

De esa multitud de aproximaciones posibles al medio, la que aquí hemos privilegiado y da sentido a este trabajo es la que, considerando a la 
fotografía como un lenguaje, englobaremos bajo el abarcador término de teoría fotográfica. Es, por cierto, el enfoque de análisis que ha sido acaso el menos exitoso a lo largo de los 170 años de existencia del medio, y su auge - la propia palabra resulta excesiva - puede situarse apenas a partir de la década de 1960, aparejado al boom de estudios en torno a diversos sistemas comunicativos, ya sea en el ámbito estético o en el funcional, siendo momentos emblemáticos de este apogeo la aventura semiológica, el surgimiento de los estudios culturales y, en general, la aparición de una diversidad de enfoques que caben con más o menos fortuna, dependiendo de cada caso, bajo el gran paraguas expresado con el concepto de crítica postestructuralista.

De lo anteriormente dicho se desprende también una dificultad que es necesario apuntar desde esta nota introductoria. Nos referimos a la convivencia en los hechos de multitud de usos de la fotografía, la cual se desenvuelve en espacios discursivos tan diversos como la ciencia, el periodismo, la publicidad, el diletantismo y, por supuesto, el arte. Entre ellos se dan influencias, préstamos, maridajes y transposiciones, de manera que, como objetos con vida social, las fotos son sujetos escurridizos, capaces de escabullirse y pasar de las maneras más insospechadas de un campo a otro. Este es un hecho que determina nuestra aproximación al fenómeno de una manera fundamental, ya que, al privilegiar el estudio de la fotografía desde una perspectiva comunicacional, en tanto que lenguaje, todas las formas de expresión fotográfica -y no solo la artística, aunque tenderemos a privilegiarla- estarán comprendidas en nuestro ámbito de intereses.

Pero, ¿por qué favorecer este punto de vista, el de desvelar los principios del lenguaje fotográfico, sobre otros? Existe en el campo fotográfico una queja que se ha convertido en un verdadero tópico y que se refiere a la falta de educación específica para la lectura de imágenes. Paradójicamente, esa queja es formulada de manera habitual por los fotógrafos, quienes se lamentan de que el público en general no sea capaz de interpretar sus imágenes de acuerdo con las intenciones creadoras que 
les dieron origen. Nuestro punto de vista es que esta idea es en gran medida ilusoria. Aunque no pretendemos negar que existen diversos niveles de lectura y que en efecto, como lo establece Barthes en la frase que utilizamos como epígrafe a esta Introducción, hay aspectos del lenguaje fotográfico cuya comprensión o apreciación parecen estar reservadas al profesional, cuesta trabajo aceptar que en un mundo sobresaturado de imágenes fotográficas, el público en general tenga que ser considerado como un analfabeto visual, para utilizar la ya añeja expresión consagrada por Moholy-Nagy en los años dorados de la Bauhaus. Como contraparte, no podemos negar que la educación enfocada al desarrollo de habilidades para la lectura y apreciación de imágenes dista mucho de acercarse a estándares mínimamente aceptables y que, por lo tanto, siguen siendo la intuición y las capacidades adquiridas a través de la experiencia las que priman en el acercamiento del lego al mundo visual. ¿Es posible conciliar estas dos posiciones?

Partamos de una analogía. Una persona común, estadísticamente prevista, con una educación media, acostumbra leer el periódico. En él, encuentra tanto textos como imágenes de muy diversas índoles. En lo que toca a los textos, se enfrenta a notas periodísticas, artículos de opinión, entrevistas, crónicas, reportajes de investigación y también —¿por qué no? - cartas, recetas de cocina, anuncios publicitarios y avisos de ocasión de todo tipo. En el suplemento cultural del fin de semana, no será raro que encuentre, asimismo, reseñas, relatos breves y poemas, así como críticas enfocadas a distintas formas de expresión artística. Todos estos textos tienen diversos grados de complejidad, sin embargo, son puestos por igual a la consideración del público en general. En el caso de los juguetes, la normativa oficial obliga a los fabricantes a establecer en el embalaje la edad aproximada para la que son aptos: para niños entre tres y cinco años... Ningún periódico establece, en cambio, como advertencia previa a un artículo de opinión: exclusivo para licenciados y posgraduados, o espeta la frase precautoria: si usted no terminó la educación secundaria, léalo bajo su propio riesgo. 
Los textos son infinitamente variados, al igual que los lectores, quienes son capaces de elaborar interpretaciones a distintos niveles de profundidad dependiendo de su educación, áreas de interés, intuición y un sinnúmero de factores más que constituyen su experiencia. Aunque de hecho existe una educación formal desde la escuela primaria y secundaria para lidiar con los textos, esta no asegura la competencia global de la persona, ni el que dos individuos que hayan recibido la misma educación cuenten con capacidades interpretativas equivalentes.

En el periódico que nuestra persona estadísticamente prevista lee, por supuesto, también hay un buen número de imágenes que, como los textos, responden a diversas necesidades comunicativas. Entre ellas, se cuentan ilustraciones, infografismos, cartones humorísticos, logotipos, símbolos gráficos y fotos. Estas últimas, al igual que los escritos, responden a una gran variedad de registros expresivos que nos permiten encontrar, entre otros: retratos, fotos periodísticas de actualidad, reportajes gráficos, paisajes, bodegones...; en el suplemento cultural del fin de semana, podremos hallar todo tipo de fotos con pretensiones artísticas y, salpicadas a lo largo de toda la publicación, la interminable gama de géneros, temas y tratamientos que proporciona la fotografía publicitaria. El periódico en cuestión es solamente un tímido representante del bombardeo de imágenes fotográficas que una persona común que vive en un entorno urbano recibe diariamente a través de incontables canales. ¿Es lícito considerar que esa persona se mueve en dicho mundo azarosamente, siendo incapaz de desentrañar el sentido de los signos que la rodean?

Si bien es cierto que, en el caso de la imagen fotográfica en particular, no existen en la educación formal asignaturas dirigidas a desentrañar sus mecanismos de significación, los hechos revelan que dicha capacidad existe $\mathrm{y}$, como en el caso de los textos, se da en mayor o menor medida dependiendo de cada persona en particular debido a factores intangibles, como la sensibilidad o la intuición. La experiencia muestra, sin embargo, que no hay una relación de proporcionalidad directa entre el nivel educativo y la capacidad lectora, salvo en el caso de determinados campos 
específicos de superespecialización, como pueden ser el del diseño gráfico, la edición o el de las artes visuales, por ejemplo.

El lugar común del que parte nuestra reflexión podría ser considerado, así, como un reproche de los fotógrafos profesionales y críticos especializados en relación a la creciente heteronomía de su campo, la cual se ha desdoblado exponencialmente durante las últimas dos décadas de la mano, no digamos de la digitalización, sino de algunas de sus consecuencias, como son la extraordinaria modificación que en ese período han sufrido y están sufriendo de la mano de Internet los hábitos en tres áreas principales: la producción, distribución y consumo de imágenes.

No puede soslayarse, sin embargo, el hecho de que, como en el caso del análisis textual, en el de la imagen fotográfica existe una teoría especializada dirigida a desentrañar y explicar sus mecanismos de significación. Con las anteriores reflexiones no deseamos minimizar la importancia de dicha teoría. Muy al contrario, es precisamente debido a que estamos convencidos de su utilidad y que a lo largo de más de 25 años de actividad académica y creadora hemos asistido a sus avatares, que las dudas expresadas nos inquietan al punto de motivarnos a proponer este trabajo de investigación.

En el planteamiento que hacemos, partimos de un presupuesto general —casi una petición de principio-y de dos hipótesis específicas. El presupuesto general consiste en la convicción, arriba expresada, de que la persona común cuenta efectivamente con una capacidad lectora de la fotografía, al margen de no haber pasado por un proceso de educación formal específica. Por supuesto, dicha capacidad se desenvuelve en una muy amplia gama de competencias. Si aceptamos esta afirmación como válida —de ahí su carácter de petición de principio-, es necesario que nos preguntemos acerca de cuáles son los procesos de formación, interiorización e incorporación de dicha capacidad, ya que no podemos aceptar simplemente el hecho de que la fotografía sea un lenguaje natural o, para aludir a un concepto barthesiano sumamente polémico en su momento, un mensaje sin código. 
Por su parte, la primera hipótesis específica que fundamenta nuestra propuesta se deriva de que, aun cuando existe un importante corpus teórico dedicado al análisis de los procesos de significación en la fotografía, este invariablemente se ha desviado del estudio específico de los procesos de codificación fotográfica -que involucran tanto al emisor como al receptor, codificador y decodificador-, los cuales solo han sido abordados parcialmente o se han eludido. Es a la reflexión en torno a este vacío teórico a la que proponemos abocarnos en este trabajo. Nuestra hipótesis, expresada de manera sucinta, consiste en que es precisamente a través del estudio de los procedimientos de codificación propios del medio que podemos desentrañar la especificidad del signo fotográfico, propiciando un análisis no solo inmanente —que nos permita responder a la cuestión de cómo significa, cómo se expresa la fotografía-, sino también un análisis pragmático que incorpore los elementos contextuales que son puestos en acto durante el proceso interpretativo.

Dando continuidad al anterior planteamiento, la segunda hipótesis específica que da pie a nuestra reflexión se relaciona con ese cambio reciente al que hemos aludido y propone la interrogante de si la introducción de los procesos digitales ha derivado en la creación de un nuevo lenguaje fotográfico o si, por el contrario, debemos situar su aportación más vinculada con el ámbito de los usos de la imagen. En su expresión más general, lo que nos interesa desentrañar a partir de este cuestionamiento son las formas en que la digitalización de los procesos fotográficos han modificado, no solo los aspectos expresivos del lenguaje fotográfico, sino también los extrínsecos, esto es, el giro pragmático experimentado por el campo fotográfico en los últimos veinte años.

Ambas hipótesis se entrelazan para conformar el título que hemos propuesto como síntesis de nuestras inquietudes: La teoría fotográfica contemporánea: hacia una nueva pragmática del campo fotográfico.

Cabe enfatizar el hecho de que el movimiento así propuesto desde un análisis inmanente hacia otro extrínseco entraña, en sí mismo, una dirección y, por qué no decirlo, una evolución. Hay implícita en el presente 
trabajo una línea de tiempo que subyace en las teorías que se van planteando desde 1957 - fecha que en el Capítulo 3 situamos de manera emblemática como el inicio de nuestro ámbito de reflexión- y que presentan un desarrollo continuado que refleja la manera como tanto en la teoría como en la práctica artística han ido cambiando las inquietudes y los acentos. En particular existe un tema específico que sintetiza y engloba los virajes de esos dos ámbitos durante un período que comprende, derivado de lo dicho, cinco décadas: nos referimos a los cambios en la concepción de las actividades productora y receptora de la obra, hasta llegar a un entorno, el actual, en el que ya no se sostienen los modelos tradicionales, lineales, de comunicación.

Simbólicamente, hemos englobado esta inquietud, expresada en su forma más general, en la tríada: Ventana / Espejo / Pantalla. Con ello aludimos a las actitudes fotográficas que tienden a utilizar al medio, en el primer caso, para ver hacia la realidad, conocer algo que es otra cosa, al estar situados frente a ella; en el segundo, para voltear hacia uno mismo, también frente, pero de igual manera dentro de esa realidad; y, en el caso del tercer elemento, la pantalla, para propiciar una especie de inmersión en un espacio virtual, fragmentado, ante el que debemos llevar a cabo permanentemente una labor de recomposición, y que abarca de manera creciente cada vez más aspectos de nuestras vidas.

Este movimiento, esta direccionalidad de una teoría obsesionada por plantear nuevos modelos que permitan explicar unos modos de hacer y unas maneras de formar términos en los que en su momento ahondaremos- en permanente fuga hacia el futuro, no solo está presente en el trabajo a través de esa línea abstracta que acabamos de definir y que lleva del fotógrafo ante la ventana, del Capítulo 1, al fotógrafo ante la pantalla, frase que da título a las conclusiones del trabajo. Dicha direccionalidad que parte del análisis inmanente hasta llegar al planteamiento de un nuevo giro pragmático, contextual, está también presente de manera continua a lo largo del trabajo en las citas de aquellos autores que han marcado el camino. Desde el punto de vista metodológico, 
siendo esta una investigación documental, hemos por ello optado por el sistema autor-fecha para, al mismo tiempo que acreditamos esas aportaciones, permanentemente situar al lector en el momento en que fueron presentadas, a través de su año de publicación original.

Una vez hechas estas precisiones de carácter general, pasaremos ahora al comentario paso a paso de ese desarrollo, reflejado en la estructura interna del trabajo de la manera que a continuación se describe.

En el Capítulo 1 abordamos, a manera introductoria, algunos de los prejuicios y tópicos que han acompañado al medio fotográfico, incluso desde su mismo surgimiento. Señalaremos la tendencia a crear polaridades o dicotomías que no solo han propiciado formas opuestas de abordar el acto de creación fotográfica sino, por supuesto, también la manera de concebir la teoría en torno al medio, lo que la ha escindido y, en ocasiones, desviado de sus objetivos. En este marco, proponemos la necesidad de incidir en el fenómeno fotográfico a partir de la cautela respecto de ciertas preconcepciones y giros ideológicos que tradicionalmente lo han sesgado.

Los dos siguientes capítulos conforman propiamente el marco teórico de nuestro trabajo. En el Capítulo 2 damos fundamento a nuestro presupuesto general, introduciéndonos en el tema de la codificación, aunque todavía desde un punto de vista extrasemiótico, esto es, con mayor énfasis en aspectos filosóficos y sociológicos que en los de su consideración desde una perspectiva comunicacional. Ponemos el énfasis en la forma como, a nivel social, se incorporan las reglas del juego, esto es, las habilidades en el uso de los códigos. A partir de este momento la metáfora del juego, en particular la del juego de ajedrez -de inspiración flusseriana-, es retomada en diferentes momentos del desarrollo del trabajo. Por su parte, en el Capítulo 3 entramos de lleno en la revisión de las teorías que a partir de la fecha emblemática de 1957 han tenido mayor peso en la aproximación al medio. En este caso, aunque no hacemos propiamente una revisión cronológica, la línea de tiempo de las diversas propuestas que han existido, y de la que hablamos anteriormente, queda implícita en el trabajo, por lo que optamos por la reducción de las diversas 
propuestas a sus rasgos principales, comentando sus aspectos disonantes y delimitando nuestro campo de acción.

Dada la diversidad de enfoques a partir de los cuales se ha abordado tradicionalmente el fenómeno fotográfico -técnico, histórico, estético, semiótico, sociológico, antropológico, etcétera-, nos hemos decantado por la teoría semiótica como enfoque principal, aunque no único, por ser el más útil para la consecución de nuestros fines. Hemos de reconocer que encontramos en este enfoque una herramienta útil de aproximación al fenómeno fotográfico desde una perspectiva inmanente. $\mathrm{Si}$ bien la semiótica ha perdido fuerza en las últimas dos décadas frente a otros enfoques, nuestra posición es que tanto su lenguaje como aportaciones metodológicas han sido incorporadas por aquellos. Cabe subrayar el hecho de que, siendo que este trabajo se presenta en el marco de una Facultad de Bellas Artes, esto podría hacer presuponer una preeminencia del enfoque estético. Sin embargo, en nuestra aproximación hemos de otorgar igual relevancia a los diversos campos de la actividad fotográfica, tanto el artístico como otros de carácter funcional. Así, aunque nuestra tendencia natural es la de primar a la fotografía considerada artística por su carácter propositivo y experimental, no podremos omitir la consideración de los campos de la imagen funcional -periodística, científica, publicitaria, de viajes, etcétera-, para los cuales la teoría semiótica es una excelente puerta de entrada. Este sesgo, como es lógico, se ve reflejado en la selección bibliográfica que hemos efectuado para conformar nuestro marco teórico.

Los Capítulos 4 a 6, por su parte, constituyen el cuerpo principal de nuestra propuesta de análisis inmanente. En ellos abordamos los diferentes procedimientos de codificación fotográfica. Estos, como ya establecimos, han sido estudiados solamente de manera parcial, por lo que en dichos capítulos recurrimos a las aportaciones de diversos autores con la intención de crear un diálogo entre ellos y finalmente, con la adición de nuestra visión personal, dar consistencia a un cuerpo teórico que hasta ahora se ha encontrado disperso. A fin de ejemplificar algunos de los principales conceptos para dar más solidez didáctica a la investigación, al final de cada 
uno de estos capítulos hemos incluido algunos trabajos fotográficos, principalmente tomados del campo artístico, con un carácter ilustrativo.

No obstante la importancia del análisis inmanente, y aunque lo consideramos fundamental como puerta de entrada a la interpretación de la imagen fotográfica, es también indudable que ha mostrado históricamente sus limitaciones, como lo evidencia el declive que en su momento experimentó el enfoque estructuralista. De ahí que, en ese proceso de adquisición de preeminencia por parte de los procesos receptivos al que ya aludimos, se haya mostrado como fundamental el complementarlo con otras aproximaciones de carácter extrínseco que integren, como parte del proceso de lectura, factores contextuales y de la situación de comunicación, es decir, que aborden el acto interpretativo desde una perspectiva pragmática. Es con este objetivo en nuestro horizonte que en el Capítulo 7 acometemos la tarea de sistematizar los principales elementos contextuales que intervienen en el proceso de creación-recepción del mensaje fotográfico. Para ello, nuestra propuesta consiste en plantear un modelo conceptual al que denominamos triángulo pragmático, que integra las interacciones entre tres factores, a saber: el género, el espacio discursivo de difusión de la imagen y, finalmente, el canal y la situación de comunicación.

Forma parte de nuestra convicción el que dicho marco pragmático dista mucho de ser estable. Por el contrario, en el conjunto de los avatares que conforman la historia del medio en las últimas dos décadas, sobresale el hecho de que la digitalización de los procesos ha transformado, o al menos incidido, en prácticamente la totalidad de los flujos de trabajo. Es a ello, precisamente, a lo que nos referimos al introducir la noción de un giro pragmático -tema del Capítulo 8-, abarcador de los tres ámbitos a los que ya anteriormente aludimos: la producción, distribución y consumo de las imágenes. Si el giro pragmático en la teoría nos incumbe, ello se debe a que no es sino el reflejo de lo que actualmente se está viviendo en los hechos. En relación a este asunto en particular, nuestra manera de abordarlo es teniendo siempre en mente la pregunta por el hecho de si la digitalización ha traído consigo una modificación de la fotografía como 
lenguaje, lo cual es el asunto de fondo de nuestra investigación expresado anteriormente en nuestra segunda hipótesis.

Inevitablemente, en su empeño por explicar los fenómenos que se suceden hoy a la velocidad de la luz, la teoría fotográfica ha de abordar el panorama cambiante en que se desenvuelve el medio fotográfico en la actualidad y enfrentar el reto de arrojar luz sobre él mientras que la expansión provocada por su estallido está aún en proceso. Como ya hemos apuntado y en su momento lo desarrollaremos, la teoría dedicada de manera específica al estudio del lenguaje fotográfico cumple, grosso modo, una cincuentena de años. Es tiempo de ver en perspectiva sus ires y venires, sus debates y aportaciones. En un momento histórico en el cual la fotografía manifiesta profundas transformaciones, la reflexión en torno al fenómeno se impone como una necesidad vital. 
PRIMERA PARTE: MARCO TEÓRICO

CAPÍTULO 1

\section{LA TEORÍA FOTOGRÁFICA VISTA A TRAVÉS DE LA VENTANA DE SUS AMBIVALENCIAS FUNDAMENTALES}





\subsection{DERIVA INICIAL: EL FOTÓGRAFO ANTE LA VENTANA}

Empecemos por el principio. Tenemos ante nuestros ojos un cierto tipo de imagen, eso que durante el siglo XIX se conocía como una vista. (Imagen 1) ¿Qué es lo que observamos?

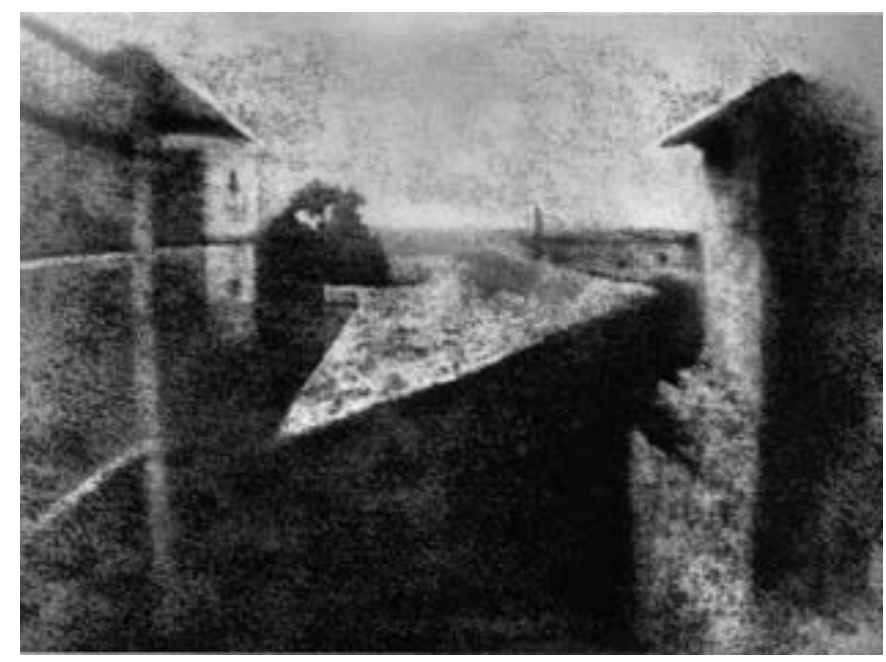

Imagen 1. J oseph-Nicéphore Niépce

Punto de vista desde la ventana en Le Gras, 1826

Vemos una imagen rectangular -de 20.3 por 25.4 centímetros, aunque aquí está impresa sobre papel a menor escala y se trata de la reproducción de una reproducción, que a su vez reproduce un número indefinido de reproducciones previas, también impresas en papel, de una placa original de peltre-, en cuya superficie se observa una vista. En ella, las diferencias tonales demarcadas por algunas líneas rectas delimitan lo que interpretamos como volúmenes. Una cierta textura se encuentra presente en todo el plano de representación. Se aprecian algunas figuras geométricas, como triángulos, romboides y rectángulos; también alguna 
que otra forma irregular. Las líneas son muy dominantes: hay verticales, horizontales y líneas oblicuas con diversos ángulos de inclinación. La parte superior es clara y su tono, inestable. Contrasta con el tercio inferior, el cual es significativamente más oscuro, aunque tiene también cierto degradado. Hay una peculiar difuminación en los extremos superior y derecho.

¿Verdaderamente alguien describiría así esta imagen? Replanteemos: ¿Verdaderamente alguien describiría así esta imagen, hoy? ¿Y qué decir de esta? (Imagen 2) ¿Qué vemos?

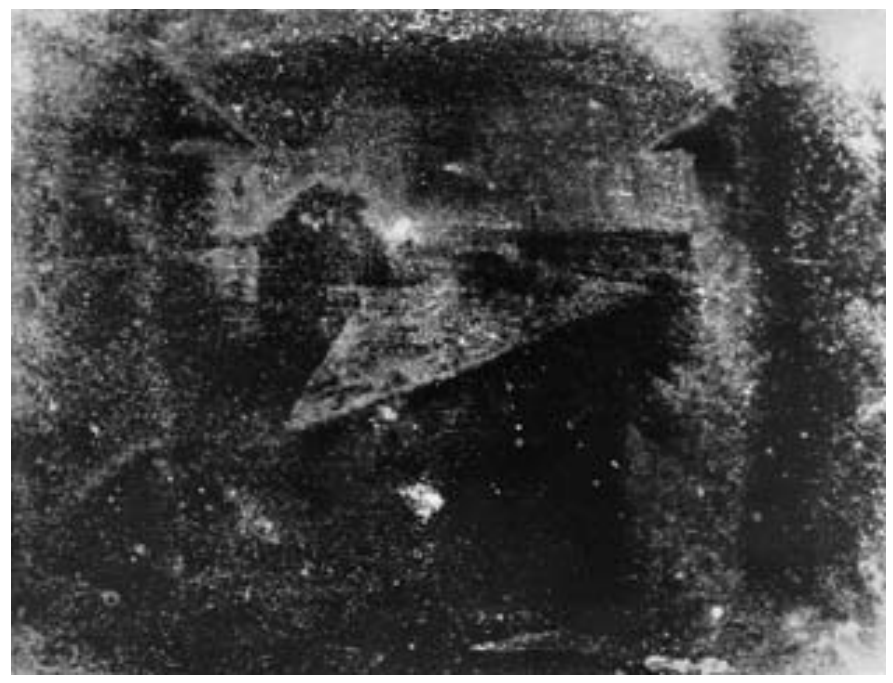

Imagen 2. J oseph-Nicéphore Niépce

Punto de vista desde la ventana en Le Gras, 1826

Vemos una imagen rectangular —de 20.3 por 25.4 centímetros, aunque aquí está impresa a menor escala sobre papel y se trata de la reproducción de una reproducción, que a su vez reproduce un número indefinido de reproducciones previas, también impresas en papel, de una placa original de peltre-, en cuya superficie se observa una vista, por lo cual, dada nuestra educación, tendemos a considerar el anverso de este objeto como algo poco significativo. En dicha imagen monocromática, las 
diferencias tonales son mínimas; algunas de sus zonas están demarcadas por líneas rectas que delimitan lo que interpretamos como volúmenes. Sin embargo, la dominante textura que se encuentra presente en todo el plano de representación prácticamente impide el reconocimiento de las formas. Es posible distinguir algunas figuras geométricas apenas insinuadas, como triángulos, romboides y rectángulos; también alguna que otra silueta irregular. Las líneas no son dominantes, aunque haciendo un esfuerzo se pueden apreciar algunas verticales, horizontales y líneas oblicuas con diversos ángulos de inclinación. La parte central es oscura y su tono, irregular. Contrasta, sobre todo, con los extremos izquierdo, superior y derecho, los cuales presentan un cierto degradado. Hay una peculiar sensación de suciedad impregnada en la imagen, principalmente tres puntos blancos situados aproximadamente en su eje central vertical.

¿Verdaderamente alguien describiría la imagen de esta manera? Replanteemos: ¿Verdaderamente alguien la describiría así, hoy? ¿Y qué decir de esta? (Imagen 3) ¿Qué vemos?

Vemos una placa de peltre de formato rectangular —de 20.3 por 25.4 centímetros, aunque aquí aparece impresa sobre papel y se trata de una reproducción a una escala menor, por supuesto, y seguramente reproducida a partir de un número indefinido de reproducciones previas en papel e impresas con diversos métodos-, en una de cuyas superficies se observa una imagen, por lo cual, dada nuestra educación, tendemos a considerar el anverso de este objeto como algo poco significativo, aunque de hecho, por su carácter histórico, la información contenida en dicho anverso es relevante. La vista registrada en lo que consideramos el frente de este objeto, presenta una escala cromática muy limitada. El material del objeto tiene un cierto efecto tornasolado que provoca, según dicen, que al cambiar la posición del observador frente a él, se distingan diferentes aspectos; dicho efecto, claro está, se pierde ante su reproducción en papel. Algunas de las zonas de la imagen están demarcadas por líneas rectas que sugieren volúmenes de manera casi imperceptible. Sin embargo, la dominante textura que se encuentra presente en todo el plano de representación 
prácticamente impide el reconocimiento de las formas; esta textura parecería corresponder a la de una sustancia que fue untada en la placa y que, al secarse, dejó su huella.

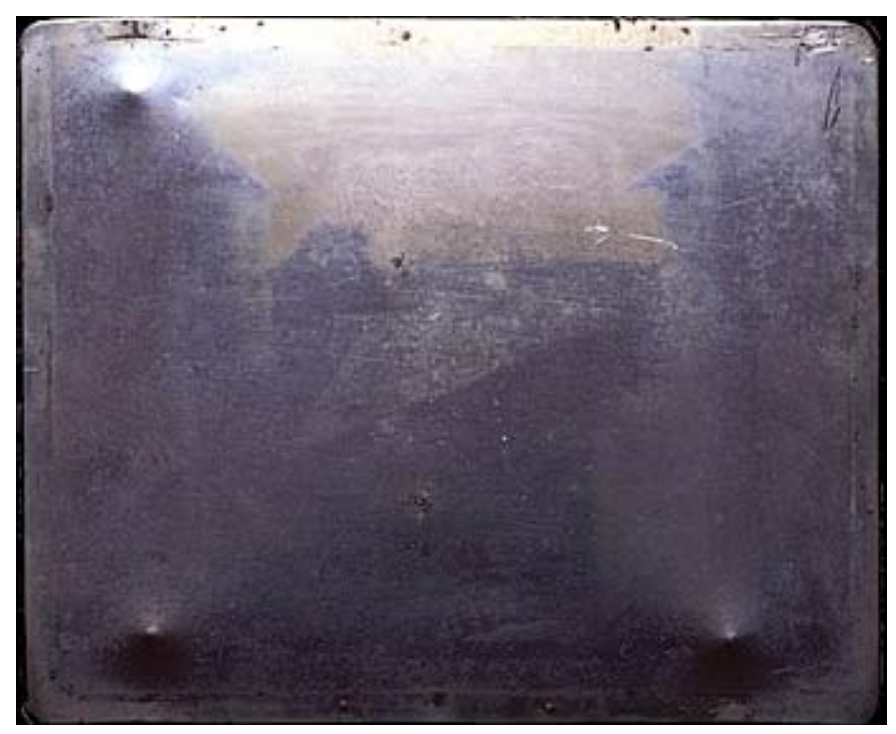

Imagen 3. J oseph-Nicéphore Niépce

Punto de vista desde la ventana en Le Gras, 1826

Al forzar la atención, es posible entresacar levísimamente algunas figuras geométricas, como triángulos, romboides y rectángulos, los cuales se pierden en el conjunto debido a la falta de contraste; también se logra distinguir alguna que otra silueta irregular. Las líneas no son dominantes, aunque si el espectador se esfuerza, puede percibir algunas verticales, horizontales y líneas oblicuas con diversos ángulos de inclinación. La parte superior es clara, ya sea debido al objeto en sí o al exagerado reflejo producido al iluminarlo para su reproducción. En los bordes se observan diversos rayones, así como uno particularmente notable en el cruce de los tercios superior y derecho. Hay una peculiar sensación de suciedad impregnada en la placa, principalmente algunos puntos y manchas situados 
aproximadamente en su eje central vertical. Finalmente, en las dos esquinas inferiores y en la superior izquierda se distinguen, de manera notable, unas abolladuras o irregularidades en el relieve del metal.

Eso es lo que vemos, no lo que intuimos o lo que sabemos, después de cerca de dos siglos de aprendizaje — ¿entrenamiento o condicionamiento?_visual en relación a la fotografía.

Lo que hoy sabemos, por supuesto, es mucho más. Sabemos que esa imagen, esa foto ${ }^{1}$ que en su momento no tenía nombre, fue tomada por Niépce desde la ventana de su estudio en Saint-Loup de Varennes en 1826. Él la llamó heliografía, ya que su intención era escribir con el sol, y se dice que requirió de aproximadamente ocho horas de exposición para registrarla. Es sabido que antes de esa imagen hubo otras, ya que sus experimentos se iniciaron diez años antes, en 1816. Se sabe, también, que más personas, en diversos lugares, experimentaron por caminos similares, pero las imágenes se desvanecían ante el continuo efecto de la luz. La heliografía de Niépce seguramente no es la primera, pero sí la más antigua imagen fotográfica que se conserva, y esto nos provoca un cierto estremecimiento al contemplarla. Pero, ¿cuál de las imágenes que hemos comentado es la heliografía de Niépce?

Aquí se han presentado tres versiones precisamente para dar pie a un hilo argumentativo. La primera parece una foto. Ello se debe, simplemente, a que alguien la produjo y retocó en 1952 precisamente para que pareciera una foto, o al menos lo que dicha persona en ese momento consideraba como tal de acuerdo con una tradición ya bien establecida. La persona en cuestión era Helmut Gernsheim, historiador que rastreó, hasta hallarla en un archivo olvidado, la placa de peltre que había sido expuesta públicamente por última vez en 1898. Con la ayuda del laboratorio de investigación de la compañía Kodak, Gernsheim elaboró esta reproducción en plata sobre gelatina corrigiendo la subexposición del original, y personalmente la retocó con acuarela -a lo que se debe parcialmente la

\footnotetext{
${ }^{1}$ Nos apropiaremos en este trabajo de la distinción hecha por Soulages (1998) y hablaremos de «fotografía» para aludir al medio o la disciplina fotográfica, mientras que para referirnos a imágenes fotográficas particulares utilizaremos el término «foto».
} 
textura de aspecto puntillista-, obteniendo como resultado una verdadera idealización. Si es una foto, hagamos que lo parezca, sería la consigna. Esta imagen ha sido, por cierto, la más reproducida en los libros de historia de la fotografía durante más de cinco décadas, la mayoría de las veces sin especificar que se trata de una reproducción alterada y retocada.

La segunda imagen aquí mostrada fue un intento previo del mismo Gernsheim quien, también en 1952, con la ayuda del mismo laboratorio y valiéndose de toda clase de recursos de iluminación rasante, objetivos de alta resolución y películas de alto contraste, entre otros, generó esta imagen con apariencia de negativo. La aspiración de lograr una reproducción más apegada al original paradójicamente lo condujo en sentido opuesto. El propio historiador la consideró como una distorsión del original y prohibió su reproducción hasta 1977. Hoy, como consecuencia, esta ambivalente foto no nos habla tanto de los esfuerzos de Niépce, sino más bien, en una lectura no exenta de malicia, de las penosas dificultades para reproducir fotográficamente, de manera realista, ya a mediados del siglo $\mathrm{XX}$, determinado tipo de objetos. Sorprendentemente, a pesar de haber sido desautorizada por el propio Gernsheim, la hemos seguido encontrando reproducida en buen número de libros de historia del medio. El equívoco parece perpetuarse incluso en obras (cfr. Batchen 1997: 121 y ss.) que se empecinan en aclarar el oscuro origen del medio fotográfico, origen que en su momento no fue documentado con minuciosidad y que llegó a convertirse en una obsesión para los historiadores.

Finalmente, la tercera imagen aquí presentada es una reproducción técnica realizada en el año 2002 en el Getty Conservation Institute de California. Otra vez se presenta una paradoja, ya que siendo la que más se acerca al objeto como tal, prácticamente impide reconocer la vista registrada en él. La reproducción forma parte de un reporte científicotécnico destinado a asegurar su correcta conservación y modo de exhibición. El sitio web de la Universidad de Texas en Austin, donde la placa se conserva desde que Gernsheim donó su archivo personal a la institución, pone énfasis en la forma como este estudio fue realizado: 
La placa fue sujeta a una cuidadosa atención por parte de los fotógrafos técnicos del Instituto, quienes pasaron un día y medio con la heliografía original en sus estudios fotográficos a fin de registrar fotográfica y digitalmente todos los aspectos de la placa. El objeto fue documentado bajo todo tipo de luces científicas, incluyendo los espectros infrarrojo y ultravioleta. Adicionalmente, los fotógrafos siguieron los pasos de los Laboratorios Kodak medio siglo antes y produjeron nuevas copias de la placa en película de color y digitales/ electrónicas, en un intento de revelar más de la imagen sin retoque, y al mismo tiempo proporcionar la sensación del complejo estado físico de la fotografía. (En: http:// www.hrc.utexas.edu/ exhi bitions/ permanent/ wfp. La traducción es nuestra.)

La deliciosa ingenuidad del tono cientificista del anterior fragmento revela el interés por hacer creer que, al contemplar esta reproducción, el espectador se encuentra ante the real thing, el objeto mismo, y hay que morderse la lengua para no mencionar la palabra aura ni apelar al fantasma de Walter Benjamin, ya que esto desviaría el curso de este trabajo. (Solo queda apuntada la paradoja: la fotografía destruye el aura, pero ante esta vista, se intenta recuperar su aura.) El texto no está exento de ambivalencias, por ejemplo: se afirma que la placa fue registrada fotográfica y digitalmente; pero, ¿̇acaso la reproducción digital que se hizo no fue también fotográfica? Se enfatiza el carácter científico del proceso, incluso se afirma que fueron utilizadas luces científicas. ¿Existe tal cosa? ¿No es posible que al revelar más de la imagen se la convierta en otra imagen? Lo que finalmente se comprueba es que el solo lenguaje de las descripciones delata - verdad de Perogrullo, pero en la que habremos de ahondar para desmenuzar sus mecanismos- preconcepciones e ideologías que no solo sesgan, sino que definen la lectura.

El trabajo sobre la placa producida por Niépce también manifiesta indirectamente el interés de la historia de la fotografía por establecer un origen, ya que, como es bien sabido, el invento se da a lo largo de un extenso período en el cual se van sumando pequeñas aportaciones y algo de serendipia, si vale el barbarismo, hasta que varios personajes interesados en el asunto logran resolver el problema de la fijación de la imagen. Ante la pregunta, ¿cómo se inventó la fotografía?, la respuesta bien podría ser: inevitablemente. Por lo tanto, y para desconsuelo de algunos, en el caso de 
la fotografía «parece que ninguno de los relatos de origen pueda realmente considerarse como mito fundador». (Durand 1998: 12)

Pero, demos un vuelco de la imagen al gesto que la produjo. Dejemos de lado lo que vemos y también lo que sabemos, esto es, que se trata de una vista del patio de la casa de Niépce en Saint-Loup-de-Varennes y que los triángulos, rectángulos y romboides que apenas se distinguen representan las construcciones contiguas, un granero, un árbol, el horizonte... Especulemos, en cambio, acerca de lo que había detrás de la cámara, no enfrente.

¿La cámara? Sí. Niépce colocó próxima a la ventana una cámera obscura algo voluminosa, de madera, adaptada para sostener un elemento sensible a la luz -la placa de peltre impregnada con betún de Judea-en el plano de formación de la imagen. Así que la vista en cuestión fue producida por un dispositivo, en su caso, apenas un prototipo de lo que desde entonces llamamos cámara fotográfica. Pero no perdamos de vista que la palabra prototipo se refiere a una esencia. Y es precisamente en esencia que el aparato utilizado por Niépce para producir esa imagen es igual a la infinita variedad de cámaras fotográficas que se han producido en el brevísimo lapso de 18 décadas.

La fotografía más antigua que conocemos no solo inaugura un gesto -el de fotografiar-, sino que entraña otro: el de asomarse por la ventana. A propósito de estos gestos, dice Flusser:

Yo creo que mucha gente estará de acuerdo en entender los gestos como movimientos del cuerpo y, en un sentido amplio, como movimientos de los instrumentos y herramientas unidos al cuerpo.

[...]

El tipo de movimientos a los que nos referimos cabe describirlos como «formas de expresión» de una intención. Lo cual nos proporciona una hermosa definición: «Los gestos son movimientos del cuerpo que expresan una intención». (Flusser 1991: 7-8)

En efecto, para llevar a cabo su experimento, Niépce se asomó hacia afuera, buscó la luz. Y tras quitar la tapa al objetivo que iba a permanecer abierto durante ocho horas, se dio la vuelta y buscó recogimiento en los 
familiares objetos de su estudio. ¿Cómo era el estudio de Niépce? ¿Cómo era un estudio en 1826? En el estudio de Niépce no había luz eléctrica; no había un fonógrafo o un medio cualquiera de generar música para hacer esas ocho horas más llevaderas; no existía una nevera a la que acudir para tomar una bebida de refresco; no había la posibilidad de llamar por teléfono al confidente, al amigo, para compartir la incertidumbre del momento; ni siquiera la de consumir parte de esas ocho horas en apresurarse a la oficina del telégrafo para desahogar el ansia con una frase breve, pero esperanzada; no había la posibilidad de obviar el ritual de los alimentos sin bajar al comedor y simplemente abrir unas latas de conservas, ya que las latas de conservas no existirían sino hasta muchos años después. ¿Qué hizo Niépce durante esas ocho horas de su vida? ¿Qué hizo, además de exponer en la placa de peltre una imagen histórica? ¿Cuántas veces rondó el aparato? ¿Fumó? ¿Intentó leer una novela sin lograr concentrarse en su trama? ¿Atendió algún asunto doméstico? ¿Salió a dar un paseo para calmar su ansiedad? ¿Se quedó todo ese tiempo en el estudio, agazapado, nervioso y excitado? ¿A qué olía ese estudio, repleto de sustancias químicas? Probablemente una de las chicas encargadas de hacer la limpieza de la casa se asomó y no se atrevió a interrumpir al ensimismado Niépce, pero para sus adentros pensó: «Menos mal que abrió la ventana, este aire es irrespirable».

¿Somos capaces de ver ese contexto en la imagen Punto de vista desde la ventana de Le Gras; esas carencias, que entonces no lo eran, pero que para nosotros lo son?

No sabemos qué es lo que hizo, pero sí estamos seguros de lo que Niépce no pudo haber hecho... No encendió la televisión para matar el rato; ni aprovechó ese lapso para ir al banco a pagar el gas y la luz; ni llamó por el móvil al confidente, al amigo, para compartir su emoción; ni puso un disco compacto con música que lo ayudara a reflexionar; ni telefoneó a algún proveedor de fast food con servicio a domicilio; ni tomó el automóvil para dar un paseo y despejar la mente; ni navegó en Internet para buscar información que le fuera útil; ni hojeó el periódico que habría sido 
entregado puntualmente en la puerta de su casa como todos los días por un repartidor en motocicleta.

Nuestros mundos son otros y lo son precisamente, en gran medida, debido a que por aquella época se inventó la fotografía.

Podríamos especular acerca de cómo vemos hoy la imagen conocida como Punto de vista desde la ventana de Le Gras. Pero en cambio, especulemos acerca de cómo era vista esa imagen en los tiempos de Niépce. Ha quedado establecido que apenas se puede imaginar desde el presente el entorno en el que apareció ese peculiarísimo objeto. ¿Cuál era la reacción de la gente ante esa misteriosa placa de peltre? ¿Cuántas pulsaciones por minuto tenía el corazón de Niépce al comprobar que la imagen se había fijado, que no se desvanecía como las anteriores? ¿Hubo algún grito de ¡eureka!? ¿A qué emoción era comparable lo que sentía una persona común al enfrentar esa rareza?

Sin duda alguna, la placa, así como el aparato que la producía, eran en su momento, algo verdaderamente extraño. ¿Mágico? No hablemos ya de 1826, sino incluso de 1839, fecha a partir de la cual una de las versiones de dicho aparato, con modificaciones menores, fue ampliamente divulgada. La arrogancia de su inventor lo llevó a nombrarla con su propio apellido, daguerrotipo, y el más antiguo que se conserva es también, de manera emblemática, una vista tomada desde una ventana.

Una vez más: quedémonos con el gesto, ese gesto de asomarse a través de la ventana -muchos años después de esa época que estamos reseñando, John Szarkowski (1978) diría que las fotografías pueden ser espejos... o ventanas-. Si nos encontramos frente a una ventana, al igual que ante una fotografía, eso significa que vemos desde un lugar. La ventana siempre está inscrita en un muro, y este, en un edificio, en una construcción. El objetivo de esta investigación no enfatiza el responder la interrogante de qué es lo que vemos a través de la ventana, sino que está centrado en el cómo vemos, dónde estamos parados, como Niépce en su estudio, cimentado en la Modernidad. Explícitamente, buscamos dilucidar en qué edificio conceptual está inserta esa ventana y qué hemos hecho, qué 
trayectoria hemos tenido que seguir, como observadores, para entrar en él. Así, la anterior reflexión no pretende ser —o no serlo solamente- un juego retórico. Al mirar a través de la ventana de una fotografía, es tan importante el panorama observado como el edificio que sirve de mirador y lo que hay dentro de la piel de quien observa.

\subsection{UN MEDIO FALSAMENTE ESCINDIDO}

En la anterior deriva, en la que a partir de la imagen producida por Niépce hemos realizado una especie de elipsis -si cabe el término- que nos ha llevado de 1826 a la actualidad, planteamos una serie de afirmaciones que conllevan presupuestos: implícitamente hemos aceptado nuestra sujeción a algunos de ellos y también hemos denunciado otros.

Aunque en el momento de su surgimiento esos objetos misteriosos, las fotos, hayan sido insólitos, desde la perspectiva de la historia, hoy tendemos a considerar el camino que llevó a la fotografía como algo natural, en función del desarrollo de la cámera obscura y de las investigaciones químicas sobre la reacción de ciertas sustancias a la luz. La manera como anteriormente describimos el aparato que Niépce utilizó, aunque simplista, no está alejada de la realidad. El desarrollo que cada uno de sus componentes —ópticos y químicos- había alcanzado por cuenta propia, hace que el invento se pueda ver como la suma lógica y razonable de ambos. ¿Pero es solamente la suma?

No deseamos romantizar el origen, por demás difuso, de la fotografía, ni mencionaremos una vez más los eternamente repetidos nombres de quienes participaron en el desarrollo de ese invento que ya estaba en el aire. Aunque nuestro interés es reflexionar desde el presente, y por lo tanto la nuestra es necesariamente una mirada retrospectiva, no es la intención de este trabajo hacer un recuento de los documentos y puntos de vista que circularon en las primeras décadas del invento -lo cual, dicho sea de paso, 
ya se ha hecho profusamente-, sino interpretar algunos acontecimientos desde la distancia.

Hemos asumido que lo que Niépce usó fue una cámara fotográfica, aunque en ese momento todavía no pudiera ser nombrada de esta manera. En ese aparato confluyen, no solamente los ya citados logros de la óptica y la química, sino que el invento puede considerarse representativo de una época y de ideologías que cristalizan en ese momento histórico, principalmente la concepción de una ciencia que se encontraba ya dando pasos firmes en su proceso devorador de la realidad, así como de la técnica entendida como progreso y dominio de la naturaleza, tema, por otro lado, muy vinculado a la cosmovisión modernizadora del siglo XIX. La fotografía no se inventó desde las filas de la estética, surgió desde el campo de la ciencia, de la mano de experimentadores y hombres de negocios preocupados por la solución de un asunto técnico. Su presentación al mundo en 1839 fue en la Academia de Ciencias, y la de Artes fue solo una invitada. El aparato fotográfico, así, inaugura la era de la imagen técnica (cfr. Flusser 1983; Moles 1981), convirtiéndose en un desarrollo emblemático de la Modernidad.

La imagen técnica es una imagen generada por aparatos. Como los aparatos, por su parte, son productos de textos científicos aplicados, las imágenes técnicas vienen a ser productos indirectos de textos científicos. Esta característica les otorga, tanto histórica como ontológicamente, una posición diferente de la de las imágenes tradicionales. (Flusser 1983: 17)

Las consecuencias del invento se dejarán ver muy pronto. ¿Cómo encajar socialmente ese conjunto de lo que para la época eran unas insólitas posibilidades de producción de imágenes? La fotografía será inmediatamente tildada con una infinidad de calificativos, se intentará asignarle una posición, y esto se hará fundamentalmente a través del debate y de la confrontación de ideas dicotómicas que conformarán una dialéctica del ataque y la defensa, de la desautorización y la validación, de la condena y la exaltación. La primera de ellas, referente a cómo insertar el invento en la tradición histórica: ¿a través de una concepción de 
continuidad o de ruptura? (Cfr. Batchen 1997; Frizot 2009) Pero como trasfondo, permanecerá siempre la ciencia y, por lo tanto, las ideas de registro y de objetividad propias del discurso fotográfico del siglo XIX, algo que no será cuestionado sino hasta una época reciente. De lo que estamos hablando es del surgimiento del mito de la fotografía como espejo de la realidad —que culmina el camino que en Occidente va del concepto clásico de mimesis a la invención de la perspectiva cónica y a la generalización del uso de la cámera obscura desde el Renacimiento-. (Cfr. Melot 2007) Dicho mito, sin embargo, siempre ha estado minado por el conocimiento de que hay argumentos subyacentes que permanentemente ponen en cuestión su transparencia.

\begin{abstract}
Este carácter supuestamente no simbólico, pero sí objetivo de las imágenes técnicas lleva al contemplador a considerarlas no como imágenes, sino como ventanas. Las cree como a sus propios ojos. Consecuentemente, no las critica como imágenes, sino como cosmovisiones (si es que las critica). Su crítica no es un análisis de su generación, sino un análisis del mundo. [...] la «objetividad» de las imágenes técnicas es un engaño; pues no solo son simbólicas, como todo tipo de imágenes, sino que representan complejos simbólicos mucho más abstractos que las imágenes tradicionales. Ellas son metacódigos de textos que [...] no designan el mundo de afuera, sino textos. (Flusser 1983: 18. Las cursivas son nuestras.)
\end{abstract}

Una vez más: ventanas. Pero ventanas, insistimos, inscritas en edificios conceptuales, edificios que cuentan con profundos cimientos. Ideología - término cargado de innumerables connotaciones- que, por supuesto, contamina todo discurso y se filtra a través de las diversas capas que abarcan los, también innumerables, campos semánticos en que se aplica. Hablar de fotografía es hablar de ideologías, muchas veces contradictorias: ideología de la Modernidad, de la que es prácticamente compañera de viaje; ideología de las aspiraciones de emancipación, del «primer procedimiento de reproducción verdaderamente revolucionario coincidiendo con la irrupción del socialismo» (Benjamin 1936: 102); ideología, también, de la democratización, del acceso de las masas a la imagen, la imaginería, la imaginación..; ideología de la producción industrial, primero, y emblema de la era postindustrial, después; ideología 
del movimiento moderno, con sus aires de renovación; ideología de cada uno de los espacios discursivos desde los que se desenvuelve como práctica -la ciencia, el arte, el periodismo, la publicidad y tantos otros—; ideología, finalmente, de cada uno de los autores que la visten con sus propios colores.

El fenómeno es por demás notable: tras la divulgación del invento, inmediatamente van a surgir discursos provenientes de los más diversos campos, de manera que al discurso científico sobre la fotografía se sumarán el estético, el industrial, el histórico, el técnico, el de sus usos... De ahí que algunos autores, como Durand (1998), señalen la imposibilidad de hablar de una historia de la fotografía y, al contrario, subrayen la necesidad de hacerlo en plural: historias de las fotografías. Esta afirmación es mucho más que una formulación retórica, ya que precisamente el problema que infinidad de comentaristas manifiestan al hablar de la fotografía es el de saltar de manera inadvertida del comentario de un espacio discursivo a otro, por ejemplo, de la fotografía artística a la periodística, y de ahí a la fotografía familiar, de recuerdo, cuando evidentemente no hay manera de aludir a esas prácticas a partir de los mismos criterios. (Cfr. Capítulo 7) Haciendo un breve paralelismo, pensemos en la infinidad de variantes en las que los textos pueden ser aplicados. En efecto, las posibilidades son interminables, sin embargo nadie -salvo algún artista con vocación transgresora- confundiría una nota periodística con un manual de instrucciones técnicas, o este con un poema, o establecería una cadena de semiosis ilimitada a partir de las palabras contenidas en una receta médica, o haría un análisis hermenéutico del menú de un restaurante o una deconstrucción de un plato de sopa de letras. No obstante, esto es precisamente lo que, según parece, muchos teóricos fotográficos han hecho y hacen.

Dejaremos, pues, de lado, el qué se dijo de la fotografía —o las fotografías - en esas primeras décadas que siguieron al invento, y nos quedaremos momentáneamente con el cómo se dijo. Y si ese cómo es relevante, lo es porque aquello que en el fondo la historiografía, 
principalmente la generada desde el campo de la estética, deja traslucir, es el intento permanente por dotar a la fotografía de una especificidad. Krauss incide en la llaga:

Estas preguntas cobran un especial alcance metodológico en la situación actual, en un momento en que una renovada, organizada y activa historia de la fotografía está construyendo un relato de los primeros años del medio. En dicho relato, las fotografías originalmente realizadas con fines de exploración, expedición e investigación, en su mayor parte de carácter topográfico, desempeñan un papel central. Estas imágenes entretejidas, enmarcadas y etiquetadas, ingresan ahora en el espacio de reconstrucción histórica a través del museo. Decorosamente aislados sobre el muro de exposición, los objetos pueden interpretarse de acuerdo con una lógica que insiste en su carácter representacional en el seno del espacio discursivo del arte, en un intento de «legitimarlos». (Krauss 1990: 148)

Las palabras de Durand al respecto son parcas, pero acaso aún más insidiosas:

[...] la historia de la fotografía se confunde prácticamente con la del Modernismo -cronológicamente, pero sobre todo intelectualmente, ya que esta historia se elaboró muy tarde, y fue marcada por los supuestos que dominaban entonces en la disciplina más cercana, es decir en la historia del arte, especialmente a través de la idea de una especificidad y de una autonomía cada vez mayores del medio. (Durand 1998: 51)

La construcción de una identidad propia será, entonces, el leitmotiv de los escritos - históricos, técnicos, estéticos - en torno a la fotografía, identidad construida a contrapelo, a base de responder a los ataques y críticas que la desautorizaban como una forma de expresión y la condenaban a ser un simple medio de registro, y de convertir esas respuestas en declaraciones de principios.

¿Cómo se dio ese proceso? Fundamentalmente, mediante una construcción dialéctica a partir de una escisión originaria. Es imposible hablar de fotografía sin aludir, aunque sea indirectamente, a esas ambivalencias cargadas de connotaciones, las cuales han seccionado al medio desde su origen. Así, si se habla del carácter simbólico de la imagen, se hace en detrimento de su carácter objetivo; si se enfatiza su origen 
científico, resulta minimizada su carga estética; y así sucesivamente: arte frente a industria, creación frente a testimonio, construcción frente a objetividad, producción frente a reproducción, pictorialismo frente a purismo (cfr. Fontcuberta 1984), lo inacabable frente a lo irrepetible (cfr. Soulages 1998), signo icónico frente a signo indicial (cfr. Capítulo 3), o, en otra de sus expresiones recientes, el arte de los fotógrafos frente a la fotografía de los artistas (cfr. Rouillé 2005).

En su forma primaria, esencial, la dicotomía que origina el debate se reduce a los siguientes términos: óptica frente a química. Y a partir de ellos hemos de plantearnos si se trata de una cuestión legítima o de un obstáculo epistemológico.

He ahí la escisión originaria, de la cual parten una serie de malentendidos y falsas concepciones del aparato fotográfico. Aparato que es uno. Claramente lo afirmamos con anterioridad al hablar de ese extraño dispositivo que Niépce usó, el prototipo de la cámara fotográfica. Pero si se trata de un aparato, entonces la escisión que hemos señalado es una falsa escisión.

Los historiadores, los teóricos, los mismos fotógrafos, los académicos, los críticos, todos ellos se han acostumbrado a hablar desde la óptica o hablar desde la química. Muchas veces lo hacen de manera inconsciente, sin embargo, el mismo lenguaje que utilizan delata su posición. ¿Pero cuáles son estas posiciones, cómo se ve desde cada una de estas ventanas?

Hablar desde la óptica es insertarse en el discurso de la mimesis, es evocar grandes nombres de la tradición filosófica. Es vincularse al hito pictórico que parte del Renacimiento, es considerar a la fotografía como legítima heredera de la perspectiva en su carácter de esquema de representación (cfr. Gombrich 1959), de código, de manera de formar (cfr. Eco 1962b) y por lo tanto, se diría que en pleno derecho, de forma simbólica (cfr. Panofsky 1927). Más aún, quien habla desde la óptica es el sacerdote que embalsama a la perspectiva como modelo de visión; quien le otorga eternidad al integrarla como parte esencialmente constitutiva del 
hardware fotográfico; quien perpetúa esa mirada de cíclope como la manera de ver en un mundo mediatizado.

Hablar desde la óptica es leer en el vidrio despulido de la cámera obscura el discurso de la continuidad, del tiempo lineal, del desarrollo ininterrumpido de la ciencia y de la técnica. Es cabalgar en la Historia. Es considerar a la fotografía implícitamente como la cristalización de un proceso evolutivo en Occidente, como un logro en la historia de la representación naturalista. Es, por lo tanto, hablar desde las filas de la Historia del Arte.

Quien habla desde la óptica se siente autorizado a mencionar nombres fuertes sin el menor titubeo, sin temor a que su razonamiento sea tildado de fantasioso. El suyo es un discurso mítico, mas no el de un mitómano. Quien habla desde la óptica puede pronunciar, sin el menor asomo de pudor, los nombres de Platón, Aristóteles, Leonardo, Durero, Vermeer, Panofsky... Es quien considera a la fotografía como un signo icónico y se reserva el privilegio de degustar los placeres del parecido (cfr. Pérez Carreño 1988), quien exalta la pausa necesaria para pensar la imagen o detenerse a contemplar los paisajes de la forma (cfr. Zunzunegui 1989 y 1994). Es quien puede apelar al realismo, al naturalismo; quien puede espetar, sin ruborizarse, la frase: objetividad de la representación. Es quien cuenta con el salvoconducto de la psicología de la percepción para hacer una apología de la representación. Es quien sitúa al sujeto y su visión, su subjetividad, como centro del mundo; una subjetividad que, sin embargo, tiene un fundamento científico.

Quien habla desde la óptica fija un punto de vista, se reserva el papel de demiurgo, insiste en el hecho de que, más allá del carácter mecánico del aparato fotográfico, se encuentra el poder creador y la sensibilidad de su operador. Se postula a sí mismo como poseedor de un lenguaje y reconoce en el espectador la capacidad de aplicar ese lenguaje en la lectura.

La defensa de la fotografía óptica —que será explicada con detalle en el Capítulo 3- se hará desde la teoría del signo icónico, del trabajo de codificación, de la construcción de un mensaje. 
Quienes, en el otro extremo, hablan desde la química, por contraste -por alto contraste- han desarrollado un absoluto cambio de registro.

Hablar desde la química es revelar que la fotografía, además de una ciencia, es una magia. Es vincularla con la imagen ritual, que alude a lo que está detrás de las apariencias. Hablar desde la química es hacerlo desde un sitio ubicado más allá de la ciencia; más que química, alquimia. Es abandonar el discurso científico para montarse en el poético, es nombrar lo indescriptible, es construir desde el deseo, desde la ruptura.

Hablar desde la química es dotar a la fotografía de una especificidad. Es especular en torno a su ontología, es buscar su arché. Quien habla desde la química no pretende interpretar el sentido de la imagen fotográfica; está fascinado por la manera como esa imagen es generada. La palabra revelada de la química tiene a su profeta en Bazin (1945), quien anuncia el culto al índice; a su predicador en Barthes (1980), creador del sermón de la imagen fotográfica como emanación, como epifanía; a sus discípulos en Dubois (1983) y Schaeffer (1987), intérpretes de la nueva palabra vinculada con el libro ancestral de Peirce; tiene, también, a su J udas: Flusser (1983). ${ }^{2}$

Hablar desde la química es vincularse al pasado, al instante, a la imagen como corte, al vértigo, al abismo. Es reflexionar acerca de lo que fue, de lo irrecuperable, de la muerte. Quien habla desde la química es quien puede apelar al testimonio, a la prueba de verdad; quien puede espetar, sin ruborizarse, que la fotografía tiene un poder de atestiguamiento, de autentificación.

La apología de la fotografía química se hará desde la teoría del signo indicial, de la impresión física, la huella lumínica de una presencia.

\footnotetext{
${ }^{2}$ Las tesis de estos autores serán comentadas en el Capítulo 3.
} 


\subsection{HABLAR DESDE LA FOTOGRAFÍA}

Pero, si el aparato fotográfico es uno, ¿por qué insistir en esa escisión? Dicho aparato no es solamente la suma de las aportaciones ópticas y químicas que se dan en un momento histórico determinado. Es, en cambio, el complejo conjunto de posibilidades que se desprenden de su interacción, la cual se ha complicado aún más hoy, ante la expansión del campo fotográfico debido a la tecnología digital.

¿Por qué no, entonces, hablar desdela fotografía?

Consideramos que abordar el medio a partir de dualismos es una aproximación equivocada. Sin embargo, esta mirada dicotómica es parte de aquello que hemos incorporado - para utilizar un término debido a Bourdieu que será clave en este trabajo- en el transcurso de la historia de la fotografía y que ha marcado la manera como la teoría se ha desarrollado.

Se ha insistido en esta partición, incluso se ha llegado a señalar que el carácter indicial de la imagen fotográfica prima sobre el icónico o viceversa. En su extremo, se han planteado ambos enfoques como adversarios. (Schaeffer 1987: 24) Mucha tinta ha corrido desde que la palabra, la dichosa palabra ontología, hizo su aparición en los escritos teóricos de fotografía, pero ¿cómo puede llegarse a la esencia constitutiva de un medio si se parte de su fragmentación? Durand ironiza al respecto, apelando también a Bourdieu (a quien volveremos en el Capítulo 2):

Con el paso de los años se ha hecho evidente que las peleas de definiciones (cuando no se llaman pomposamente ontología), en realidad, disfrazan apuestas de competencia y de ocupación del campo. Ya que en este campo fotográfico en vía de autonomización reina una situación de anomia (analizada por P. Bourdieu) que el mundo del arte conoce bien. Allí donde verdaderamente ya no existe instancia de legitimación del arte y del artista, [y del teórico y del académico] capaz de expresar el nomos (la división legítima entre arte y no-arte, por ejemplo), se instala la anomia. (Durand 1998: 99-100)

Así, no escindamos, incorporemos y hablemos desde la fotografía. 

PRIMERA PARTE: MARCO TEÓRICO

CAPÍTULO 2

\section{EL FOTÓGRAFO ANTE EL ESPEJ O: LA CODIFICACIÓN EN SENTIDO EXTRASEMIÓTICO}





\subsection{UNA ESPECULACIÓN PRELIMINAR}

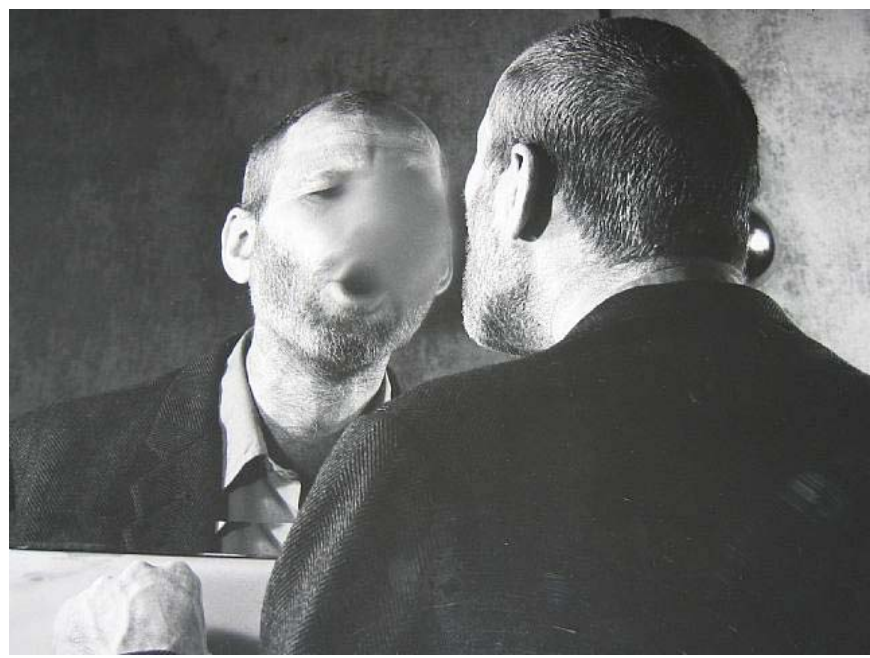

Imagen 4. Dieter Appelt

Autorretrato, 1978

Un hombre se acerca a un espejo hasta el punto de casi hacer contacto con su propia imagen. Unos centímetros antes de tocar la superficie reflejante, exhala, con lo que su propio hálito forma un cerco húmedo que enturbia parcialmente su imagen vista de frente. La escena es captada por una cámara dispuesta por él mismo: se trata de un autorretrato. (Imagen 4) Un autorretrato fotográfico que es, por lo tanto, indicial. Una foto que registra la acción de emitir una vaharada y, con ello, generar un signo también indicial, efímero, del calor y la humedad internos. El hombre, Dieter Appelt, parecería decir con ello: «Estoy vivo, necesito probarme a mí mismo que estoy vivo». Con esa tautología indicial también afirma que la fotografía es un medio capaz de captar el aliento de vida.

Pero no poeticemos, tampoco caigamos en la sobreinterpretación. Espejos y ventanas, dijimos anteriormente con Szarkowski. Toca ahora el 
turno para especular, para reflexionar -si valen las expresiones- acerca de los primeros, objetos fascinantes respecto de los que Calabrese nos recuerda, siguiendo a Eco, que

[...] en cuanto superficies reflectoras y no en cuanto objetos de puesta en escena, no son artefactos comunicativos (y por lo tanto las imágenes que ellos reflejan), en la medida en que no tienen la característica de poder mentir. Son más bien unas prótesis, unas prolongaciones artificiales del sentido de la vista mediante las cuales se pueden producir funciones semióticas. (Calabrese 1985: 186)

Así, y como ya afirmamos en el caso de las ventanas, también respecto de la utilización de los espejos por parte de los fotógrafos, quedémonos con el gesto, ese gesto al que la imagen de Appelt nos introduce. Las fotos-espejo, ya lo sean literalmente o en sentido figurado, hacen que el espectador se vuelva sobre sí mismo, como lo hace también el fotógrafo en el autorretrato. Es este el caso que ocupará momentáneamente nuestra atención.

Al ver a cuadro el propio cuerpo del fotógrafo, no podemos evitar que vengan a nuestra mente las palabras de Merleau-Ponty:

El pintor «aporta su cuerpo», dice Valéry. Y en efecto, no se ve cómo un Espíritu podría pintar. Es prestando su cuerpo al mundo que el pintor cambia el mundo en pintura. Para comprender estas transustanciaciones hay que reencontrar el cuerpo operante y actual, que no es un pedazo de espacio, un fascículo de funciones, sino un entrelazado de visión y movimiento. (Merleau-Ponty 1964: 15)

Fácilmente podemos sustituir en esa cita las palabras pintor y pintar por fotógrafo y fotografiar. Robert Adams (cfr. 1996) enfatiza el hecho de que toda foto es parte de la autobiografía de su autor, ya que además de mostrar objetos representados y, en último caso, un contenido que puede llegar a ser metafórico, es también, inevitablemente, el testimonio de un fragmento de vida de quien la produjo, de quien aportó su cuerpo. Se ha insistido en la peculiaridad de la fotografía como acto (cfr. Dubois 1983), y si el cuerpo del fotógrafo está presente metonímicamente, por alusión 
indirecta, en toda foto, en el caso del autorretrato se pasa de la alusión indirecta a la explícita.

La práctica fotográfica de este género es tan antigua como el medio mismo. Basta recordar el irónico Autorretrato como hombre ahogado de Hippolythe Bayard, realizado en 1840, como iniciador no solo del género que nos ocupa, sino también de la fotografía escenificada. Aunque no es nuestra intención aquí hacer una revisión histórica de esta práctica, no podemos dejar de mencionar los nombres de algunos autores que obsesivamente han vuelto la cámara sobre sí mismos, dejando el género firmemente establecido. Entre ellos destacan nombres de todas las épocas y estilos, desde Nadar hasta Bill Brandt, pasando por Man Ray, Florence Henri, J acques-Henri Lartigue, Imogen Cunningham o Edward Steichen. Y si decimos hasta Bill Brandt, estableciendo más que arbitrariamente un límite, es porque las décadas de 1960 y 1970, época en que este clásico realiza sus últimos autorretratos, por así decirlo, de forma canónica, es también la de la generalización de una práctica que desde entonces hasta hoy se ha repetido hasta la saciedad, convirtiéndose acaso en uno de los tópicos más desgastados en el ámbito de la fotografía artística. Si históricamente habíamos sido sorprendidos con escenificaciones, poses cuidadosamente fabricadas o encuentros fortuitos de la fotografía directa con reflejos captados en superficies como automóviles o escaparates, la fascinación de los artistas consigo mismos traerá, a partir de las décadas señaladas, un alud de trabajos donde aquellos se van a regodear con primerísimos planos de su propia fisonomía, generando incontables versiones de su capacidad de gesticulación.

Difícilmente se encontrará en otros la excepcional intensidad del trabajo de Appelt, cuyo autorretrato ante el espejo no solo puede ser abordado, como ya afirmamos, a partir de la semiótica del índice, sino también desde la estética de la performance o del arte conceptual. Dicha imagen parecería ser el registro de una acción, donde lo importante es la acción en sí misma y la foto únicamente cumpliría con la finalidad de documentarla. La cámara está implícita, pero no es protagonista. También 
puede ser abordada, por supuesto, desde otro tipo de especulación semiótica, y aunque aceptamos que hay enfoques particulares que pueden ser más o menos útiles para enfrentar trabajos concretos, intentemos, como ya quedó establecido, no hablar desde la química o desde la óptica, sino desde la fotografía.

El mayor protagonismo de la cámara se da en un tipo particular de autorretrato: aquel en el que el autor se fotografía a sí mismo ante un espejo, dejando que la cámara forme parte de la composición. «El espejo es un fenómeno-umbral, que marca los límites entre imaginario y simbólico», dice Eco. (1985: 12) La cámara en el espejo, el espejo en la foto... estamos de lleno en el universo simbólico, de manera que el propio acto de generación de la imagen queda plasmado en ella: hemos pasado de la semiótica del índice a la pragmática del acto fotográfico. Este tipo de imágenes constituyen un ejercicio de metadiscurso y, por supuesto, también proliferan a partir del período señalado, época en que la reflexión del arte acerca de sus propias posibilidades, si bien presente a lo largo de todo el siglo XX, se exacerba. No es de extrañar, por lo tanto, que este tipo de trabajos haya llamado la atención de algunos teóricos fundamentales. Nos referimos en particular a Philippe Dubois (1983), cuando comenta la obra de Michael Snow, y a Régis Durand (1998 y 1999), cuando aborda el trabajo de J ohn Hilliard.

No interpretemos, dijimos con anterioridad. La puesta en abismo realizada por Snow en Autorización (Imagen 5) es autorreferencial, narra su propio proceso de producción. Tratemos solamente de describir, aunque...

Describir esta obra no es cosa fácil, y justamente porque no es simplemente una imagen, una foto, sino más bien un dispositivo (una instalación, para retomar un término del arte contemporáneo), que pone en situación, según una estrategia compleja [...], tanto al fotógrafo como al que mira la fotografía. La obra de Michael Snow está concebida, en efecto, de tal forma que finalmente no nos muestra otra cosa que sus propias condiciones de aparición y de recepción. Las tres preguntas fundamentales que se plantean a toda obra de arte (¿qué es lo que hay representado?, ¿cómo ha sido producido?, ¿cómo es percibido?) se convierten aquí en una sola. Por tanto, describir esta obra desde el punto de vista del espectador y siguiendo al 
mismo tiempo el desarrollo de su percepción es, en el mismo movimiento, seguir el proceso por el cual esta obra ha sido constituida. Por eso Authorization -autorretrato fotográfico- es mucho más que una foto: es una puesta en acción de la fotografía misma. (Dubois 1983: 12)

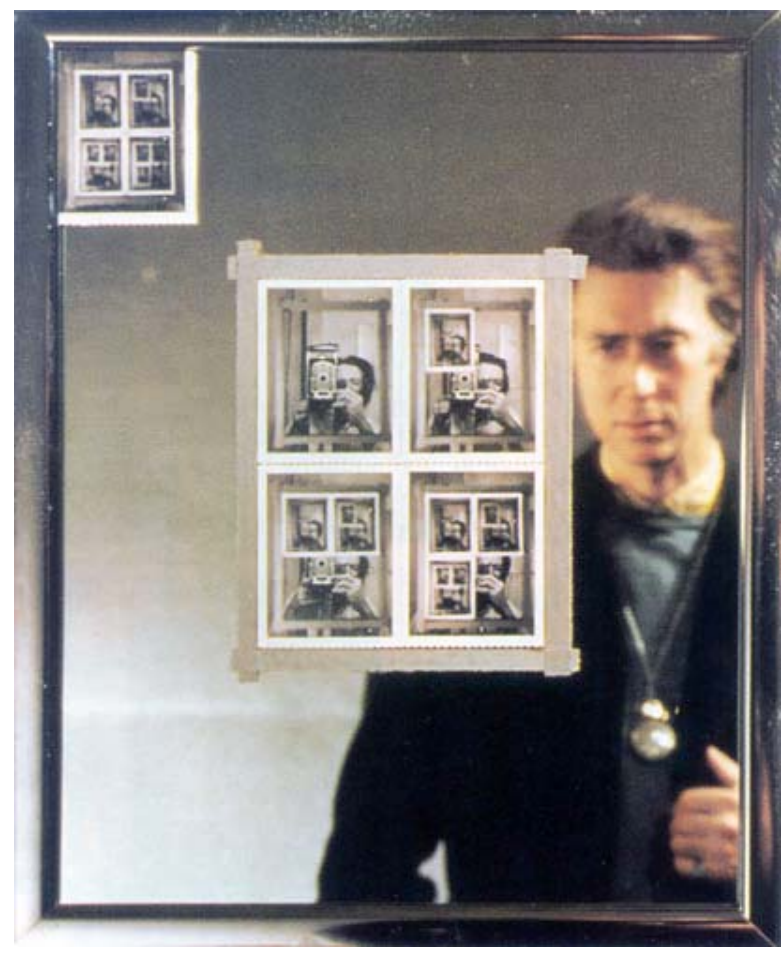

Imagen 5. Michael Snow

Authorization (Autorización), 1969

Para producir Autorización, el autor se coloca frente a un espejo y se capta a sí mismo en el acto de retratarse. Al pegar sobre el centro del espejo una por una la secuencia de cuatro imágenes instantáneas producidas sucesivamente, estas obstruyen de forma paulatina su propio reflejo hasta bloquearlo por completo; la quinta, y última, es colocada en la esquina superior izquierda. La obra terminada es el propio espejo con la secuencia de fotos pegadas con cinta adhesiva. Esto significa que, al situarse ante Autorización, el espectador no solo ve las fotos, sino también su propia 
imagen reflejada en el espejo. Este hecho, por supuesto, se pierde al ver la obra reproducida en catálogos o libros, de la misma manera en que el efecto espejo se pierde en las propias polaroids que componen la obra. Pérdidas sucesivas, estas, que nos resitúan cada vez en el universo del símbolo, recordándonos con insistencia que las fotos o improntas no son espejos. No está de más el subrayar este hecho:

En cualquier caso, por intensas que sean las ilusiones, las ambigüedades, las confusiones «sobre el umbral», la tentación de homologar imágenes especulares e improntas, basta con recurrir al experimentum crucis: reprodúzcase un espejo en una fotografía, en un encuadre cinematográfico o televisivo, en un cuadro. Estas imágenes de imágenes especulares no funcionan como imágenes especulares. [...] El espejo, en el mundo de los signos, se convierte en el fantasma de sí mismo, caricatura, irrisión, recuerdo. (Eco 1985: 40)

Al ver la obra reproducida, estamos tentados a primarla sobre el original. La reproducción es una foto, que contiene en sí misma todo un proceso. Pero recordemos que la obra de Snow no es una foto, ni cinco, ni la foto de un espejo con cinco fotos adheridas: la obra es el espejo, con las cinco fotos pegadas, esto es, con una secuencia de fotos que, precisamente en su secuencialidad, se vuelve narrativa. Desde el punto de vista del espectador, la diferencia entre original y copia, en este caso, es abismal.

Esta presentación como espejo de los clichés, introduciendo al espectador (el tiempo instantáneo y existencial de la visión) en la obra misma, no solo hace que la obra varíe, cambie, se transforme ante cada una de las miradas que se fijan en ella, sino que establecerá sobre todo un juego complejo de relaciones entre el fotógrafo (fotografiado) y el que mira (reflejado); esta presentación mezclará el autorretrato pasado de Snow con el autorretrato presente del que mira. (Dubois 1983: 15)

También a ello se debe el que las diversas reproducciones de la obra en libros y catálogos tengan reflejos diferentes en la parte correspondiente al espejo. En el libro de Dubois se utiliza una reproducción en la que ostensiblemente se ve un trípode en la parte inferior del cuadro. (Imagen 57) Lo sorprendente es que ese trípode no es, como podría pensarse, el que usó Snow en la secuencia original, sino el utilizado por el fotógrafo 
contratado para hacer la reproducción -hecho que, por cierto, parecía causar gracia al propio Snow, quien la autorizó-. La imagen que aquí presentamos es una toma a color con un fondo neutro. El espectador que observa la obra y al que en su reflejo vemos verse es, en un guiño, el propio Snow.

Si bien una obra como Autorización tiene el potencial de generar una infinidad de comentarios desde el punto de vista de la pragmática, ello se debe a que en las décadas que nos ocupan la producción tanto artística como de especulaciones teóricas, como es lógico, como siempre ha sido, se alimentan mutuamente. El ensayo de Dubois -ya clásico en el ámbito de la teoría fotográfica- es prueba de ello. Por supuesto, también habrá quien especule desde el campo de una semiótica de la codificación. Este es el caso, por ejemplo, de la obra de J ohn Hilliard titulada La cámara registrando su propia condición ( 7 aperturas, 10 velocidades, 2 espejos). (Imagen 6)

Se trata de un mosaico compuesto por setenta fotos en las que el autor, una vez más, se vuelve ante el espejo. Las tomas muestran el reflejo de la cámara y, solo parcialmente, la cabeza de Hilliard tras esta, así como su mano accionando el disparador. La secuencia es totalmente repetitiva, salvo por el hecho de que en cada toma se ha variado ya sea la apertura del diafragma o la velocidad de obturación. El resultado es una serie que va de la completa sobreexposición -el blanco casi puro- a la completa subexposición - el negro casi puro-, con una variación, aunque marginal, de la profundidad de campo. El autor nos recuerda, con ello, que cada pequeña alteración en alguno de los factores técnicos que intervienen en una toma da como resultado una imagen diferente, esto es, tiene implicaciones a nivel semántico. En palabras de Durand:

[...] en los años 70, Hilliard hace una especie de examen semiótico práctico de los diferentes componentes de la operación fotográfica [...]. Cada variación de uno de los datos del dispositivo se asemeja a una contextualización distinta, y pone de manifiesto el papel determinante de dicho dispositivo como verdadero maestro de la representación. [Y agrega:] la pretensión de la fotografía de mostrar lo que ha sido, de ser una huella de la realidad, está ahora desmontada y reducida a una serie de decisiones y de determinaciones técnicas. (Durand 1998: 125 y 126) 


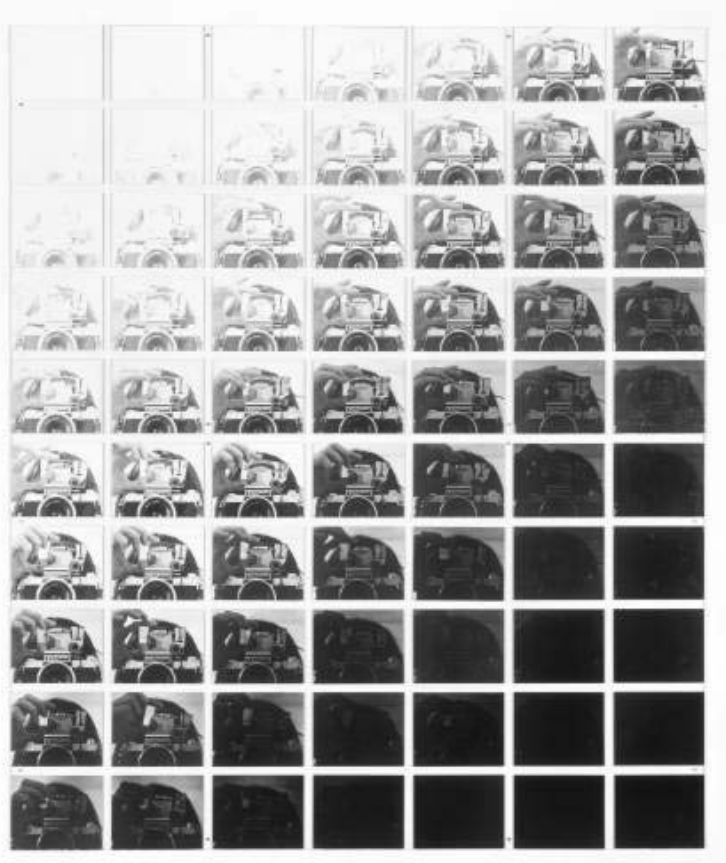

Imagen 6. J ohn Hilliard

La cámara registrando su propia condición (7 aperturas, 10 velocidades, 2 espejos), 1971

El problema, planteado aquí de manera tan simple, es de una importancia capital. El tema de fondo es hasta qué punto las diversas posibilidades de control de los elementos que constituyen el aparato fotográfico, no solo la cámara, sino todos los componentes y variables que intervienen previa, durante y posteriormente al momento mismo de la toma -recordemos: lo irrepetible y lo inacabable de Soulages (1998)— devienen efectivamente en elementos de semantización del mensaje, esto es, son manejados a manera de código por el fotógrafo y, a su vez, son decodificables por el receptor.

$\mathrm{El}$ accionar de Hilliard al hacer evidente el uso y efecto de elementos primarios como el obturador y el diafragma -así como la presencia tan 
manifiesta de la cámara en la imagen-, nos recuerda las palabras de Flusser cuando afirma: «Las categorías de la cámara están impresas en el lado exterior de esta y allí pueden manipularse, siempre y cuando la cámara no esté totalmente automatizada. Ellas son las categorías del espaciotiempo fotográfico». (Flusser 1983: 34) En efecto, en la imagen de Hilliard se evidencia este aspecto. Sin embargo, lejos de ser una apología de la actividad fotográfica, la cita del autor checo nos conducirá a una crítica soterrada de la actividad fotográfica. Mientras que el argumento de su libro es la fotografía, su tema $\rightarrow$ si vale esta transpolación de categorías de la narrativa a la ensayística - es una crítica a la sociedad postindustrial, de la cual el aparato fotográfico es un modelo.

Nos detendremos momentáneamente en la obra de Flusser ya que el esclarecimiento de algunas de sus ideas será fundamental para los apartados subsiguientes del presente estudio. La aplastante visión de este teórico supone que en las imágenes técnicas —de las cuales la fotografía es un verdadero paradigma-, una cámara y un operador humano, el fotógrafo, se interponen entre ellas y su significado. Sin embargo,

[...] no parece que este complejo «aparato/operador» interrumpa la cadena entre la imagen y el significado. Es más, el significado parece entrar en un lado (input) y salir en el otro (output), permaneciendo oculto el propio desarrollo, el proceso dentro del complejo, al modo de una caja negra. Como la codificación de las imágenes técnicas se desarrolla en el interior de esa caja negra, cualquier crítica de las imágenes técnicas debe destinarse a esclarecer su vida interior. Mientras no dispongamos de tal crítica, seguiremos siendo analfabetos en cuanto a las imágenes técnicas. (Flusser 1983: 19)

Para el autor citado, al desarrollarse la codificación en el interior de esa caja negra, el fotógrafo estará condenado a permanecer por debajo de las posibilidades del aparato, será simplemente vehículo de una producción de imágenes institucionalizada, ideologizada, agotada a priori desde del punto de vista semántico, no informativa, en el sentido de que solamente reproducirá al infinito las posibilidades previstas por y contenidas en el dispositivo. Aparato, dice, «es un juguete complejo, tan complejo que sus usuarios no lo entienden en toda su dimensión; su juego consiste en 
combinaciones de los símbolos contenidos en su programa, procediendo su programa de un metaprograma»; y remata: «la cámara (y todos los aparatos posteriores) es pensamiento calculatorio plasmado en hardware». (Flusser 1983: 31-32)

Si bien Flusser acepta la existencia de diversos usos más o menos intencionados del medio, en su visión, nadie se salva. Establece:

[...] voy a distinguir tres tipos de fotografías, en concreto, la totalmente automática, la del aficionado a la fotografía y la del fotógrafo «consciente». En las fotografías totalmente automáticas se ejecuta un programa controlado, y es indiferente que este programa haya sido escrito por personas o aparatos (que las fotos por satélite de la NASA hayan sido prescritas por personas o por ordenadores). Por su parte, las fotografías de los aficionados demuestran cómo los programas inscritos en la cámara se escapan de todo control: todo lo que la cámara sea capaz de grabar se grabará efectivamente y de todas las maneras en las que sea capaz de grabarlo. Finalmente, las «fotografías de fotógrafos» atestiguan intentos humanos de impedir el escape del control forzando el aparato a detenerse en situaciones «deseadas». (Flusser 1985: 154)

Dentro de la construcción teórica flusseriana, estas categorías quedan vinculadas a su crítica a la Modernidad. Según afirma, siguiendo un conocido modelo, como consecuencia de la situación en el siglo XIX y del surgimiento de la fotografía,

[...] la cultura se dividió en tres ramas: la de las bellas artes, nutrida de imágenes tradicionales aunque conceptual y técnicamente enriquecidas; la de la ciencia y tecnología, mantenida con textos herméticos; y la de las capas amplias de la sociedad, difundida mediante textos baratos. Para impedir que la cultura se desintegrara, se inventaron las imágenes técnicas, como código válido para toda la sociedad. [...] Se esperaba de ellas que fueran un denominador común de arte, ciencia y política (cual valores generales), es decir, que fueran a la vez «bellas», «veraces» y «buenas», y que así superaran como código universal la crisis de la cultura o el arte, la ciencia y la política. (Flusser 1983: 21)

Evidentemente, para el autor, esta expectativa no se cumplió, no se ha cumplido. Es cierto que el planteamiento puede resultar excesivamente reduccionista a la luz de otras críticas sociológicas y filosóficas - de Weber a Habermas, de Husserl a Bauman-. Así lo señala el propio Durand 
cuando arremete contra la idea del inconsciente maquínico flusseriano: «Este aspecto de la reflexión de Flusser, la crítica del automatismo funcionalista, no nos interesa especialmente aquí, en la medida en que se parece a muchas críticas de la técnica en la sociedad postindustrial, en general mucho más elaboradas que la suya». (Durand 1998: 132) Sin embargo, es precisamente ese esfuerzo de esquematización conceptual el que le da valor al ensayo Una filosofía de la fotografía.

En la Imagen 7 hacemos una representación gráfica del proceso descrito. En ella, partimos de la concepción tradicional de lo verdadero, lo bueno y lo bello (ver la cita anterior de Flusser) como componentes del saber, que en su momento quedaron establecidos como disciplinas de estudio: la lógica, la ética y la estética. En la Modernidad, estas tres esferas se escindirán, volviéndose autónomas, momento que queda sistematizado a partir de Kant; así, las esferas de la ciencia, de la moral/política y del arte seguirán el camino de la especialización.

\begin{tabular}{|c|c|c|c|c|}
\hline $\begin{array}{l}\text { Tradición: } \\
\text { Ciencia } \\
=\text { Arte }\end{array}$ & $\begin{array}{l}\text { Kant } \\
(1724-1804)\end{array}$ & $\begin{array}{l}\text { Sociología / } \\
\text { Filosofía } \\
\text { Siglo XX }\end{array}$ & $\begin{array}{c}\text { Flusser } \\
(1920-1991)\end{array}$ & $\begin{array}{l}\text { Bourdieu } \\
\text { (Campos) } \\
(1930-2002)\end{array}$ \\
\hline Verdadero & $\begin{array}{l}\text { Crítica de la } \\
\text { razón pura }\end{array}$ & CIENCIA $\rightarrow$ & Automatización & $\begin{array}{l}\text { FOTO: } \\
\text { Cientifíca } \\
\text { Experimental } \\
\text { Documental }\end{array}$ \\
\hline Bueno & $\begin{array}{l}\text { Crítica de la } \rightarrow \\
\text { razón práctica }\end{array}$ & $\begin{array}{l}\text { MORAL / } \\
\text { POLÍTICA }\end{array} \rightarrow$ & $\begin{array}{l}\text { Foto } \\
\text { aficionado }\end{array}$ & $-\begin{array}{r}\text { Familiar } \\
\text { Viajes } \\
\text { Comercial }\end{array}$ \\
\hline Bello & $\underset{\text { juicio }}{\text { Crítica del }} \quad \rightarrow$ & ARTE $\rightarrow$ & $\begin{array}{l}\text { Fotógrafo } \\
\text { consciente }\end{array}$ & $\begin{array}{l}\text { Periodística } \\
\text { |Artística }\end{array}$ \\
\hline
\end{tabular}

Imagen 7 
En su construcción teórica y, como ya se señaló, tomando en consideración a la fotografía como modelo de aparato postindustrial, Flusser hace coincidir la esfera de la ciencia, caracterizada por su avance ciego y amoral, con la automatización; la esfera de la práctica, o lo que es lo mismo, de la moral/política, es equiparada con los «abominables», dice, usos de la fotografía por parte del aficionado; y, por último, queda al fotógrafo consciente la tarea de jugar contra el código, contra la automatización, contra las prácticas canónicas del medio, en una actitud de constante revisión de sus usos a través de la generación de nuevas formas, en un proceso que es reminiscente de la estética negativa adorniana.

Si la visión de Flusser resulta, como dijimos con anterioridad, aplastante, es porque en ella se considera que esa esfera de la práctica, en el caso que nos ocupa, es capaz de deglutir, de incorporar apenas producida una nueva forma proveniente del campo del arte, o un nuevo recurso de codificación técnica originado en la esfera de la ciencia, y despojarlos de sentido, de lexicalizarlos, para utilizar un término proveniente de la retórica, en alusión a la generalización en su uso y a la pérdida, por lo tanto, de poder comunicativo, informativo en un sentido sustancial, donde «ya no suele reconocerse desvío, sino norma». (Carrere y Saborit 2000: 344) Este proceso de asimilación como parte del capital cultural, por cierto, no solo se da en la fotografía de aficionado, sino en general en todas las prácticas del campo de la fotografía que podemos llamar comercial —publicitaria, de modas, retrato, etcétera-, las cuales Flusser omite en su estudio.

De esta manera, mientras que la sociología y la filosofía nos han advertido de los peligros del avance científico desvinculado de la esfera de la moral/política, y del mismo modo en que la estética y la retórica general han señalado el vacío de sentido por la utilización irreflexiva de un recurso expresivo, Flusser nos previene: «El peligro de una cultura automática independizada consiste en que conduce, con una probabilidad que raya en la seguridad, a situaciones tales como las fotos de aficionado movidas o las guerras nucleares». (Flusser 1985: 156) Como sucede en todo proceso de codificación, en el caso de la fotografía están implicadas tanto la capacidad 
codificadora del productor como la competencia decodificadora del receptor, el cual también puede moverse en las diferentes esferas que hemos descrito. La subvaloración que ya comentamos del primero y que está representada por el proceso de la caja negra parecería, así, llevar implícita la del segundo, el cual, en la esfera de la práctica, no tendría más que aceptar en una lectura acrítica la información que le es provista, debido a que su situación de hipocodificación le impediría concretar esa aspiración ya expresada de un código universal válido para todos. Ahí, sin embargo, Flusser abre una puerta con una llamada a la actitud crítica: «Al silenciar las intenciones codificadoras dentro de la cámara y dentro de los medios de distribución, la mayoría de los críticos de la fotografía adormecen la capacidad crítica del público y desprecian la inteligencia crítica del receptor». (Flusser 1983: 99)

Así, entonces, estamos usando la construcción teórica de Flusser a contrapelo, ya que al tiempo que aceptamos y valoramos su propuesta general, no compartimos, por otro lado, su visión del fotógrafo, incluso del fotógrafo consciente, como un operador que se encuentra siempre por debajo de las posibilidades del programa del aparato, no jugando con, sino siendo jugado por las virtualidades contenidas en él. Retomemos la crítica que Durand hace de la propuesta flusseriana. Dice: «Siempre hay un punto de paranoia en análisis de este tipo que remiten los procesos a una voluntad anónima, una intención central no identificada». (Durand 1998: 132)

\subsection{EL CÓDIGO COMO LAS REGLAS DEL J UEGO}

Precisamente ese proceso de jugar o ser jugado, que hemos descrito a partir del marco conceptual de una crítica a la Modernidad, puede ser abordado también desde otro marco que ya hace algunos párrafos sobrevuela este texto. En efecto, términos como incorporación, campo o capital cultural nos remiten al edificio teórico construido por Bourdieu. 
Este pensador insiste en la coherencia de los esquemas perceptivos y clasificatorios, guiados por principios implícitos, por un sentido práctico rara vez racionalizado de manera consciente. Existen, por supuesto, quienes cuentan con un lenguaje bien formalizado y constituido. También, el autor, capaz de hacer

[...] públicas las cosas que todo el mundo sentía confusamente, alguien que posee una capacidad especial, la de publicar lo implícito, lo tácito, que cumple un verdadero trabajo de creación. [...] La publicación es una operación que oficializa, por lo tanto legaliza, porque implica la divulgación, el descubrimiento frente a todos, y la homologación, el consenso de todos sobre la cosa así descubierta. (Bourdieu 1987: 88)

Este proceso de homologación es equivalente al que hemos descrito en el esquema de la Imagen 7, mediante la absorción de los nuevos desarrollos de las esferas científica y artística por parte de la esfera de la moral/política o, con otras palabras, de la práctica.

Bourdieu nos recuerda que, socialmente, las prácticas son normalizadas, puestas en orden, codificadas -y aquí utilizamos el término en un sentido extrasemiótico, como el propio Bourdieu, quien lo equipara permanentemente con la codificación legal-ya que

[...] para dar cuenta de lo que la gente hace, es necesario suponer que obedecen a una suerte de «sentido del juego» como se dice en deporte, y que, para comprender sus prácticas, es necesario reconstruir el capital de esquemas informacionales que les permite producir pensamientos y prácticas sensatas y regladas sin intención de sentido y sin obediencia consciente a reglas explícitamente enunciadas como tales. (Bourdieu 1987: 83)

Hemos introducido, así, un nuevo factor ante las opciones de jugar o ser jugado, a saber: contar con sentido del juego, entendiéndose este como «una lógica práctica, la de lo impreciso, del más o menos, que define la relación ordinaria con el mundo». (Bourdieu 1987: 84) El término que el autor utiliza para representar esa internalización de las reglas del juego es el de incorporación. Este podría remitir a otros, como son los de inconsciente, subyacente, intuitivo, implícito, infralógico (en el Capítulo 6 
hablaremos, de la mano de Moles, de una infralógica de la visión: cfr. Moles 1984; Costa 1998), todos ellos términos que aluden al proceso anteriormente descrito por medio del cual las nuevas aportaciones de las esferas de la ciencia y del arte son asimiladas por la esfera de la práctica, convirtiéndose en parte del capital cultural.

El lector, así, incorpora las reglas de lectura de las fotos, de la misma manera que el fotógrafo incorpora el uso del aparato fotográfico, y lo hacen no solo mediante la educación formal, sino fundamentalmente a través de la práctica y de la experiencia vivencial. Así, incorporar dichas posibilidades de juego es, también, incorporarse a un entorno que comparte determinados usos sociales, codificados. Pero incorporarse es también ponerse de pie, pasar de un estado pasivo a otro activo. Es a través de la incorporación del lenguaje, que el fotógrafo logra corporeizar, dar cuerpo a su práctica. Es así como logra cumplir la aspiración de la que anteriormente hablamos al evocar las palabras de Merleau-Ponty: la de aportar su cuerpo al mundo.

Esta asimilación de las prácticas por el capital cultural es, en sí misma, un proceso de codificación:

Codificar, es a la vez poner en forma y poner formas. Hay una virtud propia de la forma. Y el dominio cultural es siempre un dominio de las formas. [...] Todos esos juegos de puesta en forma que, como se ve con el eufemismo, son otros tantos juegos con la regla del juego, y, por allí, dobles juegos, son la manera de ser de los virtuosos. Para ponerse en regla, es necesario conocer al dedillo la regla, los adversarios, el juego. Si fuera necesario proponer una definición transcultural de la excelencia, diría que es el hecho de saber jugar con la regla del juego hasta los límites, hasta la transgresión, permaneciendo en regla. (Bourdieu 1987: 85)

Appelt, Snow, Hilliard: transgresores, maestros del juego. Grandes maestros, como se dice en el campo del ajedrez, precisamente paradigma, símbolo del juego en su sentido más amplio. Flusser también apela a él para ejemplificar el funcionamiento de un aparato a partir de un hardware -el tablero y las piezas - y un software -el programa, las reglas del juego-. En el ajedrez, el pesimismo flusseriano se ha concretado en un hecho 
simbólico: en 1997 Garry Kasparov —niño prodigio, iniciado en el ajedrez a los cuatro años, campeón soviético juvenil a los 13, campeón mundial juvenil a los 17, gran maestro internacional a los 18, campeón mundial de 1985 a 1995- fue vencido por Deep Blue II, una supercomputadora capaz de calcular 100 millones de posiciones por segundo. ${ }^{1}$

Las probabilidades, en el ajedrez, son finitas. Hace ya años se ha afirmado que el juego del ajedrez ha llegado a tal grado de especialización, la educación alrededor de él es tan exhaustiva y los materiales publicados tan extensos, que las posibilidades del juego se han agotado. A nivel de los grandes maestros, el juego ya no consiste, no puede consistir en aportar nuevas probabilidades - ya no las hay-, sino simplemente en seguir estrategias y esperar el error del contrincante. Ya es conocido todo lo que es posible conocer - sin que eso impida, por supuesto, que los diletantes, en la esfera de la práctica, nos podamos divertir con él一.

Pero el programa del aparato fotográfico no es estático, como el del ajedrez. El tablero fotográfico no se compone de ocho monótonos ejes verticales y horizontales, de 64 escaques, sino que su número se incrementa de manera infinita con las aportaciones de las esferas de la ciencia y la estética. Garry Kasparov venció a Deep Thought en 1989 y perdió contra Deep Blue II en 1997. Estos años coinciden, grosso modo, con las fechas en que la fotografía digital se generalizó bajo la promesa de que el programa del aparato fotográfico, su software, se vería expandido. ¿Así como la poesía libre expandió en el siglo XIX las posibilidades de la creación poética, o como el Impresionismo expandió las de la pintura, o el dodecafonismo de la primera mitad del XX las de la música? En grandes maestros como Hilliard, Durand ha encontrado que:

Cada fragmento de conocimiento y de experiencia puede descomponerse en un mosaico infinito de imágenes. Este mosaico de discretos elementos, es en lo que se ha convertido el mundo para nosotros. Una actitud crítica (y

\footnotetext{
${ }^{1}$ Somos conscientes del manoseo comercial y político al que fue sujeto este acontecimiento. Nos quedamos, aquí, con su carácter más general y simbólico: el del enfrentamiento del hombre y la máquina.
} 
artística) posible podría consistir en restituir a algunos de dichos elementos su contenido de experiencia. En interrumpir la circulación de los programas para volver a encontrar algo de una decisión y de una intención individuales. (Durand 1998: 133)

La obra de Hilliard que hemos comentado también parece estar compuesta por escaques, pero entre el blanco y el negro puro, este tablero nos presenta 68 variantes de gris. En su universo, las cosas son mucho más sutiles; aquí, el juego es otro. En el título de la obra hay un guiño que todavía no hemos comentado. Entre paréntesis, se especifica: «7 aperturas, 10 velocidades, 2 espejos». ¿Por qué dos espejos? J uguemos. Especulemos.

Un espejo está ante la cámara: es el que el fotógrafo ha dispuesto, como decía Calabrese, como objeto de puesta en escena. Pero, ¿dónde está el segundo? Acaso se refiere al que está en el interior de su propia cámara réflex: no olvidemos que en este tipo de cámaras, las más difundidas a nivel profesional y semiprofesional, la imagen que vemos a través del visor ha pasado por una serie de reflexiones. ¿Cuál es el juego de Hilliard? ¿Acaso que, de la misma manera en que en sentido lógico dos negaciones implican una afirmación, dos espejos implican un... espejismo?

Los artistas plantean preguntas, más que respuestas. ¿Será que nuestro propio vaho -como a Appelt- paradójicamente nos impide ver nuestra imagen, al mismo tiempo que testimonia que estamos vivos? En ocasiones la extrema cercanía estorba, y los procesos de significación a través de la fotografía nos son muy cercanos, los vivimos a diario como parte de eso que hemos llamado la esfera de la práctica. Bourdieu nos ha invitado a profundizar en los componentes del capital cultural que hemos incorporado. Flusser, a hacer una crítica que aclare el interior de la caja negra y nos saque del analfabetismo visual. Durand, a valorar la intención individual a partir de la propia experiencia. Para responder a estas invitaciones, profundicemos, pues, en el estudio del cómo, de la manera de formar, en el esclarecimiento de la codificación fotográfica. 

PRIMERA PARTE: MARCO TEÓRICO

CAPÍTULO 3

\section{LA CODIFICACIÓN EN UN SENTIDO SEMIÓTICO Y EL GIRO PRAGMÁTICO}





\title{
3.1. UNA HIPÓTESIS DE TRABAJO
}

Para continuar con nuestro marco teórico, pasaremos ahora de los espejos a las improntas. El hecho de remarcar la relación entre ambos no es ocioso, el propio Eco nos recuerda que las

\begin{abstract}
comparaciones entre las improntas fotosensibles y las imágenes especulares nos dicen al menos algo muy importante para una semiótica de la imagen fotográfica, cinematográfica y televisiva: esta se encuentra dentro de los límites de lo semiósico. [...] El modo de interpretar una impronta (que ya es signo) es afín al de interpretar una imagen especular deformada o de baja definición (que no es signo). Se procede mediante relaciones proyectivas: a tal dimensión en la imagen debe corresponder tal dimensión, si no en el objeto-espécimen (referente), al menos en el objeto-tipo (contenido) de que me «habla» la imagen. Las categorías «gramaticales» propiamente dichas intervienen en el nivel del encuadre y el montaje. Las improntas no son imágenes especulares, pero se las lee casi como si lo fueran. (Eco 1985: 40)
\end{abstract}

La contradicción implícita aquí es tan antigua como la fotografía misma. El hecho de que, aun siendo signos, las fotos por lo general tiendan a no ser interpretadas como tales -seamos precavidos con esta generalización, ya que evidentemente se trata de cierto tipo de fotos, las más arraigadas a un realismo en su modo de representación- es el argumento de fondo que ha provocado la escisión entre la semiótica del índice y la semiótica del icono. Mientras que la primera ha puesto el acento en aspectos ontológicos y en el carácter de huella de la foto, la segunda, como veremos a continuación, ha insistido en explicitar los procesos de significación y, por lo tanto, de funcionamiento de las fotos como mensajes. Y aunque previamente hemos establecido que nuestro interés no es privilegiar un enfoque sobre otro, llega aquí el momento de desarrollar el segundo, a fin de responder a la pregunta esencial que nos hemos planteado: ¿cómo significa la fotografía?

En efecto, el tema es fundamental dentro de nuestra argumentación ya que estamos partiendo de un supuesto radical e indudablemente polémico: el de que, en el caso particular de la fotografía, el estudio a fondo 
de los procesos de codificación ha sido eludido reiteradamente. Desarrollemos este argumento desde el comentario de los máximos exponentes de los enfoques mencionados, ya que la contradicción antes comentada, así como el reconocimiento de la postura opuesta, pero minimizándola, se encuentran presentes incluso en los principales teóricos que han abordado el tema.

\subsection{LA SEMIÓTICA DEL ÍNDICE}

Por un lado tenemos a Roland Barthes, quien en un texto temprano verdaderamente fundacional para el estudio de la fotografía desde un punto de vista semiótico, El mensaje fotográfico (1961), coqueteó con la idea de que existen códigos fotográficos, pero no solo nunca llegó a explicitarlos, sino que los soslayó completamente. En dicho texto, incluso enumera lo que él denomina seis procedimientos de connotación -a saber: trucaje, pose, objetos, fotogenia, esteticismo y sintaxis-, pero no los desarrolla precisamente porque su interés fundamental se centra en otra característica de la fotografía: el hecho de que, para él, es un «mensaje sin código», un «analogon perfecto de la realidad», siendo que «esta perfección analógica es lo que define la fotografía delante del sentido común». (Barthes 1961: 13)

Este es un aspecto inquietante del texto barthesiano: ¿por qué insistir en minimizar el sentido común? ¿No hay aquí un desprecio a la capacidad de lectura del receptor no especializado, de la gente de a pie que, a pesar de no haber tenido una educación formal respecto de la fotografía, ha incorporado (ver supra: Capítulo 2) una capacidad decodificadora? ¿No es, acaso, la doxa, mucho más sabia que el sabio? Después de la enorme cantidad de tinta que aquel texto hizo correr tras su aparición en un momento emblemático, veinte años más tarde, en La cámara lúcida (1980), Barthes vuelve a la carga con una visión igualmente peyorativa e inquietante de dicha capacidad: 
[...] percibir el significante fotográfico no es imposible (hay profesionales que lo hacen), pero exige un acto secundario de saber o de reflexión. Por naturaleza, la Fotografía (hemos de aceptar por comodidad este universal, que por el momento solo nos remite a la repetición incansable de la contingencia) tiene algo de tautológico: en la fotografía una pipa es siempre una pipa, irreductiblemente. (Barthes 1980: 32-33)

¿Cómo debemos interpretar estas palabras de uno de los maestros de la semiología? ¿A qué se debe que el perspicaz autor de Mitologías y de El grado cero de la escritura se rehusara a abordar el asunto de la codificación fotográfica, el cual debería ser central a partir de un enfoque que en ese momento tomaba cada vez más fuerza? La cámara lúcida es un extraordinario ensayo literario en el cual la fotografía es un pretexto para hablar de otros temas -la muerte, la Historia, el paso del tiempo, la nostalgia por su madre-, pero no es, como podría pensarse, un tratado de semiótica fotográfica ya que, más que explicarla, busca poetizarla o poetizar a partir de ella. Tomemos de dicha obra una cita paradójica que es eso, literaria, y que él, a su vez, toma de Nietzsche: «Un hombre laberíntico jamás busca la verdad, sino únicamente su Ariadna». (En Barthes 1980: 130) Al leer ese ensayo, deberíamos hacerlo preguntándonos en todo momento a qué Ariadna estaba buscando a lo largo de sus páginas el laberíntico Barthes.

No es posible poner en duda la habilidad interpretativa del autor francés, quien, si no era un profesional de la fotografía, sí lo era de la interpretación. En su texto de 1980, Barthes sigue reconociendo las capacidades lectoras interiorizadas en el sentido común que corresponden, grosso modo, a su concepto de studium:

Reconocer el studium supone dar fatalmente con las intenciones del fotógrafo, entrar en armonía con ellas, aprobarlas, desaprobarlas, pero siempre comprenderlas, discutirlas en mí mismo, pues la cultura (de la que depende el studium) es un contrato firmado entre creadores y consumidores. El studium es una especie de educación (saber y cortesía) que me permite encontrar al Operator, vivir las miras que fundamentan y animan sus prácticas, pero vivirlas en cierto modo al revés, según mi querer de Spectator. Ocurre un poco como si tuviera que leer en la Fotografía los mitos del Fotógrafo, fraternizando con ellos, pero sin llegar a creerlos del todo. (Barthes 1980: 66-67) 


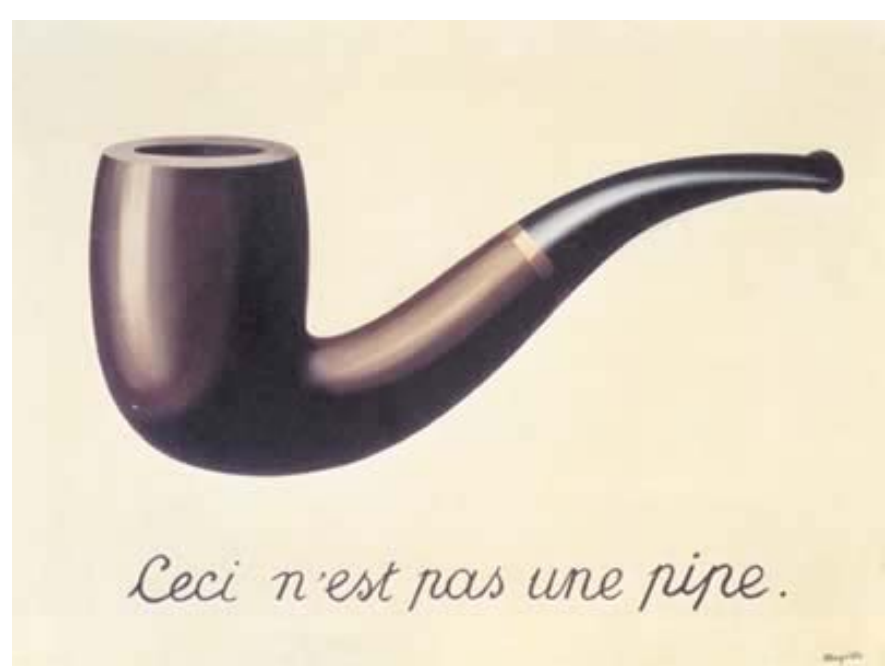

\section{Imagen 8. René Magritte \\ La traición de las imágenes (Esto no es una pipa), 1929}

A pesar de reconocer las capacidades de las que hablábamos, Barthes las soslaya; él busca en la fotografía un algo más. Otra vez, fotógrafo y receptor son planteados operando por debajo de las posibilidades del medio: ¿el inconsciente maquínico flusseriano? Pero, más allá de que respecto a la fotografía en particular, el interés fundamental de Barthes se centrara en la química, en el aspecto indicial del medio - siendo esto, precisamente, lo que desviará su discurso del tema de la codificación, secundario desde su perspectiva-, lo que deseamos hacer aquí es plantearnos la pregunta a contrario. Así, lo que nos interesa desvelar es precisamente cómo operan los mecanismos de lectura, de decodificación en un lector corriente, en una persona común que, ni es una experta en semiótica, ni una profesional de la fotografía, ni necesariamente debe efectuar un acto secundario de saber o de reflexión —como tampoco lo hace, por ejemplo, al abordar un escrito-, ni es, sobra decirlo, un connotado hombre del arte, como por ejemplo René Magritte, para tener la autoridad de afirmar ante la imagen de una pipa: Ceci n'est pas une pipe 
(Imagen 8). Nos interesa especular acerca de por qué una persona que nunca ha tenido un entrenamiento específico ni para la creación de imágenes ni para su interpretación puede, sin embargo, ser una aguda intérprete de fotografías, como sucede de hecho en el día a día.

\subsection{LA SEMIÓTICA DEL ICONO}

Por su parte en Eco, principal promotor de la semiótica del icono, encontramos una concepción de la fotografía en la cual lo que se verá soslayado es el carácter indicial del medio. Dice a propósito de ella:

Testimonio de que algo estaba ahí para impresionar la placa (muchas veces usada como prueba), provoca siempre, no obstante, la sospecha de que ese algo no estuviera. Sabemos que alguien, mediante puesta en escena, engaño óptico o misteriosos juegos de emulsión, solarización, y similares, puede haber hecho aparecer la imagen de algo que no estaba, que no ha estado, que no estará nunca. La foto puede mentir. Lo sabemos incluso cuando suponemos ingenuamente, casi fideísticamente, que no miente. El referente objetivo es conjeturado, pero corre peligro de disolverse en cualquier instante en puro contenido. Una foto, ¿es la foto de un hombre o la foto de ese hombre? Depende del uso que hagamos de ella. (Eco 1985: 37)

Para este autor, entonces, ante la foto de una pipa habría que decir: ¡Esto tampoco es una pipa! Y no lo es porque es signo, porque puede mentir. Pero si bien hemos recurrido a Eco dada su autoridad en el campo semiótico, debemos también señalar que, como estudiosos de la fotografía, consideramos que su obra adolece, vista específicamente desde el campo fotográfico, de un problema del que puede hablarse como un mal general de la semiótica de la imagen. En efecto, a lo largo de la obra de este pensador solamente se comenta de manera marginal la fotografía y esta rara vez es tratada en su especificidad. Así, al transpolar algunas de sus ideas del ámbito de la imagen en general al campo fotográfico, se han producido vacíos de conocimiento que no siempre han sido subsanados 
satisfactoriamente. Es en ese sentido que, una vez más, el tema de la codificación fotográfica ha sido eludido.

Atípica por escasa y concentrada, la teoría fotográfica se mantuvo como un coto restringido, si hemos de fijar algo arbitrariamente una fecha, hasta 1989, año en el que se celebró el 150 aniversario del invento del medio, lo que motivó la publicación de incontables estudios. Si hasta ese momento el corpus bibliográfico era tan limitado que podía ser compartido sin problema alguno por los investigadores $-\mathrm{y}$, dicho de paso, citado hasta la saciedad, lo que no dejaba de producir sonrisas sarcásticas cuando en una conferencia o coloquio reaparecían sin cesar los mismos Benjamin, Arnheim, Bazin, Bourdieu, Sontag o Freund de siempre-, a partir de entonces se ha dado una verdadera avalancha de textos, como es lógico, de mayor o menor originalidad, y en particular dentro del campo semiótico ha habido una importante aportación.

Otra consecuencia es que, si antes cabía el eclecticismo y la convivencia de una multiplicidad de enfoques —semiótico, estético, sociológico, antropológico, de los estudios culturales, psicológico, histórico-, hoy debe primar la cautela ante el exceso de lo ya escrito. Es necesario, también, considerar cómo la jerga semiótica se ha incorporado a lo largo de las últimas décadas al lenguaje de estudiosos provenientes de diversas disciplinas, lo que contribuye a mantener vivo el carácter multidisciplinar del que desde su origen se ha teñido el enfoque semiótico.

Si en las décadas de 1960 y 1970 proliferaron los estudios dedicados a diversos sistemas de comunicación, la fotografía no fue la excepción. Sin embargo, en su caso la entrada se dio tímidamente, a través de los ambiguos textos de Barthes ya comentados en el apartado anterior. Aunque hemos relativizado la importancia de Eco en el campo fotográfico, su teoría es indudablemente el marco de referencia para los autores de lo que aquí denominamos la semiótica del icono. La cita de Eco que incluimos más arriba revela ambas facetas: por un lado, caso común, la de un comentarista que adolece de ciertas limitaciones en cuanto al conocimiento de los elementos fundamentales del repertorio técnico fotográfico, puestas en 
evidencia por la vaguedad e indeterminación de algunos de los términos que utiliza — «misteriosos juegos de emulsión, solarización, y similares»—; pero por otro, encontramos también en ella la voz de una autoridad en el ámbito del estudio de los signos.

Así, de la misma forma en que antes nos detuvimos en Flusser o en Bourdieu, hagámoslo ahora en la propuesta de este autor para tratar de dilucidar, a través de su extensa obra que abarca más de 50 años, el camino que ha seguido la semiótica en ese período. Dejemos que sea el propio Eco quien fije un punto de partida:

En 1957 J. M. Castellet escribió un libro titulado La hora del lector. ${ }^{1}$ Fue un verdadero profeta. En 1962 escribí mi Opera aperta. En ese libro defendía el papel activo del intérprete en la lectura de textos dotados de valor estético. Cuando se publicaron esas páginas, mis lectores se centraron sobre todo en el lado abierto de todo el asunto y subestimaron el hecho de que la lectura abierta que yo defendía era una actividad causada por la obra (y tendente a su interpretación). En otras palabras, me proponía estudiar la dialéctica entre los derechos de los textos y los derechos de sus intérpretes. Tengo la impresión de que, en el curso de las últimas décadas, se ha hecho demasiado hincapié en los derechos de los intérpretes. (Eco et ál. 1992: 33)

En esta breve cita, queda sintetizado medio siglo de ires y venires semióticos. Eco tiene un papel paradigmático en ese período no solo en su calidad de genio de los avatares del signo, sino también en su rol de excelente mercadólogo de sus propios libros, ya que siempre ha sabido estar a la moda en lo que se refiere a las últimas tendencias en las teorías de la interpretación para así integrarlas en su propio corpus ensayístico. Hagamos, por ello, un ardid metodológico y sigamos su trayectoria cronológicamente, a través de algunos de sus títulos: ${ }^{2}$

\footnotetext{
${ }^{1}$ Existe una nueva edición presentada como la definitiva: Castellet, J. M. La hora del lector. Barcelona: Península, 2001. Esta incluye un extenso estudio de Laureano Bonet. En una nota introductoria, el propio Castellet afirma: «Salvo media docena de correcciones irrelevantes, me ha sido imposible entrar a revisar un texto escrito hace cuarenta y cinco años. En cualquier caso se trata, para mí, de un estilo correspondiente a una mentalidad y a una cultura muy de un tiempo y un lugar determinados, el de la España de los años cincuenta. También me pareœe que algunas ideas se expresan con un entusiasmo e, incluso, con un candor en los que casi no me reconozco. Me habré hecho mayor». (p. 9)

2 Las fichas completas de las obras mencionadas se encuentran en la bibliografía. El año indicado aquí es el de la publicación original.
} 
- La definición del arte (Compilación de textos, 1955-1963)

- Obra abierta (1962)

- La estructura ausente (1968)

- Signo (1973)

- Tratado de semiótica general (1975)

- Lector in fabula. La cooperación interpretativa en el texto narrativo (1979)

- Los límites de la interpretación (1990)

- Interpretación y sobreinterpretación (Con otros autores, 1992)

- A paso de cangrejo. Artículos, reflexiones y decepciones (2000-2006)

Como es reconocido, la semiótica de las décadas de 1960 y 1970 está en deuda con la lingüística y la teoría literaria. Si bien la semiótica, como ciencia general de los signos, había sido más postulada que desarrollada desde mucho antes - existiendo consenso en considerar como sus precursores a Charles S. Peirce y a Charles W. Morris-, no es sino hasta el período señalado que adquiere un cuerpo relevante como disciplina autónoma. A partir de entonces, algunos de los nombres más destacados de la disciplina serán Sebeok (discípulo de Morris), Barthes o Greimas, pero ninguno será tan identificado como referente a través de sus obras ni tendrá un impacto, no solo académico, sino mediático, comparable al de Umberto Eco.

En algunos de sus textos tempranos compilados posteriormente en La definición del arte, Eco establece una verdadera declaración de intenciones que, a partir del reconocimiento de las influencias que lo motivan, señala la dirección que tendrán sus posteriores investigaciones. Citemos in extenso el texto Un balance metodológico (1963):

[...] no llevo a cabo una actividad crítica en el sentido habitual de la palabra: burocráticamente hablando pertenezco al genus de los filósofos y me ocupo de la estética. Especialmente me interesa la historia de las poéticas: y esto porque creo que la primera operación en estética, hoy más que nunca debe consistir en una fenomenología de las distintas concepciones del arte presentes en los artistas y en las corrientes de los diversos países y las distintas épocas.

Dado que a menudo el estudioso de las poéticas no dispone de documentos explícitos, sino que debe determinar la poética implícita de un artista examinando la estructura de sus obras y determinando las intenciones de sus operaciones, el estudio de las poéticas se convierte en un análisis concreto de 
las obras. No para distinguir lo bello de lo feo ni para juzgar lo que en ellas hay de válido o no: sino para describir modelos estructurales. En este sentido, por consiguiente, la misma determinación de las poéticas puede ser considerada como una especie de actividad crítica y sus resultados pueden utilizarse como contribución a la comprensión crítica de una obra o de un autor. Más aún, dado que en el arte contemporáneo está manifestándose un progresivo predominio de la poética sobre la obra (de la «poesía sobre la poesía» de tradición romántica y decadente se llega ahora a complejas obras de arte que parecen ser su propia teoría: pensemos en el Finnegans Wake) cabe preguntarse, aunque sea, como hipótesis paradójica, si en un próximo futuro el estudio de las poéticas no se convertirá en la única forma de crítica posible. (Eco 1955-1963: 278-279)

Y, más adelante, agrega respecto a uno de sus principales libros, entonces recién publicado:

Mi último estudio sobre las poéticas contemporáneas [Obra abierta], en efecto, no es más que el intento de elaborar modelos de poética que demuestran que en la actualidad está en juego una profunda transformación del concepto de arte. La obra de arte se está convirtiendo cada vez más, desde Joyce hasta la música serial, desde la pintura informal a los films de Antonioni, en obra abierta, ambigua, que tiende a sugerir no un mundo de valores ordenado y unívoco, sino un muestrario de significados, un «campo» de posibilidades, y para conseguirlo es preciso una intervención cada vez más activa, una opción operativa por parte del lector o del espectador. Para elaborar este modelo de obra abierta me ha sido muy útil (otra influencia en gran parte anglosajona) la teoría de la información. Y por otra parte he tratado de relacionar este modelo estético con otros modelos localizados en el ámbito de la cultura contemporánea: desde los modelos metodológicos de la física a los modelos de la lógica plurivalente, de la psicología, etc. Se trataba del intento de recuperar una unidad en los diversos aspectos de un momento cultural, aquel en el que vivimos. No estoy seguro de haber evitado los riesgos de la fácil analogía. Y precisamente por esto estoy centrando en estos momentos mi atención en diversas metodologías estructuralistas (desde la lingüística de Saussure a la antropología de Lévi-Strauss; pero siempre me ha parecido estimulante la noción de stratified structure propuesta por René Wellek y me interesan, igual que le han interesado a él, los estudios de los formalistas rusos) para tratar de resolver este problema: reducir a modelos estructurales rigurosos los distintos fenómenos culturales de un período para revelar después las semejanzas de estructura entre los distintos modelos. (Eco 1955-1963: 283)

Acaso nos hemos excedido en la extensión de estas citas. Ello no se debe a que nuestra intención sea saturar al lector con nombres de autores y escuelas de crítica, sino dejar sentado ese intento de recuperar una unidad en los diversos aspectos de un momento cultural en que los estudios de los 
sistemas de comunicación se empiezan a desarrollar y que es un verdadero crisol de tendencias teóricas y metodológicas. Es notable en las palabras de aquel Eco la influencia tan presente del gran paraguas del estructuralismo; también de otras formas de crítica inmanente del texto, que fueron tomando forma en la primera mitad del siglo pasado. Asimismo, podemos destacar el reconocimiento de la influencia de la teoría de la información. A propósito de esta, y sin perder de vista el título de Castellet al que ya nos hemos referido, aventuraremos una gran reducción seguros de que no resultará una reductio ad absurdum, sino que nos permitirá apreciar el desarrollo teórico que estamos planteando desde una distancia óptima para valorarlo en conjunto.

Si bien los modelos comunicativos desarrollados por la teoría de la información ${ }^{3}$ reconocen -salvo matizaciones-la interacción de elementos que incluyen primariamente un mensaje, un emisor y un receptor, así como también los mecanismos codificadores y decodificadores involucrados en el proceso y un canal de transmisión, podemos afirmar que los diferentes enfoques teóricos han puesto el énfasis en uno o en otro de estos elementos. La crítica literaria y artística heredada del siglo XIX subrayaba el papel del emisor y su intencionalidad creadora: más que estudiar la obra, frecuentemente el análisis se desviaba a la consideración de aspectos psicológicos, sociales o históricos alrededor del autor, su circunstancia y época, teniendo, por lo tanto, un carácter extrínseco. Las corrientes - de las que Eco es heredero- que han sido englobadas bajo el concepto de crítica inmanente, de las cuales el estructuralismo será el exponente más radical, centrarán el énfasis, en cambio, en el mensaje.

En el Eco de finales de la década de 1950 y principios de la siguiente, encontramos un intento - explicitado por él mismo en las citas arriba incluidas-de sistematizar las poéticas del mensaje y, partiendo de ello, dar

\footnotetext{
3 No deja de ser conflictivo referirse al arte en estos términos ya que no se trata propiamente de un proceso de comunicación, sino, si vale el término, de expresión. Sin embargo, dado que en nuestro planteamiento estamos abordando por igual la fotografía artística como los campos de la imagen fotográfica funcional, y que el autor aquí comentado también pasa de manera continua del comentario del arte al de los textos funcionales, hacemos la petición de principio de aceptar como válida esta categorización.
} 
un paso más: introducirse en las poéticas del receptor, cuya hora, según Castellet, había llegado. Cuando, en el texto citado, alude a Obra abierta, Eco seguramente aún no imagina la repercusión que ese libro tendrá. Hoy, viendo su corpus ensayístico en conjunto y conociendo la influencia de aquel, podemos considerarlo como su libro más influyente y al que él ha vuelto - se ha visto obligado a volver una y otra vez para explicar y matizar- sistemáticamente. En los siguientes años, Eco, como otros autores, vivirá la transición del énfasis teórico en el mensaje al énfasis en el receptor, aunque en su caso, como ya quedó establecido y advertido por él mismo, nunca se decantará completamente por el segundo, sino que buscará un equilibrio siempre anclado en la obra o, como veremos, en la intentio operis. Aunque el filósofo especialista en estética seguirá teniendo al arte en su horizonte, sus obras inmediatas se volcarán al estudio de los procesos comunicativos que abarcan el intercambio de mensajes funcionales en general en el marco de la sociedad de masas. Serán los años de la fundamentación de su teoría semiótica, primero definida negativamente en La estructura ausente, en la cual se aleja de la influencia estructuralista, y después definida positivamente, en Signo y el Tratado de semiótica general.

Pero, paralelamente al desarrollo de las ideas de Eco, por supuesto, había otras cosas sucediendo. Entre ellas, podemos apuntar principalmente dos. En primer lugar, el desarrollo de la teoría de la recepción literaria, representada fundamentalmente por la Escuela de Constanza, heredera de los principios hermenéuticos de Roman Ingarden, Hans G. Gadamer o Paul Ricoeur, los Peirce y Morris de aquel campo de conocimiento. Esta tendrá, en los años que venimos reseñando, un desarrollo notablemente paralelo al de la semiótica y al de la teoría anglosajona de los actos de habla. Como veremos en el siguiente apartado, las ideas de algunos de estos autores serán una influencia declarada para algunos de los representantes de la semiótica del índice, como Dubois y Schaeffer. En el caso de la semiótica del icono, y siguiendo nuestro rastreo de la evolución de Eco, será notable la confluencia de conceptos con la teoría de la recepción en su Lector in 
fabula, obra en la que, además, el autor insiste, como lo hará después en Los límites de la interpretación y en Interpretación y sobreinterpretación, en matizar y poner fronteras a su tan abusado concepto de apertura interpretativa. Así, ese resto de inmanencia en la crítica se manifestará en la consideración de ambas: la intentio lectoris, pero sin nunca perder de vista la intentio operis. Con sus propias palabras:

[...] la única alternativa a una teoría interpretativa radical orientada hacia el lector es propugnada por quienes afirman que la única interpretación válida apunta a encontrar la intención original del autor. En algunos de mis escritos recientes he indicado que, entre la intención del autor (muy difícil de descubrir y con frecuencia irrelevante para la interpretación de un texto) y la intención del intérprete que (citando a Richard Rorty) sencillamente «golpea el texto hasta darle una forma que servirá para su propósito», existe una tercera posibilidad. Existe una intención del texto. (Eco et ál. 1992: 35)

Y lo remarca de manera, si cabe, aún más explícita: «Entre la inaccesible intención del autor y la discutible intención del lector existe la transparente intención del texto, que desaprueba una interpretación insostenible». (Eco et ál., 1992: 92) Esto nos lleva a la segunda influencia, que para Eco ha funcionado a contrario, a saber, la de la teoría de la deconstrucción, identificada por él como el extremo de esa discutible intención del lector. Al respecto, argumenta:

[...] la noción de semiosis ilimitada no conduce a la conclusión de que la interpretación carece de criterios. Afirmar que la interpretación (en tanto característica básica de la semiosis) es potencialmente ilimitada no significa que la interpretación no tiene objeto y que fluye (riverruns) solo por sí misma. Afirmar que un texto no tiene potencialmente fin no significa que todo acto de interpretación pueda tener un final feliz. (Eco et ál. 1992: 33-34)

Sin que este sea el lugar para desarrollar dicho debate, solo apuntaremos la respuesta que Culler le dirige en su texto En defensa de la sobreinterpretación, incluido en la misma obra colectiva citada:

Muchas de las formas más interesantes de la crítica moderna no preguntan qué tiene en mente la obra, sino qué olvida, no lo que dice sino lo que da por sentado. [...] 
Umberto Eco parece considerarla [la deconstrucción] como una forma extrema de la crítica orientada al lector, como si afirmara que un texto significa lo que un lector quiera que signifique. (Culler, en Eco et ál. 1992: 134 y 139)

La confluencia durante las últimas décadas del pasado siglo de la semiótica, la teoría recepción, incluso de la neorretórica, se dará también en el marcado enfoque pragmático que adoptarán. Ya de manera temprana Morris se había referido a la semiótica como un tipo de análisis sintácticosemántico-pragmático. Sin embargo, mientras que en las décadas de 1960 y 1970 el impulso del análisis inmanente siguió privilegiando a los dos primeros, el vuelco hacia el receptor provocó que, desde los años 1980 hasta hoy, por supuesto con continuas matizaciones, la pragmática haya adquirido cada vez más relevancia. (Dada la importancia de este aspecto para el presente trabajo, le dedicaremos un espacio privilegiado en el apartado 3.5, para después desarrollar una propuesta de pragmática fotográfica en los capítulos 7y 8 .)

Por su parte, Eco, tal vez más centrado en su ya prolífica faceta de novelista y en sus ensayos filosóficos, se ha alejado de la corriente semiótica de la que hace tiempo es un referente, para atender a otras inquietudes. Llama la atención, en una reciente recopilación de escritos periodísticos, A paso de cangrejo, no solo el título, sino el subtítulo: Artículos, reflexiones y decepciones. Efectivamente, en él encontramos a un Eco decepcionado, acaso, de lo mal que nos seguimos comunicando después de haber especulado tanto acerca de la comunicación; también expresa su decepción repecto del uso irresponsable, si cabe el término, que se sigue haciendo de los medios masivos, tras haber reflexionado tan extensamente acerca de ellos. En particular, hay una manifiesta decepción en lo que toca a la política y los media en su Italia. ¿Será que Eco, como el profeta Castellet, se ha hecho mayor? 


\subsection{LA CODIFICACIÓN ELUDIDA EN EL ANÁLISIS INMANENTE}

Permítasenos la licencia de iniciar este apartado con una pirueta literaria. Dice un escritor, a su vez, citando a otro:

«¿Cómo escribir sobre Constantinopla si todo ha sido dicho?», se lamentaba, no sin razón, a mediados del siglo XIX, uno de los autores románticos adeptos al sistema de l'education par le voyage. [Y agrega que, respecto del tema,] la ingente masa de informes compone un formidable corpus textual dotado de vida autónoma, en el cual los libros se apoyan unos en otros, se alimentan unos a otros hasta formar un verdadero árbol genealógico literario cuyas hojas, brotes y ramas extraen su savia de un tronco integrado a menudo de informes dudosos, relatos de segunda mano, fantasías, leyendas, mitos. 4

¿Existe en la actualidad —nos preguntamos- algún campo de conocimiento al que no se puedan aplicar las anteriores palabras? ¿Qué hay de la teoría fotográfica? En La cámara lúcida, Barthes (1980: 152) advertía de la dificultad de abordar el tema de la fotografía por ser esta «un objeto antropológicamente nuevo». En los apartados anteriores establecimos que, grosso modo, hasta 1989 la bibliografía sobre el tema se mantuvo como un conjunto bastante restringido de textos —para reafirmar esta idea bastaría compararla, por ejemplo, con la vastedad de la dedicada a un objeto antropológicamente aún más nuevo y descendiente directo de ella: el cine- Esta es una particularidad atípica que, puede pensarse, habría permitido a sus estudiosos construir un edificio teórico sólidamente cimentado. Sin embargo, la realidad contradice esta suposición: la teoría fotográfica se edificó precisamente sobre informes dudosos, relatos de segunda mano, fantasías, leyendas y mitos, y no fue sino hasta la década de 1980 cuando -junto con otros fenómenos complejos en los que no podemos detenernos, entre ellos: su plena incorporación al mercado del arte y a la academia, las nuevas propuestas para historiarla, sus nuevas formas de distribución, su absoluta masificación y espectacularización-, al

\footnotetext{
${ }^{4}$ Goytisolo, Juan [1989]. Estambul otomano. Barcelona: Península, 2003.
} 
iniciarse un intento de sistematización, se encontró con el hecho de que sus cimientos eran débiles.

Debido a ello, en la disciplina semiótica, los autores que en esa época comienzan la labor de traducción de los conceptos generales sobre imagen que se encuentran en la corriente representada por Eco al campo específicamente fotográfico, caerán en algunos usos léxicos irritantes. Principalmente nos referimos a dos circunstancias: por un lado, la semiótica, como hemos visto, es aún en ese entonces una disciplina en construcción, por lo que es frecuente que los ensayos de diferentes teóricos no compartan una misma terminología, lo que los tiñe de hermetismo y los hace parecer rebuscados. Por otro lado, si bien los libros y autores de primera generación están bien identificados, la proliferación de estudios de segunda y tercera generación no solo crece exponencialmente, sino que acrecienta el efecto Babel. La combinación de ambos factores provocará que, en sus propuestas, los nuevos autores de la década de 1980 no aborden directamente y con naturalidad los temas tratados, sino que dediquen interminables capítulos introductorios al establecimiento de genealogías y, más aún, a hacer una verdadera arqueología de algunos términos especializados. Es en este marco que se entienden esfuerzos de compilación y consenso como por ejemplo el de Greimas y Courtés con su Semiótica: diccionario razonado de la teoría del lenguaje (1979) o el de Beristáin con su Diccionario de retórica y poética (1988).

Al mirar retrospectivamente los ensayos de ese momento, las características reseñadas nos parecen ingenuas $\mathrm{y}$, en cierta medida, también engorrosas, ya que confieren a los textos una excesiva densidad. A partir de la década de $1990 \rightarrow$ y aquí hacemos la gran petición de principio de aceptar como válida una generalización tan abrupta- la semiótica ha devenido una especie de herramienta intermedia para el análisis y la interpretación, más que un fin en sí misma. La terminología semiótica se ha ido asimilando a otros enfoques, incluso a textos divulgativos, con el resultado de que sus propuestas de análisis inmanente han logrado una mayor aplicabilidad en la práctica. Esta tendencia de simplificación con 
vistas a la claridad se percibe incluso en grandes nombres de la disciplina, como Sebeok (1994), o en la propia evolución de autores que empiezan a producir de manera más reciente. Tal es el caso de J oly (1993, 1994 y 2002), quien, sosteniendo posiciones claramente semióticas, acusa también una gran influencia de otros enfoques que han ido ganando preeminencia, como son, por ejemplo, los estudios visuales.

Si bien algunos autores se han volcado al estudio de la especificidad fotográfica, sus propuestas teóricas en torno a los procesos de codificación frecuentemente son parciales. Así sucede, por ejemplo, con Vilches (1983 y 1987), quien habla fundamentalmente desde el campo de la imagen periodística, o con J oan Costa (1977, 1988 y 1991), quien elabora una teoría del lenguaje fotográfico desde la óptica del diseñador gráfico, para quien la fotografía es más bien un producto intermedio que un fin en sí mismo. Cabe señalar que, mientras que el primero está claramente influido por la semiótica de Eco, en el caso de Costa asistimos a un pensamiento original el cual, aunque permeado de una terminología propia de esa disciplina, se encuentra más fundamentado en la teoría de la información. En cualquier caso, destaca el hecho de que ambos autores construyen sus propuestas desde campos ajenos al de la estética.

Mención aparte merece el caso de Philippe Dubois. Mientras que este autor hace en su célebre El acto fotográfico (1983) una apología de la semiótica del índice y la semiótica del icono en un aparente intento de reconciliación de ambos enfoques, finalmente acaba decantándose hacia el primero. Hay en el libro de Dubois, además, una promesa sin cumplir: nos referimos al aspecto pragmático de la fotografía. Indudablemente, la construcción teórica de Dubois está influida por las ideas de la teoría de la recepción literaria; desde el título de su obra, resuena el eco de El acto de leer (1976), de Wolfgang Iser. ${ }^{5}$ Sin embargo, la antigua aspiración de Morris de ver concretada la semiótica como un análisis de tipo sintácticosemántico-pragmático tampoco se ve aquí cristalizada. Si bien el subtítulo

\footnotetext{
${ }^{5}$ No olvidemos, asimismo, que desde 1969 se difunden las ideas de J ohn Searle acerca de los actos de habla, cuya influencia ha sido plenamente asumida por J ean-Marie Schaeffer (cfr. 1987), otro de los representantes de la semiótica del índice.
} 
del libro de Dubois es de la representación a la recepción, es esa precisamente la promesa incumplida a la que nos referimos: mientras que se profundiza en la pragmática del acto de producción fotográfica, la pragmática del acto de recepción permanece sin ser desarrollada. Por su parte la semiótica del índice, como ya señalamos (ver supra: Capítulos 1 y 3.2), caerá enferma de ontología y se alejará del intento de explicación de los procesos de codificación fotográfica.

$\mathrm{Si}$ hemos hecho un comentario somero de las ideas y enfoques de estos teóricos —quienes, dicho sea de paso, son solamente unos cuantos de los que constituyen nuestro marco teórico- es porque de esa forma dejamos traslucir una pequeña parte del debate que caracterizó a la semiótica fotográfica durante las décadas de 1960 a 1980. Como disciplina en formación, el enfoque semiótico produjo un gran entusiasmo en ciertos medios, aunque hoy en día este se encuentra diluido. Nuestro particular punto de vista es que la semiótica tiene la virtud, al abordar el fenómeno fotográfico, de proporcionar criterios aplicables a imágenes provenientes de diversos campos y espacios discursivos, como el arte, el periodismo, la publicidad, la ciencia o incluso el de sus usos a nivel de memoria familiar. Este tipo de transpolaciones entre campos es particularmente conflictivo al ser aplicado a otros marcos conceptuales, como son el estético o el socioantropológico.

Ese carácter intermedio, de herramienta, que hemos apuntado respecto de la semiótica, la convierte desde nuestro punto de vista en un enfoque ciertamente limitado - tanto como otros- en términos de su capacidad interpretativa del mensaje fotográfico. Al mismo tiempo, reconocemos en ella su extrema utilidad para abordar la pregunta específica de cómo significa, cómo está construido el mensaje, pregunta que hemos fijado como un paso previo a la interpretación, esto es, la respuesta al qué significa. Aunque en la mente del receptor ambas preguntas no se plantean de manera secuencial, sino simultánea e interdependiente, valga aquí la disyunción. 


\subsection{EL ANÁLISIS EXTRÍNSECO: LOS CÓDIGOS CONTEXTUALES Y EL GIRO PRAGMÁTICO}

Apelemos, una vez más, a los clásicos. En La fotografía como documento social, Gisèle Freund (1974: 159 y ss.) reflexiona a partir de una foto de Doisneau (Imagen 9) acerca de la forma en que los significados de la imagen varían en función del canal de comunicación en que es difundida.

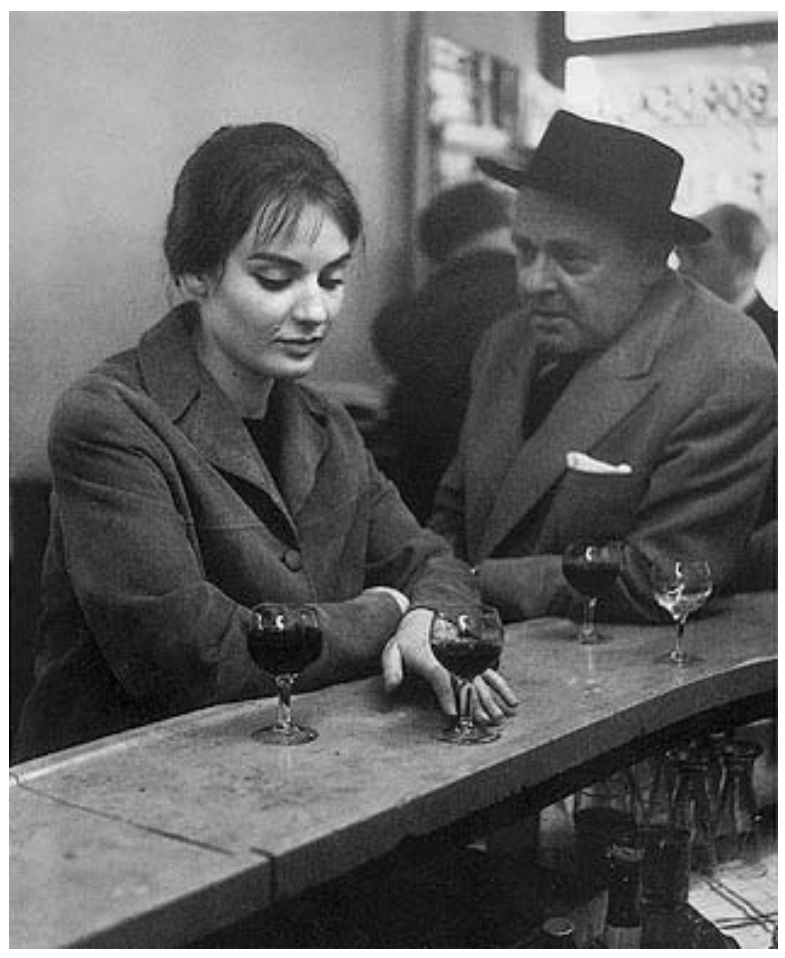

Imagen 9. Robert Doisneau

Sin título, 1958

La anécdota es muy conocida: un hombre maduro y una joven que no se conocen entre sí son fotografiados en un bar haciendo lo que infinidad de 
franceses hacen a diario: tomar una copa. La foto es utilizada por una revista para ilustrar un texto acerca de los bares de París y, posteriormente, pasa a una agencia. Tiempo después, aparece en otra publicación ilustrando un artículo sobre el alcoholismo y, más tarde, es plagiada para uno en torno a la prostitución. Se produce un escándalo legal debido a la denuncia que hace el hombre retratado, pero... veamos la imagen. Él mira frontalmente a la chica; ella, por su parte, baja tímidamente su mirada y juega nerviosamente con la copa. Su actitud no verbal denota que está inquieta, pero, ¿lo está debido al hombre a su lado o más bien por la presencia del fotógrafo y la cámara, por verse súbitamente en una situación extraña que no puede controlar? ¿Hay algo en su actitud o su arreglo que nos haga verla como una prostituta? ¿O a alguno de los dos como un alcohólico? ¿La narración está en la mente del espectador...o en el texto que acompaña a la imagen y el tipo de publicación que la difunde? Si un análisis inmanente de la imagen no nos da elementos suficientes para soportar la segunda y tercera lecturas reseñadas, en el momento en que entran en acción factores extrínsecos, lo que Joly llama «el invisible y todopoderoso contexto» (2002: 99), una interpretación descuidada de la imagen puede tomar los cauces más insospechados.

La anécdota que hemos traído a colación también remite a lo señalado en otro clásico y que, a pesar de su amplísima divulgación, no está de más mencionar. Nos referimos a la concepción introducida por Barthes en un texto tan temprano como El mensaje fotográfico, en el que advierte que, en el caso de la fotografía de prensa, el canal de transmisión es

[...] el propio periódico o, para hablar con más precisión, un complejo de mensajes concurrentes que tienen a la fotografía como centro, pero cuyo entorno está constituido por el texto, el titular, el pie de foto, la compaginación y, también, de un modo más abstracto pero no menos «informativo», la misma denominación del periódico (puesto que su nombre constituye un saber que puede pesar muchísimo en la lectura del mensaje propiamente dicho [...]. (Barthes 1961: 11)

En esta breve revisión, hemos mencionado un término sobre el que necesariamente debemos detenernos, a fin de afrontar la difícil tarea de 
pasar del ámbito del análisis inmanente al del análisis extrínseco: nos referimos a la palabra contexto. Para ello, es necesario que ampliemos nuestro campo y no solo consideremos, como ya habíamos establecido, el edificio teórico a partir del cual abordamos la imagen, sino incluso el factor de en qué tipo de terreno y entorno está construido dicho edificio. Si ya habíamos comentado que la misma foto no se interpreta igual desde un edificio-museo que desde un edificio-agencia noticiosa, o un edificioacademia, o un edificio-centro comercial, ahora habremos de aspirar a ir más lejos y considerar, adicionalmente, en qué entorno geopolítico, sociológico y cultural está situado el edificio - esto adicionalmente al contexto temporal一, el cual aporta lo que Eco (1968: 446) denomina los significados epocales. Así, vemos cómo esta aproximación puede hacerse desde distintas perspectivas disciplinarias.

Pero, ¿no es acaso el término contexto una palabra saco, que en su extrema ambigüedad y en sus innumerables connotaciones acepta cualquier significado y, por lo mismo, deja de ser significativa? Desde un punto de vista sociológico, por ejemplo, resuenan aquí una vez más los conceptos de Bourdieu a los que ya apelamos (ver supra: Capítulo 2), como el de habitus, el cual nos recuerda que «las conductas pueden ser orientadas con relación a fines sin estar conscientemente dirigidas hacia esos fines, dirigidas por esos fines. La noción de habitus fue inventada [...] para dar cuenta de esta paradoja». (Bourdieu 1987: 22) El contexto, en un sentido amplio, también se vincula con las nociones del mismo autor de ethos, de campo o inclusive de clase. Si en la comunicación funcional el productor de imágenes apela al saber social, codificado, contextual, para lograr que los mensajes que produce se traduzcan en una comunicación fluida, en el campo artístico el productor también lo tiene como marco de referencia, aunque en su caso muy probablemente lo sea a contrario, para problematizarlo:

El estetismo, que hace de la intención artística el principio del arte de vivir, implica una especie de agnosticismo moral, antítesis perfecta de la disposición ética que subordina el arte a los valores del arte de vivir. La 
intención artística no puede sino contradecir las disposiciones del ethos o las normas de la ética que definen en cada momento, para las diferentes clases sociales, los objetos y los modos de representación legítimos, excluyendo del universo de lo que puede ser representado ciertas realidades y ciertas maneras de representarlas: ¿acaso la manera más fácil, y por lo tanto la más frecuente y la más visible de «épater le bourgeois», poniendo a prueba el alcance del poder de constitución estética, no consiste en transgredir cada vez más radicalmente las censuras éticas (en materia sexual, por ejemplo) que las otras clases se dejan imponer incluso en el terreno de lo que la disposición dominante constituye como estética? $\mathrm{O}$, expresado con mayor sutilidad, ¿en construir como estéticos objetos o maneras de representarlos que están excluidos por la estética dominante del momento u objetos constituidos estéticamente por unas «estéticas» dominadas? (Bourdieu 1979: 44)

De lo anterior se desprende que el ethos constituye, de la manera más amplia, un contexto ético y estético marcado por la ideología y, por lo tanto, el concepto de dominación al que Bourdieu apela tampoco es gratuito. A partir de este hilo discursivo podríamos vincular la aportación contextual a la significación del mensaje con otras disciplinas que, sin ser nuestras plataformas teóricas fundamentales, sí se encuentran dentro de nuestro horizonte. Tal es el caso, por ejemplo, de la mediología cuando afirma que

[...] la acción que nuestras figuras ejercen sobre nosotros varía con el campo de gravitación en el que las inscribe nuestro ojo colectivo, ese inconsciente compartido que modifica sus proyecciones de acuerdo con nuestras técnicas de representación. [La mediología] tiene, pues, por objeto los códigos invisibles de lo visible, que definen de manera sumamente ingenua, y referido a cada época, un estado del mundo, o sea, una cultura. (Debray 1992: 15)

La teoría de la información, por su parte, también ofrece aportaciones respecto de los intercambios entre el creador y el receptor con el, en ocasiones, etéreo e indeterminado marco de incontables influencias epocales. Desde esta perspectiva y respecto de la actividad creativa, por ejemplo, Moles señala que

[...] los pensamientos - brutos, fantasiosos- terminan por permanecer estrechamente condicionados, modelados por el lenguaje que a la vez es almacén de conceptos imaginarios y de modos, aunque solo sean gramaticales, de ensamblado. «El pensamiento no puede ser más preciso que la lengua de la que se sirve» y Wittgenstein añadía: «El límite de mi 
pensamiento son los límites de mi lenguaje» («The limits of my thinking are the limits of my language»). [Y concluye:] La gramática nos parece entonces ser una infralógica, el primer impacto de la razón y la seriedad sobre el pensamiento más íntimo y más individual. (Moles 1984: 143-144)

Esta concepción se vincula con la idea planteada por Eco en un texto temprano cuyo título es en sí casi una declaración de principios y a partir del cual puede leerse gran parte de su extensa producción posterior. Nos referimos a De la manera de formar como compromiso con la realidad (Eco: 1962b), reflexión centrada en la discusión acerca de la posibilidad de una alienación en el lenguaje. Pero volvamos a Moles para cerrar el apunte en torno a la concomitancia entre estos dos grandes pensadores de la comunicación, pertenecientes a un mismo espíritu de época:

Para el hombre de ciencia como para el artista, concepción del mundo y tendencia personal están estrechamente relacionadas con su época; esta sitúa a los creadores en un ambiente conceptual cuya descripción es tarea de los filósofos. Hay, pues, una correlación estrecha entre ciencia y filosofía, no siendo el espíritu de una y otra más que «el espíritu de la época» en la medida en que es susceptible de enunciarse y definirse objetivamente. Se debe, sin embargo, advertir aquí un sistemático desajuste temporal de una relación con la otra. [...] Parece, sin embargo, que este retraso, que se diría corresponde al plazo necesario para que una doctrina influencie a una nueva generación por medio de la enseñanza, disminuye poco a poco con la aceleración de los intercambios de ideas y de información. (Moles 1984: 362363)

Puestos en este juego asociativo de diversas disciplinas y enfoques con el concepto de contexto, no podemos dejar de señalar que el mismo hilo nos puede conducir también a la perspectiva de los estudios culturales, marcados precisamente por la concepción de que en toda interpretación, el énfasis está puesto en el contexto ideológico a partir del cual se aborda el acto comunicativo en su conjunto, esto es, en sus facetas tanto productiva como receptora, y en un énfasis en la idea arriba planteada, en la cita de Bourdieu, de las estéticas dominantes y las dominadas. Así, podemos proponer que la dimensión del contexto es variable y puede abarcar desde la consideración del receptor — respecto del que en las últimas décadas se ha creado un verdadero culto-, esto es, la persona entendida como un 
contexto ambulante con su museo imaginario (Malraux 1947) y su enciclopedia (Eco 1975), hasta la dimensión absoluta, infinita, de esa constelación que tanto la sociología como la teoría de la comunicación han bautizado con distintos apelativos tan sugerentes como espectaculares, más o menos vinculados a la imagen, más o menos vinculados a la técnica, más o menos vinculados a los medios de comunicación, a saber: semiosfera (acaso el más abarcador, debido a Lotman 1971-1993), iconosfera (Gubern 1987), mediasfera (Moles 1981; Debray 1992) o sociedad red (Castells 1996 y 2001). La amplitud de estos conceptos contrasta con una visión estrictamente semiótica. En este sentido, es el propio Eco quien advierte de un uso más cerrado y disciplinar del término contexto, entendido como

[...] la posibilidad abstracta, registrada por el código, de que determinado término aparezca en conexión con otros términos pertenecientes al mismo sistema semiótico. Por consiguiente, dado un término como /gato/, una buena representación semántica debe considerar una selección contextual que advierta que, cuando aparezca en conexión con expresiones como /coche/, / rueda/, / neumático/, etc., dicho término designará determinado artificio mecánico que se usa para cambiar una rueda de coche. En un contexto biológico más amplio, donde aparezcan marcas como /animado/, etc., el término en cuestión será desambiguado como referido a un animal [...]. (Eco 1979: 28)

La semiótica actual, heredera de las bases teóricas sentadas por Eco, no ha dejado, sin embargo, de abrir el alcance de su concepción del contexto, aun teniendo en su horizonte los fundamentos establecidos por el maestro. En el campo específico de la semiótica de la imagen, parecería que la ineludible vinculación del mensaje a factores externos $-\mathrm{y}$ aquí aparecen una vez más las concepciones barthesianas- hace que su sentido sea particularmente susceptible a la influencia de los elementos contextuales. Así lo establece Joly, una especialista en el campo de la semiótica iconal cuyas ideas no han dejado de enriquecerse a lo largo de las últimas dos décadas:

[...] la imagen, es necesariamente polisémica en la medida en que es un enunciado icónico complejo; pero no podemos hacer de la polisemia su especificidad en la medida en que todo enunciado complejo (verbal o no 
verbal) es polisémico. La polisemia tiende a esta complejidad que exige entonces un contexto para dispersar las ambigüedades que suscita. Esta misma complejidad necesita, si queremos reducir una gran cantidad de significaciones y de interpretaciones inducidas, recurrir a un contexto y a un contexto verbal o icónico a su vez, así como a medios de transmisión particulares (prensa, lienzos, muros, pantallas, etc.), ellos mismos inscriptos en situaciones e instituciones particulares. (J oly 1994: 95)

En el campo del arte, en las últimas cinco o seis décadas se ha asistido a una creciente inclusión del espectador o receptor en el proceso interpretativo, lo cual no solo se ha visto reflejado en las propuestas de producción artística, sino también en las construcciones teóricas alrededor del fenómeno artístico. Consctrucciones que, en algunos casos, han partido de los mismos artistas. Como muestra podemos citar las elaboraciones tanto artísticas como teóricas que a partir de las concepciones tempranas de Barthes, arriba citadas, hicieron en su momento creadores como Victor Burgin o Allan Sekula, quien

[...] se muestra particularmente preocupado por el «grado extremo en que el significado de la fotografía depende del contexto», de acuerdo con una reflexión teórica originada por Barthes acerca de la falacia de la fotografía como pura denotación. La crítica de Barthes establece la existencia de un nivel de connotación, que viene dado por el contexto de presentación, sobre el cual la fotografía adquiere significado y fuera del cual carece de él. (Ribalta 1989: 52)

En un campo más amplio, una de las construcciones teóricas más exitosas se ha fundado en el concepto de horizonte de expectativas, enmarcado en la teoría de la recepción literaria de Jauss. El nivel de participación solicitado al receptor no ha dejado de crecer durante toda la segunda mitad del siglo pasado y los inicios del presente, y lo mismo puede decirse del nivel de implicación social del artista. Así lo atestiguan, por ejemplo, dos construcciones teóricas recientes que intentan dar cuenta de esta tendencia: nos referimos a la estética relacional (Bourriaud 2002) y a la concepción de una arte contextual (Ardenne 2002), adherido estrechamente a eso, en ocasiones tan paradójicamente vago, que llamamos realidad y basado en la co-presencia, en «una lógica de implicación que ve 
la obra de arte directamente conectada a un sujeto que pertenece a la historia inmediata». (Ardenne 2002: 13) Como consecuencia, si con anterioridad nos referimos —como con Eco- a formas más o menos cerradas de connotar la palabra contexto, en este campo enfrentamos acaso las más abiertas:

\begin{abstract}
El «contexto» $[. .$.$] designa el «conjunto de circunstancias en las cuales se$ inserta un hecho», circunstancias que están ellas mismas en situación de interacción (el «contexto» etimológicamente es «la fusión», del latín vulgar contextus, de contextere, «tejer con»). Un arte llamado «contextual» agrupa todas las creaciones que se anclan en las circunstancias y se muestran deseosas de «tejer con» la realidad. [Y agrega:] Si el arte arcaico se aplicó a darle forma al pensamiento simbólico, si el arte clásico se lanzó sin medida en la búsqueda de una expresión que tendía a dominar lo visible y a reglamentarlo, si el arte moderno se realiza en su tiempo en la libertad creadora, corriendo a veces el riesgo del solipsismo (hacer de la creación una producción autónoma hasta en su significado), el arte que ha tomado el relevo será mejor definido por la preocupación de la contextualidad. El arte «contextual» deja el territorio del idealismo, le da la espalda a la representación, pretende sumergirse en el orden de las cosas concretas. (Ardenne 2002: 141)
\end{abstract}

Con base en el carácter multidisciplinar de las anteriores reflexiones, podemos entonces apuntar algunas de las innumerables connotaciones de la palabra contexto:

- Contexto como enciclopedia.

- Contexto como tradición.

- Contexto como museo imaginario.

- Contexto como inconsciente colectivo.

- Contexto como inconsciente óptico.

- Contexto como espíritu de la época.

- Contexto como marco ideológico.

- Contexto como el conjunto de las maneras de formar.

- Contexto como el medio que es el mensaje.

- Contexto como estructura del propio mensaje.

- Contexto como el conjunto de la propia obra de un autor.

- Contexto como situación o circunstancia de comunicación.

- Contexto como marco participativo, relacional.

- Contexto como horizonte de expectativas.

- Contexto como entorno geo-socio-político.

- Contexto como entorno histórico-temporal.

- Contexto como semiosfera. 
A esta multitudinaria constelación de atributos hemos de sumar la transformación reciente de esa que ocupa el último lugar en la lista anterior, la semiosfera a la que ya antes aludíamos, así como de la sociedad red, respecto de cuyas profundas implicaciones para el campo fotográfico en particular reflexionaremos en el Capítulo 8. De momento, centrémonos en el hecho de que si el contexto es todo esto que acabamos de reseñar, la tarea de abordarlo para plantear un análisis pragmático nos deja, en principio, perplejos. Y aquí aparece el segundo concepto en el que hemos de detenernos: el de pragmática, acerca del cual se hace imperativo profundizar en este punto de nuestra reflexión ya que su relevancia para nuestro discurso viene establecida desde su presencia en el título de este trabajo.

Hagamos un poco de genealogía. El sentido general que actualmente se le atribuye a este término tiene que ver precisamente con la influencia del contexto en la conformación del sentido de los mensajes. Mientras que, como ya hemos apuntado, el análisis inmanente se centra en el mensaje mismo, el enfoque pragmático abre la puerta de un análisis extrínseco. Esta concepción va mucho más allá de la simple consideración de los deícticos o expresiones indexicales, en los que han puesto énfasis diversos autores, principalmente en torno a la teoría de los actos de habla, en relación a la cual hay que considerar que su influencia no apunta exclusivamente al estudio del lenguaje verbal, sino que abarca los lenguajes icónicos, como sería el caso, por ejemplo, del uso de flechas de dirección en la señalética o de los actantes mirando directamente a la cámara y, por lo tanto, asumiendo la presencia del espectador, recurso de amplia utilización en la fotografía publicitaria. Pero es en el terreno de la lingüística que las concepciones pragmáticas toman fuerza para, como se he dado en infinidad de casos, ser adoptadas posteriormente en el campo del iconismo. Así, considerada en un sentido amplio, la pragmática puede vincularse con la concepción saussureana de habla como puesta en acto, enfrentada a la de lengua entendida como sistema. Esta concepción está en el trasfondo que subyace a formulaciones posteriores como son la teoría del acto de leer, de 
Isser, o la de los arriba referidos actos de habla o speech acts de Searle, que en el campo específico de la teoría fotográfica han influido en autores como Dubois (1983) o Schaeffer (1987), respectivamente. (Ver supra: 3.4)

De la misma manera en que lo apuntamos en relación al término contexto, el ángulo de cobertura de la palabra pragmática se empieza a abrir debido a la heteronomía de autores que lo derivan a diversos campos. Así, por ejemplo, no es extraño encontrar a un pensador -historiador, psicólogo social, antropólogo- como de Certeau haciendo las siguientes reflexiones:

En el caso del consumo, uno podría casi decir que la producción proporciona el capital y que los usuarios, como arrendatarios, adquieren el derecho de efectuar operaciones sobre este fondo sin ser los propietarios. Pero la comparación vale solamente para la relación entre un conocimiento de la lengua y unos «actos de habla» (speech acts). Por esta sola razón, se cuenta ya con una serie de cuestiones y de categorías que han permitido [...] abrir en el estudio del lenguaje (semiosis o semiotic) una sección particular (llamada pragmatics) consagrada al uso o a las indexical expressions, es decir, «a las palabras y a las frases cuya referencia no puede determinarse sin conocer el contexto de uso». (de Certeau 1980b: 397)

El propio de Certeau hace un recorrido a través de conceptos vinculados a la consolidación de la noción que nos ocupa, mencionando, entre otros, a Peirce (pragmática), Russell (egocentric particulars), o incluso Wittgenstein (Don't ask for the meaning, ask for the use). El comercio transversal de conceptos no deja, sin embargo, de ser una actividad riesgosa en la que comúnmente la importación y exportación de bienes intelectuales se ve sujeta a aranceles y cargas impositivas, pero también al contrabando, la piratería y a los avatares del mercado negro. Cuando se trata de conceptos generales y abarcadores, equiparables a materia prima, es posible dar seguimiento a sus fascinantes transformaciones. Así, y en este caso dentro del ámbito del comercio justo, vemos cómo la genealogía del término establecida por de Certeau forma parte de la manufactura de su propio concepto de lo relacional, ya que finalmente lo que a él le interesa es que uno de los aspectos de la enunciación es «la implantación de un interlocutor (real o ficticio), y por 
tanto la constitución de un contrato relacional ${ }^{6}$ o de una alocución (se habla a alguien)». (de Certeau 1980b: 397) Siendo más específicos, si damos seguimiento al hilo conceptual subyacente, el giro pragmático también está presente en la estética de la recepción, expresión que, por supuesto, también hace resonar el eco de otra influyente y seminal teoría surgida en la década de 1970, a saber, la de Hans Robert J auss.

Otra línea conceptual paralela que ya hemos mencionado sesgadamente, pero en la que es necesario ahondar en este punto, es la de los estudios culturales, que desde su inicio en Birmingham en la década de 1960 han presentado vaivenes y, si bien se caracterizaron en algún momento por «la utilización de disciplinas nuevas como la semiología» (Mattelart y Neveu, 2003: 109), con el tiempo no solo la han incorporado plenamente, sino que su destino en cuanto a presencia en el ámbito académico ha sido inversamente proporcional al de aquella, que la ha ido perdiendo paulatinamente en los últimos quince años. Así lo muestra, por ejemplo, una estadística elaborada por Elkins (2007: viii) con base en las palabras clave utilizadas para etiquetar trabajos de investigación en el ámbito de la teoría e historia del arte y que concluye que, mientras que el uso de la palabra semiótica ha descendido ligeramente a partir de la década de 1990, la deconstrucción ha mantenido una tendencia positiva, aunque comparativamente de carácter marginal; sin embargo, frente a esto, otras etiquetas más directamente vinculadas a los estudios culturales han presentado un incremento, como en el caso de la de teoría visual, que siendo menor en proporción a la semiótica, ha tenido un leve repunte, y sobre todo la etiqueta feminismo, en cuyo caso la frecuencia de uso era ligeramente menor al de semiótica hasta el año 90, pero que desde entonces se ha disparado hasta prácticamente doblarla.

No puede dejar de verse en los estudios culturales un esfuerzo específico del ámbito académico anglosajón por situarse en el mapa de las teorías en boga en el marco de la nueva valoración del acto de recepción en el que hemos venido insistiendo en este capítulo. En este caso, sin embargo,

\footnotetext{
${ }^{6}$ Años más tarde, este concepto será incorporado por Bourriaud en su teoría estética.
} 
tal vez el énfasis fue desmedido, más aún que en el caso de la deconstrucción, cuya crítica hemos hecho unos párrafos más arriba al rememorar el debate entre Eco y Culler. En el caso de los estudios culturales, la visión desmitificadora de Mattelart y Neveu (2003) nos sirve como un termómetro, ya que está planteada desde afuera de los intereses viciados económicamente de la propia industria del libro anglosajona, con la editorial Routledge a la cabeza -la misma, por cierto, que publica al recién citado Elkins-. Pero, volviendo al asunto de la valoración del sujeto receptor, que es en el fondo lo que une a los enfoques que venimos discutiendo, encontramos la siguiente posición:

No puede negarse el mérito de las nuevas reflexiones sobre las audiencias que no hacen sino insertarse en un movimiento epistemológico más general de «retorno al sujeto» y a los juegos de la intersubjetividad [...]. Perturban las teorías deterministas que, en el transcurso de las décadas anteriores, han puesto demasiado énfasis en el peso de los «invariantes», en la estructura, y en la alienación que produce en un consumidor reducido a la condición de receptáculo. Semejante cambio de óptica permite interrogarse acerca del margen de maniobra que, entre la autonomía individual y la obligación, el orden social y productivo le deja efectivamente a «los que practican», pero es necesario señalar su ambivalencia. Existe un riesgo real de pasar de la clausura del texto soberano a la reclusión en la recepción soberana. (Mattelart y Neveu 2003: 98)

Parecería que estamos hablando de la propia situación de la semiótica y de la escuela de Constanza cuando los propios autores citados tachan a los estudios culturales de padecer recepcionitis, en su afán de dejar atrás los dogmas inmanentistas del estructuralismo. Una vez más, estamos frente a interpretaciones diversas de algo que flota en el aire como denominador común de un espíritu de época. Sin embargo, mientras que la escuela de la recepción de Constanza permanecerá vinculada al análisis literario, tanto la semiótica como los estudios culturales extenderán infinitamente su ámbito de intereses, en el caso de los segundos, con un marcado énfasis pragmático.

Birmingham será uno de los primeros equipos en atraer la atención de las ciencias sociales sobre bienes tan profanos como la publicidad o la música rock [...]. Pero [...] son los medios audiovisuales y sus programas de 
información y entretenimiento los que poco a poco serán objeto de estudio mediante encuestas. Merece ser destacado un texto importante. En «Codificación/descodificación» (1977, Réseaux, nº 68, 1994, pp. 27-39), Hall desarrolla un marco teórico que pone de relieve que el funcionamiento de un medio no puede limitarse a una transmisión mecánica (emisión/recepción) sino que ha de darle forma al material discursivo (discurso, imágenes, relato) en el que intervienen datos técnicos, condiciones de producción y modelos cognitivos. Este marco analítico, hoy en día, puede parecer trivial. Pero entonces implicaba tener en cuenta todas las situaciones de desfase, de equívocos entre códigos culturales, es decir, las gramáticas mediáticas que prevalecen en la producción del mensaje, por un lado, y las referencias culturales de los receptores, por otro. Bastaba con eso para trastornar las rutinas de la sociología empírico-funcionalista de los medios, escasamente preocupadas por las condiciones de producción de los mensajes. La noción de descodificación invita a tomarse en serio el hecho de que los receptores tienen sus estatus sociales, sus culturas, y que ver o escuchar un mismo programa no implica darle un sentido o evocar un recuerdo similar. (Mattelart y Neveu 2003: 57)

La aparente novedad de este abanico de estudios implicará siempre para los anglosajones, no obstante, tener la espina clavada de un origen francés, ya que es su establecimiento estarán presentes de manera incuestionable Barthes y otros autores vinculados a las revistas Tel Quel y Communications - Christian Metz, Julia Kristeva - en lo que de manera retrospectiva se conoce como la aventura semiológica. En el caso del interés específico de los estudios culturales, ahora desde el campo de la sociología, por las manifestaciones y apreciaciones de las clases populares y los grupos concretos de consumidores, faltará, asimismo, el rigor de un Bourdieu. En síntesis, la propuesta del enfoque que nos ocupa, reducida a su expresión mínima, sería que en los estudios culturales

Se trata de considerar la cultura en sentido amplio, antropológico, de pasar de una reflexión centrada en el vínculo cultura-nación a un enfoque de la cultura de los grupos sociales. Aunque permanece sujeta a una dimensión política, el meollo de la cuestión consiste entonces en comprender de qué manera la cultura de un grupo, y sobre todo la de las clases populares, funciona como rechazo del orden social o, a la inversa, como forma de adhesión a las relaciones de poder. (Mattelart y Neveu 2003: 15)

Es necesario reconocer que, en una época en que las minorías tenían la necesidad imperiosa de hacerse escuchar, el enfoque aportó una plataforma de expresión de sus inquietudes. De ahí su expansión: 
Lo que al principio no era más que un foco marginal de investigación [Birmingham] entre el mundo universitario y las redes de la nueva izquierda británica, experimentará a partir de 1980 una expansión considerable. Los trabajos se extienden gradualmente a los factores culturales relativos al «género», a la «etnicidad» y al conjunto de las prácticas consumistas. Adquieren una notoriedad planetaria. Pero esta expansión viene acompañada de rupturas. Los rebeldes de ayer ocupan parcelas de poder en el mundo académico. Deudora del marxismo, su inspiración teórica ha de hacer frente a la devaluación de este enfoque y enfrentarse al auge de nuevas ideologías y teorías, a los efectos de los cambios sociales; es decir, a la revalorización del sujeto, a la rehabilitación de los placeres ligados al consumo de medios, al ascenso de las visiones neoliberales, a la aceleración de la circulación mundial de bienes culturales. Aunque los estudios culturales siguen siendo un paradigma, este ya no es el mismo de los orígenes. A partir de entonces ponen de relieve la capacidad crítica de los consumidores, cuestionan nuevamente el papel central de la clase social como factor explicativo, con el fin de revaluar los de la edad, el género o las identidades étnicas. (Mattelart y Neveu 2003: 16)

Actualmente, en una época marcada por el eclecticismo, son demasiados los productos teóricos que se engloban bajo el paraguas de los estudios culturales, con su infinidad de variantes. La obsesión por establecer como elemento esencial de un estudio el factor del lugar desde donde está parado ideológicamente quien lo produce, da lugar a interpretaciones que priman ese sesgo sobre cualquier otro factor. El resultado ha sido, en muchas ocasiones, una falta de rigor.

Gran parte de los partidarios vanguardistas de los estudios culturales han querido reunir en su trabajo intelectual las posturas y los prestigios del científico y del político, de las ciencias sociales y las humanidades, de la investigación y la creación artística. El resultado, con demasiada frecuencia, han sido producciones que no hacen honor a ninguno de estos registros de acción e invención. (Mattelart y Neveu 2003: 131)

Con base en lo anteriormente expuesto, y retomando nuestro tema de fondo, podemos concluir de manera provisional que, considerada en sentido extenso, la pragmática - presente en todos los enfoques hasta aquí mencionados - constituye una aportación esencial en lo que se refiere al estudio de los procesos interpretativos, de ahí que surja inevitablemente la pregunta de cómo ha sido enfocada desde la perspectiva semiótica. Si bien, como ya indicamos, los precursores de la incipiente semiótica -Peirce y 
Morris- postularon la necesidad de un análisis pragmático, lo cierto es que, en los hechos, esta intención tardó en tomar forma. Los planteamientos semióticos tempranos de las décadas de 1960 y 1970, aún muy influidos por el estructuralismo con su sesgo marcadamente inmanentista, tardaron en abrirse a este enfoque. En el caso de la obra de Eco, que hemos considerado como paradigmática, no es sino hasta Lector in fabula (1979) cuando el enfoque pragmático se incorpora plenamente, incorporación que se da en paralelo a los planteamientos del análisis literario de la ya aludida escuela de Constanza.

Pareceríamos encontrarnos inmersos en una especie de escollo terminológico donde el énfasis o las connotaciones dominantes del concepto que nos ocupa varían significativamente en función de las modas al uso en un momento determinado. Con el afán de ser precavidos ante la euforia actual de la valoración de los aspectos contextuales de recepción, y tal como lo hicimos en relación al término contexto, apelemos a la prudencia de un Eco atento a la elusión de excesos sobreinterpretativos. Para dicho autor, en el proceso para desambiguar un mensaje, el receptor apela a su propia enciclopedia o thesaurus -concepto afín, insistimos, al del museo imaginario de Malraux-; este proceso es equiparable al que sigue el emisor del mensaje al crearlo, teniendo en su horizonte un lector modelo con un determinado nivel de competencias. Así, la intentio auctoris se ve cristalizada en una concreción con valores independientes: la obra (intentio operis). El nivel de ambigüedad de esta permite cierta apertura interpretativa y, como estamos viendo, la aportación contextual incide en su interpretación, aunque la intentio lectoris no deja de estar sujeta al ancla de la estructura intrínseca del mensaje. (Cfr. Eco 1979) Si bien estas ideas ya las hemos desarrollado previamente (ver supra: 3.3), con lo que deseamos vincularlas en este punto, y atar así un cabo suelto, es con la función que en el proceso interpretativo tienen las elecciones circunstanciales que, siguiendo al autor que nos ocupa, «representan la posibilidad abstracta (registrada por el código) de que un término aparezca en conexión con ciertas circunstancias de enunciación», tomando en 
consideración, además, que «la circunstancia aparece más o menos semiotizada». (Eco 1979: 29) Así, las hipótesis interpretativas y previsiones del receptor no se dan de manera arbitraria, sino con base en «una serie de informaciones que circulan en forma estandarizada, precisamente como 'cuadros' de eventos posibles y probables». (Eco 1979: 31) En momentos posteriores de su producción ensayística, Eco no se cansará de afinar estos conceptos, insistencia debida al abuso al que se verán sujetas sus ideas tempranas respecto a la apertura interpretativa:

En mis trabajos anteriores (1975) proponía distinguir el contexto de la circunstancia. El contexto es el ambiente en el que una expresión se da junto a otras expresiones pertenecientes al mismo sistema de signos. Una circunstancia es la situación externa en la que puede darse una expresión junto a su contexto. Más tarde (1979) definía como contexto una serie de posibles textos ideales, de los cuales una teoría semántica puede prever la ocurrencia en conexión con una expresión determinada, mientras que reservaba el nombre de co-texto para el ámbito efectivo de una expresión en el curso de un proceso de comunicación real. (Eco 1990: 296-297)

Eco apelará también a la noción greimasiana de clasema, la cual «enriquece las representaciones semánticas con una selección contextual», abriendo una puerta a la intervención del «mundo idiolectal del destinatario». (Eco 1990: 297-298) Esta noción es, asimismo, reminiscente de la de culturema, aportada por Costa (1977).

Vemos así que la suerte de escollo terminológico al que aludíamos a raíz de la ambivalencia de los dos términos que nos ocupan —contexto y pagmática-, crece. ¿No fue acaso durante un tiempo un vicio de la teoría semiótica el complicar su propio discurso sumando un concepto sobre otro donde, adicionalmente, cada autor creaba sus propios neologismos y aportaciones léxicas? Ya comentamos que, en una evolución posterior de la disciplina, se verá que esa Babel terminológica más que aclarar, oscurecía, y se dará una tendencia a la simplificación en el lenguaje. Por otro lado, en esa misma etapa tendrá lugar el salto definitivo, el desplazamiento al énfasis en el análisis pragmático, pudiendo ser condensada la posición actual de la semiótica iconal como sigue: 
Dentro del desciframiento de los mecanismos de producción de sentido de las imágenes, al que se viene consagrando la semiótica visual desde hace muchos años, no es ninguna novedad completar el análisis textual de los mensajes visuales mediante un análisis contextual, también llamado semiopragmático. La interacción entre texto y contexto institucional, en particular, es decir, las condiciones de producción y difusión de imágenes ya lo dicen casi todo, como sabemos, sobre el sentido que hay que atribuirles, sobre el camino a seguir en la interpretación. Se ajusta entonces su recepción en función del uso y de la función del mensaje visual, inmediatamente reconocidos e interpretados. La elección de la tecnología del soporte también influye por supuesto en la interpretación global del mensaje, al enlazar con universos de referencia y de legitimidad distintos y específicos.

En otras palabras, el análisis sintagmático de un mensaje visual (localización de unidades de significado y de las modalidades, por no decir las «reglas», de ordenación entre sí), no basta [...] para ilustrarnos acerca del sentido global del mensaje. Para ello el analista ha de tener en consideración el eje paradigmático de la organización del mensaje, es decir, los campos asociativos ausentes que los elementos presentes a pesar de todo designan y ponen en práctica. (J oly 2002: 99)

\subsection{LA CODIFICACIÓN ASUMIDA}

Ante este planteamiento, nuestra propuesta como puerta de entrada para abordar el fenómeno de la significación fotográfica es profundizar en la comprensión de sus procesos de codificación. Buscamos probar que, a nivel de la producción del mensaje, el fotógrafo consciente, sea cual sea su campo concreto de actividad, no se encuentra por debajo del código (véase la crítica a Flusser en el capítulo precedente), sino que juega con las diversas posibilidades del medio -aunque evidentemente hay campos, como el artístico, en los cuales la libertad de juego es mayor e, incluso, es considerada como un valor-.

Pero acaso lo más importante es que la codificación opera en dos sentidos: así como los productores deben codificar sus mensajes, los receptores se encuentran ante la necesidad de decodificarlos. Como resultado, al especular acerca de los códigos fotográficos, lo estaremos haciendo también respecto de la capacidad de lectura de diversos tipos de receptores, desde el fotógrafo experto o el crítico, hasta la persona común 
que podría responder al perfil de lo que Barthes llamaba el sentido común, de la doxa, de quien de la mano de Bourdieu (ver supra: Capítulo 2) hemos considerado que tiene incorporadas, ya que forman parte del capital cultural social, las habilidades de decodificación que le permiten distinguir las intenciones comunicativas del mensaje fotográfico y los potenciales expresivos del medio. En este punto, entonces, ha llegado el momento de definir algunos términos esenciales, que de hecho hemos venido utilizando de manera libre ya que se encuentran ampliamente generalizados. Para ello, y ante la ya comentada sobreabundancia de definiciones, quedémonos con la parquedad, y al mismo tiempo la frescura, de un septuagenario Sebeok en la sabia simplicidad de una de sus últimas obras:

La materia sobre la que versa la semiótica, de forma más extendida, es el intercambio de cualquier mensaje, sea cual fuere -en una palabra, la comunicación. A esto hay que añadir que la semiótica está íntimamente relacionada con el estudio de la significación. La semiótica está clasificada, por otra parte, como disciplina impulsora de una ciencia integrada de la comunicación a la que su carácter de investigación metódica de la naturaleza y de la constitución de códigos otorga un contrapunto indispensable. (Sebeok 1994: 21-22)

Este proceso de intercambio implica la existencia de «seis factores clave -mensaje y código, fuente y destino, canal y contexto- [que] separada y conjuntamente constituyen el rico dominio de las investigaciones de la semiótica». (Sebeok 1994: 26) Para el autor citado, el concepto esencial es el de signo. Así parece haberlo afirmado en los hechos el que el debate entre la semiótica del índice y la del icono se haya centrado, precisamente, en el intento de dar preeminencia a un tipo de signo -índice o icono, según la teoría peirceana- sobre otro. Quedémonos, a este respecto, con la prudencia de Dubois: «puede haber perfectamente iconos indiciales o índex icónicos». (Dubois 1983: 59) La fotografía, de hecho, cae en esta categoría mixta. Si en el presente estudio nos hemos concentrado en los códigos fotográficos es debido a que, desde nuestro punto de vista, una vez agotada la discusión acerca del signo fotográfico, es en el estudio de los códigos donde reside la posibilidad de acercarse a aquello que podemos 
considerar como la especificidad fotográfica - especificidad que, como veremos en el Capítulo 8, en los años recientes ha sido puesta en crisis-, más allá de los estudios generales sobre la imagen. Sigamos construyendo el concepto de codificación desde un punto de vista semiótico:

Codificación y descodificación implican la existencia de un código, de un conjunto de reglas claras según las cuales los mensajes son susceptibles de convertirse de una representación en otra. El código es lo que supuestamente tienen en común, sea de forma completa o parcial, de hecho o por asunción, las dos partes que intercambian un mensaje. (Sebeok 1994: 25)

Tenemos así que, en su forma más general y abierta, un código es un sistema que permite la estructuración de elementos con base en ciertas reglas de combinación. En el caso de la fotografía resulta imposible hablar de un código; por el contrario, plantearemos aquí la existencia de varios códigos que operan de manera simultánea en diferentes niveles. Desde un punto de vista inmanente o intrínseco, esto es, considerando la imagen fotográfica como un idiolecto, un mensaje que contiene en sí mismo diversas claves para su lectura, es fundamental señalar en principio que el estudio de la imagen puede realizarse en dos planos: el icónico o figurativo, por un lado, y el plástico o no figurativo, por otro. Un estudio que ponga énfasis en el primero valorará fundamentalmente los aspectos de representación, temáticos, narrativos, estéticos, ideológicos, etcétera, de la imagen; en el otro extremo, dichos aspectos corren el riesgo de ser pasados por alto o minimizados en los análisis centrados en desvelar el funcionamiento de una gramática de la imagen y en los estudios de psicología de la percepción, por ejemplo, tendentes a centrar su atención en los aspectos plásticos de la representación. Es nuestro punto de vista que ambos planos son interdependientes, como se mostrará en los capítulos 4 a 6. Una vez más caemos en el ámbito de las dicotomías fuertemente arraigadas en la tradición crítica de la imagen, ya que de lo que estamos hablando, en su reducción más general, es del eterno binomio formacontenido, de ahí que debamos insistir, como tantos otros han hecho, en su indisolubilidad en la práctica. 
Como ya se apuntó, el estudio de los códigos fotográficos será nuestra puerta de entrada para la comprensión de esa interrelación. Cabe señalar también que si hablamos de códigos, y no de un solo código fotográfico, es porque la amplitud y continuo crecimiento del programa (software) permite combinar los elementos visuales utilizando diversos métodos. En este sentido, una de las clasificaciones que sigue resultando más operativa a pesar del tiempo transcurrido desde su planteamiento y de las necesarias correcciones y precisiones que requiere, es la de Costa (1977: 155), quien propone el estudio de tres códigos: el código de la realidad —nosotros preferiremos referirnos a los códigos miméticos (Capítulo 4)—, basado en la manera en que percibimos visualmente la realidad misma y, por lo tanto, en una aparente ausencia de código (Barthes); el de lo que él llama lenguaje fotográfico - preferiremos, para mayor claridad, códigos técnicos (Capítulo 5)—, que se desprende de la utilización de signos exclusivos del medio; y la codificación retórica, fundamentada en el uso de culturemas (Capítulo 6). Aunque Costa propone esta clasificación, a lo largo de su obra básicamente profundiza solo en el aspecto del código técnico. Los otros temas quedan apuntados, pero sin desarrollarse in extenso. En los capítulos siguientes, tomaremos su propuesta como fundamento de nuestra propia construcción teórica, alimentándola con aportaciones de otras fuentes y autores.

Pasado este estadio dedicado a la crítica inmanente, en el Capítulo 7 desarrollaremos nuestra propuesta de análisis pragmático con base en un modelo personal que comprende diferentes aspectos interdependientes en torno a la fotografía, a saber: el género, el espacio discursivo y el binomio del canal y la situación de comunicación. Finalmente, en el Capítulo 8 reflexionaremos acerca de la profunda transformación que el marco pragmático de la fotografía ha presentado en las últimas dos décadas debido a la introducción de los procesos digitales, los cuales han revolucionado los hábitos de producción, distribución y consumo de las imágenes, lo que nos llevará a plantear nuestra posición respecto de la especificidad de la fotografía en el marco de la actual cultura digital. 

SEGUNDA PARTE: EL ANÁLISIS INMANENTE

CAPÍTULO 4

\section{LOS CÓDIGOS MIMÉTICOS}





\subsection{PREFACIO: DESPUÉS DEL PROBLEMA DEL ICONISMO}

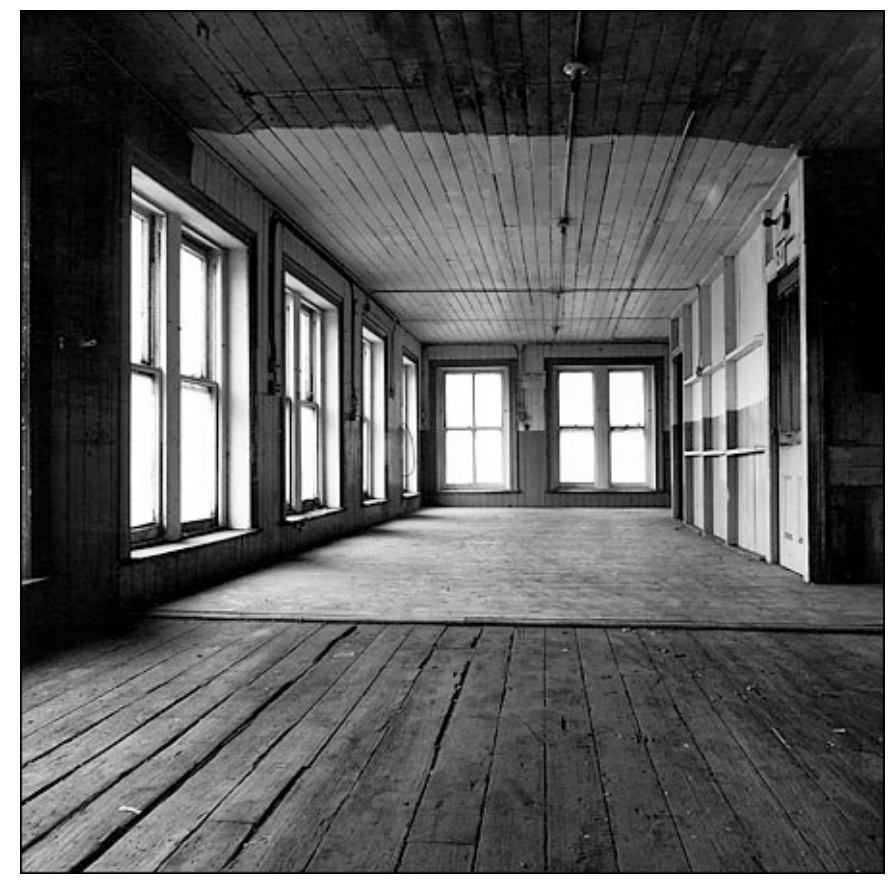

Imagen 10: Danny Lyon

55 Fulton, de: La destrucción del bajo Manhattan, 1967

La Imagen 10 muestra simplemente un espacio vacío, ¿pero qué representa? O mejor aún, ¿cómo representa? Al margen de su tema y de su inserción en una serie de fotos constitutiva de un ensayo extenso, desde el punto de vista estrictamente plástico, esta imagen de Lyon presupone, implica, alude de manera subyacente a todo un universo de convenciones culturales de representación que, por formar parte de manera inextricable del repertorio de representación de un medio que nos es tan familiar como la fotografía, nos es absolutamente transparente, no reparamos en él de manera consciente. 
La imagen en cuestión incluye un cúmulo de gradientes, funciona mediante convenciones en las cuales, a fuerza de sernos familiares, ya no reparamos, pero que no por ello dejan de ser eso precisamente: convenciones plásticas de representación, formas codificadas.

Si en la década de 1970 el debate al que ya hemos aludido entre la semiótica del índice y la del icono dio pie a lo que en su momento se conoció como el problema del iconismo, el reconocimiento de los mecanismos de codificación fotográfica provocó que dicho problema se diera por zanjado (ver supra: 3.2 a 3.4), aceptándose que la idea de una imagen sin código no se sostenía. (Cfr. Eco 1975: 325 y ss.) Sin embargo, mientras que la semiótica iconal prosiguió con su camino de cimentación de sus bases conceptuales, la teoría fotográfica solo dilucidó de manera parcial los mecanismos de codificación propios y específicos del medio. Es por ello que nos hemos referido a este particular como la codificación eludida, a cuyo esclarecimiento dedicaremos este capítulo y los dos siguientes. Entremos, así, en materia.

La fotografía opera mediante un corte de la realidad. Esto tiene una implicación: necesariamente habrá una relación entre lo que se incluye en la imagen y la realidad fuera de cuadro.

El espacio fotográfico, en tanto corte, extracción, selección, separación, toma, aislamiento, cercamiento, es decir, como espacio siempre necesariamente parcial (en relación con el infinito del espacio referencial), implica pues constitutivamente un resto, un residuo, un otro: el fuera-de-campo, o el espacio «off». Es el estatuto de esta porción de espacio excluido del marco y ausente de lo visible fotográfico lo que querría evocar en parte, en su relación con el espacio retenido, que constituye el «campo» de la foto. (Dubois 1983: 159)

Esta relación acentúa la importancia de la información incluida en el cuadro y de la manera como es registrada. Implica, en cierto modo, la reducción de lo que constituye nuestro campo perceptivo a su plasmación en la imagen, y esa reducción se da en diversos niveles. Es solamente a partir de ella que podemos deducir cómo estaba constituida la escena original. Es así que podemos hablar de la foto como la parte de un todo, que 
esta contiene virtualmente. Es necesario apelar al concepto de saber del lector, el cual le permitirá ampliar, desdoblar, continuar fuera de cuadro la información contenida en la imagen y, recíprocamente, leer lo contenido en el cuadro.

Excluyendo los casos críticos en los que la capacidad de reconocimiento es exigida al máximo -abstracciones, microfotografía, etcétera-, incluso cuando la foto pretenda ser literal, podemos decir que la imagen elaborada con fines realistas intentará apelar a los códigos de reconocimiento (cfr. Gombrich 1959) que aplicamos a la realidad misma. Una práctica de este tipo, por lo tanto, buscará

[...] que el espacio representado en la foto quede en perfecto acuerdo estructural con el espacio de representación que lo capta (el horizonte será paralelo a las horizontales del marco; la vertical de los árboles, de las casas, de las personas, etcétera, corresponderá lo más exactamente posible a la verticalidad de los bordes izquierdo y derecho del cuadro); por fin, esta foto ordinaria y equilibrada, la miraremos como de ordinario: manteniéndola bien recta ante nuestros ojos, sin balancearla, haciendo corresponder las ortogonales del espacio representado y del espacio de representación -ya homogéneas entre sí- con nuestra posición (topológica) en el espacio. (Dubois 1983: 184)

De lo que estamos hablando aquí es del establecimiento de criterios de normalidad, lo cual nos remite al concepto de grado cero como expresión neutra, sin estilo. (Cfr. Barthes 1972) Toda adecuación a estos criterios de normalidad contribuirá a la consideración de una foto como literal; por el contrario, toda desviación (tomas en picado y contrapicado, tomas cenitales, distorsiones ópticas, etcétera) introducirá en la imagen un cierto nivel - aunque en ocasiones sea muy primario- de ficción. (Cfr. Costa 1977) Evidentemente, una foto que se aparte de la normalidad como la hemos definido, seguirá siendo reconocible, lo que nos lleva a concluir que los códigos de reconocimiento dependerán en gran medida de los, así llamados, gradientes, que en la fotografía, dadas las características ópticas del aparato, tienen un valor fundamental y son susceptibles de ser previsualizados y controlados por el fotógrafo desde el momento de la toma. 
Un gradiente es un aumento o disminución gradual de alguna cualidad perceptual en el espacio y en el tiempo. James J. Gibson, el primero en llamar la atención sobre el poder de los gradientes para crear profundidad, hizo hincapié en los gradientes de textura, como es la densidad gradualmente cambiante de una granulación o sombreado, estando la textura más burda correlacionada con la proximidad, la más fina con la distancia. (Arnheim 1974 : 305)

El concepto de gradiente, por lo tanto, estará estrechamente ligado al de constancia perceptiva, fenómeno que hemos de transpolar del campo de nuestra experiencia sensible de la realidad al de la representación bidimensional. En nuestra experiencia sensible,

[...] pese al cambio permanente —de tamaño, de forma, de intensidad-a que se ven sometidas las imágenes retínicas, el mundo en que nos movemos presenta unas características básicas de estabilidad que hacen que los objetos que lo conforman no solo permanezcan iguales a través del discurrir del tiempo, sino que en buen número de ocasiones no se vea alterada la percepción de su tamaño, color o forma. (Zunzunegui 1989: 32)

Hablaremos, así, de tres gradientes básicos'1: de contraste (tono), cuyos extremos son el blanco y el negro; de escala (tamaño), que nos permiten discriminar entre lo cercano y lo lejano; y de escorzo (espacialidad), fundamentada en las desviaciones de la armazón básica horizontal-vertical. (Cfr. Vilches 1983) Es con base en estos criterios que podremos hablar de códigos miméticos.

\subsection{Contraste}

El contraste puede ser considerado como la condición primaria de la representación fotográfica, que es de tono continuo y en la cual la forma viene dada por diferencias tonales. No solo en la percepción de la imagen,

\footnotetext{
${ }^{1}$ El tema de los gradientes y las constancias perceptivas ha sido desarrollado extensamente desde un punto de vista fenoménico por Gaetano Kanizsa (1980). Debido a que la profundización en él nos desviaría de nuestro objetivo fundamental, haremos solamente un planteamiento somero de estos valores, remitiendo a dicha obra.
} 
sino también en la percepción de la realidad misma, el reconocimiento de la forma de un objeto se debe fundamentalmente a la experiencia. Intentemos imaginar una situación en la que se dé a un objeto monocromo una iluminación completamente uniforme; en este caso no seríamos capaces de distinguir su volumen, sino que lo percibiríamos como una mancha plana. Normalmente es la experiencia -y sobre todo la experiencia táctil- del objeto, la que nos permite distinguir su volumen.

La percepción del volumen en fotografía depende principalmente de la iluminación; esta, además, cumplirá otras funciones como la de orientar la atención hacia determinados elementos. La preeminencia de un objeto dentro del cuadro estará también en función de otros factores, como su lugar en el mismo o su tamaño, o de cómo esté iluminado en relación a los demás elementos que componen la imagen. Evidentemente, «la luminosidad observada del objeto depende de la distribución de los valores de luminosidad dentro de la totalidad del campo visual». (Arnheim 1974: 338) Profundicemos:

Puesto que la luminosidad de la iluminación significa que una superficie dada está vuelta hacia la superficie luminosa, mientras que la oscuridad significa que está vuelta hacia el lado contrario, la distribución de luminosidad ayuda a definir la orientación de los objetos en el espacio. Al mismo tiempo, muestra de qué modo se relacionan entre sí las diversas partes de un objeto complejo. Las áreas de orientación espacial similar están visualmente correlacionadas por su luminosidad similar. Cuanto más se aproximan a recibir perpendicularmente la luz incidente, más luminosas parecen. Sabemos que en la percepción se agrupan las unidades de luminosidad similar; así, un agrupamiento por semejanza de luminosidad produce indirectamente un agrupamiento por semejanza de orientación espacial. El ojo asocia entre sí las superficies paralelas en cualquier lugar del relieve en que aparezcan, y esta red de relaciones es un medio poderoso de crear orden espacial y unidad. (Arnheim 1974: 345-346)

Para situar un objeto dentro de la escala contrastado-no contrastado, hay que sumar la luminosidad producida por su propia coloración a la degradación tonal producto de la combinación entre la forma del objeto y la posición de la fuente luminosa. La manera más sencilla de establecer un orden visual por medio de la iluminación en fotografía de estudio será 
utilizando una sola fuente de luz o, en el caso de que se usen varias, dando preferencia a una de ellas (key light o luz principal) al balancear su intensidad, dejando las demás para controlar los contrastes (fill lights o luces de relleno). Este procedimiento tiene implicaciones a nivel semántico, ya que elegir una iluminación con preferencia a otras supone hacer una interpretación del objeto.

La neutralidad vendría dada aquí por una iluminación difusa y uniforme, que no produjera sombras ni contrastes - como la de un día nublado-; en este caso, las diferencias tonales en la imagen serían producto únicamente de las diferencias de color local entre los objetos que componen el cuadro.

Como consecuencia, los gradientes de tono dependerán en primer instancia de este factor y, secundariamente, de la distribución de la luminosidad. La relación puede invertirse en casos extremos como el contraluz, en el que se obtiene un resultado de alto contraste debido exclusivamente a la oposición entre la luz posterior y un cuerpo opaco, no importa cuál sea su color.

Con esta base, resulta claro que en fotografía la luminosidad constituirá un primer nivel de semantización de la imagen, con un alto potencial para ser explotado por parte de la retórica visual. Este factor, como es lógico, se exacerba en las situaciones de control extremo de los elementos fotográficos, como es el caso de la fotografía publicitaria. En este sentido, será normal una foto que reproduzca una amplia gama de tonos entre el blanco y el negro, lo cual desde una época temprana de la fotografía se convirtió en el canon; y se entenderá como subjetiva, por el contrario, una imagen en llave alta (predominio de tonos claros), en llave baja (predominio de tonos oscuros) o contrastada (ausencia de tonos intermedios).

Aunque a lo largo de estas páginas hemos aludido fundamentalmente a la fotografía en blanco y negro, no hay que perder de vista que, con las precauciones que merece el caso, estas consideraciones son igualmente aplicables a la fotografía en color. 


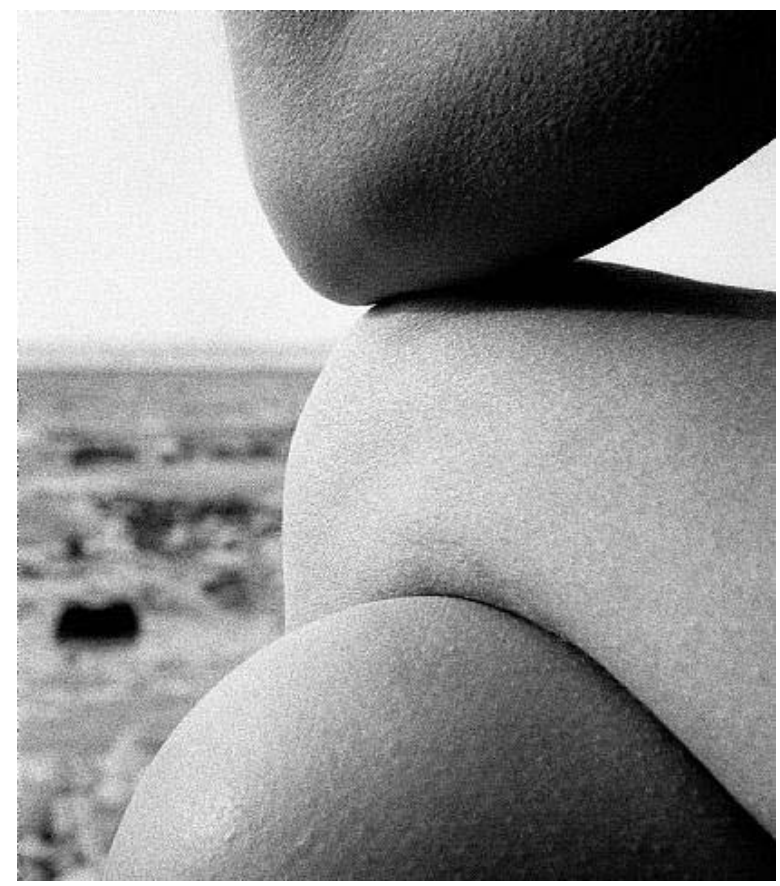

Imagen 11. Bill Brandt

Desnudo, 1959

La forma es dada por las diferencias tonales, generándose el paso de una tonalidad a otra de manera gradual. Los gradientes de tono se convierten, así, en uno de los principales factores para el reconocimiento de la forma de los objetos representados. Adicionalmente, la relación entre las zonas más luminosas y las oscuras contribuye a que se pueda establecer la posición de la fuente de luz. 


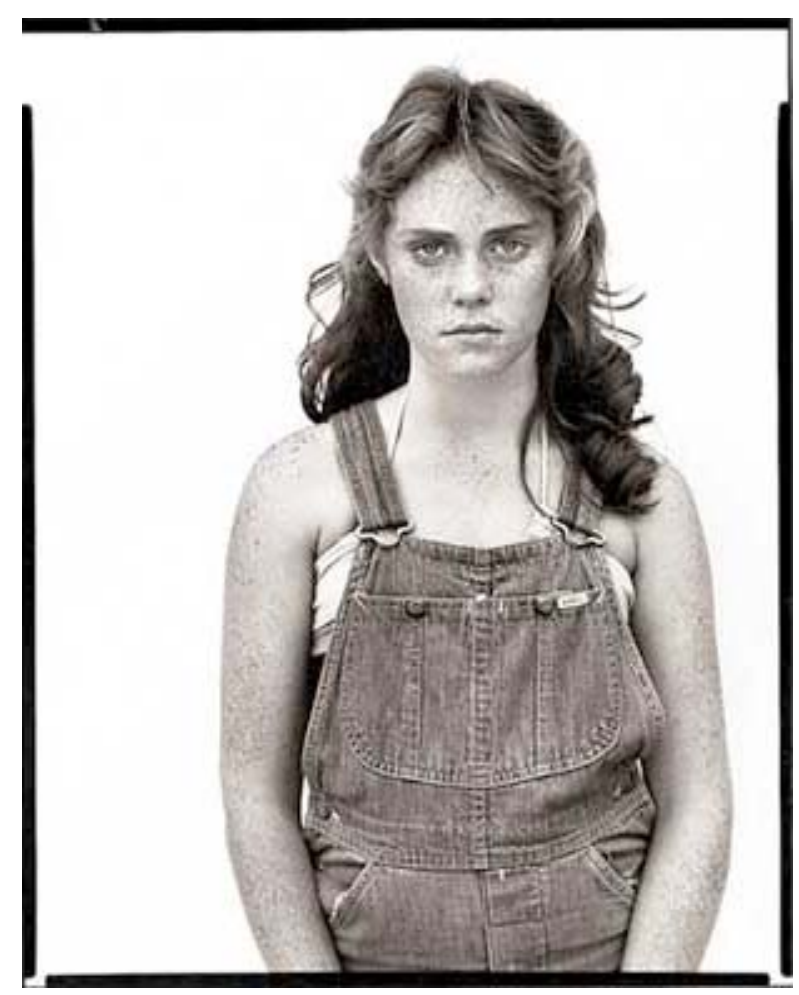

\section{Imagen 12. Richard Avedon \\ Sandra Bennett, 12 años, 1980 \\ (De: En el Oeste americano)}

En este retrato es difícil establecer la posición de la fuente de luz, ya que se trata de una iluminación difusa que no genera sombras acentuadas. Este estilo, convertido en marca registrada de los retratos de Avedon, es en ese sentido cercano al grado cero en cuanto a contraste. 


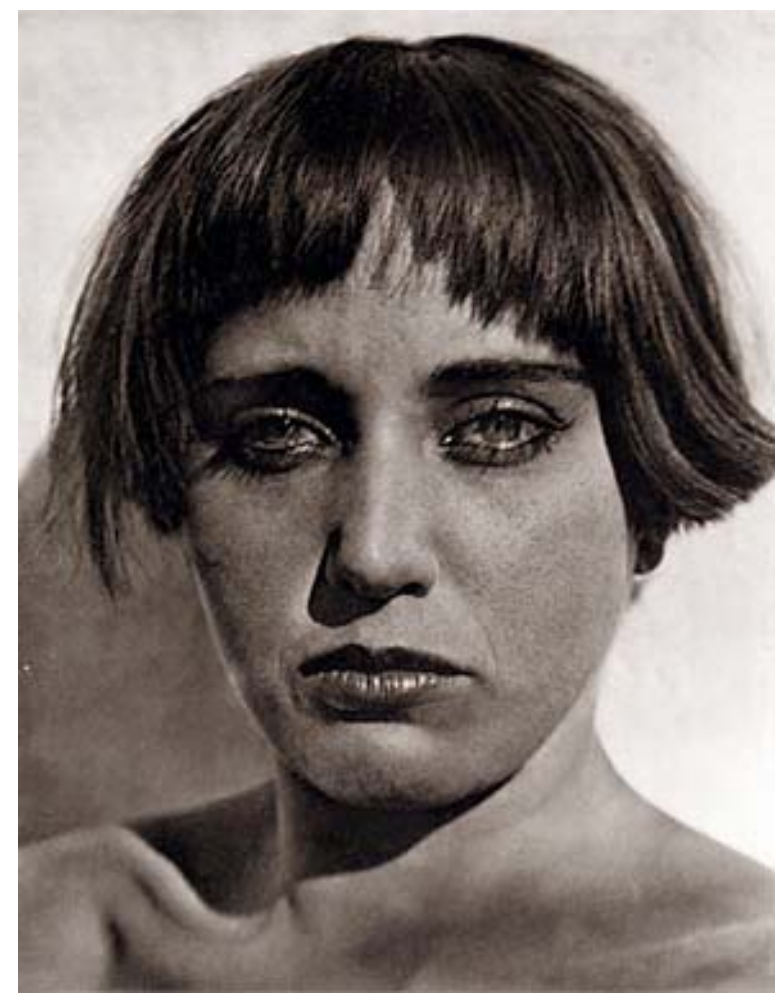

Imagen 13. Edward Weston

Nahui Olin, 1924

$\mathrm{Al}$ contrario de la imagen anterior, este retrato está muy contrastado, presentando sombras acentuadas que le dan cierta dureza. Las sombras funcionan en la imagen como figuras geométricas que pueden tener un fuerte valor compositivo. Son, asimismo, un elemento que contribuye a definir la posición de la luz y su tipo, ya sea difusa o directa, como aquí. 


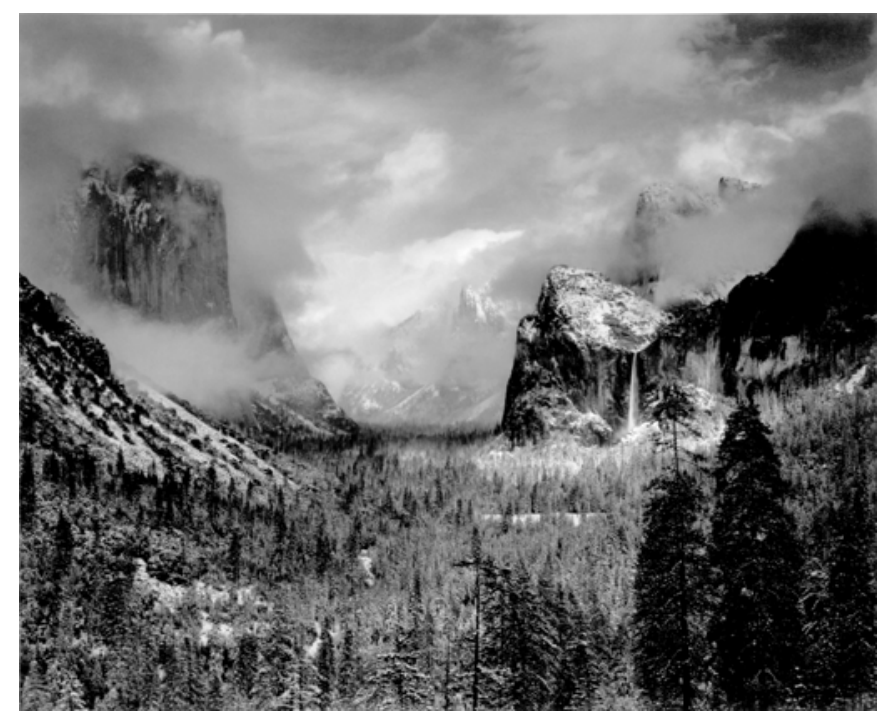

Imagen 14. Ansel Adams

Parque Nacional de Yosemite, 1942

El canon fotográfico establece que una foto debe tener blanco y negro puros, pasando por una amplia gama de grises. Adams, miembro del purista Grupo f64, llevó esta tendencia al extremo con el sistema de zonas. Esto podría identificarse con el grado cero; llevado a la fotografía en color, correspondería a un valor de contraste normal. 


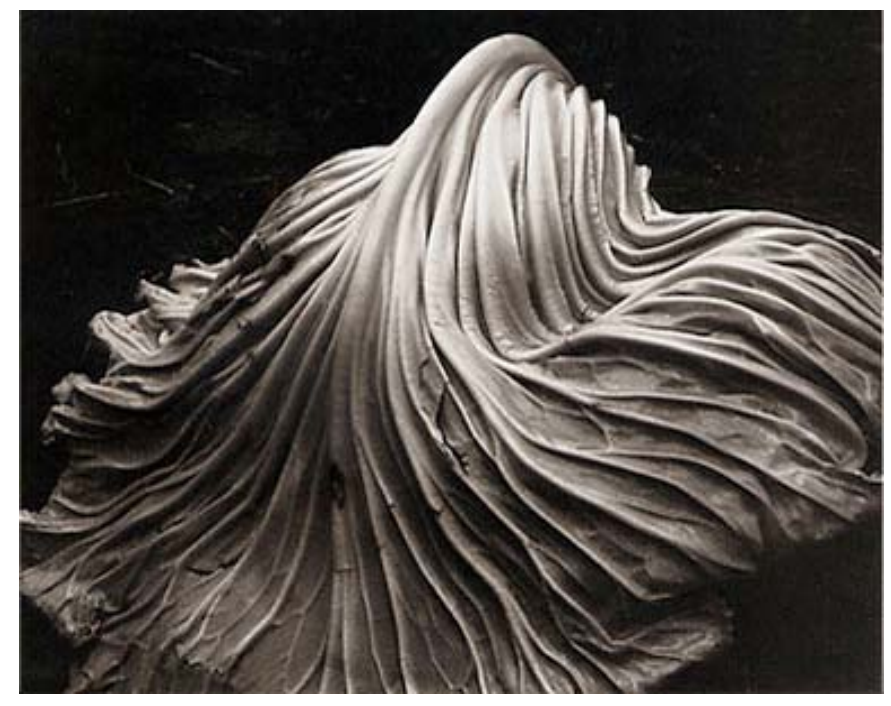

Imagen 15. Edward Weston

Col, 1931

Weston, también miembro del Grupo f64, en un ejemplo de la misma intención purista ya no en el paisaje, sino en el bodegón. En ambos casos se trata de géneros que permiten un amplio control por parte del fotógrafo, hecho que resulta mucho más difícil de lograr en la fotografía directa. 


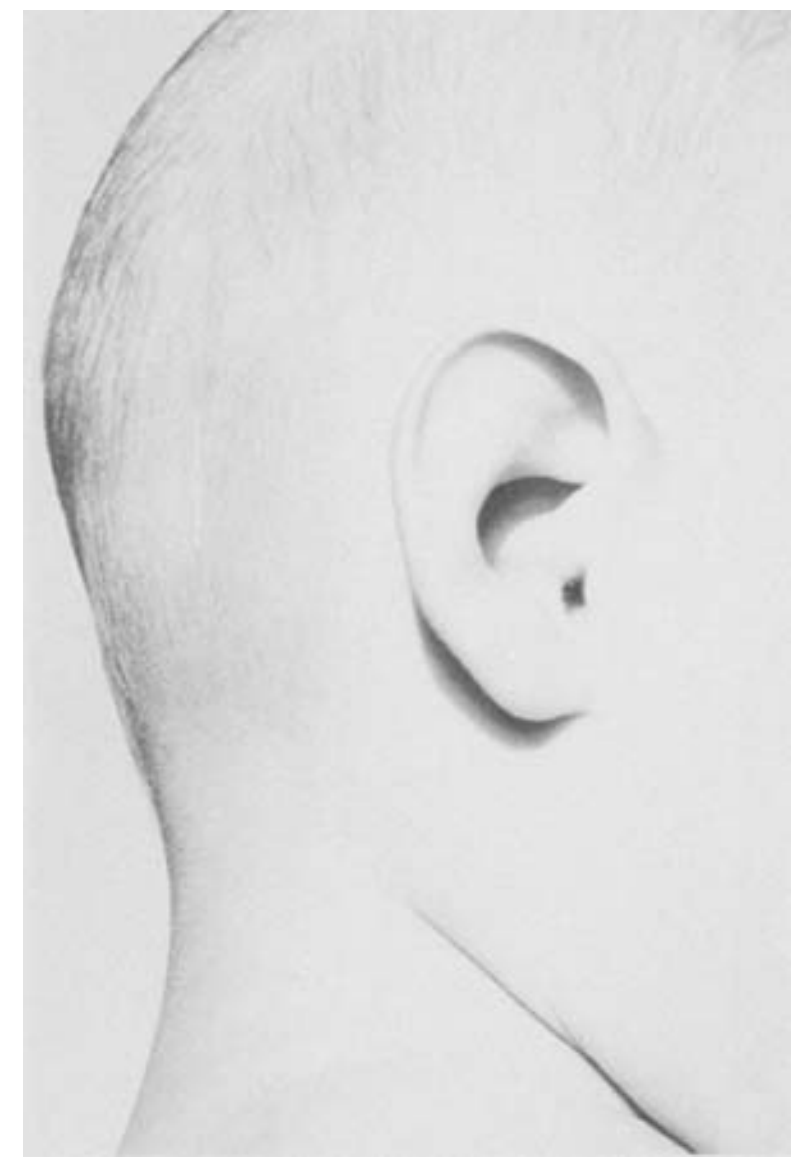

Imagen 16. Ralph Gibson

Perfil, 1985

Una foto en llave alta, donde el predominio de los tonos claros no solo es poco naturalista y, por lo mismo, alejado del grado cero, sino que incluso lleva a la pérdida de texturas en el sujeto. 


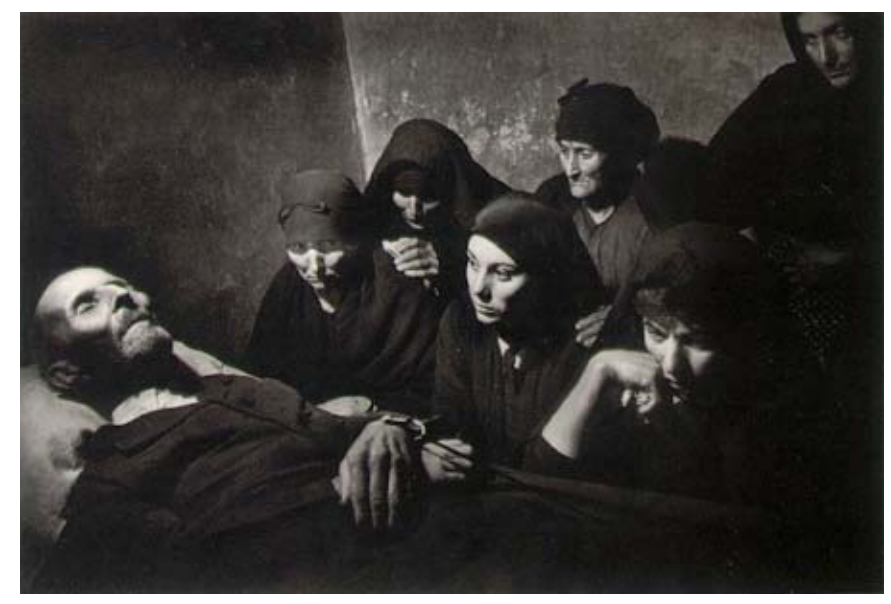

Imagen 17. W. Eugene Smith De la serie: Pueblo español, 1950

En el polo opuesto a la anterior imagen, esta, en llave baja, se vale del oscurecimiento exagerado para sobredramatizar la escena. También observamos aquí el contraste selectivo, que resalta el rostro del difunto (ambos efectos seguramente acentuados por Smith al trabajar la impresión en el cuarto oscuro, lo que era una práctica habitual en él). 


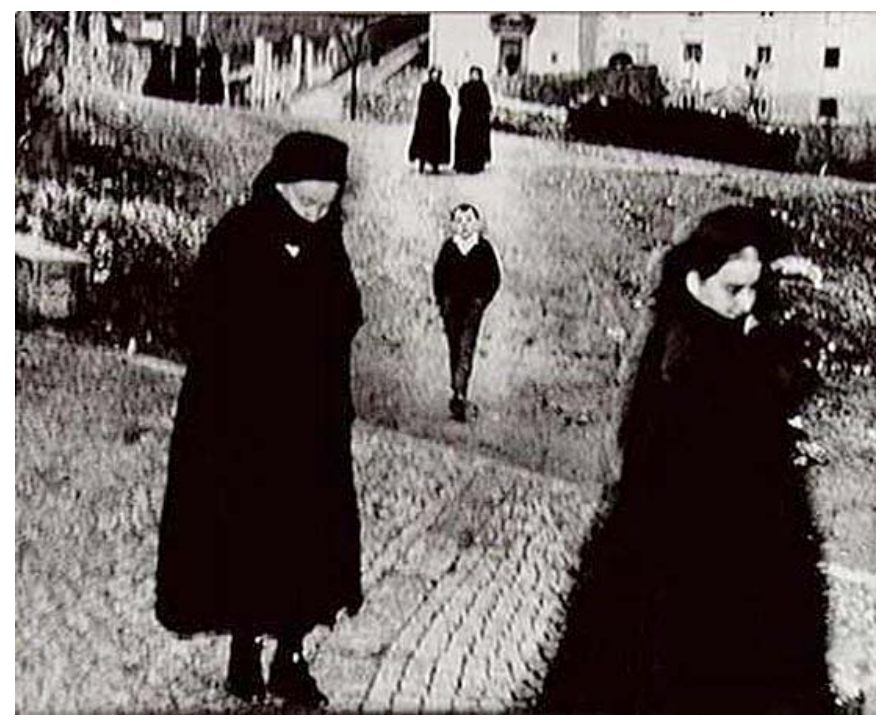

Imagen 18. Mario Giacomelli De la serie: Scanno, 1957-59

Un contraste exagerado, parte del estilo propio de Giacomelli, que en este caso contribuye, junto con otros factores, a otorgarle a la imagen un cierto tono onírico al alejarla de un tipo de representación naturalista. 


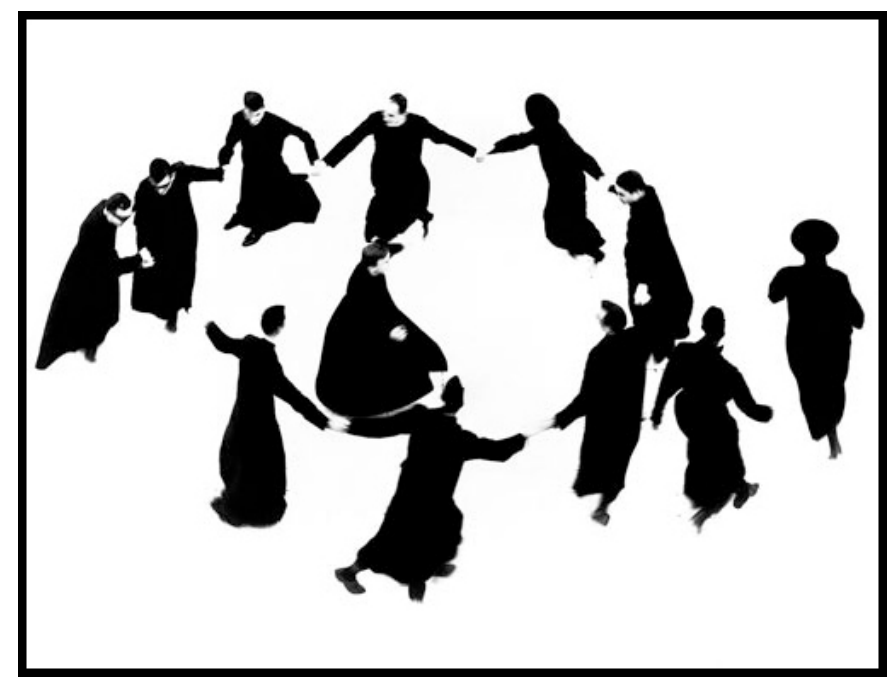

Imagen 19. Mario Giacomelli

De la serie: Yo no tengo manos que me acaricien el rostro, 1961-63

Aquí observamos el alto contraste absoluto, mediante la supresión de los tonos intermedios. La imagen se lee, entonces, como totalmente retorizada, subjetivada. 


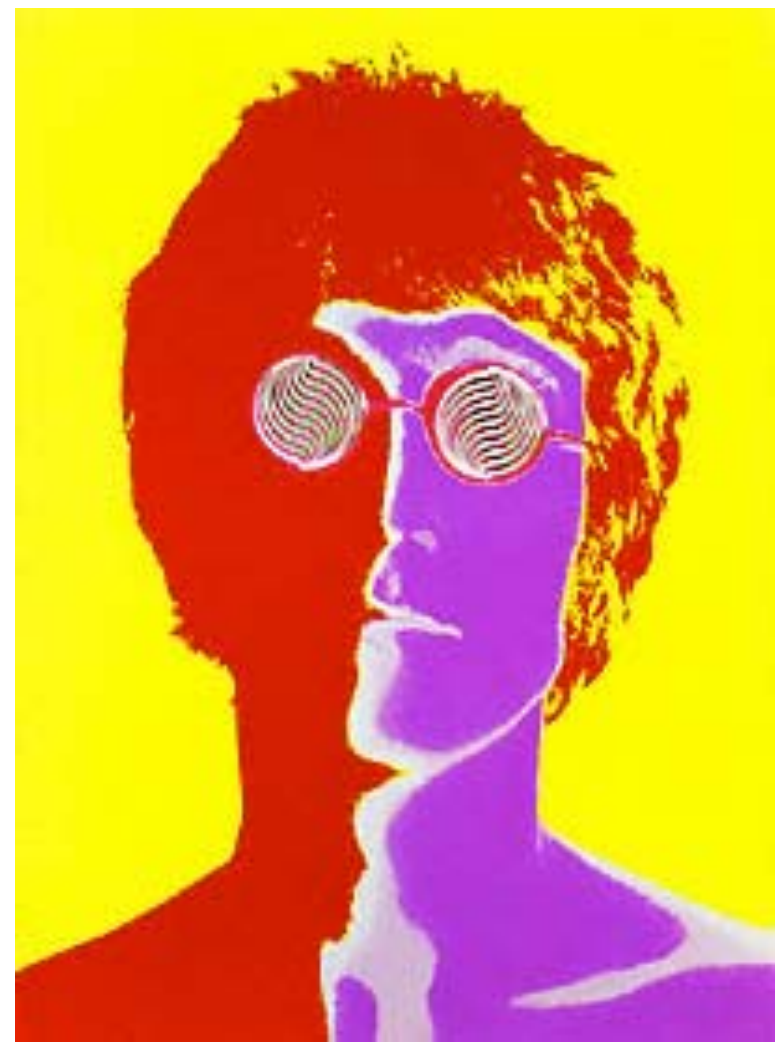

Imagen 20. Richard Avedon

John Lennon, 1968

El valor del contraste no solo está presente en la fotografía en blanco y negro, sino también, por supuesto, en la de color. Aquí se presenta un ejemplo extremo de alto contraste logrado mediante la combinación compleja de un original en blanco y negro, la solarización de su copia en diapositiva de color y la manipulación de la impresión por transferencia de tintes. Estamos en el nivel máximo de retorización, que el receptor identifica con los efectos especiales, aunque siempre conservando la conciencia de que el punto de partida para obtener la imagen es fotográfico. 


\subsection{ESCALA}

Podemos hablar de escala en dos sentidos, a saber: como una relación de tamaño entre diversos objetos presentes en la imagen, por un lado, o «como la relación entre la superficie del cuadro de la fotografía ocupada por la imagen de un objeto determinado y la superficie total del mismo cuadro» (Vilches 1983: 50), por otro. La escala en fotografía dependerá, por lo tanto, en ambos casos, de la interrelación entre el tamaño real del objeto, el tipo de objetivo utilizado (su distancia focal) y la posición de la cámara (ángulo de toma y distancia en relación a los objetos).

Los objetivos no alteran la perspectiva, pero un objetivo de fuerte curvatura abarca un ángulo mayor de espacio desde poca distancia. Con ello se producen gradientes abruptos entre el primer término y el fondo, que se traducen en una tensión barroca al encogerse y expandirse rápidamente los personajes según se alejen de la cámara o se aproximen a ella. (Arnheim 1974: 325)

De esto se desprende que la percepción va enfocada a la escala, no al tamaño real del objeto, el cual solo puede deducirse de la primera. En lo que toca a la relación que hemos apuntado inicialmente, la escala como relación de tamaño entre los objetos a cuadro, esta depende, según Arnheim de la armazón espacial transpuesta de la realidad a la imagen, lo que significa que solo puede ser percibida con base en las relaciones arriba mencionadas. Los gradientes de escala se convierten, así, en el factor esencial de interpretación del tamaño. La disminución o aumento graduales de la escala en la imagen, de elementos iguales o similares en la realidad, constituyen el factor esencial de transpolación de la pirámide visual al plano bidimensional.

A este respecto, juegan un rol fundamental los gradientes de textura, en los cuales, como ya señalamos (ver supra: 4.1), Gibson fijó su atención como elementos correlacionados con la distancia, estando las texturas granulosas asociadas con la proximidad y las más finas con la lejanía. Con 
otras palabras, es la escala de los elementos que conforman la trama de una textura la que aumentará o disminuirá gradualmente para contribuir a la representación del espacio.

Los gradientes de tamaño, asimismo, nos permiten leer en la foto una serie de datos, como son la distancia focal aproximada del objetivo utilizado en la toma y el espacio entre el fotógrafo y el sujeto. Aunque esta percepción es sumamente especializada $\mathrm{y}$, por lo tanto, queda prácticamente reservada a receptores que cuentan con un cierto dominio de la técnica fotográfica (Barthes dixit), su efecto final sí que es fácilmente reconocible por la persona no especializada, quien ha aprendido a apreciar, con base en su experiencia, los casos en que el sujeto ha sido dramatizado ópticamente -como sucede con el uso periodístico de objetivos angulares a muy corta distancia- Este factor está estrechamente vinculado a los gradientes de escorzo, que serán comentados en el siguiente apartado.

En lo que toca a la escala como relación entre el tamaño del objeto representado y el cuadro o espacio de representación, una vez más, como en relación al contraste, la utilización de los polos opuestos es esencial; en este caso, los polos cercano-lejano y sus niveles intermedios tendrán implicaciones semánticas y, por extensión, serán un recurso retórico (como lo veremos en el apartado 6.2 al hablar de la retórica de los actantes). Sobra recordar que, para la retórica, ese objeto representado es por norma, esto es, como criterio de normalidad, el cuerpo humano.

El Plano Medio se presenta como la presencia equilibrada de dos polos contrarios, el Cercano [...] y el Lejano [...], o como la presencia de una contradicción igual para ambos polos: el objeto en plano medio puede desaparecer por acercamiento o lejanía. En este sentido, se puede hablar del plano medio como inmovilidad; es decir, de un lugar ideal de indiferencia que podría dar lugar al estudio de la retórica del plano medio como normalidad de situaciones, como equilibrio de tensiones, como mediocridad de valores, etcétera-. (Vilches 1983: 53)

Conviene aquí hacer un breve recuento de los planos cinematográficos, ya que su clasificación, de amplísima difusión en aquel ámbito, ha pasado de forma natural a la terminología fotográfica: 
- Primerísimo plano o big close up2: muestra solo un detalle del rostro.

- Primer plano o close up: muestra el rostro completo.

- Plano medio o medium shot: se muestra el cuerpo cortado en el pecho.

- Plano americano o american shot: el cuerpo se corta a la altura de las rodillas.

- Plano general o wide shot: una persona o grupo de personas de cuerpo completo, dejándose ver parte de su entorno.

- Gran plano general o extreme wide shot: vista amplia de un paisaje o locación, donde el sujeto humano es minimizado por el entorno.

La reflexión anteriormente citada de Vilches respecto del plano medio, lo deja establecido como lo que aquí hemos llamado el grado cero, esto es, el criterio de normalidad. Claramente esto es una convención cultural, profundamente incorporada en nuestros códigos de lectura.

Para terminar este subapartado, mencionaremos dos elementos asociados con la escala. El primero son los traslapos entre objetos, que contribuyen a su ordenamiento en el espacio representado, facilitando la comprensión de qué está en primer plano y qué en un plano más lejano. El segundo son las sombras, que para la teoría de la percepción, junto al sólido que las origina, «funcionan como un único objeto al cual se aplican las normas que rigen la apariencia espacial de los objetos». (Arnheim 1974: 351) La dirección, tamaño y nitidez de las sombras ayudarán a establecer la posición y tipo de la fuente de luz, y serán, a la vez, un elemento compositivo sumamente gráfico.

\footnotetext{
${ }^{2} \mathrm{Si}$ incluimos sus nombres en inglés es debido a que esta terminología se maneja de manera casi universal. Como es habitual, esta categorización ha sido interminablemente matizada, por lo que solo presentamos su versión mínima.
} 


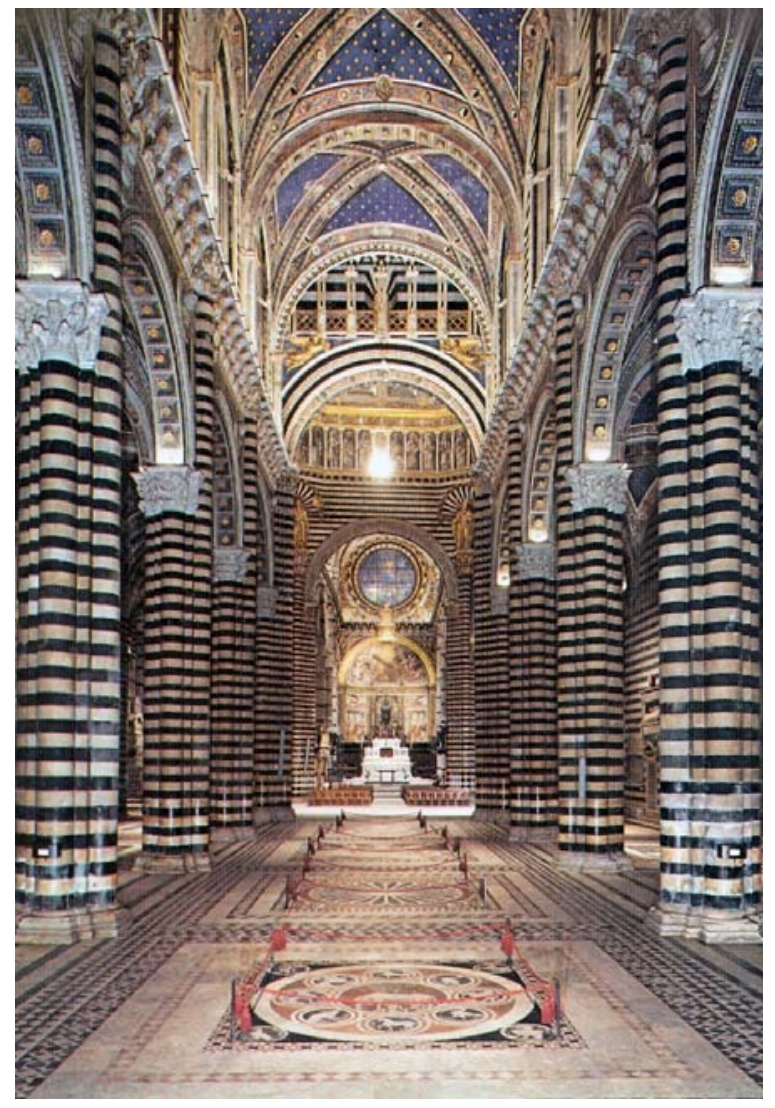

Imagen 21. Tarjeta postal anónima Catedral de Siena, s.d.

Juego con los gradientes de escala, en un exquisito trompe l'oeil. Al entrar en la Catedral de Siena, esta es la perspectiva que el visitante tiene, sin sospechar que está siendo engañado. Un gradiente se encuentra, por ejemplo, en la disminución gradual de escala de las columnas. Sin embargo, hay aquí otro gradiente que ha sido alterado de manera artificial: las bandas horizontales de mármol blanco y negro de las columnas no son iguales en cada fila de columnas, sino que se van haciendo más estrechas. Con ello, se logra que el gradiente óptico se altere, esto es, la disminución de escala ya no es gradual. El efecto es que el visitante tiene la ilusión óptica de que la nave de la iglesia tiene más profundidad de la real. 


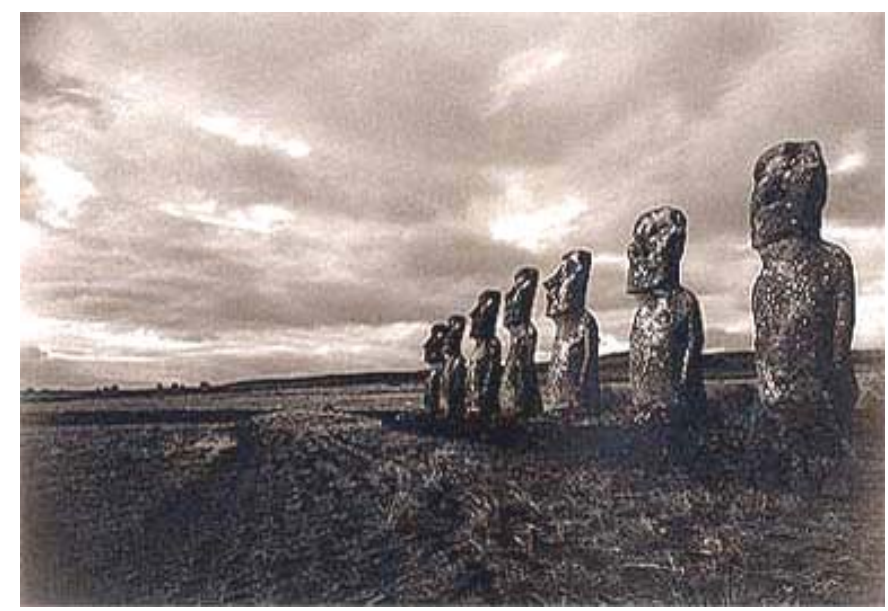

Imagen 22. Kenro Izu

Moai \# 30, siete moai, Isla de Pascua, Chile, 1989

El gradiente de escala en su expresión mínima: la disminución gradual del tamaño de los monolitos da un evidente efecto de distancia. Adicionalmente, el gradiente de textura actúa tanto en los moai como en el suelo y en las nubes, acrecentando el efecto de fuga. 


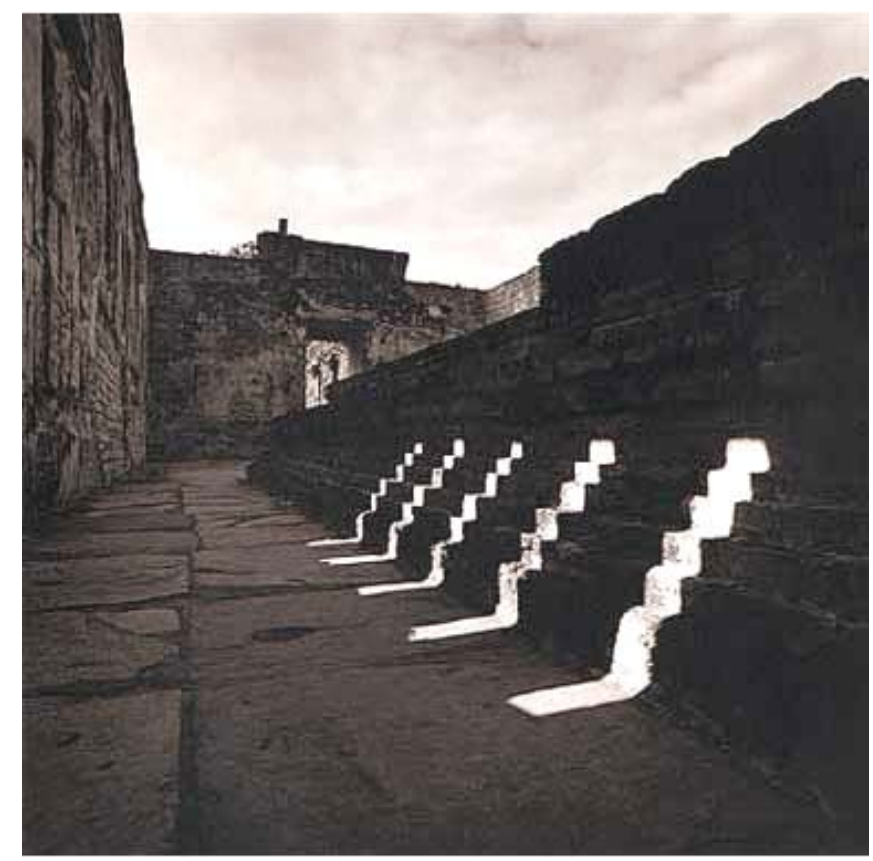

Imagen 23. Rolfe Horn

Escaleras de luz, Wat Sri Sawai, Tailandia, 2000

Una verdadera colección de gradientes de escala y textura: la disminución de tamaño de los haces de luz que aluden metonímicamente a las ventanas fuera de cuadro, el estrechamiento de las paralelas de los escalones en escorzo, así como la disminución en la textura desde el primer plano al fondo tanto en los elementos arquitectónicos como en las nubes. 


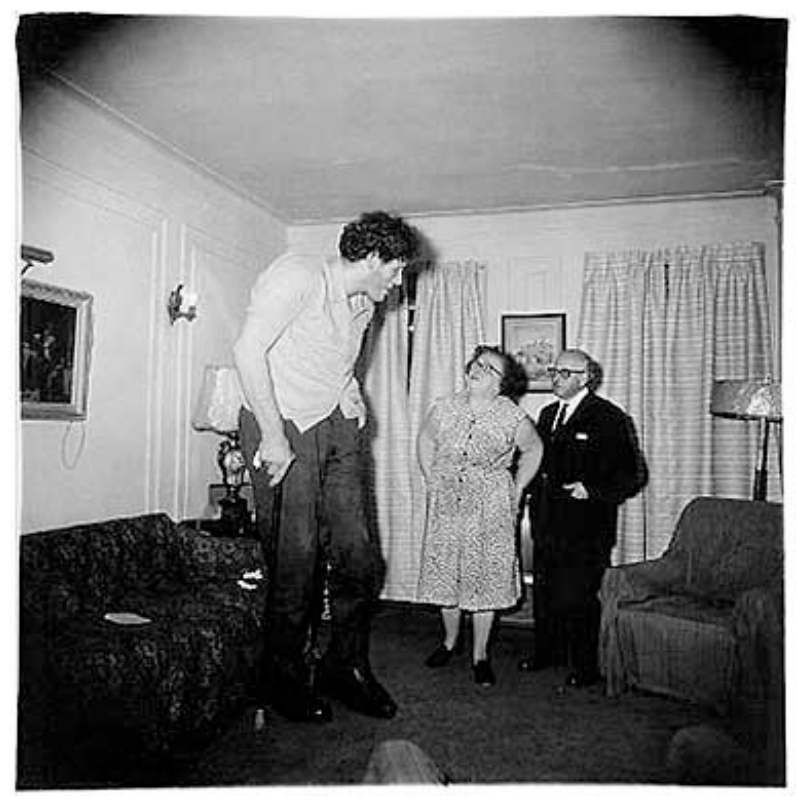

Imagen 24. Diane Arbus

Gigante judío con sus padres en el Bronx, 1970

La ironía de Arbus llega al extremo en la Imagen 24, en la cual el juego de escala para convertir a un sujeto en monstruo no se debe a la óptica, sino a la relación de tamaño entre los sujetos a cuadro. Las Imágenes 25 a 30 no solo nos sirven para ilustrar los diferentes planos, sino también para comentar algunos elementos más sutiles. En la Imagen 26, por ejemplo, la distorsión óptica de barril, debida a la curvatura de un objetivo corto, hace que la nariz de la mujer sea prominente, esto es, hay un gradiente de escala sumamente abrupto afectando al sujeto. Este efecto, aunque presente, se atenúa en los planos medio (Imagen 27) y americano (Imagen 28), también debido a que las tomas son frontales. En el plano general (Imagen 29), a pesar de la mayor distancia al sujeto, observamos que el uso de un objetivo corto en picado tiene dos efectos: los gradientes abruptos en el propio sujeto - la desproporcionada cabeza del niño-y entre el primer plano y el fondo, cuyo escorzo es exagerado. Este efecto se pierde, por la distancia, en el gran plano general (Imagen 30). 


\section{Primerísimo plano}

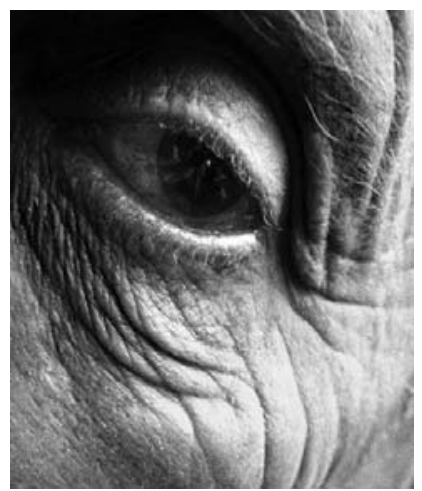

Imagen 25. Bill Brandt

J ean Arp, 1960

\section{Plano medio}

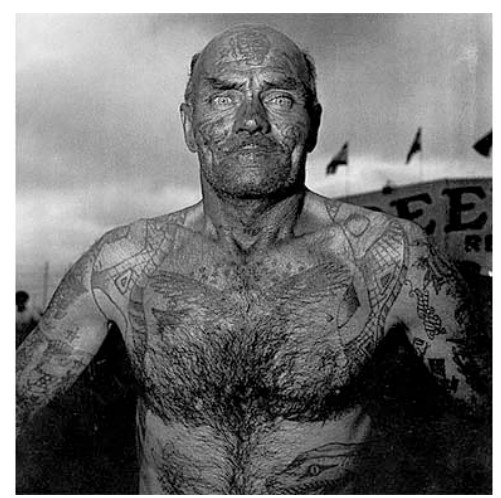

Imagen 27. Diane Arbus

Hombre tatuado en un carnaval, 1970

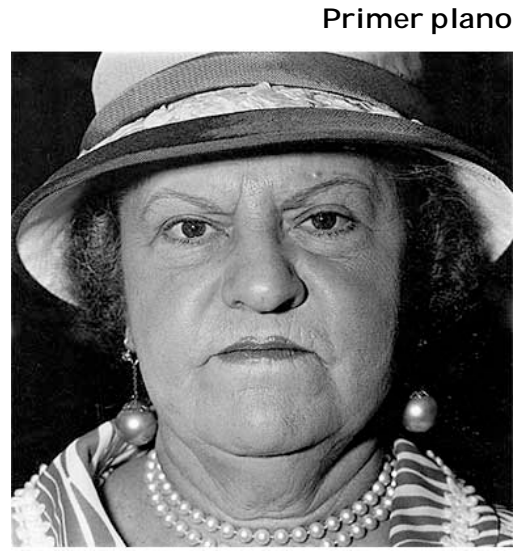

Imagen 26. Diane Arbus Mujer con collar y aretes de perlas, 1967 


\section{Plano americano}

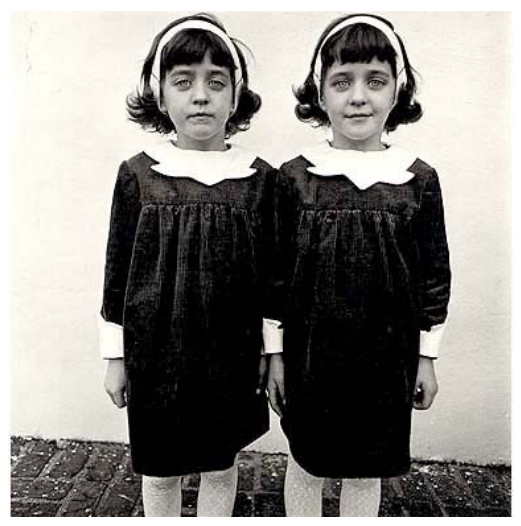

Imagen 28. Diane Arbus

Gemelas idénticas, 1967

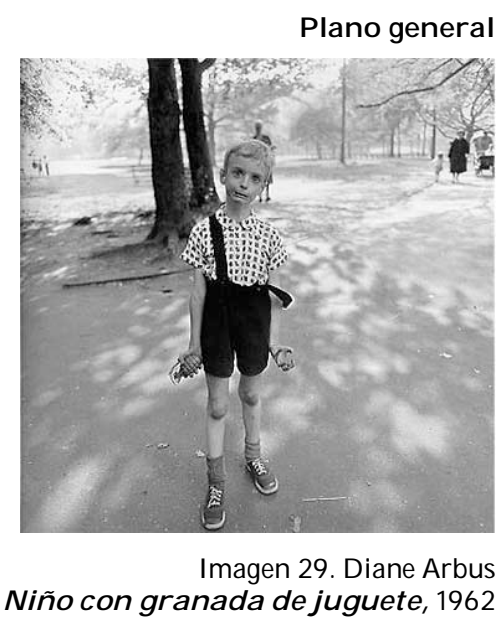

\section{Gran plano general}

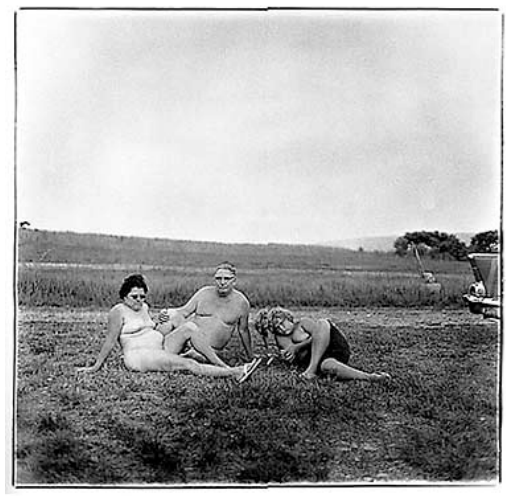

Imagen 30. Diane Arbus

Familia en un campo nudista, 1965 


\subsection{EsCORZo}

La fotografía hereda de la cámera obscura una forma convencionalizada de representación, la perspectiva central o cónica, que «aspira a una ecuación correcta: quiere que la imagen aparezca como el objeto, y el objeto como la imagen». (Gombrich 1959: 226) Esta aspiración se traduce en la representación de un espacio continuo-tridimensional que, hasta el Renacimiento, estaba fuera del alcance de los esquemas bidimensionales de representación.

El principio básico de la percepción de la profundidad se deriva de la ley de simplicidad, y afirma que un esquema parecerá tridimensional cuando pueda ser visto como proyección de una situación tridimensional que sea estructuralmente más simple que la bidimensional correspondiente. (Arnheim 1974: 276)

Fotográficamente, una primera solución a este problema sería adecuar en lo posible ambas situaciones -bi y tridimensional-, para lo cual el recurso más evidente es la toma frontal del objeto. Esta constituiría el grado cero o criterio de normalidad fotográfica en cuanto al valor que hemos denominado escorzo, en parte, también, debido a que «la visión frontal es la que proporciona más información. Es el que llamamos el 'aspecto característico' del objeto, el aspecto [...] que exhibe un máximo de los rasgos distintivos mediante los cuales clasificamos y nombramos las cosas de nuestro mundo». (Gombrich 1959: 263) Pero lo más importante respecto del tema que nos ocupa: la toma frontal permitirá transponer los ejes verticales y horizontales de la realidad a la imagen, evitando la deformación.

Dicha deformación, que los fotógrafos profesionales han aprendido a corregir a toda costa desde el siglo XIX, ha sido teñida incluso de ideología. En este sentido, Durand nos recuerda: «La preocupación por la exactitud geométrica intervenía entonces como el índice de una preocupación moral no formulada». (Durand 1998: 44) La añorada neutralidad u objetividad se 
irá perdiendo conforme se sustituya la visión frontal. En este sentido, el punto de vista físico de la toma será el elemento primario para establecer el punto de vista intelectual del autor. La deformación que en este sentido crea el fotógrafo es, además, tiránica, ya que se impone por extensión al espectador. Si es necesario matizar el término deformación al hablar de sus implicaciones subjetivas, no lo es, en cambio, cuando nos referimos al aspecto formal: como desviación de la armazón básica vertical-horizontal.

La orientación oblicua constituye probablemente el medio más elemental y eficaz de obtener una tensión dirigida. La oblicuidad se percibe espontáneamente como un esfuerzo dinámico de aproximación o alejamiento respecto a la armazón espacial básica de horizontal y vertical. (Arnheim 1974: 464)

La deformación oblicua producto de líneas escorzadas, considerada en ese sentido, será lo que nos permita leer la tercera dimensión, apelando para ello a nuestro saber no solo óptico, sino al que se desprende de nuestra experiencia táctil de la realidad derivada de nuestra vivencia del espacio físico. Se convertirá así en un recurso expresivo al ser utilizada bajo ciertas reglas:

Claro está que no todas las formas oblicuas originan profundidad, sino solo aquellas que pueden ser leídas como desviaciones respecto a la armazón normal de vertical y horizontal. Cuando se cumple esta condición, la oblicuidad desaparece a favor de una reversión a la armazón más simple. (Arnheim 1974: 293)

Esta reversión será posible gracias a la constancia de tamaño y forma fundamentada en la lectura adecuada de los gradientes, debida, a su vez, a la experiencia previa. Con base en lo expuesto podrá comprenderse que Moles (cfr. 1981) dé a la perspectiva el carácter de una jerarquización del mundo representado.

Se evidencia, así, la estrechísima e indisoluble relación entre los gradientes de escala y de escorzo. Estos últimos quedan definidos, en su expresión más simple, como la mayor o menor inclinación de la armazón vertical-horizontal. 
La inclinación de los planos podría estudiarse como marcas de enunciación del fotógrafo que estarían más cerca de una aproximación interpretativa, intencionalmente no objetiva, mucho más cerca de la ficción; mientras la frontalidad estaría más cerca de un cierto realismo. (Vilches 1983: 59)

En su traducción a términos ópticos, obtendremos que los objetivos de distancias focales medias proporcionarán un escorzo normal que correspondería al grado cero, tomando como referencia nuestra percepción óptica de la realidad. Por este motivo en la jerga fotográfica se le llama, emblemáticamente, objetivo normal al que tiene un ángulo de cobertura de aproximadamente 50 grados $(50 \mathrm{~mm}$ para cámaras de formato universal o de $80 \mathrm{~mm}$ para cámaras de formato medio). Esto no tanto como consecuencia de dicho ángulo, limitado comparativamente a la visión humana, sino, como ya se apuntó, por el tipo de perspectiva que proporciona. Algunos fotógrafos incluso han llegado, en aras de una pretendida objetividad, a privilegiar su uso a la altura de los ojos, evitando tomas en picado o contrapicado, así como puntos de vista rebuscados.

Las desviaciones del grado cero vendrían dadas, por un lado, por el uso de objetivos cortos. Estos, al acercar el punto de fuga, provocan diferencias abruptas entre el primer plano y el fondo. Asimismo, debido a la curvatura del objetivo, deforman al sujeto. En el polo opuesto, los objetivos extremos de larga focal cuentan con distorsión de almohada y aplanan la imagen. Al tener un punto de fuga muy lejano, las distancias entre los objetos representados se diluyen, siendo difícil ubicarlos en el espacio si no se cuenta con el auxilio de elementos formales adicionales, como son las sombras y los traslapos, ya comentados.

Es fundamental considerar que la angulación de la cámara respecto del sujeto operará siempre en conjunto con la óptica. Así, el control de estos elementos por parte del fotógrafo quedará integrado, en muchas ocasiones, no solo como parte de su modus operandi, sino también, en último extremo, de su posición intelectual y ética de trabajo. En el caso del diletante, por su parte, estos factores técnicos frecuentemente han sido traducidos a consejos o recetas del tipo hágalo usted mismo. 


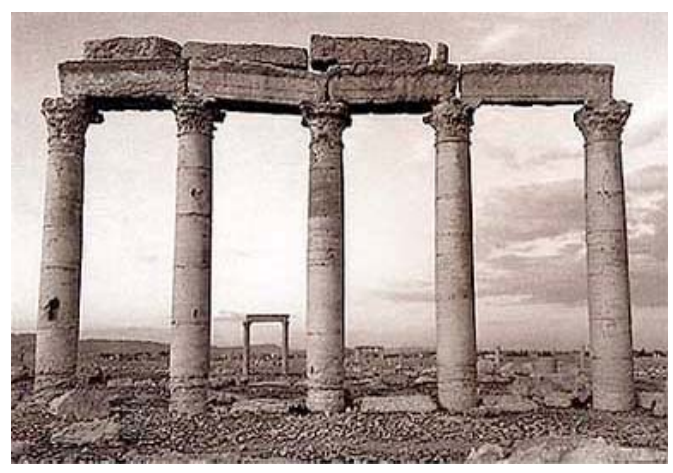

Imagen 31. Kenro Izu Palmira \# 34, Siria, 1995

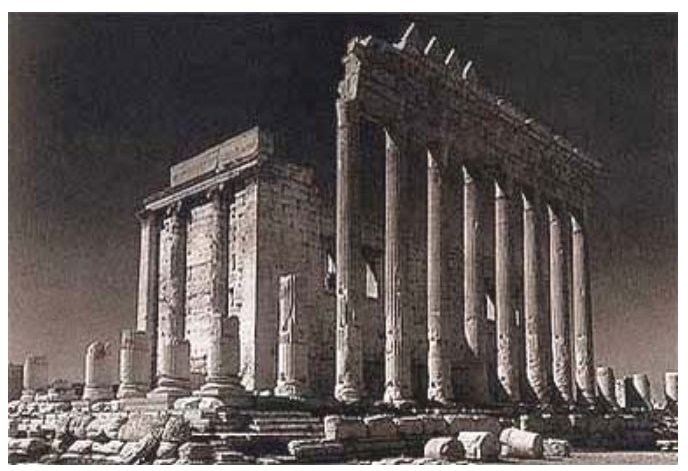

Imagen 32. Kenro Izu

Palmira \# 43, Siria, 1995

El canon fotográfico: evitar la deformación a toda costa. La acción conjunta de la toma frontal con la corrección óptica de la perspectiva hace que en la Imagen 31 la armazón vertical-horizontal se mantenga, sin que las columnas presenten una deformación aun cuando la cámara está situada por debajo del centro del sujeto. En la Imagen 32 la corrección óptica se mantiene, por lo que las columnas conservan su verticalidad; sin embargo, al ser el ángulo de toma oblicuo, las columnas se ven escorzadas, entrando en acción el gradiente de escala. 


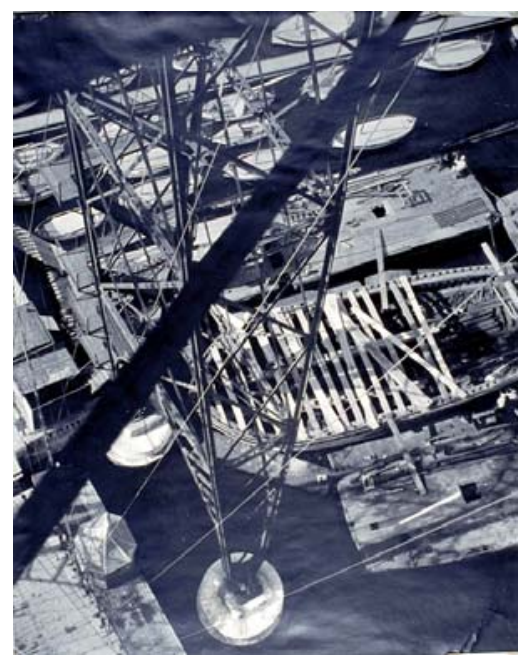

Imagen 33. László Moholy-Nagy

Vista desde puente, Marsella, 1929

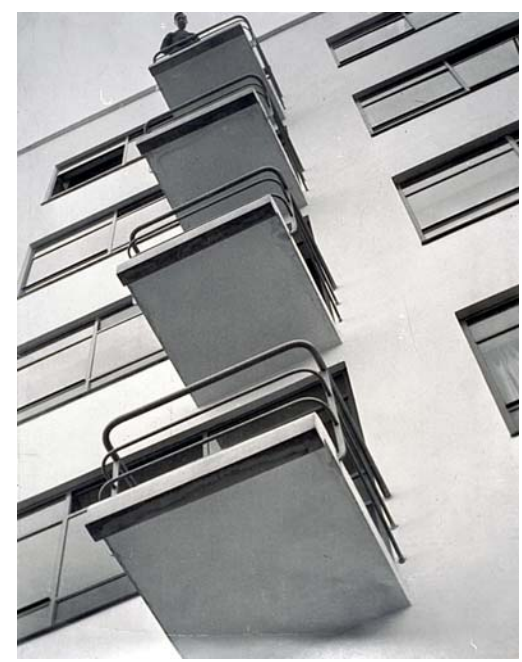

Imagen 34. László Moholy-Nagy Balcones de la Bauhaus, 1926

Al abandonarse la frontalidad, la armazón vertical-horizontal se rompe, siendo las líneas escorzadas más pronunciadas conforme el ángulo de toma se vuelve más abrupto, como en el caso de la toma en picado de la Imagen 33 o el contrapicado de la Imagen 34. Aunque este efecto es muy fácil de percibir en sujetos arquitectónicos, no olvidemos su efecto en otro tipo de sujetos, como los humanos, y su uso retórico. 
SEGUNDA PARTE: EL ANÁLISIS INMANENTE

CAPÍTULO 5

\section{LOS CÓDIGOS TÉCNICOS}





\section{1. Prefacio: en el LABerinto de la téCNicA}

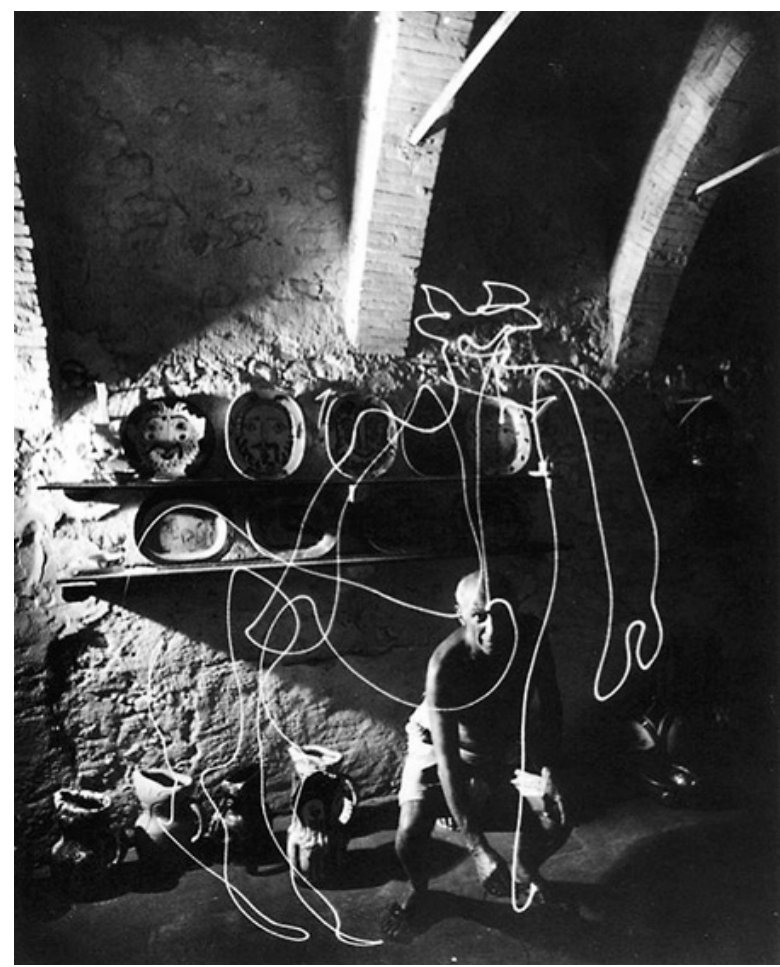

Imagen 35. Gjon Mili

Picasso dibujando un minotauro con luz, 1949

Picasso se encuentra en un lugar totalmente oscurecido. ¿Será, acaso, el laberinto de su mente? En la mano tiene una antorcha encendida. Se escucha el sonido de la apertura de un obturador, al tiempo que el destello de una luz congela la imagen del pintor en la placa del negativo; es una luz instantánea, efímera, que sin embargo, dada su velocidad, tiene el poder de imprimir dicha imagen en la película como si aquel se encontrara inmóvil. A partir de ese momento el genio se mueve y utiliza la antorcha para trazar sutilmente en el aire el contorno del minotauro, pero el obturador de la 
cámara, fija en un trípode, sigue abierto, y para una cámara con el obturador abierto, una antorcha en movimiento es como el hilo de Ariadna. La huella cinético-lumínica de la obra efímera dibujada en el aire ha sido registrada. Nunca nadie la vio, más que el Teseo-Picasso que la produjo, pero en este caso la técnica fotográfica nos ayuda a salir del laberinto con la imagen de su silueta. El obturador se cierra. ¿Es posible fotografiar lo que nuestros ojos no ven?

En este punto hemos de dirigir nuestra atención a la técnica fotográfica para hablar de uno de sus aspectos fundamentales. Nos referimos al hecho de que «una de las especificidades más características de la estética del medio $-\mathrm{y}$ una de las menos estudiadas, incomprensiblemente- es la aptitud de la fotografía para generar sus propios signos visuales, que no proceden de la «analogía», sino de la tecnología». (Costa 1991: 47)

Estos signos tienen su origen en lo que la teoría de la comunicación denomina como ruidos o parásitos, esto es, elementos generalmente de origen técnico que interfieren en la transmisión del mensaje o se introducen en el medio como errores. (Cfr. Chéroux 2003) Estos elementos, por lo tanto, no serán propios de la realidad fotografiada, sino que se encontrarán únicamente en la imagen. Costa señala que la conversión de un ruido en mensaje depende de la utilización que el autor haga de él; esto significa que los parásitos son integrados progresivamente al programa del aparato (cfr. Flusser 1983) y, por lo tanto, que pueden ser visualizados de antemano como un recurso más al servicio de la intencionalidad comunicativa del autor. Profundicemos:

¿Cómo se introducen estas partículas en una imagen? De tres modos distintos: inevitablemente, o por azar, o bien por una utilización intencionada (creativa) por parte del fotógrafo. En los dos primeros casos -inevitabilidad y casualidad-puede hablarse en rigor de parásitos (aunque en ambos casos estos puedan ofrecer efectos visuales de notable eficacia estética, con lo cual ya no serían parásitos). En el tercer caso [...] lo que en principio eran parásitos devienen finalmente signos: signos que son propios y específicos de la fotografía [...] ya que es solo ella - y no otro sistema de signos- la que tiene la capacidad de producirlos y superponerlos automáticamente en un mensaje visual. (Costa 1977: 76) 
Más allá del carácter parasitario que se encuentra en el origen de estos elementos, la industria fotográfica en infinidad de ocasiones los ha codificado y explotado. El constante desarrollo de la técnica fotográfica implica un incremento paralelo de estos signos; basta echar un vistazo a los catálogos de accesorios para efectos especiales -el fabricante de filtros Cokin sería un buen ejemplo- o a los menús de los programas de retoque digital para comprender que la lista que de ellos podría elaborarse es infinita. Adicionalmente, los nuevos usos generados por parte de artistas son lexicalizados e integrados a la publicidad y a los usos vulgares del medio, aunque no puede dejar de notarse que, en ocasiones, este proceso se da en sentido inverso, ya que la creatividad y los grandes presupuestos de la foto comercial también son capaces de generar prácticas que posteriormente se transfieren al ámbito del arte. En cualquier caso, se da la paradoja de que el error técnico se ve institucionalizado, comercializado y convertido en moda. Tal es el caso, por ejemplo, de la Holga, lanzada al mercado en 1982, una cámara china de juguete, muy barata, para película de formato medio, cuyo objetivo plagado de aberraciones ópticas da lugar a resultados impredecibles y a lo que algunos consideran, no sin cierto candor, como una estética de baja fidelidad. Lo mismo podemos decir de la, así llamada, lomografía, la cual parte del uso de la cámara soviética modelo LOMO-LCA, contemporánea de la Holga y cuyas aberraciones características son el viñeteado, el error de gama y la saturación de color. Los lomógrafos cuentan incluso con un decálogo que se sintetiza en el lema: ¡No pienses, dispara! El uso masivo de estas cámaras-juguete demuestra que no solo la técnica puede codificarse y lexicalizarse, sino también las actitudes de quienes las usan.

Sin embargo, seamos cautos: hablar de efectos especiales nos puede llevar a equívocos, ya que esta es solamente la parte más visible del asunto y también, como se desprende de los ejemplos anteriores, la más integrada a los usos comerciales y populares de la fotografía. Intentemos, por lo tanto, explorar la actitud creativa que se encuentra detrás de esta vocación experimental de cierto tipo de prácticas fotográficas. 
Ya anteriormente aludimos a una de las eternas dicotomías que han escindido al medio fotográfico desde su origen: nos referimos a la oposición entre purismo y pictorialismo. Ante la ambigua polisemia con la que dichos términos han sido utilizados a lo largo de la historia, quedémonos con la definición de Ward ${ }^{1}$ glosada por Fontcuberta:

El pictorialismo está basado en la premisa de que una fotografía puede ser juzgada con los mismos patrones con que se juzga cualquier otro tipo de imágenes (por ejemplo, grabados, dibujos y pinturas); la postura purista está basada en la premisa de que la fotografía tiene un cierto carácter intrínseco y que el valor de una fotografía depende directamente en la fidelidad a este carácter. Para el pictorialista, la fotografía es el medio, y el arte es el fin; para el purista, la fotografía es a la vez fin y medio, y se muestra reticente a hablar de arte. (Ward, citado en: Fontcuberta 1984: 18-19)

Prolonguemos brevemente este discurso, ya que la profundización en estos términos no solo es fundamental para el presente capítulo, sino que nos será de utilidad en diversas etapas de nuestra reflexión. Mientras que la noción de purismo ha sido alimentada en diversos momentos —por ejemplo el ya comentado Grupo f64 (ver supra: 4.2) -, conformando el canon fotográfico como aquello que se vincula con un tipo de expresión específicamente fotográfica (estrechamente ligada, dicho sea de paso, a los criterios que en el apartado anterior hemos identificado con el grado cero de la expresión fotográfica), el término pictorialismo, por su parte, ha recorrido un largo camino de abusos y malentendidos, principalmente debido a una utilización peyorativa asociada a la imitación de la pintura. Como precisa el propio Fontcuberta, en cierto período se llegó incluso a desacreditar al pictorialismo, y aclara, siguiendo en la vía de las distinciones semánticas:

Es [...] conveniente esclarecer que, contrariamente a lo que se tiende a pensar, pictorialismo no equivale a pictoricismo. Etimológicamente, el término «pictorialismo» se emparenta con la voz inglesa picture, que tiene una pluralidad de significados: imagen, cuadro, pintura, fotografía, película; «pictorial» se traduciría, por tanto, como «icónico», «gráfico», «plástico» o

${ }^{1}$ Ward, J ohn L. The Criticism of Photography as Art. Gainesville: University Press of Florida, 1978. 
«creativo-visual», según los contextos. El hecho de que en muchas ocasiones los autores pictorialistas tuvieran una voluntad claramente mimética de la pintura - pictoricista-, no debe condenar el verdadero espíritu del movimiento: la supremacía de los resultados por encima de los métodos observados. Y a quienes hoy siguen pensando que el pictorialismo era sinónimo de una lamentable imitación de la pintura académica victoriana, convendría recordar que toda la fotografía sintética moderna (mixed-media, manipulaciones, experimentalismo, etc.) tiene de hecho su base en aquella formulación estética. (Fontcuberta 1984: 19)

A las últimas palabras del texto citado, escrito antes de la irrupción de la fotografía digital, habría que sumar la consideración de que, de la mano de esta, las técnicas pictorialistas se han potenciado, llevando la posibilidad de intervención sobre la imagen fotográfica al extremo del control píxel por píxel.

Es necesario también tomar en consideración que, si bien muchas de las actitudes experimentales a las que nos referimos parten del campo del arte, su incorporación al ámbito de la imagen funcional es plena -también se da, como ya lo indicamos, el camino en sentido inverso-. En los campos del diseño gráfico y la publicidad, estas actitudes se potencian debido a que, para los diseñadores, la imagen fotográfica no constituye un fin en sí misma - si vale tomar prestada la expresión de Ward arriba citada—, sino que es un producto intermedio que será modificado al integrarse a un texto informativo, como el impreso, que es en sentido estricto multimedia en tanto que se compone de una diversidad de elementos: texto, tipografía, grafismos, fotografías, ilustraciones, infografismos, puesta en página, etcétera. Es precisamente desde esta óptica funcional que los mismos autores que venimos siguiendo, Costa y Fontcuberta (1988), definen en una obra conjunta el concepto de fotografismo, aclarando que, más allá de su lectura desde el ámbito de los efectos especiales,

[...] el fotografismo presupone una actitud de creación de imágenes fotográficas concebidas para y destinadas a su aplicación en una pieza de diseño gráfico. Por tanto - esto es lo fundamental-, en base a nuestro criterio, puede haber creación fotográfica ya en el momento del disparo, previo a la imagen, simplemente partiendo de un tratamiento fotocreativo del modelo. (Costa y Fontcuberta 1988: 130) 
Así, el fotografismo, visto desde la perspectiva de la imagen funcional, sería algo muy similar al pictorialismo, visto este desde el ámbito de la estética. Es remarcable el hecho de que, aun cuando algunos de estos procedimientos llevan a la obtención de imágenes que se podrían considerar como más cercanas al diseño gráfico que a la fotografía, la mente del receptor de tales mensajes conserva la idea de su referencialidad. El resultado, así, son imágenes completamente insertas en el campo de la ficción, mas, a la vez, imbricadas íntimamente en la realidad. Esta ambivalencia, esta doble raigambre, da a los códigos técnicos muy particulares posibilidades retóricas y expresivas.

El comentario de las anteriores categorías nos lleva a plantear que lo que finalmente se deriva de la evolución de la ya añeja propuesta expresada por Costa - permanentemente renovada a través de su producción tanto individual como en colaboración a lo largo de más de tres décadas-es una especie de paradoja, en el sentido de que si el purismo buscaba lo específicamente fotográfico en el canon, Costa lo propone desde otra óptica, la que se desprende de las posibilidades de la técnica, y desde otra perspectiva, la de la imagen funcional, vinculándolo precisamente con la alteración del canon.

Más allá del gran interés que suscita, vista en conjunto, la propuesta de estudiar estos parásitos y, en general, los elementos de origen técnico, que han devenido en signos, dicho interés acaso se diluye en cierta medida al verlos en su plasmación concreta y en su reducción, por parte de la industria, a fórmulas lexicalizadas que originan imágenes-tópico. La definición técnica de cada uno de dichos elementos sería, por otro lado, materia de un volumen completo, por lo que nos limitaremos en los incisos siguientes a mencionar algunos de los más frecuentes y conocidos. De momento, señalaremos sucintamente que Costa (cfr. 1977 y 1991) los clasifica en las siguientes categorías: ópticos, lumínicos, cinéticos y químicos. Algunos de ellos, los que se encuentran entre los más comunes y en los que posteriormente ahondaremos a partir de las maneras en que pueden ser categorizados, son: 
- Las estrellas y formas geométricas provocadas por la incidencia de luz en el objetivo.

- Las estelas luminosas producto de luces en movimiento con el obturador de la cámara abierto.

- Los fotomontajes y sobreimpresiones.

- Las secuencias de imágenes integradas en un solo cuadro, como la fotografía estroboscópica.

- La oposición entre dinámica y estática.

- La oposición entre enfocado y desenfocado.

- Las deformaciones, como las producidas por filtros.

- La ruptura de la perspectiva usual, como la producida por los objetivos ojo de pez.

- La combinación de imágenes negativas y positivas.

- La exclusión de tonos intermedios, el alto contraste.

- La transformación y modificación óptico-química de la imagen, como sucede en las solarizaciones.

- La exageración del grano fotográfico.

- Las texturas irreales, debidas a la utilización de tramas.

- La alteración del color.

Aquí adoptaremos la misma clasificación que hemos indicado arriba, estableciendo dos precisiones para ampliar su alcance. La primera es la de considerar también como parte de los códigos técnicos al material de soporte de la fotografía. Este -aunque por supuesto no tiene un origen parasitario tal como ya hemos definido el concepto- es un elemento vinculado a la técnica que en ocasiones alcanza un elevadísimo nivel de relevancia a nivel semántico, como lo propone Soulages (1998: 33), máxime en la presentación de fotografías originales en el ámbito del museo o galería. Como es lógico, es un factor que se pierde al ser reproducida la imagen en medios ya sea impresos o electrónicos, proceso en el cual frecuentemente sí llega a incorporar elementos parasitarios; acaso es por este motivo que su importancia suele ser minimizada. Si bien este factor tenía relevancia desde la aparición del medio, hoy por hoy esta es valorada particularmente en ciertas prácticas. Tal es el caso de la fotografía con medios alternativos (que será comentada más adelante en este mismo apartado), para la cual el material de soporte es fundamental. También hay que mencionar la facilidad de acceso a la reproducción en gran formato que han traído consigo los medios de impresión digital a partir de la década de 
1990, sumada a la diversidad de materiales disponibles, lo que ha supuesto una verdadera revolución en este sentido no solo en el nivel de la exhibición de foto artística, sino también en el del display mercadotécnico y publicitario.

La segunda precisión radica en que, al estar la propuesta de Costa formulada antes de la introducción de la fotografía digital, no incluye en su clasificación los efectos, tanto parasitarios como intencionados, de retoque, asociados a esta tecnología y respecto de la cual, dado lo reciente de su divulgación, deseamos ser cautos. Esta cautela consiste, en nuestro caso, en intentar otorgar su justa medida a las posibilidades digitales, al margen de la desmedida exaltación que la industria hace de ellas como parte de sus estrategias de mercadeo.

Hechas estas reflexiones —que serán ampliadas, en lo que toca a la foto digital, en el Capítulo 8, aunque desde otro punto de vista-, a continuación presentamos un breve recuento, a través de ejemplos, de algunos componentes de los códigos técnicos. No es nuestra intención hacer un catálogo exhaustivo a la manera de Costa (1977 y 1991) y Fontcuberta (1988), lo cual nos llevaría a poner un énfasis en la técnica que excede nuestros fines, sino que simplemente buscamos dejar constancia de la lógica subyacente en la clasificación presentada. Para ello, utilizaremos imágenes provenientes principalmente de la tradición fotográfica y de la utilización de estos recursos por parte de grandes maestros. Tomamos esta opción con absoluta conciencia de que dichas prácticas están en diálogo permanente con los campos de la fotografía funcional, como la publicitaria y comercial, que es probablemente donde dichos recursos se explotan con mayor asiduidad. En el comentario de las imágenes se percibirá, asimismo, que frecuentemente en una imagen los recursos de los códigos técnicos no se presentan en estado puro, sino que en la mayoría de los casos se entremezclan y combinan -óptico-químicos, químico-lumínicos, ópticocinéticos, etcétera-. A ello hay que añadir otra circunstancia que quien ha practicado la experimentación fotográfica conoce bien: en ocasiones existen diversos caminos para llegar a resultados similares. 


\subsection{Código óPtico}

Los componentes del código óptico son, acaso, los que se han caracterizado por una mayor estabilidad a lo largo de los cerca de dos siglos de existencia de la fotografía. Como ya se sugirió al hablar de los valores de escala y escorzo correspondientes a los códigos miméticos (ver supra: 4.3 y 4.4), el canon fotográfico ha establecido un uso de la óptica que tiende al grado cero, esto es, a una representación de la realidad naturalista, mimética, centrada en el concepto de analogía. Mientras que la gran mayoría de las distorsiones ópticas son aceptadas por la percepción, que inconscientemente restablece la imagen a valores aceptables, cuando se sobrepasa cierto umbral la distorsión es interpretada como parte de la intencionalidad del fotógrafo, como un recurso expresivo per se. Tal es el caso de la distorsión óptica de barril, característica de los objetivos cortos, que llega a un extremo al usar objetivos ojo de pez, siendo tan abrupta que el naturalismo de la representación se vuelve irrecuperable.

Pero más allá de las distorsiones derivadas de la distancia focal de los objetivos y de ciertas prácticas específicas para exacerbarlas, el código óptico comprende una infinidad de recursos derivados del paso de la luz a través de las lentes o incluso de la ausencia de estas, como es el caso de la fotografía estenopeica. Entre ellos podemos mencionar de una manera general, solo por enumerar algunos, los efectos de enfocado y desenfocado, de basculación y descentramiento, de profundidad de campo, los derivados del uso de lentes suaves o con aberraciones tanto perspectivas como cromáticas y de definición, así como un amplísimo menú de posibilidades tanto de variación cromática como de distorsiones de la forma derivadas del uso de filtros de efectos especiales y artículos -como los ya mencionados en torno a la lomografía y la cámara Holga, o su versión adaptable a las cámaras SLR, como es el Lensbaby_producidos ad hoc por la industria. 


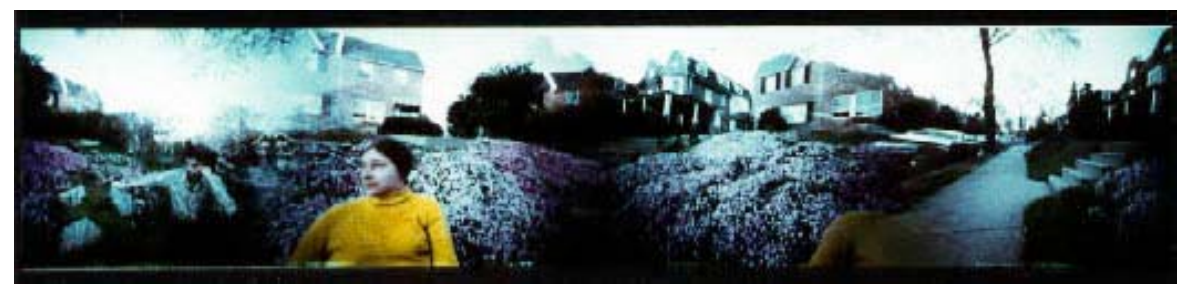

Imagen 36. David Lebe

B.B. y yo, 1974

Fotografía estenopeica tomada con cámara de cuatro agujeros, coloreada manualmente. Óptica en estado puro, esto es, la sola acción de la transmisión de la luz, sin siquiera pasar por la mediación de una lente. La fotografía estenopeica, la cual ha tenido un verdadero renacimiento desde la década de 1960, retoma este principio que podría calificarse de arcaico, ya que las lentes fueron utilizadas en la cámera obscura para mejorar la calidad de la imagen desde mucho antes del invento de la fotografía. Aunque es cierto que en general estas fotos no tienen la nitidez de las obtenidas a través de lentes, esto es considerado por algunos como un atractivo. Las cámaras, que son producidas artesanalmente con infinidad de variantes $\mathrm{y}$, por lo general, preparadas para aceptar película comercial, no requieren ser enfocadas y producen una imagen nítida desde unos cuantos centímetros hasta el infinito. 


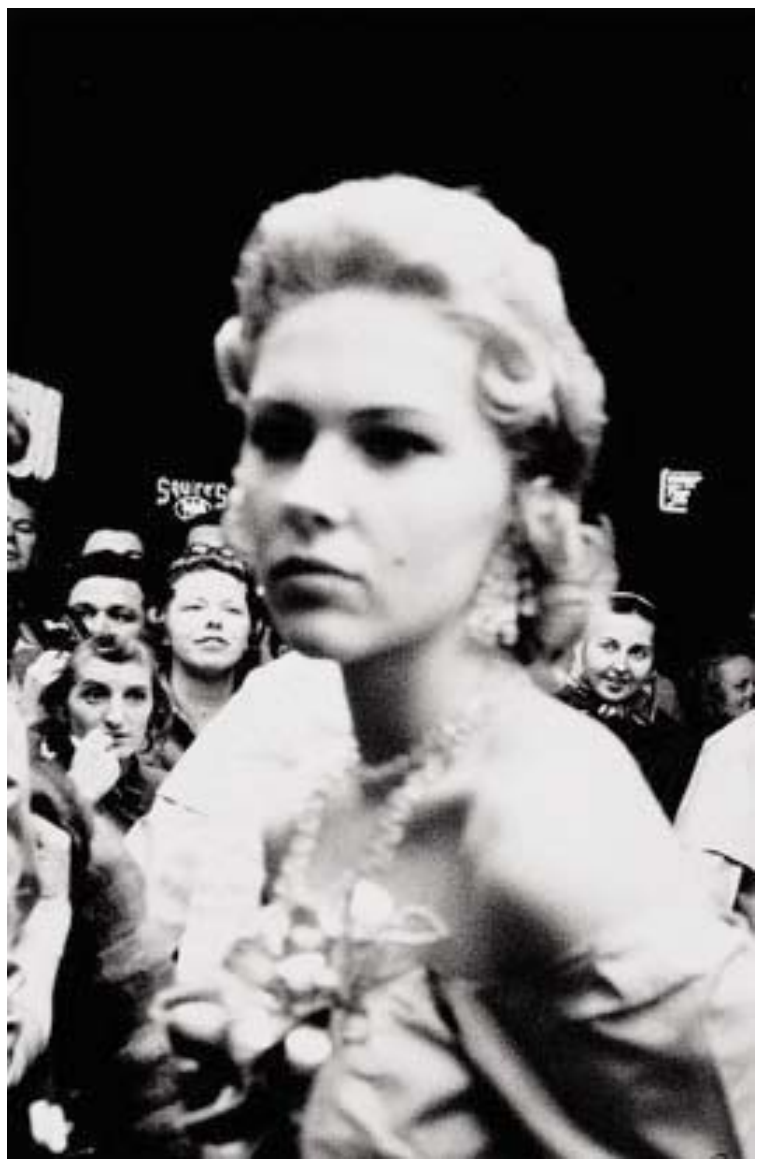

Imagen 37. Robert Frank

Premiere de cine, 1955-56

Un simple efecto de enfocado-desenfocado es utilizado aquí para ironizar, lo cual se logra con una gran efectividad. La foto de Frank está compuesta conforme a la tradición y resulta absolutamente convencional, salvo por el hecho de que invierte el enfoque y, con ello, desplaza la atención del primer plano -la estrella de cine-al segundo - los mirones-. 


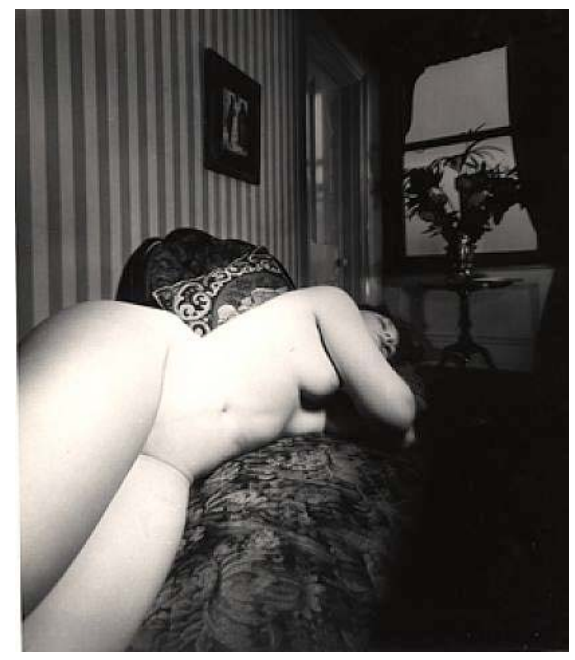

Imagen 38. Bill Brandt

Desnudo, 1950

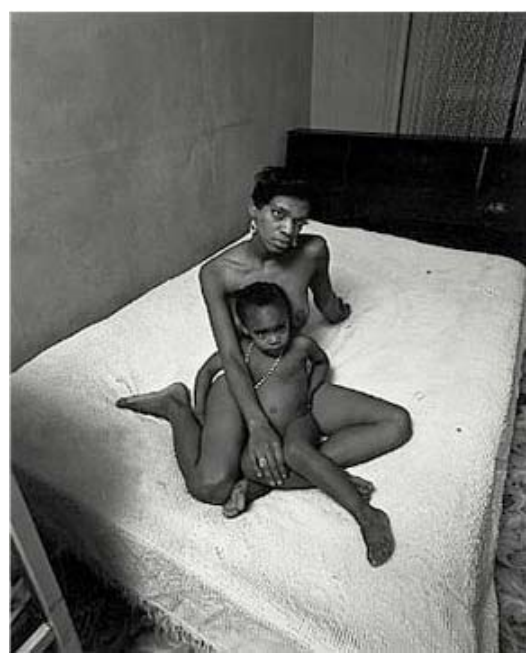

Imagen 39. Bruce Davidson De: East 100'th Street, 1970

Dos ejemplos de distorsión óptica. En el primero, Brandt juega con la forma: la cámara se encuentra perpendicular al suelo, como lo revelan las verticales y horizontales del fondo; sin embargo, la presencia de un sujeto a muy poca distancia del objetivo de corta focal introduce la distorsión. En el segundo caso, Davidson hace la toma en picado, también con un objetivo de corta focal a poca distancia, con lo que distorsiona a los sujetos, obteniendo un primer plano desproporcionado. 


\subsection{CóDigo Químico}

Dentro de esta categoría se cuentan, en general, los efectos resultantes de las intervenciones en el laboratorio fotográfico, las derivadas de la película y las del material de impresión. Si la formación del canon o grado cero del contraste se vinculó con el desarrollo de la sensitometría para asegurar la estabilidad de los materiales fotográficos $\mathrm{y}$, como resultado, permitir la previsualización de los tonos a obtener -el sistema de zonas sería el paradigma en este sentido-, las posibilidades de intervención en el laboratorio para alejarse de dicho canon son infinitas. Entre las más difundidas cabe mencionar la solarización, el efecto Sabatier, la posterización, el revelado cruzado, la exageración del grano, el alto contraste, el enmascarado, el tramado, la negativación, la separación de tonos, la inversión y los virajes. Mención aparte merece la película instantánea Polaroid la cual, desde su lanzamiento al mercado en 1947 hasta su descatalogación en 2008, fue una fuente de continua de experimentación mediante alteraciones durante el proceso de revelado.

También pertenecen al ámbito de la química el fotomontaje, el fotocollage y la sobreimpresión con sus diversas técnicas, y en especial el positivado combinado, procesos que, si bien obedecen a una lógica pictorialista vinculada no tanto a efectos formales, sino de contenido, se realizan asimismo, aunque con excepciones, dentro de la húmeda oscuridad del laboratorio.

Un ámbito más que puede ser destacado es el de la, así llamada, fotografía alternativa:

Hacia finales de los años setenta surgió en los medios fotográficos estadounidenses [...] una corriente que se caracterizó por su voluntad de romper los límites impuestos por aquellos que propugnaban una fotografía pura y directa sin intervenciones manuales. Así empezó todo un proceso de recuperación de las antiguas y olvidadas emulsiones y técnicas fotográficas del siglo XIX, que permitían una libertad casi absoluta en la elección de superficies, tamaños y formas y ofrecían la posibilidad de intervenir directamente en el color de la copia final. (Zelich 1995: 9) 
Fotografía alternativa, pero alternativa, ¿a qué? Una vez más, a la norma, a lo convencional. En este sentido, se considera como fotografía convencional a la que

utiliza papeles y películas sensibles producidos por la industria y comercializados. Sin embargo, existen una serie de procesos fotográficos que no se encuentran preparados en el comercio y en los cuales la emulsión o sensibilizador es preparada por uno mismo, y que aplicados sobre distintos soportes (papel, tejidos, madera...) producen imágenes de una gran calidad y valor creativo. (Tió 1988: 150)

Finalmente, hemos de comentar que, si bien con la fotografía digital algunas de estas prácticas han acusado un marcado declive, muchas de ellas se han incorporado al lenguaje digital, produciéndose efectos similares con un simple golpe de tecla o selección de un filtro en un menú del programa de retoque, aunque ciertamente obteniéndose en la mayoría de los casos un resultado que tiene un relativo grado de artificiosidad comparado con el procedimiento original. Es de resaltar que, durante los años de introducción de los programas de retoque digital, muchos de estos procesos cumplieron la función de un verdadero modelo a seguir, máxime tratándose de un momento en el que la convivencia en el mercado de imágenes analógicas escaneadas, junto con otras ya de origen digital, exigía que las características de ambas se hicieran compatibles.

No es necesario insistir, por otro lado, en que la práctica por excelencia de cortar y pegar, el fotocollage producto de la técnica de positivado combinado, es la más difundida en el ámbito del retoque digital. Con ella se perpetúa, modificada y potenciada, una de las principales aportaciones pictorialistas de origen químico, habiendo perdido ahora su aura de excelencia técnica y estando al alcance de un público masivo que la puede realizar de manera sencilla a través de programas de software que incluso puede descargar de manera gratuita de Internet. 


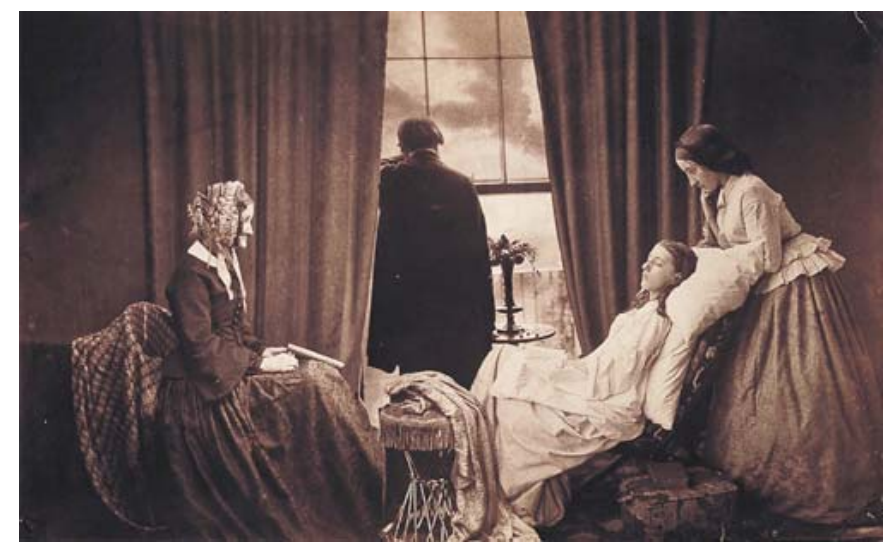

Imagen 40. Henry Peach Robinson

Los últimos instantes, 1858

Imagen emblemática de la estética pictorialista decimonónica, esta escena posada se creó por positivado combinado, que en aquella época solo podía ser realizado en impresión por contacto, siendo utilizados cinco negativos. 


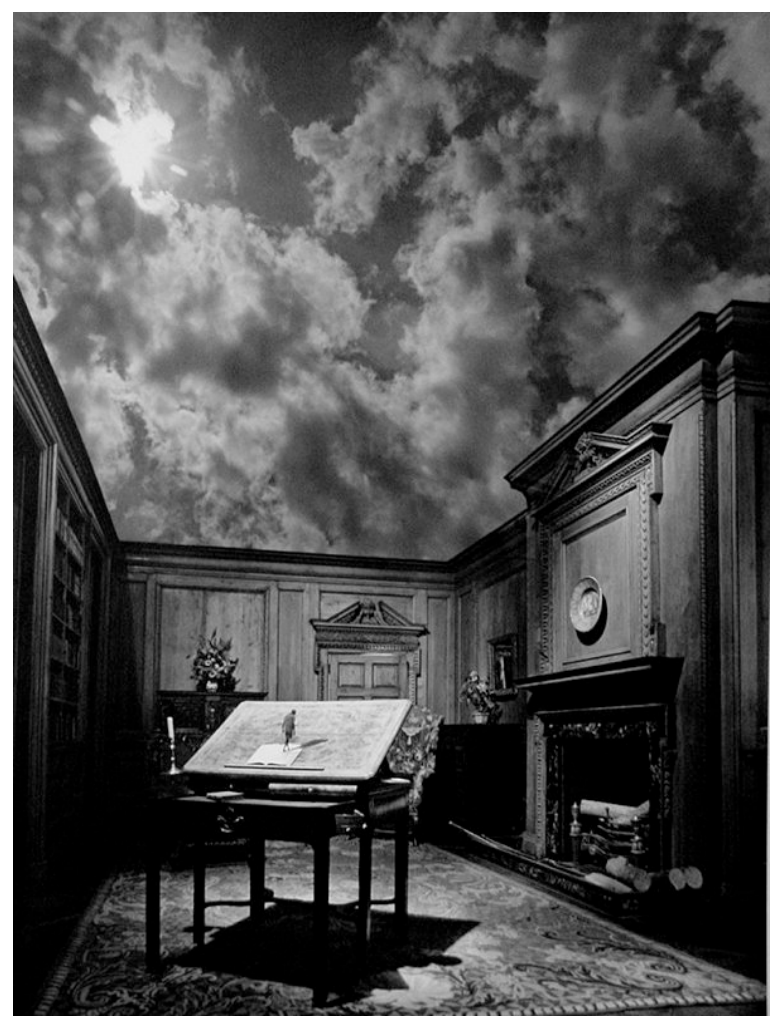

Imagen 41. J erry Uelsmann

Sin título, 1976

La maestría de Uelsmann en la técnica del positivado combinado, en su caso trabajando la composición enteramente en el laboratorio, nos recuerda que muchas de las prácticas realizadas hoy en día con el retoque digital tienen claros antecedentes tanto en las artes plásticas en general como en la fotografía en particular. 


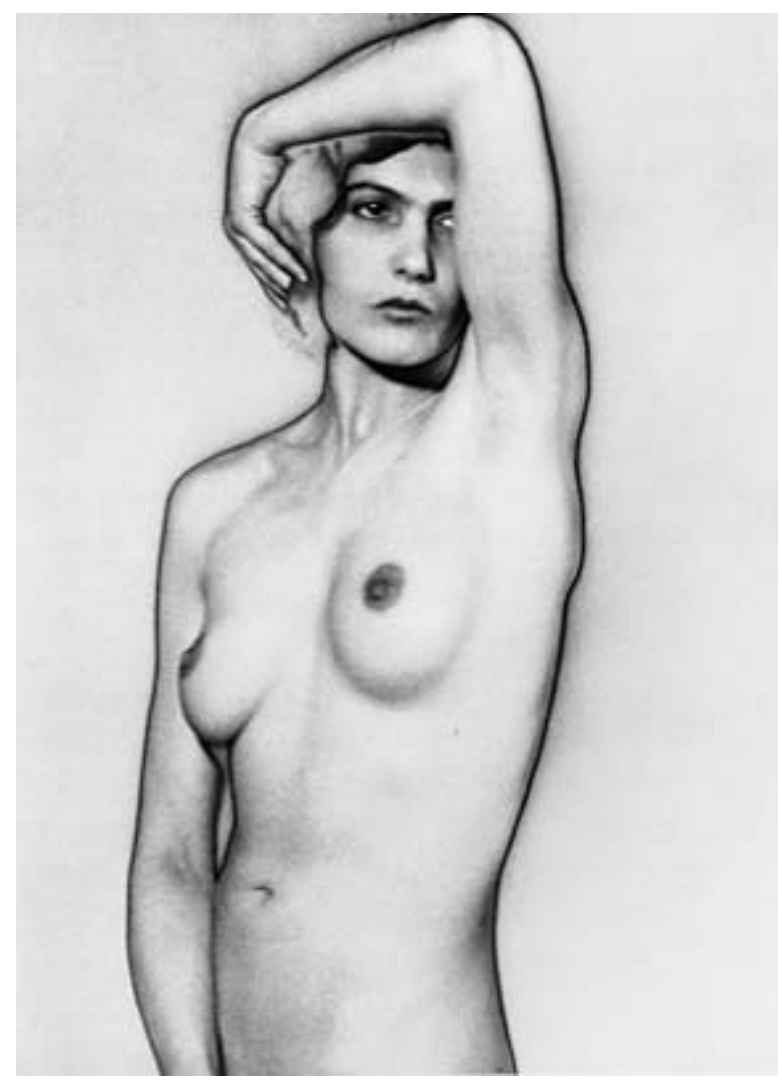

Imagen 42. Man Ray

Natacha, 1931

La solarización -con todas sus variantes para lograr inversiones de tonos, como el efecto Sabatier, línea Mackie, etcétera-, es uno de los recursos químicos más clásicos, muy caro a la estética surrealista. Puede considerarse como químico-lumínico ya que el efecto resulta de la acción de la luz para sobreexponer el material sensible durante su procesamiento químico. 


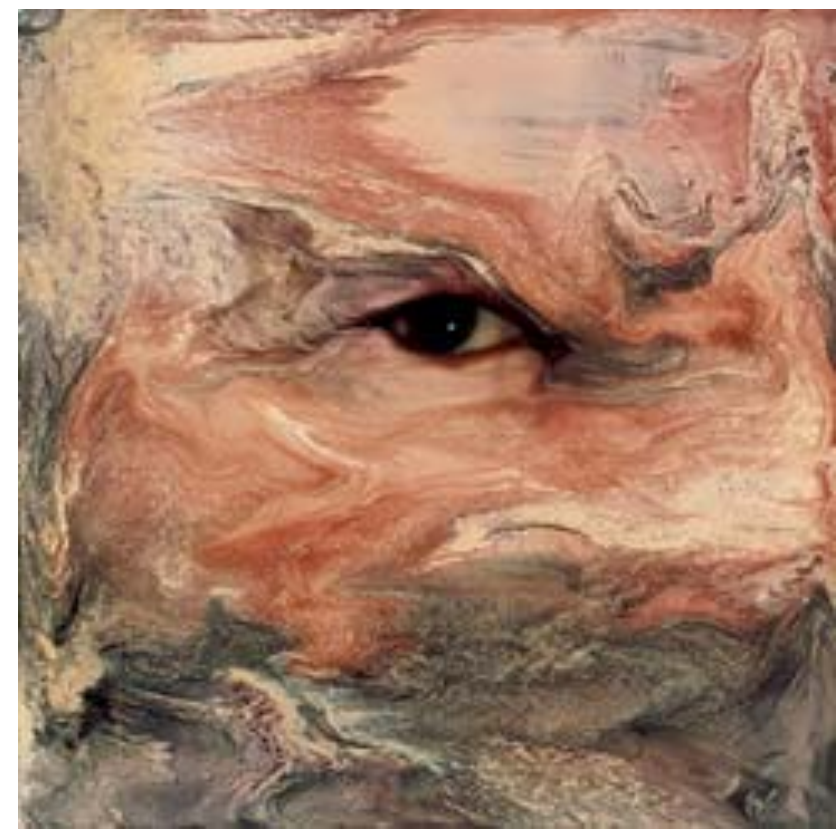

Imagen 43. Lucas Samaras

Foto-transformación, 11/ 1/ 73, 1973

La alteración de la película Polaroid -en este caso de tipo SX-70-mediante recursos como la manipulación durante el revelado, la alteración de su temperatura o la transferencia, entre otros, fue una técnica socorrida principalmente en el ámbito artístico. Su época dorada fue la década de 1970. 


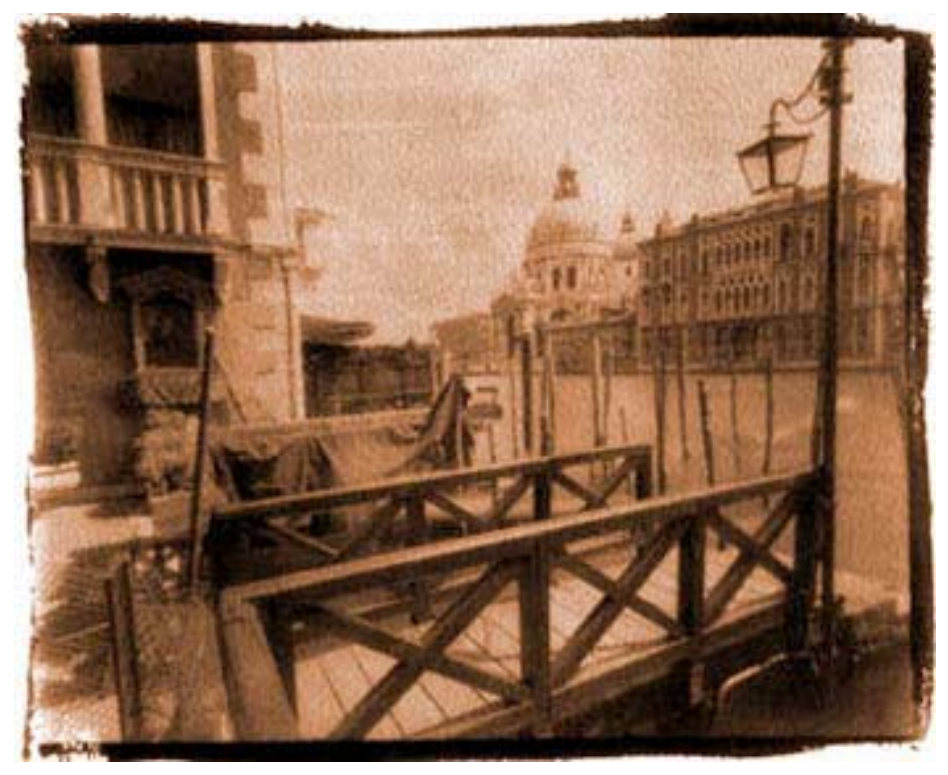

Imagen 44. Marcia C. Sheer

Venecia 2, s.d.

La kalitipia, o proceso Vandyke, fue inventada por el químico inglés W.W. Nichol en 1889 y está basada en el uso del nitrato de plata y una sal de hierro. La imagen está compuesta por plata metálica y es muy similar a la platinotipia, aunque de un coste mucho menor. Por su coloración, puede también asemejarse a la técnica del papel salado, aunque con mucho mayor detalle en las sombras. En este caso, adicionalmente, como reverencia a los procesos antiguos, la foto está hecha con una cámara estenopeica. 


\subsection{Código LUMínico}

Materia prima esencial de la fotografía, la sensibilidad hacia la luz y sus efectos sigue siendo acaso el elemento que más distingue lo que se conoce como mirada fotográfica. Aun hoy, cuando las imágenes casuales se producen diariamente por millones con todo tipo de dispositivos, el manejo de la iluminación marca distancias entre el profesional y el diletante.

Los artilugios ópticos, mecánicos, electrónicos y químicos del dispositivo fotográfico están diseñados para someter a este elemento tan omnipresente y, a la vez, tan intangible. Siendo así, como es lógico, son muchos los componentes del código lumínico que se desprenden tanto de resultados parasitarios de la técnica como de efectos buscados ex profeso. Entre ellos, podemos citar a las luces parásitas por la incidencia de luz frontal en el objetivo, las variaciones cromáticas derivadas de la temperatura de color de las fuentes de luz así como su modificación por el filtraje, el uso intencionado de las sombras y una enorme variedad de efectos lumínico-cinéticos derivados del juego conjunto de diversos tipos de iluminación con tiempos de exposición variados.

Mención aparte merece el fotograma o fotografía sin cámara -que no debe ser confundido con cada una de las imágenes de la tira de película cinematográfica, designada en aquel ámbito con el mismo nombre-. El fotograma, aunque es una práctica de excepción en el contexto del vasto campo fotográfico, tiene ganado un lugar histórico vinculado principalmente a las prácticas surrealistas y a la escuela de la Bauhaus. Se trata de imágenes producidas por el simple efecto de la luz sobre el papel sensible, encima del cual se han colocado objetos ya sean opacos, translúcidos o transparentes para lograr, en combinación con el tiempo de exposición, siluetas y difuminados de diversas tonalidades, a fin de obtener como resultado composiciones generalmente abstractas. 


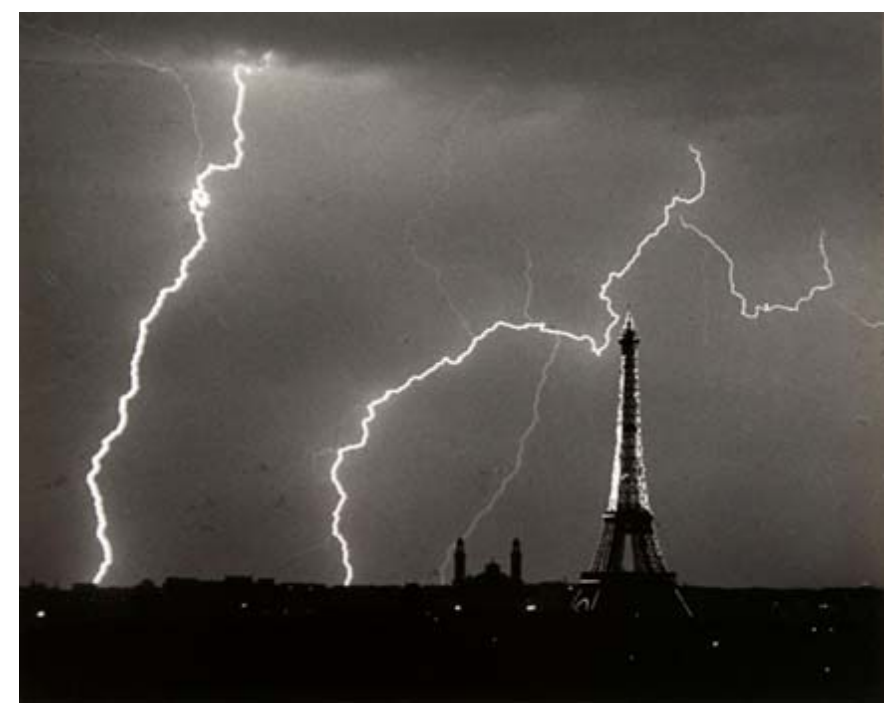

Imagen 45. André Kertész

Paris, l'été un soir d'orage, 1925

Un instante de luz invisible para el ojo humano, captado gracias al efecto instantáneo de huella del rayo sobre la película. 


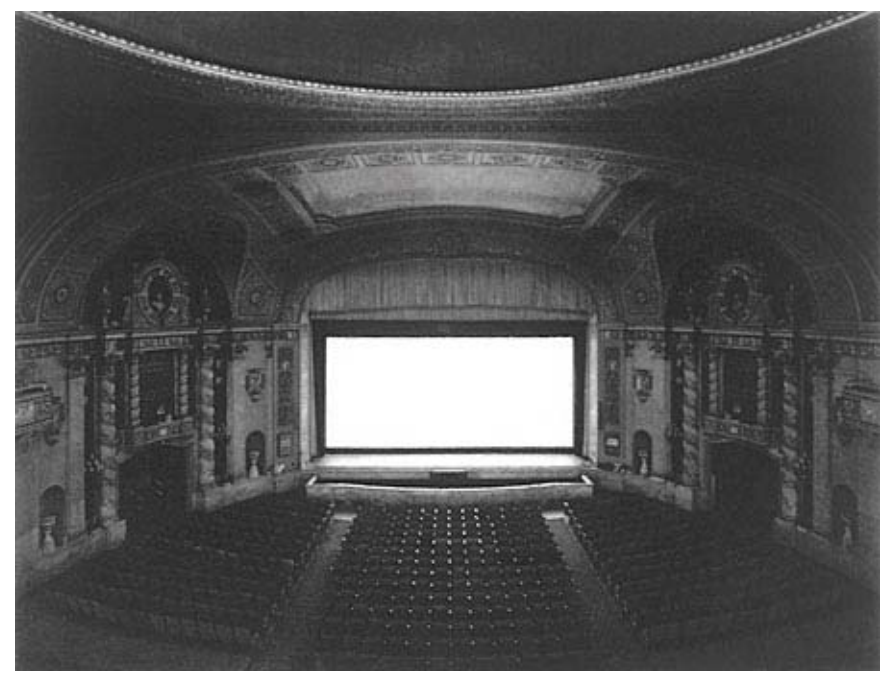

Imagen 46. Hiroshi Sugimoto

Teatro Walker, Nueva York, 1978

Luz-tiempo. El intenso blanco de la pantalla en la serie Teatros, de Sugimoto, es el resultado de la sobrexposición por un larguísimo tiempo de obturación equivalente a la duración completa de la película que está siendo proyectada. Un filme entero condensado en un solo fotograma. 


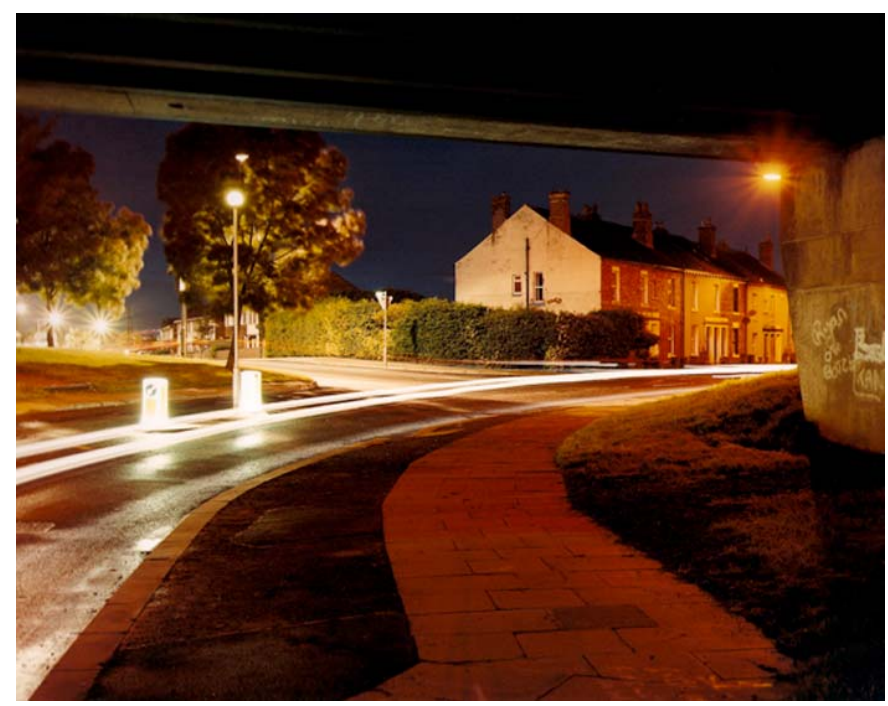

Imagen 47. Marcus Doyle

Botch, s.d.

En esta fotografía de archivo podemos apreciar varios efectos lumínicos. Los más evidentes son la estela de luz continua generada por los faros de un coche -gran tópico de la fotografía turística urbana- y la desviación cromática general hacia el ámbar, que es producto de la temperatura de color de las luces de tungsteno. Esta podría corregirse para acercarse al grado cero, esto es, a nuestra percepción de los colores reales, mediante un filtro azul. En la fotografía digital, dicha corrección ya no se hace mediante un filtro óptico, sino modificando valores de balance de blancos ya sea en la cámara o, posteriormente a la toma, en el ordenador. En adición, vemos el efecto de estrella en algunas de las luces puntuales. 


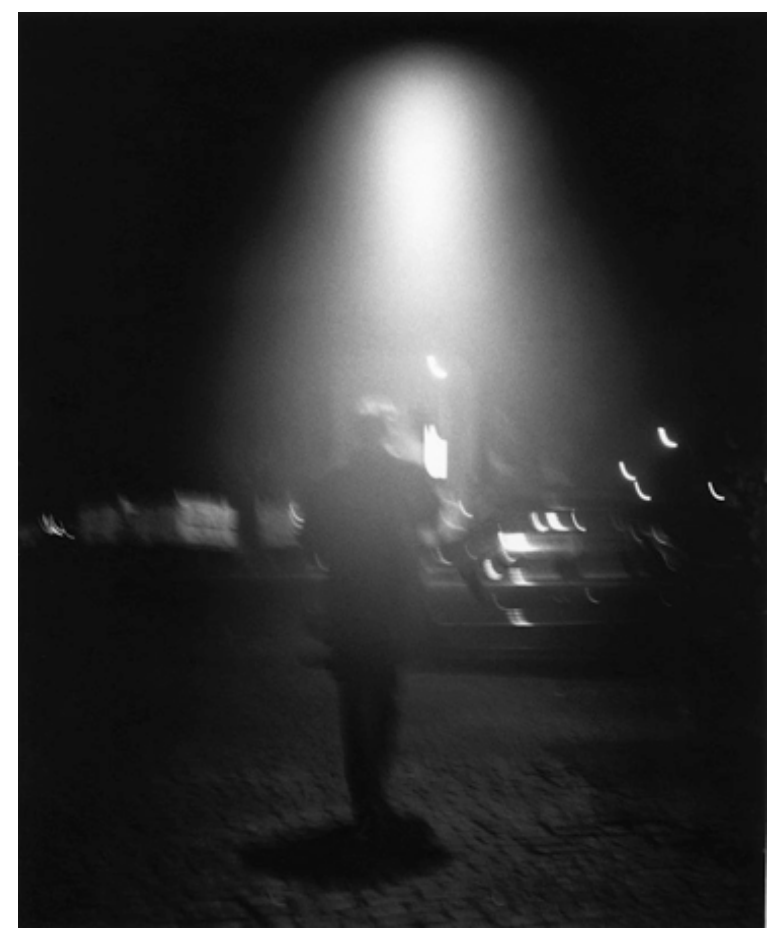

Imagen 48. J ason Langer

Llegada, 1997

Un efecto de flou, una especie de barrido de la luz, producto de la posición frontal de la fuente luminosa en relación al objetivo. También, percibimos el efecto cinético de la foto movida tanto por lo borroso de la misma como porque los puntos de luz aparecen como pequeñas estelas. Adicionalmente, es notable el efecto químico del grano reventado. 


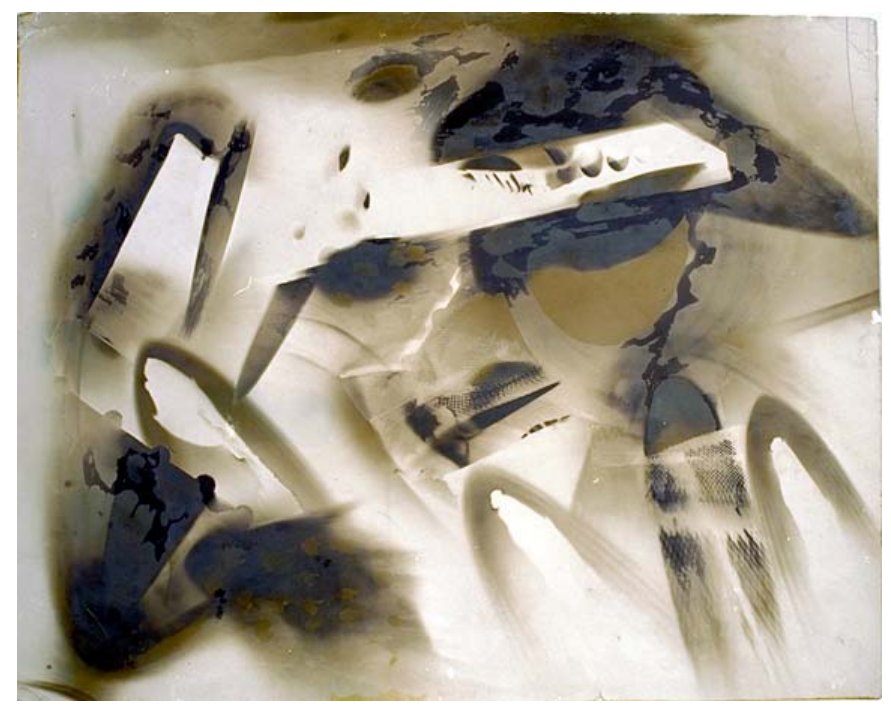

Imagen 49. László Moholy-Nagy

Fotograma coloreado, 1939

Fotografía sin cámara. Un fotograma abstracto, en este caso, coloreado a mano, con lo que el material de soporte de la imagen adquiere un valor semántico adicional dado su carácter de pieza única, el cual evidentemente se pierde en la reproducción aquí presentada. 


\subsection{CóDigo CinÉtico}

Siendo la detención del movimiento una de las aspiraciones de la fotografía desde su aparición, gran cantidad no solo de desarrollos técnicos, sino también de efectos parasitarios, están vinculados a este factor. A lo largo de la historia del medio la técnica ha generado cámaras más manejables, objetivos más luminosos, obturadores más rápidos, películas o sensores digitales más eficientes... Aun así, hoy por hoy el usuario no deja de requerir de los fabricantes innovaciones que eviten que sus fotos salgan movidas.

Por supuesto, en manos del fotógrafo creativo esta limitación ha sido usada de manera consciente y se ha convertido en fuente de incontables efectos fotografísticos. Como es evidente, son varios los elementos que pueden estar en movimiento, así como múltiples sus combinaciones. Fundamentalmente, pueden moverse la cámara, el sujeto e incluso la luz y la película. Adicionalmente, pueden darse relaciones cinéticas entre la figura y el fondo. Algunos de los efectos que se desprenden del movimiento son: el barrido, el paneo, el zoom, el desplazamiento de película, las estelas de movimiento, la detención ultrarrápida del movimiento, el flash combinado con barrido, y el uso de estroboscopios y luces multidestello, entre otros.

Estos efectos son, acaso, los que con más frecuencia observamos en el día a día, tanto en la fotografía de prensa como en la publicitaria e incluso, aunque en esta más vinculada al error que a la creatividad, en el ámbito de la fotografía de aficionado.

Cabe recordar también que, durante el siglo XIX, fueron precisamente los esfuerzos por estudiar el movimiento y lograr detenerlo los que originaron el principio del cinematógrafo. 


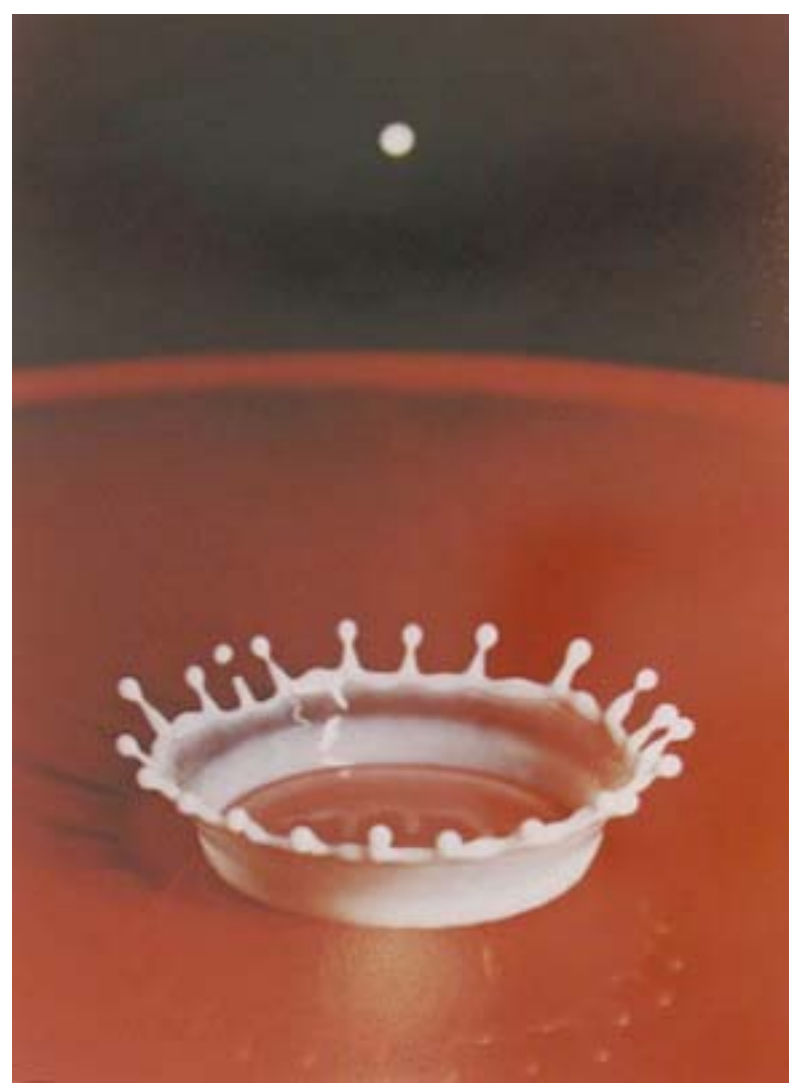

Imagen 50. Harold E. Edgerton

Gota de leche, 1957

La detención ultrarrápida del movimiento, ya sea por la utilización de flash o por el uso de tiempos de obturación extremadamente cortos, hace visible lo que el ojo desnudo no puede captar. Este efecto no solo ha derivado en usos científicos sino también, por supuesto, de tipo creativo. 


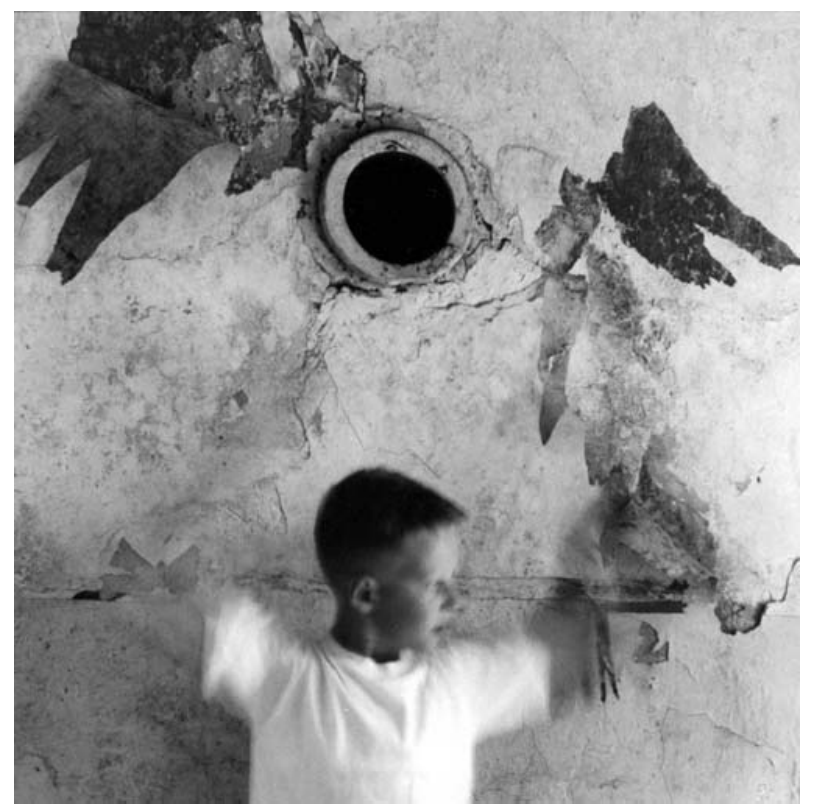

Imagen 51. Ralph Eugene Meatyard

Sin título, 1960

El simple efecto del barrido es utilizado por Meatyard de manera sistemática en su obra, generalmente oscura, pero que en este caso pone alas al chico retratado. 


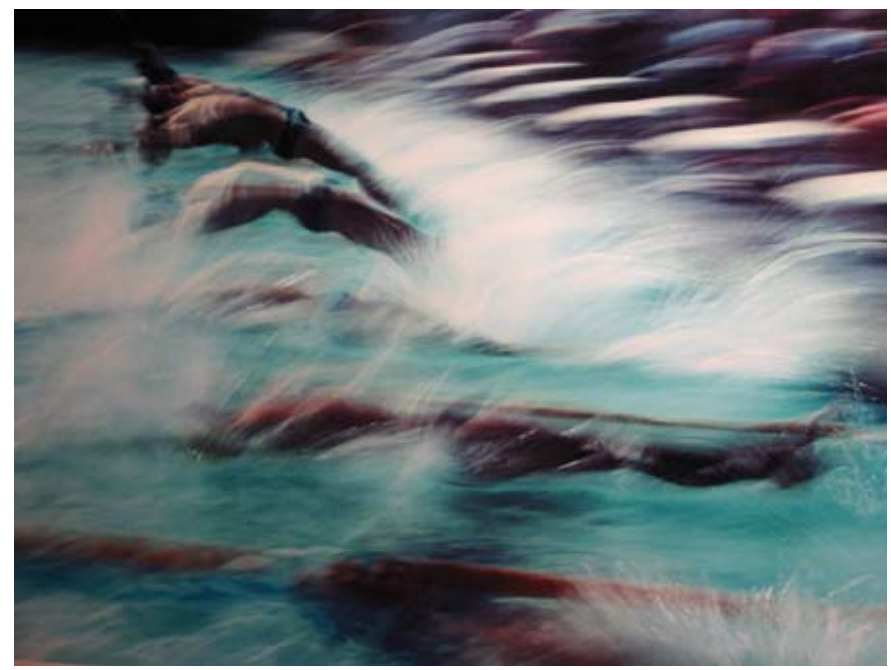

Imagen 52. Ernst Haas

Nadadores olímpicos, 1984

El movimiento combinado de los sujetos y la cámara da lugar a este barrido total. Si fuera solo el sujeto el que se moviera, el fondo aparecería nítido. Cuando el fotógrafo panea la cámara a la misma velocidad de un sujeto con movimiento continuo y estable - no es el caso de estos nadadores-, el sujeto puede aparecer estático contra un fondo barrido. 


\subsection{Código digITAL}

La rápida expansión de la tecnología fotográfica digital, así como la vulgarización de sus posibilidades de incidir en la imagen final, hacen que sea imperativo considerarla dentro de los códigos técnicos. Si bien sus primeros desarrollos datan de mediados de la década de 1970, no es sino hasta alrededor de 1990 que las grandes compañías de equipo fotográfico empiezan a promover cámaras digitales destinadas al gran público.

Sin embargo, la transición de la fotografía analógica a la digital tardó más de lo que dichos fabricantes hubieran deseado. Toda la década de los años noventa estuvo llena de desencantos debidos a la falta resolución de los equipos, su rapidísima obsolescencia, su alto costo, la ausencia de estándares que permitieran un flujo de trabajo estable entre fotógrafos y diseñadores, y la falta de calidad de los procesos de impresión digital, entre otros factores. No es sino hasta, grosso modo, el primer tercio de la década del año 2000, cuando se alcanzan estándares que no solo son equiparables a los de la foto analógica, sino también duraderos -aunque bien sabemos que hablar de duración, en este ámbito, es equívoco-. La evolución del mercado desde entonces puede ser revelada -iqué desafortunada expresión en este contexto! - por un dato significativo: en el año 2005 el fabricante Nikon, líder del mercado, dejó de producir toda su línea de cámaras analógicas para centrarse solamente en la fabricación de equipos digitales.

Hechas estas precisiones, señalemos que hay en la tecnología fotográfica digital, al igual que en todos los casos que hemos revisado en este apartado, tanto elementos parasitarios que en ciertas prácticas profesionales tratan de evitarse, como otros que, también en contextos específicos, son exacerbados a fin de retorizar la imagen. Todo parásito o ruido comunicativo puede ser utilizado como elemento creativo. Prueba de ello es que el ruido por excelencia en la fotografía digital, que es el pixelado sobre todo en las zonas oscuras de la imagen cuando se trabaja a 
sensibilidades (ISO) muy altas o a resoluciones muy bajas, es también un filtro en el programa de retoque digital, a fin de pixelar - para usar uno de tantos barbarismos de moda en la jerga digital- las imágenes que no lo están.

En una visión de conjunto, podemos hablar de tres categorías de componentes del código digital. Por un lado, las prácticas que se desprenden de la lógica de cortar y pegar, que ya hemos comentado (ver supra: 5.3) como una de las estrategias más difundidas del retoque digital y, además, como una continuadora de las estéticas pictorialistas del positivado combinado y el fotocollage, de gran aceptación en el siglo XIX y las primeras décadas del XX, respectivamente. Esta es, asimismo, la aplicación del código digital que más ha influido en la pérdida de credibilidad de la fotografía como testimonio a partir de la década de 1990, aunque no es nuestra intención banalizar este complejo fenómeno y atribuirlo solo a esta causa, ya que venía perfilándose desde varias décadas atrás y cuenta, además, con profundas implicaciones tanto de tipo semiótico como socio-antropológico. (Ver infra: Capítulo 8)

La segunda categoría consiste propiamente en la aplicación de filtros a la imagen, los cuales están ya incluidos como parte del repertorio de los programas informáticos de retoque digital e incluso de los menús de opciones de la propia cámara, lo que les da un carácter mecánico e impersonal. Como ya se indicó, muchos de ellos están diseñados para emular los resultados de efectos tradicionales de la fotografía analógica, como son los virados, solarizaciones, posterizaciones, granulado de la película, etcétera. En su extremo, es posible afirmar que en el ámbito de lo digital incluso el blanco y negro se ha convertido en un efecto especial, ya que hoy por hoy puede lograrse con toda facilidad a partir de un archivo a color, contándose con un amplísimo abanico de opciones de control del contraste. En su mayoría, los filtros ofrecen la posibilidad de aplicarse en diversas gradaciones y de combinarse entre sí, lo que produce variantes muy amplias. Adicionalmente, es de remarcar el factor de la facilidad y velocidad de aplicación de los filtros: mientras que con las técnicas 
analógicas es necesario que la imagen pase por un proceso que implica tiempo -los propios términos imagen latente y revelado hoy son fuentes de nostalgia- y gasto de recursos y que, en caso de desear obtener una pequeña variante, el proceso completo se repita, la aplicación de los filtros digitales se da simplemente mediante el uso de algunos comandos del teclado o el ratón y puede ser visualizada en el monitor de manera inmediata, corregida, graduada y modificada reiteradamente.

La tercera categoría, también la menos usual y, acaso, la que expresa una vocación más auténticamente experimental, es la que consiste en generar ya sea imágenes sintéticas que emulan fotografías o imágenes fotográficas modificadas, mediante la alteración de programas informáticos o del uso de estos de maneras alternativas a aquellas para las que fueron creados. Siendo este un uso particularmente vinculado a propuestas de tipo artístico y experimental, no cabe la generalización, sino solo la alusión a propuestas autorales específicas.

Finalmente, hemos de señalar una paradoja: si bien cuando se habla de retoque digital inmediatamente se piensa en imágenes sintéticas de tipo ficcional, la inmensa mayoría del retoque que se realiza es simplemente correctivo. No es necesario insistir en la amplitud del uso del retoque como forma de estetización en la fotografía publicitaria y comercial para eliminar las antenas de televisión de un paisaje urbano, o un incómodo cable de luz eléctrica de una fotografía arquitectónica, o las imperfecciones de la piel de una modelo. Y si afirmamos que es una paradoja es porque en infinidad de ocasiones lo que se corrige son precisamente efectos fotográficos parasitarios. Esta práctica tampoco es nueva, siempre ha existido. Una vez más, los factores a resaltar son su vulgarización y la velocidad de su aplicación: mientras que antes era necesario contar con una gran habilidad artesanal en el laboratorio, con el aerógrafo o con cualquier otro medio manual, hoy la técnica está prácticamente al alcance de cualquiera que aprenda el uso de algunas funciones del programa informático. 


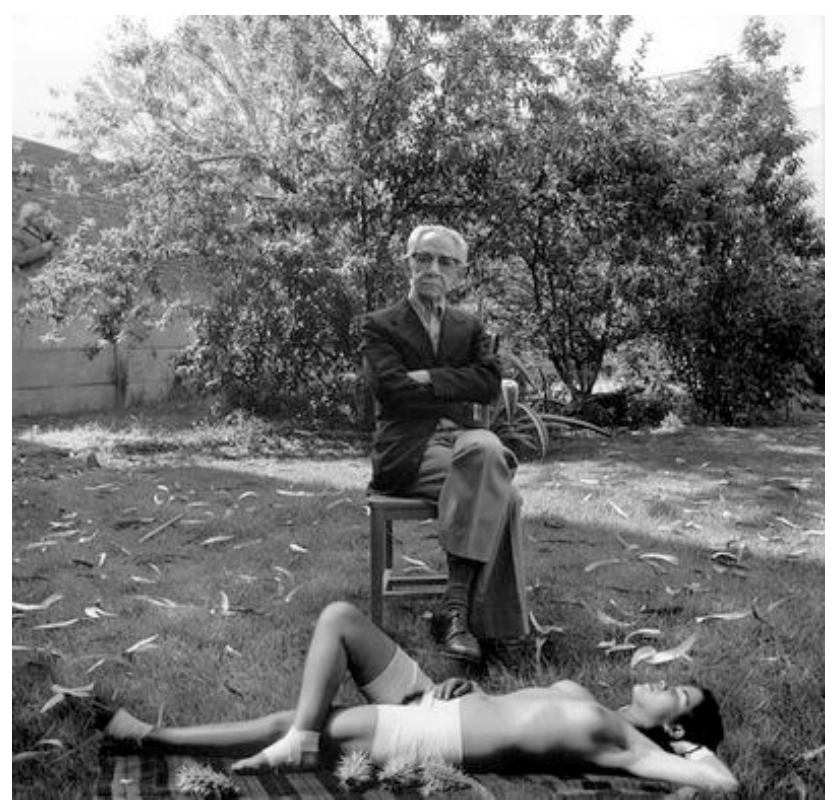

Imagen 53. Pedro Meyer

Manuel Álvarez Bravo, 2002

En el retrato del fotógrafo mexicano Manuel Álvarez Bravo (1902-2002) posando en su jardín, se pega digitalmente la modelo desnuda, cortada de una de sus imágenes emblemáticas, La buena fama, durmiendo (1938). Una referencia intertextual, dado el carácter naturalista del retoque, que solo es apreciable si el receptor conoce previamente aquella obra. 


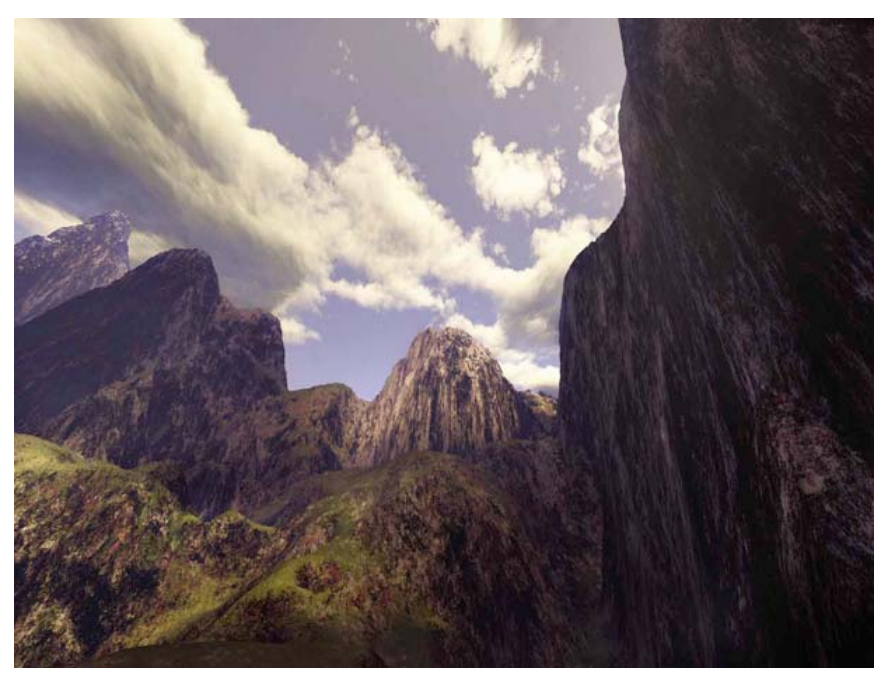

Imagen 54. J oan Fontcuberta

Kandinsky, 2004

«En esta serie de imágenes denominada Orogenesis me he servido de programas informáticos que generan paisajes virtuales como Vistapro, Vue d’Esprit, Bryce, Terragen o Worldbuilder. Estos programas, cuyo principio funcional estuvo orientado a usos militares o científicos, permiten la modelización de un territorio sin necesidad de interpretar los códigos de representación cartográfica. A partir de archivos digitales que contienen información altimétrica, el software realiza una simulación del relieve. No obstante, dado que todo archivo digital (sea del formato que sea, trátese de texto, imagen o sonido) no es más que una cierta secuencia de algoritmos, mi estrategia aquí consiste en engañar al programa forzándolo a interpretar no mapas sino [cuadros pertenecientes a la tradición pictórica], que actúan como fuente. Como estos programas solo saben hacer montañas, valles, lagos, nubes, etc. cualquier input será transformado dentro de ese repertorio limitado de outputs gráficos.» (J oan Fontcuberta, tomado de: http:// www.adf-photo.org/article. php?id_article=34, consultado: junio de 2008.) 

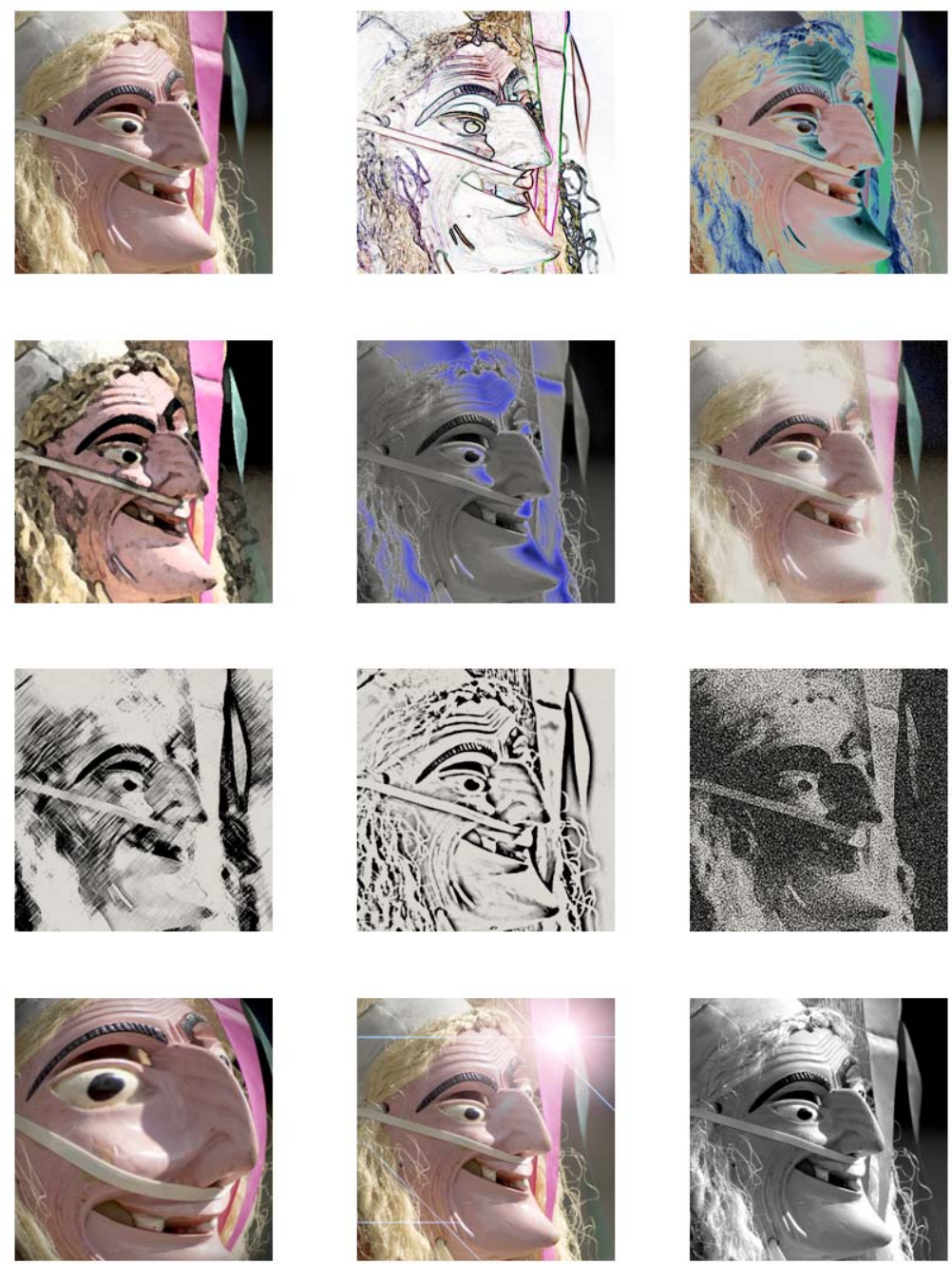

Imagen 55

A simple golpe de tecla, una fotografía común, la primera de la anterior secuencia, es modificada con diversos filtros y funciones de un programa de retoque digital, incluyendo su conversión a blanco y negro. Los ejemplos aquí mostrados son solamente una pequeñísima muestra del repertorio de alteraciones que es posible obtener por esta vía. 


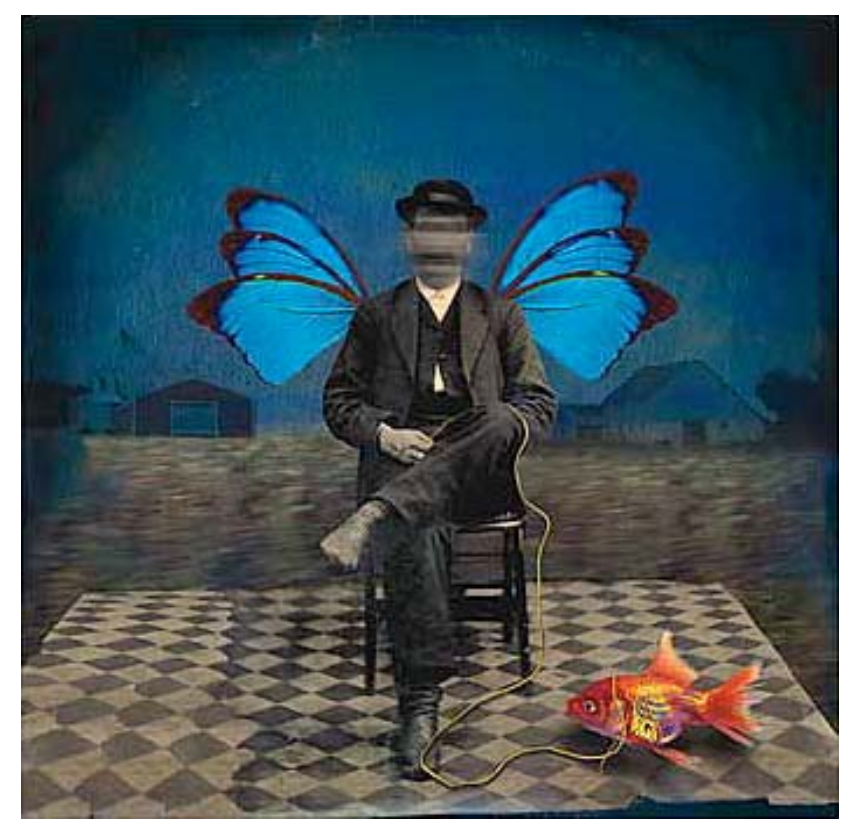

Imagen 56. Maggie Taylor De la serie: Paisaje de sueños, 2005

Al integrarse las posibilidades del retoque digital, pueden obtenerse imágenes sintéticas como esta, de clara influencia surrealista, en la que no solamente se combinan elementos de fotografías antiguas con otros fotografiados ex profeso, sino que también se emulan algunos efectos pictóricos. 


\subsection{EL SOPORTE Y EL FORMATO COMO CÓDIGOS}

Mencionado por algunos autores (cfr., por ejemplo, Soulages 1998: 33) como parte fundamental de la fotografía, aunque por lo general paradójicamente soslayado de manera casi inevitable, hemos de considerar dentro del código técnico tanto al material de soporte de la fotografía como a un factor estrechamente vinculado a él, a saber, el formato. En este caso particular, el motivo primordial de su inclusión en este apartado no es el posible efecto parasitario de algunos soportes o tipos de reproducción, sino simplemente el carácter enraizadamente técnico de ciertas prácticas que tienen evidentes implicaciones a nivel semántico. Enfatizamos el hecho de que solo nos referiremos aquí al soporte material de la fotografía. Las fundamentales consideraciones acerca del contexto de exhibición o del medio de distribución habrán de analizarse en otro momento. (Ver infra: Capítulo 7) Hecha esta precisión, entremos propiamente en materia.

Puede afirmarse que a lo largo de la historia de la fotografía, en términos generales, se ha minimizado la importancia de la pieza original. Acaso la razón de este hecho es que, desde un momento muy temprano en su desarrollo, el medio quedó vinculado indisociablemente a la idea de reproductibilidad. Esta se convirtió en uno de sus sellos distintivos que acentuaban su carácter mecánico frente a la esencia manual, de pieza única, propia de la pintura o de diversos tipos de improntas.

La relevancia de la foto como objeto y, por lo mismo, de su carácter material, está en función directa del campo fotográfico específico en que se produzca, distribuya o conserve. Así, por ejemplo, dentro del flujo de trabajo que durante décadas caracterizó (se utiliza aquí el tiempo pasado por razones obvias, aunque en muchos casos bien se podría describir esto en presente) a la imagen periodística, la foto que se generaba para ser reproducida en un diario carecía de un valor objetual: su valor era informativo e incluso la calidad de la impresión original —probablemente radiotransmitida, tecnología disponible desde la década de 1920 — quedaba 
en un segundo plano, ya que la rotativa no iba a ser capaz de generar una amplia gama tonal ni tampoco la resolución ideal. Sin embargo, la misma foto, al pasar al archivo, tomaba otro carácter, a saber, el de documento de la memoria histórica. Como tal, era imperativo conservarlo físicamente en buen estado, tanto la impresión, como las hojas de contacto y el negativo. Para ello, se desarrolló un ampliamente documentado protocolo de preservación de materiales fotográficos. Si la imagen era requerida por alguna editorial o medio de comunicación, podía generarse sin problema otra copia en papel o diapositiva, la cual volvería a insertarse en el flujo del trabajo editorial y tendría, una vez más, el carácter de objeto intermedio. La impresión resultante en una revista o libro, tras haber pasado por todo un proceso fotomecánico, tendría también un carácter informativo, no objetual -en todo caso este carácter objetual pertenecería al libro como producto final-. En el no tan improbable caso de que, por una de esas piruetas del mercado o del destino, la misma imagen fuera requerida para otro contexto, digamos, el de una exposición, su carácter objetual, de pieza original, pasaría por primera vez a ser relevante. Previsiblemente la copia producida para tal fin se haría en un formato mayor al que se había generado para su reproducción en medios impresos y se utilizarían materiales de mayor calidad; asimismo, idealmente debería ser una copia, si no realizada directamente por él, al menos autorizada por su creador. En el caso de que este último periplo se hubiera dado posteriormente a la muerte de aquel, de existir alguna copia de época, una vintage, esta, aunque no fuera de la mejor calidad, adquiriría en términos del mercado del arte un aura particular -Benjamin dixit-que acrecentaría su valor.

Si transpolamos este flujo de vida de la imagen fotográfica al momento actual, en el cual la digitalización abarca el proceso de principio a fin, encontraremos que acaso el énfasis se ha visto desplazado de la reproductibilidad a la transmisibilidad. Permítasenos la licencia de citar a Fontcuberta in extenso:

La dramática metamorfosis del grano de plata al píxel no representa más que una pantalla que eclipsa la evolución operada en todo el marco que 
proporcionaba un encaje cultural, instrumental e histórico a la fotografía. Las razones acerca de la inestabilidad de nuestras concepciones de lo fotográfico son múltiples [...]. En la fotografía han coexistido necesariamente dos facetas, indisociables y perfectamente soldadas: por un lado, la imagen como información visual; por otro, el soporte físico, el objeto dimensional. El daguerrotipo como punto de partida de las imágenes producidas por una cámara no era una imagen fijada sobre una plancha, sino una plancha que contenía una imagen; su presencia material resultaba inevitable. La tendencia se decantó por motivos prácticos hacia la obtención de soportes más livianos. Pero a lo largo de la historia, ciertos usos sociales o ciertos enfoques han privilegiado uno u otro componente; en el dominio del archivo, por ejemplo, prevalece el aspecto informativo, y en el del museo, en cambio, el objetual. La tecnología digital lo que hace es acentuar la fractura entre imagen y soporte, entre información y objeto. Dicho en otras palabras, la tecnología digital ha desmaterializado la fotografía emplazándola en una nueva configuración que vedará su acceso a antiguos territorios o impulsará la exploración de otros. La fotografía deviene hoy información en estado puro, contenido sin materia cuyo poder de fascinación pasará a regirse por otros factores. Cuestiones de sentido predominarán sobre cuestiones de representación. Así, no es extraño que en el terreno de la expresión artística la fotografía digital desfavorezca ciertos desarrollos formalistas mientras acentúa otros, narrativos y conceptuales. (Fontcuberta [ed.] 2002: 10-11)

Si en general las prácticas fotográficas comerciales ya apuntaban a la relativización del original al estar la imagen reproducida masivamente en algún medio de comunicación, la amplísima circulación de imágenes fotográficas en la forma de archivos digitales que hoy en día ocurre a través de medios electrónicos favorece esa fractura entre imagen y soporte a la que se alude en la cita anterior. Desde hace ya algunos años, una fotografía que vemos reproducida por ejemplo, en una revista, nunca ha sido, hasta su impresión final en offset, más que información en estado puro. Muchas otras nunca llegarán a conocer el papel.

Como consecuencia de lo expuesto con anterioridad, nos centraremos aquí exclusivamente en las prácticas artísticas y experimentales que dan al material de soporte y al formato un valor tanto objetual como expresivo. $\mathrm{Si}$ bien es cierto que en algunos campos, como es el caso del display mercadotécnico, estos elementos también son relevantes, por lo general se insertan dentro del ámbito de prácticas estereotipadas, por lo que dejaremos de lado su consideración.

Nos vemos en la necesidad, entonces, de fijar un grado cero como referencia a partir de la cual establecer una desviación. En este caso, dicho 
grado cero podría estar constituido por los materiales producidos masivamente por la industria, los cuales, a fuerza de uso, se convirtieron en norma. En la época de la fotografía plenamente industrializada, se vulgarizaron determinados materiales de soporte, fundamentalmente el papel de plata sobre gelatina, y algunos formatos, llegando a ser los más comunes los de proporción $4 \times 5$ y 2x3, así como el consagrado por las revistas de circulación masiva: 3x4. El primero de los mencionados es, además, el que se estableció para los papeles fotográficos de uso comercial, por lo que cualquier otro formato incómodo de toma -como el cuadrado, debido a las cámaras réflex de 6x6 cm. - tendría, finalmente, que ajustarse a él. No es este el lugar para profundizar en las razones históricas y de mercado que establecieron dichas constantes; lo que nos interesa simplemente es apuntar cómo no solo la práctica fotográfica, sino también la percepción, fueron condicionadas por este factor. Otro elemento destacable ligado al desarrollo técnico es la suplantación del blanco y negro por el color. Es en la década de 1980 cuando la balanza se decanta definitivamente hacia el segundo, de la mano de la generalización del uso de los minilaboratorios o minilabs de revelado automático rápido, que relegan al blanco y negro a un estadio artesanal y provocan que su costo sea proporcionalmente mayor.

Ante el gran impulso inercial de la megaindustria fotográfica, las propuestas artísticas supondrán una voz que, a través de su vocación experimental, en muchas ocasiones cuestionará la estandarización de los modos de hacer. Una primera práctica que habría que resaltar es la de los métodos alternativos -impresión al platino, kalitipia, goma bicromatada, papel salado, cianotipia, bromóleo, etcétera-, ya mencionados en relación al código químico. (Ver supra: 5.3) Si aquí los volvemos a traer a colación es debido a que a través de estos procesos no solo se buscan calidades diferentes derivadas del procesamiento químico, sino también $-\mathrm{y}$ habría que sumar aquí a la fotografía estenopeica - de utilizar superficies de impresión de diversas calidades y texturas, así como formatos poco convencionales. La técnica pictorialista de intervención manual en la copia, 
la cual la convierte en original, también ha sido una práctica recurrente, con un renacimiento a partir de la década de 1970. Otra práctica apreciada por los artistas que se valen de la fotografía como medio ha sido el uso de la película instantánea Polaroid, tanto por su carácter de pieza única como por la facilidad para intervenir su procesamiento o de integrarla a una acción debido a su instantaneidad.

Hemos de insistir en el hecho de que a partir de las décadas de 1960 y 1970 se desata un furor experimental debido a la adopción de la fotografía por los artistas plásticos como un medio expresivo más. Como consecuencia de lo anterior,

\begin{abstract}
A partir de los años ochenta se vislumbran síntomas de cambio que nos permiten asistir a un florecimiento de la fotografía como manifestación cultural y artística. La vocación autoral encamina decididamente la fotografía. Por ese motivo, teóricos fundamentalistas se aprestan a recriminar que la fotografía ha vendido su alma al diablo para acceder al parnaso del arte. Y entretanto irrumpen la tecnología digital y los programas de procesamiento de la imagen, que tan intensamente han afectado al paradigma original de la fotografía. En la última década hemos presenciado justamente la radicalización de ese cuestionamiento. El cambio tecnológico no ha hecho más que asestar el golpe definitivo a una dinámica que ya no tenía marcha atrás. Si conceptualmente la creación fotográfica evolucionaba adoptando el gesto artístico, con los soportes digitales, además, regresamos a la estructura icónica de la pintura y de la escritura. Los píxeles que proporcionan la textura de la imagen electrónica funcionan estructuralmente como las pinceladas para el pintor: constituyen unidades de configuración sobre las que podemos operar particularmente. Me gusta en este sentido insistir en que la fotografía analógica se inscribe y la fotografía digital se escribe. Inscripción y escritura señalan dos estadios de competencia epistemológica entre los que se debate la creación contemporánea: de la descripción al relato. Por eso en la fotografía actual se acusa una crisis del documentalismo y una proclividad a la narración y a lo discursivo. (Fontcuberta 2010: 187)
\end{abstract}

Lo que en este punto nos interesa remarcar es la voluntad de los artistas para extender las posibilidades del aparato fotográfico (cfr. Flusser), la cual se vuelve un objetivo en sí mismo, dando pie a expresiones que muchas veces son metalenguaje puro, esto es, su contenido es una reflexión acerca de las posibilidades comunicativas del propio medio. De la mano del avance tecnológico, a partir del período señalado, las galerías y museos se verán tomados por fotografías presentadas en formatos atípicos, 
fotoinstalaciones, imágenes impresas en toda clase de superficies, proyecciones donde la materialidad misma de la fotografía desaparece y monitores en los que la luz que estábamos acostumbrados a ver reflejada en el papel fotográfico se convierte en luz irradiada por el dispositivo electrónico, en el cual la imagen es para verse, no ya para poseerse.

La tecnología digital, por supuesto, ha ejercido una sensible aportación, generando desde la década de 1990 una nueva oleada de especulaciones y de experimentación en torno a la materialidad de la fotografía. Por un lado, las técnicas de impresión digital han facilitado la presentación de formatos, variedades de materiales de soporte y opciones museográficas que antes eran impensables o podían lograrse solamente a base de muchas horas de trabajo y de un gran dispendio de recursos. Pero, indudablemente, la máxima implicación de la tecnología digital se encuentra precisamente en la desmaterialización de la imagen fotográfica y en su abrumadora incorporación a la circulación global de datos como información pura. Así, conviven hoy la miniaturización del monitor frente a la espectacularidad museística. ${ }^{2}$

\footnotetext{
2 En este apartado en específico seguiremos una estrategia de ilustración distinta a la de los anteriores: en lugar de incluir simplemente ejemplos de algunas de las prácticas comentadas, aquí reseñaremos la obra de un solo autor, Michael Snow -quien, por cierto, no es propiamente un fotógrafo, sino un artista plástico que se vale de la fotografía al igual que de otros medios-, desde la década de 1960 hasta la del año 2000. Con ello pretendemos dar cuenta de ciertas tendencias en la fotografía museística en los últimos 40 a 50 años, vinculada a las diferentes posibilidades que la técnica ha ido proporcionando. En el caso de algunas de estas obras es necesario conservar los títulos originales en inglés ya que, por tratarse en muchas ocasiones de juegos de palabras, su traducción al español es imposible. Para más información sobre Snow, ver el capítulo que le dedica Damisch, 2001: pp. 59 y ss.
} 


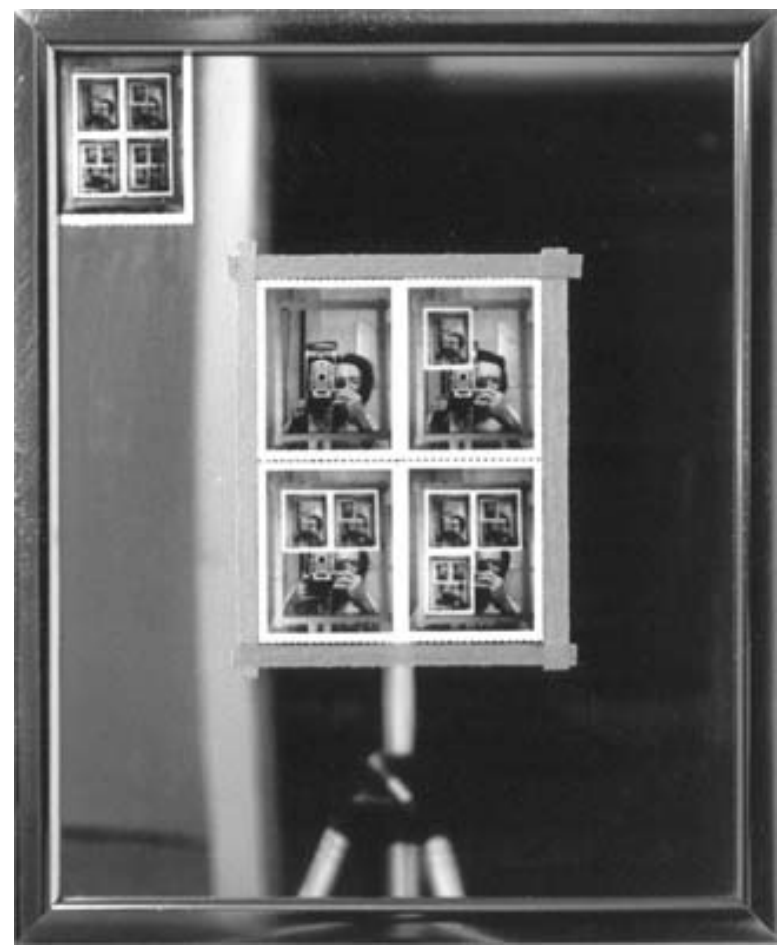

Imagen 57. Michael Snow

Authorization (Autorización), 1969

A fin de mostrar la continuidad del trabajo de Snow, repetimos aquí esta obra ya presentada en el Capítulo 2 (Imagen 5), aunque aquí se trata de otra reproducción. Consiste en una secuencia de cinco fotografías instantáneas Polaroid que registra el propio proceso de producción de esta pieza única, y un espejo con las instantáneas fijadas con cinta adhesiva, el mismo espejo ante el que el artista se ha autorretratado. Al situarse frente a la obra, el espectador se ve reflejado a sí mismo, quedando integrado en ella. Como es lógico, este aspecto no puede reproducirse. 


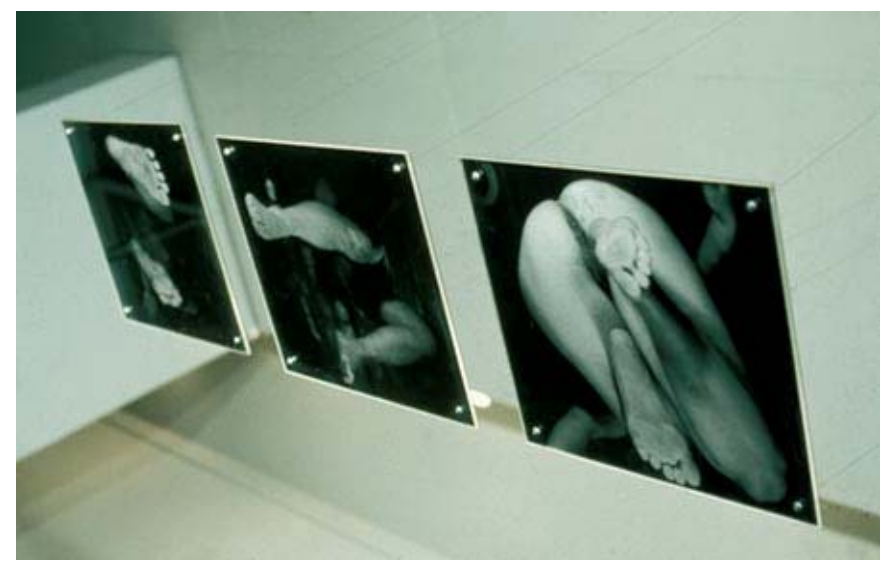

Imagen 58. Michael Snow

Crouch, Leap, Land (Agacharse, saltar, caer), 1970

Tres fotos en blanco y negro, pérspex y metal, materiales de esta instalación suspendida del techo que obliga al espectador a situarse en el mismo punto de vista que debió tener el artista para producir las imágenes. 

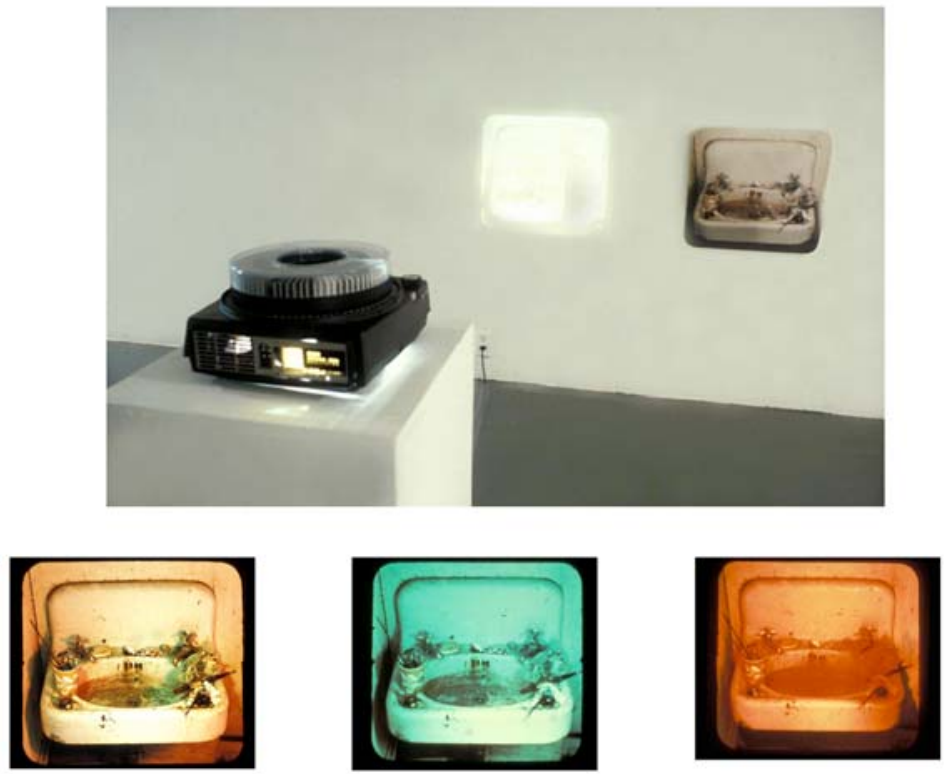

Imagen 59. Michael Snow

Sink (Lavabo), 1970

Los proyectores de diapositivas, omnipresentes en las galerías durante tanto tiempo, hoy han sido sustituidos por dispositivos de proyección electrónicos, pero con un efecto similar: la evanescencia e inmaterialidad de la imagen. Aquí, Snow juega con el contraste lado a lado de una imagen impresa del lavabo a tamaño natural, junto a la proyección de otras imágenes del mismo lavabo producidas a lo largo de varios días. 

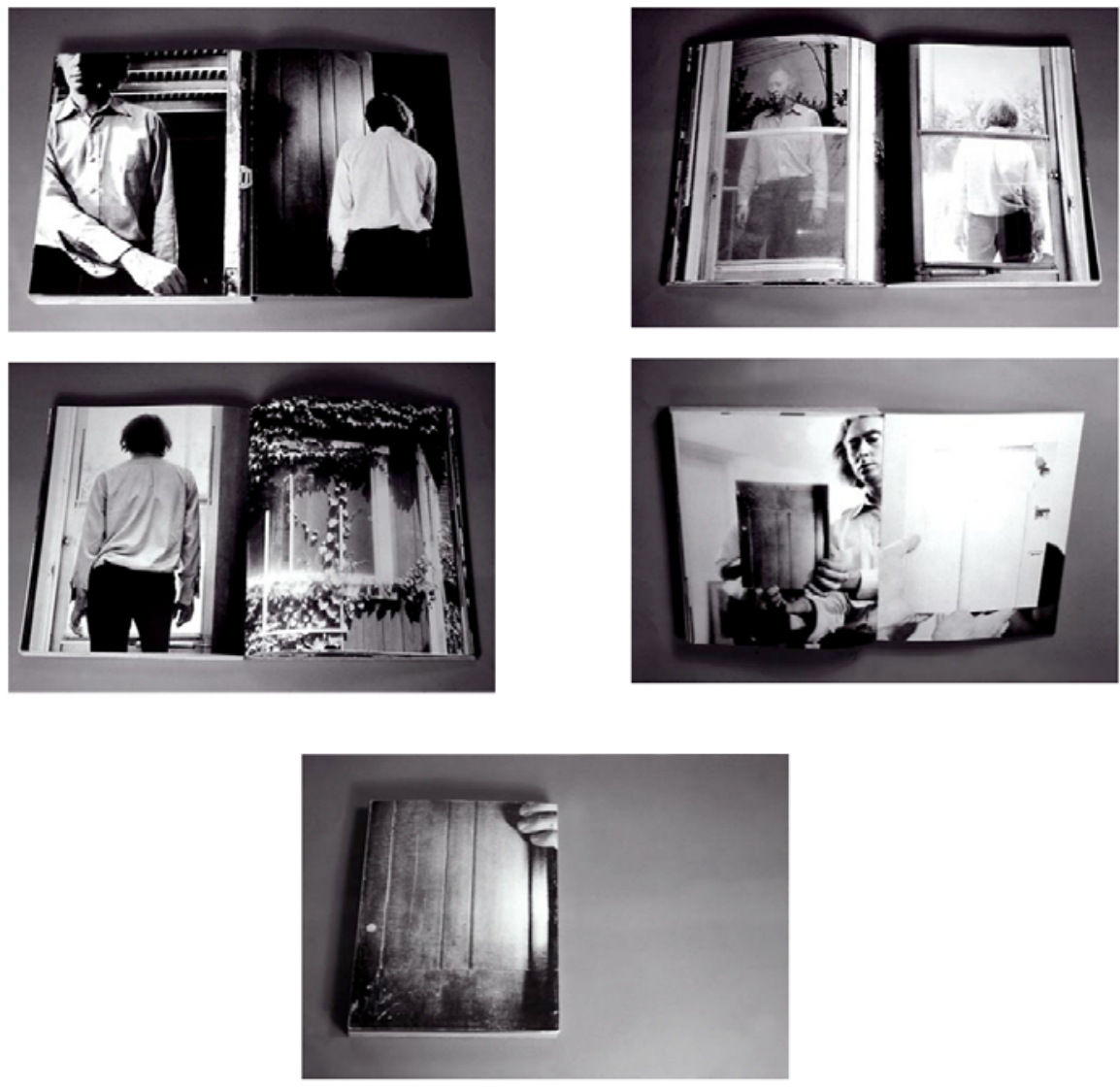

Imagen 60. Michael Snow

Cover to Cover (De cubierta a cubierta), 1975

Otro soporte: el libro de artista, con fotografías específicamente producidas para su formato y método de impresión. En este caso, Snow especula a partir de la secuencialidad propia de ese medio. 


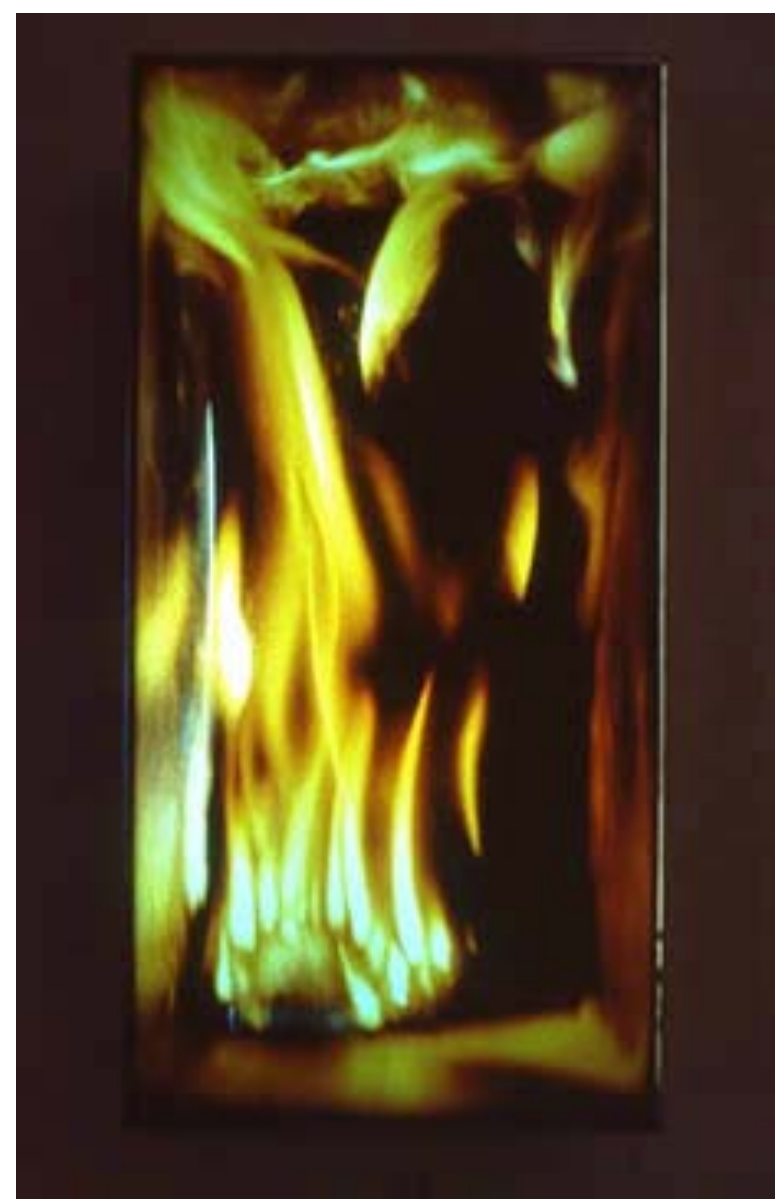

Imagen 61. Michael Snow

Lit Box (Caja encendida), 1979

Caja de luz con iluminación posterior, que aprovecha los materiales comerciales de impresión translúcidos, como el duratrans. Este recurso, verdaderamente omnipresente en el display mercadotécnico, es aquí sujeto de la reflexión de Snow, quien lo enciende. 

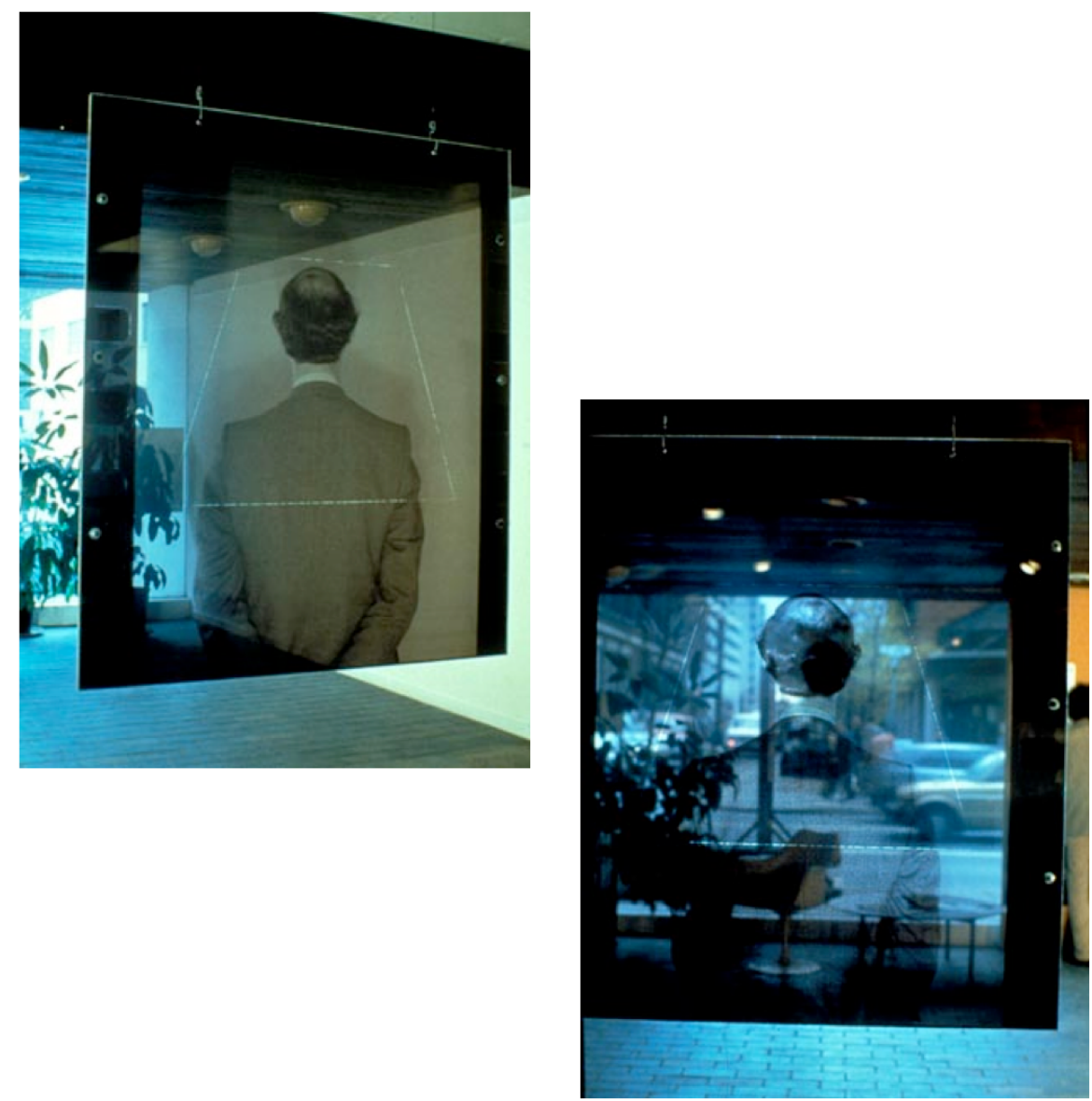

Imagen 62. Michael Snow

Shade (Sombra), 1979

Instalación de transparencia fotográfica en blanco y negro entre plexiglás, suspendida con hilos. Se juega con la expectativa del público que esperaría ver al sujeto fotografiado de frente al rodear la pieza, lo que evidentemente no ocurre. 

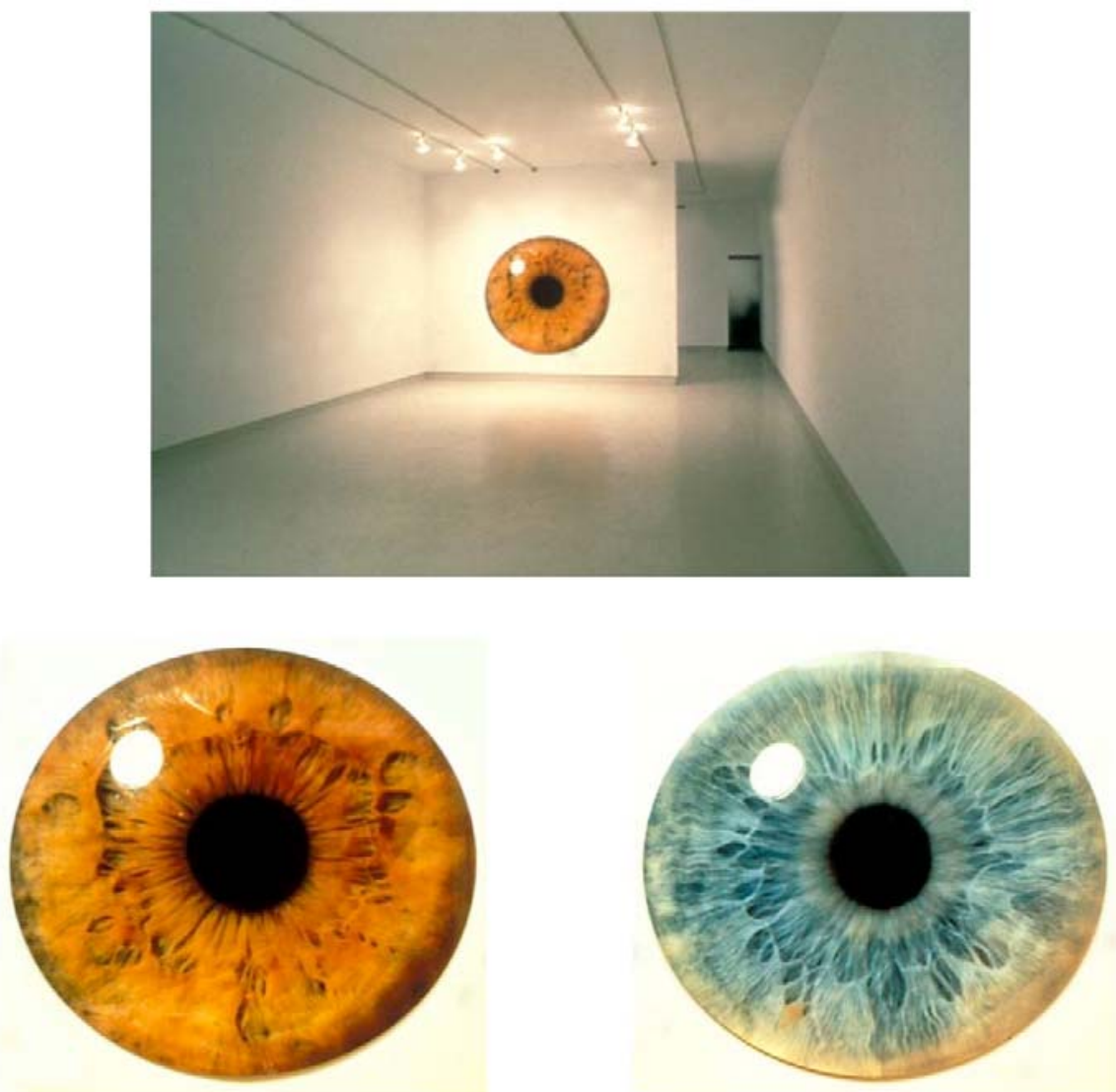

Imagen 63. Michael Snow

Conception of Light (Concepción de la luz), 1992

Fotografías en gran formato del iris del ojo del propio Snow y el de su esposa, colocados frente a frente en la galería. 

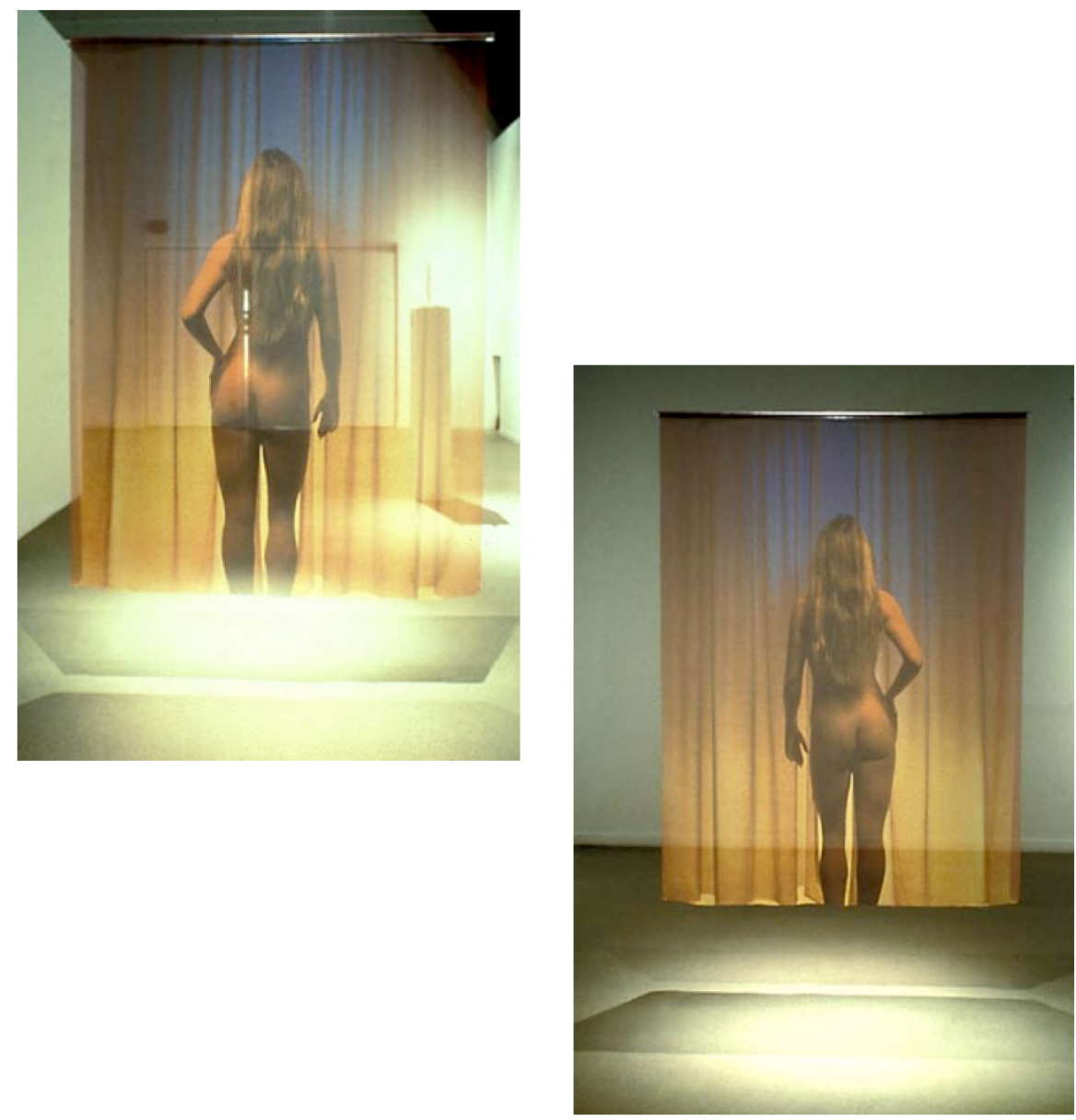

Imagen 64. Michael Snow

VUEEUV, 1998

Foto a color de gran formato impresa en tela, colgada de un tubo. Pieza única. Una vez más, el autor juega con la idea de la doble vista. 

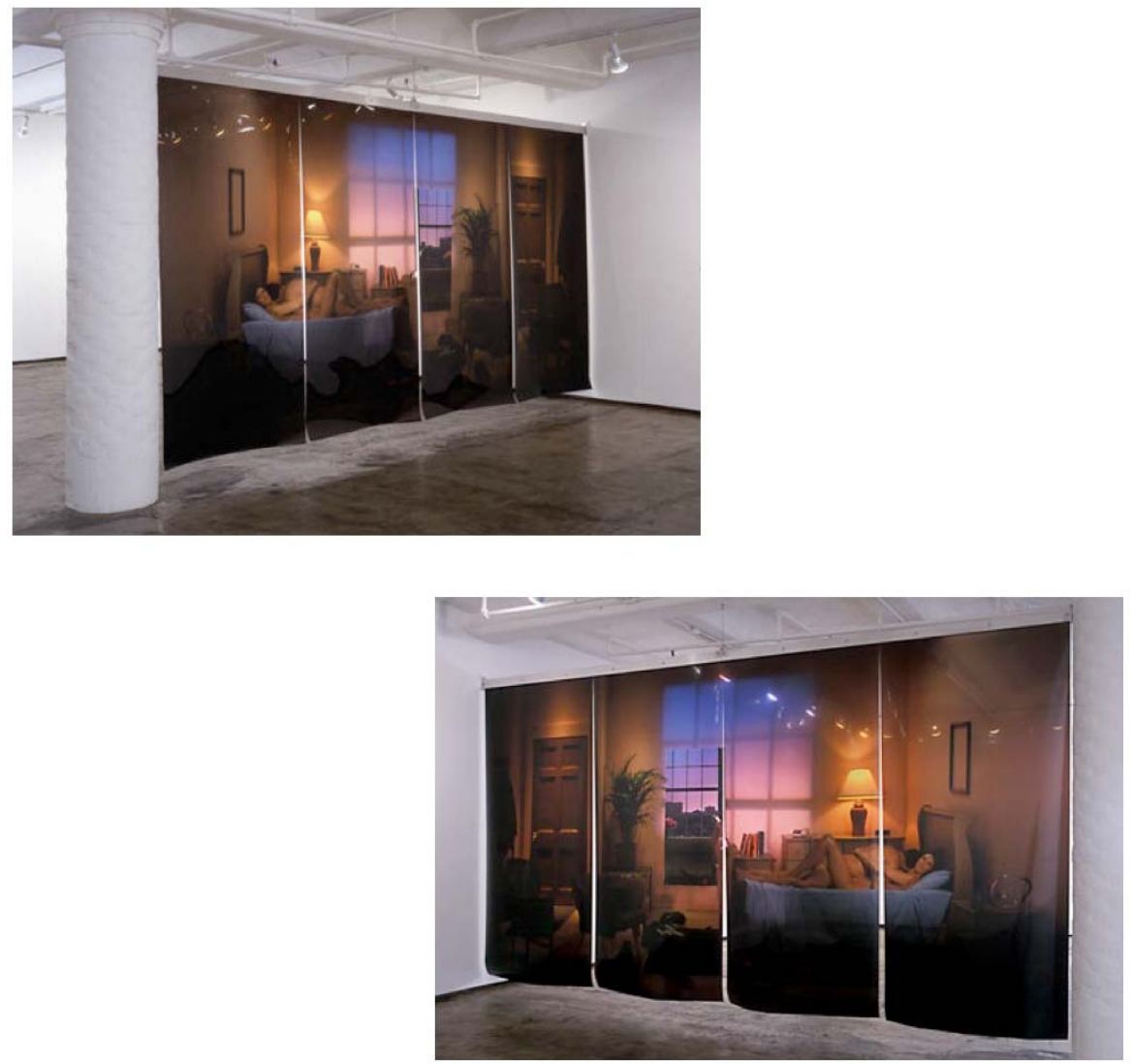

Imagen 65. Michael Snow

Powers of Two (Potencias de dos), 2003

Doble vista de cuatro fotografías transparentes en plástico, colgadas. La anchura limitada de los materiales de impresión, que por lo general son presentados en rollo -lona, papel, plástico-, ha vuelto común el recurso de colocarlos en paralelo para lograr una imagen de mayores dimensiones. 


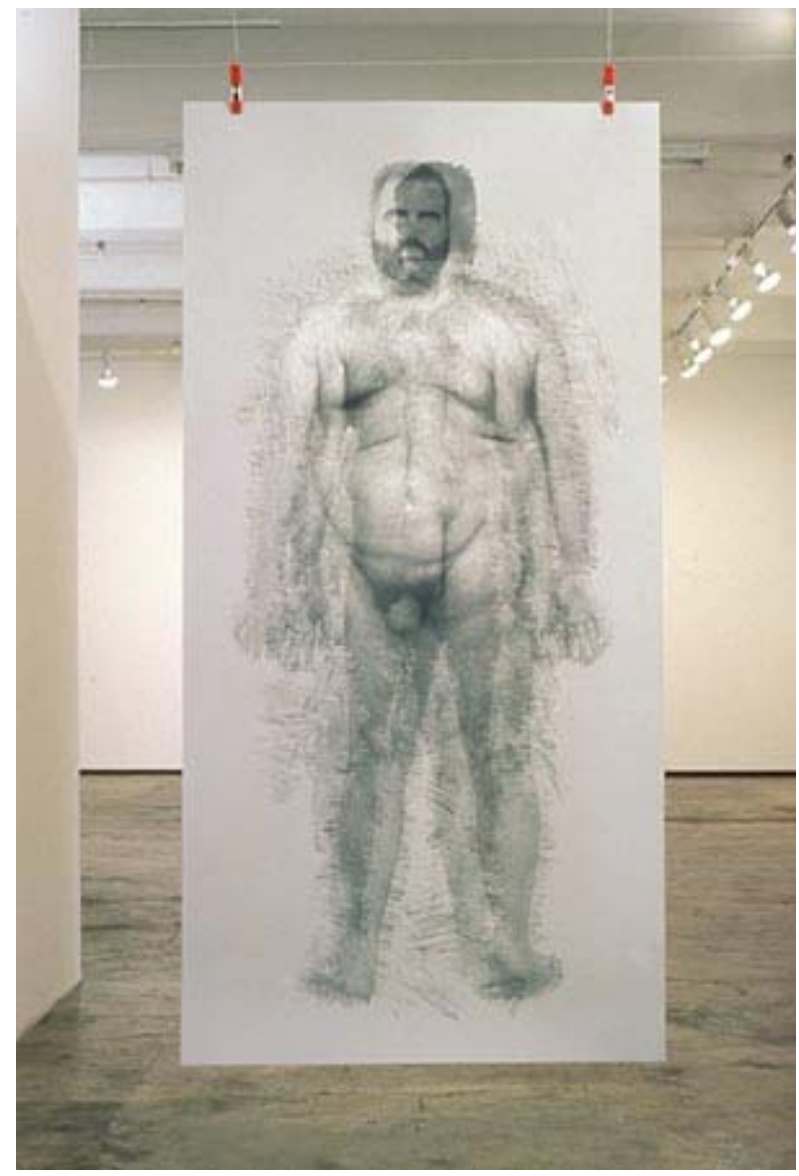

Imagen 66. Michael Snow Engraving J im, Male Heir,

(Grabando a J im, herencia de varón), 2003

Fotografía en blanco y negro de doble cara, laminada. En este caso, sí podemos ver el frente y la espalda del sujeto, pero superpuestos. 


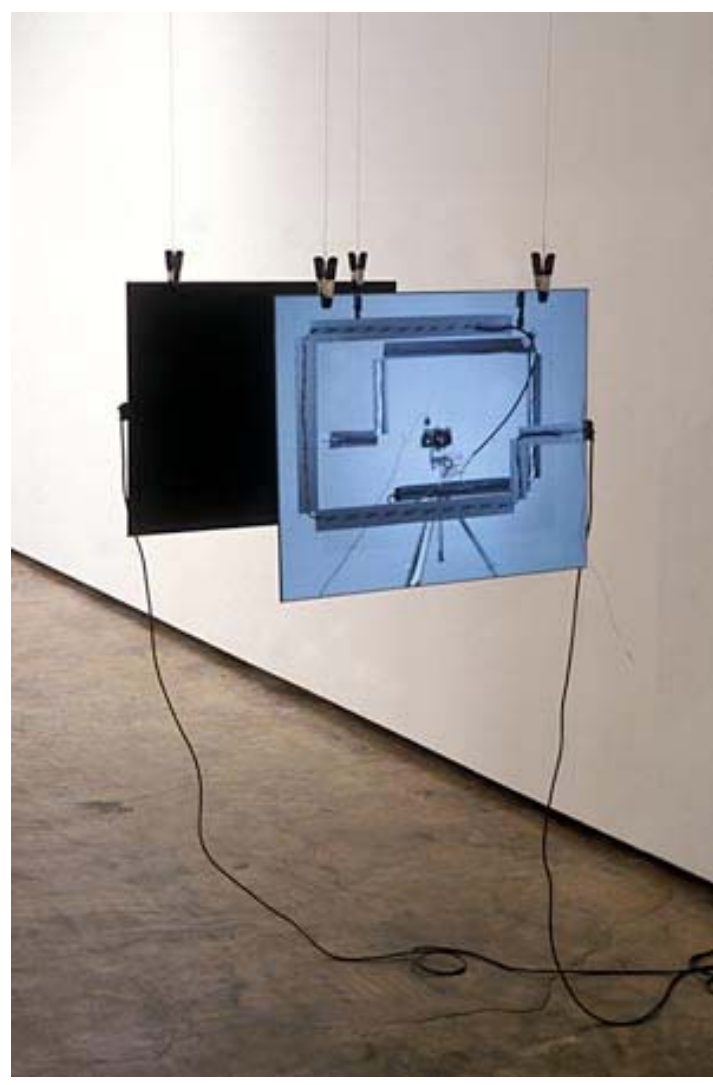

Imagen 67. Michael Snow

Line Drawing with Synapse, (Dibujo a línea con sinapsis), 2003

Dos monitores fotográficos luminosos de tipo LCD o de pantalla de cristal líquido. La instalación electrónica se completa con pinzas, transformadores, cableado eléctrico y cinta adhesiva, desplegados con ostentación como es común en el autor. En la imagen, una cámara: otra reflexión fotográfica metadiscursiva. 


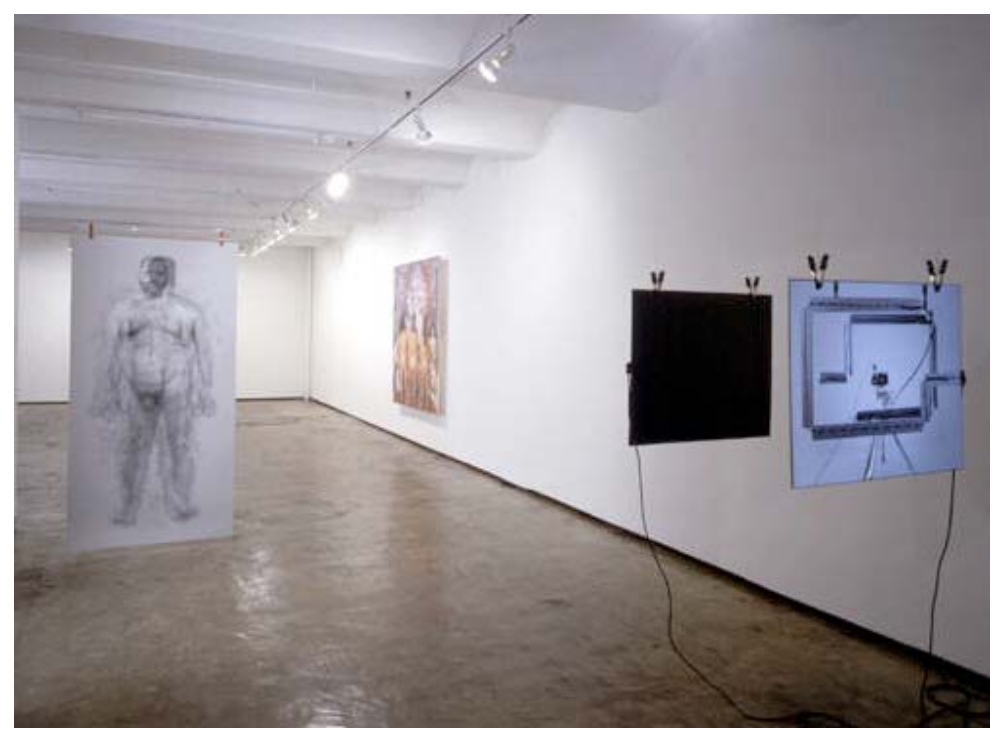

Imagen 68. Michael Snow

Exposición en la Galería J ack Shainman, Nueva York, 2004 
SEGUNDA PARTE: EL ANÁLISIS INMANENTE

CAPÍTULO 6

\section{LOS CÓDIGOS RETÓRICOS}





\subsection{Prefacio: la Suma, el súmmum}

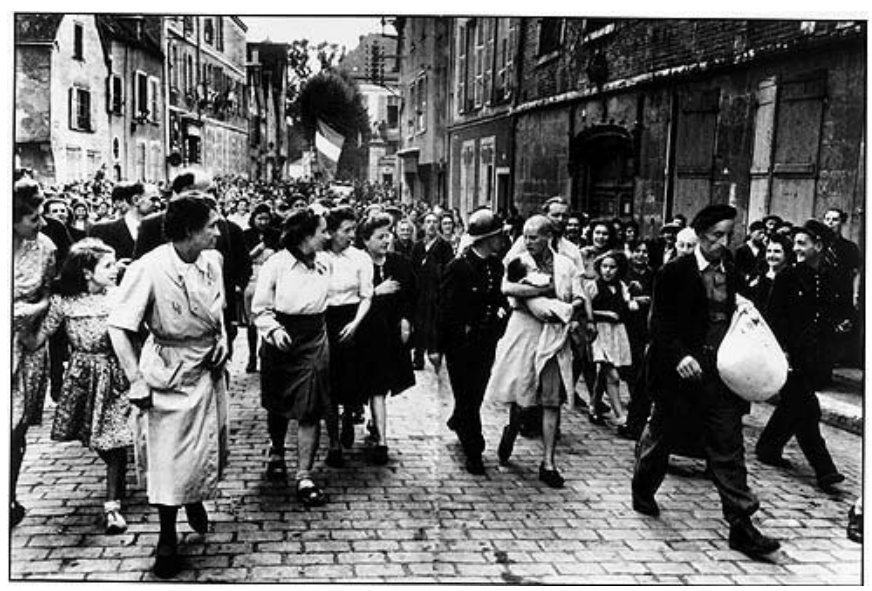

Imagen 69. Robert Capa

Colaboracionista, Chartres, 1944

La suma: en algunas fotos todos los elementos parecen confluir. Tal es el caso de esta clásica de Capa (Imagen 69), donde sujetos, miradas, comunicación no verbal, vestido y uniformes, objetos claves -bandera, atillo de ropa-, arquitectura, composición y, por supuesto, el símbolo infamante de la cabeza rapada, nos plantean la situación de esta colaboracionista, precedida por su padre, quien parece aprobar el castigo, aun a su pesar. Mientras que todo el pueblo solo tiene ojos para ella, ella solo los tiene para su bebé. Incluso una persona totalmente lejana a aquella situación histórica puede descifrar lo que ocurre, aun omitiéndose el título. El fotógrafo, a contraflujo de la acción, ha encontrado el punto de vista exacto para representarla: la pirámide visual sobrecargada de elementos que abordan al espectador desde el lejano punto de fuga tiene un orden perfecto: hay dirección, tensión y movimiento en ese ciclón de pasiones en cuyo vórtice se encuentra la protagonista de la imagen, flanqueada por un 
guardia. ¿Narratividad? No, apenas la afirmación de un estado de cosas. $\mathrm{Si}$ en los dos capítulos precedentes nos centramos en el análisis de aspectos plásticos o no figurativos del medio fotográfico, llega ahora el momento de plantear cómo aquellos dialogan y se complementan con los icónicos a través de la retórica para ser vehículo del significado. El súmmum.

En una primera aproximación, el término retórica es sin duda conflictivo debido a su polisemia, que remite inmediatamente a la retórica clásica como arte del buen decir, de la argumentación o como discurso persuasivo, entre otros sentidos. ${ }^{1}$ Sin embargo, hoy por hoy bien podemos hablar de análisis retórico sin temor a ambivalencias, como una disciplina autónoma, aunque frecuentemente vinculada a estudios de diversos tipos, tanto literarios como de artes plásticas y de lenguajes audiovisuales. En un campo extra-artístico, también destaca la abundancia de materiales teóricos más o menos recientes dedicados al análisis de un área específica: la del mensaje publicitario. En efecto, se trata de una útil herramienta a la que han recurrido indistintamente, como parte de su estrategia metodológica, enfoques de tipo estructural, semiótico, iconológico y hermenéutico, entre otros. Si bien la retórica de orden lingüístico fue el modelo para las aplicaciones en otros campos, actualmente dicha visión está ampliamente superada. Nuestro punto de partida, así, es el siguiente:

En la pregunta ¿qué se mira en una imagen? ¿cómo se ve una imagen? interviene el estudio de lo que podemos llamar ahora «retórica iconal», la búsqueda del modo en que el creador de imágenes [...] pretende llevar al conjunto de individuos receptores al conocimiento de algunas cosas, evocar ciertos elementos del mundo figurativo o bien de otros elementos agregados incluso cuando estos últimos no se representan. (Moles 1981: 76)

Dentro de los avatares de la retórica para desprenderse de su origen lingüístico y avanzar hacia la consolidación de una retórica general, destaca la actividad del Grupo $\mu$ (1982, 1992 y 2003), también conocido como Grupo de Lieja. La clasificación de los procedimientos retóricos es

\footnotetext{
${ }^{1}$ Para ver documentado el proceso de transformación desde la retórica clásica hasta el análisis retórico actual, ver por ejemplo: J oly 1999: 83-97 o Mortara 1988.
} 
una especialidad en sí misma, que ha sido ampliamente desarrollada en el ámbito de la imagen por dicho grupo y posteriormente ampliada por otros autores a campos específicos (v. gr.: Carrere y Saborit 2000; Carrere 2009). Hemos de destacar que si en un principio se consideró implícitamente que la comprensión del mensaje icónico pasaba por la traducción de las connotaciones de su cadena de semiosis a términos verbales, desde hace ya tiempo está firmemente consolidada la concepción de un pensamiento visual —para tomar prestada la expresión de Arnheimautónomo, que supera la confusión que se desprende

[...] de la posibilidad que siempre hay de nombrar una cosa; y de la posición tomada -que en otros tiempos formulaba Barthes- según la cual «solo existe el sentido nombrado». Si hubiera que seguir esta vía, en lo visual no llegaría a haber nunca más que iconismo, y las tentativas para devolverle su autonomía a lo plástico estarían condenadas al fracaso. (Grupo $\mu$ 1992: 105)

Más adelante, en este mismo apartado, profundizaremos en los conceptos de icónico frente a plástico. De momento, dejemos establecido que ese principio al que antes aludimos, en el caso del campo fotográfico, está representado por los breves textos fundacionales de Barthes, El mensaje fotográfico (1961) y Retórica de la imagen (1964). Aunque pronto se vio que su alcance era limitado, su importancia radica en la capacidad que tuvieron para abrir nuevas puertas y generar discusiones que enriquecieron enormemente el ámbito de conocimiento que nos ocupa.

La retórica tiene una cierta incidencia en cualquier género o tipo de producción fotográfica; esta incidencia, sin embargo, se acentúa en aquellas prácticas que permiten una planeación minuciosa por parte del creador. Como consecuencia de esto, la aplicación de procedimientos retóricos es más evidente en la foto publicitaria —aunque frecuentemente rozando aquí el tópico y el estereotipo (cfr. J oly 2002: 223 y ss.) — y en aquella realizada con fines estéticos a partir de una puesta en escena. Paradójicamente, en el ámbito de la fotografía artística de las últimas décadas -acaso dado su carácter más centrado en lo conceptual que en lo propiamente fotográfico, que ha sido desplazado a otros campos como el de la fotografía directa y 
documental - prevalece la tendencia del sentido nombrado, de la imagen conceptual que no se sostiene a sí misma sin el apoyo de un discurso verbal paralelo. Así lo atestigua, por ejemplo, Régis Durand:

Mi posición es que se puede considerar a la fotografía como un acto de discurso: puede que no sea siempre una obra, pero casi siempre es un acto de palabra, a través del cual se transmite necesariamente algo de un sujeto, de su condición mental, de su deseo, aunque a veces todo esto quede expresado con poca claridad. (Durand 1998: 66)

En nuestro enfoque, dejaremos de lado esta concepción, que consideramos reaccionaria, para centrarnos en la creación de sentido puramente visual. Para ello, partiremos de que la codificación retórica, como la llama Costa, hace depender el mensaje de las asociaciones de ideas, por lo que la connotación se convierte en «la esencia del código». (Costa 1977: 167) Esas asociaciones se desprenderán de la manera en que interactúen, dentro del cuadro de la foto, infinidad de elementos como actantes, objetos, formas, gestos, espacios, colores, miradas, iluminación, relaciones de proximidad, de escala, etcétera —por supuesto, también los elementos de los códigos miméticos y técnicos-, tomando como fundamento su significado cultural; estamos hablando, pues, de culturemas. La combinación de estos por medio de la utilización de distintos procedimientos de connotación ${ }^{2}$ permitirá establecer el tópico del texto fotográfico. Con otras palabras, la codificación retórica impondrá una jerarquía visual que dirigirá la lectura y que dependerá de aspectos culturales, en ocasiones intangibles, en constante cambio, por lo que el significado de los connotadores nunca podrá ser agotado.

Algunos de los primeros desarrollos de este tipo de retórica visual aplicada se dan en el campo publicitario, enfocados al intento sistemático de crear un repertorio de figuras. Quedan como testimonios de este segundo momento, el que sigue a Barthes, los estudios de J acques Durand

\footnotetext{
2 Roland Barthes introduce esta expresión en El mensaje fotográfico (1961), y elabora una clasificación que incluye los siguientes elementos: trucaje, pose, objetos, fotogenia, esteticismo y sintaxis. Sin embargo, como ya lo indicamos en el apartado 3.2, el desarrollo que hace de ellos es apenas un primer apunte de las elaboraciones posteriores debidas a la semiótica.
} 
(1970) y Georges Péninou (1970, 1972) —a quienes Moles (1981: 78) se referirá como «los técnicos de la iconología, cuyo objetivo es la interpretación de las imágenes utilitarias»-. Hemos de apuntar que gran parte de los estudios dedicados al mensaje publicitario se centran en la interacción entre la imagen -no necesariamente fotográfica-y el texto del anuncio, ya sea que esté presentado en forma de eslogan o de otra manera más extensa. Este carácter bimedia de dicho mensaje abre líneas de análisis que exceden el alcance de este estudio. En cuanto a la retórica visual aplicada a otros campos, será posteriormente, en gran medida de la mano del ya mencionado Grupo $\mu$ y a partir de multitud de estudios que surgirán derivados de las propuestas de él, cuando la disciplina alcanzará su madurez.

No sugeriremos aquí, por lo tanto, una clasificación ni tampoco una aplicación de figuras y procedimientos retóricos, la cual sería redundante con los estudios citados y nos desviaría de nuestro propósito. Plantearemos, sin embargo, una clasificación somera de los principales aspectos involucrados en la puesta en escena fotográfica, a partir de los cuales esos efectos retóricos pueden ser desencadenados. Nos situamos, así, en una fase previa al análisis específico de aquellos, para considerar, si vale la expresión, la materia prima fotográfica de la que la retórica del medio se sirve para operar a través de elementos incorporados por el creador y el receptor, siendo esta la aportación que realizamos desde nuestro campo.

El factor desencadenante del que partimos es la capacidad de los procedimientos retóricos para desatar procesos semiósicos connotativos. Ya hemos tocado tangencialmente este punto de una manera general al plantear el concepto de grado cero (ver supra: 4.1) como criterio para establecer la norma y, concomitantemente, la noción de desviación. En última instancia, lo que el fotógrafo intenta mediante los procedimientos retóricos es dotar a sus imágenes de una cualidad expresionista:

El expresionismo es uno de los métodos de construcción de un tema. Es experimentado intuitivamente por el operador como perteneciente a un estilo estético; pero la búsqueda de la expresión es uno de los objetos del 
documento fotográfico. El expresionismo puede definirse como un esfuerzo consciente para que una fotografía exprese la realidad mejor que la misma realidad. (Moles 1981: 203)

Así, en nuestro estudio enfocaremos el análisis a partir de tres categorías: la retórica de los actantes, la retórica de los objetos y del espacio, y la retórica de la forma. Estas categorías se enmarcan, a su vez, en dos ámbitos generales, a saber: el icónico o figurativo —correspondiente a las dos primeras- y el plástico o no figurativo -relacionado con la tercera-. Los teóricos de Lieja señalan que tradicionalmente en los estudios sobre imagen, incluida la semiótica, ha prevalecido lo icónico sobre lo plástico: «lo plástico aparece frecuentemente como subordinado a lo icónico: constituiría el plano de la expresión, o significante de un contenido icónico. El icono tendría, así, el estatuto de significado». (Grupo $\mu$ 1992: 103) Es necesario enfatizar que lo esencial es considerar la acción conjunta de ambos y que, si bien su separación puede ser práctica desde el punto de vista teórico y metodológico, en la lectura se funden y afectan mutuamente.

Incluso si existe por derecho, la distinción icónico-plástico no debe hacernos olvidar que hay interacciones entre estos signos. Por ejemplo, si queremos construir una retórica visual, podemos esperar que la estructura retórica de los mensajes (puesto que la retórica se ocupa de los discursos y no de los signos aislados) actúe a la vez sobre los diferentes tipos de unidades constitutivas de estos mensajes. (Grupo $\mu$ 1992: 100)

Dicho en palabras menos técnicas, pero igualmente contundentes: «las cualidades formales de estilo - meta central de la pintura - a lo sumo tienen importancia secundaria en la fotografía, mientras que siempre tiene importancia primaria qué es lo fotografiado». (Sontag 1973: 103)

$\mathrm{Si}$ bien la tendencia, como se ha señalado, ha consistido en primar lo icónico, también se ha dado el caso opuesto, sin embargo esto ha sido desde otras disciplinas paralelas:

Cuando, a la inversa, los teóricos han tomado en consideración el nivel plástico de las imágenes, sus intenciones, que se apoyan frecuentemente en 
géneros históricos ya provistos de un potente discurso ideológico (tal es el caso de la pintura), dependen más de la especulación estética, de la sociología de la percepción o de la crítica psicoanalítica que de la semiótica propiamente dicha. (Grupo $\mu$ 1992: 101)

Hemos de advertir que, en el caso de nuestro planteamiento, este es el punto de confluencia de los estudios retóricos con el vastísimo campo de la teoría de la percepción, cuya sobreabundancia $\rightarrow$ y podríamos decir también redundancia- de materiales teóricos y enfoques nos impide adentrarnos en él por exceder al alcance de este estudio. Dentro de este capítulo lo consideraremos, por ello, de la manera más general, en tanto en cuanto afecta al nivel infralógico de la lectura del plano plástico de la imagen. (Ver infra: 6.4)

\subsection{RETÓRICA DE LOS ACTANTES}

Fotografía, pero fotografía ¿de qué? La inmensa mayoría de las fotos, que se producen por millones cada día, son imágenes de personas. La interacción entre los actantes -en general, como veremos, se prefiere este término sobre el de personajes, cuya connotación está mas vinculada a lo literario o ficcional- presentes en el encuadre obedece a una serie de factores que se transfieren a la imagen, entre ellos: su fisonomía, su gestualidad, su postura y, en general, todos los elementos que constituyen su comunicación no verbal, la cual es precisamente otro campo de estudio que se ha desarrollado ampliamente, en paralelo a la teoría de la comunicación y la semiótica, en los últimos 50 años. Son todos ellos, también, culturemas, y como tales pueden ser leídos e interpretados. Más allá de la obviedad que puede atribuirse a esta afirmación dado que la gestualidad humana es probablemente el elemento más familiar y, por ello, acaso el más fácil de interpretar que existe, hay que considerar que la iconicidad del medio transfiere estos valores de la realidad a la fotografía, la 
cual los utiliza como parte fundamental de su expresividad, como lo han demostrado en su obra algunos de los más grandes fotógrafos.

La relación entre las personas [...] se expresa por la posición del cuerpo, el movimiento, el juego de las miradas. En la medida que los gestos forman parte de un comportamiento, y este comportamiento forma parte de un ritual interactivo, el comportamiento de las personas está codificado según convenciones sociales. De modo que la gestualidad, la expresión del rostro y el movimiento sirven como indicadores pragmáticos; nos revelan un tipo de información sobre el personaje (porque es un rol), y sobre el ambiente que le rodea. (Vilches 1983: 208-209)

Mientras que en la fotografía escenificada -artística, publicitaria y, por supuesto, en el cine- se predetermina y exagera la gestualidad, en el ámbito de la fotografía directa tradicionalmente se ha considerado como un valor la habilidad del fotógrafo para hacerse transparente y lograr captar la esencia de una situación o de un sujeto vivo mediante la congelación del instante en el que más información revelan, sin incidir en ellos alterando su devenir. Se habla, así, de foto cándida. La quintaesencia de esta concepción fotográfica, de este candor, quedó expresada en la poética del momento decisivo, de Henri Cartier-Bresson, y su comparación del fotógrafo con el arquero zen, cuya identificación con el blanco es tan perfecta que puede acertar en él incluso con los ojos cerrados. ${ }^{3}$ En la visión crítica de Sontag, sin embargo: «Que las fotografías sean frecuentemente elogiadas por su candor, su honestidad, indica que la mayor parte de las fotografías, desde luego, no son cándidas». (Sontag 1973: 96)

Pero afinemos nuestra posición, ya que la denominación de actante no deja de ser conflictiva y merece ser precisada. Si bien, como ya indicamos, ha prevalecido en la teoría semiótica sobre la de personaje, para algunos autores se refiere a la persona, animal u objeto que realiza un acto dentro de un discurso narrativo. Transpolada de la literatura a la fotografía,

\footnotetext{
3 Las declaraciones de principios del fotógrafo francés han sido recogidas en multitud de antologías. Ver, por ejemplo: Fontcuberta (ed.) 1984: 188 y ss. También han sido sujeto, más recientemente, de la ironía de Soulages (1998). Pero, ¿acaso no es posible ironizar a partir de la poética de cualquier autor, sea cual sea su disciplina? Bástenos la consideración de que, en el caso de Cartier-Bresson, hay una gran congruencia entre la expresión verbal de su poética y la realización de esta en la práctica.
} 
esta concepción puede acarrear algunas confusiones. Así, por ejemplo, Vilches establece:

Estos actantes pueden ser de tres tipos: actantes fijos, actantes móviles y actantes vivientes. Los actantes fijos son los elementos visuales estáticos, tales como los elementos de la naturaleza que no se desplazan, como árboles o montañas. Los actantes móviles son elementos naturales o artificiales que se desplazan en el espacio: el río, los medios de transporte, etcétera. Finalmente, los actantes vivientes pueden, a su vez, ser subdivididos en personas (actores humanos) y animales. (Vilches 1983: 166)

Sin entrar a debatir, con perdón de Heráclito, acerca de si lo que se desplaza es el río o el agua que su cauce lleva, nuestra posición es que difícilmente los sujetos inanimados, fijos o móviles, soportarán el peso de la acción, salvo que se trate de una prosopopeya. Adicionalmente, la concepción de moda en la actualidad, de una fotografía narrativa, es ya suficientemente ambigua. Así, en este estudio llamaremos actantes solamente a los sujetos vivientes, aquellos dotados de voluntad y autodeterminación de movimiento, como son las personas y animales. Para referirnos a los demás elementos que pueden aparecer a cuadro utilizaremos la distinción entre objetos -ya sean fijos o móviles-y espacio (categorías que analizaremos en el apartado 6.3) - ya sea arquitectónico o paisajístico, creado por el hombre o natural-. Esta categorización nos parece mucho más operativa ya que, desde un punto de vista pragmático, toda la actitud del fotógrafo, así como su forma de abordar al sujeto e incluso su equipamiento, varían sensiblemente ante unos y otros para utilizarlos como elementos significantes. Otro factor influyente es, por supuesto, la reacción de los sujetos ante el fotógrafo y el control que este tiene sobre ellos. Con esta base, Moles propone la siguiente categorización que afecta más a lo que se refiere al acto de creación fotográfica que a la lectura de la foto:

Los elementos visuales del mundo se descomponen en objetos pasivos y en seres animados, pero sobre todo por el grado de dominación que ejerce el observador, muy distinto según se trate de seres o de cosas. En general, el mundo del fotógrafo se dividirá en tres contenidos: 
- Los seres o cosas sobre los cuales el hombre fotográfico ejerce su dominación: su familia, sus objetos familiares, las cosas materiales e inmóviles del mundo.

- Las cosas o los acontecimientos del universo que ignoran al fotógrafo en cuanto tal y de los cuales es un testigo pasivo y subrepticio: el tren, el paisaje, la vaca, el barco, que no saben de su presencia.

- Finalmente, los elementos reactivos que van a dominar al fotógrafo [...], para los cuales el problema fundamental será un problema de interacción entre observador y observado. (Moles 1981: 211-212)

Una vez hecha esta precisión, volvamos a Vilches, quien establece unas reglas de topicalización que permiten al receptor atribuir preeminencia a un actante sobre los otros. La primera regla «es la existencia de una jerarquía de actantes. Esta jerarquía puede manifestarse a partir del funcionamiento de los actantes vivientes que dominan las relaciones establecidas con los otros actantes, fijos o móviles». La segunda regla «consiste en la determinación del actante dominante, por medio de los elementos de la expresión visual». Y la tercera dice que, si los elementos de la expresión visual son de igual peso, «serán los actantes vivientes los que prevalecerán en la percepción del sujeto Lector. La información obtenida dará, por tanto, predominancia a las personas o animales sobre el resto de los actantes inanimados». (Vilches 1983: 166-171)

Concentrándonos en los actantes vivientes, podemos decir que la representación del movimiento es el principal medio de captar la atención del receptor. La teoría de la percepción ha puesto énfasis en el hecho de que las posturas del cuerpo, al ser variaciones de la postura normal, pueden ser utilizadas para imprimir dinamismo a la imagen. Para Dubois, uno de los aspectos principales de la inclusión de actantes vivientes en la imagen es que los indicadores de movimiento y de desplazamiento generan un fuera de campo particular: [se] pone fuera de campo al tiempo mismo (la duración crónica)». (Dubois 1983: 162) La relación campo-fuera de campo será en estos casos un recurso retórico sumamente efectivo. Otra manera de establecer esta relación es por medio de los juegos de miradas. (Dubois 1983: 163) Para Péninou (1972), en el discurso visual publicitario - y podríamos extender esto al cinematográfico-, una persona fotografiada 
mirando de frente a la cámara establece un relato en primera persona; la imagen frontal de un actante que no mire hacia la cámara equivale a un relato en tercera persona, y lo mismo sucede cuando los actantes aparecen de perfil; los grados intermedios (personajes fotografiados de tres cuartos) serían, por su ambigüedad, ideales para la presentación de situaciones por medio de anécdotas. Desde un punto de vista menos sistemático, pero no menos agudo, Sontag propone:

En la retórica normal del retrato fotográfico, enfrentar la cámara significa solemnidad, sinceridad, la revelación de la esencia del sujeto. Por eso las fotos de frente parecen apropiadas para las ceremonias (como bodas y graduaciones) pero no tanto para los cartelones publicitarios de los candidatos políticos. (En los políticos es más común el retrato de tres cuartos de perfil: una mirada que se pierde en vez de enfrentar, sugiriendo en vez de la relación con el espectador, con el presente, la relación con el futuro, más digna y abstracta). (Sontag 1973: 48)

En la fotografía directa, por su parte, la utilización de todos estos recursos, sumada a la estructuración formal del cuadro y a la interacción de los actantes vivientes e inanimados, dará una cierta preeminencia a la fotografía de lo vivo. El fotógrafo, sin embargo, busca un momento decisivo y, si no lo capta, en ocasiones lo provoca mediante algún elemento que introduzca artificiosidad, expresionismo, en el sentido molesiano, como puede ser a través del uso del flash -Diane Arbus sería un caso paradigmático - o una velocidad extremadamente alta, los cuales, al provocar un corte temporal abrupto y antinatural, suelen tener el efecto de convertir el gesto en una mueca grotesca. Así, el fotógrafo maneja la gestualidad del sujeto tanto compositiva como fotográficamente, ya sea relacionándola con otros elementos dentro del encuadre o modificándola mediante recursos del medio, como puede ser la deformación óptica. Tal es el caso de la ya comentada (ver supra: 4.3) sobredramatización en cierta fotografía de prensa, una vez más, para volverla expresionista, debida al uso de objetivos muy cortos con gran cercanía al sujeto.

Esta tendencia no debe ser obviada. Los actantes actúan, en el sentido de que son captados mientras llevan a cabo acciones, si vale el 
juego de palabras. Retomando la anteriormente apuntada noción de narratividad, hemos de ser precavidos con el uso de esta palabra, ya que si bien la imagen fotográfica puede plantear una acción, no hay en ella —no puede haberla - una narración. La fotografía simplemente describe; haciendo un parangón con la jerga de la lógica, diríamos que una foto es una proposición, mas nunca un silogismo y mucho menos un razonamiento discursivo. Simplemente presenta un estado de cosas y no es sino la mente del receptor, o en su caso algún mensaje externo como un pie de foto o un texto adjunto, los que la pueden convertir en una narración, sea falsa o verdadera. En este marco, puede valorarse la siguiente afirmación de Sontag: «Las fotografías, que por sí solas son incapaces de explicar nada, son inagotables invitaciones a la deducción, la especulación y la fantasía». (Sontag 1973: 33) Así, destaca el rol activo del receptor para completar el sentido de acuerdo a diversos criterios:

En cuanto al relato, conviene recordar que pese a ser también una estructura, esta puede «rellenarse» tanto con los estereotipos de la experiencia como con los de la ficción. Su función es la de transformar la cosa vivida, soñada o imaginada en cosa contada en un discurso de acciones sometido a una doble estructura, temporal y actancial. La actualización del relato puede hacerse con cualquier medio de comunicación: palabra, escritura o imagen. Pueden narrativizarse textos muy distintos (publicidad, reportaje, informe) desde el momento en que someten su sistema de expresión a una estructura temporal. Ciertas imágenes fijas, y especialmente la fotografía, pueden tener o bien un efecto narración o bien un efecto ficción. El efecto ficción aparecerá tan pronto como la imagen (la foto) se refiera al imaginario colectivo mientras que el efecto narración, por su parte, se producirá si la imagen incluye una reserva temporal.

Se sabe que la fase elemental de la lectura de la imagen, y más concretamente de la foto de aficionado, está orientada hacia un más allá ilusorio de la imagen que pone a esta entre paréntesis mientras que el «spectator» antepone los estereotipos de su propia recepción a los signos producidos por la imagen. (J oly 2002: 95)

De lo que estamos hablando, desde cierto punto de vista, es de la credibilidad frente al valor de verdad. Como ya hemos sugerido, es común que en la fotografía más fotográfica, la directa, se valore la captación de la espontaneidad de los actantes. Durante muchos años el desarrollo técnico del medio estuvo enfocado a permitir esa posibilidad mediante la 
introducción de equipos cada vez más compactos, objetivos más luminosos, películas más rápidas y motores de avance automático, entre otros factores. Esto ha permitido a los fotógrafos moverse ante el sujeto con velocidad y desenvolverse en las situaciones más difíciles, aunque no siempre lo logren. Como consecuencia, se ha tendido a considerar que

[...] la calidad de una fotografía sociológica es inversamente proporcional al «tamaño del fotógrafo». Efectivamente, el término «tamaño» significa en este caso la identificación del sociofotógrafo en la esfera visual del observado en tanto que observador y, naturalmente, el aparente tamaño de ese observador es proporcional al volumen de sus extensiones tecnológicas: cámara, teleobjetivo, tripié, flash; toda esta parafernalia que lo instituye como observador y, por ende, como observado. (Moles 1981: 214)

El reportaje gráfico, desde los tiempos emblemáticos de la época de oro de la revista Life, nos ha acostumbrado a que, aun cuando el fotógrafo está inmerso en una situación en la que el sujeto fotografiado es consciente de estar participando en el acto fotográfico $\mathrm{y}$, por lo tanto, puede condicionar su actitud y, con ello, comprometer el valor de verdad de la situación mostrada, si los elementos de comunicación no verbal son convincentes y proyectan espontaneidad, la imagen tendrá credibilidad. Así, queda descargado de parte de su romanticismo el modelo de la foto cándida: «Si, en verdad, el aficionado cree poder cristalizar la realidad al pasar [...] el profesional [...] ya no cree en esta ilusión, sabe que muchas veces es más sabio reconstruir la realidad después de haberla percibido que tratar de captarla, y organiza su vida de observador en consecuencia». (Moles 1981: 189)

La credibilidad es, también, la vocación de cierta fotografía publicitaria y comercial. Aun cuando el receptor está consciente de que las situaciones mostradas han sido escenificadas, el manejo de los elementos de la codificación retórica irá enfocado a que aquel las acepte, si no como naturales, sí como verosímiles. Péninou subraya la diferencia entre la actitud del fotógrafo periodístico y el publicitario: «El primero capta una escena cuyo sentido ha intuido, pero la escena preexiste al sentido. El segundo construye una escena en torno a un sentido; el sentido preexiste a 
la escena». (Péninou 1972: 17) En el extremo opuesto a la estrategia publicitaria arriba señalada -lo que es la tendencia publicitaria dominante en la actualidad - el nivel de artificiosidad se lleva a tal grado que la imagen se inserta de lleno en el ámbito de la ficción, de lo aspiracional, de lo espectacular. Es el caso, también, de la lomografía (ver supra: 5.1), en la cual la artificiosidad que ponga de manifiesto el estar participando en el acto fotográfico y convirtiéndolo así en una vivencia, deviene un valor. Como consecuencia parcial de este aspecto, no podemos entonces afirmar que una fotografía espontánea sea mejor que una fabricada. De hecho, es posible que esta cumpla su función comunicativa mejor que la primera. (Un ejemplo paradigmático es el de la Imagen 75.) Lo que sí podemos afirmar es que cada tipo de fotografía tiene una manera distinta de abordar al sujeto, y que esta implica una forma de codificación determinada, reflejada en aspectos pragmáticos como el equipamiento técnico utilizado, la dirección de escena y la composición, entre otros. Moles señala:

Hay un principio de incertidumbre de la fotografía, según el cual la relación entre el observador y el observado determina la precisión, la verdad, de la escena tomada en el documento; mientras más grande sea esta interacción, mayor será la probabilidad de que la escena ha sido transformada por la presencia del operador. (Moles 1981: 212)

$\mathrm{Si}$ bien en los campos fotográficos que venimos comentando la actitud del sujeto ante la cámara se decodifica fundamentalmente a partir de la dirección de su mirada y su gestualidad, es en el género clásico del retrato fotográfico en el que acaso estas claves de interpretación se utilizan con una mayor intencionalidad. A pesar de la aceptación mutua de participar en el acto fotográfico, el retrato constituye una verdadera dialéctica de amo y esclavo, un ritual en el que el fotógrafo y el sujeto retratado frecuentemente luchan, ya sea consciente o inconscientemente, por imponerse al otro: imponer su visión, en el caso del primero, o su máscara, en el caso del segundo. Esto se debe a que en el retrato artístico lo que se busca no es mostrar una identidad, sino una personalidad la cual es, por supuesto, captada o interpretada por el temperamento de un autor. 


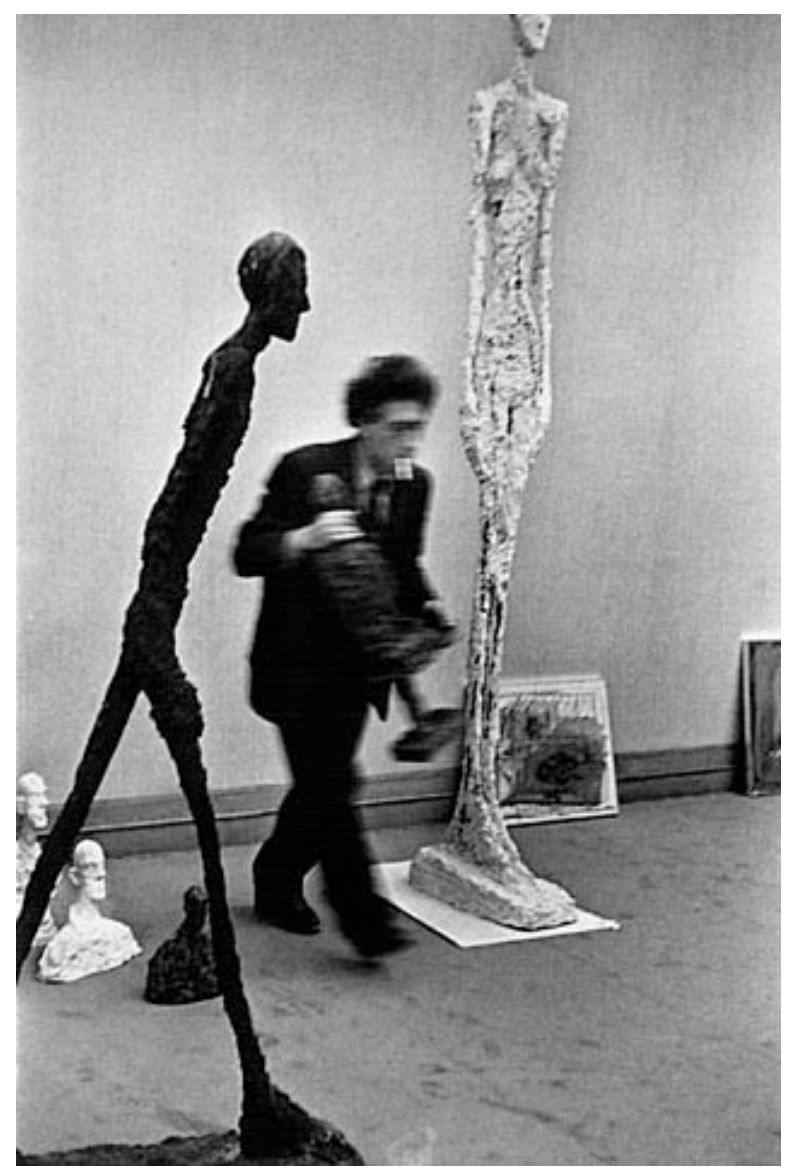

Imagen 70. Henri Cartier-Bresson Alberto Giacometti, 1961

Giacometti es captado durante el montaje de una de sus exposiciones. El barrido provocado por su movimiento difumina su identidad, mientras que la definición de las esculturas acentúa la suya: dejan de ser objetos y se convierten, metafóricamente, en actantes vivos. Formalmente, el paralelismo entre las diagonales de los cuerpos del escultor y las esculturas los equipara, los hace participar de un mismo ritmo vital. 


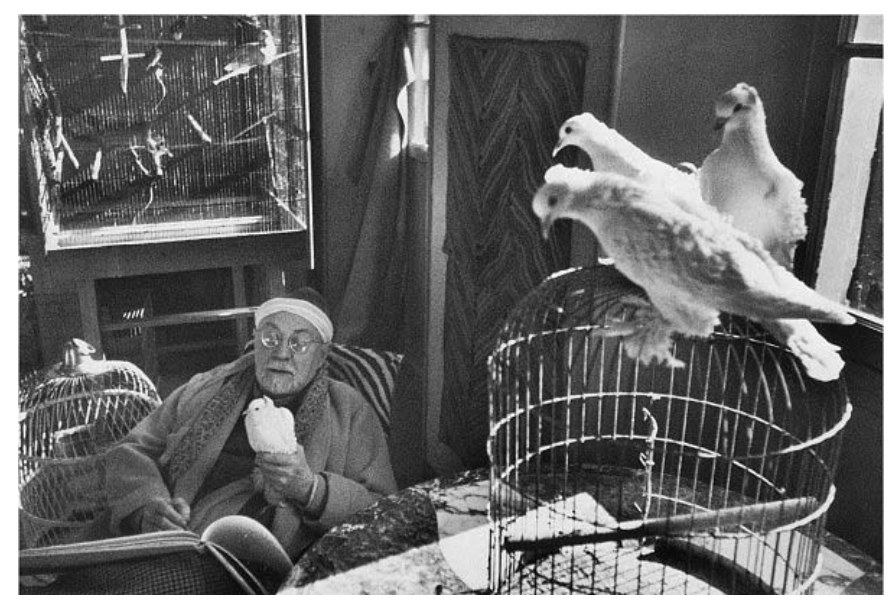

Imagen 71. Henri Cartier-Bresson

Henri Matisse, 1944

Los maestros de la foto cándida también hacen retratos. Matisse, en su estudio, dibuja una paloma ante la mirada de las compañeras de esta, actantes más que expresivos. A pesar del pequeño espacio que el pintor ocupa en el encuadre, la jerarquía de la figura humana atrae al ojo del espectador. Esta atracción se ve acentuada por el manejo de diversos elementos, entre los cuales el más evidente es el diálogo entre lo enfocado y lo desenfocado. El momento decisivo no solo está dado por el juego de las miradas: las palomas y su protagonismo, los claroscuros, el carácter sosegadamente festivo de la imagen, ¿no remiten, acaso, a la obra del propio Matisse, creando un fuera-de-campo metafórico? 


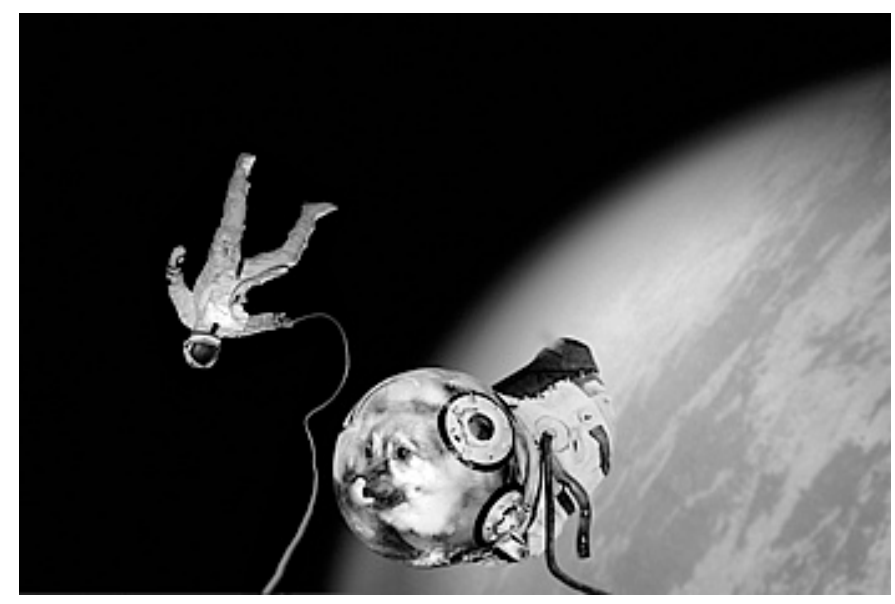

Imagen 72. J oan Fontcuberta

Ivan Istochnikov y la cosmoperra Kloka, Sputnik, 1996

Si en la anterior imagen de Matisse por CartierBresson las palomas en primer plano, a pesar de su gran presencia visual, pierden protagonismo ante el sujeto humano, aquí la cosmoperra Kloka atrae las miradas... y el enfoque. Sin embargo, al ver esta imagen sintética, nos preguntamos si su autor no exageró: si bien los animales son actantes animados, llegar al extremo de realizar actividad exterior en una nave espacial ¡sobrepasa el límite de cualquier actuación! 


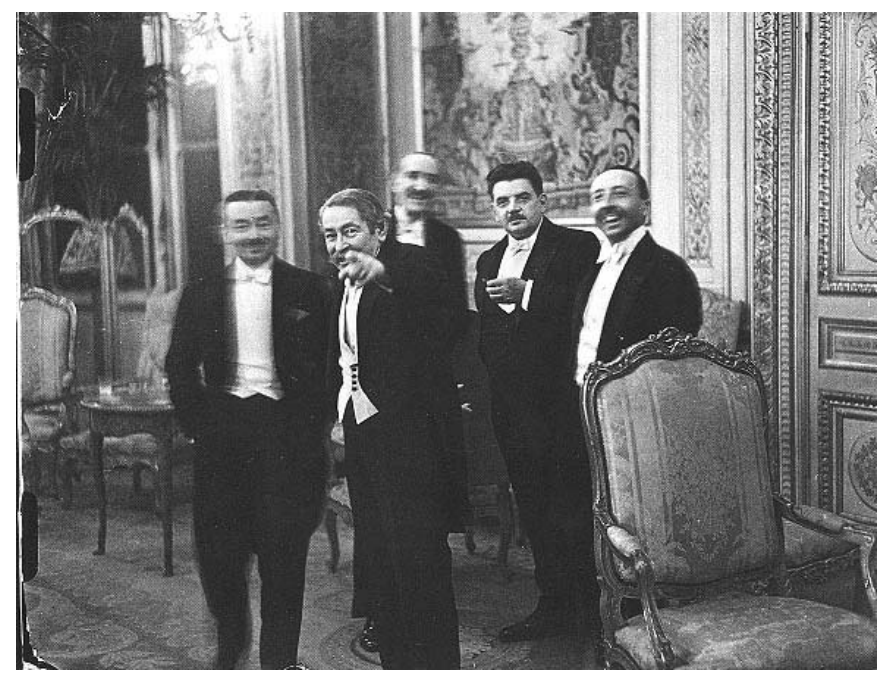

Imagen 73. Erich Salomon

¡El rey de la indiscreción!, 1931

Salomon, el rey de la indiscreción, era conocido por fotografiar subrepticiamente a personajes connotados, principalmente de la política, en sus reuniones privadas. El éxito de este temprano paparazzo, por supuesto, dependía de no ser descubierto... como en este caso, en el que la actitud de los actantes está claramente determinada por el hallazgo de la cámara. 


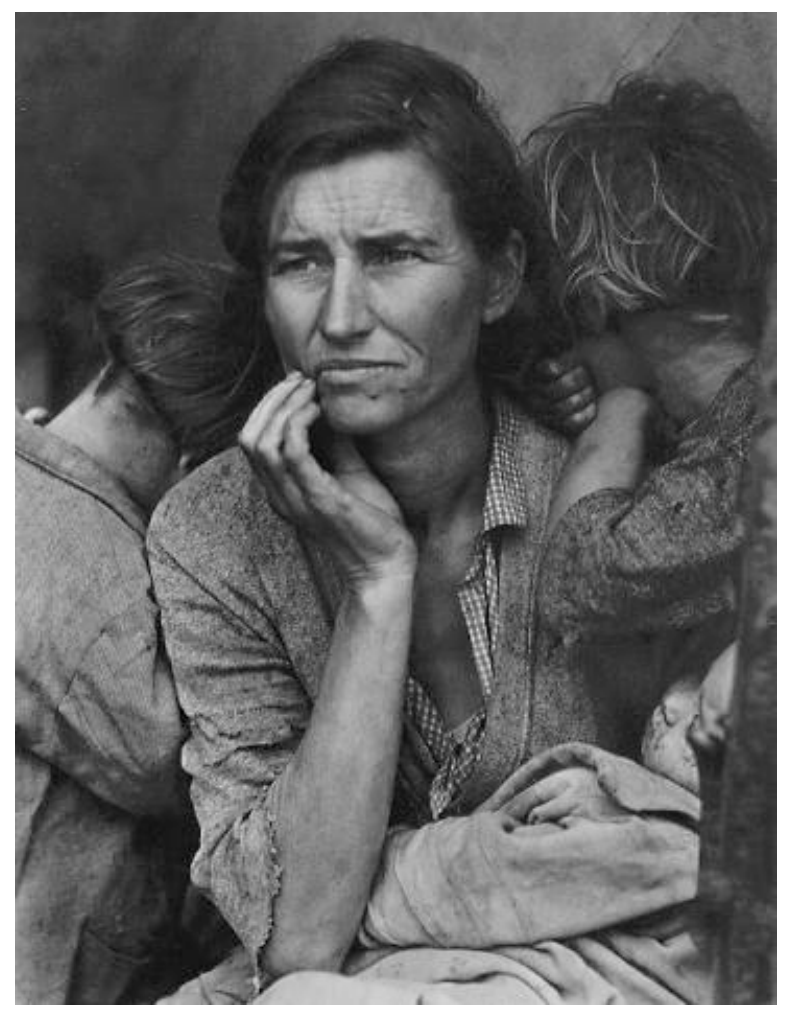

Imagen 74. Dorothea Lange

Madre emigrante, 1936

En esta famosa foto, del emblemático proyecto documental financiado por la Farm Security Administration -y tachado, digámoslo de paso, como «desvergonzadamente panfletario» por Sontag (1973: 72) - se nos pretende transmitir el dramatismo de esta familia golpeada por la crisis. Se nos invita a considerarla como una escena objetiva, pero si vemos la imagen con cierta suspicacia, el sentido cambia. La madre mira al infinito, perdida en sus pensamientos, con el ceño fruncido por la preocupación. Su situación precaria se revela por el mal estado de la ropa. Los niños se refugian en la madre con desesperación, ¿pero ante qué, ante la crisis, o ante esta señora que les hace fotos? «iQue se vaya con su cámara!» 


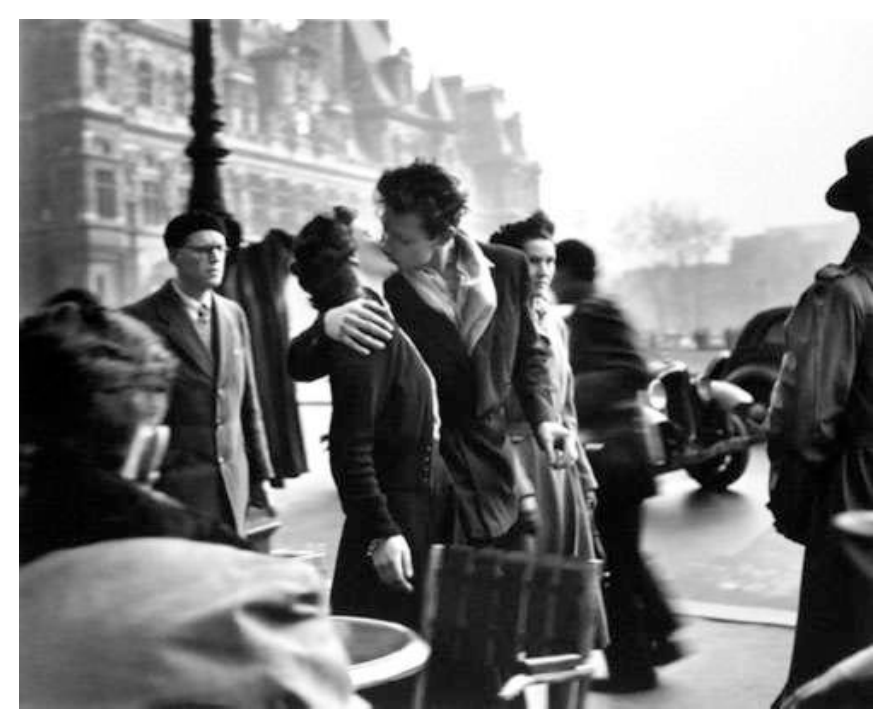

Imagen 75. Robert Doisneau

El beso de l'Hotel de Ville, 1950

Un caso emblemático: Doisneau realiza para un reportaje de Life una serie de fotos de parejas besándose. Con el tiempo -Paris, l'amour-, la foto se vuelve un icono, se reproduce y vende cientos de miles de copias. En 1992, el autor es llevado a juicio por la pareja, que exige una indemnización por derechos de imagen. El fotógrafo no tiene más remedio que aceptar ante el juez que la foto no era espontánea: él había contratado a una actriz de teatro y a su novio para que posaran... iy no eran aquellos vivillos que solicitaban la indemnización! En una entrevista, declaró: «Jamás me habría atrevido a fotografiar a una pareja así en la calle. Los amantes besándose en público raramente tienen una relación legítima». ¿Por qué no se sospechó antes de su veracidad? Espontaneidad, candor, vivacidad, movimiento, composición y otros elementos aleatorios le dan... ¡credibilidad! (Solo para cerrar la anécdota: en el año 2005, la modelo original subastó su copia de la foto, firmada por Doisneau, obteniendo 200 mil dólares.) 


\subsection{RETÓRICA DE LOS OBJ ETOS Y DEL ESPACIO}

Pensemos en la historia de un objeto, que todos la tienen. No un objeto artesanal, único, cargado de connotaciones individuales y con la impronta de su creador; pensemos en un objeto industrial, producido en serie y asequible para un gran número de personas. La historia de cualquier objeto puede ser impredecible, inusual. Si bien no es este el lugar para plantear ficciones, este pequeño ejercicio imaginativo nos permitiría seguir las transformaciones del significado cultural de un objeto y su ciclo (Moles 1972a). Cualquier objeto puede, potencialmente, significar una infinidad de cosas debido a los usos que se le van dando con el tiempo y a sus cambios de contexto, tanto espacial como temporal: puede pasar de ser un objeto funcional, símbolo de vanguardia tecnológica o herramienta especializada, a símbolo de estatus, juguete, objeto decorativo, baratija, antigüedad, icono de una época, aparato experimental... Puede, con el tiempo, inspirar nostalgia, alegría, admiración, envidia, deseo, avaricia, desapego...

Hablamos de una verdad evidente: en efecto, los objetos son signos, están cargados de significados, de connotaciones, son culturemas, y dado el carácter icónico de la fotografía, estos sentidos se transfieren del objeto real a la imagen en la que están incluidos. Vemos, así, que un objeto es en realidad muchos objetos y que, representado en una foto, puede despertar en el receptor infinidad de cadenas de sentido.

En las décadas de los años 1960 y 1970, a las que ya hemos aludido como las de la explosión del estudio de diversos sistemas comunicativos, surgen inevitablemente ensayos con este enfoque. Entre ellos, solo por rememorar algunos hitos, podemos aludir a El sistema de los objetos (1968), de Baudrillard, la Teoría de los objetos (1972a), de Moles, o uno dedicado al vestido, el Sistema de la moda (1967), de Barthes. El espacio, categoría asociada a la de los objetos dentro del ámbito de lo inanimado, también tendrá sus apologistas. Recordemos, simplemente, al menos 
sistemático y más poético Perec y sus Especies de espacios (1974), por no retrotraernos hasta el clásico La poética del espacio (1957), de Bachelard.

La relación entre los objetos y la fotografía será una vía de doble sentido. En su versión pesimista, Durand, por ejemplo, señala «esta catástrofe que representa la fotografía en la conciencia que tenemos del mundo. La fotografía transforma el mundo en museo, en colección de especímenes, de muestras. Geometriza, iguala, clasifica». (Durand 1998: 103) En cualquier caso, el catálogo fotográfico de los objetos, su función intrínseca de archivo histórico, incluirá todas las variantes de aquellos en la sociedad de consumo: material, diseño, tipo de producción, funcionalidad, valor comercial, valor simbólico, unicidad, serialidad, técnica, utilidad, personalización, esteticismo, obsolescencia psicológica, obsolescencia funcional, moda, autenticidad, género...

El fotógrafo apela a los significados culturales del objeto al construir la imagen, de la misma manera que el receptor lo hace al decodificarla. $\mathrm{Si}$ en el apartado dedicado a los actantes nos remitimos a las declaraciones de intenciones de Cartier-Bresson respecto de la fotografía de lo vivo, ahora podríamos hacerlo a las de uno de los clásicos de la fotografía de objeto encontrado, Minor White, para quien «lo que el hombre ve o lo que el hombre encuentra es tan creativo como lo que el hombre hace». (En: Fontcuberta [ed.] 1984: 203) Realicemos esta aproximación, sin embargo, con cautela, ya que en las declaraciones de intenciones de un artista el juego de las palabras puede justificar cualquier cosa. ${ }^{4}$ Así lo demuestra, por ejemplo, la forma en que se recurre a las palabras de los poetas para... sí, poetizar, respecto de la propia actividad. Un autor socorrido en este sentido es William Carlos Williams, cuya frase «No ideas, but in things», 5 es tomada por el fotógrafo y ensayista Robert Adams para defender su concepción de que «las generalizaciones no son permisibles a menos de que emerjan ante nuestros ojos de lo específico, de la evidencia concreta, de las

\footnotetext{
4 Véase, por ejemplo, la mordaz crítica a las declaraciones de intenciones de Cartier-Bresson en Soulages (1998), ya aludida en la nota precedente a esta.

5 «No hay verdad salvo en las cosas», como se cita en la versión castellana del libro de Sontag, aunque nosotros preferimos: «No hay ideas, sino en las cosas».
} 
cosas». ${ }^{6}$ (Adams 1996: 23) Seguramente Adams, además de a Williams, había leído a Sontag, quien a propósito de la misma cita del poeta, da una versión sucinta de lo que es la retórica de los objetos y del espacio:

El compromiso de la poesía con la concreción y la autonomía del lenguaje es paralelo al compromiso de la fotografía con la visión pura. Ambos implican discontinuidad, formas desarticuladas y unidad compensatoria: arrancar a las cosas del contexto (para verlas de una manera nueva), enlazar las cosas elípticamente, de acuerdo con las imperiosas aunque a menudo arbitrarias exigencias de la subjetividad. (Sontag 1973: 106)

En efecto, es a través de los procesos de retorización que se canaliza la subjetividad. Volviendo a Adams y los poetas:

Si el paisajismo fuera solo reportaje, no tendría una aportación más que para la ciencia, lo que no ocurre. Siempre hay un aspecto subjetivo en el arte del paisaje, algo en la imagen que nos habla tanto de quien está detrás de la cámara como de lo que se encuentra enfrente de ella. Las fotografías nunca son tan limpiamente tautológicas como, digamos, la descripción de una rosa por Gertrude Stein. Ello debido a que el sujeto es demasiado grande; un objetivo fotográfico normal, a pesar de que puede abarcar una rosa, nunca puede cubrir la totalidad del paisaje, de la misma manera en que al pararnos en medio del campo sin una cámara y después de dar un giro completo, debemos decidir qué parte del horizonte encarar. (Adams 1996: 15)7

Los géneros por excelencia de la categoría que nos ocupa, el de la fotografía de objeto encontrado, el bodegón y el paisaje, nos recuerdan, así, que en la fotografía una rosa nunca es una rosa, nunca es una rosa, nunca es una rosa..., de la misma manera en que la pipa de Magritte (Imagen 8) no puede ser una pipa.

La nuestra es una época nostálgica, y las fotografías promueven la nostalgia activamente. La fotografía es un arte elegíaco, un arte crepuscular. Casi todo lo que se fotografía está impregnado de patetismo por el solo hecho de ser fotografiado. Algo feo o grotesco puede ser conmovedor porque la atención del fotógrafo lo ha dignificado. Algo bello puede suscitar amargura porque ha envejecido o decaído o ya no existe. (Sontag 1973: 25)

\footnotetext{
${ }^{6}$ La traducción es nuestra.

${ }^{7}$ La traducción es nuestra.
} 
En los géneros mencionados, el fotógrafo suele tener la posibilidad de una interacción pausada con el sujeto: mover y moverse, regresar, esperar. La «búsqueda expresionista se hará más fácilmente en un entorno dominado completamente por el fotógrafo: sujetos, esclavos o pagados, y sobre todo objetos: el expresionismo fotográfico de los objetos es uno de los métodos de la retórica de la imagen». (Moles 1981: 209) En el caso del espacio habrá un factor añadido: no solo habrán de tomarse en cuenta las características del espacio-tema fotografiado, sino que en ocasiones habrá que «reemplazar la idea de escenas fotografiables por una noción muy diferente: la idea de lugares desde los cuales se puede fotografiar». (Moles 1981: 216) Como consecuencia, el fotógrafo buscará espacios con una alta densidad de acontecimientos, iluminación suficiente y posibilidad de aislarse o de no ser afectado por el flujo del lugar; esto determinará también, a contrario, el valor que se atribuye a ciertas imágenes debido al grado de dificultad que denotan por haber sido producidas en sitios que no cumplen con dichas características.

Los espacios, como los objetos, también estarán cargados de sentidos culturales, históricos, simbólicos. Se hallarán, de igual modo, sujetos a interpretación por la subjetividad del receptor. De ahí, acaso, la nostalgia de Perec:

Me gustaría que hubiera lugares estables, inmóviles, intangibles, intocados y casi intocables, inmutables, arraigados; lugares que fueran referencias, puntos de partida, principios [...].

Tales lugares no existen, y como no existen el espacio se vuelve pregunta, deja de ser evidencia, deja de estar incorporado, deja de estar apropiado. El espacio es una duda: continuamente necesito marcarlo, designarlo; nunca es mío, nunca me es dado, tengo que conquistarlo. (Perec 1974: 139)

Esta nostalgia, llevada al campo fotográfico, nos propone infinidad de dudas. Si el sociofotógrafo, como lo llama Moles, busca lugares antropológicos para interpretarlos o para jugar con sus significados culturales, la sociedad espectacular los despersonaliza. Tal es, también, la nostalgia de Augé (1992: 111), quien rememora una expresión muy 
pertinente en este punto de nuestra reflexión, la de país retórico, y nos recuerda:

En la situación de supermodernidad, una parte de ese [espacio] exterior está constituida por no lugares, y una parte de los no lugares, por imágenes. Hoy, la frecuentación de los no lugares ofrece la posibilidad de una experiencia sin verdadero precedente histórico de individualidad solitaria y de mediación no humana (basta un cartel o una pantalla) entre el individuo y los poderes públicos. (Augé 1992: 120)

Con base en los factores comentados, como conclusión de este apartado, baste recordar que todo objeto y espacio tienen un significado cultural, son culturemas, y que su uso retórico por parte del fotógrafo se fundamenta en la apelación a él. Las relaciones de oposición, concordancia, extensión, transferencia, contigüidad, figura-fondo, etcétera, entre los objetos y actantes representados en un espacio serán producto de la utilización de figuras de la retórica visual como la comparación, el énfasis, la metáfora o la metonimia. Estas relaciones se lograrán básicamente por tres medios: la inclusión de varios objetos en la imagen (relación objetoobjeto), la presentación de un objeto en un determinado espacio (relación objeto-contexto espacial), y el recurso a indicadores del momento histórico (relación objeto-contexto temporal). Como veremos en el apartado siguiente, las significaciones logradas partiendo de estos medios serán reforzadas por el tratamiento formal que se dé a la imagen. 


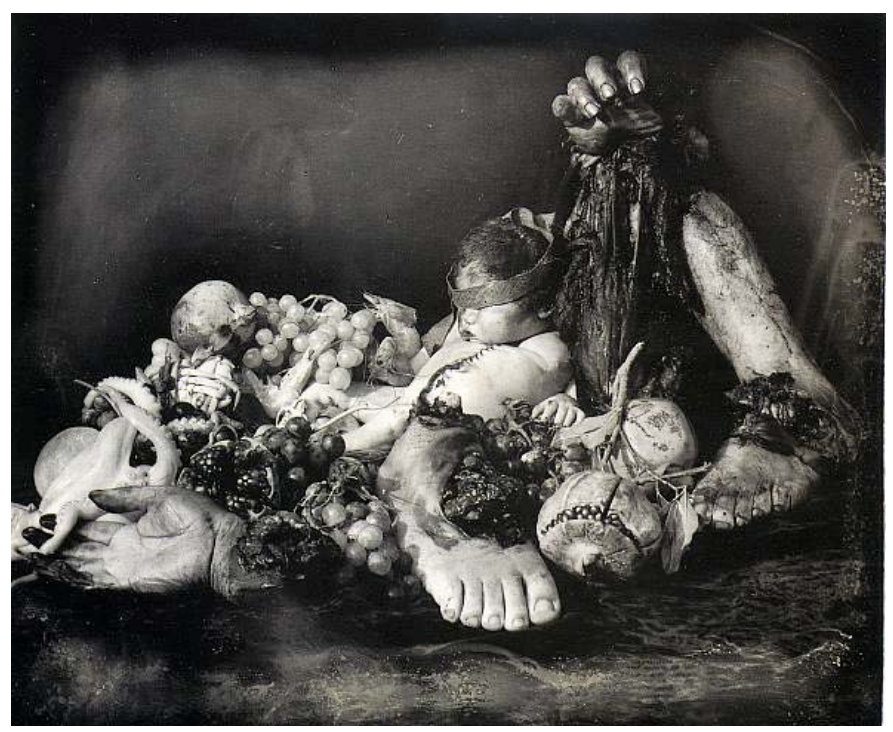

Imagen 76. J oel Peter Witkin

Festín de locos, 1990

El bodegón o naturaleza muerta, género clásico de representación a partir de objetos. En este caso, lo que en un primer golpe de vista podría parecer un bodegón tradicional debido a su composición, se revela como un espectáculo macabro en el momento en que nuestra mirada descubre que algunos de esos elementos compositivos no corresponden a los objetos que esperaríamos encontrar en él. Los componentes son descontextualizados, y con ello se modifican las expectativas del receptor. Es lo que Moles llamaría un poderoso recurso expresionista. 


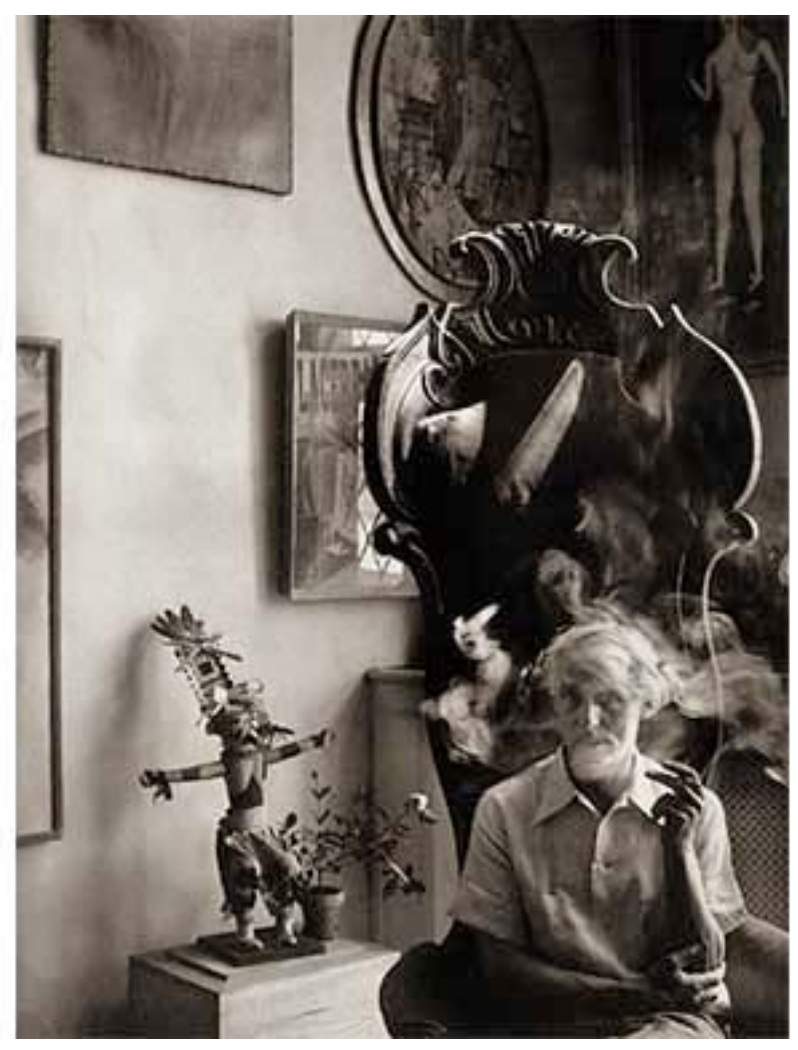

Imagen 77. Arnold Newman

Max Ernst, 1942

$\mathrm{Si}$ en el caso de Avedon (Imagen 12) hemos visto el recurso de aislar a sus sujetos del entorno mediante un fondo blanco y dejar que hablen por sí mismos, generalmente solo con su propio vestido como información objetual añadida a su fisonomía y gestualidad, otro retratista clásico, Newman, utiliza la estrategia contraria. El caso de su conocido retrato del pintor surrealista Max Ernst es un paradigma de su forma de crear un diálogo entre el actante, los objetos y el espacio, de manera que la personalidad del primero sea aludida de forma indirecta por aquellos elementos inanimados presentes en el cuadro. 


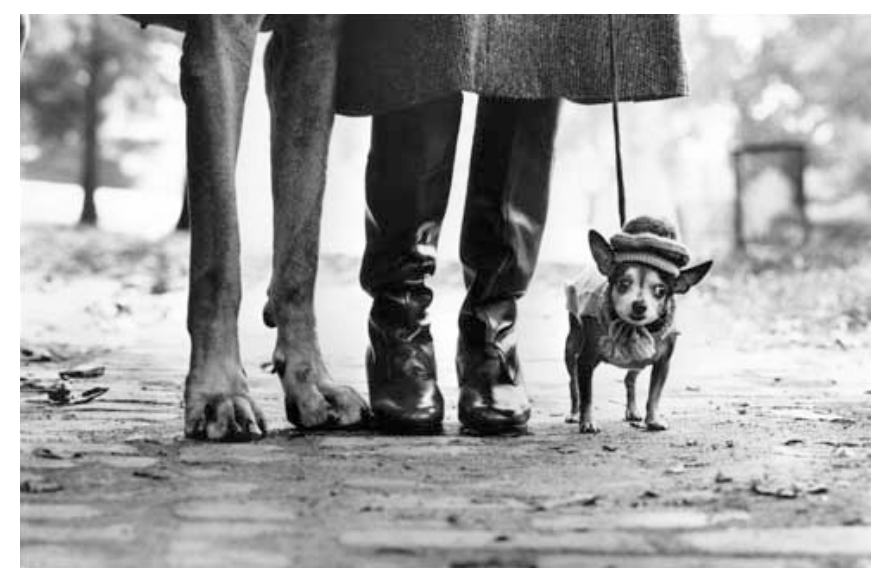

Imagen 78. Elliott Erwitt

Perro y botas, 1974

Una mujer a la que se alude metonímicamente a partir de su abrigo y botas, un gran perro cuya presencia se incluye utilizando la misma estrategia retórica a través del encuadre y del corte, $\mathrm{y}$, en una ironía fundamentada en las relaciones de contigüidad y de escala, el pequeño animal -que adquiere relevancia debido a la posición de la cámara y al encuadre, que lo convierten en el actante principalmirando inquisitivo al objetivo y humanizado, en una prosopopeya visual, mediante el atuendo que parecería hablar de él, cuando en realidad no se refiere sino a la personalidad de su dueña - estrategia recurrente en las fotos de perros de Erwitt-. ¿Tendrá este distinguido can algún parentesco con la cosmoperra? (Imagen 72) La importancia del espacio, por cierto, resulta minimizada mediante el desenfoque, que es una manera común de aislar al sujeto del entorno. 


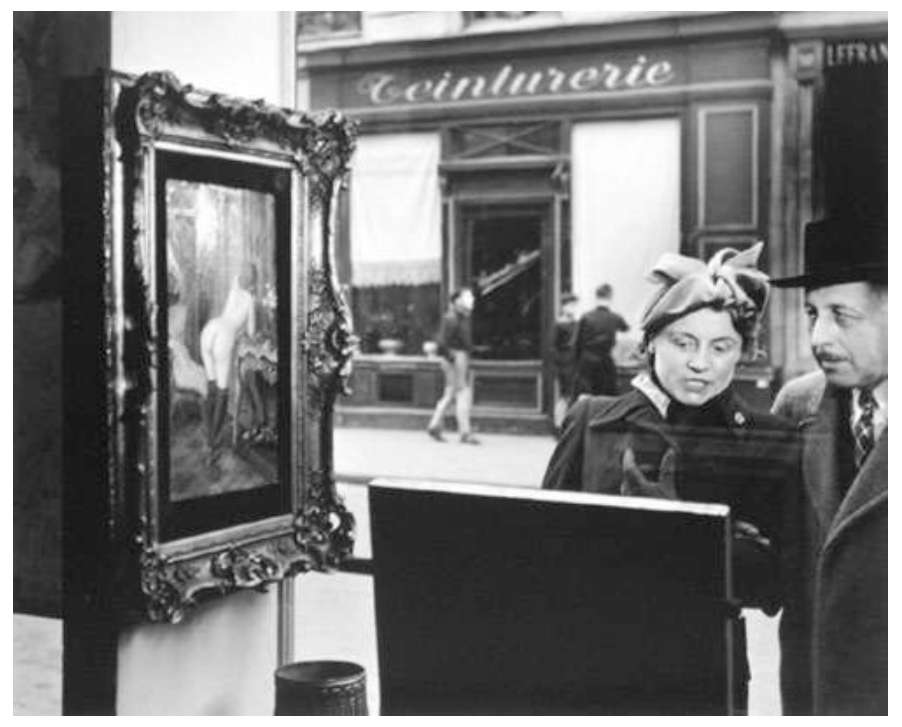

Imagen 79. Robert Doisneau

La mirada oblicua, 1948

El fotógrafo encuentra un lugar y se esconde, como el cazador, al acecho de la presa. La imagen solo puede funcionar si su presencia no es notada. El juego de las miradas es perfecto, así como la interacción actantes-objetosespacio; dados los aspectos no verbales de los sujetos, ¿alguien dudaría que esta pareja está casada? Doisneau publicó una serie de fotos con igual encuadre, registrando las expresiones de diferentes tipos de personas y revelando que, en ocasiones, lo esencial es encontrar un lugar y esperar hasta captar en él un momento decisivo. 


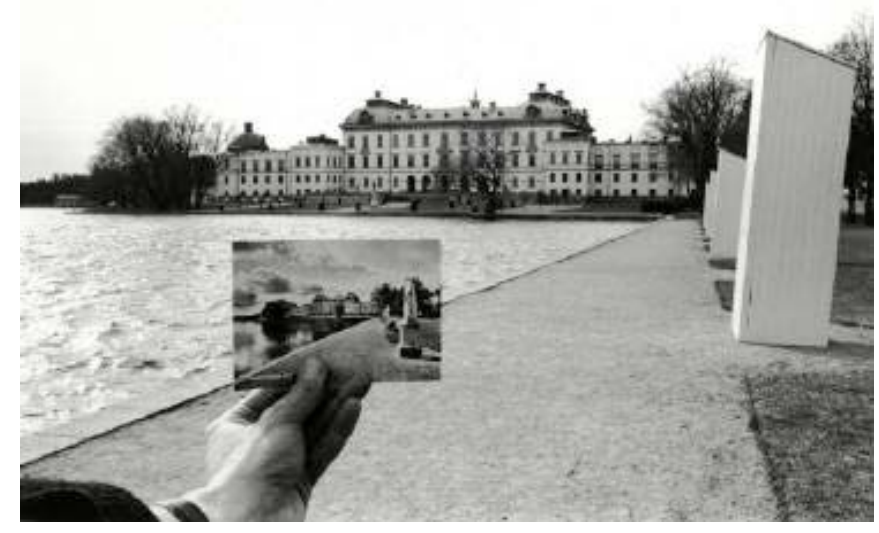

Imagen 80. Kenneth J osephson

Drottingholm, Suecia, 1967

La tarjeta postal, visión idílica del espacio y los objetos realizada en condiciones privilegiadas y frecuentemente retocada, que invariablemente provoca la decepción del viajero al confrontar con ella la realidad. Elocuente e irónica visión de J osephson, que contrasta la foto-objeto con el sujeto real percibido en otro momento, creando así un metadiscurso. La inclusión a cuadro de su propia mano también es relevante: si bien toda foto alude indirectamente a la presencia del fotógrafo en la escena, en este caso la idea de una afirmación hecha en primera persona se ve reduplicada y el fotógrafo ya no es solo un observador, sino un actante. 


\subsection{RETÓRICA DE LA FORMA}

El significado intrínseco de un determinado personaje u objeto, tema de los anteriores apartados, se verá reforzado o modificado por las caracerísticas formales - plásticas o no figurativas-de la imagen. Así, por ejemplo, los tres componentes de los códigos miméticos se pueden utilizar intencionadamente para crear la figura retórica del énfasis —dándole más iluminación a un objeto, exagerando su escala, concediéndole una mayor jerarquía por medio de la elección del punto de vista y de su posición en el cuadro- Lo mismo se puede decir de los códigos técnicos: se cargará de expresionismo a un objeto por medio de la utilización de enfoque selectivo, del color, de la repetición, el contraste, etcétera. Habiendo ya revisado estos factores, intentaremos ahora darles cierta sistematicidad para ahondar en las permanentes relaciones que, dentro de la imagen fotográfica, se dan entre lo icónico y lo plástico, esto es, entre el qué se representa y el cómo se representa.

El ámbito de lo plástico o no figurativo ha sido estudiado ampliamente a partir de los hallazgos de la escuela de la Gestalt y, en general de la teoría de la percepción en los, así llamados, estudios de gramática o sintaxis visual. Siendo un tema en extremo amplio, nos limitaremos aquí a reproducir, a manera de apéndice para este capítulo, la síntesis hecha por Moles de las leyes de la teoría de la forma y de sus consecuentes leyes de infralógica visual. ${ }^{8}$ Las distintas posibilidades retóricas centradas en la forma, en su versión más sintética, se desprenden directamente de este inventario.

Hemos de enfatizar el hecho de que, dentro de nuestro planteamiento, se ha identificado el nivel infralógico molesiano con los procedimientos inconscientes de lectura, que el receptor ha incorporado. (Ver supra: Capítulo 2) Profundicemos en el concepto de infralógica.

\footnotetext{
8 Tomadas de Costa (1998: 95 y ss.), quien las sistematiza a partir de Moles. La versión citada es la más completa de las aparecidas reiteradamente en diversas obras de ambos autores.
} 
Denominaremos «infralógicas» a los modos de ensamblar conceptos verbales, visuales o simbólicos, a las gramáticas de las ideas; estos son relevantes, es decir, orientan al pensamiento en sus procesos de elaboración hacia «buenas formas». Estas infralógicas constituyen el primer contacto del pensamiento con una constricción racional. (Moles 1984: 148)

La infralógica se identifica, así, con aquellos mecanismos de creación de sentido, lógicas naturales, repertorios de modos elementales de pensamiento que la persona maneja aun sin tener una conciencia clara de ellos, y que «son el producto de su educación, de su cultura, de sus conocimientos, de su aprendizaje de situaciones, son la suma de su bagaje en un momento dado». (Moles 1984: 143) La consecuencia: «La gramática nos parece entonces ser una infralógica, el primer impacto de la razón y la seriedad sobre el pensamiento más íntimo y más individual». (Moles 1984: 144) Para el autor citado, las infralógicas tienen una importancia equiparable a la de las lógicas tradicionales y su carencia de rigor encuentra una compensación, dice, en su potencia. Nos movemos, sin embargo, en un terreno pantanoso, ya que «son arbitrarias, poseen una coherencia variable, a menudo débil, y dependen de la estructura mental del individuo». (Moles 1984: 301) Veamos el recuento de las leyes de la teoría de la forma y las leyes de infralógica que Moles y Costa, colaboradores en diversas obras, han perfeccionado a lo largo de los años:

\section{Leyes de la teoría de la forma (Gestalt):}

1. Ley de totalidad:

El todo es diferente y es más que la suma de sus partes.

2. Ley estructural:

Una forma es percibida como un todo, con independencia de la naturaleza de las partes que la constituyen.

3. Ley dialéctica:

Toda forma se desprende del fondo sobre el que está establecida. La mirada decide si tal o cual elemento del campo visual pertenece alternativamente a la forma o al fondo. 
4. Ley de contraste:

Una forma es mejor percibida en la medida en que se establece un mayor contraste entre ella y su fondo. (Es el principio de lo que llamamos «buena forma».)

5. Ley de cierre:

Una forma será mejor en la medida en que su contorno esté mejor cerrado.

6. Ley de completación:

$\mathrm{Si}$ un contorno no está completamente cerrado, la mente tiende a completar o continuar dicho contorno incluyéndole los elementos que son más fáciles de aceptar en la forma, o que son de algún modo inducidos por ella.

7. Noción de pregnancia:

La «pregnancia» es la fuerza de la forma. Es la dictadura que la forma ejerce sobre el movimiento ocular, así como su capacidad por imponerse en la mente y en el recuerdo. (La pregnancia es subsidiaria de la «buena forma».)

8. Ley de simplicidad:

En un campo gráfico dado, las figuras menos complejas tienen una mayor pregnancia. Una figura simple es aquella que necesita un menor número de grafemas para construirla.

9. Ley de concentración (llamada también de simetría, de equilibrio y de inclusión):

Los elementos que se organizan alrededor de un punto central, que es su núcleo, constituyen en todos los casos una forma pregnante.

10. Ley de continuidad:

Los elementos que se desarrollan siguiendo un eje continuo constituyen una forma pregnante.

11. Ley de contorno:

Las figuras cuyas formas poseen mayor contraste sobre el fondo son agrupadas y asociadas por la percepción, y poseen un alto potencial de pregnancia. 
12. Ley del movimiento coordinado:

Los diferentes elementos que participan de un mismo movimiento constituyen una forma pregnante.

13. Ley de continuidad de dirección:

Una línea curva es percibida como un fragmento de circunferencia y un segmento de línea.

14. Principio de invarianza topológica:

Una forma resiste a la deformación en que se la hace incurrir. Esta resistencia se da en la medida en que la forma es más pregnante.

15. Principio de enmascaramiento:

Una forma resiste a las diferentes perturbaciones a las que está sometida (ruido, manchas, elementos parásitos). En la medida en que la forma sea más pregnante, será más persistente.

16. Principio de Birkhoff:

Una forma será tanto más pregnante en la medida en que contenga un mayor número de «ejes de simetría» (regularidad, estabilidad).

17. Principio de proximidad:

Los elementos del campo perceptivo que están aislados, pero que son vecinos, tienden a ser considerados como «grupos» o formas globales.

18. Principio de similaridad:

En un campo de elementos equidistantes, aquellos que tienen mayor similitud por su forma, tamaño, color y dirección, se perciben ligados entre ellos para configurar una cadena o grupos homogéneos.

19. Principio de memoria:

Las formas son tanto mejor percibidas por un individuo en la medida en que le son presentadas con mayor frecuencia.

20. Principio de jerarquización:

Una forma compleja será tanto más pregnante cuando la percepción esté mejor orientada de lo principal a lo accesorio; es decir, que sus partes estén mejor jerarquizadas. 


\section{Leyes de infralógica:}

1. Ley de centralidad:

Los elementos que se presentan en el centro de la figura son más importantes, o mejores, que los presentados en la periferia.

2. Ley dela correlación:

La correlación es siempre una (presunción de) causalidad: si A está junto a B, es porque A y B mantienen una relación causal; A es causa principal de B, o bien a la inversa, B es causa principal de A.

3. Ley de no transitividad:

Si A implica B y B implica C, ello no significa que A implique a C.

4. Ley dela ampliación de la causalidad de las series:

Si A implica B y si B implica C y si C implica D, el hecho de que A implique B es más evidente, que si solo estuvieran presentes A y B.

5. Ley deinfinidad:

$\mathrm{Si}$ en una serie infinita de elementos representados, todos ellos son idénticos, la mente se forma la idea de que esa serie es limitada si la serie comporta al menos tres términos yuxtapuestos; la noción es de infinito riguroso cuando el número de elementos supera a siete.

6. Ley de percepción de la complejidad:

El concepto de complejidad emerge en la conciencia cuando el número de elementos presentes en el espacio gráfico es superior a siete.

7. Ley dedominancia:

El elemento que está en primer plano tiene más jerarquía que los del fondo o segundo plano.

8. Ley perspectivista:

En una composición, el orden cercano es a priori independiente del orden lejano.

9. Ley de perspectiva dinámica:

Una perspectiva que tenga un punto de fuga muy cercano es más dinámica que una con un punto de fuga lejano (pequeñas o grandes distancias focales en fotografía). 
10. Ley de dominio del ángulo recto:

Los elementos u objetos cuyos contornos están formados por ángulos rectos están más elaborados que los formados por otro tipo de ángulos.

11. Ley de cuantificación de los ángulos:

Los únicos ángulos que poseen existencia autónoma en el mundo visual de ensamblaje de contornos lineales son los ángulos de $90^{\circ}$, 60ํㅜ, 45ํㅡ y $30^{\circ}$. Todos los demás que aparecen en una figura plana se consideran a priori deformaciones o aberraciones de los ángulos precedentes, o combinaciones de estos.

12. Teorema de Franck:

Cuando, en un conjunto amplio de elementos uniformes, un determinado número de elementos está provisto de una propiedad única, la percepción subjetiva estima que se ha producido un cambio cualitativo en el conjunto a partir del momento en que el cambio afecta a más del 34\% de los elementos del conjunto.

13. Ley de coloración:

Las cosas representadas en colores tienen mayor carga connotativa y expresiva, en igualdad de condiciones, que las representadas en negro o monocromas.

14. Ley del valor cualitativo de los colores:

Los elementos que poseen una crominancia intensa son superiores a los que poseen una crominancia débil, si todos los demás factores son iguales.

15. Ley de pureza cromática:

Los objetos de color puro saturado son superiores a los objetos de color mezclado o tonos intermedios en cualquier situación connotativa (más fuerte, mejor, más joven, más vivo, superior, etcétera).

16. Ley de fuerza cromática:

Los objetos de color puro y «fuerte» (rojo, amarillo, negro, blanco, etcétera) dominan la atención con respecto a los objetos o cosas de colores débiles (gris, verde, azulado, violeta, rosa). 
Siendo estas leyes generales y aplicables a cualquier tipo de imagen, su transpolación al ámbito de la fotografía no deja de ser conflictiva ya que la instantaneidad del corte fotográfico parecería eludirlas como estrategias de construcción de la imagen. Sin embargo, basta apelar a la actividad de un editor ante decenas de fotos similares colocadas en una mesa de luz o desplegadas en el monitor de su ordenador, y a su capacidad para elegir la mejor, aquella en la cual todos los elementos icónicos y plásticos confluyen para hacerla más pregnante, para darnos cuenta de cómo estos procesos están interiorizados; capacidad, dicho sea de paso, que no es exclusiva del editor o del fotógrafo como profesionales, sino que está presente en el lector intuitivo. La experiencia del fotógrafo, asimismo, le permite tomar estos factores en consideración, ya sea consciente o inconscientemente, en el curso de la construcción de la imagen -así esta construcción sea inmediata, en el propio visor de la cámara-, logrando el ideal de la foto expresionista, que es cuando «la pregnancia de la forma real que propone es mayor que la pregnancia del original del cual tomó la imagen». (Moles 1981: 204) Este factor está vinculado a lo que en el ámbito fotográfico se suele llamar visualización o previsualización, esto es, la capacidad de prever las características finales de la imagen bidimensional ante la presencia del sujeto real.

En una reducción casi al absurdo, el fotógrafo suele crear para sí mismo una estrategia de trabajo, de maneras de hacer en ocasiones cercanas al tic o a la receta fácil, que guiarán su actividad en busca de dicho expresionismo:

Fuera de los «trucos individuales» que forman parte del oficio o del arte personal, pueden enunciarse algunas reglas:

- la unidad de la forma sobre un fondo bien contrastado;

- el enfoque nítido sobre el sujeto propuesto;

- el contraste de luz y sombra entre forma y fondo;

- la unidad de jerarquía;

- la sencillez relativa de la expresión propuesta;

- la convergencia de las líneas de fuga hacia el tema o el objeto fotografiado;

- la severa reducción del número de elementos distinguibles en el objeto fotografiado (escenas con dos o tres personas como máximo, o donde las personas están estrechamente jerarquizadas, etc.); 
- siempre hay demasiadas cosas en una foto, el problema es quitar un poco (encuadre, objetivos); [...] es una de las constantes que distinguen la vista del aficionado de la fotografía profesional. (Moles 1981: 207)

En su versión más banalizada, este tipo de consejos prácticos para el logro de imágenes pregnantes ha sido reducido a fórmulas en los abundantísimos manuales fotográficos del tipo hágalo usted mismo, dirigidos fundamentalmente al aficionado o al fotoclub, y que han proliferado desde que la fotografía se masificó, esto es, a lo largo de todo el siglo pasado. Pero en el extremo contrario, en su versión más efectiva, debemos reconocer que tanto para el fotógrafo creativo y experimental como para el profesional de la foto comercial, siguen siendo principios constructivos, ya sea que se utilicen en un sentido ortodoxo o a contrario, parodiándolos o problematizándolos.

Finalmente, no podemos concluir este apartado sin hacer un breve comentario acerca del color, elemento fundamental tanto desde el punto de vista formal como del que se refiere a la psicología de la percepción.

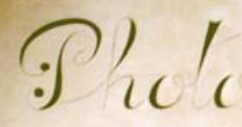


Como se desprende de su presencia en buen número de las leyes antes enumeradas, este elemento esencial parece en muchas ocasiones haber sido dejado de lado por la crítica debido al predominio de la fotografía en blanco y negro durante el siglo XIX y gran parte del XX, predominio que, sin embargo, ha quedado atrás.

Una misteriosa obra de J oan Miró (Imagen 81) nos da pie para esta reflexión. En ella se incluye la palabra Photo. Aunque no se muestra ninguna imagen fotográfica concreta, podemos intuir, por haber sido aquella obra producida en 1925, que en la mente del autor esa foto sería una en blanco y negro. En el lado opuesto de esa palabra vemos una mancha azul con la leyenda: Este es el color de mis sueños. ¿Será que el artista, cuyos sueños tenían color, extrañaba en las fotografías ese elemento fundamental?

En el listado que hemos incluido unos párrafos arriba de las leyes de la teoría de la forma y las de infralógica, el color queda bien establecido como uno de los elementos primarios que inciden en la percepción e interpretación de las imágenes. Evidentemente no solo las connotaciones derivadas de dichas leyes deberán ser tomadas en cuenta en la consideración de este elemento para el análisis de fotos concretas, sino también todas las que se derivan del extensísimo campo de la psicología del color, la cual, por exceder los límites de este trabajo, simplemente apuntamos como un elemento más a incorporar ya que sus implicaciones inciden en ambos planos de aproximación al sentido visual, tanto el icónico como el plástico. 


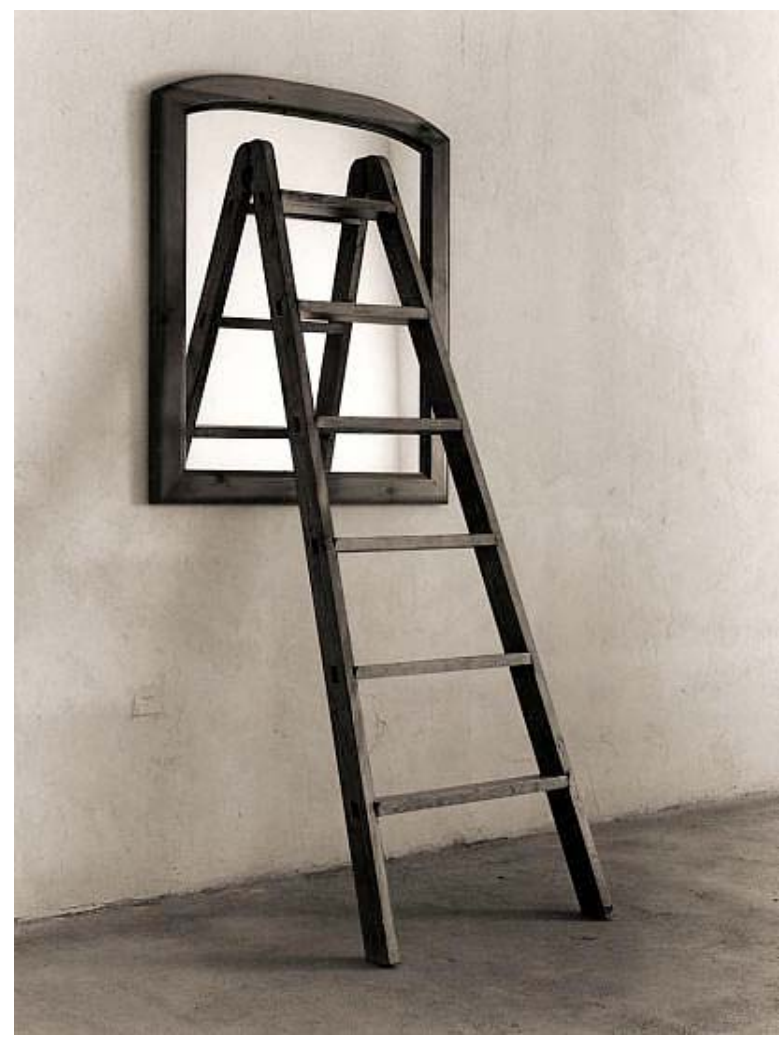

Imagen 82. Chema Madoz

Sin título, 1990

Un juego formal perfectamente planeado y llevado a cabo con la pausa característica de la fotografía construida, en una propuesta donde los elementos plásticos predominan sobre los figurativos y se convierten, ellos mismos, en sentido. 


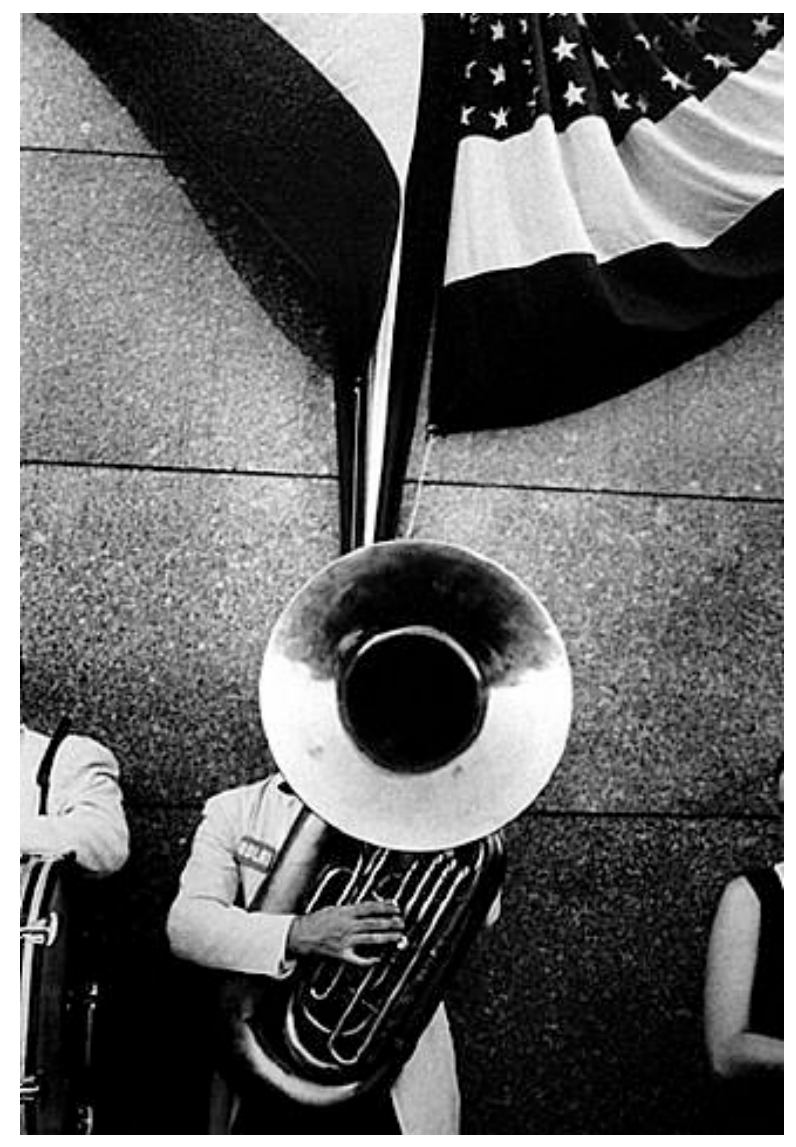

Imagen 83. Robert Frank

Campaña política, Chicago, 1956

Un encuadre que, desde el punto de vista del canon del fotoclub, sería considerado como completamente errático: el eje compositivo centrado, el círculo dominante de la tuba tapando la cara del sujeto principal, los personajes a izquierda y derecha torpemente cortados. Pero... ¿hay en esta imagen un sujeto principal? Frank cuestiona el tema fotografiado mediante la parodia de lo que sería el buen hacer compositivo, logrando, no obstante, una imagen expresionista muy pregnante. 


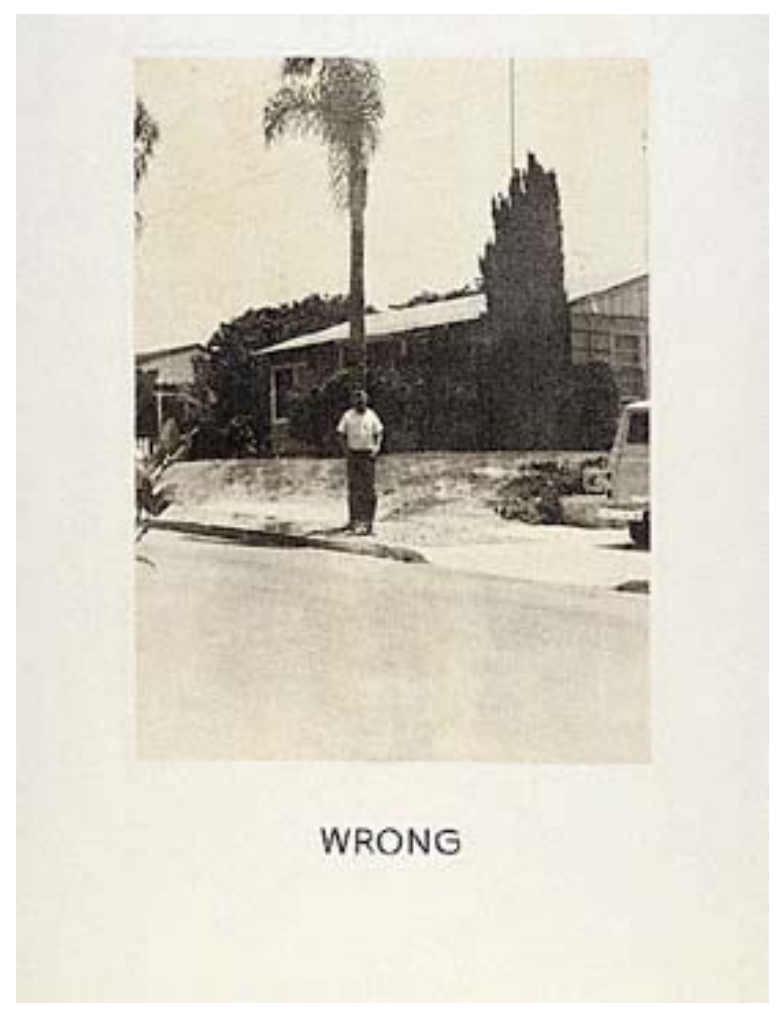

Imagen 84. J ohn Baldessari
Wrong (Equivocado), 1967

Si la mirada fotográfica de Frank en la imagen anterior es capaz de generar una potente ironía directa, en manos de un artista conceptual lo fotográfico se debilita y el concepto tiene que ser mediatizado, explicado, y como paradoja resulta menos conceptual. Baldessari también arremete contra los manuales simplistas de tips fotográficos $\mathrm{y}$, premeditadamente, viola toda norma posible en esta instantánea digna del peor álbum familiar: el sujeto principal está lejos y alineado con la palmera, que parece salirle de la cabeza; hay un gran primer plano sin información; hay cortes ambiguos a ambos lados... Sin embargo, el autor no confía en la fuerza de la imagen -seguramente su intención es privarla de toda fuerza- $y$, aunque sea con una sola palabra, la explica. Pero, ¿no resulta obvio en su crítica de la obviedad? 


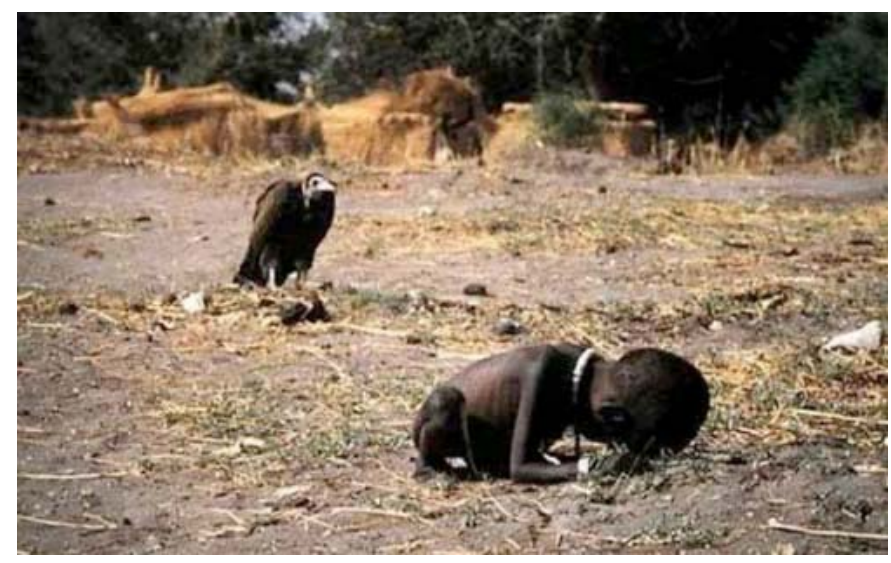

Imagen 85. Kevin Carter
Ayod, Sudán, 1993

Una polémica imagen ganadora del Pulitzer, con el tema de la hambruna en Sudán. El recurso plástico del fotógrafo es tan burdo que habla mal del jurado que la premió: al colocar dos sujetos juntos dentro de un encuadre, nuestra mente crea un vínculo temático entre ellos (v. gr.: principio de proximidad, ley de correlación), máxime si, como en este caso, se les aísla del contexto mediante el aplanamiento que proporciona el telefoto y el desenfoque del fondo. Tuvo que ocurrir un escándalo para que se aclarara que la niña -quien, en efecto, se encontraba desnutrida - estaba defecando a unos pasos del campamento y que el buitre no esperaba a que ella muriera para devorarla, sino que estaba en ese páramo porque ahí había desechos orgánicos. La opinión pública podría ahorrarse polémicas absurdas si, antes de externar declaraciones acerca de una foto, se detuviera a mirarla pausadamente. Pero, en el fondo, son las polémicas absurdas las que alimentan el espectáculo... como por desgracia muchas veces también lo hacen los fotógrafos de prensa. 

TERCERA PARTE: EL ANÁLISIS PRAGMÁTICO

CAPÍTULO 7

\section{LOS ANCLAJ ES INTERPRETATIVOS CONTEXTUALES}





\subsection{CONSIDERACIONES EN TORNO AL ANÁLISIS PRAGMÁTICO}

En el Capítulo 3, como parte de nuestro marco teórico, reflexionamos acerca de los difusos límites de la pragmática, así como de las aportaciones contextuales a la interpretación del sentido de una imagen. Posteriormente, en los Capítulos 4, 5 y 6, analizamos los criterios para el estudio de la imagen fotográfica desde un punto de vista inmanente. Llega ahora el momento de abordar el análisis extrínseco a sabiendas de que, debido a las diferencias entre las recepciones concretas, este es inabarcable en la práctica. Ante el reconocimiento de dicho escollo, nuestra estrategia será la de proponer un modelo que ponga en juego la interrelación de algunos factores que, aun siendo más o menos externos a la imagen, inevitablemente inciden en el acto de recepción y en la atribución de sentido que el espectador elabora. Nuestra intención es que, mediante la reflexión acerca de las influencias y reciprocidades que se dan entre ellos, se cuente con una herramienta metodológica para adentrarse en la complejidad del acto interpretativo en el marco del análisis semiopragmático.

Para abordar esta reflexión, haremos una disertación introductoria: imaginemos, para ello, la imagen de un cuerpo desnudo.

Ante este reclamo, evidentemente cada persona evocará una imagen distinta, la cual acaso provenga de campos tan dispares como el arte, el cine, la publicidad, la pornografía, o incluso de ámbitos vivenciales como la sexualidad personal o la experiencia del propio cuerpo. Algunas de las respuestas seguramente serán consideradas por otros como extrañas o atípicas. Planteemos, por ejemplo, un caso en el que la imagen referencial provenga del campo científico. Imaginemos a una persona que, siendo hija de un médico, crece en una casa en la que abunda el material gráfico, no solo referente a los estudios canónicos de anatomía, sino también a la documentación fotográfica de todo tipo de malformaciones, imágenes perturbadoras -fotografías crudas, de registro, realizadas en el polo 
opuesto al esteticismo-que siembran en la mente de un niño una peculiar comprensión de cómo la deformación subyace, agazapada, bajo la normalidad; imágenes que, por otro lado, le provocan una disonancia cognitiva al ser contrastadas inconscientemente con las representaciones sobreestetizadas del cuerpo en el arte, la cinematografía, la televisión o la publicidad, y que ponen en predicamento la comprensión que tiene de sí mismo, ya que si hacemos caso a Merleau-Ponty (1964) -al que ya evocamos a propósito de esta idea en el Capítulo 2-, es a partir de la percepción de su propio cuerpo que se desarrollará su vinculación con el mundo. Así que partamos una vez más, como en aquel capítulo, del autorretrato de un hombre frente a un espejo, en este caso un hombre desnudo. En efecto, la vinculación de que hablamos puede verse profundamente problematizada, como parecerían manifestar los autorretratos de David Nebreda (Imagen 86), expresión de su esquizofrenia, los cuales parecerían llevar al extremo la siguiente consideración:

En un contexto como el que estamos viviendo, resulta difícil utilizar el referente corporal sin que este actúe como paráfrasis del desaliento y de la contrariedad. De ahí que cualquier aportación que busque desvincularse del dictum mediático constate una similar frustración: la derivada del choque producido entre lo que racionalmente percibimos y/ o conjeturamos y lo que irracionalmente se configura desde esos nuevos modelos de representación institucional que se desprenden del entramado mediático. Unos modelos en los que el cuerpo - ya sea en su vertiente publicitaria o pornográfica- es presentado como referencia desproblematizada y productiva. Vivimos, pues, entre múltiples cuerpos. O, mejor aún, entre numerosos fantasmas. Los mismos no son más que metáforas de una sociedad agotada: reflejos estereotipados de un modelo social que oculta su debilidad en la hiperproducción de un exceso que solo conduce a la nada. (Pérez 2004: 37)

Regresaremos a las consideraciones del autor citado, pero antes habremos de hacer un recorrido amplio a través de esa frustración, producto de una verdadera disonancia cognitiva-colectiva - si vale una analogía con el concepto de inconsciente colectivo- que convierte a la representación fotográfica actual del cuerpo en un retrato involuntario de la sociedad. 


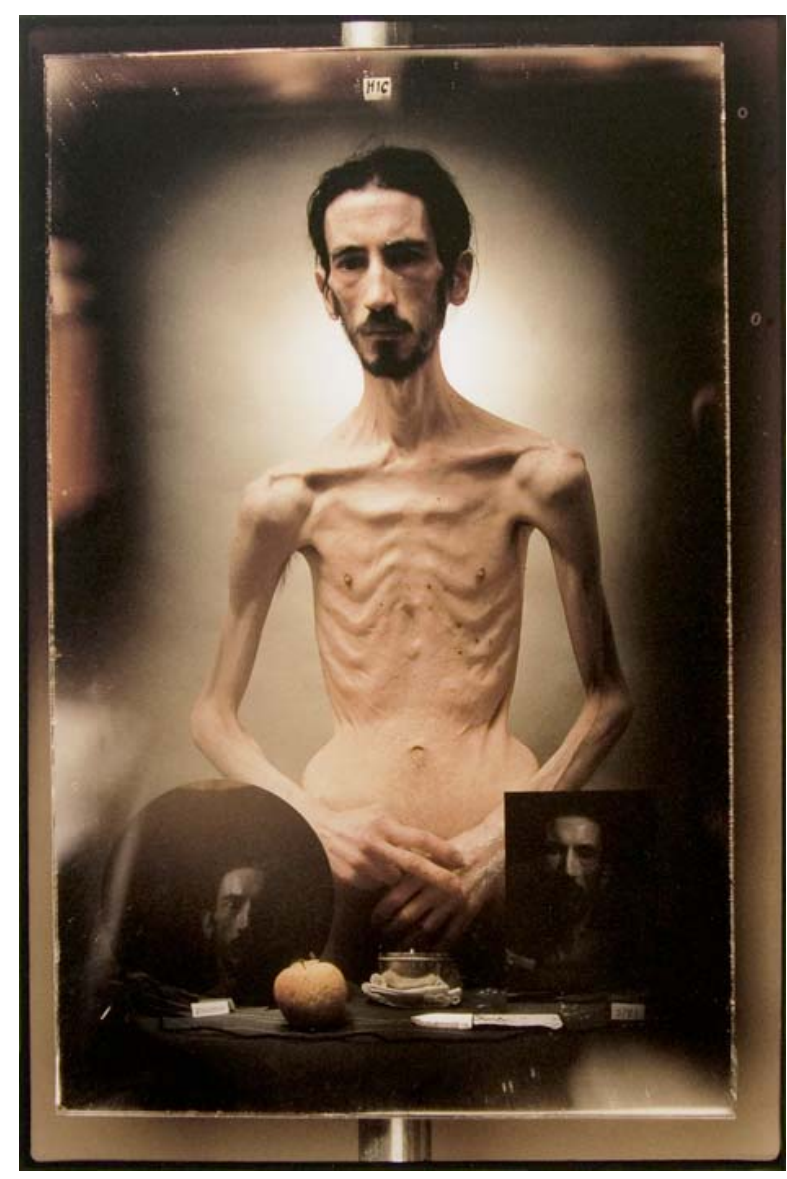

Imagen 86. David Nebreda

La trinidad de los espejos. Hic-quadrum spei, 1989-1990

La representación del cuerpo ha estado históricamente en el centro de la problemática fotográfica. Se sabe que la abrumadora mayoría de las imágenes que se producen son de personas. (Cfr. Moles 1981) En lo que toca a los géneros, a excepción del retrato,

[...] el desnudo es, evidentemente, la forma dominante de representación del cuerpo en la historia de la fotografía. Subcategoría particular de la representación fotográfica, se distingue radicalmente de la imagen del cuerpo desnudo tal como la hallamos en las representaciones médicas, 
etnográficas o documentales. Al margen de sus distintas transformaciones, el desnudo debe ser considerado como una construcción estética, una forma sublimada de representación. Es, además, propio del arte occidental. (Solomon-Godeau 2001: 166)

Cierto es que el desnudo así definido, como género artístico, lleva ya un período prolongado a la baja y que el arte contemporáneo se ha centrado en otro tipo de asuntos en torno al cuerpo y la sexualidad. Pero no nos adelantemos, ya que el camino hacia estas concepciones contemporáneas ha sido largo. Partamos, así, de la tradición de este género. Ante este planteamiento, surge una primera interrogante, a saber: ¿cuál es el baremo que marca la gradual distancia existente entre el desnudo -género artístico- y la desnudez - experiencia vivida-, por utilizar dos términos consagrados en el campo de la teoría estética por Kenneth Clark (1956)? El arte ha cambiado mucho en el medio siglo transcurrido desde que se escribió ese texto canónico. Incluso también desde que John Berger reflexionara acerca de este género pictórico en su Modos de ver (1972), donde precisamente se ocupa de los conceptos de Clark. Siguiendo al maestro, a decir de Berger, «un desnudo no es el punto de partida de un cuadro, sino un modo de ver propio del cuadro» (1972a: 61), de lo que deducimos que el modo de ver, equiparable también a la manera de formar (cfr. Eco 1962b), está dado cultural, contextualmente. Y lo que más nos incumbe es aquello con lo que Berger continúa su reflexión:

Esto es verdad en cierta medida, aunque el modo de ver «un desnudo» no es necesariamente exclusivo del arte: hay también fotografías de desnudos, poses de desnudo, gestos de desnudo. Lo cierto es que el desnudo está siempre convencionalizado, y que la autoridad de sus convenciones procede de cierta tradición artística. (Berger 1972a: 61-62)

Parecería entonces que la sola apelación al género, en este caso el desnudo, sesgaría totalmente tanto la manera de formar -codificación, emisor - como el modo de ver —decodificación, receptor- y que el acto creativo estaría sumido en un repertorio limitadísimo de posibilidades, por supuesto, ya agotadas. (Cfr. Flusser 1983) El crítico de arte, sin embargo, 
busca las excepciones que hacen que valga la pena continuar en el intento de bregar por un camino, aunque este haya sido ya muy transitado. Así, la intuición de Berger propone que:

En la tradición europea de la pintura al óleo hay unos cuantos desnudos excepcionales [...]. En realidad, ya no son desnudos, pues rompen las normas de la forma-arte; son cuadros de mujeres amadas y más o menos desnudas. Entre los cientos de miles de desnudos que constituyen la tradición hay quizá unas cien excepciones de este tipo. En todos los casos, la visión personal que tiene el pintor de aquella mujer concreta que está pintando es tan intensa que no hace concesión alguna al espectador. La visión del pintor vincula la mujer al artista con tal fuerza que se hacen tan inseparables como esas parejas talladas en piedra. (Berger 1972a: 67)

Esas concesiones al espectador están en el centro de nuestro interés. La apelación a las convenciones del género es fundamentalmente una estrategia para permitir que el espectador sitúe la obra, un verdadero manual de instrucciones dictado por la tradición-academia acerca de cómo la debe interpretar. Dentro del discurso de Berger, el actor fundamental que rige el sistema es el espectador-propietario para el cual —en el desnudo más que en cualquier otro género- está construido el cuadro tanto temática como formalmente, espectador que no solo posee la obra sino, a través de ella, a la mujer objetivada que representa, a la que exhibe ante otros en la intimidad como reafirmación de su poder -iel macho dominante, se diría en términos zoológicos!-, como lo muestra exquisitamente Carlos Saura en una de las secuencias de la película Goya.

Berger desmitifica —no digamos deconstruye, para no salpicarlo ideológicamente-, así, la tradición del desnudo. Al mismo tiempo, pone el dedo en la llaga, máxime si se trata de la fotografía, que aparentemente no tendría la capacidad, como la pintura, de disfrazar a una mujer real con los atributos de una ideal.

Ahora comprendemos la dificultad de crear una imagen estática de la desnudez sexual. En la experiencia sexual vivida, la desnudez es un proceso, más que un estado. Si se aísla un instante de ese proceso, su imagen parecerá banal y su banalidad, en lugar de servir de puente entre dos estados intensamente imaginativos, resultará fría. Esta es una de las razones de que las fotografías expresivas de la desnudez sean más raras aún que los cuadros. 
La solución más fácil para el fotógrafo es convertir la figura en «un desnudo» que, al generalizar tanto el espectáculo como el espectador y reducir la sexualidad a algo no específico, torna el deseo en fantasía. (Berger 1972a: 69-70)

Las estrategias para esa conversión de la foto en desnudo, para su codificación como tal, no nos son ajenas; en el capítulo precedente hemos analizado cómo la retorización de la imagen fotográfica, mediante la distanciación de su grado cero a través de una diversidad de estrategias, puede ser dirigida precisamente a la consecución de un efecto tal. Dicha retorización es, asimismo, una despersonalización del sujeto representado, esto es, su constitución precisamente en modelo. Cabe aquí la siguiente concepción:

Durero creía que el desnudo ideal debía construirse tomando el rostro de un cuerpo, los pechos de otro, las piernas de un tercero, los hombros de un cuarto, las manos de un quinto, etc.

El resultado glorificaría al Hombre. Pero esta práctica suponía una notable indiferencia hacia cualquiera que fuese realmente una persona. (Berger 1972a: 72-73)

Llevemos esta consideración al extremo, como de hecho lo fue posteriormente al momento histórico aludido:

Los criterios que definen el estatuto ideal del desnudo están también relacionados con procedimientos de exclusión. Para Quatremère de Quincy, ideólogo del neoclasicismo, este ideal se distinguía completamente del modelo vivo: «La imagen ideal del hombre poseerá 'todos los tipos de regularidad que comporta'. Las formas serán modeladas con amplitud, simplificadas, purificadas, depuradas de cualquier detalle individual, de cualquier defectuosidad accidental. Las proporciones y las relaciones de las partes se fijarán con todo el rigor de una construcción matemática». Y sigue: la «misión [del artista], podríamos decir, consiste en destilar la realidad para mostrarnos su esencia. Así que evitará a toda costa intentar, con el vano pretexto de animar sus figuras, imprimirles los caracteres que en la realidad denotan vida: la flexibilidad de la carne, la transpiración de la piel, la elasticidad de los músculos. Evitará que se adivine lo que se halla bajo el envoltorio exterior, el afloramiento de la estructura ósea, los músculos y las venas, ya que todo esto no es más que detalle 'animal'». De este modo, el desnudo accede a la trascendencia por eliminación de los aspectos del cuerpo relacionados con su existencia carnal, con su movimiento, lo que se justifica racionalmente por la asimilación de la carne y del músculo vivos a la animalidad. Esta perfección marmórea e inanimada indica, además, una 
exclusión suplementaria, la de la amenaza que presenta el «otro» del cuerpo ideal, es decir, el cuerpo grotesco. Muchos de los atributos del desnudo clásico, su forma cerrada, sus contornos claramente delimitados, su decencia, su armonía y sus ritmos formales, sirven para alejar el espectro de su doble monstruoso con sus orificios, sus apetitos, sus excrecencias y sus expulsiones. También descubren una gran ansiedad frente a los límites del cuerpo, tanto que la interioridad orgánica se ve confinada al interior de los contornos de un envoltorio exterior, exento de defectos. (Solomon-Godeau 2001: 167)

En el relevo que a partir de la segunda mitad del siglo pasado la imagen publicitaria ha hecho del arte como expresión de los cánones estéticos -heredando, por supuesto, las maneras de formar de la tradición- siguen presentes las prácticas y métodos para, como Durero, como el neoclasicismo, crear esos verdaderos Frankensteins que, precisamente por ser modélicos, resultan perversos. Los cuerpos y rostros de maniquíes humanos en las portadas de las revistas de actualidad y moda son un claro ejemplo de cómo el retoque con pincel de aire (hace apenas unos años) y su heredero a partir de la década de 1990, el retoque digital, aunados a los procedimientos convencionales de estetización de los sujetos -iluminación, pose, maquillaje, encuadre, icirugía plástica!, etcétera-son capaces de engendrar dichas aberraciones. «El contexto en el que nos desenvolvemos - un ámbito en el que la publicidad inventa el cuerpo y el cuerpo se construye como publicidad- propicia la hiriente y grotesca simultaneidad de todo un anómalo conjunto de dispares acontecimientos». (Pérez 2004: 29) Dispares, sí, en un entorno de profundas desigualdades sociales que propicia esa disonancia cognitiva-colectiva que ya sugerimos, al contrastar dichas imágenes con la realidad del hombre de a pie.

Despidamos así, momentáneamente, al autor que en en los últimos párrafos ha dado hilo a nuestro discurso. Dice Berger: «En el arte moderno ha perdido importancia el desnudo. Los propios artistas empezaron a ponerlo en entredicho». (Berger 1972a: 73) Si eso hizo el arte moderno, ¿qué podemos decir del posmoderno? Cabría preguntarse, por poner solo un caso, dónde situar algunas imágenes de los proyectos ¿La viva imagen de la salud? y Cancer shock, de J o Spence. (Imagen 87) 


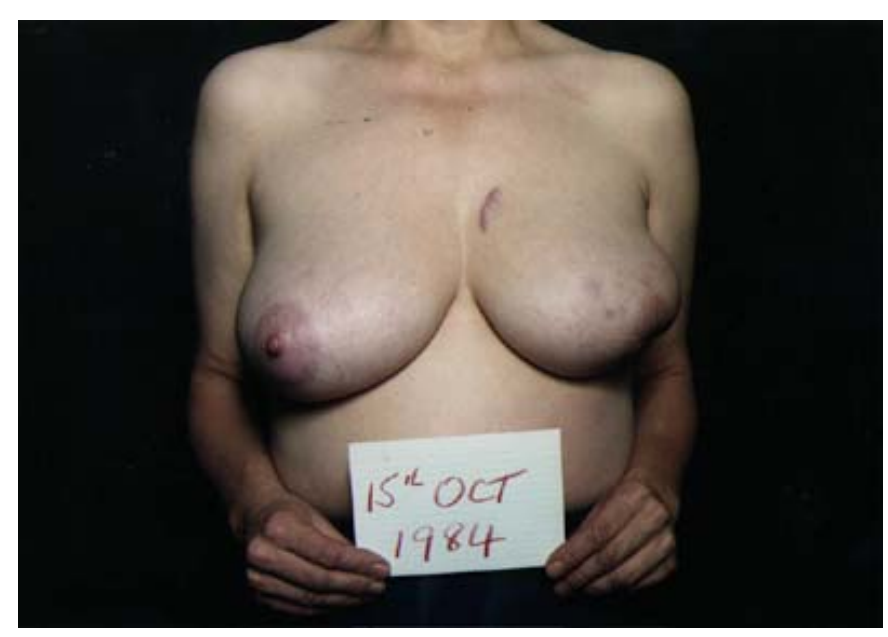

Imagen 87. Jo Spence

De: ¿La viva imagen de la salud?, 1986

Hay en estos proyectos fotos que bien podrían pertenecer a una de esas revistas o libros médicos que el niño al que anteriormente hemos aludido y ahora retomamos, veía subrepticiamente, a hurtadillas, en los momentos en que sabía que no podría ser descubierto.

En ese ejercicio de evocación de un cuerpo desnudo que antes sugerimos, iqué diferente sería el caso de una persona para la cual su imagen modélica fuera La Fuente, de Ingres, o la muñeca Barbie, que recientemente festejó su aniversario número cincuenta! Qué diferente sería tener como arquetipo una foto sobreestetizada como la de Man Ray, sugerentemente titulada Retorno a la razón (Imagen 88), o alguno de los primerísimos planos de la serie Dos mil fotos del sexo de una mujer (Imagen 89), de Henri Maccheroni. Pero, una vez más, ¿son estos últimos desnudos, imágenes de la desnudez, registros anatómicos sublimados, o simple y llanamente fotos del sexo de una mujer? Hay también en ellos, se diría que a pesar de $\multimap$ acaso debido a - la eliminación de la distancia derivada del encuadre cercano, una objetivación del cuerpo, cuerpo que no es el de tal mujer, concreta y única, sino el de una mujer, como lo refrenda 
el título. ¡Qué diferente si este fuera: Dos mil fotos del sexo de Fulana, de ella, irrepetible!

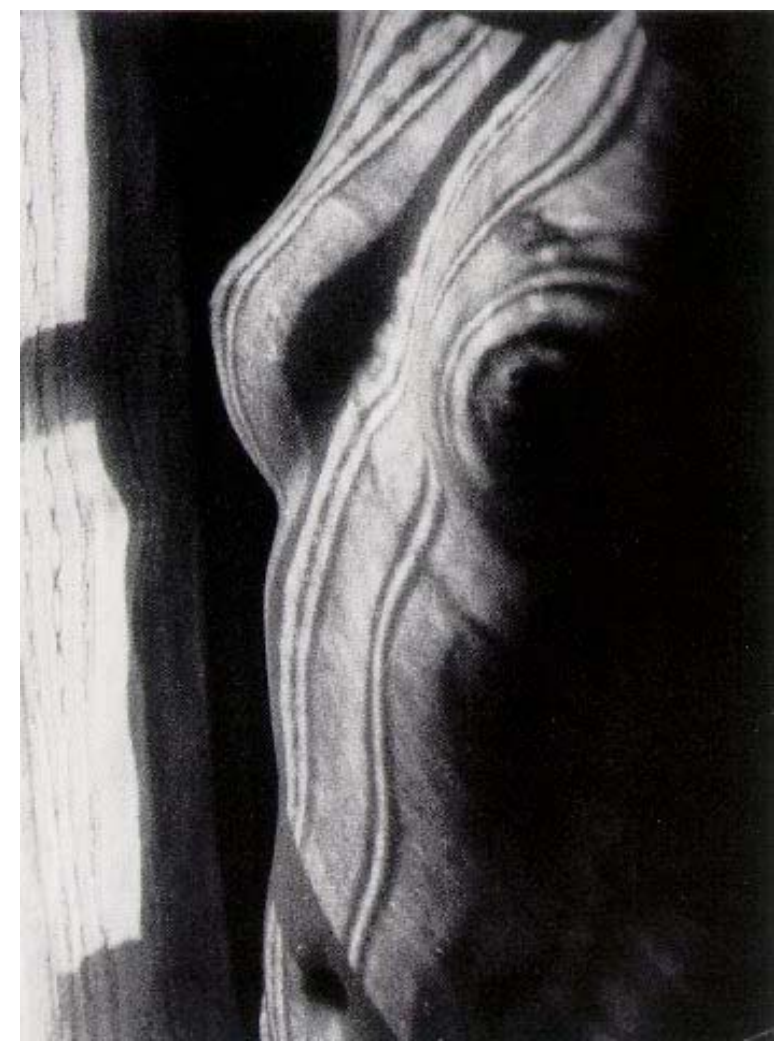

Imagen 88. Man Ray

Retorno a la razón, 1923

No estamos hablando aquí del carácter explícito de ciertas fotos, dicho carácter -del que, por cierto, se regodea la fotografía actual, que ha encontrado en la explicitud la salida más fácil a la plastificación del cuerpo exacerbada por los diversos usos de la fotografía comercial- no es una condición suficiente para abstraer a una imagen concreta de las convenciones del género, las cuales, como estamos viendo, operan a un nivel profundo. 


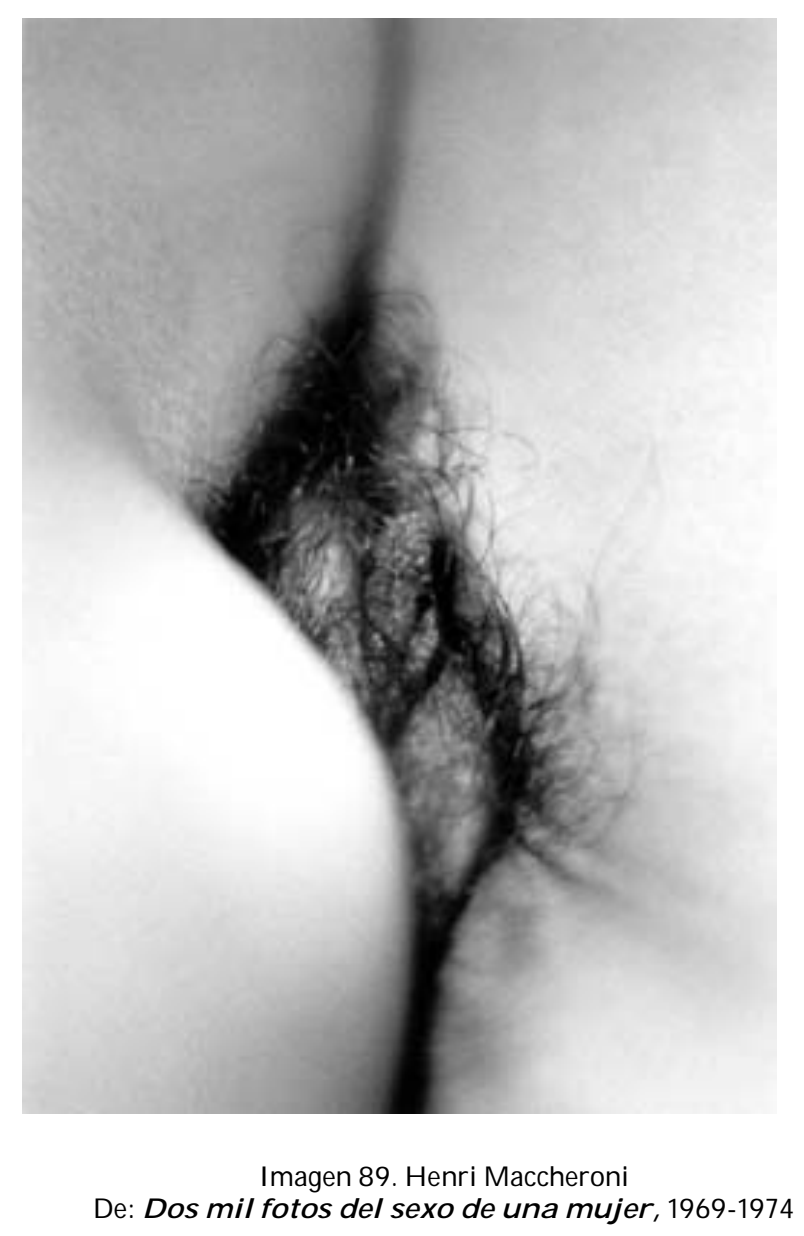

Para nosotros, este es precisamente el punto álgido que queremos tratar y que nos ha llevado a introducir nuestra reflexión acerca del género artístico utilizando al desnudo como pretexto discursivo. No en vano se ha señalado que «existe una dificultad real para distinguir, por un lado el desnudo artístico de la fotografía erótica y, por el otro, estos dos del desnudo académico». (Solomon-Godeau 2001: 169) El punto de reflexión al que finalmente estamos arribando lleva a considerar que, en este género en particular, la difusa línea entre el erotismo y la pornografía, entre la fruición estética y el voyeurismo narcisista, depende de factores externos a 
la imagen. Este es el factor crucial que hemos de considerar y que sería, de hecho, aplicable a cualquier otro género. Para apoyar esta idea basta considerar, por ejemplo, las concomitancias de nuestras reflexiones sobre el desnudo con las que Roger efectúa en torno al paisaje como construcción cultural, la cual, si deviene artística, es debido a que la mirada del receptor la somete a un proceso de artealización. (Cfr. Roger 1997)

Pero retomemos el hilo de nuestro discurso, esta vez mediante la alusión a una representación explícita de lo que aparentemente podría ser la sexualidad vivida, el cuadro de Courbet titulado El origen del mundo. (Imagen 90)

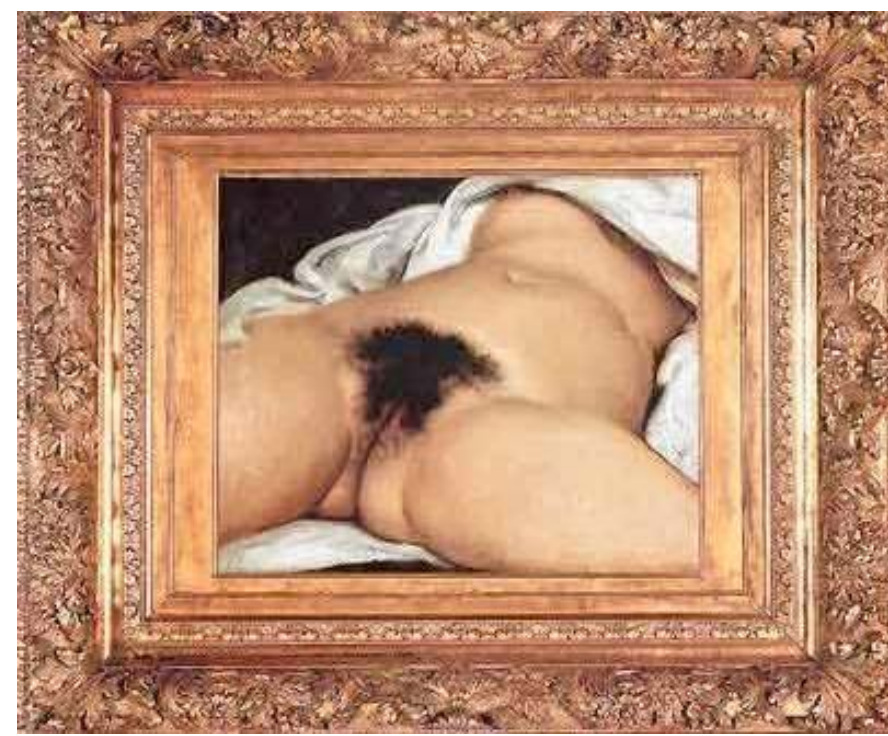

Imagen 90. Gustave Courbet

El origen del mundo, 1866

Lo reproducimos aquí incluyendo su marco, ya que este es un elemento que realza su consideración social como obra. Atípico en su época en el campo pictórico, no lo habría sido tanto en el de la incipiente industria pornográfica, recién reconvertida de las técnicas de la ilustración, la 
litografía y el grabado, a la fotografía. Rodeado a través de los años de incontables relatos y mitos, El origen del mundo, título que le fue asignado con posterioridad a su realización, goza actualmente de un estatus dentro de la historia del arte debido a su excepcionalidad y a la notoriedad de su autor.

Visto desde el presente, se le pueden asignar valores de extrema novedad respecto de la pintura de su época; por ejemplo, su escala (55 x 46 cm), punto de vista, tipo de escorzo y ángulo de cobertura, adicionalmente al realismo de su textura, parecerían destinarlo a un uso más allá de la mera contemplación. Oculto tras un paisaje del propio Courbet en un bastidor construido ex profeso, el cuadro estaba concebido para su disfrute en la intimidad. Se sabe que cambió de manos repetidas veces, siempre destinado a la clandestinidad, hasta ser adquirido por J acques Lacan, quien también lo conservó oculto; tras su muerte en 1981, y después de más de un siglo en la oscuridad, el cuadro pasó a formar parte de la colección del Museo de Orsay, donde permanece en la actualidad -ubicado junto al conocido Entierro en Ornans-, no exento de polémica y causando aún la sorpresa de los visitantes.

Pero, El origen del mundo, ¿fue el producto de un arrebato sensual de su autor o un simple encargo a cambio de dinero? A pesar de todo, el cuadro sigue siendo una representación en la cual el principal personaje es el espectador-propietario. Producido, e insistimos en este hecho dada su importancia dentro de nuestro discurso, para ser contemplado en la intimidad, los avatares del tiempo lo han llevado fuera de ese ámbito, hasta uno de los templos del arte occidental. Su mismo título, que como ya mencionamos le fue atribuido posteriormente, es engañoso, ya que le concede un aura metafórica, una carga simbólica de la que carece. En realidad es mucho más prosaico, probablemente un título más acertado debería ser —como sugerimos anteriormente en relación a las fotos de Maccheroni- Pubis de Fulana, amante de Mengano, siendo Mengano, diría Berger, quien habría pagado por la pieza destinada a su propio placer o a canalizar su exhibicionismo dentro de su círculo íntimo. Pero no solo es 
el título el que niega la identidad de Fulana, también lo hace el cuadro mismo, ya que precisamente los cortes en sus bordes, la elusión del rostro o de alguna seña de identidad, convierten a la modelo real que hubiera posado para el pintor en cualquiera, facilitando que las buenas conciencias que se aproximan a él la vean, asimismo, como una cualquiera. Pero, no cometamos el error de generalizar a partir de una grandísima excepción, como es El origen del mundo. Lo que primaba en la pintura del XIX era el canon académico y, para que una pintura de desnudo pudiera consagrarse a través del escaparate del Salón de París, todavía era necesario que estuviera camuflada moralmente a través de una escena mitológica o histórica. Cuando en la primera mitad de ese siglo se invente la fotografía, surgirán con ella nuevos cuestionamientos:

A su vez los fotógrafos, alimentando ambiciones artísticas, no dejaron de buscar una legitimidad estética en los géneros acreditados por las bellas artes. Sin embargo, el desnudo, masculino o femenino, todavía no había accedido al estatuto de género, en el sentido pleno del término, excepto en la escultura. En pintura, cuando se codificó la teoría académica, en el siglo XVII, el desnudo era solo un elemento de la pintura de historia que estaba situada en la cima de la jerarquía oficial de géneros. Y, a pesar de que la academia, estudio extremadamente acabado y trabajado del desnudo masculino, hubiese alcanzado su apogeo en la segunda mitad del XVIII, el desnudo, como tal, permaneció fuera de las clasificaciones oficiales. (Solomon-Godeau 2001: 168)

Podemos aceptar, siguiendo todavía a Solomon-Godeau, que «las fotografías o los daguerrotipos del cuerpo desnudo presentaban dificultades que la pintura y la escultura ignoraban. Al documentar la presencia de cuerpos reales, de mujeres reales, la fotografía amenazaba el montaje de la sublimación del desnudo y su vulnerable coartada estética». (SolomonGodeau 2001: 168) Pero lo cierto es que el medio desarrolló sus propios mecanismos para lograr esa sublimación. Incluso la pornografía, en cierto sentido polo opuesto de la artisticidad, solía -y suele- caer en la trampa de perpetuar el estereotipo, lo cual se da hasta en sus versiones más prosaicas. Contemporáneas del cuadro de Courbet y también destinadas a la contemplación en la intimidad eran, por ejemplo, las fotografías 
obscenas de Auguste Belloc. (Imagen 91) Se trata de estereoscopías que, por lo mismo, debían contemplarse con la mediación de un visor, esto es, un dispositivo de uso individual. Podría especularse incluso acerca de la posibilidad de que Courbet hubiera tomado como modelo para su cuadro una foto similar a estas. Pero al contrario de aquel, las fotografías en cuestión distan mucho de gozar de reconocimiento en los ámbitos de la historia del arte y de la fotografía; son simplemente curiosidades de época, testimonios, como tantos, de los primeros años de pornografía fotográfica, y a pesar de ser aún más explícitas en cuanto a detalle que el cuadro de Courbet, carecen del poder inquietante de este.

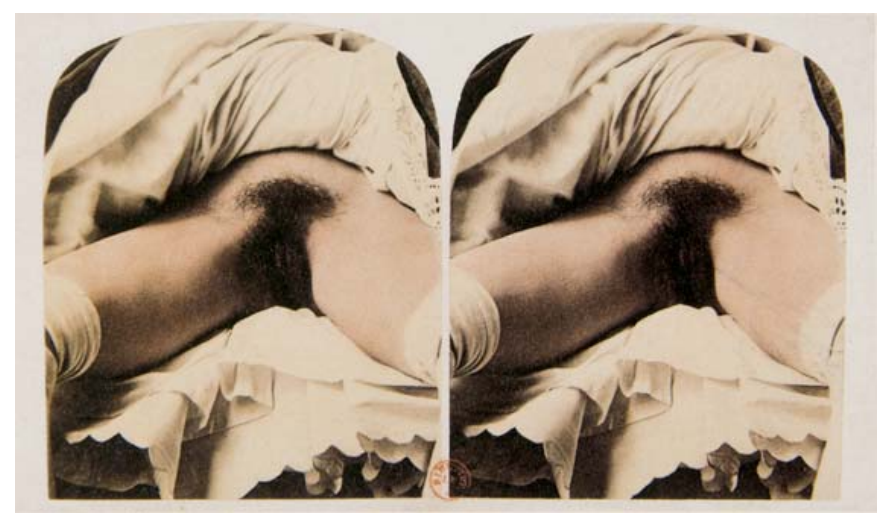

Imagen 91. Auguste Belloc

Estereoscopías obscenas, ca. 1860

En efecto, sorprende que hoy en día el cuadro siga teniendo un efecto provocativo, en un momento histórico en el que Internet cuenta con millones de imágenes fotográficas en las que personas comunes exhiben su intimidad sin pudor alguno, en la época de la vida expresada como reality show, que no es más que mucho show y poca reality, en un momento en el que la explicitud y el exhibicionismo son la norma y donde, a pesar de la crudeza de las imágenes a las que estamos expuestos, el desnudo —como ya sugerimos, ahora regulado desde los campos discursivos de la publicidad y 
la pornografía, que han sustituido en este género específico al del arte, obsesionado por deconstruirlo- sigue vigente como referencia. En lo que respecta al campo del arte, por su lado, hay voces que nos advierten de una profunda transformación que ya hemos venido insinuando, y ahora desarrollaremos. Partamos, una vez más, de Solomon-Godeau:

[...] el desnudo, como cualquier forma fotográfica utilitaria o estética, es solo un ejemplo entre otros del poder de la inscripción, poder que se asemeja al lenguaje que precede al tema, al fotógrafo y al modelo, sean cuales fueren, y que «escribe» el cuerpo de una manera que, en lo esencial, sirve para afirmar las relaciones sociales vigentes. Si bien es cierto que el pretendido género del desnudo se esfuerza por contener, controlar y sublimar la anarquía del cuerpo humano, parece que las prácticas contemporáneas, no conformistas, se dedican precisamente a explorar estas fronteras permanentemente amenazadas, para desublimizarlas. (Solomon-Godeau 2001: 174)

A la luz de las prácticas artísticas más recientes, se generan también nuevos discursos teóricos que provocan el envejecimiento de los anteriores, requisito indispensable para que la rueda de los sistemas del arte y la academia sigan girando. Así, por ejemplo, una lectura de corte freudiano como la que Dubois (1983: 133 y ss.) sugiere a propósito de las imágenes antes aludidas de Maccheroni, en la cual apela a la mitología griega para establecer la cadena semiótica Medusa-vagina-fascinación/repulsióncastración, acaso hoy suscite una cierta complacencia irónica al contrastar sus tintes androcentristas con los discursos provenientes de otros campos teóricos. Hoy, es claro que las visiones han variado: «Transcurrido más de un cuarto de siglo desde que se iniciaran no solo los análisis feministas de los Women's Studies -con el correspondiente correlato de estudios gay/lésbicos-, sino también las aproximaciones de los denominados Cultural Studies, el potencial crítico e instrumental de estas perspectivas no puede quedar eludido». (Pérez 2004: 12) Si hay algo que estas visiones comparten, si cuentan con un denominador común, este es su afán por connotar al cuerpo a partir de sus «representaciones codificadas -a la par que codificadoras- dotadas de un plural carácter simbólico, económico, cultural, político, sexual, etc.» (Pérez 2004: 10) 


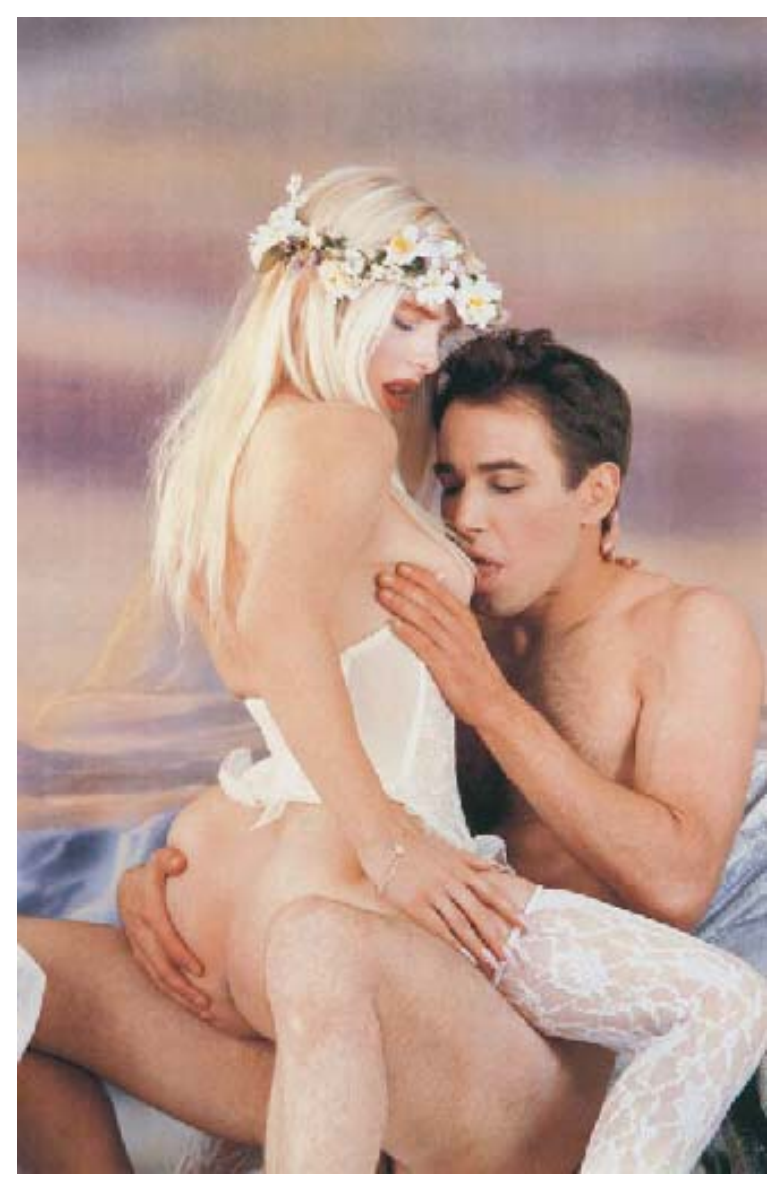

Imagen 92. J eff Koons

Ponies, 1991

En el campo fotográfico, cada vez más lejos parece haber quedado el canon de la fotografía moderna, con su tendencia a una estetización que fue denunciada tempranamente por Sontag, en un texto ya añejo, como un peligro en términos de su capacidad para anestesiar conciencias, para promover un voyeurismo crónico, para idealizar mediante la búsqueda de lo fotogénico, para despolitizar el tema de la propia imagen, para eliminar la realidad ante la ilusión de una experiencia vicaria. (Cfr. Sontag 1973) Si en ese texto se planteaban las fotografías documentales vinculadas a los 
genocidios de la Segunda Guerra Mundial como un punto de inflexión para la delimitación de lo fotografiable, podemos afirmar que no hay un tema que se haya visto más transformado, cuestionado y haya sido sujeto a más reflexiones que la representación del cuerpo humano, a partir de entonces vinculado más que nunca, por la misma fotografía, a la violencia, el abuso, la desazón. Exactamente tres décadas más tarde —período, además, de profundas transformaciones en el campo de la imagen y su difusión-, en Ante el dolor de los demás (2003), la autora volverá sobre sus pasos para reflexionar una vez más acerca de las imágenes de la violencia y de nuestra sobreexposición a ellas.

Al igual que en cierto momento Sontag se pronunció contra la interpretación, en el género que nos ocupa podríamos afirmar que la segunda mitad del siglo XX constituyó un camino gradual contra la estetización. Durante este período se asume que la fotografía de un cuerpo desnudo puede ser también la de un cuerpo torturado, sujeto a abusos. Contrasta con ello que, mientras que cierto arte continuará con su incansable deconstrucción de las representaciones del cuerpo, para algunos artistas el camino más sencillo será optar por la estrategia del escándalo, acercándose así a los métodos publicitarios y de relaciones públicas para granjearse la atención de las grandes audiencias. Veremos desde la constucción de la propia vida en un show sin reality, como es el caso de J eff Koons (Imagen 92), quien se convierte a sí mismo, junto con su temporal y conveniente pareja, en protagonistas de un kitsch pornográfico. También optará por el escándalo una publicidad desesperada por no encontrar más caminos hacia la espectacularización, como lo atestigua Ardenne:

Hace un año, yo publiqué un libro acerca de todas las formas de estética extrema - en la televisión, en los reportajes de guerra, en el porno-, en fin, un libro muy duro y violento. ${ }^{1}$ Allí, entre otros casos, me ocupé de Oliverio Toscani, un fotógrafo que ha cultivado el escándalo y que se ha hecho, cómo no, famoso. Toscani ha expuesto afiches de índole sexual en las paredes de las ciudades europeas, primeros planos de penes. [Imagen 93] ¿Y cuál es el pensamiento que debe asaltar, de todas maneras, al transeúnte que se topa con un pene en una esquina? Pues, el mensaje resulta claro: «iOh, en qué

\footnotetext{
${ }^{1}$ Ardenne, Paul. Extrême, esthétiques de la limite dépassée. París: Flammarion, 2006.
} 
gran libertad vivimos!» Y no, la reflexión tendría que ser distinta, más suspicaz: si las imágenes de Toscani se ven por todas partes, y los ciudadanos de una ciudad equis las han aceptado, entonces hay que desconfiar, porque ya se ha modelado un consenso. Yo me pregunto, yo les pregunto... ¿y si los carteles mostrasen a un sujeto, en cuclillas, feliz mientras caga? ¿Los habitantes de ese burgo equis lo aplaudirían y lo celebrarían como una muestra de libertad y de tolerancia? Habría una recepción muy distinta, ¿no? La verdadera cultura, para mí, siempre ha estado del lado de la prohibición, nunca del consenso. (Ardenne 2007: s.n.)

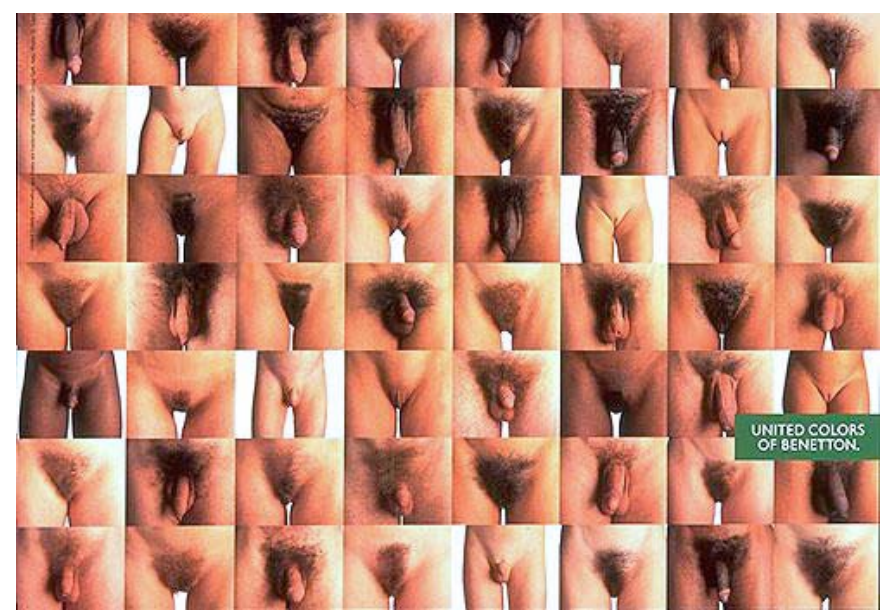

Imagen 93. Oliverio Toscani

Campaña publicitaria para la marca Benetton, 1993

Retomemos: «El dolor, el cansancio, el abatimiento, el extravío y la ocultación cartografían un ingrato espacio de certeza: el que subyace a nuestra propia vulnerabilidad». (Pérez 2004: 14) Las consecuencias de esta certeza no han dejado de sentirse y tendrán las implicaciones más profundas en términos de representación. Como afirma el mismo Pérez: «El discurso de la vergüenza histórica quedará [...] mutado en vergüenza discursiva». (Pérez 2004: 27) Estas palabras remiten a las reflexiones del joven Eco, cuando, para ejemplificar este mismo proceso, afirmaba que «adoptando el sistema tonal comprometido con toda una civilización y una sensibilidad, Schönberg no nos habría dado el Superviviente de Varsovia, sino el Concierto de Varsovia, que es precisamente la argumentación en 
torno a un 'tema' casi análogo, hecho en términos de tonalidad». (Eco 1962b: 307) Esto es, que «el músico rechaza el sistema tonal porque este [...] traspone al plano de las relaciones estructurales todo un modo de ver el mundo y un modo de estar en el mundo». (Eco 1962b: 301)

Una vez más nuestra atención se dirige a lo que hemos llamado la manera de formar - frase que a lo largo de este trabajo ha adquirido el carácter de un estribillo-, reafirmando una y otra vez su carácter esencial. Volviendo a nuestra reflexión en torno a las transformaciones en la representación del cuerpo, tras el cuestionamiento de su sistema tonal -el canon moderno- y la propuesta de diversas atonalidades, encontramos que hoy

[...] el uso artístico al que se ve sometido el cuerpo y sus diversas referencias metonímicas, pone de relieve el interés existente en estos momentos por releer la corporalidad desde planteamientos que conjugan intimidad y colectividad, desolación y extravío, convulsión e incertidumbre. No es por ello gratuito que en una época dominada por el temor a los desastres ecológicos y a las enfermedades infecciosas hayan resurgido comportamientos de carácter xenófobo y racista. A través de estas actitudes se acentúa no tanto el desprecio al otro como el temor al propio cuerpo, un temor que nuestra cultura no fomenta de manera contingente sino estructural, es decir, como elemento integrante y determinante de la misma. (Pérez 2004: 36)

\subsection{UN MODELO DE ANÁLISIS: EL TRIÁNGULO PRAGMÁTICO}

En la introducción a este capítulo hicimos un planteamiento, es momento ahora de desmenuzarlo. A propósito del caso específico del desnudo, hemos hablado, fundamentalmente, del género artístico. Sin embargo, enfrentamos dos problemas: el primero es que el concepto de género ha sido ampliamente cuestionado por el arte contemporáneo, al grado de ser considerado por algunos como obsoleto; el segundo, que dicho concepto es sistemáticamente mal utilizado, siendo frecuentemente confundido con denominaciones alusivas al contexto en que se difunde una imagen, al espacio discursivo de que participa, a su ámbito utilitario o, 
incluso, a su técnica. Veamos: fotografía... de desnudo, naturaleza muerta, de retrato, de paisaje, directa, de objeto encontrado, de bodegón, fotomontaje, periodística, documental, publicitaria, escenificada, de moda, de arquitectura, de producto, de autorretrato, de ensamblaje de objetos, erótica, etnográfica, antropológica, de identificación, macrofotografía, artística, de reportaje informativo, de reportaje social, analógica, digital, de procesos alternativos, estenopeica, instantánea, científica, microscópica, industrial, editorial, subacuática, nocturna, médica, forense, judicial, familiar, de recuerdo, microfotografía, astronómica, deportiva, turística... Todas estas denominaciones han sido utilizadas en algún momento como géneros, cuando lo cierto es que la mayoría no lo son.

En otro momento (ver supra: Capítulo 1.2) hicimos una crítica a la tendencia de algunos autores a atribuir criterios globales a la fotografía, sin distinguir entre la fotografía artística —cuyas vertientes en sí ya son imposibles de reunir bajo un mismo paraguas-y la aplicada o utilitaria, y elogiamos en ese momento la ya extendida tendencia a hablar de fotografías, así, en plural. De igual manera, debemos ahora advertir acerca de la gran confusión que se desprende de una alusión descuidada a los tres conceptos que aquí estableceremos como vértices del triángulo pragmático que propondremos como modelo de análisis, a saber: el género, el espacio discursivo y el canal de comunicación. (Profundizaremos en cada uno de estos tres conceptos en los apartados siguientes.)

Tomemos un ejemplo concreto de la teoría reciente. Se trata de Marzal Felici, autor con el cual compartimos profundas resonancias, pero con quien también guardamos discrepancias. En un apartado precisamente titulado «Una perspectiva pragmática en la aproximación a los géneros fotográficos» (Marzal Felici 2007: 84 y ss.), el autor hace una revisión de diversas denominaciones genéricas englobándolas en grandes categorías, por ejemplo: «según la naturaleza del objeto o sujeto fotográfico representado», según «una dificultad técnica específica» o «según el tipo de formato fotográfico empleado». De esta manera, identifica con géneros a categorías incompatibles entre sí, como pueden ser la macrofotografía, 
derivada de un factor técnico, y la fotografía deportiva, subgrupo de la fotoperiodística, cuando en realidad el periodismo no es un género sino un espacio discursivo. Lo cierto es que la confusión es añeja. Tomemos otro caso, a saber, el de Bourdieu, cuando afirma que la

[...] «estética», que subordina la forma y la propia existencia de la imagen a su función, es necesariamente pluralista y condicional: la insistencia con la que los sujetos tienen presentes los límites y las condiciones de validez de su juicio, distinguiendo para cada fotografía los usos y los públicos posibles o, con mayor precisión, el uso posible para cada público ( «como reportaje, no está mal», «si es para que las vean los críos, de acuerdo»), da fe de que ellos rechazan la idea de que una fotografía pueda complacer «a todo el mundo». [...] Al ser siempre juzgada la imagen por referencia a la función que cumple para el que la contempla, o que puede cumplir, según este, para tal o cual clase de espectadores, el juicio estético toma naturalmente la forma de un juicio hipotético, apoyándose, implícitamente en el reconocimiento de «géneros», de los cuales un concepto define a la vez la perfección y el campo de aplicación: cerca de las tres cuartas partes de los juicios comienzan con un «si» y el esfuerzo de reconocimiento se acaba con la clasificación en un género o, lo que viene a ser lo mismo, con la atribución de un uso social, al ser definidos los diferentes géneros por referencia a su utilización y a sus utilizadores («es una foto publicitaria», «es un documento al estado puro», «es una foto de laboratorio», «es una foto de concurso», «es de tipo pedagógico», etc.). Y las fotografías de desnudos casi siempre son acogidas con frases que las reducen al estereotipo de su función social: «Está bien para Pigalle», «Es la clase de fotos que se venden a escondidas». Se comprende que esta «estética», que hace del interés informativo, sensible o moral, el principio de apreciación, no pueda hacer otra cosa que rechazar la imagen de lo insignificante o, lo que resulta lo mismo en esta lógica, la insignificancia de la imagen: el juicio nunca separa la imagen del objeto de la imagen. (Bourdieu 1979: 39)

Como vemos, es precisamente el autor del concepto de campo, muy cercano al que aquí manejamos de espacio discursivo -tomado de Krauss-, quien incurre en este error de generalización, si vale el juego de palabras. Bourdieu confunde los conceptos de género, función que cumple la imagen, campo de su aplicación y utilización, o explícitamente, cae en su equiparación y habla de género o, lo que viene a ser lo mismo, la atribución de un uso social. Precisamente nuestro empeño en este punto se enfoca a demostrar que dichos valores no vienen a ser lo mismo, aunque comúnmente se encuentren estrechamente asociados, y en explicitar la manera como interactúan en el proceso de atribución de sentido. En el 
marco de las investigaciones del sociólogo francés, cuya rigurosa metodología estadística en ocasiones parecería llevarlo a conclusiones banales, las alusiones al arte resultan insípidas y poco profundas. ¿No peca el sociólogo, en este sentido, de heteronomía? Precisamente desde el campo del arte, Krauss minimiza esta sospecha, matizando:

Nos hallamos de pleno en la tesis de Pierre Bourdieu. Para él, el discurso fotográfico no puede ser nunca estético propiamente dicho, es decir, que no puede poseer criterios estéticos propios; el juicio fotográfico más común no se refiere a su valor sino a su identidad, ya que lee las cosas desde un punto de vista genérico y representa la realidad en función de la naturaleza del «sujeto», de ahí los juicios repetitivos formulados por «es esto o es aquello» [...]. Cuando el juicio toma la distancia necesaria para poder englobar la fotografía en su totalidad y no, simplemente, sus componentes separados, entonces clasificación y juicio actúan generalmente por géneros. «Es un paisaje», «es un desnudo», «es un retrato». Pero, naturalmente, el juicio por géneros solo tiene en cuenta el referente. Si una fotografía pertenece al género «retrato» o «paisaje», es debido a que la lectura de su contenido le permite ser identificada y clasificada por tipo, y, si creemos a Bourdieu, en la naturaleza de estos tipos está el ser gobernados por los límites estrictos del estereotipo. (Krauss 1990: 220)

Así, la aguda crítica estadounidense, quien no cae en confusiones terminológicas, apunta que lo sustancial en Bourdieu es precisamente el enfrentamiento del campo artístico con el ethos, y el análisis de las interacciones, ya sea de la obra artística con otros campos, o el análisis de las formas utilitarias de ese arte medio, formas que, como hemos establecido en diversos momentos, son de nuestra plena incumbencia. Es particularmente en ese sentido que las ideas de Bourdieu nos son útiles:

Enfrentados a las obras de arte legítimas, los más desprovistos de competencia específica les aplican los esquemas del ethos, los mismos que estructuran su percepción ordinaria de la existencia ordinaria y que, engendrando productos de una sistematicidad no querida e inconsciente para ella misma, se oponen a los principios más o menos explicitados de una estética. De ello resulta una «reducción» sistemática de las cosas artísticas a las cosas de la vida, una puesta entre paréntesis de la forma en beneficio del contenido «humano», significativo por excelencia desde el punto de vista de la estética pura. Todo ocurre como si la forma solo puediera aflorar al primer plano al precio de una neutralización de cualquier especie de interés afectivo o ético por el objeto de la representación, neutralización que va a la par (sin que se pueda suponer una relación de causa y efecto) con el dominio de los medios para captar las propiedades distintivas que se dan en esta forma 
particular en sus relaciones con otras formas (es decir, por referencia al universo de las obras artísticas y a su historia). (Bourdieu 1979: 40-41)

El caso de Bourdieu nos invita a considerar otras aproximaciones a la pragmática del género y a la valoración del contexto:

A la polisemia inducida por el enunciado «X es un género fotográfico», es conveniente añadir también los efectos del contexto (exposición, edición, difusión) así como el doble uso del género como categoría receptiva y/o creativa. Al perseguir la trasposición literal de la pragmática del género fotográfico, podemos decir que el acto fotográfico es un acto semiótico complejo, que debe considerarse desde múltiples puntos de vista, en función de los intereses cognoscitivos y de las actitudes perceptivas del espectador; un estudio de la fotografía bajo el punto de vista semiológico examinará fundamentalmente el valor de comunicación de la imagen; un análisis académico de la fotografía, derivado de la historia de las bellas artes, analizará las convenciones reguladoras; un análisis institucional mostrará de qué modo el campo fotográfico selecciona lugares con una fuerte carga simbólica; una estética de la creación artística sacará provecho del carácter genérico hiperfotográfico; por último, una mirada culta se preguntará sobre los parentescos no genealógicos que puedan existir entre diferentes obras: fotográficas, plásticas, literarias, cinematográficas, teatrales [...]. (Picaudé 2001: 26)

Así, el asunto en cuestión es cómo lograr que esa multiplicidad de puntos de vista se convierta en un elemento enriquecedor de la interpretación, y no en un escollo para la misma, máxime cuando el proceso de interacciones entre los elementos puestos en juego es dinámico y no deja de transformarse en relación a la modificación del contexto espaciotemporal de la interacción obra-espectador. Esto nos lleva a reflexionar en torno a la que es «una de las epecificidades del arte fotográfico: su reorganización potencial indefinida». (Soulages 1998: 193) La dinámica de esta reorganización debe quedar, por lo tanto, enmarcada en un modelo de análisis que conjunte los distintos momentos del proceso creativo, de la difusión de la obra y de la actividad receptiva:

La particularidad del estilo en fotografía es que no se trata de un mero trabajo formal sino del trabajo de una forma y una imagen, un material (el negativo, luego la foto, luego su contexto) explorado fotográficamente y de un referente enfocado fotográficamente, del mundo fotográfico y del mundo exterior o interior, etcétera. La fotografía y el estilo en fotografía, para ser 
comprendidos, requieren una estética del «a la vez»: para recibir de la mejor manera posible una obra fotográfica hay que recibir a la vez todos sus aspectos, sobre todo lo que se ha reunido gracias a la fotografía, ya sea el referente, del que queda una huella fotográfica y el material fotográfico, el pasado que es enfocado fotográficamente y el presente de la obra, la particularidad de una foto y la universalidad de su aproximación, etcétera. (Soulages 1998: 223)

Como consecuencia del marco que venimos planteando, cabe resaltar el hecho de que, si bien hemos seccionado el análisis de la imagen fotográfica en sus facetas inmanente y extrínseca, es necesario anclar la segunda en el mensaje y no identificarla con otros modos de análisis, como pueden ser la crítica histórica, social, psicoanalítica, etcétera, que plantean elementos confluyentes de manera centrípeta, para la conformación de la obra. La estética del a la vez propuesta por Soulages no es sino otro modo de nombrar esa necesidad de considerar a la obra como vórtice, centro estable con sus propias características y, al mismo tiempo, eje de una serie de fuerzas puestas en juego para conformar el torbellino del sentido, pero fuerzas, y esto es fundamental, centrífugas, que crean sentido a partir de la obra. Esta es, precisamente, la inercia propiciadora de interacciones que buscamos representar con el modelo triangular cuyos componentes desarrollaremos a continuación.

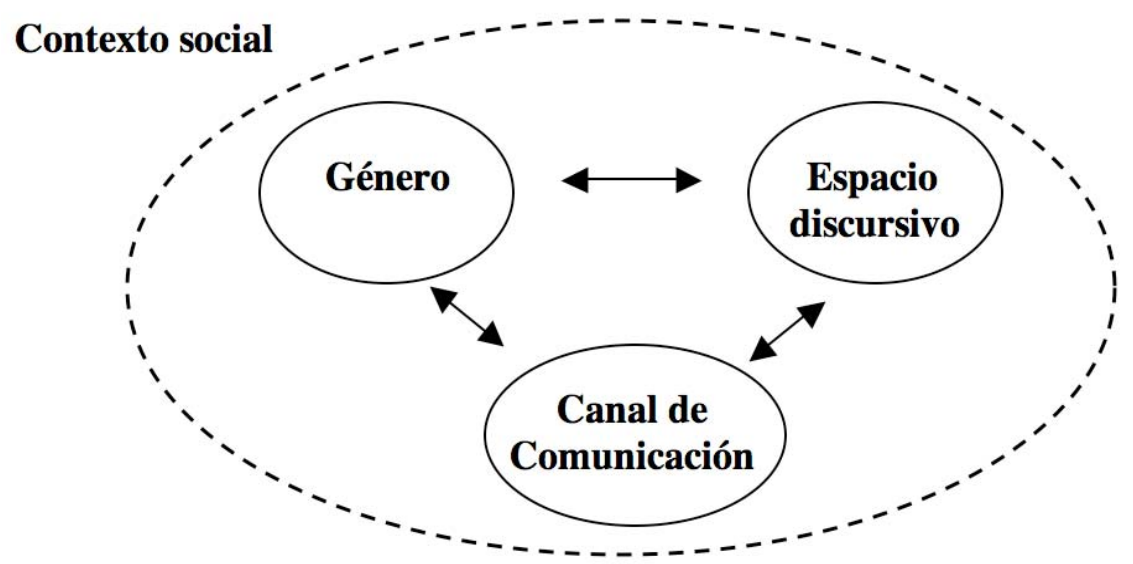

Imagen 94 


\subsection{LOS GÉNEROS FOTOGRÁFICOS: ORTODOXIAS, MARIDAJES, HIBRIDACIONES, DECONSTRUCCIONES}

La acera, el metro, el centro comercial, la estación de ferrocarril... cualquier espacio público es un lugar adecuado para ese monstruo en el que ya no reparamos a fuerza de sernos cotidiano, una máquina cuya automatización pone en acto de manera casi perversa la profecía flusseriana del fin del juego fotográfico. Nos referimos al fotomatón, cámarahabitáculo en la que el retratado debe literalmente adentrarse, cumpliendo con las etapas de un ritual perfectamente codificado, para ser deglutido y entonces expulsado, después de que el procesamiento del aparato haya generado a partir de él una representación bidimensional. El interior del aparato es un espacio de recogimiento donde el sujeto, casi sin libertad de movimiento debido a la estrechez del espacio, ve reducida al mínimo su capacidad de acción. No hay aquí dialéctica de amo y esclavo entre el fotógrafo y el retratado. Cualquier posible dialéctica ha sido eliminada por la hipercodificación. Adicionalmente, hay que considerar también los constreñimientos de una estipulación legal que define el deber ser de ese retrato oficial, imagen utilitaria destinada a ser usada en documentos legales, donde al pelo recogido, a la frente descubierta y al ángulo frontal del sujeto, hay que sumar el requerimiento de la formalidad en la expresión, una formalidad en la cual no cabe la frivolidad de una sonrisa. Solo quien desvirtúa el ritual y lo convierte en juego, logra generar una expresión relativamente personal a partir de ese paradigma de la automatización. Aun así, las posibilidades de alteración del código son mínimas y se reducen prácticamente a recursos como el disfraz, el maquillaje y la gesticulación. Incluso las empresas que manejan a estos robots accionados por una moneda se han dado cuenta de esta vertiente lúdica y la han lexicalizado, promoviéndola para beneficiarse económicamente de ella al ampliar el espectro de los usuarios. Así, actualmente leemos en el exterior de la máquina -ique también ha incorporado algunas de las capacidades del 
fotomontaje digital, no faltaba más!-, la existencia de una serie de posibilidades entrañables, como insertar la propia fotografía dentro de un corazón color de rosa o crear un engendro en el cual el rostro del retratado se integre en el cuerpo de un súper-héroe. De esta manera, el uso convencional y el lúdico quedan amalgamados, aunque el primero sigue primando. Más allá de estas consideraciones, llama la atención un reclamo publicitario que también leemos en el exterior del aparato, a saber: Cuatro fotografías tamaño pasaporte y un retrato. La imagen que acompaña esta extraña consigna es notable: muestra un conjunto de cuatro fotos tamaño pasaporte al lado de una de mayores dimensiones; sin embargo, dejando de lado el factor del tamaño, la imagen de la hermosa chica que se observa en los cinco recuadros... jes la misma! —por cierto, completamente estetizada mediante una iluminación de estudio impensable para las fotografías de identificación, y en ángulo de tres cuartos, lo cual implica una violación a la estrictamente normada frontalidad de las fotos de pasaporte- ¿Qué significa esto? ¿Acaso la única diferencia entre una foto de identificación, utilitaria, y un retrato, es... el tamaño? ¿Es este factor lo suficientemente potente para hacerla digna de un marco de plata, de una posición privilegiada en la sala de la casa? ¿No implica esto una banalización inexcusable de uno de los géneros más prestigiosos dentro de la historia de la fotografía?

La discusión en torno al género dista de ser nueva. En la introducción a este capítulo hemos ya esbozado algunas líneas de reflexión tomando como punto de partida la especulación en torno al género del desnudo. Toca ahora profundizar en la importancia del género dentro del marco de una pragmática fotográfica. Hagamos una primera aproximación al respecto partiendo de una interpretación de la propuesta expresada en la estética adorniana:

Los géneros a lo largo de la historia han ejercido una función didácticoclasificatoria por lo que no solo han limitado la naturaleza de las obras a unas características superficiales sino que esa misma función pedagógica de los géneros les ha llevado a la disolución en cuanto las obras de la modernidad se han resistido a su encorsetamiento preestablecido. Adorno 
otorga a los géneros el carácter de lo universal en contraste con la obra individual. De ahí que el tratamiento de los géneros como universal social le lleve a entenderlos esencialmente como convenciones que se han presentado tradicionalmente y han sido instituidas como modelo de lo auténtico artístico y para evitar el relativismo de lo individual. (Fernández Orrico 2004: 83-84)

En principio, los géneros tendrían entonces un carácter normativo, pero también, por lo mismo, de constreñimiento:

La purificación de las obras al pasar por el cuello de botella de los géneros equivale a la delimitación formal de las obras, y por ello mismo, a su represión. Según esto, solo lo reglamentado, lo que ha pasado por la disciplina de las normas se aproxima a la pureza; lo concreto, por el contrario, es considerado impuro en cuanto los principios que debían permitir su comprensión les son ajenos. El carácter de convención de los géneros se hace aquí evidente: la individualidad de la obra, que en sí misma tiene todos los caracteres de la realidad, es obligada a recibir las etiquetas de los géneros y si no satisface sus determinaciones se le retira el carácter de realidad estética. (Fernández Orrico 2004: 84)

El carácter normativo de los géneros, sin embargo, habría llegado a un punto de saturación en el arte moderno, el cual constituye el centro de atención de la estética de Adorno, en un proceso similar al ya señalado respecto de otros aspectos que hemos englobado bajo el concepto de maneras de formar, como pueden ser la rima en la poesía o el sistema tonal en la música. (Cfr. Capítulo 7.1; Eco 1962b) En la concepción adorniana, este agotamiento es, de hecho, uno de los ejes que dan sentido al arte moderno, que al poner en entredicho el concepto de género entendido en un sentido de imposición canónica y problematizarlo sistemáticamente, crea una tensión entre tradición y novedad fácilmente identificable con el marco de su dialéctica negativa.

Ya en el apartado anterior, de la mano de Bourdieu -para continuar al menos momentáneamente en una línea de pensadores que rondan la estética desde un marco sociológico-, comentamos que la primera apreciación que la persona común hace de una foto proviene de la vinculación de esta a un género, que le permita anclar su significado. Profundicemos: 
Todas aquellas personas que se interesan por la fotografía profesional, la artística, o incluso por la historia de la fotografía con su tropa de «grandes fotógrafos», hallarán el análisis que realiza Bourdieu sobre la actividad fotográfica de las clases populares muy alejado de su problemática. Sea cual sea la comicidad de su simbolismo sexual inconsciente, ¿qué tienen que ver las mediocres instantáneas de J. B*** tomadas durante su luna de miel, con la práctica de una fotografía de autor? Sin embargo, es precisamente aquí donde la manera en que Bourdieu aborda la cuestión, en tanto que sociólogo, se vuelve más dolorosa, ya que se aproxima al núcleo de la misma. Desde un punto de vista sociológico, afirma Bourdieu, la fotografía cumple otra función, es decir, la de índice social. La práctica omnipresente de estos paletos con sus Instamatics actúa como un indicador de clase o de casta frente al cual los miembros de las otras clases reaccionan para distinguirse. Una de las formas de hacerlo es abstenerse de tomar fotografías, otra es identificarse con una forma particular de práctica fotográfica que se considera diferente. Sin embargo, para Bourdieu, la idea de que existe realmente una fotografía artística con respecto a una fotografía primitiva de uso común, no es más que una prolongación de la expresión de las diferencias sociales. Su impresión de que la diferencia de la fotografía artística es más un efecto sociológico que una realidad estética deriva de su convicción de que la fotografía no posee reglas estéticas propias; toma prestado su carácter de los movimientos artísticos a los que se refieren los distintos fotógrafos profesionales; también toma prestados conceptos estéticos de las otras artes (como, por ejemplo, la expresividad, la originalidad, la singularidad, etc.), aunque estos conceptos son totalmente incompatibles con lo que pretende ser el discurso crítico de la fotografía, y, en definitiva, el discurso fotográfico no es fundamentalmente distinto de los juicios que realiza la persona de la calle y su Instamatic [o sus versiones actuales: la point and shoot digital, o la cámara del teléfono móvil]. Se reducen, por un lado, a un conjunto de reglas técnicas sobre el encuadre, el enfoque, el contraste, etc., que son, en definitiva, totalmente arbitrarias y, por el otro, a un juicio por género, es decir, «es esto o aquello». (Krauss 1990: 222)

Y, efectivamente, el proceso puede suponer un cierto grado de banalización, ya que implica dejar de ver la imagen particular para aplicarle criterios que son, precisamente, genéricos. Nos corresponde en este punto profundizar en estos aspectos, y lo haremos a partir de la pregunta planteada por Picaudé: «El género es utilizado por cualquier espectador que regule su percepción nombrando lo que ve. ¿Cuál es la pertinencia del género en una pragmática de la recepción?» (Picaudé 2001: 25) Más allá, la autora insiste en los valores interpretativos del género por encima de los taxonómicos: «[...] el género sirve más para dar unos puntos de referencia que para etiquetar, es decir, que sirve más para interpretar que para clasificar». (Picaudé 2001: 25) Es precisamente esta dimensión semio- 
pragmática la que en este punto se encuentra en el centro de nuestra atención.

La pregunta planteada por Picaudé es vasta, sus dimensiones y alcances resultan incalculables desde el momento en que, más allá de ese anclaje significativo al que nos hemos referido como una aportación del género para una primera lectura, es precisamente en torno a este factor que se ha desarrollado una extensísima especulación dentro del ámbito artístico a partir de la época ya señalada del arte moderno y a lo largo de toda la segunda mitad del siglo XX. En el campo de la fotografía se dará así un intenso diálogo entre las formas utilitarias, las canónicas y las estéticamente propositivas del medio, convirtiéndose en una sustancial materia de discusión ya que, si bien en el campo del arte es donde se produce una especulación activa alrededor del concepto, es en los campos utilitarios, extraestéticos $-\mathrm{y}$ recordemos una vez más la concepción de Bourdieu de la fotografía como arte intermedio (1965)—, donde más se utiliza:

[...] se supone que la práctica artística de la fotografía, de un modo u otro, desenclava, neutraliza, trastorna, etc., en resumen, deconstruye los géneros. [...] En efecto, decir que la función de los que practican la fotografía como artistas es desplazar las distinciones de género o confundirlas, solo tiene sentido si los géneros en cuestión poseen el estatuto de un horizonte de espera instituido por las prácticas no artísticas de la fotografía e interiorizadas por los receptores. (Schaeffer 2001: 16)

Este planteamiento nos exige llevar a cabo el intento de rastrear las características y desarrollo de las diferentes concepciones genéricas dentro de la especificidad del campo fotográfico. La tarea no es sencilla, desde el momento en que la propia polisemia del término género, reflejo, a su vez, de los múltiples usos y abusos a los que ha sido sometido, dificulta e imposibilita su acotación. Dice Schaeffer: «El término mismo de 'género' lo es todo menos unívoco. En sentido estricto, se refiere a prácticas intencionales reguladas e identificadas como tales por los creadores y los receptores». (Schaeffer 2001: 16) Picaudé plantea nuevas preguntas, que agravan y magnifican el alcance del asunto: 
El género es a la vez un tipo de imágenes que poseen cualidades comunes y una categoría mental según la cual se regula la percepción de las imágenes. Puede completarse, para cada imagen, con múltiples informaciones: es una foto tomada el año pasado, de ella se han hecho dos copias, etc. El género permite clasificar las imágenes según criterios esenciales (que responden de forma adecuada a la pregunta de qué es) pero insuficientes (ya que no determinan la individualidad de lo que es). ¿Cómo conocer de forma suficiente esta fotografía? ¿Acaso es posible? (Picaudé 2001: 22-23)

Acometamos, así, la difícil tarea de responder a las interrogantes arriba citadas a partir de diversos marcos teóricos que nos permitan una aproximación plural al asunto.

Desde el campo histórico-crítico, el cual mira al pasado con un afán interpretativo y clasificatorio —retomemos la idea de Perec (1985) de que pensar y clasificar son actos afines-, el recurso al género como indicio interpretativo es un factor crucial de ordenamiento:

Actualmente se percibe por todas partes un intento de desmantelar el archivo fotográfico - el conjunto de prácticas, instituciones y relaciones al que originalmente pertenecía la fotografía decimonónica- - y reunificarlo en el seno de categorías previamente constituidas por el arte y su historia. Aunque es fácil hacerse una idea de cuáles son los alicientes para proceder así, es más difícil comprender la tolerancia para con el tipo de incoherencia que produce. (Krauss 1985: 163)

Hablamos aquí de la crítica artística como disciplina promotora de esta reunificación, mas no del punto de vista de la producción, a la que nos referiremos posteriormente y de la cual solamente adelantamos de momento la idea de que se fundará en «la confusión erigida en paradigma artístico». (Picaudé 2001: 24)

Desde otra perspectiva, la semiótica, abocada a esclarecer y eliminar dichas incoherencias, se puede afirmar que

[...] hay una forma de memoria que se activa en el meollo mismo de la lectura: es sabido que en toda lectura la comprensión de un texto se ventila entre memorización y anticipación. Puede apreciarse en este tipo de memorización el efecto género o memoria de las reglas genéricas (como en el caso del famoso «horizonte de expectativa» de las obras teorizadas por H.R. Jauss) donde se encuentran no ya imagines en unos loci (géneros), sino loci (géneros) en unos loci (programas). 
En efecto, no se reconoce sino lo que ya se conoce y no se ha olvidado. Por eso, la memoria en la lectura no solo se refiere al género sino también a los otros géneros y por tanto a la intertextualidad, del mismo modo que el estereotipo también reconstruye a partir de consignas de lectura. (J oly 2002: 216-217)

La propuesta de J oly es consistente con la que plantea Soulages, esta vez desde la estética: «El arte fotográfico funciona como un sistema: una foto solo adquiere sentido y fuerza gracias a las relaciones reales, probables y posibles que mantiene con las otras fotos». (Soulages 1998: 192) Más adelante, el mismo autor nos recordará que esta idea no es original y que ha sido planteada de forma añeja como parte de concepciones tan ampliamente divulgadas como la del museo imaginario: «Para Malraux, la materia prima del artista nunca es la vida, ni lo real, sino siempre otra obra de arte». (Soulages 1998: 247)

La visión de J oly también se corresponde con una de las propuestas metodológicas planteadas en relación al tema por Marzal Felici (2007: 81), quien afirma que: «Un punto de encuentro entre las diferentes perspectivas de estudio es la consideración de los géneros literarios, fílmicos o fotográficos como sistema de convenciones». Sin embargo, este aparente consenso se verá irremediablemente problematizado en el campo artístico, lo cual también es tomado en consideración por Marzal Felici en otra de sus propuestas metodológicas, en la cual advierte acerca de la apertura que adquiere el concepto como consecuencia de la propia práctica artística:

Así pues, dentro de esta lógica que el género parece imponer — «como horizonte de expectativa' para los lectores, como 'modelos de escritura' para los autores»-, el origen y evolución de los géneros está marcado por la constante mutación de su configuración, lo que dificulta aún más la posibilidad de definir (de caracterizar, de un modo cerrado) los géneros literarios, fílmicos o fotográficos. Este origen de los nuevos géneros solo podrá hallarse en la transformación de otros géneros anteriores, «por inversión, por desplazamiento, por combinación». (Marzal Felici 2007: 81)

Más arriba hemos advertido acerca de la intrusión en la estructura de géneros fotográficos de categorías ajenas, más propiamente identificables 
con espacios discursivos o situaciones contextuales de uso y de lectura. Enfaticemos este aspecto: en el marco de

[...] la evolución histórica de la fotografía: sus categorías genéricas más familiares son de hecho ejemplificaciones de algunas de nuestras categorizaciones perceptivas y cognoscitivas más fundamentales y universales, no estructuran tanto géneros en el sentido histórico del término sino situaciones fotográficas arquetípicas, que no cesan de ser reactivadas y moduladas a lo largo del tiempo por los fotógrafos. (Schaeffer 2001: 21)

Ahora bien, las labores archivística, historiográfica, crítica y académica se verán, así, imbuidas de una vocación sistematizadora, clasificadora. Pero, ¿puede decirse lo mismo de la labor creadora, de producción? Si hasta aquí hemos aludido en paralelo tanto a las prácticas fotográficas artísticas como a las no artísticas en relación al marco de referencia genérico, centremos ahora nuestra atención en las primeras, ya que es en ellas en las que encontraremos propuestas más radicales en lo que toca a la especulación en torno al tema.

El arte modernista, como ya lo hemos hecho notar, cuestiona, remodela, juega con el género. El arte posmoderno, por su parte, lo transgrede y deconstruye. En ambos casos el género, paradójicamente, permanece como referencia.

Decía Todorov que la transgresión, para existir, necesita una ley. La ley del género (por emplear la expresión de J acques Derrida) exige la pureza de la identidad que conseguimos determinar gracias a la repetición. Sin embargo, esta repetición produce impurezas, corrupción, contaminación, «incluso cancerización o degeneración». El sistema genérico proclama, a través de su degeneración (término cuya etimología procede de «género», «generación», «genealogía»), una nueva ley que Derrida denomina «la ley de la ley del género», esto es, un exceso de sus propios límites. La repetición -no idéntica- del ritual genérico se vuelve contra la propia identidad del género, provocando su disolución. La propuesta derridiana es bastante radical respecto a la tradición de estudios sobre los géneros: un texto no puede pertenecer a un género de un modo exclusivo; por el contrario cada texto participa de uno o varios géneros. (Marzal Felici 2007: 84)

Siguendo esta línea, podemos hablar, entonces, de un arte degenerado, pero que sin embargo mantiene de forma subyacente los 
valores que le dan sentido al arte, así como la deformación solo es concebible desde la concepción ideal de determinada forma. Como consecuencia, la manera de formar de este arte se plantea obligadamente como metalenguaje, como especulación acerca de sus propias posibilidades expresivas, ni más allá del continuo histórico de largo plazo heredado de la tradición, ni más acá de lo que dictatorialmente permiten las estructuras del campo artístico, un verdadero establishment cultural acatado a contrapelo por las instancias pertenecientes a su sistema -críticos, instituciones museísticas, marchantes, academia, editores y, por supuesto, creadores-. Desmitifiquemos, en este sentido, a la práctica artística:

Las prácticas transgenéricas, al igual que las de deconstrucción genérica, nunca aparecen como tales si no es en relación con los géneros cuyas fronteras han borrado o deconstruido. En ese momento dichas categorías dejan de ser operativas, el carácter «subversivo» o «transgresor» de los distanciamientos desaparece al mismo tiempo: lo que hasta entonces era «distanciamiento» se instaura como categoría genérica nueva. (Schaeffer 2001: 19)

Una vez más estamos en el ámbito de la lección adorniana de la estética negativa, ya que el corolario es que la práctica artística que pretende moverse a contracorriente del status quo del arte, no hace sino afirmarlo. Estas prácticas se insertan dentro del marco más amplio del arte como lenguaje, como comentario de las posibilidades del arte mismo, que en su pretendida novedad no hacen sino perpetuar algunas consignas ya consagradas. Esto da lugar a que la pretendida resistencia bien podría ser calificada de reaccionaria, ya que contradice en los hechos las aparentes intenciones deconstructivas posmodernas. Es por ello que se acentúa lo siguiente:

El género resiste a pesar de poseer todo lo necesario para ser ridiculizado por los partidarios de los mestizajes artísticos y ser cuestionado por los partidarios de la poética posmoderna. ¿Cuál es la relación entre la resistencia del género y la insistencia del signo, insistencia con la que desde los años setenta, el modelo semiológico y, de un modo más amplio, la teoría literaria, dominan los intentos de refundación en la historia del arte? (Picaudé 2001: 24) 
Siendo nuestro enfoque un híbrido que valora y reconoce las propuestas del campo artístico, pero también relativiza sus postulados al considerarlos en gran medida equivalentes en importancia, mas no superiores, a los de otros campos de lo que hemos englobado bajo el amplio concepto de imagen funcional -periodística, publicitaria, científica, doméstica-, nos sentimos con libertad de hurgar en la tradición de manera irreverente, sin el apego decoroso característico de los discursos que, al estar insertos en un particular ámbito de saber, tienden a forzar su pertenencia, a la vez legitimante de sí mismos y legitimadora de aquel. Esta ambivalente posición se presenta, de hecho, implícita en las paradojas que invariablemente se muestran en la traslación de los conceptos del arte a la fotografía. Entre las influencias y modelos que la fotografía - e insistimos: arte nuevo e intermedio (cfr. Bourdieu 1965), objeto antropológicamente nuevo (cfr. Barthes 1980) - , ha tomado a lo largo de su corta existencia, indudablemente el más problemático y también el más sustancial ha sido el de la pintura. Es el momento, así, de hacer una breve revisión del eterno tema de la pintura como referente de la fotografía, en el marco de la discusión en torno al género.

Durante el siglo XIX, en su inmadurez de medio de expresión recién nacido y balbuciente, la «fotografía tomó a la pintura como modelo y muchos fotógrafos pensaron que esta era la manera de conseguir su reconocimiento artístico. No se tenía en cuenta que la dinámica pictórica ya había devaluado esa referencia a los géneros». (Arbaïzar 2001: 75) Al margen de las connotaciones sociales derivadas del hecho de ser considerada una actividad como artística, estrictamente desde el punto de vista de su condición de lenguaje, la fotografía nace con instintos bien inscritos en su memoria genética, estando su ADN totalmente inserto en la cadena evolutiva del arte occidental vinculado, desde el Renacimiento, a la perspectiva cónica como esquema de representación dominante.

Pero como hemos venido planteando, además de una memoria genética, hay también una genérica. Esta memoria, inscrita en la tradición del arte occidental, no impedirá que la fotografía desarrolle, una vez 
alcanzada la madurez técnica, formas de representación propias, manifestadas en géneros específicamente fotográficos. La tensión subyacente en esta discusión es la añeja, pero aún vigente, entre pictorialismo y purismo. (Cfr. Fontcuberta, 1984; también véase supra: Capítulo 1.2) La testarudez con la que, desde el campo del arte, se ha insistido históricamente en el menosprecio de la fotografía, solo es comparable a los esfuerzos que, desde el campo fotográfico, se han invertido en autovalidarse como expresión artística. Esta discusión, que parecería ya más que agotada, sigue encontrándose de manera subyacente, en argumentos que pretenden perpetuar hegemonías de campo. Veamos:

La evolución progresiva de ambas formas artísticas ha propiciado una interminable sucesión de encuentros (y desencuentros), al extremo de cuya cadena ha querido recientemente verse motivo de convergencia pacificada -hasta el punto de querer presentar el reciente desarrollo de las prácticas fotográficas como puesta en escena aggiornada de «los géneros de la pintura». La consigna baudeleriana que destinaba la fotografía a la esclavitud servil de la pintura se habría con ello cumplido: la fotografía no sería sino un mero instrumento técnico puesto al servicio de una forma artística preexistente, incapaz de encontrar y desarrollar su forma narrativa propia.

(...)

Es preciso [...] seguir la huella de la tensión mutua que fotografía y pintura se ejercen desde su origen -para poder percibir que la fotografía es, todavía, un potencial no colmado de trastorno radical del orden de la representación. E incluso, que en el seno del campo fotográfico está teniendo lugar, recientemente y todavía, la más revolucionaria de las contemporáneas transformaciones de las formas artísticas visuales -ligada justamente a una espeluznante transformación tecnológica. Ponerla al servicio de un marco estrechamente academizado de comprensión de los órdenes de la representación y de las formas artísticas - en los términos de una obsoleta taxonomía de «géneros»- es justamente el más flaco favor que puede entonces hacérsele a la comprensión del sentido y alcance de sus desplazamientos actuales. (Brea 1996: 29-30)

Lo que encontramos en esta ambigua sentencia es la opinión de un intelectual montado en la teoría posmoderna de la fotografía —con el espectro de Rosalind Krauss en todas sus entrelíneas-, teoría de cuño anglosajón la cual, a pesar de la relevancia que ha obtenido en las últimas décadas en ciertos medios del arte - en parte debido en el mundo hispanohablante, hemos de reconocerlo, a las carencias de la industria 
editorial y de la producción teórica en español- no es más que una posición entre tantas posibles. Ambigua, sí, ya que tras la aparente apología que hace del potencial expresivo del medio, rezuma el eterno menosprecio de la existencia y validez de una estética -que no forma narrativa ${ }^{2}-$ propiamente fotográfica, así como el también eterno problema de considerar a la fotografía desde el marco del arte, sin atender a su especificidad como medio de expresión. De este modo, la cita peca de lo mismo que condena. Hay aquí una disminución implícita de la fotografía como campo autónomo, muy común en el ámbito artístico contemporáneo, y que sorprendentemente se sigue repitiendo, lo que vuelve a traer una y otra vez a la luz una discusión que parecería ya totalmente superada. Insistimos en una idea que ya hemos planteado: «Las prácticas transgenéricas y deconstructoras no son más agenéricas que los géneros 'tradicionales', simplemente su categorización es diferente». (Schaeffer 2001: 20) Desmitifiquemos la práctica artística: las formas de deconstrucción se topicalizan, se generalizan: no se llaman géneros, pero operan como tales.

Rouillé (2005), por ejemplo, ha intentado zanjar definitivamente la discusión así polarizada al hablar de las dicotomías constitutivas de la esencia fotográfica, una de las cuales da subtítulo a su libro: entre documento y arte contemporáneo. Introduce, de esta manera, una nota conciliadora en el marco de esa discusión añeja a la que nos hemos referido, al distinguir, sin pretender que se anulen mutuamente, entre «el arte de los fotógrafos» y «la fotografía de los artistas» (cfr. Rouillé 2005), posiciones, en su esencia, muy próximas a las que Fontcuberta (1984) asocia con el purismo y el pictorialismo, respectivamente.

La idea de fondo se repite una y otra vez, en expresión de un verdadero hartazgo ante esos tópicos, ya apuntados, de la visión de la fotografía desde el campo artístico:

\footnotetext{
2 En torno al abuso que recientemente se ha hecho de esta expresión, convertida en moda y consecuentemente topicalizada, remitimos al lector a la discusión que ya establecimos en torno a ella: cfr. Capítulo 6.2.
} 
De forma más profunda, creo que la hipótesis de una dinámica de transgresión genérica se adapta particularmente mal a la fotografía. En efecto, la tesis, tal como ha sido formulada por la literatura o por las artes plásticas, se refiere a las relaciones que dichas artes establecen con su propia tradición. [...] Ahora bien, lo que se cuestiona en fotografía es una supuesta relación externa entre el arte fotográfico y las prácticas funcionales de la fotografía: las categorizaciones genéricas que el uso artístico de la fotografía debe desplazar se supone que son las del uso no artístico de la fotografía; además, el horizonte de espera genérico estaría formado por las categorizaciones de estos usos no artísticos. Así pues, la tesis no se refiere a las relaciones entre la obra individual y la tradición artística, sino a las relaciones entre el ámbito artístico y la experiencia no artística de los receptores. Lo que se cuestiona, ya no es una dinámica artística sino una relación agonística entre el arte y las categorías en curso en nuestra existencia cotidiana. (Schaeffer 2001: 20)

En una época en la que las manifestaciones artísticas y las comerciales confluyen cada vez más dentro de ese complejo entorno de influencias y tensiones mutuas englobado bajo el concepto de cultura visual, la relación entre estética y funcionalidad está totalmente replanteada.

Consecuentemente tenemos respecto de los géneros, por un lado, una actitud que tomaría como referente las maneras de formar tradicionales -el pictorialismo en su versión neo, «la fotografía de los artistas»-, y que en sus manifestaciones posmodernas se centraría en su puesta en crisis y deconstrucción. Por otro lado, estaría la visión correspondiente a una esencia de lo fotográfico - la purista, la de «el arte de los fotógrafos»-, basada en los géneros específicamente fotográficos y que desde el punto de vista de la historia del medio correspondería a una interpretación de su desarrollo sustentada en el paralelismo entre las innovaciones técnicas y las posibilidades expresivas que estas permiten, y algunos de cuyos puntos álgidos estarían marcados por el surgimiento de la estética de la instantánea a finales del siglo XIX, la expresión de una poética vinculada al movimiento de Secesión Fotográfica promovido por Alfred Stieglitz en la primera década del siglo XX y por la construcción de una historia del medio basada en la exaltación de la estética fotográfica por Beaumont Newhall $-\mathrm{y}$ otros directores de la sección de fotografía del MoMA en Nueva York-, inicialmente publicada en 1937, revisada en 
incontables ocasiones, y cuya dominante influencia estaría presente durante décadas.

Ante estas reflexiones, no podemos evitar hacer un breve paréntesis para retomar un tema señalado desde el inicio de este trabajo, subyacente en toda su estructura y que aquí vuelve a resaltar por su importancia. Nos referimos a la escisión del medio, que señalamos desde el Capítulo 1 y que ha vuelto a hacerse presente en los párrafos precedentes. Dicha escisión, que como hicimos ver en aquel momento está activa desde el origen de la fotografía, queda representada mediante una serie de dicotomías: ópticaquímica, icono-índice, purismo-pictorialismo, documento-arte, entre otras. Una vez más, debemos insistir en nuestra posición de sumar, no de restar o dividir. De hablar, como propusimos entonces, no desde una posición u otra, sino desde la fotografía, que abarca todas, ya que el potencial expresivo del medio visto de esta manera es mucho mayor que el de las posiciones parciales, en ocasiones mezquinas, en ocasiones reduccionistas, incluso en ocasiones representativas de intereses institucionales o de mercado. Hablar desde la fotografía es, entonces, integrar posiciones, no oponerlas.

Hecha esta reflexión, continuemos con la discusión en torno a los géneros, teniendo ahora en mente esta visión integradora. Para ello, partamos de la siguiente cita que redunda en algunos aspectos ya señalados, pero que nos da ocasión de introducir un nuevo giro en la argumentación:

En el antiguo sistema pictórico, que se basaba en el orden académico de los temas, la pintura de historia se hallaba en la cima y la naturaleza muerta en la base de la escala de valores. Esta jerarquía no solo consagraba la superioridad de los temas humanos sobre la representación de objetos, la de la narración histórica sobre la descripción literal o la presentación deíctica, sino que privilegiaba también una cierta manera de representación que, referida a un corpus de textos anteriores, constituía un lenguaje y daba su unidad al mundo representado. En resumen, se trataba de un sistema en el que el anima ganaba a la materia inanimada, el signo al hecho en bruto, lo Uno a lo múltiple; en este sistema dominaba todo lo que no es la fotografía -y no puede serlo-. (Armstrong 2001: 147) 
Más allá, entonces, de los géneros pertenecientes a la tradición pictórica, habría que considerar que desde un punto de vista figurativo o icónico, esto es, el que se centra en el qué está representado en la imagen, la jerarquía de los objetos funciona en la conciencia a un nivel previo al de las convenciones genéricas, esto es, si se nos permite, a un nivel infralógico. ${ }^{3}$ Esa jerarquía que privilegia a los sujetos humanos sobre los animales y a estos sobre los objetos, se traducirá, si apelamos una vez más a la sentencia de Perec en relación a que pensar es clasificar, en criterios de agrupación de los cuales los géneros académicos serían la consecuencia, mas no el motivo. Aunque bien codificados por la tradición, dichos géneros no harían sino representar una voluntad perceptiva y ordenadora preconsciente, y habría que preguntarse si la voluntad deconstructora del arte posmoderno no está destinada a fracasar al toparse con la pared una y otra vez, ya que la percepción invariablemente tenderá a imponer la lógica de esas estructuras esenciales de pensamiento.

En un segundo momento de este planteamiento, hemos de proponer una pregunta que se desprende de la última reflexión de Armstrong recogida en la cita anterior: si ese sistema genérico fue codificado de manera previa al invento de la fotografía y, por lo tanto, dominaba todo lo que no es la fotografía $-\mathrm{y}$ no puede serlo-, ¿cómo se codifica en una instancia posterior al invento, esto es, a partir de lo que la fotografía sí es y puede ser?

Precisamente lo que la fotografía es y puede ser se engloba en un sustancial concepto que parecería banal incluso por la forma en que está expresado, la cual es casi coloquial. Nos referimos al concepto molesiano del universo de lo fotografiable. (Moles 1981: 182 y ss.) Parecería que nos estamos moviendo en un ámbito de reflexión marcado por la obviedad, por el sentido común, y es justamente por ello que debemos andar con tiento y tratar de desentrañar sus implicaciones, que son profundas. El universo de lo fotografiable coincide en buen número de aspectos, pero no es igual ni

\footnotetext{
${ }^{3}$ Remitimos al lector a la jerarquía de actantes y objetos representados establecida en los apartados 6.2 a 6.4, así como al concepto molesiano de infralógica, desarrollado en ellos.
} 
equivalente, al universo de lo pictórico o, en general, al de lo representable por cualquier otro medio de producción de imágenes, sean técnicas o no. Este asunto es crucial para nosotros ya que incide de manera frontal en lo que es el tema del presente trabajo en un sentido más amplio, a saber: la especificidad del lenguaje fotográfico, primero, en sus manifestaciones históricas, y segundo, en sus desdoblamientos más recientes -asunto al que dedicaremos fundamentalmente el Capítulo 8-.

La fotografía, dado su indisoluble vínculo con el factor técnico en constante cambio, se ha encargado desde su origen, y sin cesar, de establecer y de expandir ${ }^{4}$ lo que sí es y sí puede ser, lo que pertenece y lo que no pertenece al universo de lo fotografiable. Este proceso, no se ha interrumpido en sus poco menos de dos siglos de historia. Moles plantea que dicho universo está conformado por la interacción —que podría ser representada tridimensionalmente, en un esquema en el que a cada uno de estos elementos correspondería uno de los ejes cartesianos x, y, z- entre el individuo que tiene la intención de fotografiar, la técnica y lo que esta le permite hacer, y «las escenas 'cristalizables' de la vida, situadas en la línea del universo del ser». (Moles 1981: 183) Este proceso, por lo tanto, está sujeto a factores totalmente dispares, algunos controlables y otros azarosos, desde la presencia de ánimo del fotógrafo hasta la posible falta de consentimiento del sujeto, pasando por todos los aspectos que constituyen su equipamiento técnico en un momento dado. La visión molesiana, con esta concepción, resulta por lo tanto diametralmente opuesta a la de Flusser, que propone el agotamiento del potencial expresivo del medio. (Cfr. Capítulo 2.1)

Del anterior esquema se desprende, en relación a los géneros, que parecería estar implícita la idea de que estos engloban y expresan, norman y clasifican, ese universo de lo fotografiable, estableciendo no solo el qué se puede fotografiar, sino también el cómo es posible hacerlo, extendiendo así sus implicaciones del nivel icónico al nivel plástico. Llegado este punto, sin

\footnotetext{
${ }^{4}$ Esta expansión es, por supuesto, identificable con el concepto de campo expandido debido a Rosalind Krauss (1985) y que Ribalta desarrolla en torno al medio fotográfico. (Ver infra: 8.2)
} 
que sea nuestra finalidad plantear una clasificación exhaustiva de los géneros fotográficos, ya que el propio dinamismo del medio la hará inevitablemente limitada y parcial, sí hemos de aventurar una aproximación que considere las dos tendencias ya aludidas, aclarando que no implica, en momento alguno, una jerarquización:

1. Los géneros que se desprenden de la tradición pictórica:

- Retrato

- Desnudo

- Naturaleza muerta o bodegón

- Paisaje

2. Los géneros específicamente fotográficos:

- Objeto encontrado

- Fotografía directa

-Escenificación

- Fotografía construida

La patente simplicidad y, diríase, casi banalidad de esta solución es engañosa. No perdamos de vista que precisamente el aspecto esencial de nuestra propuesta pragmática es que el género, como elemento orientador de la lectura de la imagen, nunca opera aisladamente, sino que su valor invariablemente se encuentra en relación con el espacio discursivo y el canal de comunicación, los cuales desarrollaremos en los próximos apartados.

Asimismo, en el Capítulo 8 ahondaremos en un aspecto concerniente a la expansión del universo de lo fotografiable en las últimas dos décadas, que ha problematizado y, acaso, restado importancia a la discusión genérica. No solo nos referimos a las prácticas artísticas que suponen hibridaciones, maridajes o deconstrucciones, sino sobre todo a la verdadera democratización de que ha sido sujeto la producción transmedia, poniéndose al alcance de cualquier persona debido a la divulgación y simplificación de las herramientas informáticas tanto de producción y 
retoque de imágenes como de autoedición, fenómeno que ha desplazado definitivamente el campo de influencia del concepto de género ligado al arte. Así, podemos refrendar la idea de que:

La fotografía permanece, como siempre, obsesionada con acreditarse a sí misma como arte; pero cuanto más prolifera, más se convierte en simples imágenes, nada más (la fotografía digital, que puede hacer cualquier cosa con una imagen, ha acelerado el proceso). (Hirsch 1999: 26)

En su momento especularemos acerca de si esta consideración implica la anulación de la especificidad fotográfica en el entorno de la nueva cultura visual.

\subsection{EL ESPACIO DISCURSIVO COMO ELEMENTO SIGNIFICANTE}

En el inicio del apartado anterior, a propósito del fotomatón, afirmamos que en el ritual aparejado a su funcionamiento no hay lugar para la sonrisa salvo como juego, como violentación del código. No solo el tamaño de la imagen, como ya vimos, puede tener consecuencias insospechadas y marcar la diferencia entre, como en aquel ejemplo, una fotografía de identificación y un retrato, también puede hacerlo una simple sonrisa.

La sonrisa va tan estrechamente aparejada a la fotografía en el ámbito privado que algunos fabricantes han desarrollado un recurso de automatización aún más peculiar que el del fotomatón: nos referimos a la tecnología de detección de rostros con Smile Measurement Software, diseñado por la compañía japonesa Omron en 2007 e incorporado inmediatamente a sus cámaras por Sony, Olympus y otros fabricantes, bajo la denominación Smile Shutter. (Imagen 95)

${ }^{5}$ La traducción es nuestra. 


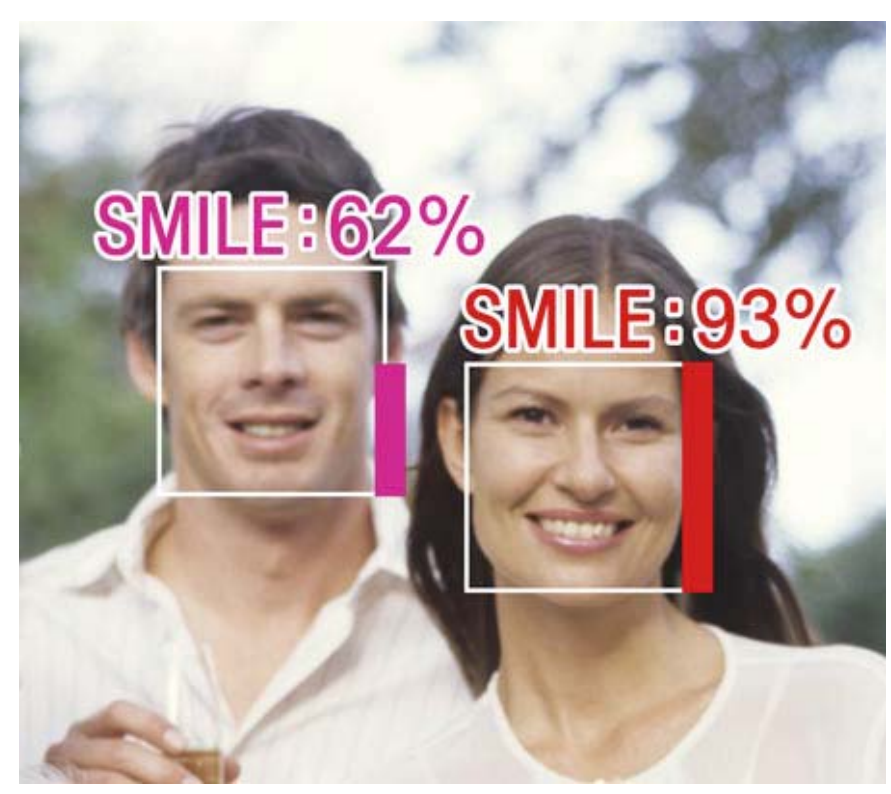

Imagen 95. Fotografía promocional del Smile Measurement Software, Omron Corporation, boletín de prensa del 26 de septiembre de 2007

La tecnología tiene la capacidad de detectar los rostros y, cuando los sujetos a cuadro sonríen, hacer que la cámara dispare automáticamente un número de veces predeterminado por el usuario desde el menú de opciones. ¿Será que las sonrisas así obtenidas son mucho más espontáneas que las del ritual de decir chis o patata ante la presencia del aparato? ¿Será que una conditio sine qua non para ser fotografiado en el siglo XXI es la de ser feliz? O por el contrario, ¿encerrará la denominación de este peculiar artilugio el no poco irónico deseo - expresado en un inconsciente y verdadero oxímoron-de dispararle a quien sonría? El Smile Measurement Software es capaz de detectar las sonrisas y, de hecho, de valorarlas en un rango que va del cero al cien por ciento, incluso cuando aquellas presentan un ángulo de desvío de hasta 30 grados respecto del eje de la cámara. Es inevitable preguntarse cómo se comportaría este dispositivo ante la enigmática sonrisa de La Gioconda. 
Bien sabemos que hay sonrisas que confunden. Hay sonrisas capaces, incluso, de confundir el espacio discursivo al cual se asocia una imagen.

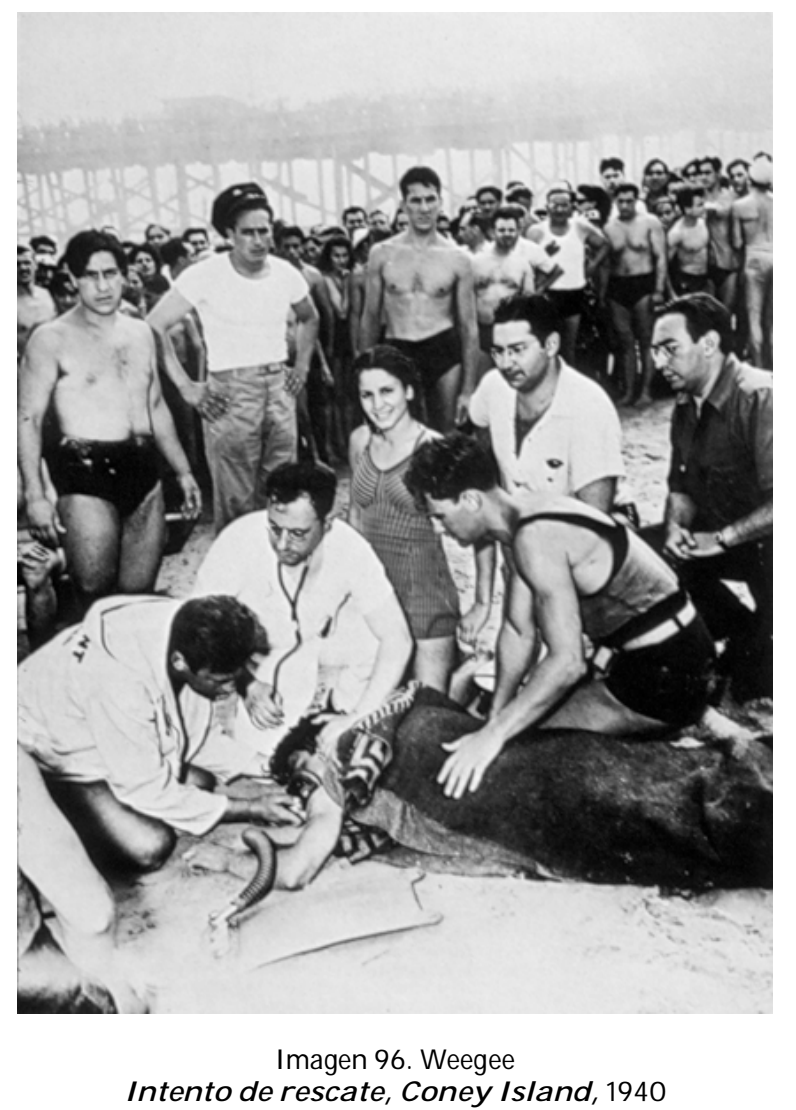

La foto del rescate de un joven que estuvo a punto de ahogarse en la playa de Coney Island podría pasar por una imagen periodística. (Imagen 96) Sin embargo, el solo nombre de su autor al pie de la misma nos hace sospechar que acaso debemos esperar algo más. En la imagen, de Weegee, curiosos y mirones observan la escena en segundo plano, a la distancia. En el primer plano, hincadas al lado del hombre que está siendo atendido, se encuentran seis personas; cinco de ellas, socorristas o miembros de servicios médicos, están en actitud de ayuda. La sexta destaca por varios 
motivos: uno de ellos es que ha sido colocada por Weegee exactamente en el centro de la imagen; otro, que de las personas cercanas físicamente al joven, es la única que lleva bañador y no parece socorrista, por lo que también podemos inferir una cercanía sentimental con el accidentado; $\mathrm{y}$, finalmente, llama poderosamente la atención el que la chica en cuestión mira directamente a la cámara y... sonríe. En efecto: sonríe. ¿Será una sonrisa de alivio al ver que su amigo, pariente o pareja ya está a salvo y la situación controlada? ¿O más bien será una mueca producto del acto reflejo de sonreír ante la presencia de una cámara, actitud insólita dada la situación, y que hizo al irreverente Weegee disparar obedeciendo a su propio y bien integrado Smile Measurement Software, llamado ironía?

Salvo por ese detalle, la imagen tiene todos los ingredientes de una foto testimonial. Pero, insistimos: ¿lo es? ¿O más bien deberíamos considerarla como una fotografía directa que plantea un comentario social y, en ese sentido, como parte del corpus de producción artística de su autor? La imagen, así, parece moverse de un espacio discursivo a otro. Y si lo hace es debido a que la actitud manifestada por la joven, a su vez, está asociada con las fotografías pertenecientes a un espacio discursivo particular: el de las fotos de aficionado, que aquí englobaremos bajo el concepto de diletantismo.

No solo Weegee estaba consciente de esta movilidad, característica de la vida social de las fotografías. En el boletín de prensa con el que Omron informó del lanzamiento de su Smile Measurement Software, leemos lo siguiente:

«La tecnología tiene un gran potencial para una variedad de aplicaciones, desde productos electrónicos de consumo hasta cuidado de la salud», dijo Masato Kawade, gerente senior del Laboratorio de Detección y Control de Omron. "Imagínese una cámara que le asegure que no se perderá ese momento en que todo el mundo tiene su mejor sonrisa. ¿O qué tal un chequeador-de-sonrisas para empleados que trabajan en el sector de servicios? El software podría utilizarse con la misma eficacia por los profesionales de la salud mental, como un medio de seguimiento de la condición de los pacientes, y en la investigación de mercados para evaluar las respuestas de los consumidores a los nuevos productos».

La medición de sonrisas es la más reciente función de la suite de software de reconocimiento facial Omron Okao Vision. Con más de diez años de 
investigación incorporada, Okao Vision utiliza una técnica patentada de modelos 3D para detectar y analizar los rostros en forma rápida y precisa, incluso en imágenes borrosas o parcialmente oscurecidas, o cuando el sujeto no mira directamente a la cámara. Es capaz de verificar la identidad, edad aproximada y sexo, y estimar los movimientos de las pupilas y los párpados de forma instantánea, ya sea que la imagen facial esté en movimiento o estática. Suficientemente compacto como para ser integrado en un chip para dispositivos móviles, el software ofrece una amplia gama de aplicaciones incluyendo la prevención de robo de identidad, administración de ingreso a edificios, sistemas de vigilancia del conductor en los coches y control de acceso a contenidos para edades restringidas. ${ }^{6}$

Observamos, así, que para los promotores del producto, no solo es relevante el espacio discursivo del diletantismo - los aficionados con sus fotos familiares, de viajes, etcétera—, sino también los de la ciencia, la mercadotecnia y publicidad, el de la identificación iy el de la vigilancia y control! De hecho, el potencial de desarrollo parece infinito. En el mismo boletín de prensa se agrega:

«El rostro es una de las más ricas fuentes de información sobre los seres humanos abierta a la interpretación por los ordenadores. Omron está comprometida a desarrollar en el futuro tecnologías de detección de emociones aún más sofisticadas, que permitan a las máquinas entender mejor a sus usuarios y contribuir directamente a mejorar su seguridad y comodidad», dijo Kawade. (Ibídem.)

El anterior ejemplo no es ocioso. Nos valemos de él para introducir el tema de la importancia del espacio discursivo al que pertenece una imagen como marco de referencia para que el receptor pueda interpretarla. De los componentes de eso que hemos llamado el triángulo pragmático, tanto el espacio discursivo como el canal de comunicación -al que dedicaremos el próxmo apartado- adquieren un peso específico en el contexto de la pragmática ya que, a diferencia del tercer componente, el género, se trata de factores que en infinidad de ocasiones se escapan al control del creador del mensaje $\mathrm{y}$, por lo tanto, detonan una cadena imprevisible de significados y connotaciones.

\footnotetext{
${ }^{6}$ (Tomado de: http:// www.omron.com/media/press/2007/09/n260907.html, consultado el 16 de febrero de 2010. La traducción es nuestra.)
} 
Los párrafos precedentes insisten en el hecho de que las fotos son «susceptibles de pertenecer a varios espacios discursivos». (Armstrong 2001: 155) Es precisamente ese hecho, comúnmente obviado o pasado por alto por el receptor, el que aquí pretendemos subrayar, al tiempo que desarrollamos sus implicaciones. Dentro de la tradición del medio fotográfico, existe una primera dicotomía —una más, dentro de tantas que hemos apuntado a lo largo de este trabajo- que el receptor inmediatamente pone en juego:

Hay una postura del sujeto que, frente a una foto, la recibe en un horizonte de expectativa que depende o de la documentación o del arte; la expectativa, lo sabemos, puede ser decepcionada, tanto para el arte como para la documentación, y no desembocar en la declaración: «Esto es una obra» o «Esto es un documento». (Soulages 1998: 161)

Una vez más nos encontramos con el tan socorrido concepto del horizonte de expectativa, tomado en préstamo de la teoría de la recepción de Jauss. (Cfr. 1977; como ejemplo ver también Joly 1994 y 2002.) La dicotomía que en la anterior cita plantea Soulages es, asimismo, consistente con la propuesta esencial de Rouillé (2005), centrada en los vaivenes de la fotografía entre documento y arte contemporáneo, como reza el ya citado subtítulo de su libro. Consecuentemente, comenzamos a percibir que la confusión, aquella a la que aludían Picaudé y Arbaïzar (2001), en realidad va mucho más allá del género. De hecho, acaso la confusión más común es la de referirse al espacio discursivo como género.

Todo se complica desde el momento en que el arte contemporáneo mezcla lo simplemente visual con algunos usos que son reflejos de la confusión. Le corresponde al espectador enumerar los grados de reflexión. Esta tarea se remonta al pop art, en el momento en que las artes visuales se «reapropiaron», utilizando un término que ha pasado al lenguaje crítico con el nuevo realismo, de las imágenes invasoras de nuestro entorno. El arte institucional se veía desposeído de su monopolio en la fabricación de imágenes. De la confrontación del arte con las imágenes de todo tipo - de todo "género», bueno o malo-, que inspira las múltiples estrategias artísticas desde los años ochenta (asimilación, interferencia, recuperación, reproducción, cruce, transversalidad, desencasillamiento, mezcla, mestizaje, hibridación..., confusión) nació la cuestión crucial para el artista: la de saber 
qué hacer con las imágenes y cómo criticar el pluralismo de géneros. (Picaudé 2001: 31-32)

Sin embargo, confusión la hay también en esta concepción ya que, como señalamos en el apartado anterior, la palabra género es comúnmente utilizada -y la obra citada no es la excepción-con una amplitud excesiva. De ahí la importancia crucial que atribuimos al hecho de que el espectador sea capaz de situar el espacio discursivo -documento o arte, sí, pero también publicidad, ciencia, diletantismo- que, más allá de simplemente transferir sentidos a la imagen, es capaz de ubicarla en completos campos semánticos. Las expectativas del receptor pasan entonces, a través de la definición probablemente inconsciente del espacio discursivo al que la imagen pertenece, al establecimiento que aquel hace de un contrato comunicacional que le permite privilegiar una interpretación sobre otra.

Así, para alejarnos de otra posible confusión de tipo semántico, detengámonos en la exploración a fondo del propio concepto de espacio discursivo, ya que es acaso la fotografía, tan vinculada por el momento histórico de su desarrollo, no solo al arte moderno, sino también a la comunicación masiva, el campo en el que aquel factor ha tenido un mayor peso. Para ello, seguiremos las argumentaciones de Rosalind Krauss, a quien consideramos la autora que con más claridad ha enfocado el tema.

En su origen, la fotografía nace como un híbrido. Es significativo el hecho de que quienes en principio la desarrollan y avalan pertenecen al ámbito de la ciencia, no al del arte. Nuestro objeto antropológicamente nuevo, como lo hemos denominado reiteradamente de la mano de Barthes (1980), tardará en crearse un espacio dentro del ámbito de las artes e, incluso hasta el día de hoy, no cesará de reinventarse. Pero abordemos el asunto con un cierto orden cronológico. Dice Krauss:

El discurso estético desarrollado en el siglo XIX se organizó progresivamente alrededor de lo que podríamos llamar «el espacio de exposición». [...] Dada su función como vehículo físico de exposición, el muro de la galería se convirtió en el significante de la inclusión y, por tanto, pudo contemplarse como una representación de lo que podríamos llamar exposicionabilidad [...]. (Krauss 1985: 147) 
Huelga decir que, históricamente, el camino de la fotografía hacia la integración en el espacio expositivo fue largo y penoso. En el marco teórico construido por Krauss, este aspecto será fundamental para comprender, no solo los avatares de la fotografía en dicha saga, sino también su diálogo con el arte moderno e, incluso, la esencia misma de este último:

Esta constitución de la obra de arte en una representación de su propio espacio expositivo es de hecho lo que conocemos como historia del arte moderno. Hoy resulta fascinante ver a los historiadores de la fotografía asimilando su medio a la lógica de dicha historia. Si preguntamos nuevamente en qué espacio discursivo opera la fotografía [de vistas del siglo XIX] la respuesta será: en el del discurso estético. Y si preguntamos qué representa, la respuesta será que, en el seno de dicho espacio, se ha convertido en representación del plano de exposición, de la superficie del museo, de la capacidad de la galería para convertir en Arte los objetos que selecciona. (Krauss 1985: 147-148)

En efecto, incontables fotografías realizadas durante el siglo XIX sin pretensión estética alguna, no han cesado de ser recolocadas en los siempre movibles casilleros de la historia del medio. O mejor, diríamos una vez más, de las historias, ya que cada nueva historia es una verdadera construcción y esto se manifiesta incluso hasta hoy, dando testimonio de la vigencia del complejo de inferioridad de la fotografía ante las formas de expresión establecidas como canónicas en el XIX. Nuestra deriva inicial, en el Capítulo 1, centró su énfasis en buena medida en el interés de los historiadores del medio por establecer un mito fundacional y no han cejado, por otro lado, en sus intentos de justifcarlo desde el campo de la teoría estética, minimizando siempre su impacto en el ámbito de la comunicación funcional. Krauss señala insidiosamente este aspecto:

Estas preguntas cobran un especial alcance metodológico en la situación actual, en un momento en que una renovada, organizada y activa historia de la fotografía está construyendo un relato de los primeros años del medio. En dicho relato, las fotografías originalmente realizadas con fines de exploración, expedición e investigación, en su mayor parte de carácter topográfico, desempeñan un papel central. Estas imágenes entretejidas, enmarcadas y etiquetadas, ingresan ahora en el espacio de reconstrucción histórica a través del museo. Decorosamente aislados sobre el muro de exposición, los objetos pueden interpretarse de acuerdo con una lógica que 
insiste en su carácter representacional en el seno del espacio discursivo del arte, en un intento de «legitimarlos». (Krauss 1985: 148)

Pero más allá del recuento histórico, el interés de la autora no se limita a situar las incontables tendencias historiográficas de la fotografía que produjo el siglo pasado, sino que, finalmente, se encamina a hacer una crítica de las construcciones recientes, de fines del siglo, cuya obsesión en torno al asunto llegó a su culmen con el pretexto de los festejos del 150 aniversario de la fotografía, que alrededor de 1989 produjo una avalancha de publicaciones y exposiciones retrospectivas. En este contexto, Krauss insistirá en la equívoca descolocación de ciertas obras y archivos respecto de su espacio discursivo original:

Al decidir que la fotografía del siglo XIX pertenece a un museo, al decidir que se pueden aplicar a la fotografía los géneros del discurso estético, al decidir que el modelo histórico-artístico se adecua perfectamente a este material, los investigadores recientes de la fotografía han tomado (antes de tiempo) muchas decisiones. Por un lado, han llegado a la conclusión de que determinadas imágenes eran paisajes (en vez de vistas) y creen saber a qué discurso pertenecen dichas imágenes y qué es lo que representan. Por otro (aunque esta conclusión va unida a la primera), han decidido que otros conceptos fundamentales del discurso estético pueden aplicarse a este archivo visual. Uno de ellos es el concepto de artista, con la correspondiente idea de progreso continuado e intencional al que denominan carrera. El otro es la posible coherencia y sentido que revela el conjunto de una producción, es decir, la unidad de una obra. Sin embargo, puede afirmarse que la fotografía topográfica del siglo XIX no solo tiende a no respaldar estos términos, sino que incluso los pone en cuestión. (Krauss 1985: 155-156)

Para apoyar sus argumentos, la autora que venimos siguendo arremeterá contra la manera en que ha sido tratado históricamente el archivo fotográfico: «Hay otras prácticas, otras manifestaciones en el archivo que también ponen a prueba la aplicabilidad del concepto de obra. Una de ellas es la existencia de un número exiguo de trabajos; la otra es la existencia de demasiados». (Krauss 1985: 157) Como un ejemplo paradigmático de esta situación, se referirá al archivo producido por Eugène Atget. Como es sabido, este vasto archivo, el cual en realidad se piensa que fue producido por diferentes fotógrafos contratados para 
trabajar sobre unos mismos parámetros entre las décadas de 1890 y 1920, fue adquirido parcialmente por la fotógrafa Berenice Abbott a la muerte del fotógrafo francés en 1927, con lo que se convirtió en su promotora. Años más tarde, en 1968, y también por influencia de Abbott, el archivo pasaría a formar parte de la colección del Museo de Arte Moderno de Nueva York. Ya en 1931, Walter Benjamin, con un entusiasmo que hoy parece ingenuo, contribuiría asimismo al encumbramiento de Atget a través de su célebre Pequeña historia dela fotografía:

Atget fue un actor que, asqueado de su oficio, se quitó la máscara, dedicándose luego a desmaquillar también la realidad. Vivió en París pobre e ignorado; malvendió sus fotografías a aficionados no menos excéntricos que él, y hace poco ha muerto, dejando tras sí una obra de más de cuatro mil fotos. Berenice Abbott, de Nueva York, las ha recogido y una selección acaba de aparecer en un volumen, ${ }^{7}$ cuidado por Camille Recht, que destaca por su belleza. Los periódicos de su tiempo «nada sabían del hombre que se pasaba el tiempo rodando por los estudios con sus fotografías, que las malvendía por unos cuantos céntimos, a menudo por el precio de aquellas tarjetas que alrededor de 1900 mostraban vistas embellecidas de ciudades sumidas en una noche azul con la luna retocada. Alcanzó el polo de la suprema maestría, pero con la pertinaz modestia del gran maestro que siempre vive en la sombra, no se preocupó de plantar su bandera. Así no pocos creen haber descubierto el polo que Atget pisó antes que ellos». ${ }^{8}$ De hecho las fotos de Atget de tema parisino anticipan la fotografía surrealista: son tropas de avanzada de la única columna realmente importante que el surrealismo ha sido capaz de movilizar. Él fue el primero en desinfectar la sofocante atmósfera extendida por el convencionalismo de los retratos fotográficos en su época de decadencia. Purificó esa atmósfera, la asentó incluso: muy tempranamente emancipó al objeto del aura, lo que constituye el mérito más indiscutible de la más reciente escuela fotográfica. (Benjamin 1931: 38-40)

Pero no nos perdamos en el comentario del caso concreto, que es solamente un pretexto discursivo. La romántica exaltación que Benjamin hace de la figura de Atget, con todos los ingredientes de creación de un hito contemporáneo, es comparable en fuerza a la desmitificación de que lo hace sujeto Krauss décadas más tarde. Si bien, de la mano de esta, hemos tenido ya una crítica a la consideración de ciertos conjuntos de imágenes como

\footnotetext{
${ }^{7}$ Atget, Eugène. Fotografías. (Con una introducción de Camille Recht.) París y Leipzig, 1930.

${ }^{8}$ De la introducción al volumen citado en la anterior nota.
} 
obra, en relación concretamente al archivo $-\mathrm{y}$ aquí ponemos el énfasis-, insistirá:

El sistema de codificación que Atget aplicó a sus imágenes deriva de los ficheros de las bibliotecas y colecciones topográficas para las que trabajaba. Sus temáticas a menudo están regularizadas, responden a categorías establecidas de la investigación y la documentación históricas. La razón de que muchas imágenes urbanas de Atget se parezcan misteriosamente a las fotografías realizadas por Marville medio siglo antes reside en el hecho de que ambas responden al mismo plan rector documental. Un catálogo no es tanto una idea como un sistema de organización. No depende tanto del análisis intelectual como del análisis institucional. Y parece evidente que el trabajo de Atget es la función de un catálogo en cuya invención no intervino y para el que la autoría es un término irrelevante.

Las condiciones normales de autoría que el museo pretende mantener tienden a desplomarse con esta observación, conduciéndonos a una reflexión bastante sorprendente. El museo se encargó de descifrar el código numérico negativo de Atget con objeto de descubrir un alma estética. El resultado final, en cambio, fue un catálogo de fichas. (Krauss 1985: 160-161)

Así, si en el apartado anterior pusimos énfasis en el hecho de que el género es el primer elemento extrínseco al cual el receptor apela de manera inconsciente en el proceso de extracción del sentido de la foto, toca ahora atar cabos y concatenar los dos eslabones, a saber: género y espacio discursivo. El museo, como canal emblemático del discurso estético, es acaso el ámbito que con más claridad permite apreciar esta vinculación: «¿De qué forma el proceso de conservación, de acumulación, transforma un conjunto empírico en una colección? ¿Cuál es el papel del género en este proceso? ¿El museo gestiona la confusión o la produce?» (Picaudé y Arbaïzar 2001: 12)

En cierto momento de la argumentación que desarrollamos en aquel apartado en torno al género, fueron fundamentales las referencias que hicimos a los planteamientos de Bourdieu, quien, más allá del valor fundamental que, como vimos, atribuye al género como anclaje interpretativo, es conocido por su relativización de la fotografía, a la que considera como arte intermedio. Es precisamente en el marco de la reflexión en torno a los espacios discursivos, y en concreto al discurso estético, que Krauss le responde: 
[...] en un momento determinado, la fotografía, en su precaria posición de falsa copia (es decir, de imagen que solo es parecida debido a un factor mecánico y no por un lazo interno y esencial con el modelo) sirvió para deconstruir todo el sistema del modelo y de la copia, del original y del falso, de la primera copia y de la segunda. Para un sector del mundo del arte, tanto artistas como críticos, la fotografía abrió los compartimientos herméticos del antiguo discurso estético al examen crítico más severo posible, y los volvió del revés. Dado su poder para llevar a cabo este cuestionamiento del conjunto del concepto de unicidad del objeto de arte, de la originalidad de su autor, de la coherencia de la obra y de la individualidad de la susodicha expresión personal, debemos señalar que, con todo el respeto que se merece Bourdieu, existe realmente un discurso propio de la fotografía, pero tendríamos que añadir que no se trata de un discurso estético. Estamos frente a un vasto proyecto de deconstrucción en el que el arte se halla distanciado y separado de sí mismo. (Krauss 1990: 226)

De esta manera, se invierte el punto de vista más generalizado. Si bien tradicionalmente se ha reflexionado acerca de cómo puede verse la fotografía desde el campo de las artes —posición que está en la base de los planteamientos de Bourdieu-, la crítica estadounidense que venimos siguiendo hace una apología de la fotografía como un campo autónomo que, por un lado, ha obligado al replanteamiento de algunas concepciones estéticas y, por otro, obliga a tener en cuenta espacios discursivos que van más allá del estético.

Krauss pone un especial acento en el espacio discursivo de la fotografía de archivo - el cual, por cierto, y como lo desarrollaremos en el Capítulo 8, ha sido sujeto de una profunda transformación recientemente, de la mano de la digitalización y de las nuevas prácticas de difusión y consumo de imágenes a través de Internet-, pero como es evidente, existen muchos otros que, en conjunto, conforman el vasto campo fotográfico: el periodístico, el científico, el de la foto familiar, el del diletantismo, el publicitario, el legal, entre otros. 


\subsection{EL CANAL Y LA SITUACIÓN DE COMUNICACIÓN}

Para completar nuestra especulación en torno al triángulo pragmático que hemos planteado, es preciso dirigir nuestra atención en este punto a su tercer elemento constitutivo: el canal y la situación de comunicación. Lo haremos de manera transitoria, sirviéndonos este apartado como vínculo al Capítulo 8, en el cual exploraremos el factor pragmático de la profunda transformación que la distribución y consumo de imágenes fotográficas han sufrido en las últimas dos décadas, a raíz de la introducción de los procesos digitales y de la divulgación en el uso de Internet.

El canal de comunicación es, con toda certeza, el elemento más concreto de los componentes de dicho triángulo. Es, también, el más cercano al receptor, aquel que vehicula, finalmente, el contacto con el mensaje. El canal de comunicación será, además, transmisor de elementos de tipo ideológico y contextual que se incorporarán de manera inevitable a la lectura de la imagen. Resuena aquí el eco de la conocida fórmula macluhaniana convertida prácticamente en eslogan y que, sin que sea nuestra intención banalizarla, hemos de rememorar: «el medio es el mensaje».

Una vez más, la libertad interpretativa del receptor parecería estar, si no coartada, al menos puesta en entredicho debido al sesgo ideológico introducido por el canal comunicativo. Ya anteriormente, en el Capítulo 3, hemos aludido a las ideas de Michel de Certeau en torno a la posición del débil ante los embates de las comunicaciones generadas desde el sistema hegemónico y transmitidas a través de canales que forman parte del propio sistema. A partir de este marco, y situados en el punto de vista del receptor, hemos de reflexionar en torno al consumo de mensajes como una de las formas fundamentales del consumo entendido en un sentido amplio, factor determinante en las sociedades actuales. Retomemos el hilo de este autor: 
Estos elementos (realizar, apropiarse, inscribirse dentro de relaciones, situarse en el tiempo) hacen de la enunciación, y secundariamente del uso, un nudo de circunstancias, una nudosidad inseparable del «contexto» del cual, de manera abstracta, se la distingue. Indisociable del instante presente, de unas circunstancias particulares y de un hacer (producir a partir de la lengua y modificar la dinámica de una relación), el acto de decir es un uso de la lengua y una operación sobre ella. Se puede intentar aplicar su modelo a muchas operaciones no lingüísticas, al considerar como hipótesis que todos estos usos competen al consumo. (de Certeau 1980b: 398)

En lo que respecta concretamente al mensaje fotográfico, hemos de destacar la enorme susceptibilidad a que su interpretación varíe en función de la situación de comunicación que lo vehicula. Al estar tan condicionado por la forma en que es consumido, su estatuto semántico se ve inevitablemente relativizado. Diversos autores han subrayado este ambivalente hecho. Veamos algunos ejemplos. Desde el ámbito de la teoría semiótica, Schaeffer apunta:

El aspecto más irritante del signo fotográfico, pero también el más estimulante, reside sin duda alguna en su flexibilidad pragmática. Todos sabemos que la imagen fotográfica está al servicio de estrategias de comunicación más diversas. Ahora bien, estas estrategias dan lugar a lo que me propongo llamar normas comunicacionales y que son capaces de modificar profundamente su estatuto semiótico. (Schaeffer 1987: 8)

Paralelamente, en este caso desde el ámbito de la estética, Soulages pone también un gran énfasis en la importancia de las condiciones extrínsecas de recepción de la foto:

Estas condiciones dependen principalmente de la exterioridad y de los sujetos receptores; sin embargo, estos últimos difieren por su historia personal y colectiva; estas condiciones de recepción, por lo tanto, no pueden ser objeto de proposiciones universalizantes, válidas para toda recepción de cualquier foto. (Soulages 1998: 129)

Al igual que en el caso de los otros dos componentes de nuestro triángulo pragmático ya comentados con anterioridad, hemos de resaltar el hecho de que, si bien nos estamos moviendo en el pantanoso terreno del sentido común, es precisamente por ello que debemos adoptar una 
aproximación sistemática a estos elementos, fundamentada en la pragmática. Si bien Eco insiste en la necesidad de distinguir entre la intentio auctoris, la intentio operis y la intentio lectoris (Eco 1979 y 1990), cabe aquí la especulación en torno a dónde está puesto el acento en la actualidad:

[...] la fotografía no nos dice tanto la verdad del objeto como el punto de vista del sujeto que fotografía. Por eso puede depender de la creación y el arte. Reconocerlo es permitir una decodificación de las ideologías que sustentan las fotos -aspecto político y crítico-así como un juego y una construcción con sus códigos: aspecto estético. Pero, en un reportaje aparecido en la prensa, ¿quién es el creador, si lo hay? Sin duda alguna el fotógrafo [...], pero también el equipo que trabaja con él, durante los reportajes y en el diario. ¿Es compatible? Por tanto, pasamos de una visión romántica, individualista y simplificadora del creador aislado, independiente y único amo a bordo, a una visión dialéctica, material y plural del equipo de creadores. Un creador jamás está solo, siempre depende de manera específica de su entorno. (Soulages 1998: 54-55)

A partir de esta especulación, Soulages continúa con su relativización de la intención del autor, la cual, en la práctica, se ve muchas veces eclipsada debido al sesgo introducido por el canal de transmisión, que es la manifestación final y concreta del cambio al que se somete a la imagen al pasar de un espacio discursivo a otro. El ejemplo por antonomasia es el de la foto de prensa que migra - algunos dirían trasciende- a otros ámbitos, no solo interpretativos, sino también especulativos.

Para este tipo de fotografía de reportaje se plantea el problema de la recepción de una imagen: una foto [...] no se recibe de la misma manera en un diario como Libération y en un museo [...]. En efecto, el museo la pone en obra y la prepara así para una plusvalía estética del reconocimiento. Hay una economía de la estética. Por tanto, nos encontramos frente no solo al problema teórico de la recepción sino también al de la especulación intelectual y financiera posible, como para toda obra de arte. (Soulages 1998: 55)

Esta argumentación es muy próxima a la que en el apartado anterior planteamos de la mano de Rosalind Krauss. Pero si nos alejamos del ámbito estético, se impone ir más allá del campo del museo y la galería como vehículos y considerar en su conjunto la diversidad de canales de 
comunicación de nuestras sociedades tecnificadas y mediatizadas, con lo que el propio concepto de canal se ve problematizado. (Ver infra: Capítulo 8) Esta complejidad se ve reflejada en los intentos que desde una diversidad de disciplinas -sociología, antropología, teoría de la comunicación - se han dado y se dan por sugerir modelos que permitan un acercamiento al problema. A pesar de sus diferencias, se imponen, en este marco, las similitudes entre términos diversos que se han propuesto para englobar la compleja red de canales presentes en nuestro entorno, definido a la manera de un megacontexto como semiosfera (Lotman), iconosfera (Gubern), mediasfera (Moles, Debray) o sociedad red (Castells), ${ }^{9}$ entre otros conceptos que de alguna manera buscan concretar el más amplio de aldea global, profecía macluhaniana hoy, acaso, convertida en realidad de la mano de Internet.

Como parte de la alusión a las características multi, inter, trans mediáticas de los mensajes que circulan en ese megacontexto, se ha impuesto la moda de aludir a lo visual, término saco en el que cabe demasiado pero que, en su exaltación de la imagen técnica y en la homologación que propicia de los productos de la alta cultura y los de la cultura popular, ha vuelto a poner a la fotografía —en cierta época eclipsada por otros medios- en el centro de la atención y el debate. Si en la discusión en torno a los géneros, como ya lo subrayamos en el apartado 7.3, se ha hecho notar una confusión en torno a los géneros, cabe preguntarse en qué medida dicha confusión está vinculada y cómo se manifiesta en relación a los canales de comunicación.

Así pues, reinaría un solo género que denominamos «visual» o «arte contemporáneo». La cultura dominante es la de los media. Se dice que la fotografía es el lugar común de una pictorialidad difusa, que la imagen fotográfica es nuestro «equivalente general». [...] Esta es la interpretación que un estudio reciente da sobre la deconstrucción de los géneros clásicos (historia, paisaje, retrato, naturaleza muerta). La fotografía se convertiría en genérica respecto al conjunto de la producción visual.

\footnotetext{
${ }^{9}$ Retomamos aquí estos términos fundamentales que ya habíamos introducido, incluyendo sus referencias de origen, en el apartado 3.5. En adelante nos quedaremos con el primero de ellos, semiosfera, por considerarlo el más cercano a la propuesta de este trabajo.
} 
Artistas y pensadores del arte del siglo XX, francófonos y anglófonos, han utilizado una gran variedad de términos para referirse al arte que se percibe a través de la vista: retiniano, opticalidad, inconsciente de la vista o inconsciente óptico, regímenes escópicos, artes visuales, lo visual, picture, image, visual arts, visual culture. (Picaudé 2001: 30)

La autora citada continúa con una reflexión que nos es, aquí, útil para dimensionar el alcance pragmático de una expresión -lo visual-que, en su apertura y ambigüedad polisémica, refleja toda una concepción del mundo actual y, como tal, influye en los contenidos de los medios, de la prensa, de la publicidad y, por supuesto, del arte.

El artista no debe confundir la ambivalencia, cualidad semántica propia de toda «imagen», con la confusión, dinámica inherente al flujo visual. Cuando el espectador está frente a una imagen (posición de confrontación), se halla en lo visual (posición de inmersión). La contemporaneidad de la imagen y de lo visual en el seno de una misma cultura «entre las bellas artes y los medios de comunicación» sirve de inspiración hoy en día para numerosos trabajos artísticos. (Picaudé 2001: 32)

A La alusión que Picaudé hace al título de Chevrier, entre las bellas artes y los medios de comunicación (2006),10 es más que significativa. En el marco pragmático de la semiosfera actual, no solo es necesario resaltar, como lo ha sido tantas veces, el ya mencionado vínculo u homologación entre la cultura popular y la alta cultura, sino sobre todo, y esto es lo más relevante en el contexto de nuestro estudio, el papel protagonista de la fotografía en el proceso, su autonomía respecto al campo artístico y, más aún, su capacidad de influir e incidir en el mismo. Una vez más, este vínculo puede ser abordado desde la óptica de los géneros, como lo subraya Picaudé: «Reconsiderar, en el momento del todo visual y del todo cultural, una historia de las relaciones entre el arte moderno y la fotografía en términos de géneros, es, en definitiva, tomar posición a favor o en contra de una poética de la fotografía». (Picaudé 2001: 32) Sin embargo, resulta más sustancial apreciarlo a partir de un marco pragmático más amplio el cual,

\footnotetext{
10 La aparente discrepancia de fechas entre la antología de Chevrier (2006) y el título de Picaudé (2001) se debe a que la primera, editada en el año señalado, reúne textos escritos originalmente desde mediados de la década de 1980 a finales de los años noventa.
} 
como hemos sugerido, integre también los otros dos componentes de nuestro triángulo pragmático.

Para profundizar en la siempre conflictiva relación entre arte y fotografía, es necesario integrar, por supuesto, visiones que permitan comprender las transformaciones que los canales tradicionalmente identificados con el campo artístico han manifestado en los últimos veinte años, que es, grosso modo, el período correspondiente a la digitalización fotográfica y la vulgarización del uso de Internet. Tras décadas -diríamos, al menos, medio siglo- caracterizadas por los cuestionamientos de los artistas, a través de sus obras, a los canales de distribución tradicionales del arte, siguen volviendo a aquellos y el debate permanece vivo.

Profundicemos en la visión crítica que al respecto propone Bourriaud: «Aunque rechacen las formas académicas de la exposición, los artistas de los años noventa consideran el lugar de exhibición como un espacio de cohabitación, un escenario abierto a medio camino entre el decorado, el estudio de filmación y la sala de documentación.» (Bourriaud 2000: 87) En la concepción de este autor, puesta en acto mediante su labor como gestor cultural, son esenciales las transformaciones en los usos de dicho espacio: «Mientras que el lugar de exposición constituía un medio en sí mismo para los artistas conceptuales, actualmente se ha convertido en un lugar de producción entre otros. [...] Un modelo, un laboratorio, un terreno de juego; en todo caso, nunca el símbolo de cualquier otra cosa, y mucho menos una metonimia.» (Bourriaud 2000: 89-90)

Los canales de distribución del arte quedan, de esta manera, replanteados, y al mismo tiempo que se reconsideran los tradicionales, se desmitifica al arte público y se asimila la utilización de otros, pertenecientes a la cultura mediática: «El socius, es decir, la totalidad de los canales que distribuyen y difunden la información, es lo que se convierte en el verdadero lugar de la exposición para el imaginario de los artistas de esta generación. El centro de arte o la galería son casos particulares, pero forman parte integrante de un conjunto más amplio, la plaza pública». (Bourriaud 2000: 90) 
La visión bourriaudiana, por lo tanto, no propone tanto un rechazo de los canales propios de la tradición artística, sino más bien una asimilación con los del espacio público; no una exaltación desmedida de este, sino una homologación de la importancia de ambos y, sobre todo, la aceptación de que a partir de ellos es posible proponer y generar nuevos usos y formas de hacer.

No se trata entonces de oponer la galería (lugar del «arte separado» y por lo tanto malo) a un espacio público fantaseado como ideal y como el lugar de la «buena mirada» sobre el arte, la de los transeúntes, que se fetichizan ingenuamente como antaño se fantaseaba con el buen salvaje. La galería es un lugar como los demás, un espacio imbricado en un mecanismo global, una base sin la cual no es posible ninguna expedición. Un club, una escuela o una calle no son sitios mejores, sino simplemente otros lugares para mostrar arte. (Bourriaud 2000: 92)

No se nos escapa el hecho de que las reflexiones de Bourriaud se dirigen a manifestaciones radicales del arte contemporáneo, por lo que surge la pregunta de cómo se inserta específicamente la producción fotográfica en el marco que venimos planteando. Si la imagen fotográfica era tradicionalmente versátil durante el siglo y medio en el que estuvo indisociablemente vinculada al papel como soporte físico, la era de la videosfera le concedió, ya en las últimas décadas de dicho período, un carácter mucho más dinámico y versátil, cada vez menos vinculado a los constreñimientos de su materialidad. ${ }^{11}$ Pero más allá de la imagen fija proyectada o vinculada al monitor, la verdadera revolución llega cuando la foto adquiere un carácter numérico, cuando se digitaliza. La imagen digital ligada a un sistema, esto es, no solo producida, sino también distribuida y consumida a través de canales digitales, es un objeto verdaderamente volátil que propicia, a su vez, nuevos usos y revoluciona conceptos como el de lo fotografiable y, por supuesto, el de lo visual. Ya hemos visto que Picaudé y Arbaïzar gustan de plantear preguntas de difícil respuesta. He ahí

\footnotetext{
${ }^{11}$ Remitimos a las reflexiones en torno a las aportaciones semánticas del soporte de la imagen que planteamos en el apartado 5.7.
} 
la que nos lanzan desde el primer párrafo de La confusión de los géneros en fotografía:

La fotografía difunde la cultura visual —ella misma es su principal modo y soporte de difusión-. De la era del nitrato de plata a la era de lo numérico, la imagen fotográfica se ha impuesto de distintas maneras en el proceso de difusión: como reproducción, estándar, modelo, referente, mensaje... Y con ella, lo visual, que designa a la vez lo figurativo y lo visible, ha reinvestido el arte, la cultura y la comunicación. ¿Acaso la difusión ha pasado a convertirse en el modelo de la creación? (Picaudé y Arbaïzar 2001: 11)

En su nuevo protagonismo, la difusión, que implica ineludiblemente la consideración del canal, se vuelve verdaderamente tiránica. Su peso específico en una sociedad caracterizada por el uso de medios digitalizados es tal, que obliga a la revisión de los modelos comunicativos tradicionales. Sigamos con el planteamiento de los autores antes citados:

Bajo el efecto de la difusión, que constituye su modo mayor de expansión, la industria cultural promueve una descalificación generalizada, una disolución de los juicios de los expertos. [...] De este modo, la difusión al ir acompañada de disolución ha producido finalmente confusión. (Picaudé y Arbaïzar 2001: 11)

Difusión... confusión...y también homogeneización. La movilidad de las imágenes en la nueva difusión es proporcional a la variedad de puntos de vista en la nueva participación homogeneizadora, componentes, a su vez, de una nueva pragmática. $\mathrm{Y}$ al hablar de estos conceptos en el contexto actual es imperante tomar en consideración a Internet. Pero, ¿qué es Internet? ¿Un medio? ¿Un nuevo medio? ¿Una plataforma? ¿Una interfaz? ¿Incluso, un espacio discursivo?

La nueva movilidad social de las imágenes propiciada por los medios digitales es un fenómeno sin precedentes en la historia. Impacta la producción, distribución y consumo de fotos. Genera una nueva pragmática. Transforma lo fotografiable. Dedicaremos a este tema el próximo capítulo. 

TERCERA PARTE: EL ANÁLISIS PRAGMÁTICO

CAPÍTULO 8

\section{UN NUEVO MARCO PRAGMÁTICO: TRANSFORMACIONES DEL CAMPO FOTOGRÁFICO EN LA ERA DIGITAL}





\subsection{ESTADO DE LA CUESTIÓN}

Los conceptos asociados a la tecnología digital o numérica -imagen digital, digitalización, fotografía digital, impresión digital, retoque digitalabarcan una enorme cantidad de áreas y funciones (esto solamente en el ámbito que compete a este trabajo, el de la imagen fotográfica, sin tomar en consideración otros campos como el científico, el de la catalogación de información, el del audiovisual, el de la imagen virtual, la edición y un larguísimo etcétera).

En el caso específico del campo fotográfico, desgraciadamente se ha asociado el término fotografía digital con la fotografía manipulada, palabra, esta, que goza de una pésima reputación. Sometámosla a una prueba acaso un poco ingenua, sin duda arbitraria, pero no exenta de cierta representatividad: al hacer una consulta en Internet a través del motor de búsqueda del portal Google, el de uso más difundido en la actualidad, los diez primeros resultados que se nos muestran de la palabra manipulación tienen que ver, entre otras, con las siguientes connotaciones: «ejercicio velado, sinuoso y abusivo del poder», «estrategias y técnicas de los Dueños del Mundo» (sic), «dominio y control sobre los seres personales», «relación asimétrica entre, al menos, dos personas», «antiguo arte, ciencia y tecnología de hacer que otros hagan lo que tú quieres que hagan», «el arte de conservarse libres ante la manipulación»... Solo un resultado se refiere al vocablo en su sentido estricto, advirtiendo de la posibilidad de lesiones en la espalda debido a «la manipulación y el transporte de cargas». Otro, correspondiente a la popular enciclopedia en línea Wikipedia, ${ }^{1}$ explica el sentido especializado de la manipulación directa como un «estilo de interacción hombre-máquina». Por último, el décimo resultado nos remite al tema de la manipulación genética, con el que en su momento estableceremos ciertas concomitancias.

1 Wikipedia: http://es.wikipedia.org/wiki/Manipulaci\%C3\%B3n_directa, consultado en mayo de 2008. 
Aunque asistemática e indudablemente cuestionable desde el punto de vista estadístico, haremos la petición de principio de considerar esta aproximación como válida. Al interpretarla, vemos que las connotaciones predominantes en el sentir general -al menos el $60 \%$ - son las que tienen que ver con aspectos negativos, relacionados con ideas conspiracionistas de dominio y control, frecuentemente por parte de una entidad superior indeterminada.

Esta discusión, aunque caprichosa, no es vana. Y no lo es debido a que históricamente la fotografía ha sido sinónimo de realismo, veracidad, objetividad, fidedignidad, neutralidad, imparcialidad, etcétera. Ha gozado, incluso, del estatus de una prueba de verdad desde el punto de vista legal. Al quedar convertido el término fotografía digital, como de hecho suele suceder, en sinónimo de fotografía manipulada, se rompe con todo este ethos. Ello no se debe simplemente a una cuestión semántica, sino a que efectivamente, en la práctica, algo que ya se venía resquebrajando desde mucho antes en cuanto a la credibilidad de la imagen fotográfica y que la fotografía artística ya cuestionaba, grosso modo, desde la década de 1960, se rompió definitivamente con la introducción en los ochenta de las técnicas de retoque digital de imágenes y su vulgarización a partir de los noventa. ${ }^{2}$ «De forma progresiva hemos alcanzado la feria de la confusión semiótica donde la identidad de la imagen ha quedado tremendamente en entredicho.» (Fontcuberta 2010: 186)

Las implicaciones psicológicas y sociológicas del cambio de conciencia al que nos referimos -aunque fascinantes- exceden las posibilidades de este trabajo. Si nos hemos detenido en esta reflexión, es simplemente para exorcizar algunos de los demonios ilusorios que rodean las nuevas prácticas fotográficas. La fotografía basada en la tecnología digital —permítasenos insistir en una verdad de Perogrullo-, no está necesariamente manipulada. La inmensa mayoría de las prácticas

\footnotetext{
${ }^{2}$ Las fechas que encontramos en los documentos suelen ser equívocas ya que, si bien tanto los equipos de toma digital como el software de retoque existen desde la década de 1980 a nivel de prototipos, su comercialización a escala masiva no se da sino hasta 1990. Asimismo, su perfeccionamiento técnico y penetración en el mercado no fue inmediata.
} 
fotográficas actuales, aun realizadas con equipos digitales, caen en el ámbito de la fotografía directa. Los así llamados -mal llamadosprogramas de manipulación digital, deben ser llamados programas de retoque digital, a fin de evitar perversiones derivadas del lenguaje. El programa de mayor difusión a la fecha, el Adobe Photoshop, cuya versión 1.0 se presentó en 1990, fue originalmente promovido por sus fabricantes como tal: un programa de retoque. Hoy en día, debido a la expansión de sus funciones y de sus usos en el ámbito general de la imagen, se promueve fundamentalmente como una herramienta de edición y composición. ${ }^{3}$

Estas discusiones estuvieron en un momento inicial en el centro del debate:

Simultáneamente a la celebración del 150 aniversario de la fotografía, la Asociación Nacional de Fotógrafos de Prensa hacía un llamado a la creación de un código de ética que regulara la manipulación digital de las imágenes, la Associated Press adoptaba una política de «no manipulación del contenido de una fotografía en ningún sentido» y la Asociación de Prensa Noruega proponía la creación de un símbolo de advertencia estandarizado internacionalmente que debía ser insertado en cualquier fotografía manipulada. ${ }^{4}$ (Mitchell 1992: 19)

Hoy, sin embargo, esta discusión está prácticamente superada y las soluciones propuestas en aquel momento, vistas con la perspectiva del tiempo, en muchas ocasiones nos resultan ingenuas.

Pero más allá de estas precisiones, el tema de fondo que aquí nos interesa considerar es si la introducción de la tecnología digital ha implicado la generación de un nuevo lenguaje fotográfico. En este sentido, nuestra posición, como ya lo hemos dejado entrever, es de reserva. El hecho de que este sea un campo en pleno desarrollo dificultó su comentario en los primeros años de la transición analógico-digital -fundamentalmente, como ya indicamos, la década de los noventa-, y lo sigue haciendo hoy en día, aunque encontremos ya un marco mucho más estable. Ya antes hemos aludido, a manera casi de estribillo, a la afirmación hecha por Barthes de

\footnotetext{
3 Web institucional de Adobe: http://www.adobe.com/es/products/photoshop/photoshop/, consultado en mayo de 2008.

${ }^{4}$ La traducción es nuestra.
} 
que es «por el hecho de ser la Fotografía un objeto antropológicamente nuevo por lo que debe situarse el margen [...] de las discusiones corrientes sobre la imagen» (Barthes 1980: 152); aquí insistimos en ella ya que hoy, ante la omnipresencia de la información fotográfica, es inevitable sentir una cierta indefensión ante la necesidad de elegir por dónde tomar la madeja, y sin embargo no podemos renunciar a intentarlo.

$\mathrm{Si}$ en principio el retoque digital tuvo como referente las posibilidades de la fotografía analógica y tendió, por lo tanto, a su imitación a fin de poder combinar en una imagen fotografías provenientes de diversas fuentes y con distintas calidades, es indudable que en un estadio posterior - el cual, sin embargo, abarca todavía muy pocos años— ha comenzado la transición de la simple imitación a la generación de posibilidades propias, aunque estas se encuentran más vinculadas al campo de la imagen sintética que al de lo específicamente fotográfico. Esto nos lleva a otra ambigüedad semántica: con frecuencia se llama fotografía digital a una imagen que puede contener en sí elementos de origen fotográfico, pero que no es ya propiamente una fotografía.

Los primeros años de divulgación del retoque digital trajeron consigo trabajos sumamente ingenuos en el ámbito artístico, los cuales se limitaban a explotar las posibilidades del proceso de cortar y pegar omnipresentes en el arte de diversas épocas, pero que ahora se veían, más que democratizadas por la amplísima difusión de la tecnología, simplemente vulgarizadas. Estas técnicas, propias del collage en el ámbito de la plástica o del positivado combinado, el fotomontaje y el fotocollage en la fotografía desde el siglo XIX, siguen siendo la actitud de base desde los modernos arcimboldos hasta los dadaístas de fin de semana, verdaderos niños con juguete nuevo que han creído, embotados frente al monitor, estar descubriendo un lenguaje innovador, sin darse cuenta de que en su mayoría no han hecho sino perpetuar la ya añeja actitud pictorialista en una versión descafeinada, personal, exactamente en el mismo sentido en que son personales los ordenadores o en que eso que llamamos escritorio desplegado en la pantalla del ordenador -para seguir con la jerga 
informática- se convierte en el centro del universo. Se trata, sin duda, de un momento de ambigüedad, donde la difusión masiva de una tecnología y de sus productos está provocando cambios que aún son difíciles de objetivar, cambios, inclusive, de actitud respecto del medio.

[...] la imagen establece nuevas reglas con lo real. Hoy tomar una foto ya no implica tanto un registro de un acontecimiento como una parte sustancial del mismo acontecimiento. Acontecimiento y registro fotográfico se funden. Aplicando la interpretación indexial de la fotografía pensábamos que algo del referente se incrustaba en la fotografía; pues ahora hemos de pensar lo contrario: es algo de la fotografía lo que se incrusta en el referente. Ya no existen hechos desprovistos de imagen ni la documentación y transmisión del documento gráfico son fases indisociadas del mismo suceso. (Fontcuberta 2010: 28)

Más allá del aspecto superficial que hemos comentado del uso de las herramientas fotográficas digitales, se encuentra el tema sustancial de la digitalización como generadora de nuevos procesos lógicos de pensamiento. Es en este ámbito, que no compete solamente a la fotografía, sino a infinidad de campos dentro de la cultura digital, en el que hay que centrar la atención. En ciertos aspectos el fotógrafo —como el músico, el escritor, el productor de vídeo, el internauta, el usuario de redes sociales...- se ha convertido en un operador, cuya actividad esencialmente se circunscribe a la realización de elecciones dentro de un universo finito de menús informáticos cuyas posibilidades están predeterminadas. De ahí que, en el otro extremo, algunos de los usos más radicales y a la vez más especializados de la informática como medio generador de imágenes se concentren en la intervención directa sobre el software.

A otro nivel, la discusión en torno a la fotografía digital frecuentemente se ha centrado en los aspectos que se refieren a la producción fotográfica, mientras que acaso el impacto mayor de la tecnología compete a las facetas de la distribución y consumo de imágenes, todo ello vinculado a la inconmensurable expansión en el uso de Internet, coincidiendo con el período que venimos reseñando. Esta idea no es propia, así lo señala, por ejemplo, Manovich, uno de los principales analistas de la 
cultura digital, cuando afirma que «la comprensión popular de los nuevos medios los identifica con el uso del ordenador para la distribución y la exhibición, más que con la producción». (Manovich 2001: 63)

En relación a esta tríada —producción, distribución, consumo-que ya hemos mencionado con anterioridad, este es un momento propicio para aclarar que su uso se ha difundido extensamente en los años recientes entre los estudiosos de Internet, para explicar los nuevos usos sociales y económicos vinculados a la red. Cabe recordar, no obstante, que el concepto proviene de la teoría económica, siendo base, por ejemplo, de la Introducción general a la crítica de la economía política (1857), 5 de Marx, título que de manera muy posterior, pero cercana a nuestros intereses, es parafraseado por Baudrillard en su Crítica de la economía política del signo (1972). De esta manera, no solamente hay que destacar su uso en relación a la explicación de fenómenos definitorios de la sociedad postindustrial y del capitalismo tardío, sino también a los referentes al sistema del arte (cfr. Acha 1997: 15 y ss.) en una época señalada por la desmaterialización de la obra convertida en información pura. Valga esta aclaración para dimensionar en su justa medida la importancia de estos conceptos dentro de una continuidad histórica.

Retomando las reflexiones de Manovich y como resultado de sus consideraciones, hemos de proponer que, en lo que toca a la teoría fotográfica, la dimensión pragmática adquiere hoy una relevancia sin precedentes como enfoque que permite abordar lo que podemos llamar la vida social de las imágenes en esos tres momentos definidos por la tríada arriba mencionada y que tan profundamente se han transformado en la cultura digital. Es a partir de dicha posición que en este capítulo abordaremos el fenómeno de la expansión de la fotografía digital durante los últimos veinte años.

${ }^{5}$ Marx, Karl. Introducción general a la crítica de la economía política (1857). México: Siglo XXI, 1989. 


\subsection{EL CAMPO HIPEREXPANDIDO DE LA FOTOGRAFÍA DIGITAL}

En los capítulos precedentes hemos hecho un recorrido que, grosso modo, corresponde al que la propia teoría fotográfica ha seguido durante el pasado medio siglo. Aspectos teóricos de fondo, como son el debate entre la semiótica del icono y la del índex o el paso de un análisis de tipo inmanente a otro que privilegia al receptor y su horizonte contextual, son manifestaciones de la profunda vinculación entre las artes de hacer y las maneras de formar propias de una época, y los marcos conceptuales que, desde la crítica y la academia, intentan explicar e incluso, en ocasiones, validar y legitimar a aquellas.

El giro pragmático presentado por los diversos enfoques críticos en épocas recientes (ver supra: Capítulo 3.5) $-\mathrm{y}$ que no es, por supuesto, exclusivo de la teoría crítica fotográfica- es resultado de la insistente necesidad de explicar los procesos creativos y comunicativos en lo que, apelando a la denominación más abarcadora posible, llamaremos la cultura del ordenador, con sus infinitas aplicaciones.

Para entrar en materia, apelaremos a un concepto que ya nos es familiar. Como parte del desarrollo que planteamos desde el inicio de nuestra reflexión, hemos aludido a diversos gestos (cfr. Flusser 1991) relacionados con el ámbito de la fotografía, concepto que aquí deseamos retomar para llegar a su consideración en el momento actual. Recordemos la definición flusseriana:

Yo creo que mucha gente estará de acuerdo en entender los gestos como movimientos del cuerpo y, en un sentido amplio, como movimientos de los instrumentos y herramientas unidos al cuerpo.

[...]

El tipo de movimientos a los que nos referimos cabe describirlos como «formas de expresión» de una intención. Lo cual nos proporciona una hermosa definición: «Los gestos son movimientos del cuerpo que expresan una intención». (Flusser 1991: 7-8) 
En nuestra deriva inicial (Capítulo 1), asistimos al gesto fundacional de Niépce, quien a partir de otro gesto, el de asomarse por la ventana mirando a través de un incipiente aparato fotográfico, inauguró el gesto de fotografiar, gesto moderno o, más aún, gesto emblemático de la modernidad, gesto omnipresente en nuestras sociedades en el transcurso de la segunda mitad del siglo XIX y durante el XX, gesto especulativo, símbolo de una manera de vincularse con la realidad:

El gesto del fotógrafo es un gesto filosófico; o, dicho de otro modo: desde que se inventó la fotografía es posible filosofar no solo en el medio ambiente de las palabras, sino también en el de las fotografías. Ello se debe a que el gesto de fotografiar es un gesto de ver. $\mathrm{O}$, lo que es lo mismo, es el gesto de lo que los pensadores antiguos llamaron theoria, a la vez que denominaban idea a la idea que se deriva del mismo. En contraste con la mayor parte de los otros gestos, el gesto de fotografiar no apunta directamente a cambiar el mundo o a comunicarse con los demás, sino que tiende a contemplar alguna cosa y a fijar la visión, a hacerla «formal». (Flusser 1991: 104-105)

A lo largo del desarrollo de este trabajo hemos aludido también, en diferentes momentos, a otros gestos igualmente asociados con el ámbito fotográfico, como son el gesto de mirarse al espejo, el gesto de sonreír a la cámara, el gesto de posar, el gesto de acicalarse para entrar en el fotomatón... Ha llegado el momento, así, de centrar nuestra atención en otro gesto característico que hoy por hoy es ya incuestionablemente fotográfico, aunque a la vez pone en crisis al tradicional gesto de fotografiar, a saber: el gesto de operar con el ordenador. En efecto: el gesto de fotografiar ha perdido especificidad y se ha equiparado, en lo que toca a la interacción del hombre con el aparato, con otros modos de producción simbólica.

En relación a estos gestos culturales, en algún momento dijimos, de la mano de Szarkowski (1978), que las fotografías pueden ser espejos o ventanas (ver supra: Capítulos 1.1 y 2.1), esto es, propician de manera metafórica actitudes semejantes a las de los gestos de mirarse en el espejo o de asomarse por la ventana: nos permiten mirarnos a nosotros mismos o asomarnos a una realidad externa. En este punto es necesario que 
incorporemos las características de esa cultura del ordenador a la que aludíamos anteriormente y que, con esa base, sumemos un nuevo elemento:

\section{Espejo / Ventana / Pantalla}

Puede ser ahora de la mano de Baudrillard que nos introduzcamos en este que es un nuevo espacio de imaginería pero, a la vez, un nuevo ámbito de relación entre el hombre y los aparatos productores de imágenes. Dejemos que sea Mirzoeff quien lo presente en primera instancia:

[Conforme] el capitalismo de consumo continuaba aumentando, pronto quedó bastante claro que la sociedad del espectáculo de Debord era en sí misma el producto del boom consumista de posguerra, más que una forma estable y reciente de la sociedad moderna. El filósofo francés Jean Baudrillard anunció el fin de la sociedad del espectáculo en 1983. En su lugar declaró la edad del «simulacro», es decir: una copia sin original. El simulacro fue la última etapa de la historia de la imagen, pasando de un estado en el que «enmascara la ausencia de la realidad básica» a una nueva época en la que «no mantiene relación alguna con ninguna realidad: es su propio y puro simulacro». (Mirzoeff 1999: 53-54)

El espacio del simulacro será precisamente la pantalla, espacio en el que se depliega la virtualidad:

Las máquinas solo producen máquinas. Esto es cierto cada vez más a medida que se van perfeccionando las tecnologías virtuales. A cierto nivel de maquinización, de inmersión en la maquinaria virtual, deja de haber distinción hombre/máquina: la máquina está en los dos lados del interfaz. Quizá ya solo seamos su propio espacio, el hombre convertido en la realidad virtual de la máquina, su operador en espejo. Eso guarda relación con la esencia misma de la pantalla. No existe un más allá de la pantalla como existe un más allá del espejo. Las dimensiones del tiempo mismo se confunden allí en el tiempo real. Y como la característica de cualquier superficie virtual es, ante todo, estar allí vacía y, por tanto, poder ser llenada por lo que sea, de nosotros depende entrar en tiempo real, en interactividad con el vacío. (Baudrillard 1996b: 205)

Adentrarse en el ámbito de la pantalla teniendo como guía a Baudrillard conlleva, por supuesto, implicaciones. Para él, se trata del 
espacio por excelencia del simulacro, de esa sociedad a la que se ha referido como pantalla total.

Vídeo, pantalla interactiva, multimedia, Internet, realidad virtual: la interactividad nos amenaza por todos lados. Lo que estaba separado se ha confundido en todas partes, y en todas partes se ha abolido la distancia: entre los sexos, entre los polos opuestos, entre el escenario y la sala, entre los protagonistas y la acción, entre el sujeto y el objeto, entre lo real y su doble. Y esta confusión de los términos, esta colisión de los polos hacen que en ningún sitio exista ya un juicio de valor posible: ni en arte, ni en moral, ni en política. Mediante la abolición de la distancia, del «pathos de la distancia», todo se vuelve indeterminable. Incluso en el ámbito físico: la excesiva proximidad del receptor y de la fuente de emisión crea un efecto Larsen que interfiere en las ondas. (Baudrillard 1996b: 203)

Otro de los aspectos teóricos que hemos considerado anteriormente como parte de nuestro marco conceptual vuelve aquí imbuido de una particular relevancia: nos referimos a las transformaciones del modelo de comunicación como esquema ilustrativo de los diversos énfasis que caracterizan a las escuelas de teoría crítica. Partiendo como momento simbólico de la publicación de La hora del lector, de Castellet (1957), analizamos en el Capítulo 3 ese gran flujo paulatino de las escuelas teóricas posteriores al estructuralismo, conducente a privilegiar el rol activo y preponderante del receptor. Baudrillard, al plantear el fenómeno de «la excesiva proximidad del receptor y de la fuente de emisión», pone el dedo en la llaga en su crítica de la sociedad actual. ¿Existe verdaderamente posibilidad de comunicación cuando el fenómeno de inmersión en la pantalla conduce invariablemente a un metadiscurso? ¿No es esto, acaso, una forma de solipsismo? Volvamos al pensamiento del pensador francés:

A diferencia de la fotografía, del cine y de la pintura, donde hay un escenario y una mirada, tanto la imagen vídeo como la pantalla del computer inducen una especie de inmersión, de relación umbilical, de interacción «táctil», como decía ya McLuhan de la televisión. Inmersión celular, corpuscular: uno penetra en la sustancia fluida de la imagen para modificarla eventualmente, del mismo modo que la ciencia se infiltra en el genoma, en el código genético, para transformar desde ahí al cuerpo mismo. Uno se mueve como quiere y hace lo que quiere con la imagen interactiva, pero la inmersión es el precio de esta disponibilidad infinita, de esta combinatoria abierta. (Baudrillard 1996b: 204) 
El planteamiento es en extremo sugerente, pero se presentan más preguntas: ¿es válido, en el estado de cosas actual, a quince años de escritas las anteriores palabras, sostener la afirmación inicial, «a diferencia de la fotografía», cuando esta ya se encuentra totalmente integrada en los procesos realizados mediante el ordenador? La fotografía, hoy por hoy, ha dejado de ser un intruso que se digitaliza mediante el escaneo para entrar en la pantalla del ordenador: es ella misma, por el contrario, información pura desde el momento de su generación, es pantalla total.

Asistimos a un proceso imparable de desmaterialización. La superficie de inscripción de la fotografía argéntica era el papel o material equivalente, y por eso ocupaba un lugar: trátese de un álbum, un cajón o un marco. En cambio, la superficie de inscripción de la fotografía digital es la pantalla: la impresión de la imagen sobre un soporte físico ya no es imprescindible para que la imagen exista, por tanto, la foto digital es una imagen sin lugar y sin origen, desterritorializada, no tiene lugar porque está en todas partes. (Fontcuberta 2010: 12-13)

La necesidad de un cambio radical en nuestro entendimiento de la fotografía ligada a la cultura del ordenador choca aún, de manera demasiado frecuente, con las concepciones del medio que se fueron construyendo a lo largo de un siglo y medio de historia. El cambio es abarcador: no solo comprende, como lo establecimos en el apartado anterior, lo tocante a la producción fotográfica, sino también $-\mathrm{y}$ nuestro punto de vista tenderá a privilegiar esta idea-a su distribución y consumo. Se trata, por lo tanto, de un giro pragmático cuya magnitud aún no es posible dimensionar plenamente.

Una visión precoz que supo captar en buena medida, aún en un momento temprano, los extensos alcances que la digitalización de la fotografía tendría en la entonces todavía incipiente cultura del ordenador, fue la de Mitchell, en su ya clásico El ojo reconfigurado (1992). También encontramos ahí espejos y pantallas, así como la idea de inmersión, que en su caso toma los nombres de habitar e interactuar.

Oliver Wendell Holmes llamó al daguerrotipo «un espejo con memoria»: podemos pensar en un sistema de creación de imágenes digitales o de 
gráficos por computadora como una memoria con un display. Al seleccionar de entre los procesos disponibles de visualización e impresión, y mediante el control de sus parámetros, es posible reflejar externamente los contenidos de una matriz de valores de intensidad almacenados internamente, esto a través de múltiples salidas. Hay, por lo tanto, un cambio fundamental en nuestra relación con las imágenes. No estamos limitados a mirar las imágenes digitales: podemos habitarlas activamente e interactuar con ellas de manera estrecha. ${ }^{6}$ (Mitchell 1992: 80)

Más adelante volveremos sobre las ideas de Mitchell que, por cierto, no han tardado en mostrar señales de envejecimiento. De momento, y a fin de seguir tramando nuestro discurso, nos quedaremos con la idea fundamental de la imposibilidad de hablar de la fotografía digital sin referirmos al marco muchísimo más amplio de la digitalización en general, con todas sus implicaciones en infinidad de campos. Engarcémonos ahora con el pensamiento de Lev Manovich, un autor fundamental en el marco de la reflexión en torno a este tema. A propósito de la cultura del ordenador, el autor ruso afincado en Estados Unidos reconoce la importancia y el privilegio de encontrarnos en un momento fundacional. «Hoy asistimos al surgimiento de un nuevo medio, que es el metamedio del ordenador digital y, a diferencia de lo que pasó hace cien años [cuando surgió el cine, proceso que no fue documentado al detalle], somos plenamente conscientes de la importancia de esta revolución». (Manovich 2001: 49)

Siendo este un aspecto positivo de la cuestión, es asimismo necesario advertir, como lo hace el mismo Manovich, del riesgo de caer en especulaciones fantasiosas, que prontamente pierdan su posible valor al ser rebatidas por la evolución de la propia realidad a corto plazo.

[...] los análisis de nuestro tiempo reconocen la importancia de la apropiación de la cultura por parte de los ordenadores, pero se componen, en general, de especulaciones sobre el futuro más que de una documentación y una teoría del presente. Los investigadores del mañana se preguntarán por qué los teóricos, con su gran experiencia en el análisis de las viejas formas culturales, no trataron de describir los códigos semióticos de los medios informáticos, sus modos de discurso y sus patrones de recepción por la audiencia. $\mathrm{Si}$ ya habían reconstruido concienzudamente el modo en que surgió el cine a partir de las formas culturales precedentes (el panorama, los

\footnotetext{
${ }^{6}$ La traducción es nuestra.
} 
juguetes ópticos y los peep shows), cabría preguntarse por qué no intentaron elaborar una genealogía similar del lenguaje de los medios informáticos justo en el momento en que llegaba a la existencia; esto es, cuando los elementos de las formas culturales previas que lo moldeaban aún resultaban claramente visibles y reconocibles, antes de fundirse en un lenguaje coherente. (Manovich 2001: 49-50)

Es precisamente en esa encrucijada en la que nos encontramos en relación a la fotografía digital como nuevo medio. Si bien en los capítulos precedentes hemos profundizado en las características de la fotografía como lenguaje, no podemos aventurarnos a concluir este trabajo sin antes esbozar nuestra visión del impacto de la transición de lo analógico a lo digital en términos de explicar cómo la nueva tecnología afecta a los procesos de codificación y, por lo tanto, propicia un nuevo -sí, no le tengamos temor a la palabra-, un nuevo lenguaje.

Cuando he puesto la palabra lenguaje en el título del libro [El lenguaje de los nuevos medios de comunicación], no pretendía sugerir que necesitamos volver a la fase estructuralista de la semiótica para comprender los nuevos medios. Pero, dado que la mayoría de los estudios sobre ellos y sobre la cibercultura se centran en sus dimensiones sociológica, política y económica, consideraba importante emplear la palabra lenguaje para hacer notar que este libro tiene un objetivo diferente, a saber: las convenciones que están surgiendo, los patrones de diseño recurrentes y las principales formas de los nuevos medios. (Manovich 2001: 56)

Estamos llegando, así, al aspecto central del asunto. La pregunta que se plantea en nuestro horizonte, llegados a este punto de nuestro discurrir, es si la digitalización ha generado un nuevo lenguaje fotográfico o si, por el contrario, simplemente ha acelerado y democratizado maneras de formar que ya existían; asimismo, se plantea la interrogante de si el impacto mayor en su incorporación a la cultura del ordenador se ha dado en lo que toca a la producción o, como ya hemos insinuado, en los aspectos relacionados con los cambios de hábitos y usos que empiezan a predominar en su distribución y consumo. Hay, por supuesto, más interrogantes. Por ejemplo: ¿Hasta que punto la digitalización ha expandido el campo fotográfico? ¿Ha existido tal expansión? 
Abramos esta puerta o, si hacemos caso a Fontcuberta (2010), abramos esta cámara de Pandora. El concepto de campo expandido ${ }^{7}$ en el arte, consagrado por Krauss en su clásico ensayo La escultura en el campo expandido (publicado originalmente en 1978), ya ha sido anteriormente, como es lógico, asociado al devenir del campo fotográfico en las últimas décadas del siglo pasado. Así lo ha hecho, por ejemplo, Ribalta, quien explicaba en un artículo publicado precisamente en el año emblemático del 150 aniversario de la fotografía:

[...] Rosalind Krauss, a propósito de la escultura de los 70, propondría el concepto de campo expandido para referirse a esta cuestión de la pérdida de la especificidad y tanto ella como Crimp entendían las consecuencias que esta nueva práctica implicaba en la concepción de las estructuras institucionales del arte organizadas según un modelo de crítica historicista. (Ribalta 1989: 50)

Pero vayamos a las palabras de la propia crítica estadounidense, quien, por aquellos años, hacía notar que se estaba utilizando el término escultura «para referirse a cosas bastante sorprendentes» y que dicha manipulación de los conceptos solo tenía sentido si la categoría en cuestión se convertía en algo «infinitamente maleable», con base en lo cual sentenciaba:

Las operaciones críticas que han acompañado el arte americano de posguerra han trabajado en gran medida al servicio de esta manipulación. En manos de esa crítica, categorías como la escultura o la pintura han sido amasadas, estiradas y retorcidas en una extraordinaria demostración de elasticidad, revelando la forma en que un término cultural puede expandirse para hacer referencia a cualquier cosa. Y aunque este estiramiento de un término como «escultura» se realiza abiertamente en nombre de la estética de vanguardia —de la ideología de lo nuevo- su mensaje encubierto es el mensaje del historicismo. Lo nuevo se hace confortable al convertirse en familiar, al contemplarlo como una evolución gradual a partir de las formas del pasado. El historicismo actúa en lo nuevo y lo diferente disminuyendo la novedad y mitigando la diferencia. (Krauss 1985: 289)

\footnotetext{
${ }^{7}$ Basado en la aplicación al campo escultórico de lo que, según explica Krauss en el propio ensayo (1985: 296), en matemáticas se conoce como el «grupo de Klein» o en la teoría estructuralista como el «grupo de Piaget», y que se define como una expansión lógica en la que «una serie binaria se transforma en un esquema cuaternario que refleja la oposición original y al mismo tiempo la despliega».
} 
La tentación de asociar estas ideas con la situación actual de la fotografía y jugar así con las palabras de Krauss es irresistible, motivo por el cual nos permitiremos la licencia de sucumbir a ella y, en el siguiente párrafo, la citaremos libremente, cambiando solo algunas palabras (las cuales indicamos en cursivas), estirándolas y haciéndolas maleables. Veamos lo que resulta de esta «demostración de elasticidad»:

«Yo diría que sí sabemos lo que es la fotografía. Sabemos que se trata de una categoría históricamente delimitada, no universal. Al igual que ocurre con cualquier otra convención, la fotografía tiene su propia lógica interna, un particular conjunto de reglas que, aunque pueda aplicarse a distintas situaciones, no puede modificarse demasiado. La lógica de la fotografía es inseparable, en principio, de la lógica del realismo. En virtud de esta lógica, una fotografía es una representación indicial. Podría decirse que con la fotografía digital se traspasa el umbral de la lógica del realismo y se entra en el espacio de lo que podríamos llamar su condición negativa. $\mathrm{Si}$ nos remitimos a las obras de principios de los noventa, probablemente sería más preciso afirmar que la fotografía había entrado en una categórica tierra de nadie. En este sentido, la fotografía asumió plenamente la condición de su lógica inversa y se convirtió en pura negatividad: una combinación de exclusiones. Como puede verse, la fotografía ya no es el privilegiado término medio entre dos términos ajenos. La fotografía no es más que un término en la periferia de un campo en el que hay otras posibilidades estructuradas de diferentes maneras. Y hemos logrado el permiso para pensar en esas otras formas. Para referirse a esta ruptura histórica y a la transformación estructural del ámbito cultural que la caracteriza es preciso recurrir a otro término. En otras parcelas de la crítica, el término que se emplea es posfotografía. No parece existir ninguna razón para no utilizarlo.»8

No pretendemos que esta pirueta verbal —que posiblemente Perec habría considerado adecuada— resulte simplemente en un ejercicio ocioso.

8 Párrafo construido a base de citas tomadas libremente de Krauss (1985: 292-300). Las palabras que se han sustituido, básicamente «escultura» por «fotografía», están en cursivas. 
Lo que deseamos plantear son cuestiones de fondo relacionadas con el hilo discursivo que venimos siguiendo. $\mathrm{Si}$ el campo fotográfico $\rightarrow$ al igual que otros campos artísticos-, como sugiere Ribalta, ya había presentado una expansión desde los años setenta, ¿no podemos hablar de una hiperexpansión a partir de los noventa, ligada a las posibilidades de la tecnología digital? ¿Qué ha ocurrido, qué está ocurriendo con el campo fotográfico, con lo fotográfico - para utilizar otro término de Krauss, para quien este alude a la fotografía como objeto teórico-? ¿Qué está ocurriendo, si se prefiere, con el universo de lo fotografiable, para apelar a otro concepto que nos es más caro, de Moles, al que ya hemos aludido en el Capítulo 7 y que no está circunscrito solamente al ámbito del arte, sino también al de la imagen funcional? El asunto es fundamental:

La importancia ontológica de las nuevas tecnologías no es tanto la de su materialidad como la de sus efectos sobre el campo en expansión de lo fotográfico en conjunto. [...] En este caso, la expansión ha sido generada tecnológicamente desde dentro, de forma continua y abierta, en lugar de estar reducida a un limitado repertorio de relaciones externas. (Osborne 2003: 70)

Volviendo a Ribalta, en su texto anteriormente referido traza una línea de lo que podríamos llamar la visión canónica del medio en su versión moderna, reafirmada en diferentes momentos del siglo $\mathrm{XX}$ por los directores de fotografía del Museo de Arte Moderno de Nueva York Beaumont Newhall, Edward Steichen y J ohn Szarkowski-, uno de los foros más influyentes a nivel mundial, y por revistas como Camera Work (Alfred Stieglitz) y Aperture (Minor White), que «sirvieron para consolidar históricamente la asimilación de la fotografía como forma de arte en base a la definición más o menos explícita de su naturaleza propia, en base a la formulación de lo fotográfico». (Ribalta 1989: 48)

[...] en 1978 Mirrors and Windows era criticada como una «presentación limitada y de miras estrechas» y como un «forzado intento de crear una estética de la fotografía que reducía a esta a un puñado de principios académicos». Esta crisis es todavía más patente si tomamos en cuenta que ya en 1977 Douglas Crimp había hecho la presentación de Pictures, la cual 
habría de convertirse en un nuevo punto de referencia para la actividad de años siguientes, en la que aparecía de manera definitiva una utilización de la fotografía que se apartaba radicalmente del modelo modernista.

Otro síntoma de la degeneración de lo fotográfico ha sido la progresiva consolidación, sobre todo a partir de los años 70, de una cultura fotográfica, cuya naturaleza habría que estudiar detenidamente, pero que parece la consecuencia de la implantación a nivel popular del modelo de la fotografía pura a través de los canales de la industria de la cultura. Esta cultura fotográfica ha dado lugar a una extensa labor con veleidades artísticas a medio camino entre la fotografía profesional y la práctica amateur, explícitamente separada de los canales y el desarrollo del arte contemporáneo (a no ser como reflejo devaluado o como sucedáneo) y ha ido consolidando una estructura institucional propia en forma de encuentros, festivales, premios, galerías y publicaciones especializadas. (Ribalta 1989: 48)

La historia se repite. Después de décadas de intentos de la fotografía por establecerse como un medio con una estética propia, una vez más es vista por arriba del hombro por aquellos que pretenden moverse en el mainstream del arte, dictado una vez más — dicho sea esto de paso—desde el mismo ámbito anglosajón que tanto se había esforzado por consolidar un imaginario propio de la fotografía $\mathrm{y}$, en ese sentido, igualmente colonizador, si cabe la expresión. ¿Pero, acaso este no se encuentra también supeditado a estructuras institucionales y a un sistema dominado por intereses económicos? Se reaviva virulentamente la dicotomía señalada por Rouillé y a la que ya hemos aludido: el arte de los fotógrafos es una vez más puesto en cuestión por los artistas que utilizan la fotografía como un medio entre otros. ¿No estamos, en ese sentido, hablando de una nueva forma o presentación de la actitud pictorialista? Sigamos con Ribalta:

Se suele situar la aparición de prácticas artísticas alejadas del uso purista del medio en los años 60, con los inicios del Pop Art en autores como Rauschenberg o Andy Warhol, aunque los estudios monográficos sobre las relaciones de fotografía y arte se esfuerzan por demostrar que las implicaciones mutuas han sido constantes desde la aparición de la fotografía. Lo que parece claro es que hasta la implantación definitiva del conceptual en la década de los 70 y la desaparición de la hegemonía de la fotografía pura modernista, no se produce la incorporación definitiva y total de la fotografía en los canales de distribución del arte. (Ribalta 1989: 50)

Es aquí donde Ribalta inserta el concepto de campo expandido. Pero, ¿no peca una vez más, acaso, esta concepción de la fotografía, de ese 
complejo de inferioridad que tantas veces en su historia la ha hecho ver al gran arte como su hermano mayor, a ella que es un arte medio?

[...] lo relevante es la aproximación a la fotografía como medio (ya no como práctica autónoma con un cierto compromiso moral/ estético consigo misma determinado por la idea modernista de expresión subjetiva y especificidad) y su implicación, en consecuencia, en una labor que se sitúa en un ámbito no limitado a un concepto técnico-material y cuya corporeidad física es cada vez más difícil de categorizar. La culminación de ese proceso de expansión que tiene lugar a lo largo de los años 60 y 70 encuentra su formalización en Pictures, la exposición [...] que organizó Douglas Crimp [quien] entendía que el trabajo más interesante que se había producido a lo largo de los años 70 había sido aquel que, precisamente, se había desarrollado en el espacio intermedio entre las diferentes disciplinas. (Ribalta 1989: 50)

Pero desde cierto punto de vista, lo que Pictures propone no es una ruptura ni un cuestionamiento de las formas de hacer que, renovadas periódicamente, habían definido las emblemáticas exposiciones predecesoras a ella. Por el contrario, Pictures puede ser leída en términos de continuidad: la de un establishment cultural obsesionado por imponer sus cánones universalmente. Basta contrastar las propuestas, tanto artísticas como teóricas, de los entornos anglosajón y francés, sus tensiones e incompatibilidades, para reafirmar esta idea.

El ámbito francés ha sido y sigue siendo un proveedor de ideas, si vale la expresión, frecuentemente interpretado de manera caprichosa y reduccionista desde el ámbito anglosajón. Sirva como ejemplo la simplista agrupación del vasto y complejo panorama de las teorías críticas a partir de 1960 bajo el paraguas unificador del concepto crítica postestructuralista. Un ejemplo de la adopción de conceptos provenientes de la teoría francesa por parte de los artistas se encuentra precisamente en uno de los campeones de Crimp, Allan Sekula, quien en su momento sustentó su trabajo en un «desinterés explícito por el desarrollo de un estilo individual». (Ribalta 1989: 52) Curiosamente, al igual que, por ejemplo, Landow (1992) ha hecho una relectura de Barthes y Derrida a partir de las nuevas posibilidades del hipertexto, Sekula la hizo de Barthes en una actitud que podría se calificada como revisionista. Sekula, 
[...] se muestra particularmente preocupado por el «grado extremo en que el significado de la fotografía depende del contexto», de acuerdo con una reflexión teórica originada por Barthes acerca de la falacia de la fotografía como pura denotación. La crítica de Barthes establece la existencia de un nivel de connotación, que viene dado por el contexto de presentación, sobre el cual la fotografía adquiere significado y fuera del cual carece de él. (Ribalta 1989: 52)

Como resultado, Sekula «recupera para la fotografía el espacio del archivo como ámbito semántico más adecuado para su postura». Adicionalmente, «la necesidad de contexto implica el reconocimiento de la fotografía como medio flexible y, más aún, de la categoría ficticia de la fotografía a favor de la más precisa de usos de la fotografía». (Ribalta 1989: 52) Curiosamente, con esta base, hoy nosotros podemos hacer una relectura de Sekula desde los nuevos ámbitos del archivo digital y la recontextualización de imágenes tomadas de Internet por los actuales usuarios. Subrayemos que, acaso, el ámbito de la fotografía de stock es el que más profundamente se ha visto transformado en el campo profesional (cfr. Frosh 2003), al grado de ser prácticamente suplantado por la producción generada por usuarios de la Web 2.0 en la década del año 2000, que han inundado la red con millones de imágenes, esto adicionalmente a los archivos digitales organizados comercialmente desde los años noventa, algunos de ellos antes privados y ahora accesibles públicamente:

[...] en diciembre de 1990 la agencia Comstock comenzó a proporcionar el acceso vía modem a su inmenso archivo fotográfico: los usuarios podían descargar fotografías en sus ordenadores personales para manipularlas con programas de procesamiento de imágenes y de diseño. Como resultado, los esquemas tradicionales de trabajo en periódicos y revistas empezaron a transformarse..$^{9}$ (Mitchell 1992: 81)

También encontramos el reconocimiento de la importancia de este factor en Manovich:

[...] asistimos al desarrollo de archivos de medios diversos que permiten al autor extraer elementos mediáticos ya existentes, en vez de tener que grabar

${ }^{9}$ La traducción es nuestra. 
otros nuevos. Por ejemplo, en 1930, el fotoperiodista alemán doctor Otto Bettmann dio inicio a lo que después se conoció como «el archivo Bettmann»; en el momento en que lo adquirió la Corbis Corporation de Bill Gates, en 1995, contenía sesenta millones de fotografías, que incluían algunas de las imágenes usadas con más frecuencia en el siglo XX. Se han creado archivos parecidos para el cine y el audio. El uso de fotografías, fragmentos de película y grabaciones sonoras «de stock» se volvió la práctica habitual de la moderna producción mediática. (Manovich 2001: 185)

Ante este marco, Barthes también se ve actualizado desde el momento en que la clasificación de los contenidos en la red o, para utilizar el término en boga, su etiquetado, se vuelve crucial para la recuperación de los contenidos. Para allá apunta, precisamente, la Web 3.0. Más aún: el desarrollo de opciones de software de recuperación como es el caso de Photosynth, presentado como prototipo por Microsoft en 2006 y lanzado al público en 2008, plantea un futuro en el que se podrá incluso omitir el etiquetado y no solo localizar fotografías con base en otras -el software detecta elementos formales similares y recupera las imágenes que los comparten—, sino también reconstruir espacios tridimensionales a partir de imágenes mutuamente complementarias existentes en la red.

Así, pasado el momento en que fueron expresadas las anteriores reflexiones, podemos decir, que la introducción de la tecnología digital trae una nueva expansión del campo fotográfico. En este nuevo campo hiperexpandido, ¿dónde quedan esas concepciones fotográficas que tan arduamente se hicieron lugar en la historia del arte, incluidas las poéticas posmodernas? ¿Qué hay del concepto de posfotografía? La incertidumbre puede ser expresada así:

[...] la fotografía ha sobrepasado el año 2000 con una sensación de crisis de identidad. El vertiginoso cambio tecnológico al que asistimos, así como el contexto político y económico que lo propician, ha trastocado la génesis y la naturaleza de la imagen fotográfica hasta un grado tal que se legitiman todas las incertidumbres sobre su estatus actual. Permanece el gesto del fotógrafo y permanecen también las apariencias de la imagen final como producto icónico, pero el recorrido entre uno y otra discurre hoy por un paisaje irreconocible [...] tan irreconocible que algunos, los más radicales, hablan de la muerte de la fotografía, y otros, más comedidos, introducen una nueva categoría, necesariamente ambigua: la posfotografía (una curiosa denominación que es muy cercana a otra: la poshistoria). (Fontcuberta [ed.] 2002: 9-10) 
Revisemos las ideas de algunos de estos radicales que postulan la muerte de la fotografía e intentemos localizar hitos que nos permitan reconocer el paisaje. Uno de los profetas, o si se prefiere, dada su contemporaneidad, de los cronistas del deceso fue Mitchell, quien sentenciaba: «Desde el momento de su 150 aniversario en 1989 la fotografía murió $\multimap$, más precisamente, fue desplazada de manera permanente y radical - como lo fue la pintura un siglo y medio antes». ${ }^{10}$ (Mitchell 1992: 20)

El eje de su discurso planteaba la idea de que las herramientas fotográficas tradicionales $-\mathrm{y}$ aquí encontramos el discurso de la continuidad histórica - apuntaban a la representación de la realidad de acuerdo con diversas convenciones vinculadas a las ideas de realismo y objetividad y, concomitantemente, eran instrumentos que transferían esos valores al sujeto perceptor. La ruptura, en cambio, que implica la tecnología digital en aspectos variados que abarcan la producción, manipulación y distribución de las imágenes representa para él una nueva intencionalidad, se trata de «un poderoso (aunque con frecuencia ambivalente y resistido) deseo de desmantelar la rigidez de la visión fotográfica y de extender el discurso visual más allá de las convenciones representativas y de las supuestas certidumbres del registro fotográfico».11 (Mitchell 1992: 59-60) Estaríamos hablando, así, de un proceso de agotamiento de un lenguaje. El paralelismo con otras épocas es prácticamente ineludible:

Actualmente, resulta cada vez más claro que se está formando un nuevo modo pixelado de intervisualización global, que es diferente de la imagen de la cadena de montaje cinematográfica y del simulacro de la cultura posmoderna de la década de los ochenta. En el siglo XIX, la fotografía transformó la memoria humana en un archivo visual. A principios del siglo $\mathrm{XX}$, Georges Duhamel lamentaba que: «Ya no puedo pensar lo que quiero pensar, mis propios pensamientos son sustituidos por las imágenes en movimiento». Enfrentado a la cuestión sobre si la fotografía era arte, Marcel Duchamp dijo que la esperada fotografía «haría que los individuos despreciasen profundamente la pintura, hasta que surgiese algo más que

${ }^{10}$ La traducción es nuestra.

${ }^{11}$ La traducción es nuestra. 
hiciera insoportable la fotografía». La imagen pixelada ha hecho insoportable a la fotografía, tanto de una forma literaria, como atestigua la relación de la princesa Diana con los paparazzi, como metafórica. El trabajo de fotógrafos contemporáneos como Cindy Sherman, David Wojnarowicz y Christian Boltanski, hace que la fotografía resulte insoportable porque es algo sublime. (Mirzoeff 1999: 56-57)

El rey ha muerto... ¡Viva el rey! Entusiasmado ante el nuevo panorama, Mirzoeff (1999: 22) se postula como fiel seguidor del profeta/ cronista: «La posfotografía es la fotografía de la era electrónica que ya no intenta reflejar el mundo sino que se encierra en sí misma para explorar las posibilidades de un medio liberado de la responsabilidad de señalar la realidad (Mitchell 1992)». Abusamos en este punto de las citas precisamente para reflejar la insistencia con la que este gurú de la cultura visual vuelve una y otra vez sobre el asunto del deceso, que parece adquirir así el carácter de una declaración de principios:

Con el surgimiento de la imagen por ordenador y la creación de medios digitales para manipular la fotografía podemos, sin embargo, decir que la fotografía ha muerto. Está claro que la fotografía seguirá utilizándose diariamente en grandes cantidades pero su reivindicación como reflejo de la realidad ya no puede mantenerse. La reivindicación de la fotografía como representación de la realidad ha desaparecido. (Mirzoeff 1999: 101)

\section{O también:}

Después de un siglo y medio dejando constancia y conmemorando la muerte, la fotografía encontró la suya propia en algún momento de la década de los ochenta, a manos de las imágenes creadas por ordenador. La capacidad de alterar una fotografía digitalmente ha anulado la condición básica de la fotografía: cuando se ha abierto el obturador, algo debe haber estado ante el objetivo, aunque las preguntas sobre la autenticidad de lo fotografiado permanezcan en el aire. Ahora es posible crear «fotografías» de escenas que jamás han existido, sin que la falsificación pueda apreciarse de forma directa. Ya en 1982, la compañía de efectos especiales Lucasfilms declaró que su trabajo suponía «el fin de la fotografía como prueba». (Mirzoeff 1999: 130)

¿Se trata de la descripción de un estado de cosas o, como señalaba Manovich, de futurología teórica con fecha de caducidad? ¿No estamos, acaso, en el terreno de lo que Krauss ha denunciado recientemente (2010: 
xiv) al afirmar que considera al concepto de condición post-media, utilizado por la crítica contemporánea y por ella misma en cierto momento, como un «mito monstruoso» que ha propiciado el desinterés por el medio? (Cfr. Bourriaud 2009: 159 y ss.)

Maticemos...

Si bien está ocurriendo una revolución digital, estamos todavía pendientes de ver sus frutos. Esta revolución no solo abarca el ámbito de la producción de imágenes fotográficas, sino, como ya lo establecimos insistentemente $-\mathrm{y}$ nuestro punto de vista tiende a considerar esto como lo esencial一, los ámbitos de su difusión y de su consumo. La fotografía digital es tratada como información pura y, como tal, se ha incorporado plenamente a la actividad de información, entendida como «una práctica de conocimiento, de comunicación y de escritura que supone como características [las] operaciones de fragmentar, homologar, almacenar, recuperar, recomponer y visualizar». (Abril 2003: 24) Coincidimos con el autor citado en el sentido de que estas actividades, aunque potenciadas en la era del ordenador, desde mucho antes formaban parte del horizonte cultural, como se desprende del posicionamiento que hemos hecho de la actitud pictorialista. (Ver supra: Capítulo 1) La fragmentación tanto de las imágenes como de todo tipo de mensajes para su recomposición en textos informativos estrechamente ligados a una determinada situación de comunicación, como sucede en la sociedad contemporánea debido al uso masivo de herramientas digitales, tiene como consecuencia evidente que se privilegie el análisis de lo que podríamos llamar la lógica digital en la cultura del ordenador, algo mucho más profundo que la sola capacidad de manipular las imágenes de acuerdo a las posibilidades contenidas en menús de opciones. En el flujo de la información fragmentada, descontextualizada, mediada, transcodificada a través del uso de las nuevas tecnologías, la fotografía es reconvertida en objeto de uso: es medio, no fin en sí misma.

De la información [...] no se puede permanecer exento, pues se ha incorporado a nuestras maneras de relacionarnos con el mundo, de mirar y de aprender. No es solo institucional, sino metainstitucional. Está integrada 
en nuestro entorno cultural, en [...] la semiosfera. No solo, pues, en nuestros archivos y textos «de cultura», ni solo en nuestra relación autorial o lectora con ellos, sino también en la organización del espacio, de la producción y del consumo. En la señalización de las calles y carreteras por las que circulamos, en la de los hipermercados donde compramos y en la de los hipertextos por los que navegamos, en los periódicos, en la tele y en los museos que visitamos; incluso en los espacios naturales culturizados, museizados precisamente por dispositivos informativos- en que nos esparcimos. (Abril 2003: 27)

No obstante esta incorporación de la fotografía al flujo de la información, ello no supone la desaparición de muchos de sus usos convencionales y, acaso lo más importante, a pesar de todo sigue siendo utilizada como medio de atestiguar la realidad. Esta convivencia de las prácticas del pasado con nuevas prácticas implica, simple y sencillamente, que se trata de un campo vivo. El impacto de la tecnología digital está por verse: ¿acaso puede hacerse la evaluación de los efectos de un estallido cuando aún está en proceso? Específicamente en el campo fotográfico podemos hacer un paralelismo: En la última década del siglo XIX y la primera del XX, la estética fotográfica comenzó a experimentar un cambio radical debido a la democratización del uso de las cámaras que se dio de la mano de aparatos fáciles de usar y muy baratos introducidos por la compañía Kodak, con la cámara Brownie como estandarte. Muy pronto, lo que podemos llamar la estética de la instantánea -errática, casual, de cortes equívocos y de composición torpe de acuerdo a los criterios pictóricos de la academia, que la fotografía decimonónica había heredadose integró al lenguaje, no solo de los grandes fotógrafos, sino también de algunos grandes pintores (pensemos, por ejemplo, en Edgar Degas). Esto es fácil de observar hoy, retrospectivamente, cuando podemos insertar la discusión en el contexto de la eterna dicotomía pictorialismo-purismo, aunque tal vez no resultara tan evidente en su momento, ya que es un proceso que requirió de tiempo para asentarse, como lo ha requerido el actual.

Aceptamos el advenimiento de la posfotografía, pero desconocemos todavía el estatuto del nuevo escenario. Ante el exorcismo imposible que le libere el 
alma de la prisión de un cuerpo ajeno, la fotografía digital sigue encorsetada en la fotografía analógica y eso representa el gran desquite del pictorialismo. Porque en ese ajuste de cuentas con el destino se han cambiado las tornas: hoy toda foto es ineludiblemente pictorialista. El pictorialismo digital inunda el mercado de la imagen. (Fontcuberta 2010: 188)

De manera emblemática, un siglo después al surgimiento de la instantánea, exactamente en la última década del siglo XX, la fotografía digital inicia el proceso, no solo de democratización, sino definitivamente de una masificación sin precedentes de ciertas prácticas que imprimen al campo fotográfico una creciente heteronomía. Masificación que, por cierto, no solo se refiere a prácticas, sino también —como hace un siglo-a lo que podríamos llamar una estética fotográfica del mal hacer, caracterizada por el encuadre accidental, la desviación no corregida de la temperatura de color, los barridos, el pixelado excesivo y, en general, un enorme repertorio de accidentes técnicos que en el pasado tendían a ser evitados y en la actualidad se han incorporado al universo de lo visualmente aceptable, siendo incluso imitados por el arte o, debido a su connotación de actualidad, por prácticas fotográficas como la publicitaria, la cual tradicionalmente hacía gala de un alto compromiso técnico. A pesar del cambio de velocidad en la implementación de las tecnologías que el pasado siglo supuso, una vez más es necesario que esas prácticas se asienten para poder ver con claridad sus aportaciones profundas en lo concerniente al lenguaje. Por ello, y utilizando como puente precisamente esta palabra que con anterioridad había sido puesta en cuestión por él mismo, volvamos a Manovich. Más que regodearnos en las posibilidades combinatorias ya antes sugeridas del juguete digital aplicado a la fotografía para obtener resultados diversos, enfaticemos la homologación que la tecnología digital propicia en el tratamiento de diversos medios de expresión y que no tiene que ver, en el caso de la fotografía, con su carácter icónico, sino con su constitución como archivo informático:

Todos los medios actuales se traducen a datos numéricos a los que se accede por ordenador. El resultado: los gráficos, imágenes en movimiento, sonidos, formas, espacios y textos se vuelven computables; es decir, conjuntos 
simples de datos informáticos. En definitiva, los medios se convierten en nuevos medios. (Manovich 2001: 71)

Profundicemos en la lógica subyacente en estos procesos, a sabiendas de que es un tema complejo que excede los límites de esta investigación y el cual, por lo mismo, solo podremos abordar de manera somera. Seguiremos, para ello, las argumentaciones de Manovich, más centrado en el tema de la cultura del ordenador que en el de la fotografía propiamente dicha. Para el autor, existen dos principios fundamentales que hay que tener en cuenta al adentrarse en el asunto:

1. Un objeto de los nuevos medios puede ser descrito en términos formales (matemáticos). Por ejemplo, una imagen o una forma pueden ser descritas por medio de una función matemática.

2. Un objeto de los nuevos medios está sometido a una manipulación algorítmica. (Manovich 2001: 72)

Estos principios nos introducen a una visión que evoca profundas resonancias con la concepción flusseriana del medio fotográfico, en la cual la libertad creativa parecería limitarse a los dictados de las posibilidades de la técnica. Donde Flusser se refería al software de manera metafórica, como las reglas del juego (ver supra: Capítulo 2), ahora podemos utilizar ese vocablo de manera literal. Está aquí también implicado, por supuesto, el tema de la automatización.

La codificación numérica de los medios (principio 1) y la estructura modular de sus objetos (principio 2) permiten automatizar muchas de las operaciones implicadas en su creación, manipulación y acceso. De ahí que pueda eliminarse la intencionalidad humana del proceso creativo, al menos en parte. (Manovich 2001: 77)

Pero, el resultado de estas operaciones automatizadas, ¿no serán, acaso, mensajes lexicalizados, tópicos producto de las posibilidades finitas contenidas en los menús del software?

Se presenta aquí, una vez más, un déjà vu teórico con Flusser: 
Durante el acecho el fotógrafo salta de una forma de espacio-tiempo a otra, ajustando de manera combinatoria la relación entre las diferentes categorías de tiempo y espacio. Su acecho es un juego combinatorio con las categorías de la cámara, y lo que apreciamos en la fotografía es la estructura de este juego, pero no inmediatamente la estructura de la propia condición cultural. [...] Uno tiene la impresión de que el fotógrafo puede elegir libremente, de que la cámara se amolda a su intención. Pero eso no es cierto: la elección está determinada por las categorías de la cámara y la libertad del fotógrafo permanece como libertad programada. (Flusser 1983: 34-35)

No solo ante el software de la cámara, sino ante el del retoque digital de fotografías, la libertad del ususario también está programada, y lo está, acaso, mucho más. Esto, por supuesto, en mayor medida en tanto en cuanto el usuario esté menos especializado, no solo en el uso convencional de las herramientas, sino en lo que se refiere a la capacidad de intervenir directamente sobre la programación, posibilidad reservada a los especialistas informáticos. Persiste, así, el paralelismo con la visión de Flusser, donde la postura del aficionado sujeto a los procesos automatizados puede equipararse a lo que Manovich llama

[...] la automatización «de bajo nivel» de la creación mediática, en la que el usuario del ordenador modifica o crea desde cero un objeto mediático por medio de plantillas o de algoritmos simples. Se trata de técnicas lo bastante potentes como para que vengan incluidas en la mayoría del software comercial de edición de imagen, gráficos 3D, procesado de textos, maquetación, etc. Los programas de edición de imagen como el Photoshop pueden corregir de manera automática las imágenes escaneadas, mejorando su nivel de contraste y eliminando el ruido. También llevan filtros que pueden modificar una imagen de manera automática, empezando por la creación de simples variaciones de color hasta llegar a cambiar toda la imagen como si la hubiera pintado Van Gogh, Seurat o cualquier otro artista de renombre. (Manovich 2001: 78)

De esto se desprenden otras características de los objetos de los nuevos medios, de estas piezas de información de la cultura del ordenador. Destacan, entre ellas, la variabilidad, que es generada por el receptor/usuario a través de los procesos automatizados. A su vez, conceptos como los de original y copia pierden relevancia y son sustituidos por el de versiones o reelaboraciones, que darían la ilusión de poder ser infinitas. 
Nos encontramos, así, ante valores tan esenciales de la cultura digital que casi estaríamos tentados a utilizar una vez más aquella peligrosa palabra: ontología. Es precisamente ese carácter esencial el que lleva al autor que viene dando hilo a nuestro discurso a definir claramente una idea que resulta vaga a fuerza de fundarse en un término del que se ha abusado. Nos referimos a la idea de representación digital:

\begin{abstract}
¿Se trata, sin duda, de la única idea que redefine de manera radical los medios? La respuesta no es tan sencilla, porque se trata de una idea que actúa como un término global para tres conceptos sin relación entre sí: la conversión de analógico a digital (la digitalización), un código común de representación y la representación numérica. Siempre que afirmemos, de alguna cualidad de los nuevos medios, que se debe a su estatuto digital, necesitaremos especificar cuál de estos tres conceptos está en juego. Por ejemplo, el hecho de que diferentes medios se puedan combinar en un solo archivo digital se debe a que utilizan un código común de representación, mientras que la capacidad de hacer copias sin que se introduzca degradación es un efecto de la representación numérica.

A causa de esta ambigüedad, evito en lo posible el uso de la palabra digital [...], la representación numérica es el único concepto de los tres que resulta crucial, porque convierte los medios en datos informáticos, y por tanto los vuelve programables; lo que de hecho cambia su naturaleza de manera radical. (Manovich 2001: 99)
\end{abstract}

Quedan así esclarecidos conceptos de base que nos advierten del riesgo de abordar la cultura del ordenador a partir de su visión más superficial, a saber: la del usuario que se enfrenta a un conjunto de menús y que tiene la ilusión de ejercer la libertad creativa solo a base de hacer elecciones de entre las posibilidades que aquellos le ofrecen. En los siguientes apartados profundizaremos en esta idea. De momento, y una vez hecho este recorrido por algunos conceptos fundamentales que aluden a la esencia de la cultura del ordenador, cabe echar una mirada retrospectiva a El ojo reconfigurado, de Mitchell, al que ya nos referimos como un texto fundacional dentro del campo de la fotografía digital.

En efecto, a pesar de la precisión hecha por Manovich respecto del término digital, nos veremos obligados a seguir utilizando la expresión fotografía digital debido a la amplísima difusión que ha obtenido, aunque ahora sabemos que el término está bajo sospecha. Y no solo lo está debido a las precisiones ya explicadas en torno a sus diversas connotaciones, sino 
también porque en la década de los noventa se alimentó -y Mitchell es el ejemplo por antonomasia—lo que podemos llamar con Manovich (2001: 99 y ss.) el mito de la digitalización, paralelo al ya apuntado megamito o «mito monstruoso» de la condición post-media denunciado por Krauss y al que aludimos unos párrafos arriba. Este monstruo, en el caso particular de la fotografía, no ha dejado de ser alimentado, como lo ejemplifican, entre otros muchos, la exposición Fotografía después de la fotografía. Memoria y representación en la era digital, organizada en 1995 con la participación conjunta de instituciones de Alemania, Austria, Dinamarca, Suiza, Finlandia, Estados Unidos y Australia, ${ }^{12}$ o ensayos con la connotación post, como After Photography (Después de la fotografía) (2009), de Fred Ritchin, o La cámara de Pandora. La fotografí@ después de la fotografía (2010), de J oan Fontcuberta, aunque en este caso el matiz es de prudencia.

Los catastrofistas anuncian ahora la muerte de la fotografía. En este caso, el cambio tecnológico que supone la implantación del ordenador en la creación gráfica va mucho más allá de un desgaste de la creatividad o del cansancio del mercado. Va más allá también de los obvios desajustes en el dispositivo fotográfico. Lo que por encima de todo pone en evidencia es su obsolescencia histórica. La fotografía electrónica, en este sentido, no constituye una simple transformación de la fotografía fotoquímica sino que introduce toda una nueva categoría de imágenes que hay que considerar "posfotográficas». La pregunta de si la fotografía digital es todavía fotografía, no tiene respuesta concluyente. (Fontcuberta 2010: 60-61)

En efecto, volviendo al precursor Mitchell, a solo una década de su publicación, el vertiginoso avance tecnológico había vuelto ya obsoletos algunos de los planteamientos de su libro, en el que de alguna manera sucumbió a la tentación de hacer una especie de recuento o inventario de posibilidades que las nacientes versiones de software para el retoque digital de imágenes ofrecían a la fotografía, con el señalamiento de algunos aspectos concretos que fueron rápidamente corregidos, superados o que tomaron caminos que eran difíciles de prever —baste señalar, a manera de

12 Existe un catálogo con textos de autores invitados: Amelunxen, Hubertus V. et ál. (eds.). Photography After Photography. Memory and Representation in the Digital Age. Ámsterdam-Múnich: G+B Arts, 1996. 
ejemplos, sus alusiones a la pérdida de detalle en el escaneo o a la compresión con pérdidas en copias sucesivas, asuntos técnicos que hoy ya parecen sumamente lejanos-. El carácter de inventario del libro lo debilita precisamente en el sentido, ya apuntado, de que la libertad creativa parecería limitarse a la selección, por parte del ususario, de entre un repertorio de opciones limitadas e impuestas desde el exterior. Más que de el ojo reconfigurado que promete el título pareceríamos estar hablando de un ojo preconfigurado.

A pesar de que, más allá del recuento de las técnicas, Mitchell pretende abocarse a las estrategias de creación de imágenes —collage, sombreado, cámara virtual, imagen sintética-, el carácter reduccionista de su propuesta es un reflejo del estado de la discusión por aquellos años, en los que las novedad, pero también, y por lo mismo, la falta de incorporación por parte de los creadores que se reflejara en un uso reposado y natural de la herramienta informática, provocaron una franca superficialidad tanto en la discusión teórica como en la producción. Esta banalidad, está presente, por ejemplo, en el capítulo del libro de Mitchell titulado «Cómo hacer cosas con imágenes», frase digna de una manual del tipo hágalo usted mismo.

Del libro de Mitchell —del que estamos haciendo, por supuesto, una crítica retrospectiva, pero sin pretender soslayar la importancia que tuvo en su momento-, habría que quedarse con sus propuestas más generales, que finalmente han resultado las menos vulnerables al avance tecnológico y al paso del tiempo. Entre ellas, podemos señalar las de la búsqueda del logro de una cohesión interna en la imagen que en principio — ¿el síndrome del niño con jugete nuevo? - invitaba a la incoherencia; la necesidad de una ética fotográfica redefinida o la del surgimiento de un nuevo marco que finalmente Internet ha convertido en realidad, el de las enormes colecciones fotográficas que han llevado a la priorización de los procesos de clasificación, acceso y contextualización de las imágenes, tema relacionado con los aspectos pragmáticos de la difusión y consumo de fotografías que hoy, como lo demuestra la discusión en torno a la Web 3.0, se considera crucial. 
Habiendo recorrido así, de una manera panorámica, el marco contextual que ha caracterizado a los primeros veinte años de la fotografía digital y habiendo hecho una crítica implícita al concepto de posfotografía, dedicaremos los siguientes apartados a reflexionar acerca de los mecanismos de creación característicos del momento presente. $\mathrm{Si}$ a partir de las décadas de 1960 y 1970 las prácticas fotográficas vinculadas al arte posmoderno nos permitían ya hablar del fotográfico como un campo expandido, nos encontramos ahora inmersos en el planteamiento de que la introducción de la tecnología digital lo ha hiperexpandido, propiciando un nuevo desdoblamiento de sus posibilidades expresivas. Habiendo ya, en los párrafos precedentes, esbozado una respuesta afirmativa a esta cuestión, profundicemos ahora en torno a la lógica subyacente en la creación fotográfica actual.

\subsection{UN GIRO PRAGMÁTICO: DIGITALIZACIÓN Y J UGARRETAS}

En el exceso de la actual semiosfera, ¿cómo vivir el universo de la información del que la fotografía forma parte? ¿Y el arte? ¿Vivir el arte? ¿Vivir en el arte? ¿Vivirlo como metáfora? ¿Vivirlo como elipsis? ¿Vivirlo como asíndeton?

Vivir en, con, para, ser... Ser metáfora. Ser elipsis. Ser asíndeton. Negarse a aceptar el grado cero de la vida: ¿nacer, crecer, trabajar, reproducirse, morir? O el grado cero en el —paradójicamente así llamadomundo desarrollado: nacer, tener acceso a educación superior, seguridad social, vivienda digna hipotecada, trabajar cuarenta horas por semana, cobrar la pensión y bien morir. O el grado cero en las -paradójicamente así llamadas- sociedades en vías de desarrollo: tener acceso a agua potable, alfabetización, vacunas, subalimentación, jornadas de doce horas de trabajo...y morir. 
Negar, por principio, el grado cero de la vida, porque una vida en grado cero no es vida. Ya antes hemos aludido a Michel de Certeau (ver supra: Capítulos 3 y 7), volvamos a sus ideas:

Diversas referencias teóricas permitirán caracterizar mejor las tácticas o la polemología del «débil». Es el caso, en particular, de las «figuras» y «giros» que analiza la retórica. [...] Son indicaciones para un consumo y un juego de fuerzas. Competen a una problemática de la enunciación. Además, aunque (o quizá porque) están excluidas en principio del discurso científico, estas «maneras de hablar» proporcionan al análisis de las «maneras de hacer» un repertorio de modelos e hipótesis. Al cabo no son sino variaciones dentro de una semiótica general de las tácticas. (de Certeau 1980b: 404-405)

¿Cómo se engarzan estas ideas con nuestro discurso? ¿Cómo vive el receptor, este receptor empoderado - para usar un barbarismo en bogapor la tecnología, este receptor ahora llamado consumidor y, aun más, usuario, cómo navega en la cultura del ordenador, en la cultura visual de la actualidad? Por supuesto que no somos los únicos que sucumbimos a la tentación de apelar a las ideas del pensador francés para abordar el asunto. Sigamos, por ejemplo, a Mirzoeff:

El concepto de imagen del mundo ya no resulta adecuado para analizar esta cambiada y cambiante situación. La extraordinaria proliferación de imágenes no se puede concentrar en una sola imagen que contemple lo intelectual. En este sentido, la cultura visual es la crisis de información y sobrecarga visual en lo cotidiano. Intenta buscar formas para trabajar dentro de esta nueva (virtual) realidad. Adaptando la descripción de Michel de Certeau sobre la vida cotidiana, la cultura visual es una táctica y «la táctica no tiene más lugar que el del otro» (de Certeau, 1984, pág. xix). ${ }^{13}$ La táctica es una maniobra que se lleva a cabo a la vista del enemigo, de la sociedad controladora en la que vivimos (de Certeau, 1984, pág. 37). Aunque algunos consideren desagradables las alusiones militares a la táctica, también se puede argumentar que las tácticas son necesarias para evitar la derrota en las guerras culturales en curso. De igual manera en que las primeras investigaciones sobre lo cotidiano intentaban dar prioridad a las distintas formas en que los consumidores creaban para sí mismos diferentes significados desde la cultura de masas, la cultura visual explorará las ambivalencias, intersticios y lugares de resistencia en la vida cotidiana posmoderna, desde el punto de vista del consumidor. (Mirzoeff 1999: 27)

\footnotetext{
${ }^{13}$ La edición citada por Mirzoeff es: de Certeau, Michel. The Practice of Everyday Life (1980). Berkeley y Los Ángeles: University of California Press, 1984.
} 
Maneras de formar, hemos repetido con insistencia: maneras de ver, maneras de hablar, maneras de hacer. Artes de hacer. He ahí un modelo posible: partir de la debilidad ante el sistema fuerte. Establecer una táctica personal frente a la estrategia abarcadora. Adoptar como esa táctica el desvío, la deriva, el juego - la jugarreta-: vivir en el intersticio. Primar las connotaciones personales sobre las denotaciones generalizadas, lexicalizadas; la huella dactilar sobre el código de barras. Sintagma, sí; paradigma, no. ¡Todo in praesentia! El nuevo receptor / consumidor / usuario juega montado en una humilde figura de expresión.

¿Jugar o ser jugado? Si es necesario, entonces que el juego sea guerra, ¡como en el ajedrez! De esta manera se hace posible introducir una vez más y desdoblar la metáfora flusseriana del juego respecto del aparato fotográfico, que ya nos ha dado pie para algunas reflexiones. El usuario juega socialmente, pero las reglas del juego cambian incesantemente y la magnitud de los cambios técnicos recientes obliga a replantear las reglas del juego. Resuenan una vez más las palabras del clásico texto de Heidegger en el cual se pregunta por la técnica:

Preguntando de este modo damos testimonio de este estado de necesidad: que nosotros, con tanta técnica, aún no experienciamos lo esenciante de la técnica; que nosotros, con tanta estética, ya no conservamos lo esenciante del arte. Sin embargo, cuanto mayor sea la actitud interrogativa con la que nos pongamos a pensar la esencia de la técnica, tanto más misteriosa se hará la esencia del arte. (Heidegger 1953: s.n.)

La eterna confrontación del hombre frente a la técnica está en el trasfondo de este replanteamiento y, en la cultura del ordenador, cuenta con un símbolo por excelencia, y aquí retomamos, para atarlo, ese cabo lanzado en el Capítulo 2:

La confrontación de un ser humano con un artefacto «inteligente» (Kasparov ${ }^{14}$ contra Deep Blue) es altamente simbólica, no solo por el

${ }_{14} \mathrm{El}$ nombre del ajedrecista suele encontrarse escrito de diversas formas. Por razones de unidad, cambiamos la ortografía con tilde utilizada en el libro de Baudrillard y nos quedamos con la que maneja el propio campeón para firmar sus libros y en su sitio web oficial. 
prestigio del juego de ajedrez, sino porque resume el dilema del hombre frente a todas las máquinas contemporáneas que utiliza: informáticas, virtuales, cibernéticas, en redes, etc. Detrás del uso instrumental, creativo o interactivo que hace de ellas, en el fondo se trata siempre de una partida, de un reto, de un desafío, de un enfrentamiento en el que uno u otro puede quedar en jaque o perder prestigio. (Baudrillard 1996a: 185)

Un optimista Baudrillard, en 1996, prosigue así:

[...] Kasparov acabó venciendo al ordenador y todo el mundo quedó muy aliviado, pues lo que estaba en juego era un poco el honor de la especie. Aunque la inteligencia humana tenga que declararse vencida algún día, hay que aplazar ese momento lo más que se pueda. Es, además, lo que vuelve ligeramente ambigua esa victoria, pues aunque no estuviera trucada ( $\mathrm{y}$ sin duda no lo estaba), Kasparov no podía dejar de ganar, de todas formas. (Baudrillard 1996a: 185)

El pensador francés no sabía que ese día de la derrota estaba sumamante cerca. Apenas un año después de escritas las anteriores palabras, Kasparov fue vencido por Deep Blue II, con lo que la lectura del pensador francés, vista retrospectivamente, resulta de una insoportable nostalgia, de una intolerable melancolía.

Volviendo a Kasparov: si ha ganado es que (metafóricamente) es capaz de hablar varias lenguas: las del afecto, de la intuición, de la estratagema, en una palabra: del juego, sin contar la del cálculo, mientras que Deep Blue solo habla la del cálculo. El día en que esta prevalezca, sea cual sea, Kasparov será vencido. El día en que el hombre solo hable esta misma y única lengua, la de los ordenadores, será vencido. (Baudrillard 1996a: 186)

¿Y el jugador/fotógrafo, al que ya en la era de la foto analógica Flusser había declarado vencido por la técnica, por la automatización, cómo encara la era digital? ¿Se han expandido verdaderamente sus posibilidades —habla varias lenguas-, o, tras una breve etapa de ilusión, la máquina lo ha derrotado una vez más - solo habla la lengua del ordenador-?

El tablero de la vida cotidiana está ahí: la imagen técnica, los media, los nuevos media, la publicidad, el espacio urbanístico, la información desbordada. También el arte institucionalizado. El tablero-hardware. Los escaques fijos. La monotonía de los ejes verticales y horizontales. Ocho por 
ocho, ni más ni menos. Las reglas: paradigma, estrategia impuesta. Las posibilidades de movimiento predeterminadas. Los ritos del antes y después, del turno alterno. El enroque. El reglamento-software. La sociabilidad reglada en un determinismo que parece llevarnos a un inevitable zugzwang, donde solo es posible ir a peor. ¿Será que a lo sumo podemos aspirar a quedar tablas? Se habla mucho de la sexta partida, en la que Kasparov jugó de manera errática, pero poco se habla de la segunda, en la que el campeón perdió por no ver una variante que le habría permitido obtener tablas por jaque perpetuo. A la postre, esto fue decisivo para definir los derroteros del match.

Pero, ante el derrotismo del zugzwang o el conformismo del empate como máxima aspiración, ¿por qué no el ajedrez jugarreta? Escaques adicionales, movimientos impensados, jugadas sucesivas, gambitos audaces $y$, entre el blanco y el negro, infinitos grises, como en la fotografía. Como en el arte no institucionalizado, esa jugarreta vivencial.

El artista se mueve dentro de las posibilidades del dispositivo que utiliza, en el marco de su hardware - lo físico, lo duro-y de su software -las variables combinatorias, lo blando-. Y lo hace siempre buscando nuevas posibilidades, nuevas formas de usar el programa del aparato. Como el fotógrafo - ambos, el fotógrafo artista y el artista que usa la foto, diría Rouillé-, por cierto, en relación al dispositivo fotográfico. Recordemos una vez más a Flusser, cuya visión de la fotografía hemos evocado desde el inicio de este trabajo:

Este tipo de actividad es comparable con jugar al ajedrez. También el jugador de ajedrez busca nuevas posibilidades en el programa del ajedrez, nuevas jugadas. Igual que él juega con las piezas, juega el fotógrafo con su cámara. La cámara no es una herramienta, sino un juguete, y el fotógrafo no es un trabajador, sino un jugador: no Homo faber, sino Homo ludens. Sin embargo, el fotógrafo no juega con, sino contra su juguete. (Flusser 1983: 28)

El arte de la segunda mitad del siglo XX y principios del XXI, el arte que abarca desde los años cincuenta hasta hoy —período, también, de la evolución teórica que en los capítulos precedentes hemos descrito-, es 
también practicado en contra de sus juguetes. Son dos las improntas que lo marcan: La primera tiene que ver con la técnica y, debido al contexto histórico del momento, con la tecnología. Es el arte de la imagen técnica, de los aparatos que permiten jugar con el espacio-tiempo, con la fotografía como precursora. La segunda impronta del arte durante las pasadas décadas - juego, al fin, que invita a jugar-se refiere, idea en la que hemos insistido repetidamente, al protagonismo otorgado al otro jugador: el espectador, cuya hora fue anunciada a fines de la década de 1950 por Castellet en lo que fijamos como el punto de partida simbólico de nuestras disquisiciones. (Ver supra: Capítulo 3) Podemos leer esta tendencia incluso en palabras de un antropólogo:

[...] si el problema de la recepción es crucial en el arte, no es simple y básicamente porque podamos desear tener, en beneficio del arte y de la sociedad, un público ilustrado. La razón es más profunda y tiene que ver con el hecho de que la pregunta que la obra de arte formula sobre lo real solo tiene sentido si es compartida, si la obra es al mismo tiempo reclamo, acto social y creación social. (Augé 2000: 126)

Si los artistas cambian las reglas, ¿quién puede jugar con el arte? Es necesario que el espectador comparta las reglas ya que, sin código común, no hay decodificación posible. Sin embargo, al problematizarse los códigos, su involucramiento tendrá que ser cada vez más activo. Llegamos, así, a una peculiar definición: el arte es el juego que consiste en cambiar las reglas del juego. En el período descrito, el receptor ya no será espectador, sino que se le exigirá que juegue, que sea co-creador y, en el camino de unas cuantas décadas, se especulará sobre su actividad a través de conceptos como lectura, concretización, actualización, semiosis, recepción, interpretación, interacción, exégesis, decodificación, deconstrucción, participación... Semiótica, hermenéutica, deconstructivismo, estética de la recepción, pragmática, estética relacional... son solo algunos de los enfoques que intentarán explicar su manera dejugar.

Manera de jugar, sí. Juego artístico jugado por dos. Porque, si en el título de ese texto ya añejo que nos ha servido como referencia en varias 
ocasiones, Eco parecía resumir toda una posición del artista ante la obra, hoy ese título -De la manera de formar como compromiso con la realidad- acaso podría ser parafraseado como De la manera de jugar como intersticio social. Así, la tan mentada transición de lo analógico a lo digital implica, en el fondo, la necesidad de una definición personal de la manera de jugar con los nuevos dispositivos, más allá de la propuesta implícita, subyacente en el aparato mismo y lexicalizada por él:

El principio de variabilidad [de los objetos de los nuevos medios] ilustra cómo, a lo largo de la historia, los cambios en las tecnologías mediáticas están relacionados con el cambio social. Si la lógica de los viejos medios se correspondía con la de la sociedad industrial de masas, la lógica de los nuevos medios encaja con la lógica de la sociedad postindustrial, que valora la individualidad por encima del conformismo. En la sociedad industrial de masas, se suponía que todo el mundo debía disfrutar de los mismos bienes; así como compartir también las mismas creencias. Y esa era también la lógica de la tecnología de los medios. Los objetos mediáticos se ensamblaban en fábricas mediáticas, como un estudio de Hollywood. A partir de un original se producían millones de copias idénticas, que eran distribuidas a todos los ciudadanos. Los medios de teledifusión, el cine y la imprenta seguían todos esa misma lógica.

En una sociedad postindustrial, cada ciudadano se puede construir un estilo de vida a medida, y «seleccionar» una ideología entre un gran (aunque no infinito) número de opciones. En vez de machacar los mismos objetos o la misma información a un público masivo, el marketing trata ahora de dirigirse a cada individuo por separado. La lógica de la tecnología de los nuevos medios refleja esta nueva lógica social. (Manovich 2001: 88)

Estamos hablando de digitalización, de cultura del ordenador, sí, pero el comentario de estos aspectos no tiene sentido alguno si no los confrontamos con la lógica social que al mismo tiempo los produce y es producida por ellos. Más adelante, Manovich es aún más explícito:

[...] las operaciones informáticas codifican en su diseño las normas culturales vigentes. Un buen ejemplo de esto lo tenemos en «la lógica de la selección». Lo que era un conjunto de prácticas y de convenciones sociales y económicas viene ahora codificado en el mismo software. El resultado es una nueva forma de control, suave pero poderosa. Aunque el software no impide a los usuarios crear directamente desde cero, su diseño, a todos los niveles, hace «natural» seguir una lógica diferente, que es la de la selección. (Manovich 2001: 184) 
¿Cuál es, entonces, en el entorno de la cultura del ordenador dominada por la lógica de la selección, la jugarreta posible? ¿Cuál es la jugarreta digital?

Dejamos, de momento, solo apuntado ese concepto fundamental, el de la lógica de selección, para reflexionar acerca de cómo esta se ha llegado a imponer y, entonces, desarrollarlo.

\subsection{HABITAR EL ASÍNDETON}

asíndeton.

1. m. Ret. Figura que consiste en omitir las conjunciones para dar viveza o energía al concepto.

Diccionario de la RAE

Simultaneidad.

En el apartado 8.2 nos referimos a las ideas acerca de la interactividad debidas a Baudrillard, quien postula la «excesiva proximidad del receptor y de la fuente». (1996b: 203) La sociedad tele ha quedado atrás, ya no podemos hablar, con Virilio, de velocidad, tenemos que hablar de simultaneidad.

Deep Blue II era capaz de calcular 200 millones de posiciones por segundo -de ellas, solo unas cuantas relevantes-. Eso no es velocidad: es inmediatez, simultaneidad. Como la simultaneidad con que son vivenciados en la sociedad contemporánea los acontecimientos que ocurren en distintos espacios.

El asíndeton no comprime el tiempo: lo destruye. El asíndeton no tiene sintaxis ni tiempo, es la abrumadora simultaneidad de lo desatado en la semiosfera, en la sociedad red, en la galaxia Internet. Es una lluvia de sustantivos que no tienen metáfora ni sustancia -insustanciales-, sin sintaxis vivencial. Vivir en el asíndeton es no vivir, es ser aplastado por la simultaneidad omnipresente de los flujos de información en el entorno 
urbano, de la fragmentación del hipertexto, es ser apabullado por un exceso que anula la acción.

Kasparov nació en 1963. Deep Blue II fue programada en 1997. Hay aquí un cambio generacional. ¿Es también un cambio de paradigma? Los niños de los años sesenta, setenta y ochenta sabían que el hombre podía vencer a la máquina. Aquellos que vieron 2001: Una odisea del espacio (1968), esperaban que un día remoto eso se revirtiera, ellos que de la mano de esa misma película aprendieron que la historia completa de la humanidad puede resumirse en una sola y escandalosa elipsis. Ellos, que vivieron la velocidad de la sociedad tele, de la elipsis, en carne propia.

El cambio generacional es el paso de la generación de la elipsis —del tiempo fragmentado en la edición cinematográfica-a la del asíndeton; de la compresión de un tiempo todavía lineal, a la aleatoriedad del zapping. El año 2001 ya pasó y, cuatro años antes, Garry Kasparov fue vencido, no por HAL 9000, sino por Deep Blue II. Los niños y adolescentes de los años 1990, que viven y se relacionan con el mundo a través de prótesis tecnológicas, traen a Deep Blue en el bolsillo: su mundo es virtual, saturado de posibilidades, de informaciones, de datos, de imágenes...

Esta sobreabundancia de imágenes utiliza nuestros espacios más íntimos, nuestra vida privada. Bajo este aspecto, entre sus efectos no solo resta realidad al mundo exterior (poco disociable de la imagen propuesta de él o, mejor dicho, de las imágenes con las que se substituye), sino que dificulta nuestra relación con los demás. La etimología atribuida a los primeros medios de comunicación rápida (telecomunicaciones, teléfonos, televisiones) subrayaba la extensión de las distancias que se habían propuesto reducir, o incluso abolir. Hoy en día el acento recae en la noción de red y de comunidad virtual: el internauta busca compañeros múltiples, pero su viaje, al partir, es una aventura solitaria. Busca con quién hablar. Esta necesidad de tomar la palabra [...] traduce una falta y un deseo. (Augé 2000: 116-117)

Y los deseantes por excelencia, los artistas, no permanecerán indiferentes a ese cambio en los años noventa. Ya no será posible hablar de narración, en el sentido literario-cinematográfico, la elipsis habrá quedado atrás como modelo de conducta. La ruptura de la linealidad, tan largamente anunciada, finalmente se habrá dado. No aquella linealidad puesta en 
entredicho más como propuesta que como acto; no como en Rayuela (Cortázar 1963) o en Chelsea Girls (Warhol 1966), sino como la concreción de la aspiración del intermedia: «utilizar las nuevas capacidades de representación del ordenador para representar la vida mental y, genéricamente, la subjetividad humana, de una manera nueva». ${ }^{15}$ (Manovich 1997: s.n.) Y también, por supuesto, en el gesto hueco del zapping o en los brincos insólitos de la navegación hipertextual en Internet.

Esta fragmentación será también la del pasado. Las obras del pasado serán hechas pedazos, deconstruidas para que, en cada lectura, algunos de sus fragmentos puedan ser vinculados con otras lexias, concretando así, gracias a la tecnología, la aspiración derrideana. El propio concepto de obra cambiará: no es lo mismo concebir una obra como hipertextual que hacer un uso hipertextual de una obra lineal. La fragmentación redundará en una pérdida del carácter idiolectal de la obra y, con ello, se difuminará la operatividad retórica concebida por el autor. Es la época de la dictadura de la intentio lectoris.

Los nexos electrónicos permiten a los usuarios recorrer distintos trayectos de lectura en un conjunto dado de lexias o bloques de texto. Esta prestación del hipertexto, de la que surge su característica esquiva de la linealidad, tiene efectos obvios e importantes sobre la concepción de la textualidad y de las estructuras retóricas. [...] El texto o más exactamente los pasajes de texto, que se sucedían los unos a los otros en una progresión lineal ininterrumpida, ahora se fracturan, se desploman, asumen identidades más individuales. (Landow 1992: 73-74)

Asistimos así, finalmente, al tan anunciado paso de la apertura de la obra (Eco), a su desbordamiento (Derrida). Asistimos a la puesta en acto definitiva del paso de la actitud interpretativa a la participativa. «Cualquier punto del rizoma puede ser conectado con cualquier otro, y debe serlo.» (Deleuze y Guattari 1976: 17) Lo que en la década de 1970 era un modelo conceptual, emerge de la tecnología como una realidad en la de 1990, como

${ }^{15}$ La traducción es nuestra. 
una manera de formar que reta a los esquemas de pensamiento vigentes hasta ese momento.

Un rizoma no cesaría de conectar eslabones semióticos, organizaciones de poder, circunstancias relacionadas con las artes, las ciencias, las luchas sociales. Un eslabón semiótico es como un tubérculo que aglutina actos muy diversos, lingüísticos, pero también perceptivos, mímicos, gestuales, cognitivos: no hay lengua en sí, ni universalidad del lenguaje, tan solo hay un cúmulo de dialectos [...]. (Deleuze y Guattari 1976: 18)

La semiosis ilimitada en plena explosión, en todas direcciones, impredecible, esquiva a cualquier codificación y, por lo mismo, también apabullante, bajo el riesgo continuo de verse pulverizada. Esa es la sociedad del asíndeton.

Atomización del espacio-tiempo. Constelación de atributos donde las elecciones no se desarrollan de manera lineal, sino fragmentada y aleatoria, y donde el tiempo, por lo tanto, no existe. Constelación atemporal que se vale de la tecnología para exprimir el valor de cada contexto específico. Tiempo indiferenciado: eternidad. (Cfr. Castells 1996) Tiempo ante el cual la persona corre el riesgo de quedar atónita, apática, paralizada ante la vastedad. Deleuze y Guattari, también Virilio, cuyas expresiones precedentes a la explosión digital hoy parecen premonitorias:

[...] estamos en el ámbito de la ilusión cinemática, del espejismo que produce la precipitación de la información en la pantalla del ordenador. Pero lo que se ofrece es justamente información, no sensación: se trata de la apátheia, esa impasibilidad científica que hace que cuanto más informado está el hombre, tanto más se extienda a su alrededor el desierto del mundo. La repetición de la información (ya conocida) perturbará cada vez más los estímulos de la observación extrayéndolos automática y rápidamente no solo de la memoria (luz interior) sino, ante todo, de la mirada, hasta el punto de que, a partir de entonces, la velocidad de la luz limitará la lectura de la información y lo más importante en la electrónica informática será lo que se presenta en la pantalla y no lo que guarda en la memoria. (Virilio 1980: 51)

¿Cómo afronta esto una persona común? Alguien con una inteligencia media o incluso algo superior a la media, alguien que no sea Garry Kasparov, niño prodigio, iniciado en el ajedrez a los cuatro años, 
campeón soviético juvenil a los 13, campeón mundial juvenil a los 17, gran maestro internacional a los 18, campeón mundial de 1985 a 1995...¿Cómo debe actuar, cómo puede actuar?

Una respuesta posible, de cara al mundo del arte, es: jugando a contrapelo de las reglas del juego, haciendo jugarretas. Retomamos aquí nuestra definición del arte expresada en el apartado anterior, como el juego que consiste en cambiar las reglas del juego.

El ideal del espectador co-creador ya está aquí. En la sociedad del asíndeton, toda la responsabilidad recae sobre el jugador-espectador, una abrumadora responsabilidad que no consiste simplemente en interpretar contenidos que ya vienen dados, sino en crear sentido a partir de la inabarcable avalancha de información disponible en su entorno. La atomizada información que le proporcionan los diversos canales de comunicación, el arte, la red y la vida urbana, entre otros factores, aunada a la falta de metarrelatos (marcos interpretativos), situación que lo fuerza más que nunca a adoptar una postura activa, de selección de información, de ordenamiento, de creación de mundo.

La pasividad del individuo medio es una falacia. ¿Qué gasto psicológico, así como de tiempo, tendría que hacer un individuo medio para analizar la información de lo que llamamos actualidad? (Esto sumado, por supuesto, a sus actividades cotidianas, su trabajo, etcétera.) La empresa es evidentemente imposible. De ahí que una opción sea recurrir a las instituciones - entre ellas, los media, la academia, los centros de culturaque ordenen la información de acuerdo a criterios que él comparta. Este recurso debe efectuarse maliciosamente para evitar caer en la falsa libertad de elección que abandera al capitalismo actual, el del ubicuo campo económico (Bourdieu) que todo lo abarca.

Desde el momento en que se le proponen unas cuantas formas, [el individuo] puede tener la sensación de estar expresándose personalmente a través de su elección. Pero en realidad solo está expresando su personalidad estadística y, en cierta manera, mimética, en función de las encuestas de mercado que han contabilizado unas opiniones mayoritariamente determinadas por los medios de comunicación, la información y la publicidad. (Augé 2000: 119) 
Pero, más allá de la ideología de los índices de audiencia, de las excepciones mediáticas manejadas como casos paradigmáticos, como modelos de vida, y que equiparan al artista consagrado con el deportista, rockero, empresario exitoso, político, estrellita fugaz o celebridad no celebrable en turno - en el sentido de que todos ellos son personas que devienen marcas registradas con sus groupies, promotores, clubs de fans y cohorte de chupasangres-; más allá de ello, el individuo tiene opciones reales. Preguntémonos: ¿Qué sentido tiene hoy la idea de Malraux del museo imaginario del individuo? ¿Es que este ha sido sustituido por el mercado imaginario -un mercado de pulgas, a decir de Bourriaud (2000)—; la Enciclopedia por las Páginas Amarillas?

Frente a los apocalípticos, la voz de Michel de Certeau se presenta una vez más como un remanso al reflexionar acerca de «las operaciones de los usuarios, supuestamente condenados a la pasividad y a la disciplina». (de Certeau 1980b: 391) La persona anónima que «insinúa maneras de habitar (una casa o una lengua) propias (...) en el sistema» que se le impone. Así,

Sobrepone esas maneras y, mediante esta combinación, se crea un espacio de juego para las maneras de utilizar el orden imperante en el lugar o en la lengua. Sin salir del sitio donde le hace falta vivir y que le dicta una ley, instaura pluralidad y creatividad. Gracias a un arte del intervalo (art de l'entre-deux), obtiene efectos imprevistos. (de Certeau 1980b: 394)

No ya, entonces, manera de formar, sino manera de utilizar, manera dejugar, manera de habitar.

[...] ningún signo debe quedar inerte, ninguna imagen debe permanecer intocable. El arte representa un contrapoder. No porque la tarea de los artistas consista en denunciar, militar o reivindicar, sino porque todo arte está comprometido, cualesquiera sean su naturaleza y sus fines. Hoy existe una querella de las representaciones que enfrenta al arte con la imagen oficial de la realidad, la que propaga el discurso publicitario, la que difunden los medios masivos, la que organiza una ideología ultralight del consumo y la competencia social. En nuestra vida cotidiana, nos codeamos con ficciones, representaciones, formas que nutren un imaginario colectivo cuyos contenidos son dictados por el poder. El arte nos coloca en presencia de contraimágenes. Frente a la abstracción económica que desrealiza la vida 
cotidiana, arma absoluta del poder tecnocomercial, los artistas reactivan las formas habitándolas, pirateando las propiedades privadas y los copyrights, las marcas y los productos, las formas museificadas y las firmas. (Bourriaud 2000: 122-123)

Una vez más, encontramos aquí la tentación de acudir a de Certeau como inspiración y fuente. Peligrosa tentación que puede llevar a una idealización, a expresar lo que es más una aspiración que una realidad posible. Así lo advierten Mattelart y Neveu (2003: 100): «Los investigadores se identifican con el enfoque que [de Certeau] propone de las tácticas propias de los consumidores en sus relaciones con los medios y otros dispositivos culturales». La notable expansión de las ideas del pensador francés evidencia su atractivo, su carácter casi redentor, pero que ha producido el fenómeno de «una visión a veces mitificada de las 'resistencias' que haya podido suscitar una lectura exageradamente optimista de L'Invention du quotidien». (Mattelart y Neveu 2003: 101) Los autores citados, jugando a ser abogados del diablo, se refieren en particular a los estudios culturales, tendecia crítica que hemos señalado como la que se ha puesto más en boga en las últimas dos décadas:

La apropiación de las tesis sobre «resistencia activa» por parte de los estudios culturales dista mucho de haberse librado de patinazos populistas [...]. Esta iniciativa enaltecedora está en las antípodas de la de Certeau, que nunca ha pecado de ingenuidad a propósito de los límites de las «antidisciplinas». El combate técnico contra el orden productivo y social se entabla entre el fuerte y el débil, incluso si este último no deja de construir su cultura. (Mattelart y Neveu 2003: 101)

Pero, en el arte de la cultura del ordenador, ¿qué nos queda sino aspirar a que esa posibilidad sea también una probabilidad? Habitar las formas. Ya no software, sino shareware. Ya no estética de la recepción, sino estética relacional. Ya no copyright, sino copyleft. Ya no originalidad, sino uso de las formas ya existentes en una cultura del copy/paste, de la apropiación, la cual pasó del montaje, la linealidad en la sucesión de imágenes y la velocidad, al recorte, la superposición de imágenes y la simultaneidad. El jugador-artista y el jugador-usuario, por igual, 
entregados al deseo. Ambos empeñados en crear esos intersticios, jugarretas del débil que les permitan hacer la guerra de guerrillas al fuerte.

Si la ilusión es fruto del deseo, como decía Freud, la paradoja es que hoy vivimos en un mundo de ilusiones que no hemos deseado, como si algún poder anónimo y planetario se hubiera encargado de desear por nosotros. Nunca, en este sentido, ha sido tan necesaria la vocación desalienante del arte. En su nueva acusación de todos los a priori que definen nuestro entorno y nuestros espacios (tomando, por ejemplo, el espacio de los museos como un elemento de su creación y ya no como el continente de un contenido autónomo, desplazándose hasta el espacio público, divirtiéndose entre las fronteras de lo público y de lo privado, tomando como objeto de observación los grandes espectáculos organizados para y por la televisión), el arte contemporáneo se propone con toda certeza volver a introducir una distancia, una separación, unos intersticios entre el individuo y su entorno, pero ante todo pretende devolverle con gran ahínco la fuerza de la mirada y la audacia del deseo a través del sentido de lo real. (Augé 2000: 126)

\subsection{LA FOTOGRAFÍA Y LA PRAGMÁTICA DE LA SOCIEDAD RED}

El ajedrez, como la metáfora, como la elipsis, se ha agotado. Habría que pensar, probablemente, en un cambio de reglas del juego: tableros con más escaques; el ajedrez tridimensional de Star Treck, con sus insospechadas relaciones de espacio-tiempo; nuevas piezas más adecuadas al contexto actual como podrían ser, acaso, el espía internacional o el congresista, acompañando a los tradicionales alfiles, torres y caballeros... Garry Kasparov venció a Deep Thought en 1989 y perdió contra Deep Blue II en 1997. Ese hecho, tal y como acabamos de ver en el apartado precedente, se ha convertido en el símbolo por excelencia de la relación entre el hombre y la máquina. Los años mencionados son también, grosso modo, las fechas en que la fotografía digital se generalizó bajo la promesa de que el programa del aparato fotográfico, su software, se vería expandido.

La fotografía digital fue una promesa de los años 1980 y anduvo a tropezones técnicos durante toda la década de los 90 hasta que llegó a 
estándares aceptables alrededor del 2000. En 1999 se presentó la primera cámara digital SLR -la Nikon D1- producida por un solo fabricante. En 2004 surgió Flickr, plataforma de la Web 2.0 para compartir fotos en línea. En 2005, el fabricante líder de equipo fotográfico, Nikon, anunció la retirada del mercado de toda su línea de cámaras de fotografía analógica; ese mismo año supuso la quiebra definitiva para Agfa de su rama de película, papel sensible y químicos de revelado AgfaPhoto, lo mismo que sucedería con Polaroid en 2008.

Pero, volvamos a la pregunta de fondo para nuestra investigación: ¿realmente ha implicado la fotografía digital una extensión del programa del aparato fotográfico, o simplemente ha introducido velocidad en los flujos de trabajo, así como una apabullante facilidad para llevar a cabo los eternos procesos de copy/paste, cortar y pegar, y una hueca utilización de filtros y menús que, tras la apariencia de facilitar la creación, solo promueven la repetición y la reutilización? Ante el exceso de la información disponible en Internet, incluida, por supuesto, la información visual, ¿cómo se han modificado los procesos creativos? ¿Hablamos de creación auténtica? ¿Se ha dado pie a una nueva lógica de creación? Manovich centra buena parte de sus disquisiciones en este asunto:

Es raro que los objetos de los nuevos medios se creen partiendo de cero; normalmente son un montaje a base de fragmentos que ya están hechos. Dicho en otras palabras, en la cultura del ordenador, la auténtica creación se ha visto sustituida por la selección a partir de un menú.

[...]

Bien mirado, seleccionar en una librería o en un menú elementos u opciones predefinidas es una operación esencial tanto para los productores profesionales de nuevos medios como para los usuarios finales. A los primeros les hace más eficaz el proceso de producción, mientras que los segundos sienten que ya no son solo consumidores sino también «autores» que crean un nuevo objeto o experiencia. (Manovich 2001: 178-179)

Ante esto, se pregunta Baudrillard (1996b: 204): «¿Apogeo o fin del espectador? Cuando todos se vuelven actores ya no hay acción ni escenario. Fin de la ilusión estética.» Si bien hemos insistido en el hecho de que este tipo de operaciones no son nuevas, su divulgación masiva derivada de la 
apabullante facilidad con que pueden ser aplicadas les da un nuevo cariz y las consolida como parte fundamental de la actual lógica de creación:

[...] la práctica de montar un objeto mediático a partir de elementos preexistentes y distribuidos comercialmente ya existía en los viejos medios, pero la tecnología de los nuevos medios la estandariza más y la vuelve mucho más fácil de efectuar. Lo que antes conllevaba tijeras y pegamento, ahora es solo cuestión de hacer clic en «cortar» y «pegar». Y, al codificar las operaciones de selección y combinación en las propias interfaces de los programas de edición y autoría, los nuevos medios las «legitiman». Sacar elementos de bases de datos y librerías se vuelve la norma, y crearlos desde cero se convierte en la excepción. La web actúa como una materialización perfecta de esta lógica. Es una gigantesca librería de imágenes, fotografías, vídeo, audio, diseños, código informático y textos, y cada elemento es gratis porque podemos guardarlo en el ordenador con un solo clic de ratón. (Manovich 2001: 185)

Es indispensable insistir, llegado este punto, en el hecho de que la posibilidad de selección y reutilización de elementos preexistentes es solamente parte de la nueva lógica, mientras que el otro aspecto fundamental a considerar es el que se refiere a la aplicación de filtros $u$ opciones de modificación de la imagen que normalmente el usuario tiene a un clic de distancia, con lo que su actividad se limita a la selección de opciones de un menú determinado por los programadores de software.

El proceso de la producción artística se ha puesto por fin al día con los tiempos modernos. Se ha sincronizado con el resto de la sociedad moderna, donde todo, desde los objetos a las identidades de las personas, resulta de un acopio de fragmentos que ya vienen hechos. El sujeto moderno, no importa si elige un conjunto de ropa, decora un piso o escoge los platos en la carta de un restaurante, va por la vida seleccionando en diferentes menús y catálogos. Con los medios electrónicos y digitales, la producción artística implica un similar escoger entre elementos prefabricados, ya sean las texturas e iconos que nos proporciona un programa de pintura, los modelos que vienen con un programa de modelado 3D o los ritmos y melodías incorporados en un programa sintetizador de música. (Manovich 2001: 181)

Con esta base, y para volver al campo concreto de la imagen, retomemos la consideración de las ideas barthesianas, que ya evocamos en el apartado 8.2 a propósito de Sekula y su concepción del archivo de imágenes: 
Si Barthes tiene razón en su propuesta de que una imagen es polisémica y tiene un significante que varía libremente -algo que solo tiene un significado determinado cuando es presentada dentro del marco de un texto específico (por ejemplo cuando es desplegada, con un pie de foto, en un artículo periodístico) y está, por lo tanto, abierta a su apropiación por una diversidad de textos-, entonces el reemplazo de textos impresos tradicionalmente rígidos y estables por ensamblajes electrónicos fluidos y recombinables ad hoc, es particularmente notable. Ahí donde una fotografía de prensa podría, en el pasado, haber sido publicada como parte de un número limitado de historias, ${ }^{16}$ su contraparte electrónica puede ser apropiada un sinnúmero de veces dentro de nuevas secuencias informativas. Es una condición que seguramente habría fascinado a Marcel Duchamp: las imágenes digitales son el readymade por excelencia, objetos manufacturados de escaso valor intrínseco a los que se atribuye sentido mediante la apropiación y contextualización, mas no como consecuencia del sentido que se deriva de la forma expresiva a partir de la cual han sido creadas. ${ }^{17}$ (Mitchell 1992: 85)

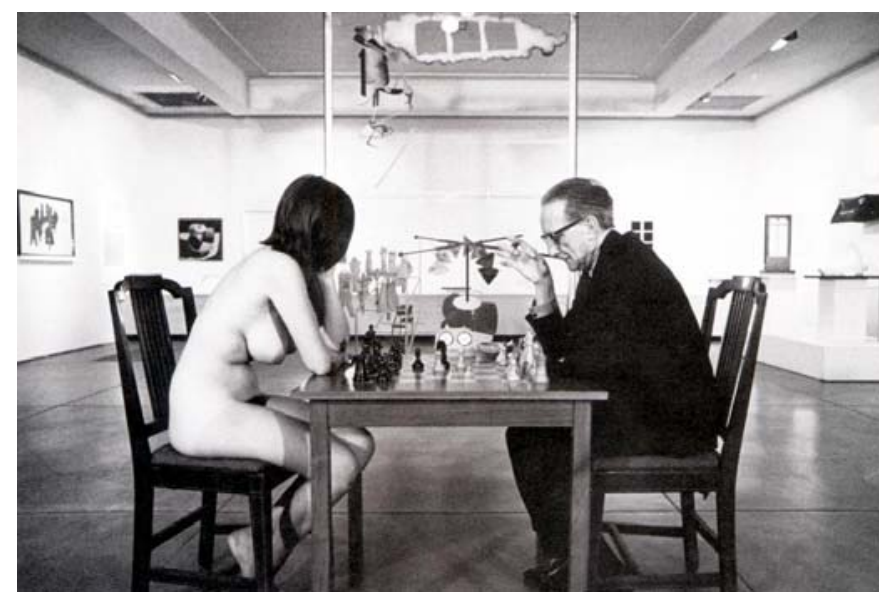

Imagen 97. Julian Wasser
Marcel Duchamp y Eve Babitz jugando ajedrez, 1963

Tomando como base la anterior cita, retomemos nuestra deriva en torno al ajedrez como caso paradigmático. En 1963, año del nacimiento de Garry Kasparov, Marcel Duchamp fue fotografíado jugando al ajedrez con una mujer desnuda. ¿Estaba acaso insinuando la necesidad de una

\footnotetext{
${ }^{16}$ Recordemos el ejemplo de la Imagen 9, de Doisneau, presentado en el apartado 3.5.

${ }^{17}$ La traducción es nuestra.
} 
extensión de las reglas del juego? Cinco años más tarde, el año de su muerte, el año de producción de 2001: Una odisea del espacio, el mismo Duchamp -introductor de algunas de las más radicales extensiones del programa del arte en el siglo XX - participaba en la performance Reunión junto con J ohn Cage, quien había acondicionado un tablero electrónico de ajedrez que respondía acústicamente a los movimientos de los jugadores.

Pero ni siquiera Duchamp, el gran transgresor que asistió a la muerte de la metáfora, reconoció el agotamiento del ajedrez. Iba a ser necesario que un niño prodigio nacido por esos mismos años se enfrentara, tres décadas después, a Deep Blue II. En ese momento que deriva en el actual, la presente década, la de la masificación del uso de la Web 2.0, ¿estamos hablando de una expansión del campo fotográfico o, por el contrario, de su progresiva reducción, como planteaba Flusser? La reflexión en torno al agotamiento de un medio expresivo no es nueva; tampoco es, por supuesto, exclusiva de la fotografía. Si bien ya hemos aludido a estas ideas a través de Flusser y de Bourdieu, conviene actualizarlas a partir del horizonte presente. Se ha señalado la década de 1960 como la que inicia un impacto social de la fotografía como un medio de democratización adquirida mecániamente, que abarata la experiencia tanto individual como colectiva. (Cfr. Stimson 2006) La consecuencia es un narcisismo social, la fascinación con las propias imágenes, las que producimos y que, por lo tanto, son imágenes de nosotros mismos. Baudrillard y Virilio también están en la línea de la reflexión en torno a la confusión entre la auténtico y lo inauténtico, lo generado por uno mismo y por los demás. La manera de producir imágenes por una sociedad queda así inextricablemente asociada a la manera en que esa sociedad se concibe a sí misma. Si la producción de imágenes, por otro lado, se facilita al extremo de que cualquiera, literalmente cualquiera, puede tener acceso a ella, se exacerba el fenómeno de la alienación en un lenguaje destinado a repetirse a sí mismo hasta el infinito, como lo representamos en el cuadro de la Imagen 7. (Ver supra: Capítulo 2) 
No solamente estamos hablando aquí de la superabundancia de fotos en la propaganda, la publicidad, los medios de comunicación, el entorno urbano e incluso, por supuesto, también en el arte, sino sobre todo de la fotografía de aficionado, con sus nuevas modalidades de producción y canales de distribución.

[...] la cultura visual no depende de las imágenes en sí mismas, sino de la tendencia moderna a plasmar en imágenes o visualizar la existencia. Esta visualización hace que la época actual sea radicalmente diferente a los mundos antiguo y medieval. A pesar de que dicha visualización ha sido algo normal en la era moderna, ahora se ha convertido en una obligación total. (Mirzoeff 1999: 23)

Dicho exceso explica, de alguna manera, el que a partir de esos años, como lo hemos establecido en este trabajo, se haya producido una creciente atención de los críticos en el fenómeno, como lo evidencia el incremento en la producción teórica en torno al tema. La tesis de Stimson incide precisamente en la pérdida que se da a partir de ese período, una pérdida cualitativa que va aparejada al aumento cuantitativo. Las características que venimos apuntando, a saber, la alienación a partir de la autorrepetición, el anonimato social que subyace como contraparte de la aparente posibilidad de expresarse, y el narcisismo implícito en el acto de producción de imágenes, ¿dan pie a la expresión de la subjetividad o, por el contrario, la niegan? ¿Cómo encaja, aquí, el problema de lo colectivo y lo privado? ¿Estamos ante la posibilidad de un nuevo ciudadano ideológicamente autoconsciente o, por el contrario, de un consumidor desideologizado, automarginado de su lugar en la historia, maquinizado?

[...] todo lo que es producido por el médium de la máquina es una máquina. Los textos, imágenes, películas, discursos y programas surgidos del ordenador son productos maquínicos y tienen esas características: artificialmente expandidos, potenciados por la máquina, las películas desbordantes de efectos especiales, los textos que se hacen largos, repletos de redundancias debidas a la maligna voluntad de la máquina de funcionar a cualquier precio (es su pasión) y a la fascinación del operador por esta posibilidad ilimitada de funcionamiento. [...] De hecho, es la máquina (virtual) la que nos habla, es ella la que nos piensa. (Baudrillard 1996b: 205206) 
No es extraño que, ante este marco, el arte se vuelva autorreflexivo, que se imponga el metalenguaje como tema y que, como ya hemos apuntado insistentemente, a partir de esa época el receptor, con sus características de particular inmersión en un contexto determinado, se convierta en el centro de atención del sistema. Tampoco es extraño que, si el arte se atribuye a sí mismo la función de atender las exigencias de la vida, de activar la conciencia del receptor, se convierta en una suerte de propaganda y copie las estrategias de esta. Pero, ¿no son las estrategias de la propaganda las de la ideología dominante?

Elipsis, dijimos; y posteriormente, asíndeton. Primero, velocidad; después, simultaneidad. El ciudadano ha pasado de ser un consumidor de la sociedad del espectáculo, un espectador de simulacros, a un usuario de la sociedad red. ¿Es acaso hoy más libre que ayer? La aparente libertad y el espíritu democratizador de la red también pueden verse con ojos suspicaces: «Internet es un espacio definido cultural e históricamente como cualquier otro. A pesar de las tan ensalzadas declaraciones sobre su igualdad radical, está determinada por la raza, el género y la clase». (Mirzoeff 1999: 153) ¿Es verdaderamente un paso adelante en la democratización, o simplemente duplica las tendencias sociales dictadas desde la economía? Insistamos en este hecho:

Las redes e industrias de la cultura y de la comunicación están en el origen de nuevas formas de construcción de la hegemonía. Por eso es por lo que los conflictos en torno a la excepción cultural, al derecho moral de los autores, la «gobernancia» del ciberespacio, han alcanzado una importancia tan estratégica. Esta nueva centralidad de lo cultural viene ratificada por la noción de soft power, cualquier forma de poder que no recurre a la fuerza y participa de la capacidad que posee la potencia hegemónica para fijar el orden del día de tal forma que modela las preferencias de las otras naciones. Inconcebible sin el arma del auge cultural, informacional y lingüística, el soft power, eufemismo que habría que traducir por la expresión menos blanda de «dispositivo de violencia simbólica», ve cómo se le asigna la tarea de cultivar el deseo de un orden planetario estructurado conforme a los valores del global democratic marketplace. El control de las nuevas redes, la information dominance, permitirá rentabilizar las inversiones en materia de representaciones del mundo que, desde hace más de medio siglo - en ocasiones, y muy especialmente en tiempos de crisis, por medio de la propaganda, la mayoría de las veces de forma metabólica, como un recurso natural del sistema social y al margen de cualquier complot-, dicha «cultura 
global» ha realizado a lo largo y ancho del mundo, «alfabetizando» a los consumidores, socializándolos con un modo de vida «global». El hecho de que la destilación ordinaria de estos valores orientados también haya engendrado antídotos, réplicas o aculturaciones contradictorias nada le resta al hecho de la instauración de una mentalidad colectiva, de un horizonte de crecientes expectativas y frustraciones.

Por el contrario, las luchas sociales y políticas iniciadas por los movimientos antiglobalización, por su parte, han puesto a la cultura y a la diversidad cultural en medio de su camino hacia «otro mundo posible». Al no ser la cultura una mercancía como las demás, estos nuevos protagonistas de vocación planetaria pero anclados en un lugar sociohistórico exigen que también sea considerada como «bien público común» a semejanza de la educación, del medio ambiente, del agua y de la salud. (Mattelart y Neveu 2003: 160-161)

En otro campo - el de su visión de los nuevos medios-, pero coincidiendo con el trasfondo de la visión expresada en la anterior cita, Manovich incide en una crítica que está en el mismo registro:

[...] la lógica de los nuevos medios corresponde a la lógica de la distribución postindustrial: a la «producción a petición del usuario» y al «justo a tiempo», que a su vez son posibles gracias a las redes de ordenadores en todas las fases de la fabricación y distribución. En este sentido, la «industria cultural» -término acuñado por Theodor Adorno en los años treinta- va realmente por delante de la mayoría del resto de industrias. [...] en el caso de los medios informatizados, esa inmediatez es ya una realidad. Puesto que la misma máquina se usa al mismo tiempo como sala de muestras y fábrica; es decir, que el mismo ordenador genera y muestra el medio; y dado que este existe no como un objeto material sino como datos que se pueden enviar por cable a la velocidad de la luz, la versión que se crea a medida para el usuario, en respuesta a los datos que ha introducido, le es entregada de manera casi inmediata. (Manovich 2001: 83)

Podemos afirmar, como consecuencia, que la lógica del ordenador basada en la transcodificación cultural de sus objetos, se impone a la de la tradicional cultura. Una vez más, como ocurrió en el siglo XIX cuando revolucionó la manera de ver y aproximarse al mundo, la fotografía es un ejemplo paradigmático de este nuevo ordenamiento.

La estructura de una imagen informatizada es relevante al respecto. En el plano de la representación, pertenece al lado de la cultura humana, y entra de manera automática en diálogo con otras imágenes, con otros «semas» y «mitemas» culturales. Pero a otro nivel, se trata de un archivo informático que consta de un encabezamiento que la máquina puede leer, seguido por números que representan la colorimetría de sus píxeles. A este nivel, entra 
en diálogo con otros archivos informáticos. Y las dimensiones de este diálogo no son el contenido de la imagen o sus significados ni sus cualidades formales, sino el tamaño y el tipo del archivo, la clase de compresión utilizada, el tipo de formato, etcétera. En resumidas cuentas, se trata de dimensiones que pertenecen a la cosmogonía propia del ordenador y no a la de la cultura humana. (Manovich 2001: 92-93)

Más allá del mero hecho de la toma fotográfica, todo el proceso, el flujo de trabajo de la producción de imágenes, está hoy copado por el ordenador y su lógica. El acto fotográfico, para utilizar la expresión de Dubois (1983), se ha transformado de principio a fin, de la preproducción a la postproducción, y mientras que lo irrepetible del acto, como diría Soulages (1998), permanece apenas como un pretexto, lo inacabable se desdobla sin parar en un juego de espejos, una verdadera puesta en abismo que no hace sino perpetuar la ilusión de originalidad. La del ordenador es una manera de formar que, de cabo a rabo, rezuma el sesgo de una lógica que más que un compromiso con la realidad revela un sometimiento:

Como los nuevos medios se crean, se distribuyen, se guardan y se archivan con ordenadores, cabe esperar que sea la lógica del ordenador la que influya de manera significativa en la tradicional lógica cultural de los medios. Es decir, cabe esperar que la capa informática afecte a la capa cultural. Las maneras en que el ordenador modela el mundo, representa los datos y nos permite trabajar; las operaciones fundamentales que hay tras todo programa informático (como buscar, concordar, clasificar y filtrar); las convenciones de su interfaz - en resumen, lo que puede llamarse la ontología, epistemología y pragmática del ordenador-influyen en la capa cultural de los nuevos medios, en su organización, en sus géneros emergentes y en sus contenidos. (Manovich 2001: 93)

Sometidos, así, a la lógica del ordenador, pasamos a un segundo sometimiento, a una de sus variantes extremas: la lógica de la red, verdadero espejismo de libertad de comunicación:

Pero, ¿existe realmente la posibilidad de descubrir algo en el ciberespacio? Internet no hace más que simular un espacio mental libre, un espacio de libertad y descubrimiento. De hecho, solo ofrece un espacio desmultiplicado, aunque convencional, donde el operador interactúa con elementos conocidos, sitios establecidos, códigos instituidos. Más allá de esos parámetros de investigación no existe nada. Cualquier pregunta es asignada a una respuesta anticipada. Uno es el interrogador automático al mismo 
tiempo que el contestador automático de la máquina. A la vez codificador y descodificador, de hecho nuestro propio terminal, nuestro propio corresponsal. Es eso el éxtasis de la comunicación. Ya no hay otro enfrente, ni tampoco destino final. El sistema gira así sin fin y sin finalidad. Y su única posibilidad es la de una reproducción y de una involución al infinito. De ahí el confortable vértigo de esa interacción electrónica e informática, similar al de una droga. Uno puede pasarse toda la vida en ella, sin discontinuidad. La droga misma no es más que el ejemplo perfecto de una interactividad enloquecida en un circuito cerrado. (Baudrillard 1996b: 206)

Retomemos nuestra analogía: el ajedrez implica una manera de jugar que representa un compromiso con la realidad; por lo tanto, una ideología. Esta, hoy, ya no se sostiene. Es una manera que tiene más en común con el pensamiento moderno, que con el arte y la producción mediática desde la década de 1990.

Ahora bien, es precisamente allí, más allá del poder mental del cálculo, donde el hombre puede plantearse ser definitivamente superior, en esa relación de alteridad que se basa en el desasimiento de su propio pensamiento, que Deep Blue jamás conocerá y que es el presupuesto sutil del juego. Es allí que el hombre puede imponerse en términos de ilusión, de añagaza, de reto, de seducción, de sacrificio. Esa estrategia de la debilidad, de un juego más acá de sus propias posibilidades, es lo que peor comprende el ordenador, pues está condenado a jugar al máximo de sus posibilidades. Este síncope, esta elipse de la presencia por la que hacemos surgir al otro, aunque sea bajo la forma del ego virtual del ordenador, es el pensamiento real del juego.

[...]

Frente a la máquina que él mismo había programado (no olvidemos que son hombres como Kasparov quienes han programado a Deep Blue), el hombre solo puede desprogramarse sutilmente, volverse technically uncorrect para seguir dominando el juego. Puede llegar incluso a ocupar la posición que era en otro tiempo la de la máquina. Como aquel ilusionista que había inventado un autómata que imitaba tan bien al ser humano que él mismo se vio obligado, en el escenario, a mecanizarse, a imitar al autómata para preservar la diferencia. Es la única estrategia posible: si nos volvemos technically correct, la máquina nos derrotará irremediablemente. (Baudrillard 1996a: 188-189)

Los artistas, deseantes que nunca han parado de buscar nuevas maneras, saben que la sociedad del asíndeton avanza más rápido que ellos. Angustiados, corretean a los aparatos tecnológicos que van a la velocidad de la luz. Y mientras tanto especulan, especulan acerca de sus propios medios, se pierden en el metalenguaje, no tienen nada que decir más allá del 
comentario acerca de las posibilidades de las formas de expresión que utilizan. Los receptores-usuarios, por su parte, tratan de subirse al tren, pero si en la época de las máquinas a vapor era posible subirse a un tren en movimiento, hoy resulta imposible hacerlo en un tren de gran velocidad.

Sin embargo, el arte sigue vivo. No ha muerto, como sí lo han hecho la metáfora —agotada-y el ajedrez —que se resiste a renovarse—.

Si hoy en día todavía existe alguna razón para no desesperarse ante la situación del arte es porque a través de sus formas más complicadas y menos espontáneamente legibles, todavía representa, frente a las evidencias comunes de la imagen, algo propio de la vanguardia, y todo ello a pesar del mercado del arte, de los esnobismos o de las facilidades. El objeto de arte, en cuanto supone una implicación y una reivindicación de una relación a tres entre el autor, la obra y quienes se la encuentran, constituye, aunque parezca imposible, la llamada de un testigo, es decir, una forma mínima de vínculo social, de relación social, un mínimo vital social que se opone de lleno a la ideología narcisista de la imagen imperante hoy en día. (Augé 2000: 131)

Una relación entre tres... ¡Nunca antes una necesidad tan apremiante de una pragmática! El juego del arte es, cada vez más, inventar nuevas reglas: jugar con el juego y proponer nuevas relaciones políticamente incorrectas. ¡Porque el grado cero de la vida es insoportable! El artista juega con las blancas...y su primera jugada es una invitación para el jugador-usuario. A partir de ahí, todo es impredecible.

Bajo el asalto de las imágenes, la imaginación enloquece o se desvanece, lo imaginario se vacía. Solo se resisten a su evidencia (que nuestro decorado cotidiano reproduce hasta el infinito) la opacidad de algunos objetos, o aun el gesto experimental de artistas que, adueñándose de algunas de ellas, les imponen posturas incongruentes y acoplamientos inéditos. Entonces se tornan misteriosamente deseables y comunican a quien las descubre la certeza todavía obscura del despertar. (Augé 2000: 101)

En la sociedad del asíndeton, el arte es una manera de jugar que se plantea como un intersticio social. Pero, ¿qué hay de la siempre debatida y ambigua posición de la fotografía frente al arte? Fotografías, en plural, establecimos desde un momento temprano de este trabajo. Mientras que las formas de la fotografía utilitaria en los hechos han tenido un boom, 
como lo muestran la omnipresencia de la imagen publicitaria, las formas incesantemente perpetuadas, pero también eventualmente renovadas de la imagen documental, o el diletantismo en constante expansión, desde el arte se insiste en un cuestionamiento de las formas fotográficas que, si bien se inició en la década de 1970 y desde entonces no ha dejado de proponer una concepción global de la interrelación entre los medios electrónicos, ha ido siempre por detrás del avance tecnológico y no ha sido capaz de construir a partir de la especificidad de dichos medios, sino que, al menos en el caso de la fotografía, se ha basado en la negación de su especificidad, mientras que la única manera de explicar un medio es a través de su afirmación.

La importancia de la imagen, y ante todo la imagen fotográfica, que ha guiado nuestra manera de ver durante 170 años, no puede ser soslayada. Parecería que en la era del mito monstruoso de la condición postmedia (cfr. Krauss 2010), la teoría crítica del arte solo ha sido capaz de referirse a la fotografía de manera negativa. Nuestra propuesta a lo largo de estas páginas ha sido verla de forma positiva a través de su especificidad, una especificidad que no ha dejado de construirse a sí misma. 
TERCERA PARTE: EL ANÁLISIS PRAGMÁTICO

9

\section{CONCLUSIONES: EL FOTÓGRAFO ANTE LA PANTALLA}





\section{CONCLUSIONES: EL FOTÓGRAFO ANTE LA PANTALLA}

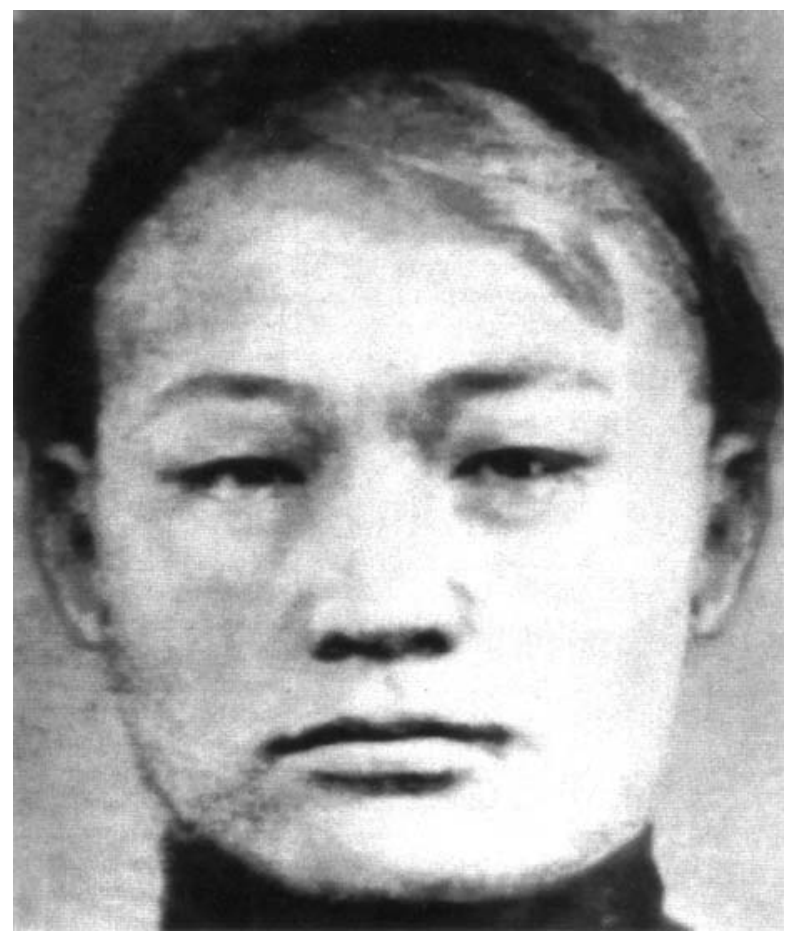

Imagen 98. Nancy Burson

Género humano (un oriental, un caucásico y un negro, mezclados conforme a las estadísticas de población), 1983-84

El rostro que nos mira de frente en la Imagen 98 no existe en la realidad. Es una imagen sintética realizada a partir de fotos y emula a una, pero no lo es, se trata de un simulacro. La obra, de Burson, suele ser referenciada en la mayoría de los ensayos que abordan el tema de la imagen digital, ya que fue pionera en la utilización de dicha tecnología en el primer tercio de la década de 1980. Para generar la imagen que nos ocupa, como lo explica su propio subtítulo, se partió de las fotos de un oriental, un caucásico y un negro, las cuales fueron integradas en porcentajes 
correspondientes a los índices de población por un software especialmente diseñado. No es, por lo tanto, una obra inclusiva, sino que maliciosamente podríamos decir que peca de una visión colonialista, ya que reduce el género humano solamente a las tres razas cuantitativamente dominantes y excluye a las periféricas. Pero, asumiendo como lo pretende su autora, que la imagen sea representativa del género humano en su conjunto, Mankind expresa una paradoja: ese rostro que nos observa con una mirada vacía es todos...y a la vez, por lo mismo, no es nadie.

Estas reflexiones nos recuerdan el dilema que en el Capítulo 7 trajimos a colación ${ }^{1}$ a propósito de Durero y de los frankensteins resultantes de combinar en una representación el rostro de un modelo, el torso de otro, las piernas de un tercero, etcétera; dilema en el que la búsqueda del ideal propiciaba un resultado que las más de las veces era aberrante. La crisis de identidad de la fotografía a la que ahora aludimos tiene connotaciones muy diversas a las de aquella práctica y puede extenderse a infinidad de procesos y maneras de formar características del procesamiento digital de fotografías. Al igual que todas las prácticas de producción técnica de imágenes, sus posibilidades y recursos se han vulgarizado, como lo muestra, por ejemplo, la Imagen 99, tomada del ámbito periodístico y que presenta un rostro femenino inexistente en la realidad, creado a partir de la mezcla de diversas razas, con lo que la propuesta de Burson se pone al servicio de otra estrategia comunicativa dentro del campo de la imagen funcional. Como consecuencia de estas prácticas que tienden a diluir lo fotográfico, si iniciamos el presente trabajo haciendo una reflexión en torno a la búsqueda de la fotografía por una identidad propia, hemos ahora de retomar esta discusión a partir del punto específico en el que la ha situado su devenir vinculado a la técnica.

\footnotetext{
${ }^{1}$ En estas conclusiones apelamos insistentemente al recurso de parafrasear conceptos de los autores que han sido troncales en los capítulos que componen el trabajo. A fin de no ser repetitivos y de propiciar una lectura fluida, indicamos estas deudas intelectuales mediante el uso de itálicas y/o de la alusión al nombre del autor, bajo el entendido de que dichos conceptos, junto con sus fuentes, han sido citados previamente a lo largo del trabajo.
} 


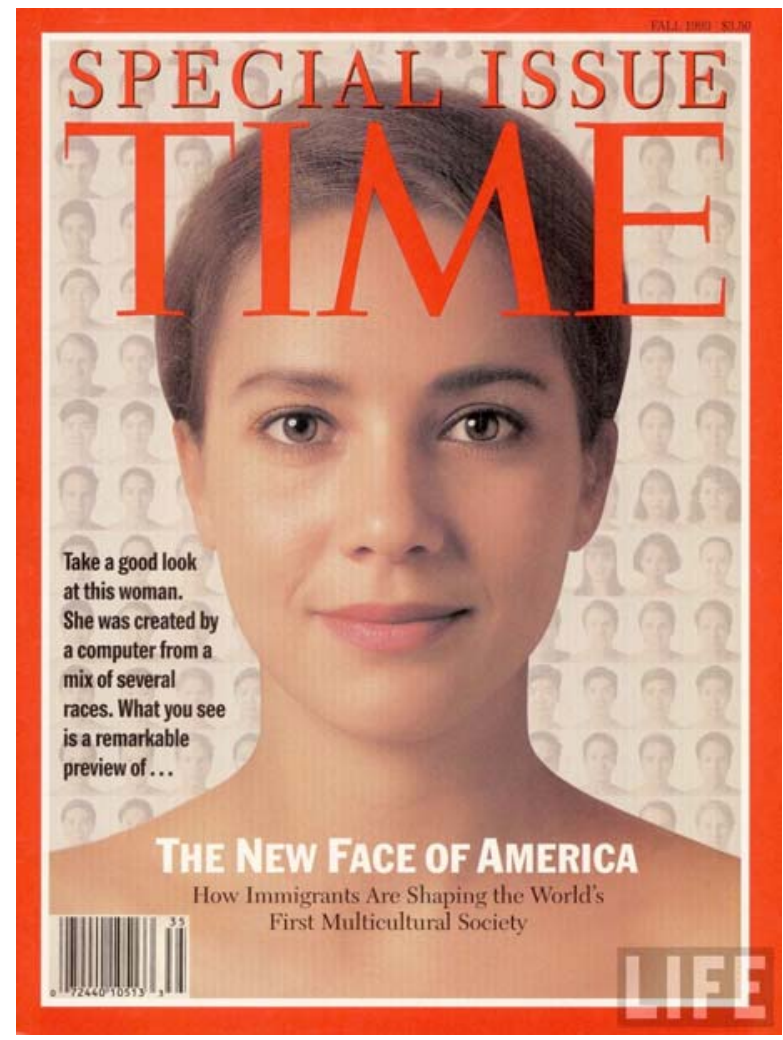

Imagen 99. Portada de la revista Time, número especial, otoño, 1993

En las páginas precedentes hemos planteado un recorrido en tres etapas que abarca la concepción de la fotografía como ventana, señalada por su capacidad de permitir que nos sumerjamos visualmente en la realidad, la fotografía como espejo, que refleja la propia subjetividad —del fotógrafo o del espectador- y, finalmente, la aparición de la fotografía como pantalla, espacio del simulacro y la virtualidad. Este devenir reaviva la eterna crisis de identidad del medio, la cual vuelve a surgir, aunque ahora con nuevas connotaciones: si la ventana, como en su momento señalamos, está inevitablemente inscrita dentro de la estructura de un edificio conceptual que le transmite sus cimientos ideológicos, ¿dónde está la 
pantalla? La pantalla, caja negra de innumerables transformaciones, no tiene raigambre, es infinitamente adaptable y, a raíz de su reciente miniaturización, la llevamos en el bolsillo, es portátil, omnipresente.

En las últimas dos décadas hemos asistido, así, a una pérdida de especificidad por parte de la fotografía, esa que fue tan arduamente buscada y, podría decirse, construida en algunos momentos de su historia. En efecto, la elaboración de una identidad propia ha sido un sello distintivo de la fotografía, marcada desde un inicio por esa escisión originaria que constituyó el hilo argumental de nuestro primer capítulo y que simbolizamos mediante la oposición entre óptica y química, conceptos alrededor de los cuales aglutinamos una constelación de atributos asociados. Escisión, por supuesto, falsa, como nos esforzamos en establecer, pero que ahora vuelve a presentarse tras la estela de lo digital. En efecto, la manera como ha tendido a abordarse el fenómeno de la fotografía digital plantea múltiples interrogantes. ¿No implica, acaso, crear una nueva escisión? ¿No es posible teorizar sin que sea a partir de dicotomías? ¿Acaso no es la última, la que opone a lo analógico frente a lo digital, la más perniciosa? ¿Por qué no ver en dicha transición una continuidad, más que una escisión o ruptura? ¿Qué ha sido de la tan polémica ontología del medio? ¿La ha suplantado la ontología de la cultura del ordenador? ¿Acaso el campo fotográfico está dominado por una nueva situación de anomia que le impide la siempre esquiva legitimación? Ante las nuevas prácticas, ¿es posible seguir hablando, como lo propusimos en su momento, desdela fotografía?

Es precisamente a partir de interrogantes como estas por lo que planteamos nuestras dos hipótesis de investigación. La primera de ellas, quedaba enfocada a la sistematización de las aportaciones teóricas en torno al estudio de los procedimientos de codificación -tanto inmanentes como contextuales- en los que queda anclada la especificidad del signo fotográfico. La segunda, por su parte, se centraba en el giro pragmático que la digitalización ha inducido en la práctica fotográfica en los niveles de su producción, distribución y consumo. Con la finalidad de abordar este 
doble objetivo, en el marco teórico que abarca los capítulos 2 y 3 , nos abocamos a hacer una revisión de los planteamientos críticos que han abordado el tema del lenguaje fotográfico tanto desde un punto de vista extrasemiótico como desde uno estrictamente semiótico. $\mathrm{Si}$ bien hemos hecho una revisión de estos asuntos a partir de un punto inicial fijado en 1957, nuestra clara intención ha sido desde un principio llegar al análisis de las transformaciones recientes, las cuales, señaladas de manera importante por los procesos de digitalización, abarcan las últimas dos décadas.

Como suele ocurrir, y según explicamos valiéndonos del cuadro de la Imagen 7 (ver supra: Capítulo 2), al que hemos vuelto en diversos momentos, las nuevas maneras de formar -estribillo que tomamos de Eco 1962b - tienden a ser inmediatamente lexicalizadas e integradas al capital cultural, por utilizar un término plenamente identificado con el marco conceptual de Bourdieu, precisamente uno de los autores fundamentales en nuestra construcción de dicho esquema explicativo. Este proceso de incorporación es, en cierto sentido, definitorio del devenir del medio fotográfico a lo largo de su breve, pero sustancial historia. La aproximación sociológica de Bourdieu a la fotografía considerada como arte intermedio y su énfasis en los usos que de ella se hacen en función de factores de clase, usos fundamentalmente tautológicos derivados de la puesta en acto de arquetipos temáticos y formas de representación estereotipadas, lo llevan finalmente al cuestionamiento de la objetividad fotográfica. Este planteamiento será, más de cuarenta años después de su propuesta inicial, revitalizado y actualizado por la masificación sin precedentes de las prácticas características de nueva pragmática fotográfica.

Las consideraciones realizadas en ese momento de nuestro trabajo en torno a la codificación en sentido extrasemiótico adquieren así, a la postre, el cariz de un pensamiento visionario que anticipará la fuerte carga que el estudio de los usos de la imagen fotográfica en una sociedad de masas, señaladamente a partir de la década de 1960, impondrá sobre las convenciones de su producción. En esta misma línea de pensamiento se insertan las aportaciones de otros autores que a lo largo del trabajo se 
imponen como fundamentales. Tal es el caso de Flusser, quien especula extensamente en torno a la fotografía como juguete complejo caracterizado por un hardware y, principalmente, un software, entendido como las reglas del juego y frente al cual el usuario, incluso el fotógrafo consciente, por lo general se encuentra por debajo de las posibilidades del aparato. Las concomitancias entre las concepciones de Bourdieu -sociólogo- y de Flusser -filósofo-, este último con su denuncia de la creciente maquinización de la sociedad y del peligro de una cultura automática, son plenamente identificables con las especulaciones recientes de autores como Manovich en torno a la cultura del ordenador. Es este, así, un cabo que lanzamos en la parte inicial del trabajo para después atarlo en relación a las limitaciones de la práctica del usuario de las tecnologías digitales en tanto en cuanto su actividad se ve frecuentemente reducida a la selección a partir de menús, lo que también afirma el movimiento que en su momento señalamos como característico de una teoría de la comunicación en la que la importancia del autor ha decrecido de manera paulatina al grado de hablarse simbólicamente incluso de su muerte, propuesta que parecería haber llegado a su concreción definitiva a la luz de concepciones como, por ejemplo, la que se refiere a la creación como postproducción, debida a Bourriaud.

Es también a partir del Capítulo 2 que introducimos un tema que servirá de hilo conductor a lo largo del trabajo. Una vez más tomando como punto de referencia a Flusser y su analogía del aparato fotográfico como juguete, así como el concepto de codificación en tanto que conjunto de reglas, apelamos al juego por excelencia, el ajedrez, para mantener presente a lo largo de nuestro discurso este vínculo entre el hombre y la máquina que en la época de la fotografía como pantalla será crucial. Pero antes de derivar en ese punto, es fundamental en nuestro planteamiento la profundización, precisamente, en esas reglas del juego, las estrategias de codificación que permiten que la producción simbólica tome forma. Por ello, en el Capítulo 3 ahondamos en el devenir de las teorías semióticas de la fotografía como enfoque, no único, pero sí central, de nuestro planteamiento. 
Si bien la semiótica ha perdido de alguna manera la fuerza que la caracterizó durante las décadas de 1970 y 1980 -lo que no es en absoluto extraño dada la necesidad del mercado de proponer nuevos enfoques-, es interesante apreciar la manera en que la terminología semiótica se ha incorporado en otros marcos conceptuales y ha devenido en una herramienta útil que sigue siendo bastante socorrida para abordar algunos aspectos del análisis de las imágenes. La suma de los enfoques inmanente y extrínseco, como su sello característico en el período posestructuralista, le permitió posicionarse como un medio sumamente completo de aproximación al estudio del sentido. Como establecemos en el marco teórico, frente a otros enfoques característicos de ese período que derivan de manera creciente en un énfasis en ocasiones desmedido en la libertad interpretativa del receptor, la semiótica insistirá en la propuesta de un equilibrio en el que no quede soslayada la obra en sí como centro de la intención comunicativa. Durante los últimos veinte a treinta años la semiótica enarbolará, así, la defensa de la crítica inmanente frente a los enfoques centrados en el receptor. Podemos, asimismo, subrayar su importancia justamente durante ese período coincidente con el boom de lo digital. $\mathrm{Si}$, como reza la frase convertida en estribillo de los teóricos de este enfoque, la semiótica estudia aquello que sirve para mentir (cfr. Capítulo 2), precisamente en el terreno de la imagen digital se encuentra un campo extraordinariamente fértil para su aplicación.

En el caso concreto de la fotografía, precisamente la semiótica representa de manera emblemática la ya mencionada escisión del medio que ha caracterizado históricamente las aproximaciones teóricas que a él se han hecho y que da pie al inicio de nuestra reflexión. Si el marco teórico establecido recorre las propuestas de lo que hemos llamado, de la mano de Barthes, la semiótica del índice, frente a la semiótica del icono debida a los teóricos que tienen en su base las ideas de Eco, este recorrido busca finalmente llegar a un equilibrio en el que la especificidad del medio se construya a partir de ambas posiciones, y no mediante el privilegio de una sobre otra. La estrategia desplegada por nuestra parte consiste, 
consecuentemente, en la sistematización de los esfuerzos de aproximación semiótica a la codificación fotográfica dentro de un plano inmanente para después, y solo con base en esta plataforma teórica, incorporar un análisis extrínseco que da cabida a lo que hemos llamado el giro pragmático, en el cual la fotografía queda asimilada a otros medios dentro de ese megacontexto al que hemos aludido a través de nombres que intentan abarcarlo extensamente, como son semiosfera, iconosfera, mediasfera y, más recientemente, sociedad red, entre otros. Este giro, asimismo, será el eslabón que vinculará a nuestra propuesta semiótica con la línea de los estudios culturales, en tanto que enfoque centrado predominantemente en la consideración de las circunstancias de recepción.

Es precisamente de esta vocación de síntesis de las dos posiciones semióticas ya referidas que se desprende una de las propuestas fundamentales del presente trabajo, vinculada a la primera de las hipótesis que hemos planteado. Si como parte de dicha hipótesis -que, como ya se recordó unos párrafos arriba, busca esclarecer los procedimientos de codificación fotográfica que dan sustento a la especificidad del signo fotográfico- se plantea como necesario el estudio de los mecanismos de creación del sentido en fotografía, esta necesidad se ve exacerbada por el hecho de que, históricamente, este estudio solo se ha abordado de manera parcial o, paradójicamente, se ha eludido. Es por ello que, una vez planteado el marco teórico en los capítulos 2 y 3, se dedica el bloque compuesto por los tres capítulos siguientes a la sistematización de los procesos de codificación en lo que podría leerse incluso como un método para abordar el mensaje fotográfico, aunque está lejos de nuestra intención el proponer una aproximación que resulte reduccionista en el sentido de plantear una guía de análisis paso a paso, con la relativa ingenuidad que ello conllevaría.

La lógica en la que se sustenta nuestra propuesta teórica en torno al análisis inmanente consiste en abordarlo primero en relación a la construcción de sentido desde un punto de vista plástico, para posteriormente integrar el plano de lo icónico o figurativo. En el ámbito de 
la fotografía como corte, como ventana, lo primordial ha sido analizar, de entrada, la manera en que opera la reducción de la realidad tridimensional al plano de dos dimensiones. Es por ello que hemos llamado precisamente códigos miméticos a aquellos que engloban las operaciones implicadas en dichos procesos de reducción, dedicando a su análisis el Capítulo 4, en el que hacemos una síntesis de ideas provenientes tanto de la semiótica como de la teoría de la forma, suficientemente ilustradas. Hay asimismo, a lo largo de ese periplo, una insistencia en el concepto de grado cero, lo que históricamente se ha establecido como el canon fotográfico, a partir del cual se presenta la desviación. El asentamiento de este concepto será fundamental como uno de los cabos a atar a la postre, al preguntarnos si ese marco de referencia sustentado en la técnica, y tan cuidadosamente construido a lo largo de siglo y medio de historia de la fotografía, sigue vigente o ha sido relegado por las nuevas prácticas vinculadas a la producción y al flujo de trabajo digitales. Provisionalmente, al margen de que más adelante retomaremos este tema, nos postulamos por la idea de su permanencia.

Todavía moviéndonos en el ámbito de lo plástico, en el Capítulo 5 abordamos los códigos técnicos, esto es, aquellos signos desprendidos específicamente de factores vinculados a la técnica fotográfica, frecuentemente parasitarios en su origen, y que se encuentran en la imagen, mas no en la realidad. Si bien Costa ha insistido en estos factores a lo largo de los años, otros autores han soslayado completamente su importancia y no los han situado dentro de sus estrategias de análisis. Así pues, tomando como punto de partida la construcción de dicho autor, nuestra aportación es doble: por un lado, la de integrarlos al corpus del análisis inmanente, y por otro, la de actualizar los criterios establecidos por Costa, algo envejecidos en relación al avance tecnológico del medio. Es en este sentido que agregamos la consideración del soporte y el formato como códigos - esencial para la comprensión de algunas de las propuestas en el campo de la fotografía artística a partir de la década de 1960 - y del código digital, con lo que introducimos una primera aproximación al tema que 
será desarrollado con amplitud en el Capítulo 8, a partir de un punto de vista que constituirá una de las aportaciones fundamentales de la presente investigación. En síntesis, la consideración de los códigos técnicos se mostrará como un elemento esencial para entender la tan mentada transición de lo analógico a lo digital como un proceso de continuidad, más que de ruptura, en el que la incorporación de elementos técnicos contrarios al buen hacer fotográfico, entendido como grado cero, se dará en la mayoría de los casos teniendo dicho canon como marco referencial, característica que en general acusan de forma exacerbada los primeros trabajos en el ámbito de lo digital ante la novedad del juguete y la falta de tiempo para incorporar sus posibilidades de manera que se asentaran naturalmente, lo que a veinte años de su introducción parece finalmente estar ocurriendo.

Este primer bloque temático, dedicado al análisis inmanente, se completa con la consideración de los códigos retóricos en el Capítulo 6, a través de la cual quedan integrados en el análisis los planos icónico y plástico. Históricamente se ha evidenciado que los análisis inmanentes de tipo exclusivamente formal resultan insatisfactorios, en el sentido de que más allá del cómo significa una imagen, la vocación interpretativa siempre nos lleva, finalmente, al intento de esclarecer qué significa -aunque, como veremos a continuación, dada la preeminencia de los enfoques centrados en el receptor, la aspiración ha derivado en aclarar qué significa, para quién y en qué contexto-. La propuesta de integrar en el análisis aspectos concernientes a los actantes, objetos y espacio representados, así como a los procedimientos retóricos implicados para generar sentido a partir de ellos, viene a cerrar, así, una forma de abordar la imagen fundamentada en los aspectos propios y característicos del medio fotográfico.

Moviéndonos todavía en el ámbito de la primera de nuestras hipótesis, podemos ya en este punto plantear una conclusión provisional la cual, por supuesto, apunte a la segunda hipótesis. Viendo en conjunto la teoría fotográfica generada en las primeras tres décadas —de 1960 a 1990— del período que hemos señalado como objeto de nuestro estudio, podemos afirmar que el análisis inmanente de la fotografía avanza a tropezones, un 
paso atrás de la semiótica de la imagen en un sentido amplio y siempre caracterizado por aportaciones parciales que no logran integrarse en un método exhaustivo. Es por ello que hemos dedicado los capítulos hasta aquí reseñados - 4 a 6-a las sistematización de dichas aportaciones como parte de un corpus teórico que proporcione un instrumental suficiente. Paradójicamente, es justo en el momento en que la fotografía parece haber adquirido la mayor estabilidad de su historia y en que los procedimientos de codificación fotográfica en gran medida se han estandarizado, que se presentará una doble revolución: por un lado, a partir de prácticas artísticas metadiscursivas que, precisamente, convertirán esa estabilidad y estandarización en blancos de sus críticas; y, por otro, debido al surgimiento de las nuevas prácticas fotográficas vinculadas a la tecnología digital. Así, el tan arduamente trabajado análisis de tipo inmanente, con su gran énfasis en lo formal, quedará convertido en una suerte de análisis introductorio respecto de la labor interpretativa. Los criterios así establecidos para el análisis —sobre todo en áreas como las de lo óptico y lo lumínico, vinculadas precisamente a la transposición de la realidad al plano en la operación de corte y al control de los gradientes- mantendrán su vigencia como característicos de lo fotográfico, mientras que la suplantación de la química por el píxel se dará de forma paulatina y, muchas veces, transparente, teniendo siempre las posibilidades de la fotografía convencional como marco de referencia, como lo muestra de manera emblemática el repertorio inicial de filtros de los programas de retoque digital, enfocado en gran medida a la imitación de lo analógico y a la correcta fusión de archivos diversos que en los primeros años de la transición frecuentemente provenían de este ámbito mediante el escaneo.

Cabe mencionar también que los criterios de análisis inmanente pasarán por un período de confusión en el que se aplicarán indiscriminadamente a imágenes sintéticas que, aun teniendo su origen en fotografías, no lo son en sentido estricto. La imagen sintética ofrece la tentadora posibilidad, inalcanzable para la fotografía tradicional, de combinar elementos provenientes de diversos contextos espacio- 
temporales, de descontextualizar actantes y objetos, y hacerlo de manera transparente o, como suele decirse en la jerga del diseño informático, sin costuras, seamless. Esta técnica tiene concomitancias evidentes con el surrealismo en tanto en cuanto permite que los juegos retóricos se vean potenciados mediante la creación de asociaciones libres de ideas y, con ello, de connotaciones insospechadas, de nuevos culturemas. Así, imágenes que en las iconosferas precedentes eran casos de excepción y requerían de una extraordinaria habilidad técnica para ser producidas, hoy saturan nuestro entorno y su realización está prácticamente al alcance de cualquiera. En una primera aproximación, parecería que esto supone un crecimiento exponencial del universo de lo fotografiable, así como la liberación del fotógrafo de la necesidad de resolver toda situación in situ, en el momento de la toma, con el solo recurso de la cámara y la luz como instrumentos de trabajo, viéndose también relativizado el tamaño del fotógrafo frente al de su aparato técnico.

Daría la impresión, entonces, que la fotografía ha dejado finalmente de ser eso que Barthes llamó un objeto antropológicamente nuevo -idea que hemos evocado en repetidas ocasiones a lo largo de este trabajo-, pasando a convertirse en el referente de esos objetos antropológicamente novísimos que son las imágenes sintéticas que están en la base de las realidades virtuales. Los procesos de codificación técnica fotográfica han pasado así a ser frecuentemente utilizados a contrapelo, para engañar al espectador mediante un acercamiento ficticio al grado cero fotográfico, para crear simulacros; pero su importancia como horizontes, como espejos a partir de los cuales crear los simulacros, no se ve minimizada sino, por el contrario, exponenciada. En términos de la labor interpretativa por parte del receptor, la primera pregunta ante una de estas imágenes debe ser: ¿estoy ante una fotografía o ante algo que simula ser una fotografía? A partir de la respuesta a esta pregunta se desencadenará la ruta del proceso interpretativo y, si se da el caso de que la respuesta sea incorrecta, toda posible conclusión estará ya viciada desde un principio. En este sentido, podemos afirmar que el programa del aparato se ha visto extendido por la 
tecnología digital, así como también los conceptos de lo fotográfico y lo fotografiable.

Más allá del plano de lo inmanente, en el caso concreto del estudio del acto fotográfico, cabe preguntarse en qué medida es posible vincular el anteriormente citado giro pragmático a las posibilidades tanto expresivas como de flujo de trabajo y de circulación de imágenes relacionadas con las nuevas tecnologías. Aunque, como acabamos de mencionar, en lo tocante a los aspectos pragmáticos relacionados con la producción los cambios ocurridos han sido abarcadores, es necesario tener muy presente que la semiótica ya había dado claras señales, desde la década de 1980, de efectuar ese giro que la vinculara cada vez más a las inquietudes teóricas relacionadas con el privilegio de los procesos receptivos y con las aportaciones de la consideración de los aspectos contextuales como parte de los actos comunicativos -relacionados también con el boom en paralelo de los estudios culturales-. A partir de ese momento dicho giro será fundamental y protagonizará las nuevas aproximaciones. A fin de profundizar en este asunto y continuando de esta manera con la línea lógica que subyace a la estructura de nuestro trabajo, dedicamos el Capítulo 7 a sistematizar el campo específico del estudio fotográfico semio-pragmático como eslabón para, en el Capítulo 8, reflexionar en torno a los cambios derivados de la transición a lo digital en relación a la tríada produccióndistribución-consumo.

En el primero de estos capítulos utilizamos como pretexto discursivo el género clásico del desnudo fotográfico para introducir el tema fundamental de cómo más allá de los criterios ya establecidos por el análisis inmanente, la interpretación de la imagen depende también de ciertos anclajes contextuales que dan fundamento al análisis extrínseco. Una vez más nos topamos de frente con el problema de la falta de rigor de algunos estudios a la moda que, si bien se refieren de manera insistente al contexto - en sentido más o menos amplio, esto es, abarcador de los diferentes momentos del proceso comunicativo- y al horizonte de expectativas del receptor -concepto tomado en préstamo de la teoría de la recepción 
literaria y cuyo uso se ha extendido ampliamente- en tanto que elementos definitorios de la interpretación, generalmente no desglosan las categorías en que dichos anclajes pueden ser sistematizados. La polisemia del propio término contexto ha significado un escollo en este sentido, ya que admite aproximaciones con connotaciones diversas dependiendo de si tienen su origen en la semiótica, la estética, la antropología o la sociología, entre otras disciplinas. Es con base en esta intención sistematizadora que proponemos el modelo que hemos llamado triángulo pragmático, que pretende incorporar en el proceso interpretativo las interrelaciones recíprocas que se dan entre el género, el espacio discursivo y el canal de comunicación con su situación específica, como campos esenciales en los que se desarrolla la vida social del mensaje.

Cabe enfatizar que, siendo estos aspectos de consideración en el caso de cualquier tipo de mensaje y, especialmente, en el desarrollo de nuestro trabajo, podemos concluir que existen particularidades que distinguen a la fotografía y le otorgan especificidad respecto de ellos. Por un lado, hemos insistido en la dificultad de aplicar criterios unívocos a todos los tipos de producción fotográfica, por lo que hemos apuntado el acierto que viene dándose por parte diversos historiadores y críticos al hablar de fotografías y de historias de la fotografía, así, en plural. En nuestro caso con ello intentamos, entre otros logros, poner el acento en los usos sociales y funcionales de la fotografía, adicionalmente a los estéticos. Esta distinción se vuelve crucial, máxime en un entorno como el actual, señalado por la homologación de expresiones que la cultura visual genera, en la cual los procesos de difusión llegan a dominar incluso sobre los de la creación en la determinación última del sentido. Finalmente, como se desprende de los ejemplos que hemos manejado en torno al desnudo fotográfico -en aquel caso entre lo erótico y lo pornográfico一, son factores externos a la imagen los que marcan el derrotero de la interpretación. Si la autonomía de la fotografía respecto del campo artístico ha sido siempre conflictiva, hoy lo es aún más en relación a la actual semiosfera. Nuestra propuesta en este capítulo se centra, así, en la consideración de que el acto comunicativo 
desde la creación o manera de formar - siguiendo a Eco- al acto de recepción o el modo de ver - siguiendo a Berger - están determinados cultural y, por lo tanto, contextualmente.

El primer elemento de nuestro triángulo pragmático es el género, debido a que incide en ambos extremos de dicho modelo comunicativo: emisión y recepción. Como en su momento desarrollamos, los géneros artísticos siempre están convencionalizados, partiendo de la tradición como marco de referencia. Esta opera como un verdadero manual de instrucciones tanto para el creador como para el espectador, que encuentra así en el género el primer indicio en cuanto a cómo debe interpretar la obra. El apego a determinadas convenciones de representación supone una manera de ver, estar, aceptar el mundo. Nos movemos dentro del ámbito del estereotipo, del choque entre la artisticidad y el ethos, razón por la cual, dicho sea de paso, es necesario abrir el marco de estudio a las consideraciones sociológicas, ya que la fotografía nunca puede expresarse desde el ámbito de lo puramente estético. La fotografía nos empuja a asomarnos a su especificidad comunicativa a partir de diversos frentes disciplinarios, ya que una de las capacidades del mensaje fotográfico es la de reorganizarse indefinidamente, lo que deriva en la concepción de la estética del a la vez, concebida por Soulages, que pretende que el espectador ha de poner en juego de manera simultánea todos los aspectos que influyen en la interpretación. Dando continuidad a la armazón estructural de nuestro trabajo, lo que consolidamos en este capítulo es la necesidad de un equilibrio entre los análisis inmanente y extrínseco. Es por ello que ya en algún punto hablamos, y ahora lo retomamos, del entendimiento de la obra fotográfica concreta como vórtice, eje de fuerzas al mismo tiempo estable a su interior y potencialmente explosivo al entrar en contacto con factores externos que desdoblan su sentido.

Queda de esta manera justificado el recurso que hacemos a visiones de la estética desde la sociología. Tal es el caso de Adorno, para quien el género aporta una función didáctico-clasificatoria y también de ubicación de la obra particular a partir de criterios universales. El género tendrá así 
un carácter normativo pero también, por lo mismo, de constreñimiento. Otro caso es el de Bourdieu, quien insiste en que las prácticas fotográficas de la gente común se reducen por lo general a la aplicación de una serie de reglas técnicas y de composición muy simples, siempre con el telón de fondo de los estereotipos de género que, asimismo, constituyen su primer recurso para la lectura. Bourdieu, a su vez, es ampliamente comentado por Krauss y se encuentra, por lo tanto, en la base de algunos de sus planteamientos, concretándose así su migración al campo de la estética. Esta multidisciplinariedad es, en sí misma, reflejo de las profundas implicaciones del género para la pragmática de la recepción.

En lo que se refiere en concreto al campo artístico, indudablemente la especulación activa en torno al género es uno de los sellos distintivos de la producción del arte contemporáneo. En el caso del medio que nos ocupa, el peso del género como criterio clasificatorio se refleja, por ejemplo, en la imposición de categorías al archivo fotográfico histórico, que ha provocado a posteriori visiones, o mejor, construcciones, tanto idealizadas como incoherentes. Soulages advierte que las fotos solo adquieren sentido en relación a otras fotos, lo que -como en Bourdieu- da lugar a esas situaciones fotográficas arquetípicas a las que es prácticamente imposible dejar de apelar. El hecho de que los géneros siempre estén, de manera inevitable, en el horizonte del creador, contribuye así a una desmitificación de la práctica artística, sobre todo al considerar que incluso las propuestas transgenéricas y deconstructoras los toman en cuenta invariablemente a manera de referentes. De ahí que podamos hablar de una resistencia del género en la cual la memoria genérica actúa como memoria genética; tan arraigada se encuentra en la conformación de los procesos creativos. Al girar nuestra especulación alrededor de lo que la fotografía es y puede ser, del lenguaje fotográfico y sus posibles desdoblamientos como formas de extensión del universo de lo fotografiable, la consideración del género se consolida, por ello, como un asunto fundamental en el marco de nuestra reflexión, en tanto que componente de carácter esencial para la expresión fotográfica. 
Pero, hoy, ¿asistimos a la afirmación de la especificidad fotográfica o a su anulación? Parecería que los factores externos a la imagen tienden a reducir el peso de los valores que hasta aquí hemos considerado. En la actual semiosfera, la cultura visual homologa no solo los productos, sino también las prácticas. La idea de que la fotografía ha derivado en simples imágenes toma fuerza ante la difuminación de las fronteras entre los diversos espacios discursivos, concepto aparejado al de género y a menudo confundido con él. Las fotos cambian de espacio discursivo y, con ello, de sentido. Si se ha hablado de la confusión de los géneros, debemos tomar en cuenta que en el presente entorno la confusión va mucho más allá. Este factor, el espacio discursivo, pertenece ya al ámbito de la difusión y consumo de las imágenes, condición que las más de las veces escapa al control del creador, ya que pertenece a la vida social de la imagen.

El último elemento de nuestra tríada de factores externos en los que el sentido queda anclado está íntimamente vinculado al espacio discursivo, ya que generalmente constituye el medio concreto a través del cual aquel vehicula el sentido. Nos referimos al canal y la situación específica de comunicación y por lo tanto, una vez más, estamos en el ámbito de la difusión y consumo del mensaje. Aquí entran en juego las normas comunicacionales de cada canal -sea del espacio discursivo del periodismo, de la publicidad, del sistema del arte-, con su ideología, procesos, equipos de trabajo, etcétera, los cuales dan variedad a la semiosfera, megacontexto de intercambios comunicacionales. Si bien en el presente somos herederos de una época en la que las tendencias culturales dominantes venían dictadas por los media, cuya influencia sigue siendo dominante, en la actual sociedad tecnificada el propio concepto de canal se está viendo cada vez más problematizado. La referencia a lo visual, término saco en el que casi cualquier cosa cabe, se ha convertido en un lugar común en el que subyacen aspectos como la exaltación de la imagen técnica y la homologación de los productos de la cultura popular con los de la alta cultura. En el caso concreto de la fotografía que se mueve en los circuitos museísticos, este espacio discursivo también ha asistido a una profunda 
transformación de sus canales en las últimas décadas. Si en su momento la innovación estuvo vinculada a los nuevos soportes de la imagen e incluso a su liberación de ellos a través de la proyección, a partir de los noventa la imagen se evapora al digitalizarse. Siendo numérica, esto es, liberada ya de su sustrato físico, adquiere una volatilidad que no solo potenciará conceptos como el del universo de lo fotografiable, sino también su distribución y consumo a través de los nuevos canales digitales que situarán al receptor -y aquí nos engarzamos con el Capítulo 8-en una posición de inmersión en lo visual, en la que los aspectos pragmáticos extrínsecos pasan a ser los predominantemente definitorios del sentido. Este capítulo se convierte, por lo tanto, en el puerto de llegada de todas nuestras anteriores reflexiones.

En este punto de nuestra investigación parecería estar agotada la propuesta de análisis inmanente y extrínseco y, con ello, cubierto lo referente a la primera hipótesis planteada: el esclarecimiento de los procedimientos de codificación fotográfica que dan sustento a la especificidad del signo fotográfico. Pero si hemos propuesto una segunda hipótesis ello se debe a que los cambios pragmáticos ocurridos en las pasadas dos décadas han sido tan abarcadores de los diferentes momentos del acto fotográfico que hacen necesaria una reflexión particular en torno a ellos. Como consecuencia, nuestra segunda hipótesis planteó la necesidad de abarcar la aportación de los procesos digitales en términos de las modificaciones que han supuesto en cuanto a lenguaje y, adicionalmente, profundizar en el giro pragmático que han propiciado en el ámbito de los usos de la imagen.

Como ya se indicó, el Capítulo 7 opera así, dentro del corpus de nuestra investigación, como un eslabón que permite concatenar el discurso teórico establecido a partir de la década de 1960 con el de los últimos veinte años, para desembocar en la reflexión en torno a la situación actual del campo fotográfico, tema fundamental del Capítulo 8. Para ello, tomamos como punto de partida la crítica a la relativa superficialidad con la que se ha abordado el tema de la transición de lo analógico a lo digital, valiéndose de 
un abuso de términos saco como por ejemplo el referente a la equiparación de fotografía digital con fotografía manipulada, la identificación abusiva de los procesos digitales con las simples posibilidades de los procesos de copiar y pegar, o la carencia de distinción entre imágenes fotográficas, fotocollage e imágenes sintéticas. Como en su momento lo establecimos, nuestra atención está dirigida a esclarecer las aportaciones de la tecnología digital al lenguaje fotográfico, para lo cual es necesario reflexionar en torno a la puesta en marcha de nuevos procesos lógicos de pensamiento materializados en el software. En el presente, asistimos a una transformación del modelo de comunicación que en dos décadas no ha cesado de desarrollarse de la mano de la digitalización y de las posibilidades que proporciona Internet. La linealidad del modelo basado en los componentes emisor-mensaje-receptor se rompe en la práctica cada vez más -hacemos la salvedad, por supuesto, de que nos estamos refiriendo aquí a sociedades con un acceso generalizado a las nuevas tecnologías-y la pragmática se centra en un renovado eje ya ampliamente difundido y que hemos comentado repetidamente, a saber: producción-distribuciónconsumo, con sus connotaciones económicas, de uso y de mercado. Salvo en el caso excepcional de aquellos que tienen los conocimientos técnicos suficientes para intervenir directamente en la modificación del software, el fotógrafo -al igual que otros productores que trabajan con archivos digitales en ámbitos como el multimedia, la música, los textos, etcétera-es un operador cuyo ámbito creativo se circunscribe a efectuar elecciones dentro de menús predeterminados. Paradójicamente, estas son las mismas acciones que llevan a cabo los usuarios de Internet, generadores de contenidos a través de redes sociales e instrumentos de la Web 2.0. Tanto emisor como receptor se identifican, así, con la nueva figura del usuario.

En este punto cabe hacer una reflexión en torno a la propia estructura de nuestro trabajo de investigación. Es necesario subrayar el hecho de que en ese recorrido de cinco décadas que hemos realizado de la mano de la teoría fotográfica, ha estado implícito un orden cronológico y, diríase, incluso secuencial, en el que hemos pasado de concepciones 
derivadas del estructuralismo y centradas en lo inmanente -en el mensaje mismo- a otras propias de la semiótica —con énfasis en los procesos codificadores y en la producción-, para de ahí derivar a una creciente concentración en los procesos receptivos. Lo que, planteado en los anteriores términos, puede parecer una reductio ad absurdum, no es sino la constatación del movimiento de una teoría que está viva y empecinada en explicar los fenómenos del ámbito comunicativo, movimiento que se da, por supuesto, en paralelo al de dichos fenómenos, también vitales. En este recorrido, hemos aludido en diferentes puntos a la derivación del enfoque de la semiótica estructuralista a uno semio-pragmático, y a la incorporación de su terminología en otros marcos conceptuales como los estudios culturales, cada vez más obsesionados por las variantes introducidas en la interpretación por las especificidades de los actos receptivos. Dentro de este planteamiento, la pregunta que emerge de manera natural apunta al esclarecimiento de cuál es el momento teórico actual.

Una respuesta posible viene dada por los mismos nombres de los teóricos que dan sustancia a nuestro Capítulo 8. Si bien están ahí, dando continuidad al discurso, los omnipresentes Barthes, Bourdieu y Flusser, si bien es imposible eludir la potencia del pensamiento de Krauss o de Bourriaud, se imponen como nuevos hitos dentro del paisaje teórico nombres como los de Mitchell, Mirzoeff o Manovich, los cuales, en sí mismos, aluden a la relevancia adquirida por los nuevos intentos de explicar el fenómeno comunicativo —con el fotográfico como uno de los protagonistas- desde una nueva lógica que bien podríamos llamar hipertextual, rizomática, no lineal, intermedia o propia de la cultura digital. A este panorama hay que sumar, por supuesto, los nombres de autores que, si bien no se centran específicamente en el fenómeno fotográfico, salpican este campo con la amplitud de sus ideas: Baudrillard, Virilio, de Certeau, Augé...

Hemos de insistir en la idea de que el medio fotográfico, como objeto de estudio, parece así perder parte de su tan buscada y trabajada especificidad, de su autonomía, quedando incorporado en enfoques 
sumamente abarcadores. En el caso específico de Manovich, la propuesta consiste en abordar la cultura digital a través de un acercamiento que permita una derivación natural de los estudios mediáticos a los estudios del software -isoftware takes control!, dice él一, que tienen en el centro de su interés la transcodificación y el análisis de las interfaces y aplicaciones de que se valen los usuarios, esos que ahora son a la vez emisores y receptores y que como tales materializan la profecía baudrillardiana de la excesiva proximidad del receptor y de la fuente. Con estas ideas como trasfondo, hemos vinculado el giro pragmático de la teoría fotográfica con el de la cultura del ordenador, planteando como eje emblemático de este giro la transformación del gesto de fotografiar en algo que cada vez se identifica más con el gesto de operar el ordenador, común a diversas formas de producción simbólica. A manera de metáfora, hemos recurrido a una tríada, tal y como ya hemos apuntado en estas mismas conclusiones, que nos ha permitido representar este proceso extenso en el tiempo, a saber: el paso de la concepción de la fotografía como ventana a la de espejo —-desarrolladas en los primeros capítulos- $y$, finalmente, a la actual de pantalla.

La fotografía digital quedará vinculada a la pantalla, espacio por antonomasia del simulacro; se alejará cada vez más de sus connotaciones tradicionales de objetividad, realismo y fidedignidad - ventana-, pero también de aquellas que la consideran expresión de la propia subjetividad a partir de su carácter indicial - espejo-. Es posible establecer un eje de continuidad que vincula a Flusser con Baudrillard: si en la reflexión del primero en torno al medio fotográfico todavía en su etapa analógica se imponían en el quehacer fotográfico el aparato y la automatización sobre la libertad del operador, en el pensamiento del segundo la inmersión del operador en la maquinaria virtual llega a tal grado que se concreta su maquinización en ambos extremos de la interfaz. Dicha inmersión tiene que ver con la misma composición esencial de esta imagen como archivo numérico, como información pura - en su momento evocamos a Mitchell y su propuesta de que ya no solo miramos las imágenes digitales, sino que podemos habitarlas e interactuar con ellas-. Memoria genética, dijimos 
más arriba, y la analogía es inevitable: no hay que perder de vista que los años en que se concreta esta posibilidad de intervención son los mismos en que se desarrolla la de adentrarse en el código genético para modificarlo.

Como corolario obtenemos que, para que se cumpla la aspiración expresada por Manovich de describir los códigos semióticos de los medios informáticos, sus modos de discurso, sus convenciones, su lenguaje, digámoslo una vez más, sus maneras de formar, es necesario sumergirse en las frías y densas aguas del software. Tenemos ya aquí, de manera implícita, la respuesta a la pregunta que en su momento planteamos en torno a si la digitalización ha dado lugar a un nuevo lenguaje fotográfico, si ha expandido sus posibilidades. Con base en lo dicho hasta aquí, la respuesta a esta pregunta es indudablemente afirmativa. Sin embargo, al respecto hemos de subrayar una paradoja: el uso del software es transparente. El usuario común no diseña ni interviene sobre el software, no es capaz de controlarlo; simplemente lo opera a través de las limitadas posibilidades combinartorias que aquel le ofrece a través de la interfaz. Mientras lo utilice a este nivel, será presa de la maquinización, un simple operario de menús predeterminados que le dan ilusión de libertad, pero siempre dentro de estrictos constreñimientos.

Hay, por lo tanto, un asunto de fondo en la discusión así planteada. Nos referimos a la dicotomía -una más-entre continuidad y ruptura, a la relación entre las prácticas del pasado y las nuevas alternativas del presente. Desde un perspectiva continuista, la fotografía digital se presenta como una prolongación de las posibilidades del medio la cual, sin abolir las prácticas ya existentes, suma otras nuevas que se van integrando naturalmente al programa del aparato. Es el punto de vista del historicismo, tendente a mitigar e incorporar lo diferente dentro del capital cultural bajo una perspectiva evolucionista. En el otro extremo, el punto de vista de la ruptura considera que la fotografía ya no consiste más que en una práctica marginal o periférica dentro del campo de lo visual, caracterizado por una multiplicidad de posibilidades productivas no identificadas plenamente con el lenguaje fotográfico, pero totalmente 
válidas. En este contexto - en el que resuena el eco de las dicotomías que dieron pie a nuestras digresiones iniciales-, el término fotografía se vuelve equívoco debido a que ya no designa aquello que históricamente ha aludido. Surge entonces la necesidad de una nueva designación, y algunos autores han recurrido al término posfotografía. La eterna dialéctica entre el arte de los fotógrafos y la fotografía de los artistas, entre el documento y el arte contemporáneo -Rouillé-, se presenta aquí una vez más, y las diferencias parecen irreconciliables.

El concepto que subyace en la segunda concepción es el de campo expandido, llevado por Krauss al ámbito del arte. Pero el asunto se complica si consideramos que dicha expansión, en el campo fotográfico al igual que en otros campos del arte, se había iniciado desde la década de 1970 de la mano de las prácticas posmodernas. Ante este horizonte, ¿cómo encaja la novedad de lo digital?, ¿podemos hablar, acaso, de un campo hiperexpandido a partir de los noventa? La fascinación por explorar las posibilidades del medio ha producido dos décadas de expresión autorreferencial, metadiscursiva. Pero, cuando lo fundamental es el concepto a expresar, pasa a un segundo plano el que la técnica empleada sea digital o no. También aquí las posiciones de los comisarios e historiadores parecen estar enfrentadas y tenemos que, ante las exposiciones y antologías que magnifican los medios por encima de los resultados -como Photography After Photography (Amelunxen et ál. 1996) - , otras, más comedidas, se centran precisamente en los resultados o fines - como La Photographie Contemporaine (Poivert 2002)—.

$\mathrm{Si}$ bien es indudable que existe una nueva intencionalidad en el proceso de creación de imágenes que busca superar los constreñimientos de la fotografía tradicional, las prácticas características de esta siguen vivas. En este sentido, nuestra posición es la de abordar el fenómeno fotográfico en términos de convivencia de las maneras de hacer, mas no en términos de superación, sustitución o desplazamiento. Retomamos aquí nuestra postura establecida al inicio de este trabajo: no hablemos desde un extremo u otro de estos planteamientos dicotómicos, hablemos desde la fotografía. Los 
términos que hemos adoptado para referirnos genéricamente a algunas de las modalidades de imaginería derivadas de la tecnología digital son fotocollage e imagen sintética. Consideramos, por lo tanto, que mientras el primero se renueva, la segunda se suma al universo de lo fotografiable y lo expande, no lo desplaza ni lo anula. En este sentido, suscribimos la idea expresada por Krauss en cuanto a que el uso que cierto sector crítico ha hecho del concepto de la condición postmedia, en el cual queda comprendido el de posfotografía, corre el riesgo de ser un mito monstruoso. Si bien Manovich hizo una llamada a la prudencia ante otro mito, el de la digitalización, en cuanto a la futurología teórica rayana en la ficción que algunos acusan ante la euforia de lo nuevo, a apenas veinte años del inicio de la divulgación de la fotografía digital las aguas parecen haberse calmado, la grandilocuencia de algunas expresiones se ha contenido y, lo que es más importante, las nuevas maneras de hacer se han asentado e incorporado al capital cultural de una manera que hoy ya podemos considerar natural. Pero, ¿acaso no es esto lo que ha ocurrido siempre?

La cultura es un campo vivo. Dentro de su infinita amplitud, la actividad de información vinculada a lo digital se ha extendido a través de operaciones ampliamente difundidas y de uso transparente, comunes a todos los medios codificados numéricamente -primer principio de Manovich-. Este hecho, aunado a la estructura modular de los objetos de los nuevos medios -segundo principio-, permite que el almacenamiento, la recuperación, la fragmentación, la recomposición y la visualización estén, hoy por hoy, en la base de la lógica operativa de cualquier interfaz en los estadios de la creación y del acceso. Pero, establecida esta lógica, queda a su vez cuestionada la libertad del proceso creativo que, como el software y por el software, está programada. Ya hemos aludido en reiteradas ocasiones a la concepción del usuario como un simple operador de menús con opciones limitadas, idea concomitante con el planteamiento flusseriano que cuestionaba la libertad del fotógrafo ante el programa del aparato. Toca ahora desarrollar sus implicaciones y, para ello, en el Capítulo 8 atamos otro cabo lanzado desde el inicio del trabajo, utilizando al juego de ajedrez 
como metáfora. Una vez más tendemos una línea directa entre Flusser y Baudrillard, y es de la mano de este último que, a pesar de que la alusión al duelo Kasparov-Deep Blue ha devenido en un lugar común, nos decantamos por utilizarlo como emblema de la confrontación entre el hombre y la máquina. El ajedrez —como la metáfora-muestra desde hace décadas síntomas de agotamiento en el sentido de que está sobrecodificado. No solo la información y educación en torno a él a los más altos niveles es excesiva, sino que algunas voces han clamado por el replanteamiento de sus reglas, incluso antes de que se incorporaran en su práctica los ordenadores. La profecía baudrillardiana quedó expresada así: el día en que el hombre solo hable esta misma y única lengua, la de los ordenadores, será vencido. Es en ese mismo sentido que nos preguntamos si no es que el fotógrafo ha sido también derrotado por la máquina -el ojo preconfigurado, dijimos, por ejemplo, parodiando el título de Mitchell: El ojo reconfigurado-. Ya Flusser había advertido de la necesidad de que el fotógrafo jugara contra su juguete y, con base en esa advertencia, introdujimos una posible definición del arte como el juego que consiste en cambiar las reglas del juego.

El espectador, por su parte, también es un jugador. Ya hemos dejado establecida la equiparación del emisor con el receptor en la cultura del ordenador, figuras que se confunden en la del usuario. Hemos insistido en que la lógica de la selección que este aplica a través de las interfaces que le permiten interactuar con los nuevos medios constriñe su libertad, que en principio parecería infinita, e impone un tipo de creación que ya no se da desde cero. Esta lógica, para autores tan distintos como Manovich y Augé, es concomitante con la de la sociedad posindustrial, con lo que el estilo de creación se ve equiparado al estilo de vida —de la manera de formar como compromiso con la realidad, dijo Eco-. Estos estilos se ven plasmados en el software, que diluye estadísticamente la individualidad.

Así expresada, la lógica del acto creativo en la cultura del ordenador implica una frustración, una derrota sutil, velada, casi intangible, equívoca, del hombre frente a la máquina. Resulta precisamente en lo opuesto de una de las señas de identidad de la propuesta del intermedia, abocada a valerse 
de las capacidades del ordenador para lograr la puesta en acto de una lógica de pensamiento no lineal o, si se prefiere, hipertextual, rizomática: la del descentramiento, los nodos, las redes, el desbordamiento. En ella, si atendemos a las advertencias de Landow, se daría una convergencia de la teoría crítica contemporánea y la tecnología, que habría llevado finalmente a la concreción de las profecías setenteras de Barthes —el de S/ Z (1970) - y Derrida —el de La diseminación (1972) y De la gramatología (1967) - Insistamos en esta idea fundamental para nuestro discurso: lo que en los años setenta emergió como la expresión de una posibilidad, como un modelo conceptual, veinte años después se concretó en la cultura del ordenador posibilitado por la tecnología, presentando cambios radicales en la lógica de creación, en las maneras de formar. Si ya la interactividad con sus crecientes manifestaciones y la emergencia de la intentio lectoris habían marcado al arte -recordemos la visión de otro profeta, Castellet, en torno al advenimiento de la hora del lector-, el nuevo entorno plantea el riesgo de caer en la apátheia, parálisis derivada del exceso de información. Hemos representado este movimiento de la lógica creativa -a lo largo de los cincuenta años que grosso modo nuestro estudio abarca- mediante la tríada: Metáfora / Elipsis / Asíndeton. Si el arte como metáfora se agota a partir de la posguerra, la sociedad tele, la de la velocidad y la supresión de las distancias -Virilio-, en fin, la de la elipsis, deriva en una de absoluta simultaneidad: la de la pantalla ubicua -Baudrillard-, la del asíndeton como figura representativa de la lógica imperante, paradójicamente apática.

Lo que parecía ser el advenimiento final del ideal del espectador cocreador, ha derivado así en la inmovilidad, en el enclaustramiento dentro del circuito cerrado y estadísticamente previsto de las posibilidades limitadas del software-interfaz-menú. Para utilizar un término lleno de resonancias -alienación- que parecería hoy demasiado cansado ideológicamente pero que podemos exhumar a la luz de las anteriores reflexiones, afirmaremos que nunca antes habíamos estado tan profundamente alienados en el lenguaje. Una alienación encriptada en la 
dictatorial secuencia de $\mathrm{ADN}$ de la memoria genético-informática que rige a la sociedad red. Y en este contexto, una vez más como alternativa necesaria, productiva y de vocación desalienante -Augé-, surge el arte, esa querella de las representaciones que nos sitúa en presencia de contraimágenes enfrentadas a la imagen oficial de la realidad - Bourriaud-.

Ante este marco, es necesario preguntarse una vez más por la fotografía. Como hemos planteado, la maquinización denunciada por Baudrillard en la cultura del ordenador es otro nombre de la tan temida automatización que Flusser ya había criticado en la época del aparato analógico. Hemos insistido en que hoy por hoy, como objeto de los nuevos medios, la fotografía está sujeta al flujo de la reutilización y la alteración a partir de menús. Internet es la concreción de esta lógica en la que archivos numéricos de todo tipo, no solo fotográficos, están disponibles de manera inmediata para un usuario que ha devenido en creador, en el sentido de que no solo es un consumidor, sino también un generador de contenidos. Esta revolución en la distribución y consumo de imágenes las convierte en ready-mades - Mitchell - sujetos a la postproducción -Bourriaud-. Se llevan así al extremo tendencias ya presentes desde la década de 1960 no solo en el ámbito artístico, sino en el social, ya que es a partir de ese momento cuando la fotografía en sus usos más vinculados a la persona común emerge como medio democratizador y homologador, que propicia la dilución de la experiencia individual en la colectiva. La alienación manifestada en esta repetición al infinito -representada en el cuadro de la Imagen 7- queda garantizada, y esta tendencia a visualizar, a narrativizar el tedio de la propia existencia - Mirzoeff, pero también Bourdieu- llega al extremo con instrumentos como las actuales redes sociales, en las cuales la persona anodina se inventa a sí misma, creándose la biografía sobredimensionada de una star mediante la magnificación de los aspectos más insignificantes de su vida. Como consecuencia, lo que estamos planteando no es solamente un aumento cuantitativo sin precedentes, sino una degradación cualitativa, una expresión desideologizada y diluida en la repetición. 
La profecía baudrillardiana está en curso: es la máquina virtual la que nos habla, es ella la que nos piensa.

En el primer tercio del siglo XIX surgió un invento que modificó sustancialmente la manera de relacionarse con el mundo, de crear cultura, de almacenar conocimiento. Un siglo y medio después, alrededor de 1990, el inconsciente óptico presentó otra revolución, fundamentada en el proceso de transcodificación de base numérica de los objetos culturales. $\mathrm{Si}$ bien la fotografía encarnó la primera de estas revoluciones, en el caso de la segunda es solo un ejemplo más -aunque uno paradigmático-del nuevo orden. Soulages utilizó dos términos para aludir a la esencia de lo fotográfico, a saber: lo irrepetible y lo inacabable. Mientras que el primero, alusivo al carácter indicial del medio, parece haber quedado circunscrito al ámbito de la fotografía documental y periodística, el segundo se desdobla incesantemente de la mano de la fotografía digital, capaz de generar, sin degradación alguna, casi infinitas variantes de una imagen, creando una ilusión de originalidad que, como señalamos en el último capítulo, genera una puesta en abismo en la que su identidad se pierde. Alienación en el lenguaje, sometimiento a una manera de formar: la de la lógica del ordenador. Lógica que, a su vez, es expresión de la lógica de la sociedad actual, en un movimiento trenzado en el que ambas se influyen mutuamente. Una pragmática de las operaciones informáticas que se corresponde con la de los usos sociales - clasificar, buscar, cortar, pegar, postproducir- y que deja traslucir, en el caso de la fotografía, un cambio a ese nivel que tanto preocupó a los investigadores hace cuarenta años, cuando empezaron a percibir en él signos de resquebrajamiento: a nivel ontológico.

Pero a pesar de la aceptación del cambio, de la revolución, estando situados ante la encrucijada de elegir entre continuidad y ruptura, nos decantamos por la continuidad. Esta afirmación tiene visos de una verdadera declaración de principios. Expliquémonos.

A lo largo de estas páginas hemos trabajado sobre la especificidad del medio fotográfico, incluso sobre la de su soporte material, que ha sido 
esencial para definirlo a lo largo de su historia. La desmaterialización de dicho soporte en los años recientes ha llevado a cierta crítica a negar su especificidad. Nuestra posición, en cambio, ha sido la de ahondar en las características de este estatus virtual de la imagen fotográfica derivado de la nueva pragmática del medio -a lo que hemos dedicado fundamentalmente el Capítulo 8- que, si bien toma forma definitiva de la mano de las nuevas posibilidades tecnológicas que se desarrollan a partir de la década de 1990, en realidad está enraizada en propuestas expresivas y fenómenos sociales que se desencadenan desde dos décadas antes. La euforia por la tecnología, en gran medida propiciada por la mercadotecnia de los grandes consorcios fabricantes de equipos y por las dinámicas de la sociedad de consumo, tiende a privilegiar los medios sobre los fines: a partir de este engañoso parámetro, podemos hablar de ruptura. Pero si centramos nuestra atención en los fines, esto es, en los potenciales comunicativos del medio, los cambios recientes se presentan de manera natural, dentro de un entorno de continuidad.

Hemos asistido a un terremoto causado por el desplazamiento de dos placas tectónicas. Pasado el primer momento de confusión -la década de 1990, señalada por la ingenuidad del copiar y pegar - el paisaje resultante no es de sustitución o reemplazo, las posibilidades digitales no han enterrado al lenguaje fotográfico, sino que han propiciado un nuevo paisaje en el que los rastros de ambos son aparentes —como en esas cañadas en las que literalmente podemos leer los estratos de la historia escritos en la piedra - y la liberación de energía ocurrida durante el proceso está mostrando consecuencias de una magnitud notable. Ante el mito monstruoso de la condición postmedia, pareceríamos enfrentar la disyuntiva de tomar posición entre la idea radical de un cambio de paradigma -tentadora a la luz de las modificaciones en la lógica de la cultura del ordenador que ya hemos comentado y que algunos identifican con una nueva episteme- o la de un continuismo que podría ser interpretado como reaccionario si se vinculara a los reiterados intentos del historicismo fotográfico de construir una identidad propia del medio. 
¿Existe un punto de equilibrio? Nuestra propuesta es que sí, y que consiste en la incorporación positiva a la teoría de aquellos elementos que conforman la especificidad fotográfica, en permanente construcción.

Una vez asentado en este nuevo paisaje el suelo para la actividad creativa y convertido en statu quo, indudablemente el arte aparece en su incansable vocación de búsqueda de intersticios, fisuras que permiten nuevas formas de cartografiar el terreno, pero también de introducir nuevas filtraciones. ¿No es este, acaso, el proceso eterno de incorporación al capital cultural, el que esquematizamos desde un momento temprano de este trabajo? Resaltemos la salud de este cuestionamiento constante que, como en el caso de cualquier organismo vivo, por un lado actualiza sus defensas y, por otro, da lugar a nuevas mutaciones que vuelven a minar los fundamentos y provocan, así, que la rueda siga girando. Hemos afirmado, con base en el eje Flusser-Baudrillard, que para prolongar su dominio sobre el juego, la persona ha de introducir una sutil desprogramación que la vuelva technically uncorrect, ya que la corrección invariablemente la llevará a la derrota frente a la máquina. Si del rostro que nos mira de frente en la imagen con la que abrimos este último apartado dijimos que es todos y, por lo mismo, no es nadie, del artista actual debemos decir que definitivamente busca ser alguien. Hoy, para el fotógrafo, la pantalla supone la posibilidad de no ser nadie, de perderse en el limbo virtual, pero también, en contrapartida, le permite crear fisuras en la pragmática del medio para ser alguien. Cada una de las pantallas, de esos millones de pantallas que conforman los embudos a través de los cuales nos conectamos en la sociedad red, tiene el potencial de provocar un intersticio a través del cual la imaginación introduzca una nueva filtración. Así, en la sociedad del asíndeton, hoy más que nunca antes, el arte es una manera de jugar que emerge como alternativa vital. 


\section{BIBLIOGRAFÍA}





\title{
Bibliografía
}

\author{
ABRIL, Gonzalo \\ 2003 Cortar y pegar. La fragmentación visual en los orígenes del texto \\ informativo. Madrid: Cátedra. \\ ACHA, J uan \\ 1997 Los conceptos esenciales de las artes plásticas. México, D.F.: Ediciones \\ Coyoacán, 2002. \\ ADAMS, Robert \\ 1994 Why People Photograph. Nueva York: Aperture. \\ 1996 Beauty in Photography. Nueva York: Aperture. \\ 2006 Along Some Rivers. Nueva York: Aperture. \\ ADES, Dawn \\ 1976 Fotomontaje. Barcelona: Gustavo Gili, 2002. \\ Adorno, Theodor W. \\ 1970 Teoría estética. Madrid: Taurus, 1980. \\ Alonso MARTínEZ, Francisco \\ 2007 Documentalidad y artisticidad en el medio fotográfico. Barcelona: UOC. \\ AMELUNXEN, Hubertus V. et ál. (eds.) \\ 1996 Photography after Photography. Memory and Representation in the \\ Digital Age. Ámsterdam-Múnich: G+B Arts. \\ Arbaïzar, Philippe y PICAUdé, Valérie (eds.) \\ 2001 La confusión delos géneros en fotografía. Barcelona: Gustavo Gili, 2004. \\ Ardenne, Paul \\ 2002 Un arte contextual. Murcia: Cendeac, 2006. \\ 2006 Extrême. Esthétiques dela Limite Dépassée. París: Flammarion. \\ 2007 «Los riesgos de la imagen. Entrevista con Paul Ardenne», en: \\ Armstrong, Carol \\ <http:// salonkritik.net/ 06-07/2008/01> (Consultado el 19/09/2010). \\ 2001 «La más bella naturaleza muerta del mundo», en ARBAÏZAR, Philippe y \\ PICAUDÉ, Valérie (eds.), La confusión delos géneros en fotografía. \\ ARNHeIM, Rudolf \\ Barcelona: Gustavo Gili, 2004, pp. 146-163. \\ 1969 El pensamiento visual. Barcelona: Paidós, 1986. \\ 1974 Artey percepción visual. Madrid: Alianza, 1984 (versión revisada de la \\ edición original de 1954). \\ 1986 Nuevos ensayos sobre psicología del arte. Madrid: Alianza, 1989. \\ AUGÉ, Marc \\ 1992 Los no lugares. Espacios del anonimato. Barcelona: Gedisa, 1998. \\ 2000 Ficciones de fin de siglo. Barcelona: Gedisa, 2001. \\ BACHELARD, Gaston \\ 1957 La poética del espacio. México, D.F.: Fondo de Cultura Económica, 1998. \\ BAÑUELOS CAPISTRÁN, J acob \\ 2008 Fotomontaje. Madrid: Cátedra. \\ BAQUÉ, Dominique \\ 1998 La fotografía plástica. Barcelona: Gustavo Gili, 2003. \\ BARTHES, Roland \\ 1957 Mitologías. Madrid: Siglo XXI, 2005.
}


1961 «El mensaje fotográfico», en: Lo obvio y lo obtuso. Imágenes, gestos, voces. Barcelona: Paidós, 1986, pp. 11-27.

1964 «Retórica de la imagen», en: Lo obvio y lo obtuso. Imágenes, gestos, voces. Barcelona: Paidós, 1986, pp. 29-47.

1967 Sistema de la moda. Barcelona: Gustavo Gili, 1978.

1968 «La muerte del autor», en El susurro del lenguaje. Más allá dela palabra y la escritura. Barcelona: Paidós, 1987.

1970 S/Z. México, D.F.: Siglo XXI, 1987.

1972 El grado cero dela escritura. México, D.F.: Siglo XXI, 1981.

1980 La cámara lúcida. Nota sobre la fotografía. Barcelona: Gustavo Gili, 1982.

BATCHEN, Geoffrey

1997 Arder en deseos. La concepción de la fotografía. Barcelona: Gustavo Gili, 2004.

BAUDRILLARD, J ean

1968 El sistema de los objetos. México, D.F.: Siglo XXI, 1988.

1972 Crítica de la economía política del signo. México, D.F.: Siglo XXI, 1983.

1978 Cultura y simulacro. Barcelona: Kairós, 2005.

1996a «Deep Blue o la melancolía del ordenador», en: Pantalla total. Barcelona: Anagrama, 2000, pp. 185-190.

1996b «Pantalla total», en: Pantalla total. Barcelona: Anagrama, 2000, pp. 203-207.

\section{BAURET, Gabriel}

1992 Dela fotografía. Buenos Aires: La Marca, 1999.

BAZIN, André

1945 «Ontología de la imagen fotográfica», en: ¿Qué es el cine? Madrid: Rialp, 2006, pp. 23-31.

BECEYRo, Raúl

1978 Ensayos sobre fotografía. México, D.F.: Arte y Libros.

\section{BENJAMIN, Walter}

1931 «Pequeña historia de la fotografía», en: Sobre la fotografía. Valencia: Pre-Textos, 2004, pp. 21-53.

1936 «La obra de arte en la época de su reproductibilidad técnica», en: Sobrela fotografía. Valencia: Pre-Textos, 2004, pp. 91-109.

\section{BERGER, J ohn}

1980 Mirar. Madrid: Blume, 1987.

2006 Con la esperanza entre los dientes. La J ornada Ediciones: México, D.F.

BERGER, J ohn et ál.

1972 Modos dever. Barcelona: Gustavo Gili, 1975.

BERGER, J ohn y MOHR, J ean

1982 Another Way of Telling. Nueva York: Pantheon Books.

BERISTÁIN, Helena

1988 Diccionario de retórica y poética. México, D.F.: Porrúa, 1995.

Bertucelli PAPI, Marcella

1993 Qué es la pragmática. Barcelona: Paidós, 1996.

\section{BILLETER, Erika (ed.)}

1985 Self-portrait in the Age of Photography. Photographers reflecting their

\section{BLACK, Max} own image. Lausana: Musée Cantonal des Beaux-Arts.

1972 «Cómo representan las imágenes?», en: Arte, percepción y realidad. Barcelona: Paidós, 1983.

\section{Bourdieu, Pierre}

1979 La distinción. Criterio y bases sociales del gusto. Madrid: Taurus, 1998.

1987 Cosas dichas. Barcelona: Gedisa, 1996.

1996 Sobrela televisión. Barcelona: Anagrama, 1997. 
BouRdieu, Pierre et ál.

1965 La fotografía: un arte intermedio. México, D.F.: Nueva Imagen, 1979.

BOURRIAUD, Nicolas

2000 Post producción. Buenos Aires: Adriana Hidalgo, 2004.

2002 Estética relacional. Buenos Aires: Adriana Hidalgo, 2006.

2009 Radicante. Buenos Aires: Adriana Hidalgo.

BREA, J osé Luis

1996 Un ruido secreto. El arte en la era póstuma dela cultura. Murcia: Mestizo.

2001 La era postmedia. Acción comunicativa, prácticas (post)artísticas y dispositivos neomediales. Salamanca: Consorcio Salamanca 2002.

2004 El tercer umbral. Estatuto delas prácticas artísticas en la era del capitalismo cultural. Murcia: Cendeac.

2007 Cultura RAM. Mutaciones dela cultura en la era de su distribución electrónica. Barcelona: Gedisa.

Calabrese, Omar

1985 El lenguaje del arte. Barcelona: Paidós, 1987.

CARRERE, Alberto

2009 Retórica tipográfica. Valencia: Editorial de la Universitat Politècnica de València.

CARrere, Alberto y SABorit, J osé

2000 Retórica dela pintura. Madrid: Cátedra.

CARRILlo, J esús

2004 Arte en la red. Madrid: Cátedra.

CARTIER-Bresson, Henri

1952-1995 Fotografiar del natural. Barcelona: Gustavo Gili, 2003.

CASTEllet, J osé María

1957 La hora del lector. Barcelona: Península, 2001.

CASTElls, Manuel

1996 La sociedad red. Madrid: Alianza, 2000.

2001 La Galaxia Internet. Barcelona: Debolsillo, 2003.

Chéroux, Clément

2003 Breve historia del error fotográfico. Oaxaca: Ediciones Ve, 2009.

CHEVRIER, J ean-François

2006 La fotografía entre las bellas artes y los medios de comunicación.

ClARK, Kenneth Barcelona: Gustavo Gili, 2007.

1956 El desnudo. Un estudio dela forma ideal. Madrid: Alianza, 1981.

CLARKE, Graham

1997 The Photograph. Oxford: Oxford University Press.

COOPER, Thomas y HiLl, Paul

1979 Diálogo con la fotografía. Barcelona: Gustavo Gili, 1980.

CoRONAdo E Húón, Diego

2005 Una mirada a cámara. Teorías dela fotografía de Charles Baudelairea

Costa, J oan Roland Barthes. Sevilla: Alfar.

1971 La imagen y el impacto psico-visual. Barcelona: Zeus.

1977 El lenguaje fotográfico. Madrid: Ibérico Europea de Ediciones.

1991 La fotografía entre sumisión y subversión. México, D.F.: Trillas.

1994 Diseño, comunicación y cultura. Madrid: Fundesco.

1998 La esquemática. Visualizar la información. Barcelona: Paidós.

2008 La fotografía creativa. México, D.F.: Trillas. 


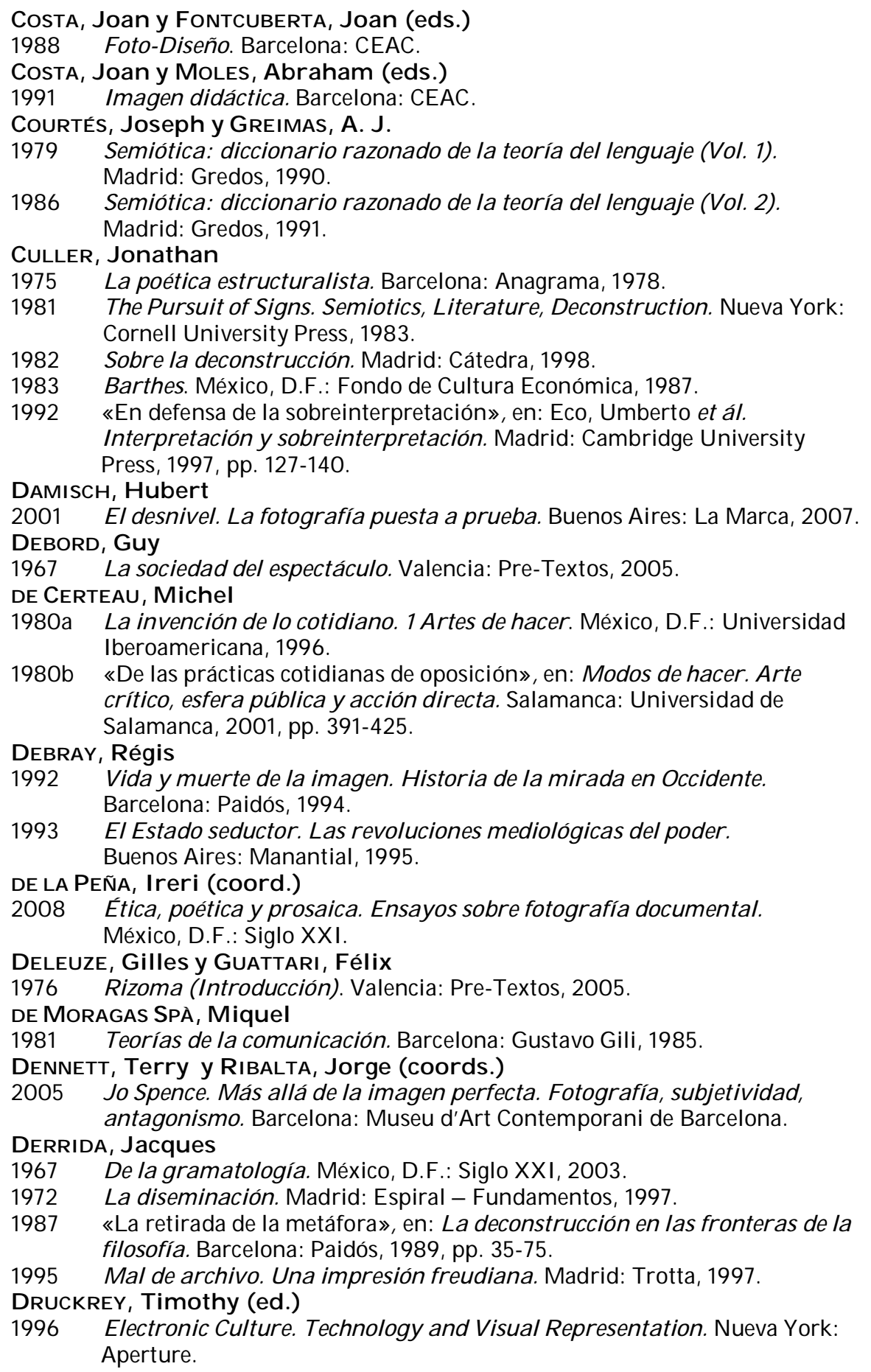




\section{DuBoIs, Philippe}

1983 El acto fotográfico. Dela representación a la recepción. Barcelona: Paidós, 1986.

1990 El acto fotográfico y otros ensayos. Buenos Aires: La Marca, 2008.

2001 Video, cine, Godard. Buenos Aires: Libros del Rojas - Universidad de Buenos Aires.

\section{DURAND, J acques}

1970 «Retórica e imagen publicitaria», en: METZ, Christian et ál. Análisis de

\section{DURAND, Régis} las imágenes. Buenos Aires: Tiempo Contemporáneo, 1972, pp. 81-115.

1998 El tiempo de la imagen. Ensayo sobre las condiciones de una historia de las formas fotográficas. Salamanca: Universidad de Salamanca.

1999 J ohn Hilliard. Salamanca: Universidad de Salamanca.

\section{DYER, Geoff}

2005 El momento interminable de la fotografía. Oaxaca: Ediciones Ve, 2010.

\section{Eco, Umberto}

1955-1963 La definición del arte. Barcelona: Martínez Roca, 1972.

1962a Obra abierta. Barcelona: Ariel, 1985.

1962b «De la manera de formar como compromiso con la realidad», en: Obra abierta. Barcelona: Ariel, 1985, pp. 277-334.

1968 La estructura ausente. Barcelona: Lumen, 1978.

1973 Signo. Barcelona: Labor, 1988.

1975 Tratado de semiótica general. México, D.F.: Nueva Imagen - Lumen, 1980.

1979 Lector in fabula. La cooperación interpretativa en el texto narrativo. Barcelona: Lumen, 1981.

1985 Delos espejos y otros ensayos. Barcelona: Lumen, 1988.

1990 Los límites dela interpretación. México, D.F.: Lumen, 1992.

2006 A paso de cangrejo. Artículos, reflexiones y decepciones, 2000-2006.

\section{Eco, Umberto et ál.} Barcelona: Debate, 2007.

1992 Interpretación y sobreinterpretación. Madrid: Cambridge University Press, 1997.

\section{EgUIZÁBAL, Raúl}

2001 Fotografía publicitaria. Madrid: Cátedra, 2006.

ELKINS, J ames (ed.)

2007 Photography Theory. Nueva York: Routledge.

\section{FABBRI, Paolo}

1998 El giro semiótico. Barcelona: Gedisa, 1999.

\section{FERNÁNDEZ ORRICO, J esús}

2004 Th. W. Adorno: mímesis y racionalidad. Valencia: Institució Alfons el Magnànim.

\section{FLUSSER, Vilém}

1983a Una filosofía de la fotografía. Madrid: Síntesis, 2001.

1983b «La crítica de la fotografía», en: Una filosofía de la fotografía. Madrid: Síntesis, 2001, pp. 97-102.

1985 «La fotografía como objeto postindustrial», en: Una filosofía de la fotografía. Madrid: Síntesis, 2001, pp. 143-161.

1988 «Nancy Burson. Chimaeras», en: AMELUNXEN, Hubertus V. et ál. (eds.). Photography after Photography. Memory and Representation in the Digital Age. Ámsterdam-Múnich: G+B Arts, 1996, pp. 150-155.

1991 Los gestos. Fenomenología y comunicación. Barcelona: Herder, 1994. 


\section{FONTCUBERTA, J oan}

1990 Fotografía: conceptos y procedimientos. Barcelona: Gustavo Gili.

2002 El beso de Judas: fotografía y verdad. Barcelona: Gustavo Gili.

2008 Historias de la fotografía española. Escritos 1977-2004. Barcelona: Gustavo Gili.

2010 La cámara de Pandora. La fotografi@ después dela fotografía. Barcelona: Gustavo Gili.

FONTCUBERTA, J oan (ed.)

1984 Estética fotográfica: una selección de textos. Barcelona: Blume.

1998 Ciencia y fricción. Fotografía, naturaleza y artificio. Murcia: Mestizo.

2002 Fotografía. Crisis de historia. Barcelona: Actar.

FONTCUBERTA, J oan y Costa, J oan (eds.)

1988 Foto-Diseño. Barcelona: CEAC.

FREUND, Gisèle

1974 La fotografía como documento social. Barcelona: Gustavo Gili, 1983.

FRIzoT, Michel

2009 El imaginario fotográfico. Oaxaca: Ediciones Ve.

\section{Frosh, Paul}

2003 The Image Factory. Consumer Culture, Photography and the Visual Content Industry. Oxford: Berg.

\section{GERNSHEIM, Helmut}

1966 Historia gráfica de la fotografía. Barcelona: Omega.

1982 The Origins of Photography. Nueva York: Thames \& Hudson (edición revisada del libro publicado en 1955 y 1969).

GOMBRICH, Ernst H.

1959 Arte eilusión. Barcelona: Gustavo Gili, 1982.

1972 «La máscara y la cara: La percepción del parecido fisonómico en la vida y en el arte», en: Arte, percepción y realidad. Barcelona: Paidós, 1983, pp. 15-67.

GóMEZ ISLA, J osé

2005 Fotografía de creación. San Sebastián: Nerea.

GONZÁLEZ FLORES, Laura

2005 Fotografía y pintura: ¿dos medios diferentes? Barcelona: Gustavo Gili.

GREEN, David (ed.)

2003 ¿Qué ha sido de la fotografía? Barcelona: Gustavo Gili, 2007.

Greimas, A. J • y Courtés, J oseph

1979 Semiótica: diccionario razonado dela teoría del lenguaje (Vol. 1). Madrid: Gredos, 1990.

1986 Semiótica: diccionario razonado de la teoría del lenguaje (Vol. 2). Madrid: Gredos, 1991.

GrundBERG, Andy

1998 «Art and Photography, Photography and Art: Across the Modernist Membrane», en J ANUS, Elizabeth (ed.). Veronica's Revenge: Contemporary Perspectives on Photography. Zúrich-Berlín-Nueva York: Scalo, pp. 43-52.

1999 Crisis of the Real. Nueva York: Aperture.

GRUNDBERG, Andy y MCCARTHY GaUSS, Kathleen

1988 Photography and Art: Interactions since 1946. Nueva York: Abbeville Press.

\section{GRUPO $\mu$}

1982 Retórica general. Barcelona: Paidós, 1987.

1992 Tratado del signo visual. Madrid: Cátedra, 1993.

2003 Figuras, conocimiento, cultura. Ensayos retóricos. México, D.F.: UNAM. 


\section{GUBERN, Román}

1987 La mirada opulenta. Exploración de la iconosfera contemporánea. Barcelona: Gustavo Gili.

\section{HEIDEGGER, Martin}

1953 La pregunta por la técnica, en: <http:// www.heideggeriana.com.ar/ textos / tecnica.htm> (Consultado el 21/05/2007).

\section{HiLl, Paul y CoOPER, Thomas}

1979 Diálogo con la fotografía. Barcelona: Gustavo Gili, 1980.

\section{HOCHBERG, J ulian}

1972 «La representación de objetos y personas», en: Arte, percepción y realidad. Barcelona: Paidós, 1983, pp. 69-126.

\section{IGLÉSIAS FRANCH, David}

2008 La fotografía digital en los archivos. Qué es y cómo se trata. Gijón: Trea. ILES, Chrissie y ROBERTS, Russell (eds.)

1997 In Visible Light. Photography and Classification in Art, Science and the

ISER, Wolfgang Everyday. Oxford: Museum of Modern Art Oxford.

1976 El acto deleer. Madrid: Taurus, 1987.

J ANUS, Elizabeth (ed.)

1998 Veronica's Revenge: Contemporary Perspectives on Photography. Zúrich-Berlín-Nueva York: Scalo.

JAUSs, Hans Robert

1977 Experiencia estética y hermenéutica literaria. Madrid: Taurus, 1986.

\section{J AY, Martin}

1993 «Regímenes escópicos de la modernidad», en: Campos de fuerza. Entre la historia intelectual y la crítica cultural. Buenos Aires: Paidós, 2003, pp. 221-251.

JoLY, Martine

1993 Introducción al análisis dela imagen. Buenos Aires: La Marca, 1999.

1994 La imagen fija. Buenos Aires: La Marca, 2003.

2002 La interpretación de la imagen: entre memoria, estereotipo y seducción. Barcelona: Paidós, 2003.

J ULLIER, Laurent

1998 La imagen digital. Dela tecnología a la estética. Buenos Aires: La Marca, 2004.

KANIZSA, Gaetano

1980 Gramática dela visión. Percepción y pensamiento. Barcelona: Paidós, 1986.

\section{Kossoy, Boris}

2001 Fotografía e historia. Buenos Aires: La Marca.

\section{KraCAUER, Siegfried}

1927 «La fotografía», en: La fotografía y otros ensayos. El ornamento dela masa I. Barcelona: Gedisa, 2008, pp. 19-38.

KRAUSS, Rosalind E.

1985 La originalidad dela vanguardia y otros mitos modernos. Madrid: Alianza, 1996.

1990 Lo fotográfico. Por una teoría de los desplazamientos. Barcelona: Gustavo Gili, 2002.

2010 Perpetual Inventory. Cambridge, Massachusetts: MIT Press.

\section{LANDOW, George P. (ed.)}

1992 Hipertexto. La convergencia dela teoría crítica contemporánea y la tecnología. Barcelona: Paidós, 1995.

1994 Teoría del hipertexto. Barcelona: Paidós, 1997. 


\section{LEDO, Margarita}

1998 Documentalismo fotográfico. Madrid: Cátedra.

LEMAGNY, J ean-Claude

1992 La sombra y el tiempo. La fotografía como arte. Buenos Aires: La Marca, 2008.

LIPKIN, J onathan

2005 Photography Reborn. Image Making in the Digital Era. Nueva York: Abrams.

LISTER, Martin (ed.)

1995 La imagen fotográfica en la cultura digital. Barcelona: Paidós, 1997.

LOTMAN, Iuri M.

1996 La semiosfera I. Semiótica de la cultura y del texto. Madrid: Frónesis-Cátedra-Universidad de Valencia.

1998 La semiosfera II. Semiótica dela cultura, del texto, dela conducta y del espacio. Madrid: Frónesis-Cátedra-Universidad de Valencia.

2000 La semiosfera III. Semiótica delas artes y de la cultura. Madrid: Frónesis-Cátedra-Universidad de Valencia.

MalrauX, André

1947 Le Musée Imaginaire. París: Gallimard, 2006 (la edición original de 1947 fue revisada en 1965).

MANOVICH, Lev

1992 «The Paradoxes of Digital Photography», en: AMELUnXEN, Hubertus V. et ál. (eds.). Photography after Photography. Memory and Representation in the Digital Age. Ámsterdam-Múnich: G+B Arts, 1996, pp. 57-65.

1997 «J ump Over Proust», en: <http:// www.manovich.net/ DOCS/ proust.doc> (Consultado el 09/05/2007).

2001 El lenguaje de los nuevos medios de comunicación. La imagen en la era digital. Barcelona: Paidós, 2005.

MARCHÁN, Simón (comp.)

2006 Real/Virtual en la estética y la teoría delas artes. Barcelona: Paidós.

MARTínEZ BARRAGán, Carlos

2004 El índice. La huella dela manualidad y la mecanicidad en fotografía y pintura. Valencia: Institució Alfons el Magnànim.

MARZAL FeLICI, J avier

2007 Cómo selee una fotografía. Madrid: Cátedra.

MARZAL FELICI, J avier et ál.

2004 «Generación y utilización de tecnologías digitales e informacionales para el análisis de la imagen fotográfica», en: <http:// www.bocc.ubi.pt/ pag/ tarinfrancisco-utilizacion-tecnologias-digitales.pdf $>$ (Consultado el 17/01/2008).

MATtelaRT, Armand y NeVEU, Érik

2003 Introducción a los estudios culturales. Barcelona: Paidós, 2004.

MELOT, Michel

2007 Breve historia dela imagen. Madrid: Siruela, 2010.

MERLEAU-PoNTY, Maurice

1964 El ojo y el espíritu. Barcelona: Paidós, 1986.

MiRzoEFF, Nicholas

1999 Una introducción a la cultura visual. Barcelona: Paidós, 2003.

MitChell, WiLliam J .

1992 The Reconfigured Eye. Visual Truth in the Post-Photographic Era.

Cambridge, Massachusetts: MIT Press, 2001.

MoHOLY-NAGY, László

1929 La nueva visión y Reseña de un artista. Buenos Aires: Infinito, 1972. 


\section{MoLES, Abraham}

1972 Teoría de los objetos. Barcelona: Gustavo Gili, 1975.

1972 Teoría de la información y percepción estética. Madrid: Júcar, 1976.

1981 La imagen: comunicación funcional. México, D.F.: Trillas, 1991.

1984 La creación científica. Madrid: Taurus, 1986 (edición aumentada de la versión original publicada en 1956).

MoLES, Abraham y CostA, J oan (eds.)

1991 Imagen didáctica. Barcelona: CEAC.

MoLES, Abraham y J ANISZEWSKI, Luc (eds.)

1990 Grafismo funcional. Barcelona: CEAC.

Monegal, Antonio (comp.)

2007 Política y (po)ética delas imágenes de guerra. Barcelona: Paidós.

\section{MONLEón, Mau}

1999 La experiencia delos límites. Híbridos entre escultura y fotografía en la

MORRIS, Charles década delos ochenta. Valencia: Institució Alfons el Magnànim.

1971 Fundamentos dela teoría de los signos. Barcelona: Paidós, 1985.

Mortara Garavelli, Bice

1988 Manual de retórica. Madrid: Cátedra, 2000.

NEBREDA, David

1998 David Nebreda. Autorretratos. Madrid: Doce Notas.

NEWHALL, Beaumont

1982 The History of Photography. Nueva York: Museum of Modern Art, 1997.

NEVEU, Érik y Mattelart, Armand

2003 Introducción a los estudios culturales. Barcelona: Paidós, 2004.

\section{Osborne, Peter}

2003 «La fotografía en un campo en expansión: unidad distributiva y forma dominante», en: GREEN, David (ed.). ¿Qué ha sido de la fotografía? Barcelona: Gustavo Gili, 2007, pp. 66-76.

\section{PANOFSKY, Erwin}

1927 La perspectiva como forma simbólica. Barcelona: Tusquets, 1985.

\section{PeIRCE, Charles S.}

1931-1958 Obra lógico semiótica. Madrid: Taurus, 1987. (Recopilación póstuma que reúne textos publicados originalmente en 1883.)

\section{PÉnINou, Georges}

1970 «Física y metafísica de la imagen publicitaria», en: METZ, Christian et ál. Análisis delas imágenes. Buenos Aires: Tiempo Contemporáneo, 1972, pp. 116-135.

1972 Semiótica dela publicidad. Barcelona: Gustavo Gili, 1976.

\section{Perec, Georges}

1974 Especies de espacios. Barcelona: Montesinos, 2004.

1985 Pensar / Clasificar. Barcelona: Gedisa, 1986.

PÉREZ, David

2000 «Una y tres fotografías: del objeto al concepto, del concepto a la imagen», en: SAN MARTÍN, FCo. J avier (ed.), La fotografía en el arte del siglo XX. Vitoria-Gasteiz: Diputación Foral de Álava.

2003 Malas artes. Experiencia estética y legitimación institucional. Murcia: Cendeac.

PÉREZ, David (ed.)

2004 La certeza vulnerable: cuerpo y fotografía en el siglo XXI. Barcelona: Gustavo Gili.

Pérez Carreño, Francisca

1988 Los placeres del parecido. Icono y representación. Madrid: Visor. 


\section{Pérez Gauli, J uan Carlos}

2000 El cuerpo en venta. Relación entreartey publicidad. Madrid: Cátedra.

PiageT, J ean

1968 El estructuralismo. Buenos Aires: Proteo, 1971.

PiCAUdÉ, Valérie

2001 «Clasificar la fotografía con Perec, Aristóteles, Searle y algunos otros», en: PICAUDÉ, Valérie y ARBAÏZAR, Philippe (eds.). La confusión delos géneros en fotografía. Barcelona: Gustavo Gili, 2004, pp. 22-35.

Picaudé, Valérie y Arbaïzar, Philippe (eds.)

2001 La confusión de los géneros en fotografía. Barcelona: Gustavo Gili, 2004.

Picazo, Glòria y Ribalta, J orge (eds.)

1997 Indiferencia y singularidad. La fotografía en el pensamiento artístico contemporáneo. Barcelona: Museu d'Art Contemporani de Barcelona.

\section{PoIVERT, Michel}

2002 La Photographie Contemporaine. París: Flammarion.

PulTZ, John

1995 La fotografía y el cuerpo. Madrid: Akal, 2003.

RENNER, Eric

1999 Pinhole Photography. Boston: Focal Press, 2000.

Ribalta, J orge (ed.)

2004 Efecto real. Debates posmodernos sobre fotografía. Barcelona: Gustavo Gili.

Ribalta, J orge y DenNETT, Terry (coord.)

2005 J o Spence. Más allá de la imagen perfecta. Fotografía, subjetividad, antagonismo. Barcelona: Museu d'Art Contemporani de Barcelona.

Ribalta, J orge y Picazo, Glòria (eds.)

1997 Indiferencia y singularidad. La fotografía en el pensamiento artístico contemporáneo. Barcelona: Museu d’Art Contemporani de Barcelona.

\section{RITCHIN, Fred}

1999 In Our Own Image. The Coming Revolution in Photography. Nueva York: Aperture.

2009 After Photography. Nueva York: Norton \& Company.

ROBERTS, Russell e ILES, Chrissie (eds.)

1997 In Visible Light. Photography and Classification in Art, Science and the Everyday. Oxford: Museum of Modern Art Oxford.

\section{ROGER, Alain}

1997 Breve tratado del paisaje. Madrid: Biblioteca Nueva, 2007.

\section{RouILLÉ, André}

2005 La photographie. Entre document et art contemporain. París: Gallimard.

SABORIT, J osé y CARRERE, Alberto

2000 Retórica dela pintura. Madrid: Cátedra.

SÁNCHEZ VIGIL, J uan Miguel

2006 El documento fotográfico. Historia, usos, aplicaciones. Gijón: Trea.

SAVEDOFF, Barbara E.

2000 Transforming Images. How Photography Complicates the Picture. Ithaca: Cornell University Press.

\section{SCHAEFFER, J ean-Marie}

1987 La imagen precaria del dispositivo fotográfico. Madrid: Cátedra, 1990.

2001 «La fotografía entre visión e imagen», en: PICAUDÉ, Valérie y ARBAÏZAR, Philippe (eds.). La confusión delos géneros en fotografía. Barcelona:

SCHARF, Aaron Gustavo Gili, 2004, pp. 16-21.

1974 Artey fotografía. Madrid: Alianza, 1994. 


\section{SCOLARI, Carlos}

2004 Hacer clic. Hacia una sociosemiótica delas interacciones digitales. Barcelona: Gedisa.

\section{SEBEOK, Thomas A.}

1994 Signos: una introducción a la semiótica. Barcelona: Paidós, 1996.

SNOW, Michael

2001 Michael Snow Almost Cover to Cover. Londres: Black Dog Publishing.

SOLOMON-GoDEAU, Abigail

2001 «Género, diferencia sexual y desnudo fotográfico», en: PiCAUDÉ, Valérie y ARBAÏZAR, Philippe (eds.). La confusión delos géneros en fotografía. Barcelona: Gustavo Gili, 2004, pp. 164-175.

\section{SoNTAG, Susan}

1966 Contra la interpretación y otros ensayos. Barcelona: Seix Barral, 1984.

1973 Sobre la fotografía. Barcelona: Edhasa, 1981.

2003 Ante el dolor delos demás. México, D.F.: Alfaguara, 2004.

\section{SoRLIN, Pierre}

1997 El 'siglo' dela imagen analógica. Los hijos de Nadar. Buenos Aires: La Marca, 2004.

SougEz, Marie-Loup

1981 Historia de la fotografía. Madrid: Cátedra, 2004.

SoulaGES, François

1998 Estética dela fotografía. Buenos Aires: La Marca, 2005.

\section{STELZER, Otto}

1978 Artey fotografía. Contactos, influencias y efectos. Barcelona: Gustavo Gili, 1981.

\section{STIMSON, Blake}

2006 The Pivot of the World. Photography and Its Nation. Londres: MIT Press.

\section{SZARKOWSKI, J ohn}

1966 The Photographer's Eye. Nueva York: Museum of Modern Art, 2007.

1978 Mirrors and Windows: American photography since 1960. Nueva York:

TAGG, J ohn Museum of Modern Art.

1988 El peso dela representación. Barcelona: Gustavo Gili, 2005.

\section{Tió, Salvador}

1988 «Procesos fotografísticos alternativos», en: FONTCUBERTA, J oan y

\section{VILCHES, Lorenzo} CosTA, J oan (eds.). Foto-Diseño. Barcelona: CEAC, pp. 150-157.

1983 La lectura de la imagen. Prensa, cine, televisión. Barcelona: Paidós.

1987 Teoría dela imagen periodística. Barcelona: Paidós.

VIRILIO, Paul

1980 Estética de la desaparición. Barcelona: Anagrama, 1988.

1988 La máquina devisión. Madrid: Cátedra.

WALL, J eff

1984-2003 Fotografía e inteligencia líquida. Barcelona: Gustavo Gili, 2007.

WELLS, Liz (ed.)

1997 Photography: a Critical Introduction. Londres: Routledge.

YATES, Steve (ed.)

1995 Poéticas del espacio. Barcelona: Gustavo Gili, 2002.

ZELICH, Cristina

1995 Manual de técnicas fotográficas del siglo XIX. Salamanca: PhotoVision.

ZUNZUNEGUI, Santos

1989 Pensar la imagen. Madrid: Cátedra.

1994 Paisajes de la forma. Madrid: Cátedra. 


\title{
Artículos en ReVistas
}

\author{
AA. VV. \\ 1991 REVISTA DE OCCIDENTE N 127, Número monográfico: Fotografía, \\ Madrid, Diciembre. \\ BARDIS, Antonia \\ 2004 «Digital photography and the question of realism», en: J OURNAL OF VISUAL \\ ART Practice, Vol. 3, № 3, pp. 209-218, (Ebsco Host, Universidad \\ Anáhuac, México, D.F., septiembre, 2009, \\ $<$ http://search.ebscohost.com>). \\ BATCHEN, Geoffrey \\ 1999 «From genre to generic», en número especial monográfico: Rethinking \\ Genres in Contemporary Photography, ART ON PAPER, Vol. 3, N 3, \\ Ene-Feb, pp. 48-49. \\ 2008 «Snapshots. Art history and the ethnographic turn», en: PHOTOGRAPHIES, \\ Vol. 1, № 2, pp. 121-142, (diciembre, 2009, \\ $<$ http:// www.tandf.co.uk/journals/ rpho>). \\ BISHOP, Claire \\ 2004 «Antagonism and Relational Aesthetics», en: OCTOBER, № 110, pp. 51-79, \\ (Ebsco Host, Universidad Anáhuac, México, D.F., septiembre, 2009, \\ $<$ http:// search.ebscohost.com>). \\ Blatt, Ari J . \\ 2009 «Phototextuality: photography, fiction, criticism», en: VISUAL STUDIES, Vol. \\ 24, № 2, pp. 108-121, (Ebsco Host, Universidad Anáhuac, México, D.F., \\ abril, 2010, <http:// search.ebscohost.com>). \\ CoHEN, J onathan y MeSKin, Aaron \\ 2004 «On the epistemic value of photographs», en: THEJ OURNAL OF AESTHETICS \\ AND ART CRITICISM, Vol. 62, № 2, pp. 197-210, (Ebsco Host, Universidad \\ Anáhuac, México, D.F., septiembre, 2009, \\ Cox, Andrew $M$. \\ $<\mathrm{http}$ ://search.ebscohost.com>). \\ 2008 «Flickr: a case study of Web 2.0», en: AsLiB ProcEEDINGS, Vol. 60, № 5, \\ pp. 493-516, (ProQuest, Universidad Anáhuac, México, D.F., octubre, \\ CusEo, Mike \\ 2009, <http:// proquest.umi.com>). \\ 2006 «Ways of skiing: digital photography, the Internet and cultural \\ narratives», en: J OURNAL OF THE NORTHWEST COMMUNICATION ASSOCIATION, \\ Vol. 35, pp. 60-78, (Ebsco Host, Universidad Anáhuac, México, D.F., \\ Di Bello, Patrizia \\ septiembre, 2009, <http:// search.ebscohost.com>). \\ 2008 «Seductions and filtrations: photographs, histories, theories», en: \\ PHOTOGRAPHIES, Vol. 1, № 2, pp. 143-155, (diciembre, 2009, \\ $<$ http:// www.tandf.co.uk/journals/rpho>). \\ FRIDAY, J onathan \\ 2001 «Photography and the representation of vision», en: THE J OURNAL OF \\ AESTHETICS AND ART CRITICISM, Vol. 59, № 4, pp. 351-362, (Ebsco Host, \\ Universidad Anáhuac, México, D.F., septiembre, 2009, \\ $<$ http:// search.ebscohost.com>).
}


HAINGE, Greg

2008 «Unfixing the photographic image: photography, indexicality, fidelity and normativity», en: CONTINUUM. J OURNAL OF MEDIA AND CULTURAL STUDIES, Vol. 22, № 5, pp. 715-730, (Ebsco Host, Universidad Anáhuac, México,

HEPP, Rolf-Dieter D.F., septiembre, 2009, <http:// search.ebscohost.com>).

2006 «The relational thinking of Pierre Bourdieu», en: THE AMERICANJ OURNAL OF SEMIOTICS, Tomo 22, № 1-4, p. 55, 16 pp., (ProQuest, Universidad

HiRsch, Faye Anáhuac, México, D.F., octubre, 2009, <http:// proquest.umi.com>).

1999 «The more photography proliferates, the more it becomes simply images», en número especial monográfico: Rethinking Genres in Contemporary Photography, ART ON PAPER, Vol. 3, N 3, Ene-Feb, pp. 26-28.

KEMBER, Sarah J.

2008 «The virtual life of photography», en: PHOTOGRAPHIES, Vol. 1, № 2, pp. 175-203, (diciembre, 2009, <http:// www.tandf.co.uk/journals/rpho>).

\section{KRAUSS, Rosalind}

1984 «Nota sobre la fotografía y lo simulácrico», en: REVISTA DE OCCIDENTE N 127, Número monográfico: Fotografía, Madrid, Diciembre, 1991.

MANOVICH, Lev

2008 «La visualización de datos como nueva abstracción y antisublime», en: ESTUDIOS VISUALES, № 5, pp. 126-135, (mayo, 2009, <http:// www.estudiosvisuales.net/revista/index.htm>).

MARTIN, Stewart

2007 «Critique of Relational Aesthetics», en: THIRD TEXT, Vol. 21, № 4, pp. 369386, (Ebsco Host, Universidad Anáhuac, México, D.F., septiembre, 2009, $<\mathrm{http}$ :// search.ebscohost.com>).

MARTín PRADA, J uan

2008 «La creatividad de la multitud conectada y el sentido del arte en el contexto de la Web 2.0», en: ESTUDIOSVISUALES, № 5, pp. 66-79, (mayo, 2009, <http:// www.estudiosvisuales.net/ revista/index.htm>).

MAZZALI-LuRATI, Sabrina

2007 «Here is the author! Hyperlinks as constitutive rules of hypertextual communication», en: SEMIOTICA, Vol. 167, № 1-4, pp. 135-168, (Ebsco Host, Universidad Anáhuac, México, D.F., abril, 2010, $<$ http:// search.ebscohost.com>).

2009 «Subjects and reading strategies in hypermedia: the re-emergence of the author», en: SEMIOTICA, Vol. 173, № 1-4, pp. 525-555, (Ebsco Host, Universidad Anáhuac, México, D.F., abril, 2010, $<$ http:// search.ebscohost.com>).

MESKIN, Aaron y CoHEN, J onathan

2004 «On the epistemic value of photographs», en: THE J OURNAL OF AESTHETICS AND ART CRITICISM, Vol. 62, № 2, pp. 197-210, (Ebsco Host, Universidad Anáhuac, México, D.F., septiembre, 2009,

NiCKEL, Douglas $R$. $<\mathrm{http}$ :// search.ebscohost.com>).

2001 «History of Photography: the state of research», en: ART BULLETIN, Vol. 83, № 3, p. 548-558, (Ebsco Host, Universidad Anáhuac, México, D.F., septiembre, 2009, <http:// search.ebscohost.com>).

REXER, Lyle

2005 «The question of outsider photography», ART ON PAPER, Vol. 9, N³, Ene-Feb, pp. 52-57. 


\section{RiBALTA, J orge}

1989 «Campo expandido», LÁPIZ. REVISTA INTERNACIONAL DE ARTE, Año

\section{SCHAFFNER, Ingrid} VI, N 59 , mayo, pp. 46-53.

1999 «Tourist snaps», en número especial monográfico: Rethinking Genres in Contemporary Photography, ART ON PAPER, Vol. 3, N 3, Ene-Feb, pp. 39-41.

\section{SoUlAGES, François}

2001 «Desde una estética de la fotografía hacia una estética de la imagen», en: UNIVERSO FOTOGRÁFICO, AÑO 3, № 4, (abril, 2010, <http:// www.ucm.es/info/ univfoto/ num4/index.htm>).

TraChTENBERG, Alan

2008 «Through a glass, darkly: photography and cultural memory», en: SocIAL RESEARCH, Vol. 75, № 1, pp. 111-132, (Ebsco Host, Universidad Anáhuac, México, D.F., septiembre, 2009, <http:// search.ebscohost.com>).

\section{SITIOS WEB}

\section{WORDS MAgAZINE}

<http:// www.1000wordsmag.com> (Última consulta el 9/09/2010).

ANÁLISIS FOTOGRAFÍA. MODELO DE ANÁLISIS DE LA IMAGEN FOTOGRÁFICA

FLUSSER STUDIES <http:// www.analisisfotografia.uji.es>(Consultado el 17/01/2008).

\section{GEORGE EASTMAN HOUSE} <http:// www.flusserstudies.net>(Consultado el 17/05/2008).

Photography Now <http:// www.geh.org> (Consultado el 23/04/2008).

Pinhole Resource <http:// www.photography-now.net> (Última consulta el 27/09/2010).

\section{UNIVERSIDAD DE TEXAS EN AUSTIN} <http:// www.pinholeresource.com>(Consultado el 20/04/2008). $<$ http:// www.hrc.utexas.edu/ exhibitions/ permanent/wfp> (Consultado el 11/02/2008).

\section{UNIVERSO FOTOGRÁFICO - UNIVERSIDAD COMPLUTENSE DE MADRID} <http:// www.ucm.es/info/ univfoto>(Consultado el 15/04/2010).

ZONE ZERO - DESDE LA PANTALLA DE LUZ <http:// www.zonezero.com/ zz> (Última consulta el 23/08/2010). 


\section{RESUMEN \\ (ESPAÑOL, VALENCIANO, INGLÉS)}





\section{RESUMEN (EsPaÑOL)}

La fotografía es un elemento definitorio de la semiosfera. Su desarrollo técnico y la democratización de sus usos no han cesado de modificarse en el transcurso del tiempo y, a partir de la década de 1990, el campo fotográfico ha presentado un cambio radical debido a la introducción de los procesos digitales. El fenómeno fotográfico ha sido estudiado a lo largo de su historia desde una gran variedad de enfoques. El presente trabajo se centra en las aportaciones teóricas que consideran la fotografía como un lenguaje; el desarrollo de estas se da a partir de la década de 1960 de la mano de diversas aproximaciones que pueden ser englobadas bajo el rubro abarcador de crítica postestructuralista.

La creciente heteronomía del campo fotográfico acentúa la necesidad de sistematizar los elementos que dan sustento a la capacidad de lectura de imágenes. La primera hipótesis específica de este trabajo propone que es a través del estudio de los procedimientos de codificación propios del medio que podemos desentrañar la especificidad del signo fotográfico, propiciando un análisis tanto de tipo inmanente -que nos permita responder a la cuestión de cómo significa la fotografía- como un análisis pragmático que incorpore elementos contextuales.

Dando continuidad al anterior planteamiento, la segunda hipótesis específica del trabajo se relaciona con ese cambio reciente al que hemos aludido y propone la interrogante de si la introducción de los procesos digitales ha derivado en la creación de un nuevo lenguaje fotográfico o si, por el contrario, su aportación está más vinculada al ámbito de los usos de la imagen. En su expresión más general, lo que este trabajo desentraña a partir de dicho cuestionamiento son las formas en que la digitalización de los procesos fotográficos han modificado, no solo los aspectos expresivos del lenguaje fotográfico, sino también los extrínsecos, esto es, el giro pragmático experimentado por el campo fotográfico en los últimos veinte 
años. Los cambios en la concepción de las actividades productora y receptora han sido tan profundos que ya no se sostienen los modelos lineales de comunicación, suplantados hoy por los que proponen una inmersión en un espacio virtual que exige una labor permanente de recomposición.

Derivado de lo anterior, este trabajo se divide en tres partes:

Los capítulos 1 a 3 conforman propiamente el marco teórico, con énfasis en la semiótica como enfoque principal, aunque no único. La segunda parte, conformada por los capítulos 4 a 6 , se dedica al análisis inmanente, centrado en el estudio de los procesos de codificación fotográfica. En la tercera parte -capítulos 7 y 8-, centrada en el estudio del acto fotográfico desde una perspectiva pragmática, se acomete la tarea de sistematizar los elementos contextuales que intervienen en el proceso de creación-recepción del mensaje fotográfico, con especial atención en la forma en que la digitalización de los procesos ha incidido en los flujos de trabajo, lo que ha acentuando el giro pragmático abarcador de los ámbitos de la producción, distribución y consumo de las fotografías.

En relación a este asunto en particular, la manera de abordarlo es teniendo siempre en mente la pregunta por el hecho de si la digitalización ha traído consigo una modificación de la fotografía como lenguaje, lo cual es el asunto de fondo de la investigación. Si el giro pragmático en la teoría nos incumbe, ello se debe a que no es sino el reflejo de lo que actualmente se está viviendo en los hechos. 


\section{Resum (VALENCiè)}

La fotografia és un element definitori de la semiosfera. El seu desenrotllament tècnic i la democratització dels seus usos no han cessat de modificar-se en el transcurs del temps i, a partir de la dècada de 1990, el camp fotogràfic ha presentat un canvi radical a causa de la introducció dels processos digitals. El fenomen fotogràfic s'ha estudiat al llarg de la seva història des d'una gran varietat d'enfocaments. El present treball pren com a punt de partida les aportacions teòriques que consideren la fotografia com un llenguatge; el desenrotllament d'aquestes es dóna a partir de la dècada de 1960 de la mà de diverses aproximacions que poden ser englobades davall la rúbrica abraçadora de crítica postestructuralista.

La creixent heteronomia del camp fotogràfic accentua la necessitat de sistematitzar els elements que donen suport a la capacitat de lectura d'imatges. La primera hipòtesi específica d'aquest treball proposa que és a través de l'estudi dels procediments de codificació propis del mitjà que podem desentranyar l'especificitat del signe fotogràfic, propiciant una anàlisi tant de tipus immanent -que ens permeta respondre a la qüestió de com significa la fotografia- com una anàlisi pragmàtica que incorpore elements contextuals.

Donant continuïtat a l'anterior plantejament, la segona hipòtesi específica de la Tesi es relaciona amb aqueixe canvi recent a què hem al-ludit i proposa l'interrogant de si la introducció dels processos digitals ha derivat en la creació d'un nou llenguatge fotogràfic o si, pel contrari, la seva aportació està més vinculada a l'àmbit dels usos de la imatge. En la seva expressió més general, allò que aquest treball desentranya a partir del qüestionament senyalat són les formes en què la digitalització dels processos fotogràfics han modificat, no sols els aspectes expressius del llenguatge fotogràfic, sinó també els extrínsecs, açò és, el gir pragmàtic experimentat pel camp fotogràfic en els últims vint anys. Els canvis en la 
concepció de les activitats productora i receptora han sigut tan profunds que ja no se sostenen els models lineals de comunicació, suplantats avui pels que proposen una immersió en un espai virtual que exigix una tasca permanent de recomposició.

Derivat de l'anterior, aquest treball es dividix en tres parts:

Els capítols 1 a 3 conformen pròpiament el marc teòric, amb èmfasi en la semiòtica com a enfocament principal, encara que no únic. La segona part, conformada pels capítols 4 a 6 , es dedica a l'anàlisi immanent, centrat en l'estudi dels processos de codificació fotogràfica. En la tercera part -capítols 7 i 8-, centrada en l'estudi de l'acte fotogràfic des d'una perspectiva pragmàtica, s'escomet la tasca de sistematitzar els elements contextuals que intervenen en el procés de creació-recepció del missatge fotogràfic, amb especial atenció en la forma en què la digitalització dels processos ha incidit en els fluxos de treball, la qual cosa ha accentuat el gir pragmàtic abraçador dels àmbits de la producció, distribució i consum de les fotografies.

En relació a aquest assumpte en particular, la manera d'abordar-lo és tenint sempre en ment la pregunta pel fet de si la digitalització ha comportat una modificació de la fotografia com a llenguatge, la qual cosa és l'assumpte de fons de la investigació. Si el gir pragmàtic en la teoria ens incumbix, això se deu a que no és sinó el reflex del que actualment s'està vivint en els fets. 


\section{Abstract (English)}

Photography is a defining element of the semiosphere. Its technical development and the democratization of its uses have changed constantly over time. Since the 1990's, the photographic field has presented radical modifications due to the introduction of digital processing.

Throughout its history, the photographic phenomenon has been widely studied from diverse approaches. The present work focuses on the theoretical contributions that consider photography as a language; that started to develop since the 1960's along with various approaches that can be included under the generic rubric of poststructuralist criticism.

The growing heteronomy of the photographic field emphasizes the need to systematize the elements that support the ability to read images. The first specific hypothesis of the present work proposes that it is through the study of the encoding procedures characteristic of the medium that the specificity of the photographic sign can be unraveled, leading both to an immanent analysis (which allows us to answer the question of how photography signifies) and a pragmatic one, that incorporates contextual elements.

Continuing the above approach, the second specific hypothesis of this work is related to the recent digital change already mentioned and poses the question of whether the introduction of digital processing has resulted in the creation of a new photographic language, or if on the contrary, this contribution is more related to the uses of the image. Starting from this question, what this work unravels in its most general approach are the ways in which the digitalization of photographic processes have changed not only the expressive aspects of the photographic language, but also the extrinsic ones, that is to say, the pragmatic turn experienced by the photographic field in the last twenty years. The changes in the conception of productive and receptive activities have been so profound that the linear 
models of communication no longer sustain themselves and have been displaced by those that propose an immersion in a virtual space that demands an ongoing work of recomposition.

As a result of the above, this work is divided into three parts:

Chapters 1 to 3 present the theoretical framework, with an emphasis on semiotics as the primary focus, although not unique. The second part, comprising chapters 4 through 6 , is devoted to the immanent analysis focused on the study of photographic encoding processes. The third part, chapters 7 and 8 , focuses on the study of the pragmatics of the photographic act, and it systematizes the contextual elements involved in the process of creation-reception of photographic messages, with special attention on how the digitalization processes have influenced the workflow, a fact that has stressed the pragmatic turn that encompasses the production, distribution, and consumption of photographs.

In relation to this particular issue, the way of dealing with it is by bearing in mind the question of how digitalization has brought a change in photography as a language, which is the core matter of this research. If the pragmatic turn in theory is of our concern, that is because it is merely a reflection of what is currently taking place in the facts. 